KAREN NICCOLI RAMIREZ

\title{
ANÁLISE DO COMPORTAMENTO ESTRUTURAL \\ DA CATEDRAL DA SÉ DE SÃO PAULO
}




\section{ANÁLISE DO COMPORTAMENTO ESTRUTURAL DA CATEDRAL DA SÉ DE SÃO PAULO}

Tese apresentada à Escola Politécnica da Universidade de São Paulo para obtenção do título de Doutor em Engenharia.

Área de Concentração:

Engenharia de Estruturas

Orientador: Prof. Dr.

Henrique Lindenberg Neto 
Este exemplar foi revisado e alterado em relação à versão original, sob responsabilidade única do autor e com a anuência de seu orientador.

São Paulo, de setembro de 2010.

Assinatura do autor

Assinatura do orientador

FICHA CATALOGRÁFICA

Ramirez, Karen Niccoli

Análise do comportamento estrutural da Catedral da Sé de

São Paulo / K.N. Ramirez. -- ed.rev. -- São Paulo, 2010. $224 \mathrm{p}$.

Tese (Doutorado) - Escola Politécnica da Universidade de São Paulo. Departamento de Engenharia de Estruturas e Geotécnica.

1. Igrejas (Arquitetura) 2. Modelos (Estrutura) 3. Gótico 4. Análise numérica 5. Cúpulas I. Universidade de São Paulo. Escola Politécnica. Departamento de Engenharia de Estruturas e Geotécnica II. t. 
À minha família pelo amor, carinho e apoio. 


\section{AGRADECIMENTOS}

A Deus, por Seu amor, pela graça da saúde e da vida e por conduzir-me por este caminho.

Aos meus amados pais pelo amor, dedicação e incentivo.

Aos meus queridos irmãos pelo apoio e carinho.

Ao amigo Prof. Dr. Henrique Lindenberg Neto, por acreditar em mim e pelas tão importantes orientações que contribuíram para o desenvolvimento e resultados desta pesquisa.

Aos Prof. Dr. Fernando Rebouças Stucchi e ao Prof. Dr. Ricardo Leopoldo e Silva França pelas valiosas sugestões e atentas observações por ocasião do Exame de Qualificação.

Aos professores do departamento de estruturas pelo conhecimento adquirido e pelo apoio.

Ao Arquivo da Cúria Metropolitana de São Paulo, Roberto e Jair, pelo acesso ao material disponível.

Aos amigos Antônio Sérgio e a Maria Fernanda pelo apoio e dicas para uso e aplicação do software de cálculo.

A Janete da secretaria de pós-graduação do Departamento de Engenharia de Estruturas e Geotécnica pela atenção e pelo apoio durante a pós-graduação.

Aos funcionários da Biblioteca da Engenharia Civil pelo apoio nas pesquisas.

À Universidade de São Paulo, pela oportunidade concedida, pelos desafios e pela realização. 
A todos que, direta ou indiretamente, colaboraram para a concretização desta pesquisa. 


\section{RESUMO}

Esta pesquisa apresenta o comportamento estrutural da Catedral da Sé de São Paulo em termos de deslocamentos e de tensões a partir do desenvolvimento de um modelo numérico tridimensional simplificado e da consideração do comportamento elástico-linear dos materiais. Construção gótica do século $X X$, a igreja matriz é um símbolo religioso, arquitetônico e social e sua praça, palco de manifestações e de expressão popular. Seu estilo gótico e o céu abobadado são interrompidos por um espaço octogonal sobre o qual se ergue uma cúpula renascentista. Inicialmente, são abordados aspectos da arquitetura da igreja e seus principais espaços são descritos; também são apresentadas as características geométricas dos elementos estruturais e as características mecânicas dos materiais, bases para a construção do modelo matemático. Em seguida, a estrutura da igreja é analisada quanto aos deslocamentos e às tensões, tendo-se feito, além do estudo da Catedral tal qual ela é, simulações em que são retirados os arcobotantes e as torres frontais, o que permite um estudo qualitativo e quantitativo da importância destes elementos estruturais para o equilíbrio do conjunto. Verifica-se que as regiões da igreja que apresentam os maiores deslocamentos também são aquelas mais críticas em termos de tensão, e algumas fissuras encontradas na igreja podem ser relacionadas aos carregamentos considerados nesta pesquisa. Constata-se que a Catedral da Sé é bem concebida e que seus elementos principais comportam-se estruturalmente como os das catedrais góticas originais.

Palavras-chave: Catedral da Sé de São Paulo. Modelagem numérica. Comportamento estrutural. Igreja gótica. 


\begin{abstract}
In this research, the structural behavior of the Cathedral of Sé in terms of displacements and stresses is presented, based on a simplified three-dimensional numerical model and the consideration of linear-elastic behavior of materials. Gothic building of the twentieth century, the Cathedral of Sé is a religious, architectural and social symbol and its square, scene of demonstrations and popular expression. Its Gothic style and vaulted sky are interrupted by an octagonal space on which stands a Renaissance dome. Initially, different aspects of the architecture of the church are discussed and its main areas are described, as well as are presented the geometric characteristics of its elements and the mechanical properties of its materials, bases for the construction of the mathematical model. In the sequence, the structure of the church is analyzed in terms of displacements and stresses, and in addition to the analysis of the Cathedral as it really is, simulations in which the flying buttresses and the front towers are removed are done, since they allow for the determination of the qualitative and quantitative importance of these structural elements to the equilibrium of the church. This research shows that the regions of the church in which the largest displacements occur are also those most critical in terms of stresses, and some of the cracks found in the building may be related to the loads considered in this study. The analysis done shows that the Cathedral of Sé is well designed and that its main elements behave structurally as those of the original Gothic cathedrals.
\end{abstract}

Keywords: Cathedral of Sé in São Paulo. Numerical modeling. Structural behavior. Gothic church. 


\section{LISTA DE FIGURAS}

Figura 2.1 - Vista da Catedral da Sé

Figura 2.2 - Espaço interior da Catedral da Sé: (a) vista do altar; (b) cúpula e abóbadas da nave central

Figura 2.3 - Elementos da fauna brasileira na Catedral da Sé: (a) tatu ornando o capitel de um dos pilares internos; (b) do lado externo da Catedral, quimera em forma mico

Figura 2.4 - Elementos da flora brasileira na Catedral da Sé: (a) vista geral do portal principal; (b) detalhe do portal principal

Figura 2.5 - Nível de referência: piso na parte frontal da igreja

Figura 2.6 - Planta da Catedral - locação dos eixos

Figura 2.7 - Dimensões do templo: corte transversal

Figura 2.8 - Dimensões do templo: corte longitudinal

Figura 2.9 - Região do octógono: (a) vista externa com um dos torreões que ladeiam a cúpula; (b) vista interna do tambor que dá apoio à da cúpula; (c) viga de cintamento e conjunto de pilares

Figura 2.10 - Corte da cúpula da Catedral da Sé

Figura 2.11 - Vista superior da cúpula externa: locação dos meridianos e dos paralelos; ao lado, a seção transversal da viga de cintamento

Figura 2.12 - Corte da cúpula externa: detalhe do meridiano 
Figura 2.13 - Vista superior da cúpula interna

Figura 2.14 - Ligação da cúpula interna com a viga de cintamento V1 Corte CC

Figura 2.15 - Detalhe do apoio dos meridianos da cúpula interna na viga de cintamento $\mathrm{V} 1$

Figura 2.16 - Classificação dos contrafortes

Figura 2.17 - Vista do alargamento da base dos contrafortes: fachada posterior da Catedral da Sé junto à Praça João Mendes

Figura 2.18 - Mudança de seção dos contrafortes tipo II

Figura 2.19 - Esquema de contrafortes: (a) com variação gradual da seção, próximo do real; (b) simplificado, com variação brusca de seção

Figura 2.20 - Seções transversais consideradas para os contrafortes tipo I e II: (a) da base; (b) até a elevação de 11,0 metros; (c) terceiro trecho, até a elevação de 16,14 metros

Figura 2.21 - Seções transversais consideradas para os contrafortes tipo III, IV e V: (a) da base; (b1) e (b3) até a elevação de 16,14 metros; (b2) até a elevação de 11,0 metros; (c2) até a elevação de 16,14 metros; (d2) até a elevação de 23,0 metros

Figura 2.22 - Seções transversais consideradas para os contrafortes tipo VI, VII: (a) da base; (b) até a elevação de 11,0 metros; (c) terceiro trecho até a elevação de 15,89 metros

Figura 2.23 - Seção transversal considerada para o maciço posterior ou contraforte tipo VIII 
Figura 2.24 - Seção retangular equivalente

Figura 2.25 - Seções transversais equivalentes para os contrafortes tipo I e II: (a) da base; (b) até a elevação de 11,0 metros; (c) terceiro trecho até a elevação de 16,14 metros

Figura 2.26 - Seções transversais equivalentes para os contrafortes tipo III, IV e V: (a) da base; (b1) e (b3) até a elevação de 16,14 metros; (b2) até a elevação de 11,0 metros; (c2) até a elevação de 16,14 metros; (d2) até a elevação de 23,0 metros

Figura 2.27 - Seções transversais equivalentes para os contrafortes tipo VI, VII: (a) da base; (b) até a elevação de 11,0 metros; (c) terceiro trecho até a elevação de 15,89 metros

Figura 2.28 - Seção transversal considerada para o maciço posterior ou contraforte tipo VIII

Figura 2.29 - Arcobotantes da Catedral da Sé: (a) vista lateral; (b) vista superior

Figura 2.30 - Vista dos pilares da nave central; à esquerda um dos grandes pilares do octógono

Figura 2.31 - Seção transversal e alargamento da base: (a) pilares centrais até o topo e pilares laterais até a elevação de 11 metros da região frontal e posterior da igreja; (b) todos os pilares da região do octógono

Figura 2.32 - Mudança de seção transversal dos pilares locados nos eixos 2 e 5 - região frontal e posterior

Figura 2.33 - Seção transversal do terceiro trecho dos pilares locados nos eixos 2 e 5 - região frontal e posterior 
Figura 2.34 - Seções transversais simplificadas para os pilares da região do octógono: (a) base; (b) corpo principal

Figura 2.35 - Seções transversais simplificadas para os pilares laterais, locados nos eixos 2 e 5 da região frontal e posterior: (a) base; (b) segundo trecho ou corpo principal; (c) terceiro trecho

Figura 2.36 - Seções transversais simplificadas para os pilares centrais, locados nos eixos 3 e 4 da região frontal e posterior: (a) base; (b) corpo principal

Figura 2.37 - Esquema genérico de apoio dos arcos no pilar e da representação das ligações dos arcos ao pilar com barras rígidas. Em azul, na ilustração à esquerda, as seções transversais dos arcos

Figura 2.38 - Detalhe da chegada dos arcos no pilar - nave lateral externa esquerda

Figura 2.39 - Classificação dos espaços da igreja - Corte da seção B 69

Figura 2.40 - Classificação dos espaços da igreja - Corte da seção J 69

Figura 2.41 - Planta da Catedral - esquema geral das abóbadas com suas nervuras; destaque para as abóbadas com cinco panos: (a) abóbadas das naves central, laterais e laterais externas; (b) abóbadas do coro e das naves baixas

Figura 2.42 - Abóbadas da Catedral da Sé modeladas - mapeamento das alturas dos anéis de fecho: (a) abóbadas das naves central, laterais e laterais externas; (b) abóbadas da região do coro e da região de apoio - naves baixas 
Figura 2.44 - Seção transversal original das torres até o nível da segunda cornija

Figura 2.45 - Seção transversal simplificada para as torres frontais

Figura 2.46 - Torres da Catedral da Sé: (a) torre direita em construção até a altura da segunda cornija; (b) vista das duas grandes torres durante a reforma; (c) torre esquerda - maciço de alvenaria de tijolos e pilar de concreto; (d) estrutura de concreto da torre direita - vigas e pilares entre a primeira e segunda cornija

Figura 3.1 - Alvenaria de granito de um dos pilares do octógono; destaque para as juntas de argamassa

Figura 3.2 - Modelo da Catedral da Sé: materiais aplicados nos pilares, contrafortes e nas duas torres frontais: (a) vista superior; (b) vista superior oblíqua

Figura 3.3 - Modelo da Catedral da Sé: (a) locação dos arcobotantes em planta; (b) seção no eixo E; (c) seção no eixo F; (d) vista da região posterior

Figura 3.4 - Mapeamento dos materiais dos arcos da Catedral da Sé: (a) marcação em planta dos arcos de alvenaria de tijolos; (b) modelo com corte longitudinal do eixo 5; (c) detalhe A; (d) detalhe $B$

Figura 3.5 - Elementos de casca no modelo da Catedral: (a) abóbadas das naves principal, laterais e laterais externas; (b) abóbadas do coro e abóbadas do nível baixo - áreas de apoio 
Figura 3.6 - Detalhe da disposição das fiadas de tijolos nos panos das abóbadas: (a) abóbadas quadripartidas da nave central; (b) abóbada sobre os arcos que suportam o coro, com vão de 12 metros; (c) detalhe do anel de fecho e da disposição das fiadas de tijolos; (d) detalhe da chegada da fiada na nervura de granito

Figura 3.7 - Modelo da região do octógono

Figura 3.8 - Modelo da Catedral da Sé de São Paulo - materiais estruturais: (a) vista superior; (b) vista oblíqua

Figura 4.1 - Modelo global da Catedral da Sé: (a) elementos modelados vista 3D; (b) vista lateral oblíqua com elementos de barra e de casca; (c) vista superior

Figura 4.2 - Catedral da Sé: (a) Vista interna do tambor, pilaretes e cúpula; (b) vista externa

Figura 4.3 - Torres da Catedral da Sé: (a) vista; (b) vista frontal 90

Figura 4.4 - Carga nos pilares, contrafortes e torres

Figura 4.5 - Esquema da carga das paredes sobre os arcos transversais das naves laterais numa seção típica da região frontal

Figura 4.6 - Locação das paredes

Figura 4.7 - Locação das paredes: (a) vista da cobertura lateral de cobre; (b) acesso pelo alçapão lateral junto à cobertura das naves laterais; (c) vista do interior; (d) alvenaria de tijolos sobre os arcos, que serve de apoio à tesoura de madeira

Figura 4.8 - Vista da parte posterior da Catedral da Sé: coberturas e paredes 
Figura 4.9 - Esquema da ação das imperfeições geométricas globais

Figura 5.1 - Orientação dos eixos globais

Figura 5.2 - Corte longitudinal no eixo 5: vista extrudada

Figura 5.3 - Planta do topo dos pilares e contrafortes

Figura 5.4 - Mapa dos deslocamentos devidos à carga permanente planta - escala dos deslocamentos 3000:1

Figura 5.5 - Deslocamento das abóbadas na direção $x$ devido à ação da carga permanente - planta - escala dos deslocamentos 800:1

Figura 5.6 - Deslocamento das abóbadas na direção y devido à ação da carga permanente - planta - escala dos deslocamentos 800:1

Figura 5.7 - Deslocamento vertical das abóbadas, na direção z, devido à ação da carga permanente - planta - escala dos deslocamentos 800:1

Figura 5.8 - Deslocamento total das abóbadas devido à ação da carga permanente - planta - escala dos deslocamentos 800:1

Figura 5.9 - Corte longitudinal no eixo 5: (a) configuração indeformada; (b) deslocamentos devidos à carga permanente - escala dos deslocamentos 1000

Figura 5.10 - Mapa dos deslocamentos devidos à carga permanente mais vento a 90 graus - planta - escala dos deslocamentos 3000:1 
Figura 5.11 - Deslocamentos transversais na seção do eixo D: (a) devidos à carga permanente; (b) devidos à carga permanente mais o vento a 90 graus - escala dos deslocamentos 1000:1

Figura 5.12 - Deslocamentos transversais na seção do eixo F: (a) devidos à carga permanente; (b) devidos à carga permanente mais 0 vento a 90 graus - escala dos deslocamentos 1000:1

Figura 5.13 - Mapa dos deslocamentos: (a) devidos à carga permanente mais desaprumo $(+\mathrm{x}+\mathrm{y})$; (b) devidos à carga permanente mais desaprumo $(-x+y)$ - planta - escala dos deslocamentos 3000:1

Figura 5.14 - Esquema de transmissão dos esforços em uma catedral gótica

Figura 5.15 - Mapa dos deslocamentos devidos à carga permanente: (a) estrutura real; (b) simulação sem os arcobotantes - planta escala dos deslocamentos 1000:1

Figura 5.16 - Deslocamentos na seção do eixo E: (a) estrutura real - (a1) vista extrudada; (a2) sob a ação da carga permanente; (a3) sob a ação da carga permanente mais o vento a 90 graus; (b) simulação sem os arcobotantes - (b1) vista extrudada; (b2) sob a ação da carga permanente; (b3) sob a ação da carga permanente mais o vento a 90 graus - escala dos deslocamentos 1500:1

Figura 5.17 - Deslocamentos na seção do eixo I: (a) estrutura real - (a1) vista extrudada; (a2) sob a ação da carga permanente; (a3) sob a ação da carga permanente mais o vento a 90 graus; (b) simulação sem os arcobotantes - (b1) vista extrudada; (b2) sob a ação da carga permanente; (b3) sob a ação da carga permanente mais o vento a 90 graus - escala dos deslocamentos 1500:1 
Figura 5.18 - Mapa dos deslocamentos devidos à carga permanente: (a) estrutura real; (b) simulação sem as torres frontais - planta escala dos deslocamentos 1000:1

Figura 5.19 - Corte longitudinal no eixo 5 sem as torres frontais: (a) vista extrudada; (b) deslocamentos devidos à carga permanente escala dos deslocamentos 1000:1

Figura 5.20 - Comparativo dos deslocamentos na direção longitudinal no eixo 5 devidos à carga permanente: (a) estrutura real; (b) simulação sem as torres frontais - escala dos deslocamentos 1000:1

Figura 5.21 - Catedrais góticas francesas - corte transversal, planta e vista: (a) Catedral de Chartres; (b) Catedral de Reims; (c) Catedral de Aims; (d) Catedral de Beauvais

Figura 5.22 - Catedrais góticas com cinco naves: corte transversal, planta e vista: (a) Catedral da Sé de São Paulo; (b) Catedral de Bourges; (c) Catedral de Milão 126

Figura 5.23 - Locação dos tirantes na Catedral da Sé 127

Figura 5.24 - Catedral de Coutances: (a) esquema da fachada frontal; (b) vista; (c) espaço octogonal no cruzeiro do transepto

Figura 5.25 - Catedral de Florença: (a) vista; (b) planta 129

Figura 5.26 - Catedral de Santos: (a) vista; (b) vista frontal 130

Figura 5.27 - Faixa em estudo

Figura 5.28 - Deformada da seção do eixo D': (a) devido à carga do peso próprio gerado; (b) devido à carga das paredes sobre os arcos transversais das naves laterais e sobre todos os longitudinais- escala dos deslocamentos 1500:1 
Figura 5.29 - Deformada da seção do eixo D' devido à carga permanente escala dos deslocamentos 1500:1

Figura 5.30 - Simulação sem o carregamento das paredes sobre os arcos longitudinais - análise da deformada da seção do eixo D': (a) devido à carga permanente sem as paredes sobre os arcos transversais das naves laterais; (b) devido à carga permanente - escala dos deslocamentos 1500:1

Figura 5.31 - Deformada da seção do eixo D' devido somente à carga das paredes sobre os arcos transversais das naves laterais escala dos deslocamentos 1500:1

Figura 5.32 - Simulação de um trecho de nave simétrica com o carregamento das paredes sobre os arcos longitudinais esquema estrutural e deformada: (a) somente arcos; (b) arcos e nervuras das abóbadas; (c) abóbadas completas escala dos deslocamentos 3000:1

Figura 5.33 - Deformada da seção do eixo D' devido somente à carga das paredes sobre os arcos longitudinais - escala dos deslocamentos 1500:1

Figura 5.34 - Esquema dos empuxos horizontais atuantes no topo do pilar central: (a) com carregamento das paredes: $\mathrm{H} 2<\mathrm{H} 1$; (b) sem carregamento das paredes: $\mathrm{H} 2<<\mathrm{H} 1$

Figura 5.35 - Deformada da seção do eixo D' devido à carga permanente sem as paredes transversais e longitudinais: (a) com os arcos das naves laterais externas; (b) sem os arcos das naves laterais externas - escala dos deslocamentos 1500:1. 
Figura 5.36 - Seção do eixo D' sem arcobotantes e sem paredes longitudinais: (a) deformada devido à carga permanente; (b) deformada devido à carga permanente sem as paredes transversais - escala dos deslocamentos 800:1

Figura 5.37 - Mapa de deslocamentos devidos à ação da carga permanente menos "parede"- planta- escala dos deslocamentos 3000:1

Figura 5.38 - A cúpula e o seu tambor. Corte longitudinal

Figura 5.39 - Modelo do espaço octogonal da Catedral: (a) vista superior; (b) região do octógono

Figura 5.40 - Mapa dos deslocamentos devidos à carga permanente: simulação em que somente ao octógono são atribuídos peso e cargas - planta - escala dos deslocamentos 3000:1

Figura 5.41 - Mapa dos deslocamentos - planta - escala dos deslocamentos 3000:1: (a) devidos ao peso próprio gerado; (b) devidos ao peso próprio gerado + paredes

Figura 5.42 - Mapa dos deslocamentos - planta - escala dos deslocamentos 3000:1: devidos às paredes + peso próprio gerado + outros $=$ carga permanente

Figura 5.43 - Mapa dos deslocamentos - planta - escala dos deslocamentos 3000:1: (a) devidos às paredes; (b) devidos às paredes + peso próprio gerado

Figura 5.44 - Mapa dos deslocamentos - planta - escala dos deslocamentos 3000:1: devidos às paredes + peso próprio gerado + outros $=$ carga permanente 
Figura 6.1 - Esquema geral dos esforços numa seção retangular

Figura 6.2 - Esquema geral da posição da linha neutra numa seção retangular

Figura 6.3 - Diagrama dos esforços solicitantes na seção do eixo $F$ devidos à carga permanente - escala 0,0007:1: (a) força normal; (b) momento fletor em torno de $\mathrm{x}$

Figura 6.4 - Diagrama dos esforços solicitantes na seção do eixo $F$ devidos à carga permanente - momento fletor em torno de $y$ - escala 0,0007:1

Figura 6.5 - Tensões normais resultantes no pilar lateral 2F devidas à ação da carga permanente: (a) elevação; (b) corte A; (c) corte B

Figura 6.6 - Tensões normais resultantes no pilar lateral 2F devidas à ação da carga permanente mais o desaprumo nas direções $\mathrm{x}$ e +y: (a) corte $\mathrm{A}$; (b) corte $\mathrm{B}$ e; devidas à ação da carga permanente mais o vento a $90^{\circ}$, no sentido +y: (c) corte $A$; (d) corte B

Figura 6.7 - Tensões normais resultantes no pilar central 3F devidas à ação da carga permanente: (a) elevação; (b) corte A; (c) corte B 
Figura 6.8 - Tensões normais resultantes no pilar lateral 3F devidas à ação da carga permanente mais o desaprumo nas direções x e +y: (a) corte $A$; (b) corte $B$; e devidas à ação da carga permanente mais vento a $90^{\circ}$ no sentido +y: (c) corte $A$; (d) corte B; (e) elevação

Figura 6.9 - Tensões normais resultantes no contraforte $1 \mathrm{~F}$ devidas à ação da carga permanente: (a) elevações; (b) corte $A$; (c) corte B

Figura 6.10 - Tensões normais resultantes no contraforte $1 \mathrm{~F}$ devidas à ação da carga permanente mais o desaprumo nas direções x e +y: (a) corte $A$; (b) corte $B$; e devidas à ação da carga permanente mais o vento a $90^{\circ}$, na direção +y: (c) corte $A$; (d) corte B; (e) elevação

Figura 6.11 - Diagrama dos esforços solicitantes na seção do eixo E devidos à carga permanente - escala 0,0025:1: (a) força normal; (b) momento fletor em torno de $x$

Figura 6.12 - Diagrama dos esforços solicitantes na seção do eixo E devidos à carga permanente - momento fletor em torno de $\mathrm{y}$ (a) escala 0,0025:1; (b) escala 0,01:1

Figura 6.13 - Tensões normais resultantes no pilar lateral 2E devidas à ação da carga permanente: (a) elevação; (b) corte $A$; (c) corte B

Figura 6.14 - Tensões normais resultantes no contraforte 2E devidas à ação da carga permanente mais o desaprumo nas direções x e +y: (a) elevação; (b) corte $A$; (c) corte $B$; e devidas à ação da carga permanente mais o vento a $90^{\circ}$, na direção +y: (d) corte $A$; (e) corte B 
Figura 6.15 - Tensões normais resultantes no pilar central 3E devidas à ação da carga permanente: (a) elevação; (b) corte $A$; (c) corte

Figura 6.16 - Tensões normais resultantes no pilar central 3E devidas à ação da carga permanente mais o desaprumo nas direções x e +y: (a) elevação; (b) corte $A$; (c) corte $B$; e devidas à ação da carga permanente mais o vento a $90^{\circ}$, na direção $+y:$ (d) corte $A$; (e) corte B

Figura 6.17 - Tensões normais resultantes no contraforte $1 \mathrm{E}$ devidas à ação da carga permanente: (a) elevações; (b) corte $A$; (c) corte B

Figura 6.18 - Tensões normais resultantes no contraforte $1 E$ devidas à ação da carga permanente mais o desaprumo nas direções x e +y: (a) elevação; (b) corte A; (c) corte B; e devidas à ação da carga permanente mais o vento a $90^{\circ}$, na direção +y: (d) corte $A$; (e) corte B

Figura 6.19 - Diagrama dos esforços solicitantes na seção do eixo G devidos à carga permanente - escala 0,0004:1: (a) força normal; (b) momento fletor em torno de $x$

Figura 6.20 - Diagrama dos esforços solicitantes na seção do eixo G devidos à carga permanente - momento fletor em torno de $\mathrm{y}$ (a) escala 0,0004:1; (b) escala 0,002:1

Figura 6.21 - Tensões normais resultantes no pilar lateral 2G devidas à ação da carga permanente: (a) elevação; (b) corte $A$; (c) corte B 
Figura 6.22 - Tensões normais resultantes no pilar lateral 2G devidas à ação da carga permanente mais o desaprumo nas direções x e +y: (a) corte $A$; (b) corte $B$; e devidas à ação da carga permanente mais o vento a $90^{\circ}$, na direção +y: (c) corte $A$; (d) corte B; (e) elevação

Figura 6.23 - Tensões normais resultantes no contraforte $1 G$ devidas à ação da carga permanente: (a) elevação; (b) corte $A$; (c) corte B

Figura 6.24 - Tensões normais resultantes no contraforte $1 G$ devidas à ação da carga permanente mais o desaprumo nas direções x e +y: (a) corte $A$; (b) corte $B$; e devidas à ação da carga permanente mais o vento a $90^{\circ}$, na direção +y: (c) corte $A$; (d) corte B; (e) elevação

Figura 6.25 - Tensões normais resultantes no pilar lateral 3I na simulação sem os arcobotantes: (a) elevação; (b) devidas à ação da carga permanente; (c) devidas à ação da carga permanente mais o vento a $90^{\circ}$

Figura 6.26 - Tensões normais resultantes no pilar lateral 2B devidas à ação da carga permanente mais desaprumo nas direções $\mathrm{x}+\mathrm{y}$ : (a) situação real; (b) na simulação sem as torres frontais; (c) elevação

Figura 6.27 - Tensões normais resultantes no pilar central 3B devidas à ação da carga permanente mais desaprumo nas direções x+y: (a) situação real; (b) na simulação sem as torres frontais; (c) elevação

Figura 6.28 - Tensões normais resultantes no pilar central 3F na simulação sem as torres frontais: (a) devidas à ação da carga permanente; (b) devidas à ação da carga permanente mais desaprumo nas direções -x+y; (c) elevação 
Figura 6.29 - Tensões normais resultantes no contraforte $1 \mathrm{G}$ na simulação sem as torres frontais: (a) devidas à ação da carga permanente; (b) devidas à ação da carga permanente mais vento a $90^{\circ}$; (c) elevação

Figura 6.30 - Tensões resultantes no contraforte 1B devidas à ação da carga permanente mais vento a 90\%: (a) situação real; (b) simulação sem as torres frontais; (c) elevação

Figura 6.31 - Mapeamento das tensões principais máximas, $\sigma 1$, nas abóbadas e na cúpula interna devidas à ação da carga permanente: (a) na face superior do elemento de casca; (b) na face inferior do elemento de casca - escala limitada superiormente pela tensão de ruptura à tração da alvenaria de tijolos

Figura 6.32 - Mapeamento das tensões principais máximas, $\sigma 1$, nas abóbadas e na cúpula interna devidas à ação da carga permanente: (a) na face superior do elemento de casca; (b) na face inferior do elemento de casca - escala mais ampla limitada superiormente pela tensão de ruptura à tração do concreto armado

Figura 6.33 - Mapeamento das tensões principais mínimas, $\sigma 2$, nas abóbadas e na cúpula interna devidas à ação da carga permanente: (a) na face superior do elemento de casca; (b) na face inferior do elemento de casca - escala limitada inferiormente pela tensão admissível à compressão da alvenaria de tijolos

Figura 6.34- Mapeamento das fissuras presentes nas abóbadas da Catedral da Sé antes da reforma 
Figura 6.35 - Envoltória para a alvenaria de tijolos pelo critério de resistência de Mohr-Coulomb

Figura 6.36 - Marcação das fissuras na região frontal da igreja sobre os mapas das tensões principais máximas e mínimas: (a) na face superior da abóbada; (b) na face inferior da abóbada .....

Figura 6.37 - Marcação das fissuras na região posterior da igreja sobre os mapas das tensões principais máximas e mínimas: (a) na face superior da abóbada; (b) na face inferior da abóbada ..... 204

Figura 6.38 - Marcação das fissuras na região do octógono sobre os mapas das tensões principais máximas e mínimas: (a) na face superior da abóbada; (b) na face inferior da abóbada ..... 205

Figura 6.39 - Fissuras mapeadas na região posterior da Catedral após a reforma 


\section{LISTA DE TABELAS}

Tabela 2.1 - Características geométricas das seções transversais adotadas para o núcleo dos contrafortes e do maciço posterior

Tabela 2.2 - Características geométricas das seções transversais adotadas para o revestimento dos contrafortes e do maciço posterior

Tabela 2.3 - Características geométricas das seções transversais adotadas para o núcleo dos pilares

Tabela 2.4 - Características geométricas das seções transversais adotadas para o revestimento dos pilares

Tabela 2.5 - Características geométricas das seções transversais adotadas para as torres frontais

Tabela 3.1 - Características mecânicas dos materiais 79

Tabela 5.1 - Deslocamentos no topo dos contrafortes da região do octógono

Tabela 5.2 - Deslocamentos no topo dos contrafortes tipo I

Tabela 5.3 - Deslocamentos no topo dos pilares da região do octógono ... 104

Tabela 5.4 - Comparativo dos deslocamentos no topo dos pilares da região posterior - eixos M e M' - sem os arcobotantes 
Tabela 5.5 - Comparativo dos deslocamentos horizontais no topo dos pilares e contrafortes do eixo $\mathrm{B}$, devido à ação da carga permanente

Tabela 5.6 - Comparativo dos deslocamentos horizontais no topo dos pilares da região do octógono, devido à ação da carga permanente

Tabela 5.7 - Comparativo dos deslocamentos no topo de alguns pilares na região do octógono sob ação da carga permanente

Tabela 5.8 - Comparativo dos deslocamentos horizontais no topo dos pilares da região octógono

Tabela 5.9 - Agrupamento dos carregamentos

Tabela 6.1- Tensões normais máximas atuantes nos pilares e contrafortes

Tabela 6.2 - Tensões normais máximas atuantes nos pilares: simulação sem os arcobotantes e variação percentual em relação às máximas da situação real

Tabela 6.3 - Comparativo de tensões normais máximas atuantes nos pilares: situação real $x$ simulação sem os arcobotantes

Tabela 6.4 - Tensões normais máximas atuantes nos pilares: simulação sem as torres frontais

Tabela 6.5 - Comparativo de tensões normais máximas atuantes nos pilares e contrafortes: situação real $x$ simulação sem as torres frontais 189

Tabela 6.6 - Tensões dos materiais na compressão

Tabela 6.7 - Tensões dos materiais na tração 


\section{SUMÁRIO}

LISTA DE FIGURAS

LISTA DE TABELAS

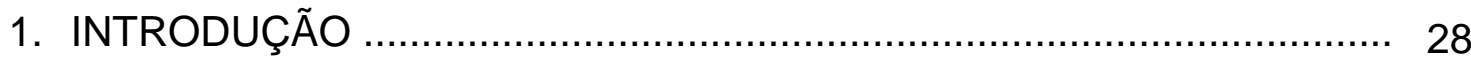

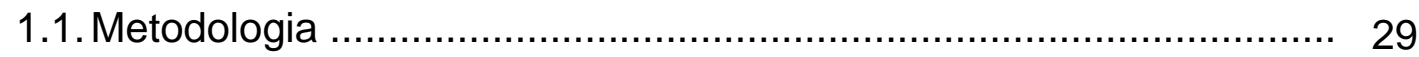

1.2. Revisão da literatura ............................................................... 31

1.3. Sequência de apresentação …………………………………...... 32

2. DEFINIÇÃO DA GEOMETRIA ………………............................ 34

2.1. A região do octógono e a geometria da cúpula ............................... 40

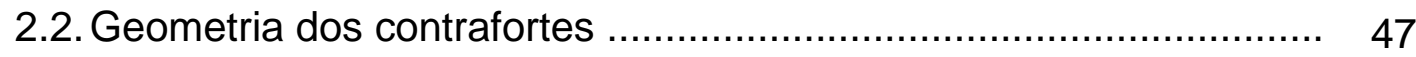

2.2.1. Características geométricas ……………………………... 53

2.3. Geometria dos arcobotantes ……............................................. 60

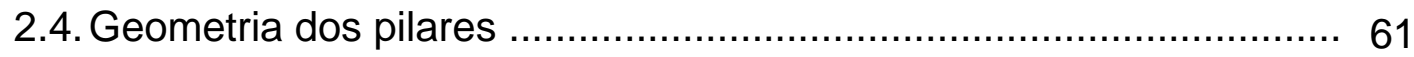

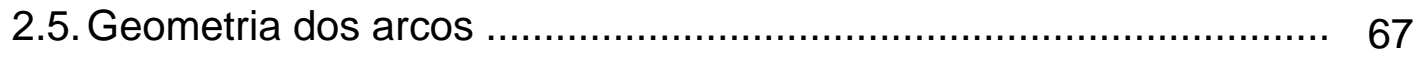

2.6. Geometria das abóbadas ........................................................ 70

2.7. Geometria das torres frontais ................................................... 72

3. MATERIAIS E SUAS CARECTERÍSTICAS MECÂNICAS ..................... 76

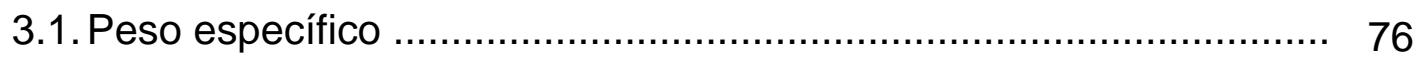

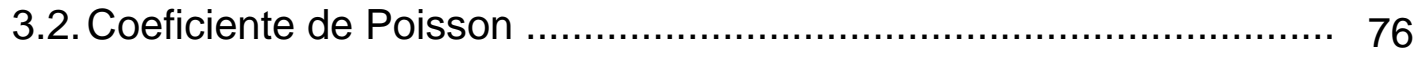

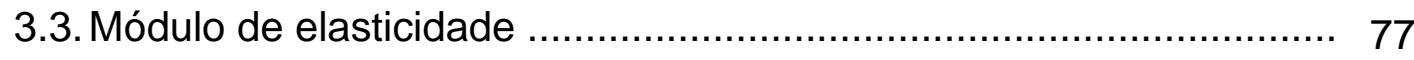

3.4. Materiais dos elementos estruturais modelados ............................. 79

4. ESTIMATIVA DOS CARREGAMENTOS …..................................... 87

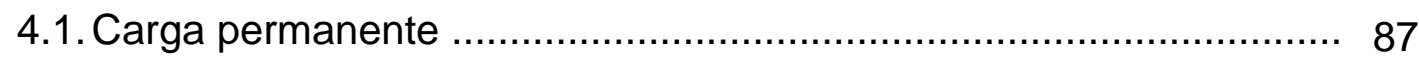


4.1.1. Peculiaridades sobre o carregamento permanente

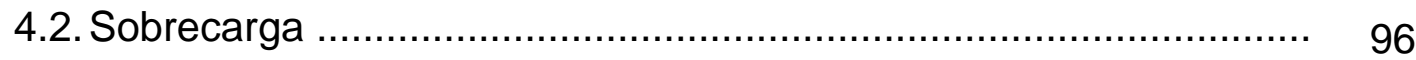

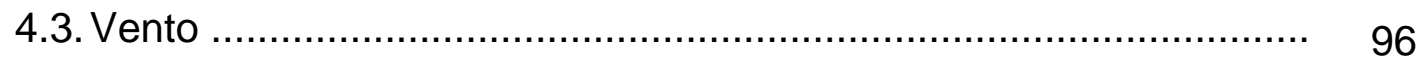

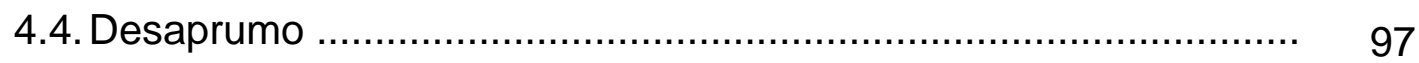

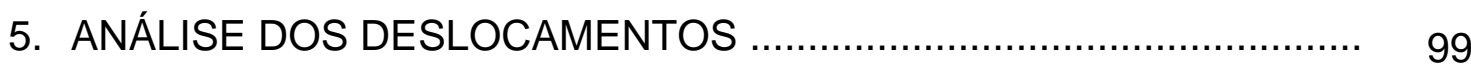

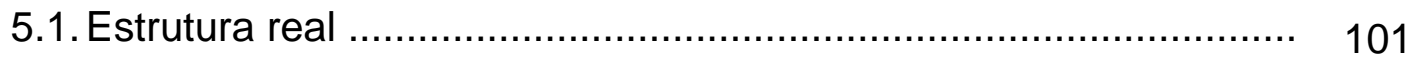

5.1.1. Ação do carregamento horizontal .................................. 108

5.2. Simulações: importância dos elementos estruturais ................. 113

5.2.1. Os arcobotantes ............................................... 113

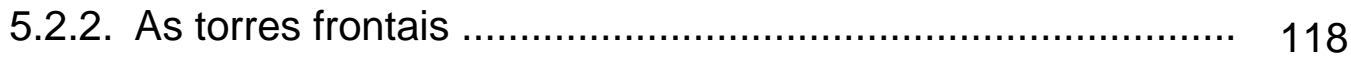

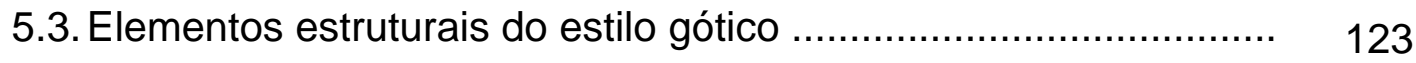

5.4. O espaço octogonal ..................................................... 141

5.5. Influência dos carregamentos permanentes na Catedral da Sé … 144

5.6. Considerações sobre a análise dos deslocamentos ................... 148

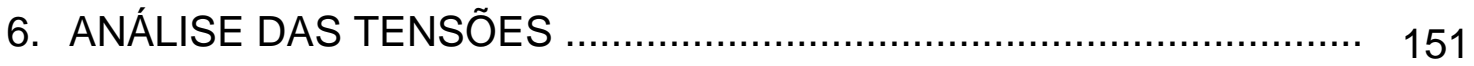

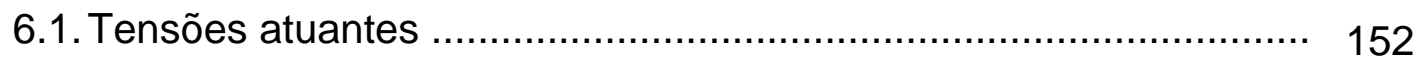

6.2. Estudo das tensões nos contrafortes e pilares ........................ 156

6.2.1. Pilares e contrafortes da seção no eixo F ......................... 156

6.2.2. Pilares e contrafortes da seção no eixo $E$........................ 165

6.2.3. Pilares e contrafortes do transepto - seção no eixo G .......... 173

6.3. Simulações: retirada dos elementos estruturais ......................... 180

6.3.1. Retirada dos arcobotantes ...................................... 180

6.3.2. Retirada das torres frontais .................................... 184

6.4. Tensões de ruptura e tensões admissíveis ............................... 190

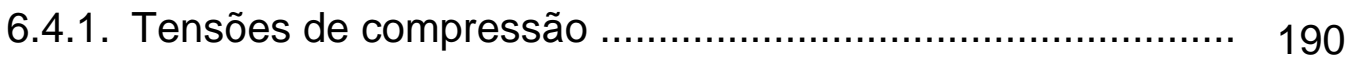


6.4.2. Tensões de tração

6.5. Estudo das tensões nas abóbadas ........................................... 195

6.6. Considerações sobre a análise das tensões ............................ 207

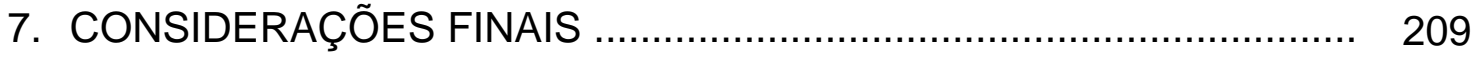

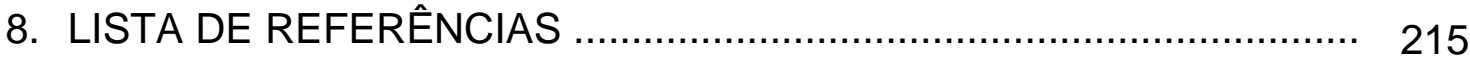

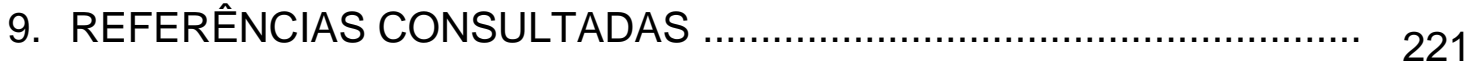




\section{INTRODUÇÃO}

A diocese de São Paulo recebeu o título de arquidiocese em 1908, em um período de vertiginoso crescimento econômico e populacional da cidade, e, neste contexto, o primeiro arcebispo de São Paulo, Dom Duarte Leopoldo e Silva, em 1911, mobilizou seus conterrâneos para que a intenção de uma nova catedral se concretizasse.

A Catedral da Sé é um símbolo histórico, religioso, arquitetônico e social; a sua arquitetura abriga as crenças de um povo e sua praça é palco de manifestações populares.

Ainda no começo da construção, em 1914, o terreno destinado ao logradouro público já recebera o comício de $1^{\circ}$ de Maio, organizado pelos sindicatos. Um ano mais tarde, houve manifestações contra a Primeira Guerra Mundial. Em 1922, na Catedral em obras, foi celebrada uma missa em comemoração ao Centenário da Independência. Doze anos mais tarde, a Praça da Sé tornou-se o marco zero da cidade e, na década de 70, recebeu a Estação do Metrô. Em 1984, o local também recebeu comícios para reivindicação por eleições presidenciais diretas, o movimento político Diretas Já e até hoje a Catedral e sua praça testemunham fatos históricos e sociais da cidade e do Brasil, confirmando seu papel como um espaço de expressão popular.

A Catedral da Sé da cidade de São Paulo, também chamada de Catedral Metropolitana Nossa Senhora da Assunção da Arquidiocese de São Paulo, teve sua construção iniciada aos 6 de julho de 1913, em estilo predominantemente gótico. Projeto do engenheiro-arquiteto alemão Maximiliano Hehl, a igreja possui algumas peculiaridades em sua arquitetura.

A brasileira catedral gótica é dotada de contrafortes, arcobotantes, arcos e abóbadas ogivais, pináculos e altas torres com flechas, elementos típicos do estilo. No entanto, no cruzeiro do transepto, a romper a seqüência das abóbadas que formam o céu da igreja, ergue-se uma polêmica cúpula renascentista, criticada na época de concepção e de construção do templo, principalmente por destoar do estilo proposto; além disso, por toda a Catedral, se vêm adornos representativos da cultura 
brasileira.

A presença do ecletismo, que se instaurou no final do século XIX e nas primeiras décadas do século $X X$ no Brasil, talvez tenha influenciado a concepção arquitetônica de Maximiliano Hehl. Esta tendência procurou reunir os diversos estilos arquitetônicos, assim não seria de se estranhar uma Catedral predominantemente gótica com elementos renascentistas e adornada com elementos da flora e da fauna brasileira.

Além dos adornos da flora e da fauna, a representatividade brasileira também está presente no mobiliário de jacarandá da Bahia, no granito nacional, e, em cenas da catequese jesuítica esculpidas junto à pia batismal.

A matriz da cidade levou algumas décadas para ser inaugurada, e a falta de recursos definiu o ritmo das obras, que, no entanto, nunca foram paralisadas. A Catedral foi inaugurada aos 25 de janeiro de 1954, por ocasião do IV Centenário da fundação da cidade de São Paulo.

Em 2000, devido à queda de tijolos de uma das abóbadas, iniciou-se a reforma da igreja, supervisionada pela Mitra Arquidiocesana de São Paulo, na época representada pelo Arcebispo Dom Cláudio Hummes.

Com o intuito de preservar a memória e a riqueza da história e do patrimônio brasileiros, particularmente da cidade de São Paulo, a Catedral da Sé teve sua trajetória descrita na dissertação de mestrado elaborada em 2005 pela autora desta pesquisa, em que são abordados sua história, sua arquitetura e aspectos estruturais do templo. Uma das propostas para futuros estudos apresentadas nesta dissertação era o desenvolvimento de uma análise qualitativa e quantitativa do comportamento estrutural da igreja.

O objetivo da atual pesquisa é a realização do proposto na dissertação de mestrado da autora, de identificar e analisar os principais aspectos do comportamento estrutural da Catedral da Sé de São Paulo, tanto em termos de deslocamentos como de tensões, a partir do desenvolvimento de um modelo matemático tridimensional simplificado e considerando comportamento elásticolinear dos materiais. 


\subsection{Metodologia}

A primeira fase da pesquisa implicou no levantamento e no estudo da geometria da Catedral da Sé e na construção de um modelo global, utilizando-se de um software de cálculo estrutural, com a inserção das características mecânicas dos materiais e dos carregamentos.

Os maiores desafios foram a escassez de informações sobre o projeto e a dificuldade de acesso às regiões elevadas, como a das abóbadas, para as medições necessárias.

Muitas das informações utilizadas para a elaboração do modelo - tais como plantas e elevações gerais - e para a descrição da cúpula foram extraídas da própria da dissertação de mestrado da autora (RAMIREZ, 2005). Somado a isto, novas visitas foram realizadas ao Arquivo da Cúria Metropolitana de São Paulo, onde novas plantas, antes em fase de restauro e inacessíveis, agora estavam disponíveis para consulta, dentre elas alguns cortes e elevações por meio dos quais as curvaturas dos arcos foram traçadas.

Visitas à própria Catedral foram realizadas no intuito de estimar as seções transversais de todos os arcos, além dos vãos e das excentricidades entre os arcos e os pilares e contrafortes, de modo a apresentá-las com maior precisão.

Foi desenvolvido um modelo numérico tridimensional, com o emprego de elementos de barra e de casca, considerando comportamento linear dos materiais. Por meio deste modelo, obtêm-se os deslocamentos e os diagramas de esforços atuantes nos elementos da Catedral. O software utilizado é o SAP 2000, aplicado em cálculo, dimensionamento e verificação de estruturas.

O modelo foi paulatinamente aperfeiçoado, sendo ao final constituído por elementos de barra que representam a maioria das peças estruturais como arcobotantes, contrafortes, pilares, arcos e nervuras e as duas torres frontais até a elevação da segunda cornija, e por elementos de casca, que simulam os panos das abóbadas e da cúpula, e o tambor.

O modelo apresenta outras simplificações, não considerando, por exemplo, a geometria dos telhados e das paredes, que entram como carga. As cargas excêntricas são aplicadas por meio de barras rígidas. 
Como comentado, o estudo é conduzido a partir de uma análise elástico-linear e os materiais são considerados isótropos e homogêneos.

Admite-se o solo indeformável, logo no modelo não estão contemplados os efeitos de recalque. Considera-se que os pilares e os contrafortes sejam engastados na base.

Outras simplificações implicam na adoção de seções transversais circulares e tubulares para representar os pilares e de seções retangulares para simular os contrafortes.

Embora seja simplificado, o modelo representa bastante bem o comportamento global da Catedral, permitindo avaliar a importância de elementos estruturais como os arcobotantes, os contrafortes e as torres frontais no equilíbrio do conjunto, sobretudo em termos de transmissão de esforços horizontais e, a partir dos esforços atuantes, a análise das tensões possibilita identificar as regiões mais solicitadas da igreja.

\subsection{Revisão da literatura}

Estudos semelhantes podem ser encontrados na literatura, muitos advindos de universidades de Portugal, onde há grupos de pesquisa voltados à análise estrutural de antigas construções, como igrejas. Muitas vezes estes estudos referem-se a edificações que já apresentam problemas estruturais e que precisam de urgente reforço.

Na antiga Igreja de São Francisco em Évora, por exemplo, iniciada em 1224 e monumento nacional a partir de 1910, fendas presentes nas abóbadas ogivais da nave junto às paredes laterais levaram ao estudo do comportamento estrutural da construção. Segundo Gago (2009), trata-se de abóbadas "botantes" que saem das paredes exteriores e vão até as paredes interiores mais elevadas; os pilares são de cantaria de granito.

A fendilhação existente deu-se de modo lento e fissuras já podiam ser encontradas há pelo menos duzentos anos, o que levou a crer que estariam ligadas ao comportamento estrutural ou ao recalque das fundações. As características 
mecânicas admitidas estão baseadas em parâmetros tabelados para granitos e alvenarias correntes. Optou-se por um modelo tridimensional do trecho em análise, utilizando elementos de casca com comportamento elástico-linear. Este estudo permitiu relacionar as fendas com os empuxos gerados pelas abóbadas e como solução imediata o atirantamento.

Os próprios autores sugerem futuros estudos e melhorias no modelo numérico a partir de melhor estimativa das cargas e das características dos materiais, introdução das considerações do solo, de ações sísmicas e simulação das fases construtivas.

Outros estudos surgem da necessidade de entender o comportamento estrutural das edificações antigas principalmente sob a ação do sismo, como é caso da região histórica de Lisboa, a Baixa Pombalina, reconstruída após o terremoto de 1755. Para tanto, utilizou-se um modelo tridimensional com elementos de casca para representar lajes de concreto e algumas abóbadas de alvenaria, e com elementos de volume para representar as paredes de alvenaria, arcos e abóbadas de alvenaria de pedra, bem como pilares de concreto armado (SILVA, 2001).

A Basílica de San Giovanni a Mare, localizada no centro histórico de Nápoles, também foi estudada sob o carregamento permanente e sob ação de sismo. Foram adotadas simplificações geométricas e desenvolvido um modelo tridimensional com elementos de barra e casca. A primeira fase consistiu numa análise linear com o objetivo de obter esforços e identificar os pontos fracos com potencial para colapso (MELE, 2001). Numa segunda fase, procedeu-se a uma análise não-linear em duas dimensões para compreender o comportamento da estrutura sob sismo.

Nota-se que, em muitos estudos, a primeira análise é linear, mas quando os resultados do modelo não condizem com a realidade procede-se à análise nãolinear. É o caso do Teatro Lethes, em Faro, cuja cobertura, uma abóbada de berço de alvenaria de tijolo cerâmico assentado com argamassa de cal e areia, apresentava fissuras no fecho da abóbada e deformações excessivas. Esta abóbada é suportada por paredes de grande espessura de alvenaria de pedra. Segundo Lourenço (2000), o deslocamento máximo de fecho obtido pela análise linear era bem menor do que o real. 


\subsection{Sequência de apresentação}

Após esta breve introdução, em que são apresentadas as motivações da pesquisa, seus objetivos, metodologia e premissas assumidas, no Capítulo 2 , seguese a descrição dos espaços e da geometria da Catedral da Sé, assim como o levantamento das características geométricas das seções transversais de todos os elementos estruturais necessários para a modelagem da igreja.

No Capítulo 3, são definidas as características mecânicas dos materiais estruturais, ou seja, do concreto simples, do concerto armado, da alvenaria de granito e da alvenaria de tijolos. As considerações de carregamento estão apresentadas no Capítulo 4.

Estes primeiros capítulos da pesquisa abordam, portanto, as premissas consideradas na construção de um modelo que representa de forma bem aproximada o comportamento global da Catedral da Sé de São Paulo. No Capítulo 5 , é feita análise em termos de deslocamentos, buscando-se compreender como a igreja se comporta e como os seus elementos estruturais funcionam, permitindo entender a importância dos diferentes elementos estruturais para o equilíbrio da igreja.

No Capítulo 6 é feita a análise de tensões de alguns elementos estruturais da Catedral como pilares, contrafortes e abóbadas. Esta análise mostra quais são as regiões da Catedral da Sé que estão submetidas a maiores solicitações e onde pode haver trechos passíveis de fissuração.

As considerações finais e as propostas para futuros estudos estão no Capítulo 7. E nos Capítulos 8 e 9, encontram-se, respectivamente, a lista de referências utilizadas e citadas e a lista de referências consultadas para o desenvolvimento da pesquisa. 


\section{DEFINIÇÃO DA GEOMETRIA}

A Catedral da Sé de São Paulo foi concebida pelo engenheiro-arquiteto alemão Maximiliano Hehl, professor da Escola Politécnica de São Paulo. O projeto da igreja, que começou a ser construída em 1913, tinha como objetivo comportar até oito mil pessoas.

Possui 111 metros de comprimento e 46 metros de largura. Apresenta estilo gótico adornado por elementos da cultura brasileira, ambiente que é interrompido por um espaço octogonal coroado por uma cúpula renascentista (Figura 2.1).

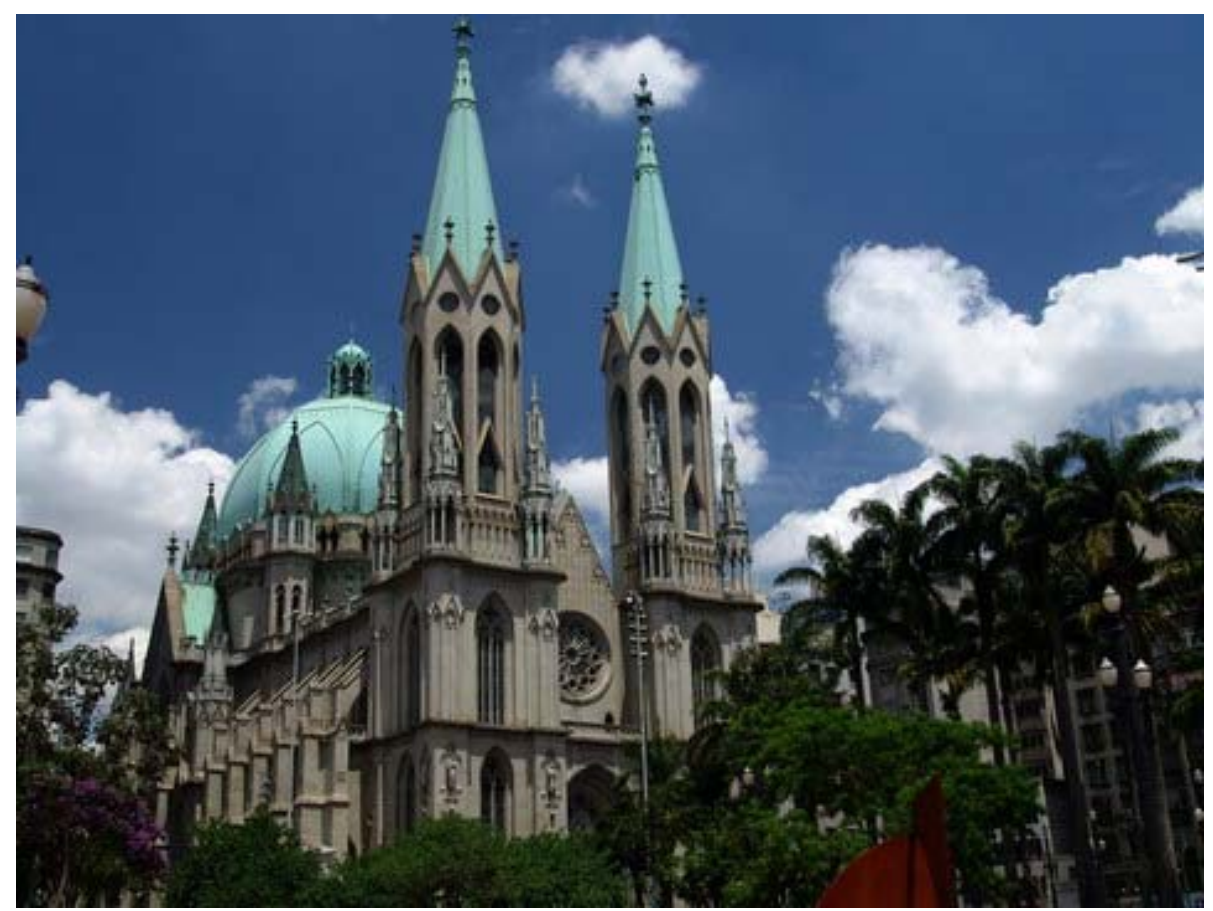

Figura 2.1 - Vista da Catedral da Sé (DACIOLE, 2008).

Nascido em 1861, Maximiliano Hehl, formado pela Escola Politécnica de Hannover, somente chegou ao Brasil em 1888, incentivado por seu irmão, também engenheiro, Rudolf, para trabalhar como membro da equipe de engenheiros da estrada de ferro Bahia - Minas, onde esteve por dois anos.

Passou depois a viver em São Paulo, onde assumiu o cargo de chefe de escritórios do Banco União e, posteriormente, do escritório do engenheiro e professor da Escola Politécnica Francisco de Paula Ramos de Azevedo, serviço este no qual permaneceu por nove anos. 
Maximiliano Hehl desenvolveu atividades em São Paulo, Santos, Rio de Janeiro e em Salvador, tendo participado da construção do Sanatório Santa Catarina, da Igreja da Ordem Terceira do Carmo, do Colégio Santo Agostinho, do hospital Ana de Alvarenga, da Nova Matriz de Santos, do Corpo de Bombeiros de Santos, de palacetes e armazéns comerciais (PONZIO, 2003).

Foi somente em setembro de 1896 que Maximiliano Emílio Hehl ingressou como professor substituto, na Escola Politécnica. Dois anos mais tarde, passou a reger, como docente oficial, as disciplinas de História da Arquitetura e Estudos dos Estilos Diversos. Hehl permaneceu na Escola Politécnica até 1916 e teve a oportunidade de lecionar outras disciplinas como Edifícios Públicos e Estética das Artes de Desenhos, no curso de engenheiro-arquiteto.

A Catedral da Sé é dotada de cinco naves cobertas por abóbadas ogivais, quase todas quadripartidas. A utilização de arcobotantes, estruturas que transmitem o empuxo das abóbadas aos contrafortes, possibilita maiores elevações.

A verticalidade e a iluminação fornecida por seus vitrais coloridos, anseios típicos das estruturas góticas, buscam a atmosfera de elevação aos céus. Este estilo é somente quebrado pela presença de um elemento estrutural incomum em edificações com esta arquitetura.

Em geral, no cruzeiro das igrejas tipicamente góticas eleva-se uma agulha; no entanto, no caso da Catedral da Sé, o ambiente é interrompido por uma cúpula renascentista, apoiada sobre um tambor octogonal como mostra a Figura 2.2, e por toda igreja se vêm adornos representativos da cultura brasileira.

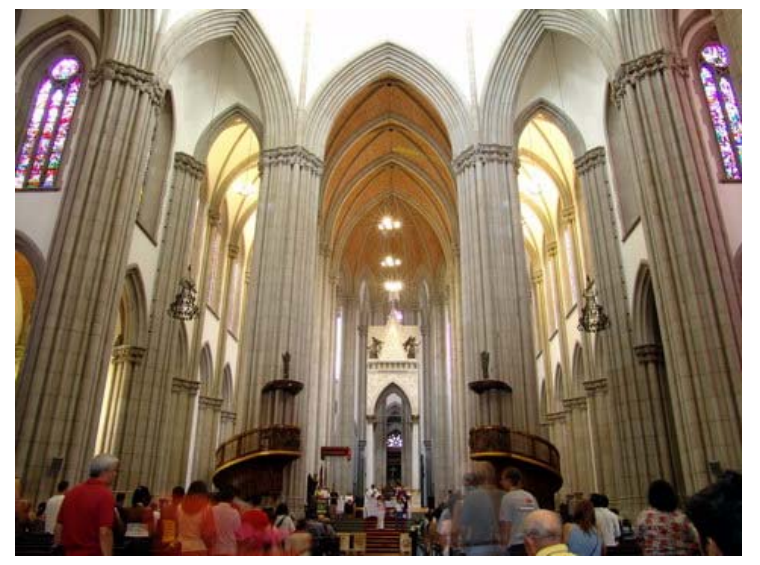

(a)

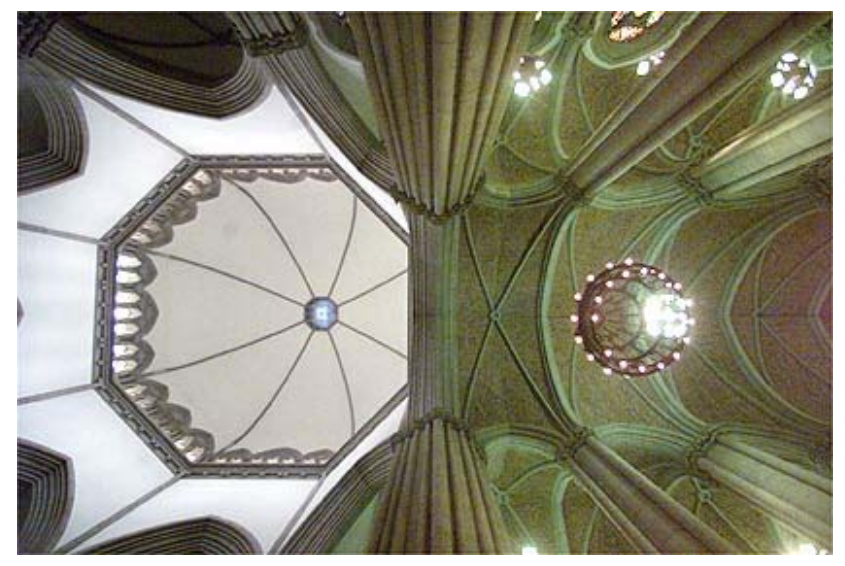

(b)

Figura 2.2 - Espaço interior da Catedral da Sé: (a) vista do altar (DACIOLE, 2008); (b) cúpula e abóbadas da nave central (CASSIMIRO, 2002, il. 4). 
São diversos elementos da flora e da fauna do país que caracterizam o estilo arquitetônico da igreja como "gótico à brasileira" (RAMIREZ, 2005); dentre eles encontram-se, talhados no granito, o café, o milho, o tatu e o mico (Figuras 2.3 e 2.4).

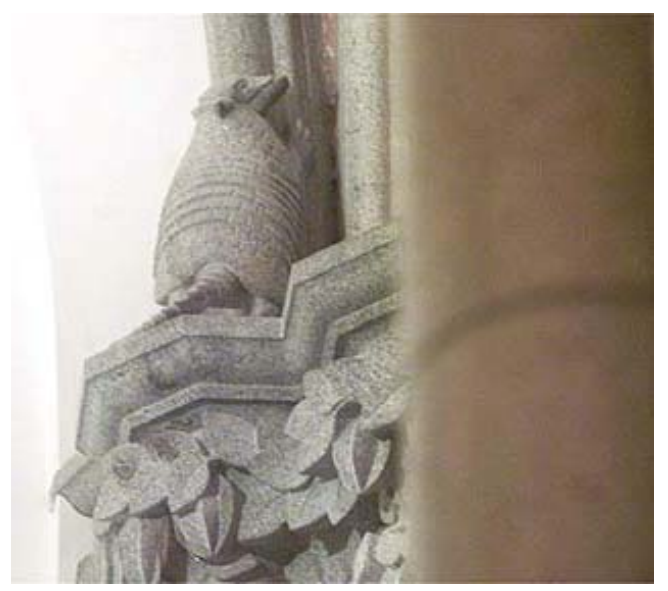

(a)

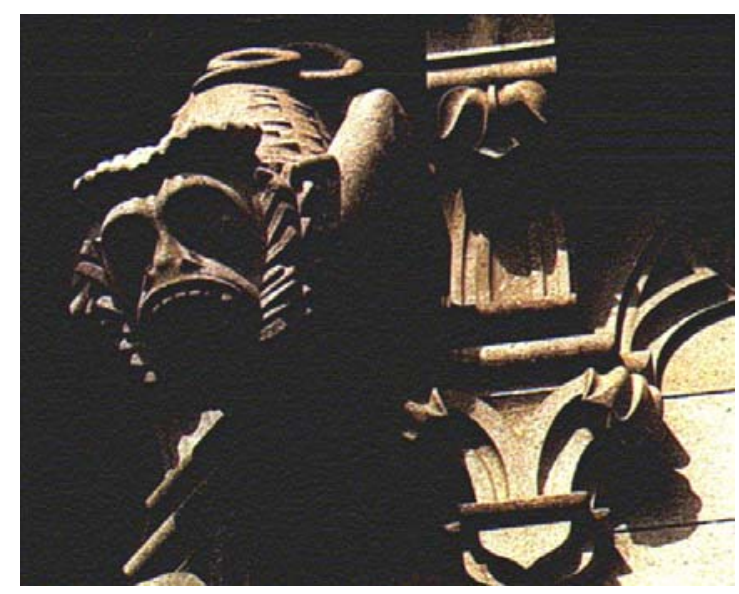

(b)

Figura 2.3 - Elementos da fauna brasileira na Catedral da Sé: (a) tatu ornando o capitel de um dos pilares internos (CASSIMIRO, 2002, il. 5); (b) do lado externo da Catedral, quimera em forma mico (PIRES; SAIA, 1997, p. 118).

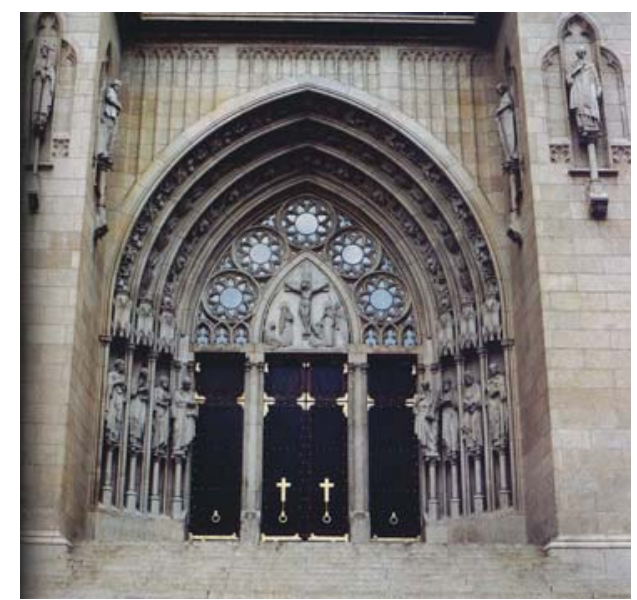

(a)

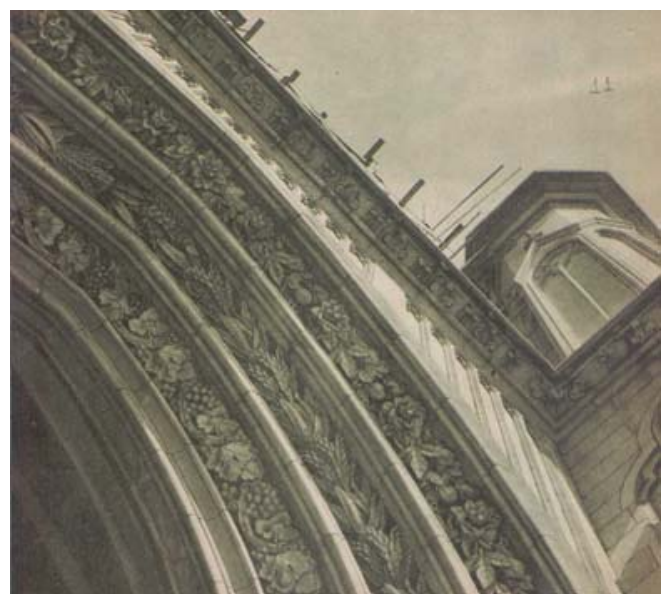

(b)

Figura 2.4 - Elementos da flora brasileira na Catedral da Sé: (a) vista geral do portal principal (DELELLIS et al, 2002, p.139); (b) detalhe do portal principal (COMISSÃO EXECUTIVA DAS OBRAS DA NOVA CATEDRAL DE SÃO PAULO, [194-], sem numeração de página).

Assim, a Catedral de São Paulo, mesmo influenciada pelo gótico praticado em muitas das antigas catedrais, apresenta uma arquitetura única, seja pela disposição de seus espaços e dimensões, seja pela inserção de temas brasileiros em sua decoração (RAMIREZ, 2005). 
A cúpula da Catedral da Sé com seu lanternim alcança 70 metros de altura e as duas grandes torres frontais, 92 metros, tomando-se como referência a base da escadaria na entrada frontal do templo. No entanto, para efeito desta pesquisa, o referencial adotado, a partir do qual todas as elevações serão mencionadas, é o piso frontal da igreja, que está 4,42 metros acima da base da escadaria (Figura 2.5).

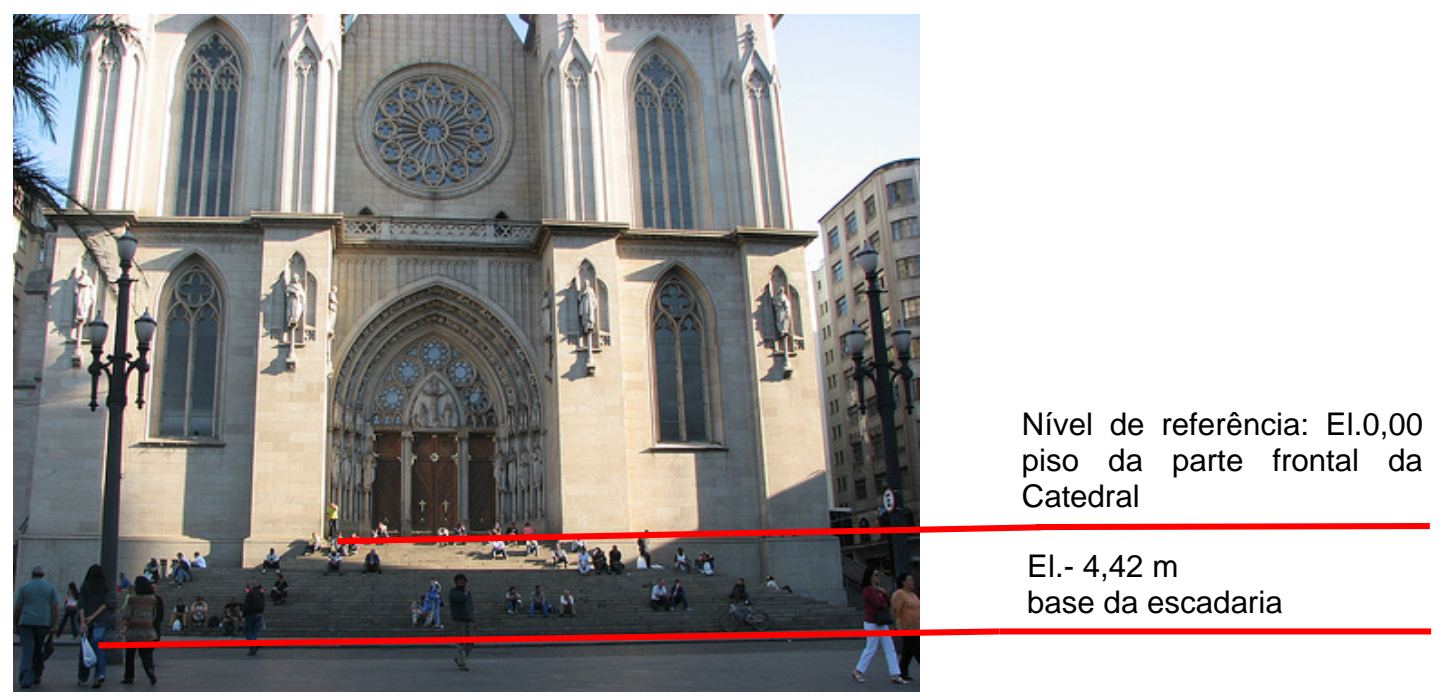

Figura 2.5 - Nível de referência: piso na parte frontal da igreja (STATIC.FLICKR, 2009).

Na planta térrea da Catedral da Sé (Figura 2.6), estão identificadas suas naves e outros espaços como o transepto, o deambulatório e as regiões de apoio. Para efeitos desta pesquisa, estão definidas três grandes regiões da igreja; são elas a parte frontal, que inclui o coro, localizado sobre a entrada principal da Catedral, a região do octógono, que inclui o transepto, e a parte posterior da igreja, que inclui o deambulatório e as regiões de apoio.

A parte posterior da igreja conta com os ambientes de apoio, localizados na região do deambulatório, que se prestam a serviços de atendimento à população como secretaria, sacristia e capela. Nesta região, há um pavimento intermediário a sete metros e sessenta e nove centímetros do piso do templo, que pode ser acessado por duas escadas de concreto armado junto à entrada posterior da Catedral.

As principais elevações do templo estão apresentadas nos cortes transversal e longitudinal (Figuras 2.7 e 2.8), e mostram as alturas aproximadas até o anel de fecho das abóbadas. 


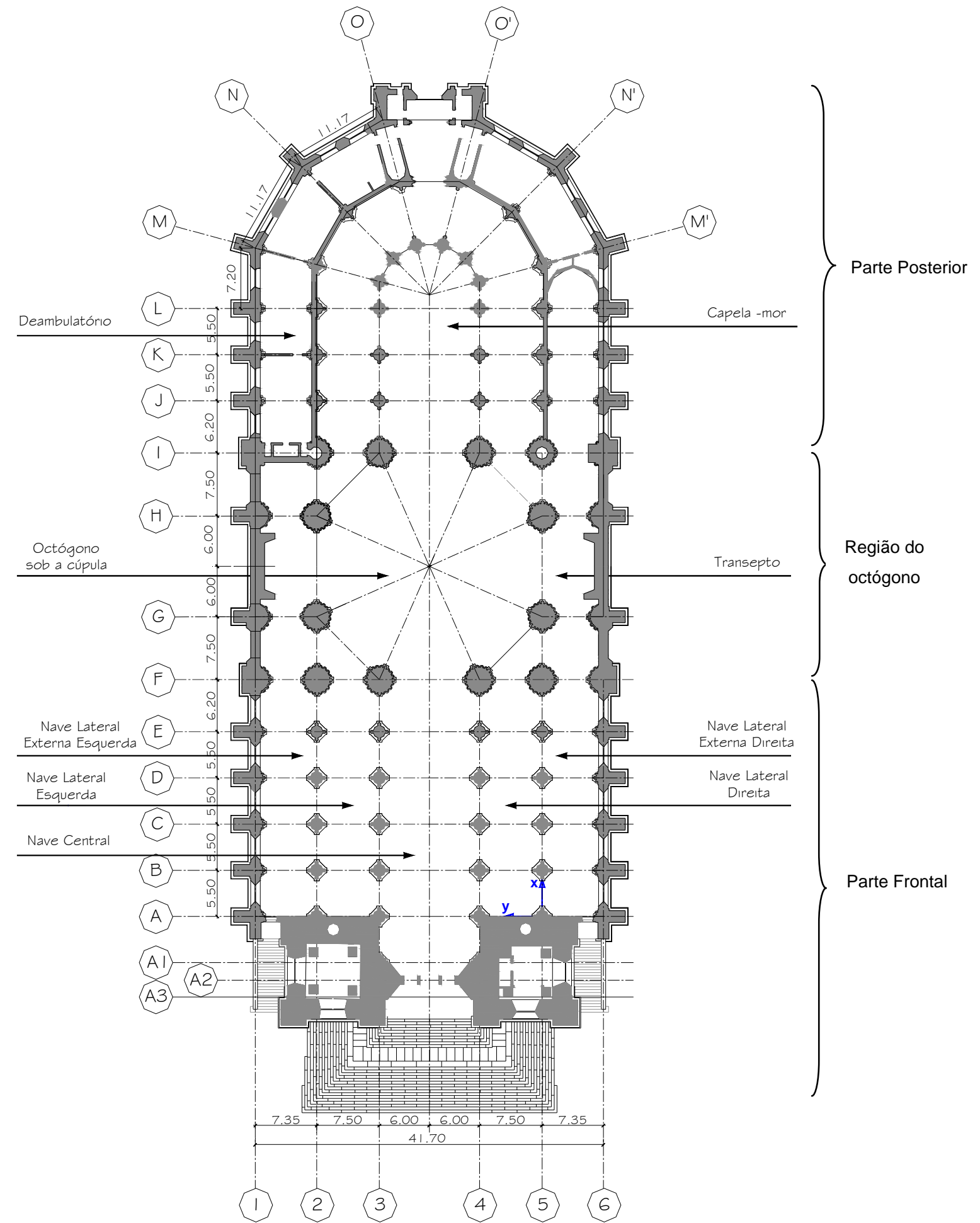

Medidas em metros

Figura 2.6 - Planta da Catedral - locação dos eixos (CONCREJATO, 2002, FL. 01/04 $\operatorname{adaptada}^{1}$ ).

\footnotetext{
${ }^{1}$ Adaptada: Desenho baseado em planta fornecida pela Concrejato, em que alguns dados foram suprimidos e outros adicionados, de modo a atender às finalidades desta pesquisa.
} 


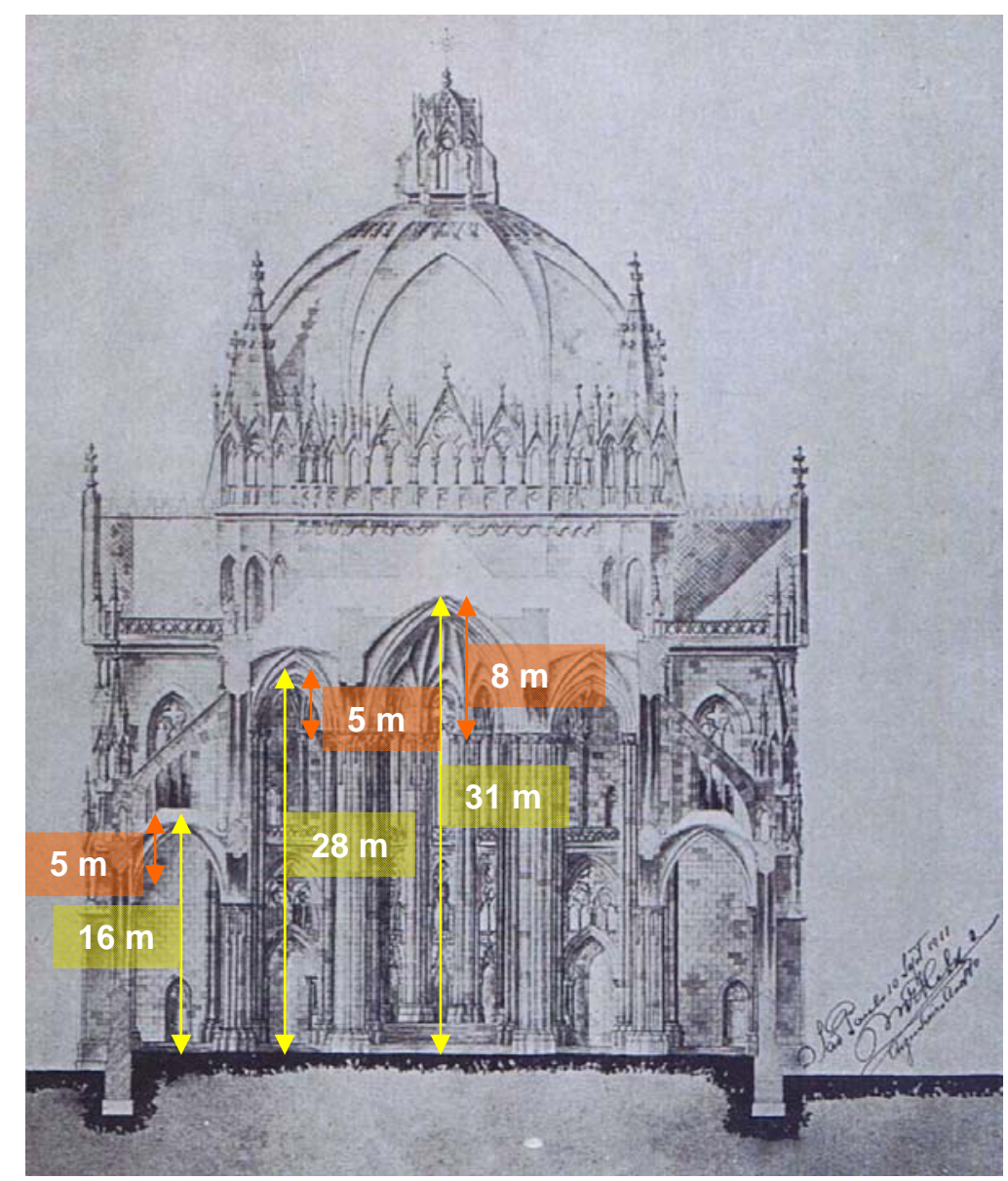

Figura 2.7 - Dimensões do templo: corte transversal (Projeto arquitetônico original de Maximiliano Hehl adaptado. A CATHEDRAL de São Paulo, [1911?], sem numeração de página).

A partir do nível de referência, a altura de todos os pilares da nave central e das naves laterais é de 23 metros; é nesta elevação que seus arcos e abóbadas se apóiam nos pilares. Já os arcos e as abóbadas das naves laterais externas estão apoiados a 11 metros de altura em seus respectivos pilares e contrafortes.

No transepto, os arcos e as abóbadas que se localizam sobre cada um dos altares laterais também se elevam a partir dos 23 metros de altura, dando à Catedral a configuração de uma cruz latina.

O modelo da Catedral foi desenvolvido a partir de informações obtidas nas plantas do arquivo da Cúria Metropolitana, nas plantas da Concrejato - empresa responsável pela reforma da igreja entre 2000 e 2004 -, por fotografias e por medições no local.

Especificamente, as seções transversais dos pilares e contrafortes estão disponíveis nestas plantas e foram confirmadas no local. 


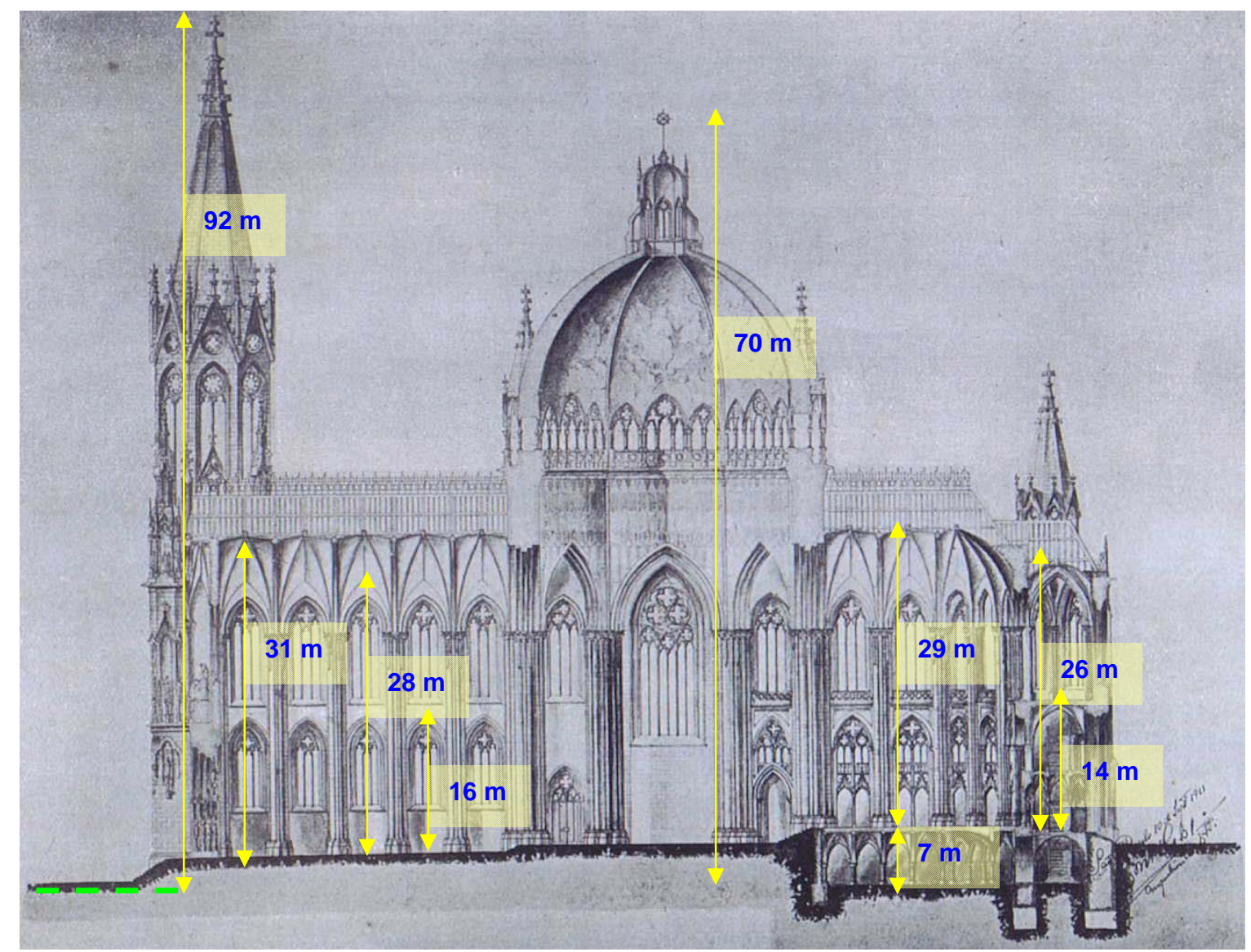

Figura 2.8 - Dimensões do templo: corte longitudinal (Projeto arquitetônico original de Maximiliano Hehl adaptado. A CATHEDRAL de São Paulo, [1911?], sem numeração de página).

\subsection{A região do octógono e a geometria da cúpula}

A cúpula é de concreto armado e tem 27 metros de vão sobre o espaço octogonal. Em sua base há uma viga de cintamento de seção vazada com 1,23 metros de largura por 3,30 metros de altura, funcionando como uma cinta que resiste aos esforços de tração decorrentes da tendência de abertura da cúpula (RAMIREZ, 2005, p.105-125).

Sob a viga de cintamento da cúpula encontra-se um conjunto de pilaretes de granito e o tambor propriamente dito, que se apóia nos arcos do octógono (Figura 2.9). Este tambor é constituído de alvenaria de tijolos de barro cozido revestido internamente com argamassa e externamente com granito.

Além dos pilares que dão apoio para o octógono, há também outros quatro pilares de mesmo diâmetro que servem de base para cada um dos quatro torreões 
que ladeiam a cúpula (Figura 2.9 (a)).

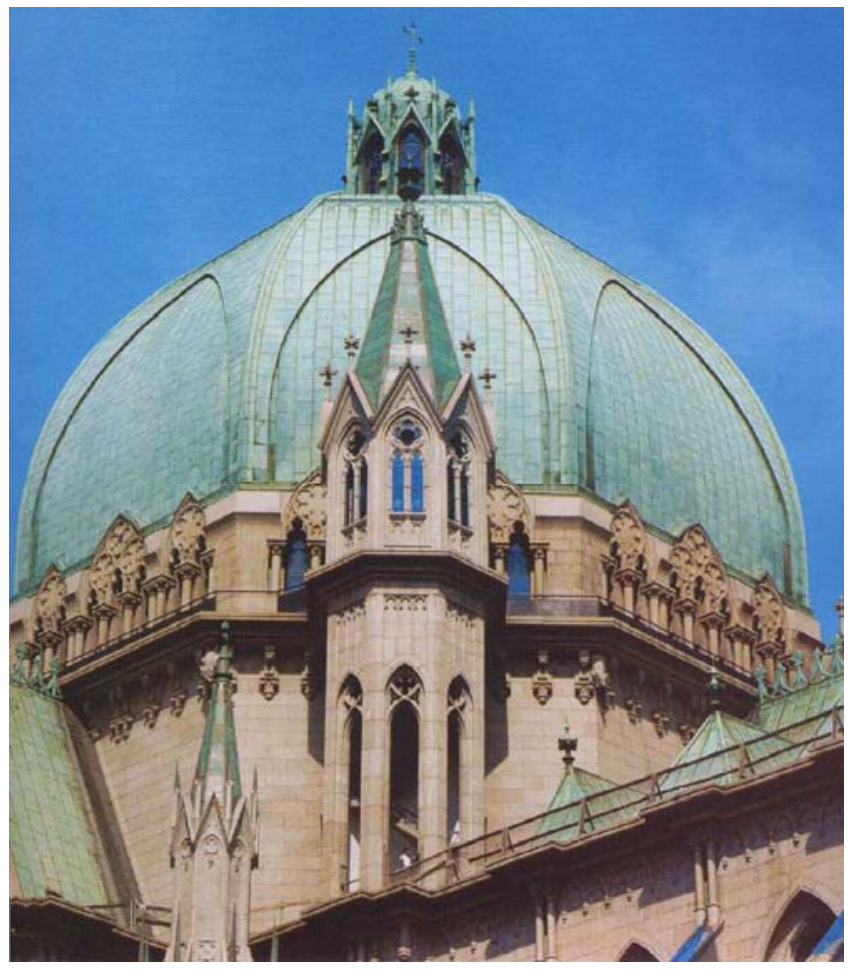

(a)

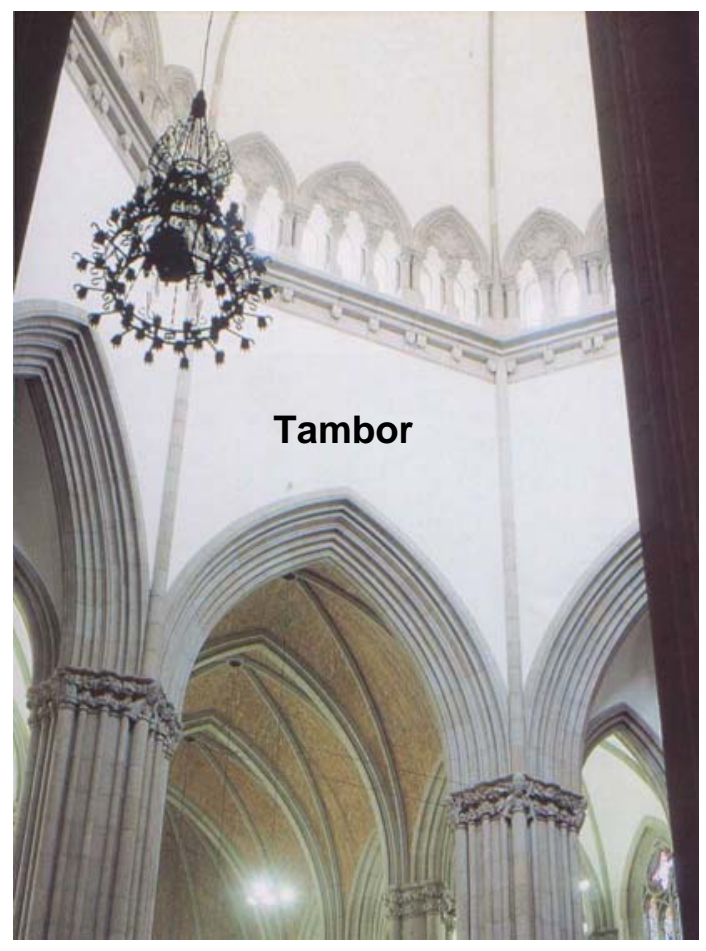

(b)

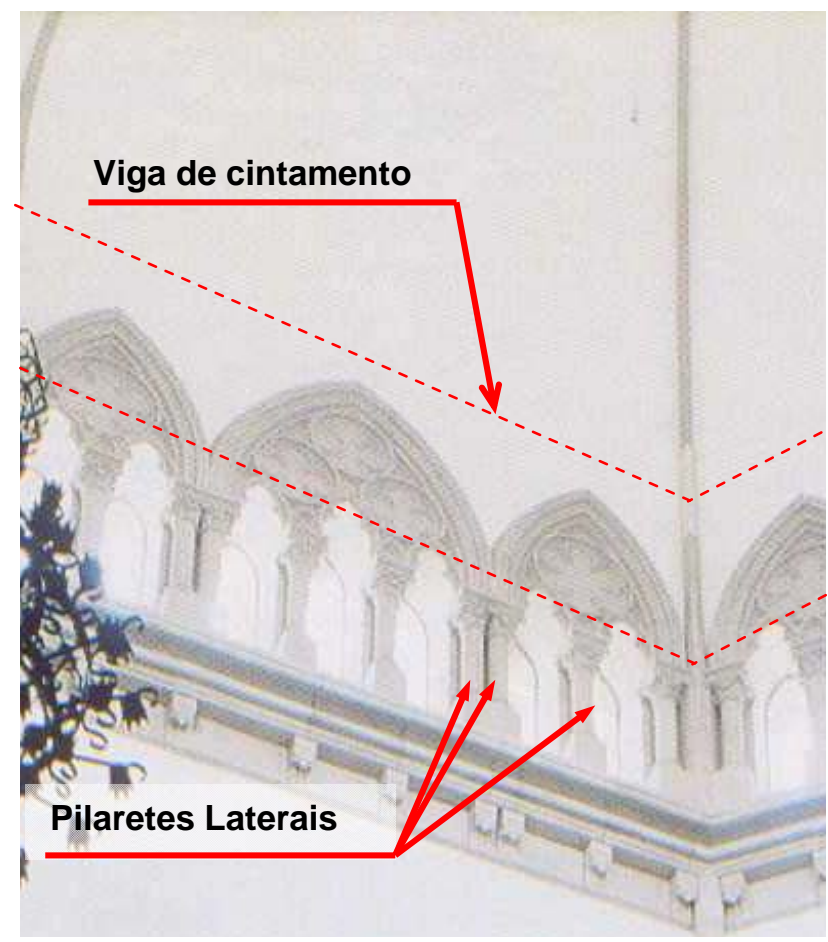

(c)

Figura 2.9 - Região do octógono: (a) vista externa com um dos torreões que ladeiam a cúpula (DELELLIS et al, 2002, p. 179); (b) vista interna do tambor que dá apoio à cúpula; (c) viga de cintamento e conjunto de pilaretes (DELELLIS et al, 2002, p. 133). 
A partir do acesso às plantas disponíveis no arquivo da Cúria Metropolitana, que datam de 1952, foi possível descobrir que, na realidade, são duas as cúpulas da Catedral da Sé, uma externa e outra interna (Figura 2.10). Esta estrutura está detalhadamente descrita na dissertação elaborada pela autora (RAMIREZ, 2005).

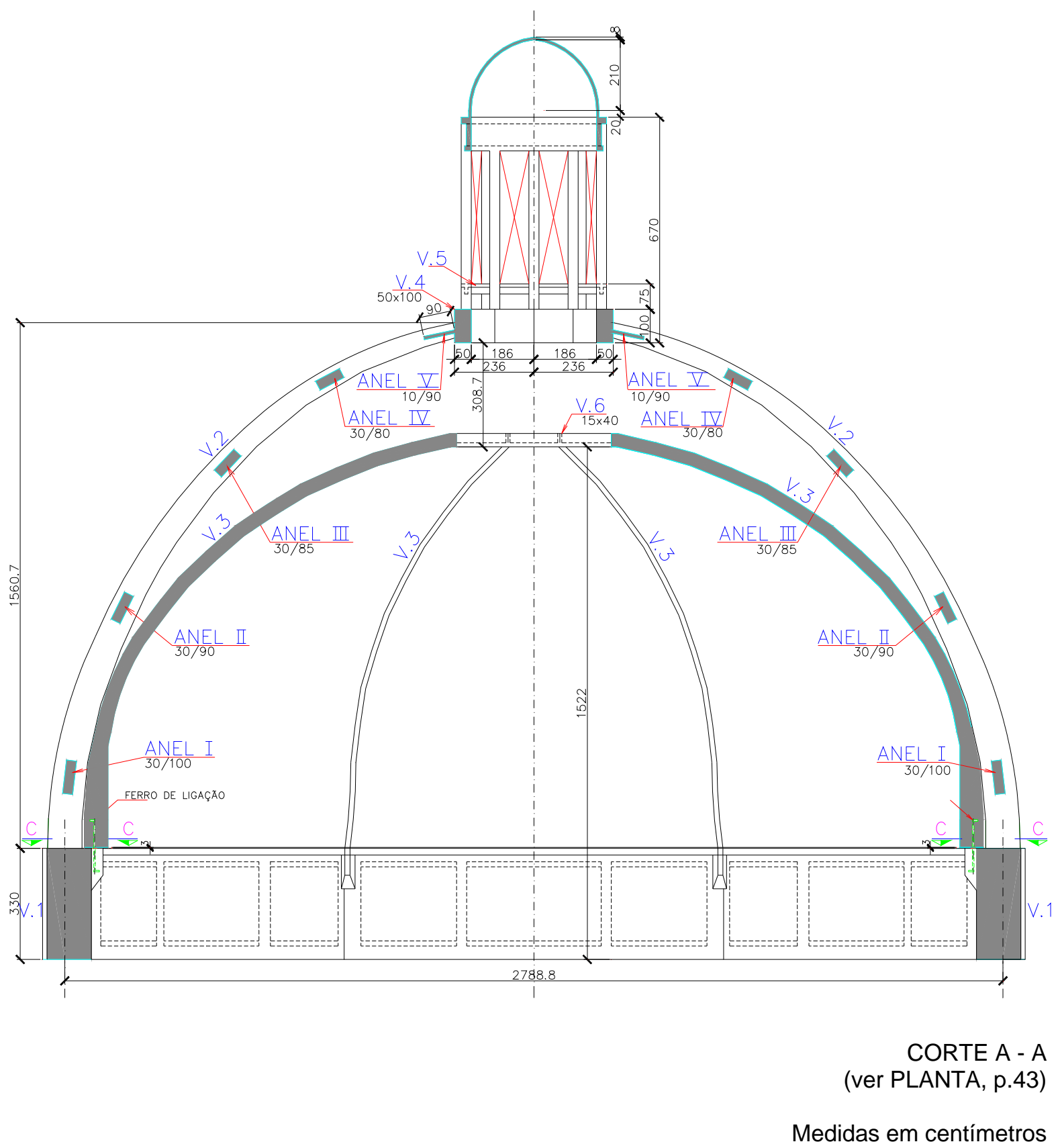

Figura 2.10 - Corte da cúpula da Catedral da Sé (RAMIREZ, 2005, p.113)

A cúpula externa, de concreto armado, não é um elemento contínuo. Possui oito meridianos, indicados como V2 na Figura 2.10, ligados entre si por cinco paralelos ou anéis. Tanto os meridianos como os anéis têm seção variável, como mostram as Figuras 2.11 e 2.12. 
A Figura 2.11 mostra a vista superior da cúpula externa e nela estão indicadas as seções transversais dos cinco anéis.

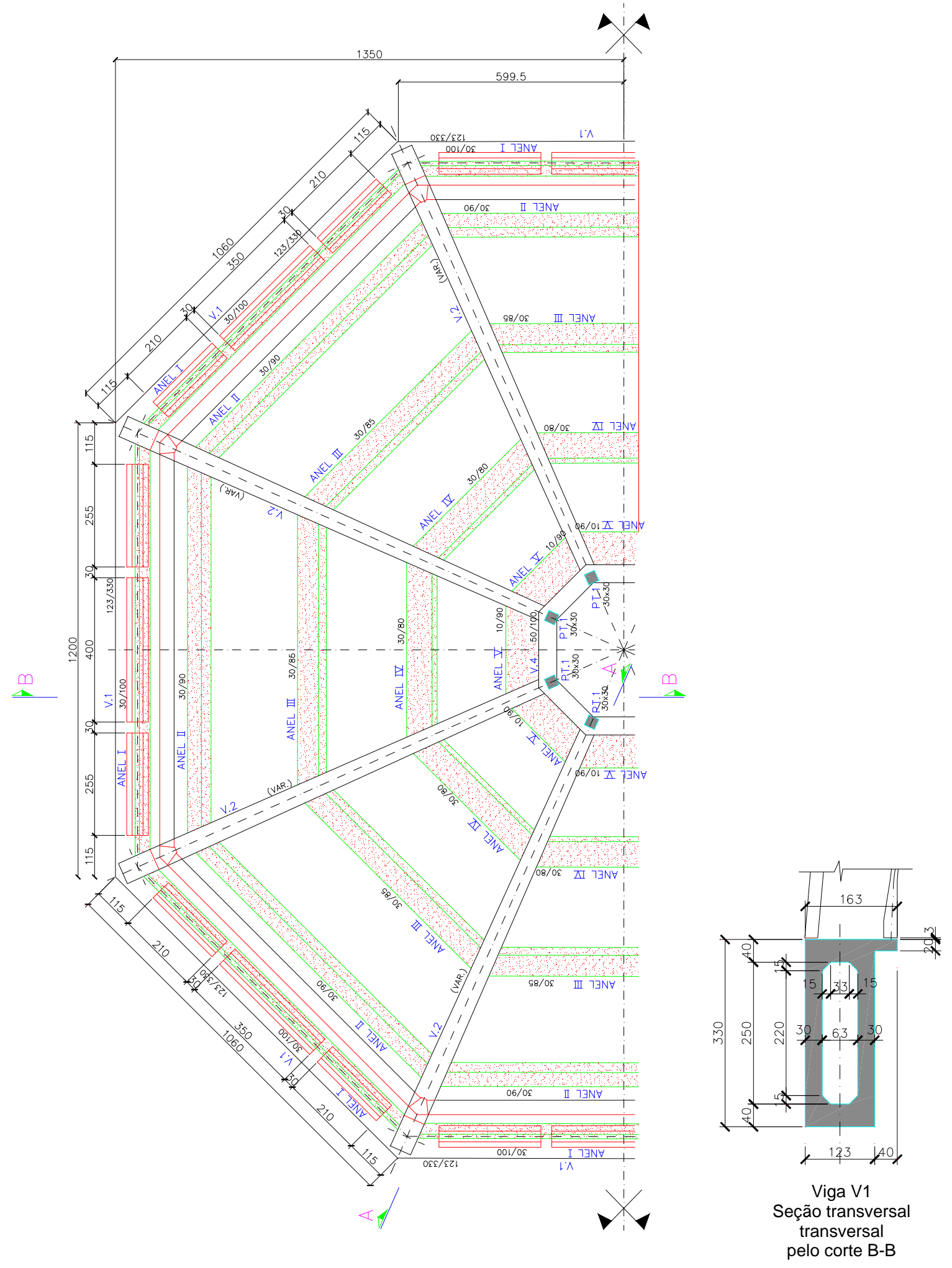

Medidas em centímetros

Figura 2.11 - Vista superior da cúpula externa: locação dos meridianos e dos paralelos (RAMIREZ, 2005, p.115); ao lado, a seção transversal da viga de cintamento. 
Já em relação aos meridianos, ressalta-se que são idênticos entre si, mas possuem seções transversais que variam ao longo do comprimento, apresentadas na Figura 2.12.
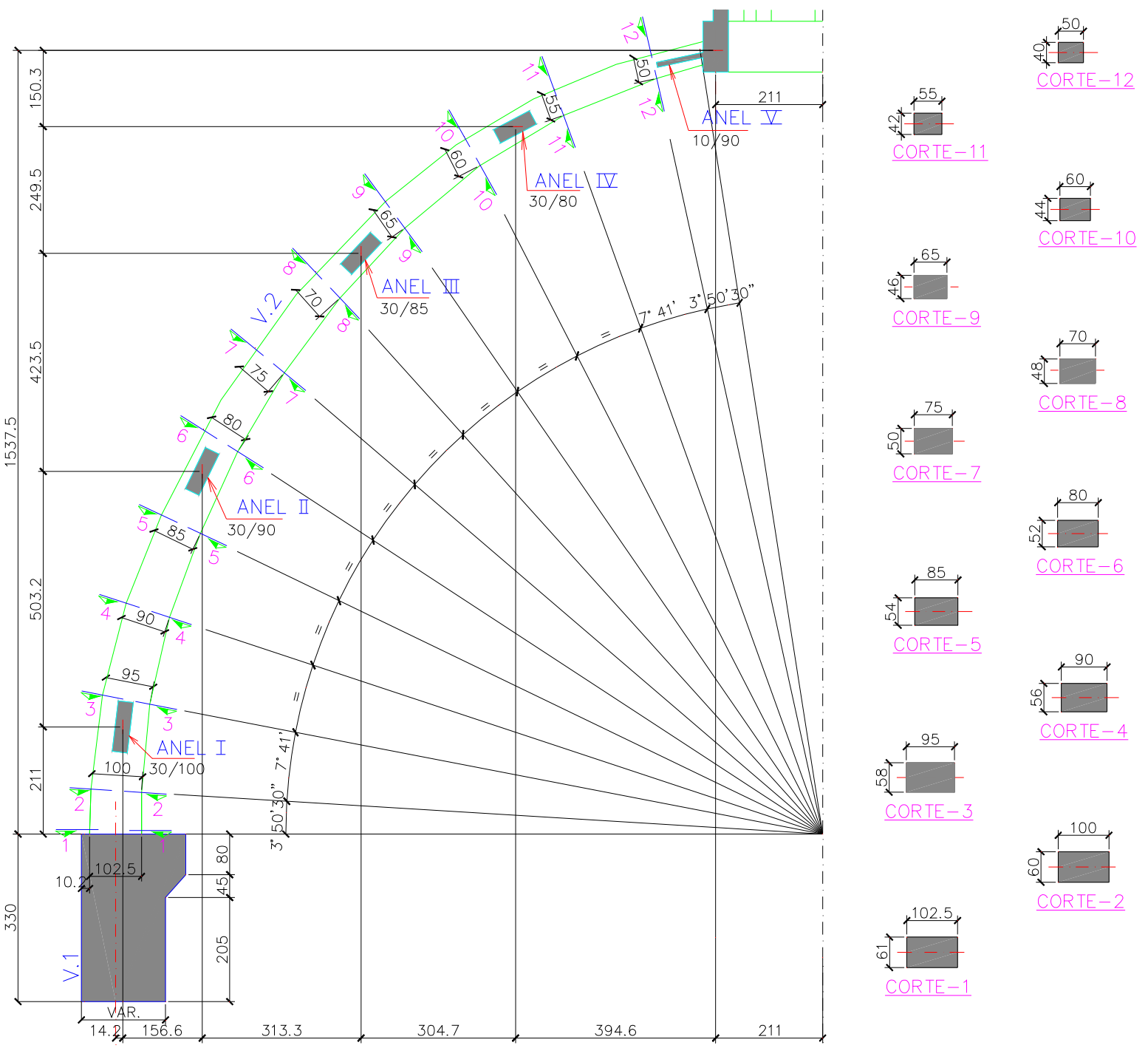

CORTE A - A ELEVAÇÃO DO MERIDIANO V2 (8x) (ver locação na PLANTA, p.43)

Medidas em centímetros

Figura 2.12 - Corte da cúpula externa: detalhe do meridiano (RAMIREZ, 2005, p.116).

Os meridianos apóiam-se na viga de cintamento e no anel de fecho, denominado V4 na Figura 2.11, octogonal e também de concreto armado.

Acima da cúpula externa, há uma estrutura de madeira que serve de apoio para o telhado de chapas de cobre. 
A cúpula interna, de concreto armado, é contínua; consiste em uma estrutura formada por oito segmentos de casca, reforçada por oito meridianos V3. Os meridianos possuem seção transversal constante, 15 centímetros de largura por 40 centímetros de altura (Figura 2.13).

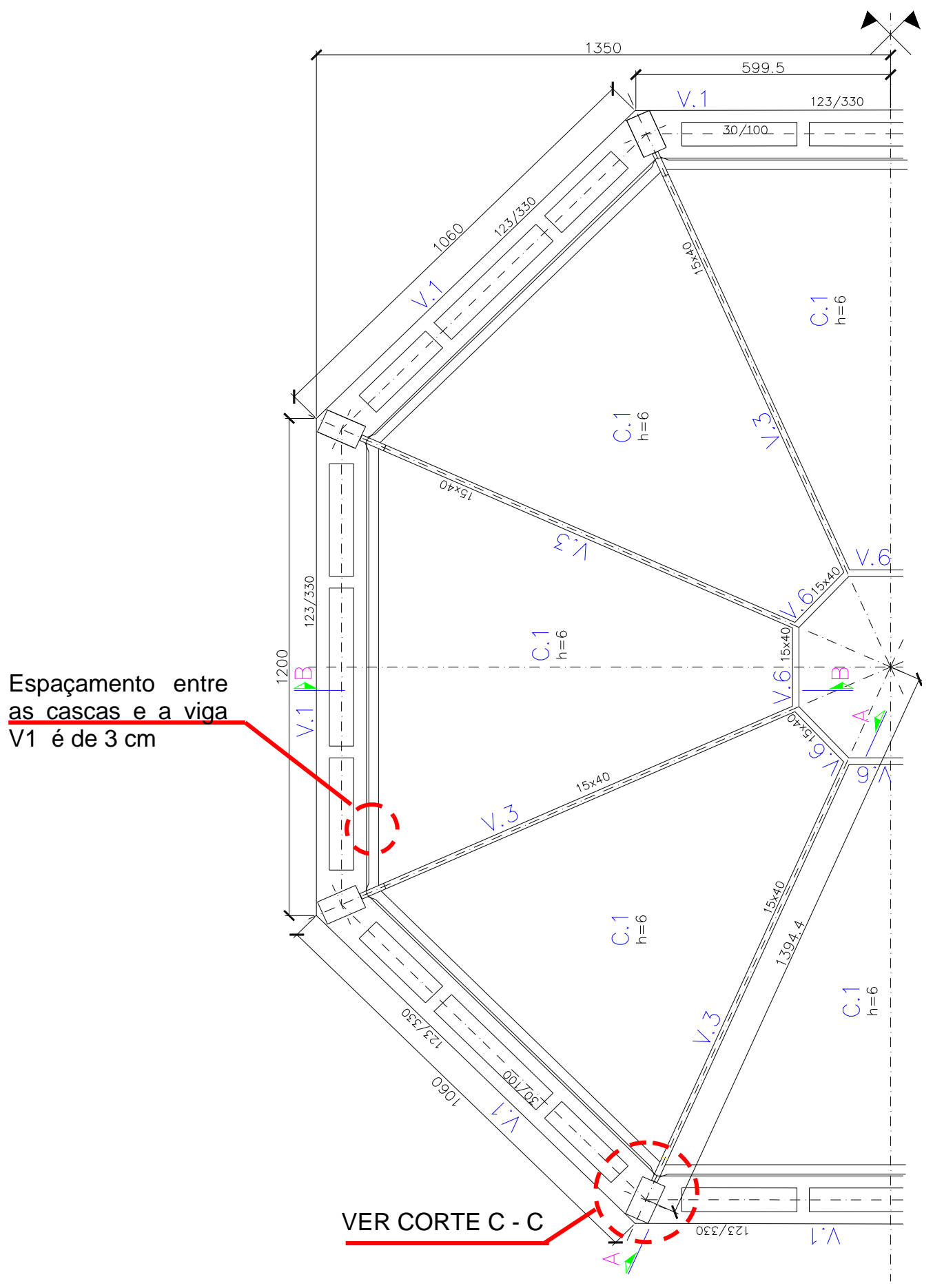

Medidas em centímetros

Figura 2.13 - Vista superior da cúpula interna (RAMIREZ, 2005, p.121). 
O único contato da casca com a viga de cintamento V1 é por meio de seus meridianos, não sendo as arestas inferiores dos segmentos de casca ligadas à viga de cintamento. Na parte superior da cúpula interna, há um anel de fecho, nomeado V6, com 15 centímetros de largura por 40 centímetros de altura.

Diferentemente da cúpula externa, os meridianos da cúpula interna se apóiam na viga de cintamento por meio de uma placa de chumbo e de um ferro de ligação, permitindo à estrutura maior flexibilidade e não gerando momentos nestes pontos (Figuras 2.14 e 2.15).

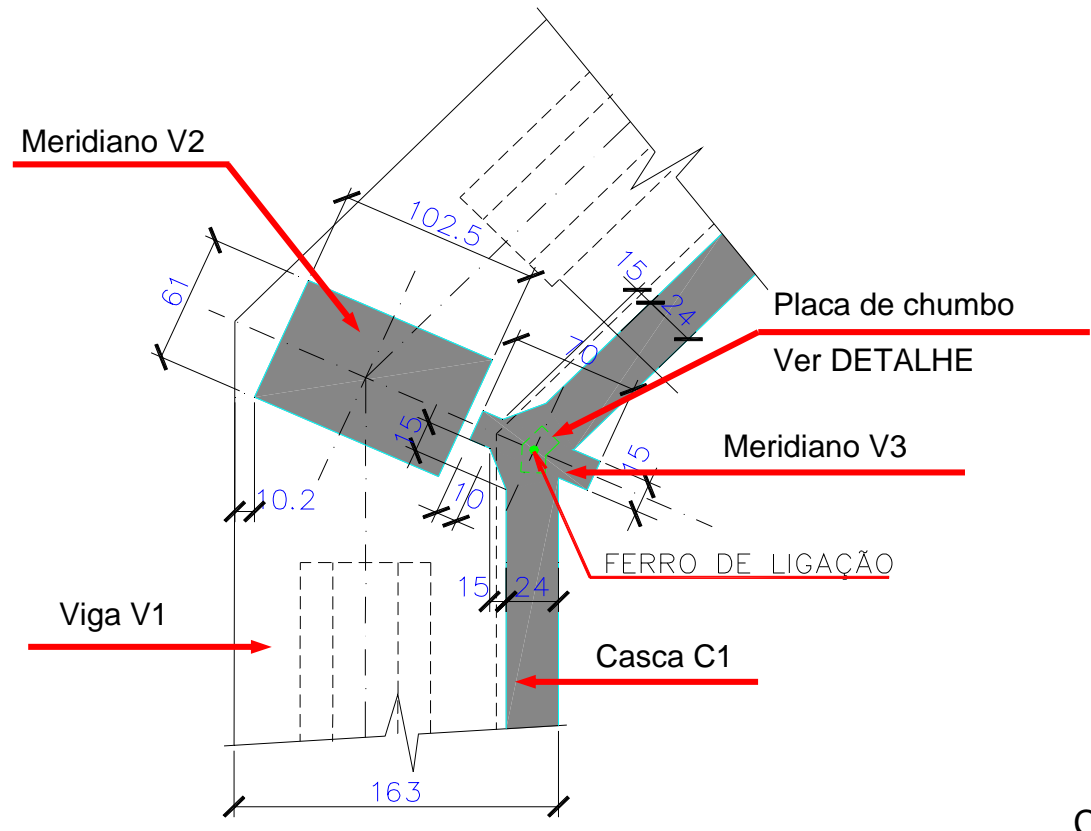

CORTE C - C (ver locação na p.42)

Medidas em centímetros

Figura 2.14 - Ligação da cúpula interna com a viga do cintamento V1 - Corte CC (RAMIREZ, 2005, p.120).

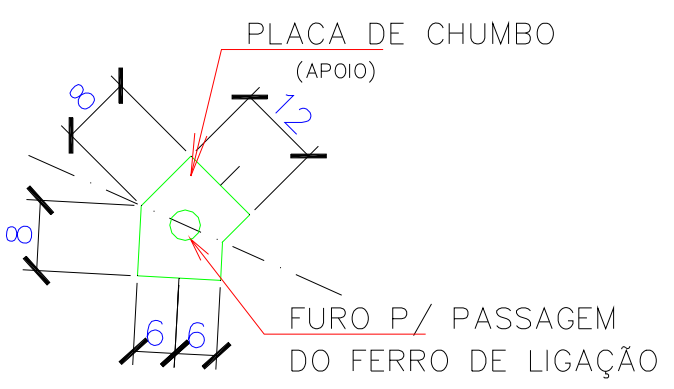

DETALHE

(ver locação na p.42)

Medidas em centímetros

Figura 2.15 - Detalhe do apoio dos meridianos da cúpula interna na viga de cintamento V1 (RAMIREZ, 2005, p.120). 


\subsection{Geometria dos Contrafortes}

De acordo com a geometria, os contrafortes estão classificados em sete tipos, além do maciço situado na parte posterior do templo (Figura 2.16).

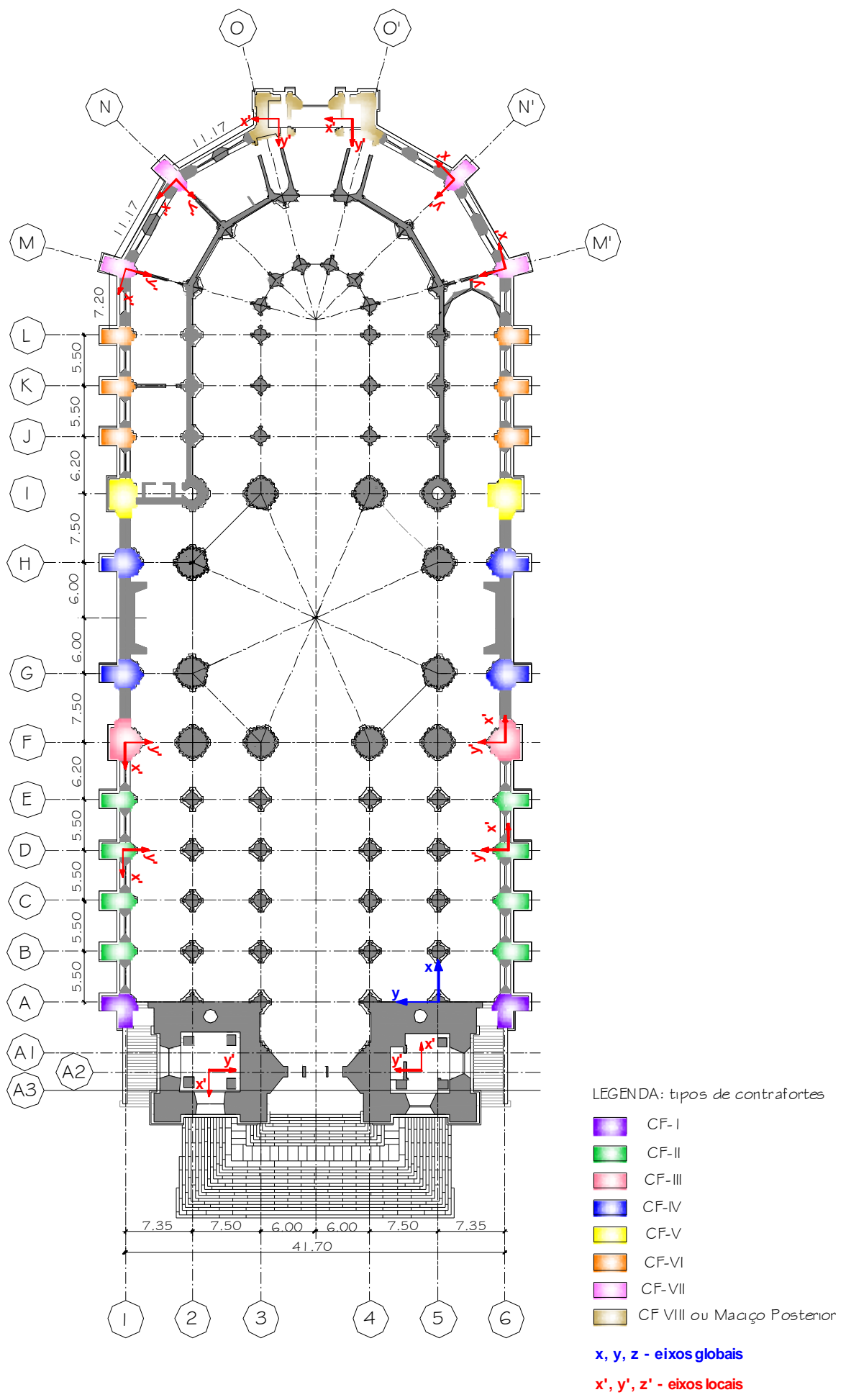

Medidas em metros

Figura 2.16 - Classificação dos contrafortes (CONCREJATO, 2002, FL. 01/04 adaptada ${ }^{1}$ ). 
Todos os contrafortes da Catedral apresentam alargamento em suas bases, do nível da calçada até o nível do piso da igreja (Figura 2.17).

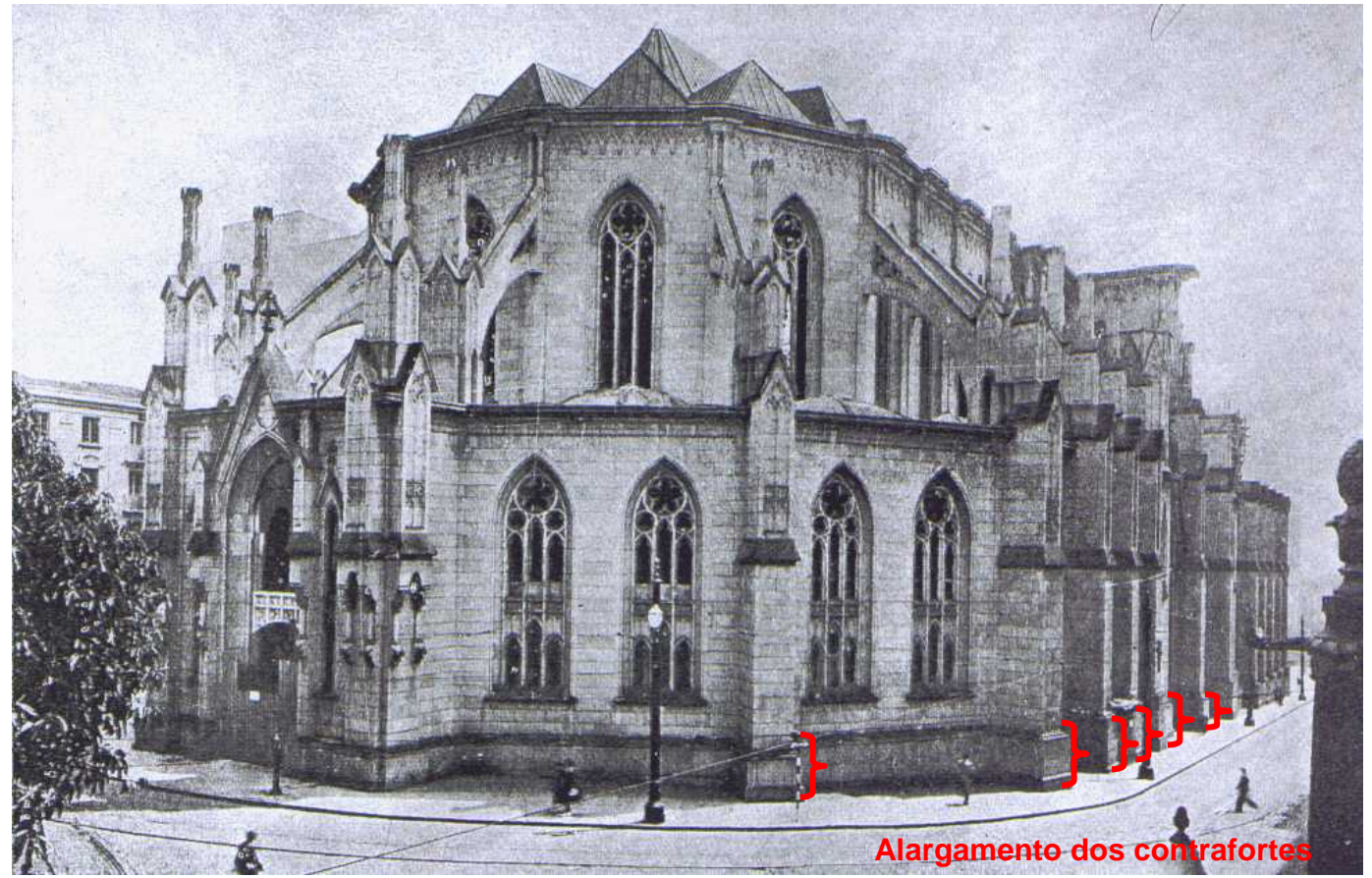

Figura 2.17 - Vista do alargamento da base dos contrafortes: fachada posterior da Catedral da Sé junto à Praça João Mendes (COMISSÃO EXECUTIVA DA CATEDRAL DE SÃO PAULO, 1942, p.6a).

Como o terreno apresenta inclinação de cerca de 5\%, a altura destas bases é variável. No modelo, as bases dos contrafortes tipo I e II têm 3,30 metros de altura; as dos contrafortes III, IV e V têm 2,0 metros e as bases dos demais se encontram a 0,5 metro abaixo do nível do piso.

Além do alargamento da base, os contrafortes tipo I, II, VI e VII apresentam outra mudança de seção transversal, na altura média de 11 metros (Figura 2.18). Este terceiro trecho segue até a elevação de 16,0 metros aproximadamente, acima da primeira cornija. 


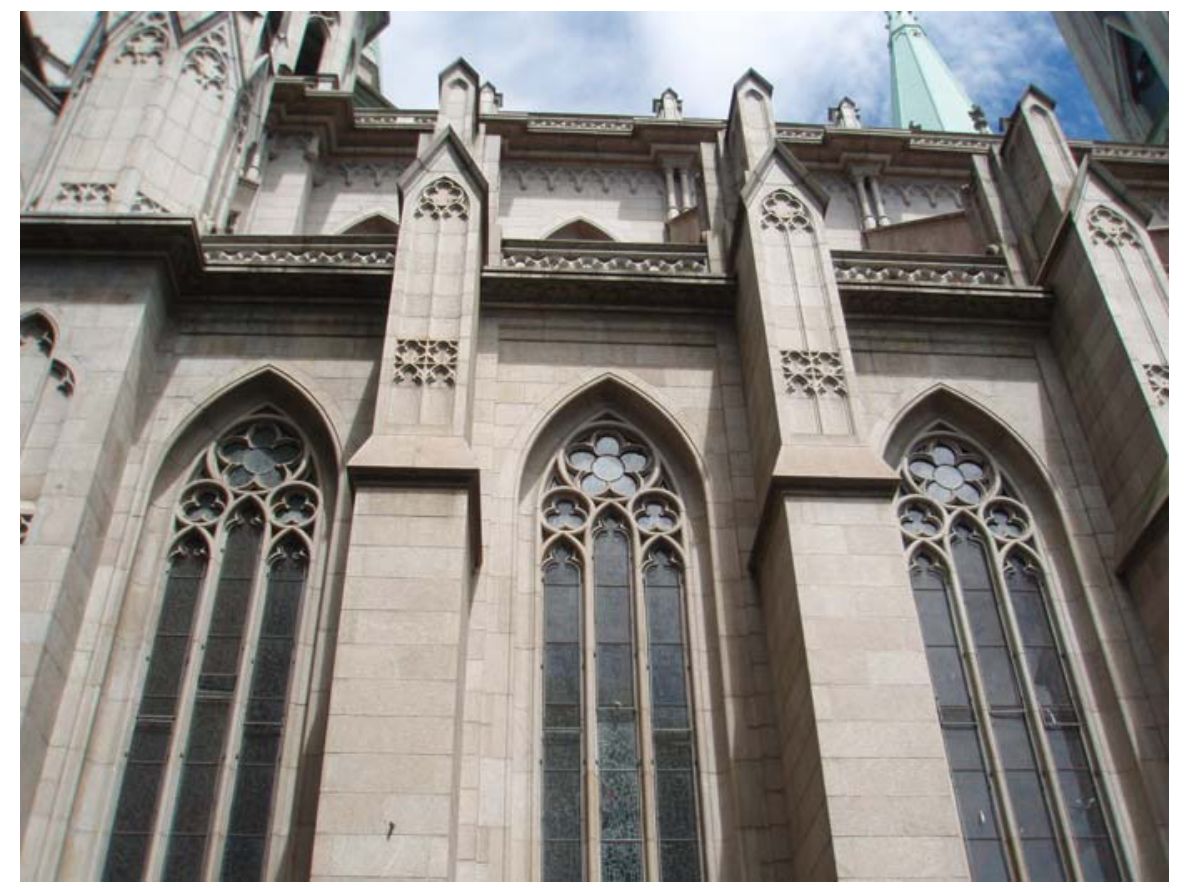

Figura 2.18 - Mudança de seção dos contrafortes tipo II (LINDENBERG NETO, 2007).

O software SAP, em que a estrutura está modelada, apresenta limitação de ferramenta computacional que permita a representação de variação gradual da seção transversal dos elementos de barras nesta situação; assim, optou-se por simplificar o modelo com variação brusca de seção (Figura 2.19).

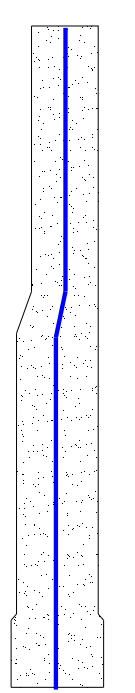

(a)

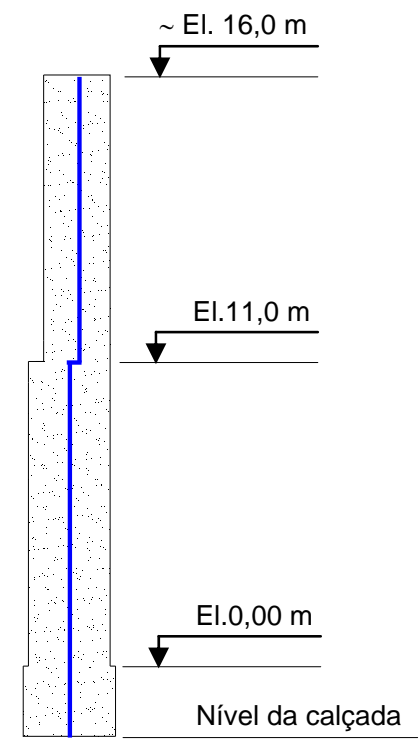

(b)

Figura 2.19 - Esquema de contrafortes: (a) com variação gradual da seção, próximo do real; (b) simplificado, com variação brusca de seção. 
Os contrafortes da Catedral da Sé são constituídos por dois materiais; possuem um núcleo de alvenaria de tijolos maciços de barro e são revestidos por granito. As seções transversais dos contrafortes são irregulares e apresentam muitas saliências, como ilustrado nas Figuras 2.20 a 2.23.

CF I (contrafortes tipo I)

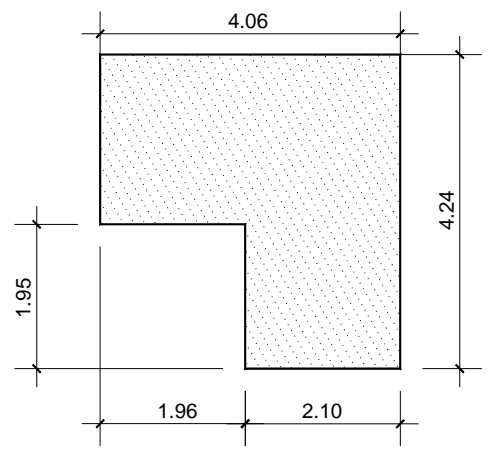

$\left(a_{1}\right)$

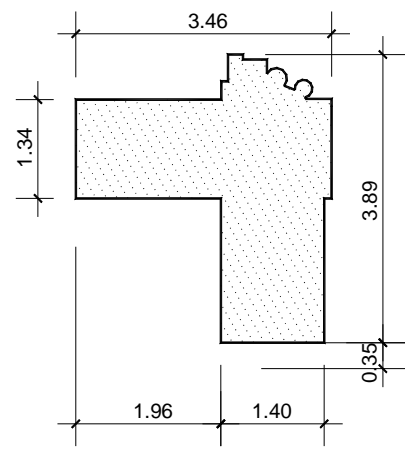

$\left(b_{1}\right)$

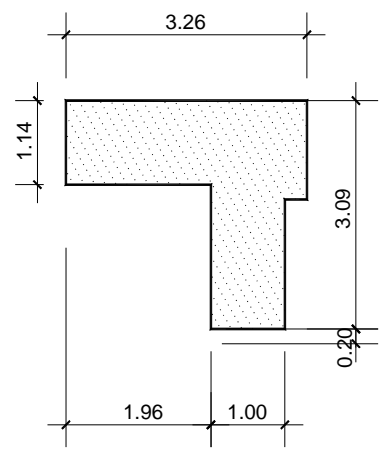

$\left(\mathrm{c}_{1}\right)$

CF II (contrafortes tipo II)

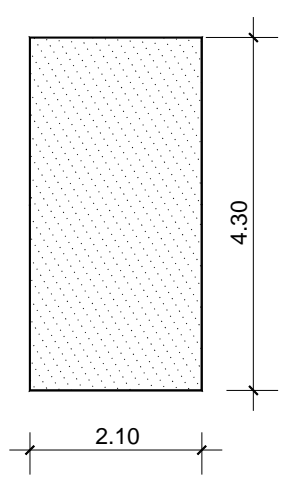

$\left(a_{2}\right)$

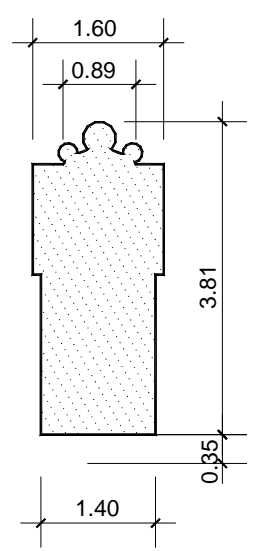

$\left(b_{2}\right)$

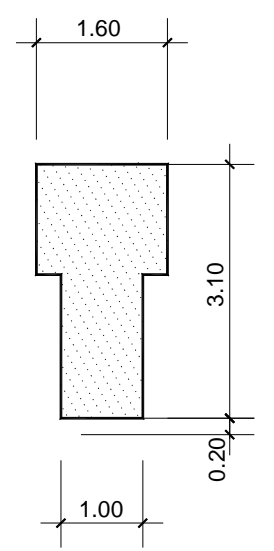

$\left(c_{2}\right)$

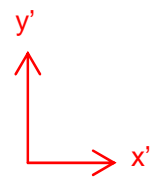

Figura 2.20 - Seções transversais consideradas para os contrafortes tipo I e II: (a) da base; (b) até a elevação de 11,0 metros; (c) terceiro trecho, até a elevação de 16,14 metros. 
CF III (contrafortes tipo III)

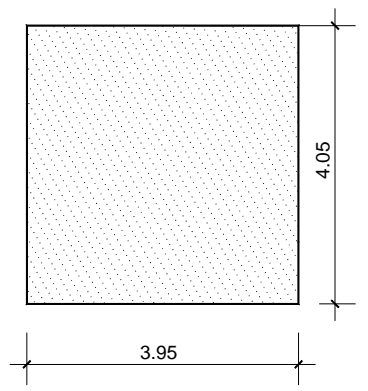

$\left(a_{1}\right)$

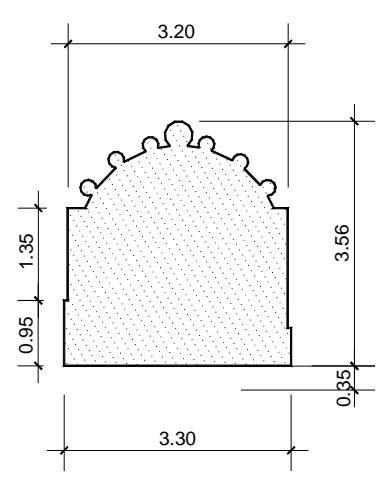

$\left(b_{1}\right)$

CF IV (contrafortes tipo IV)

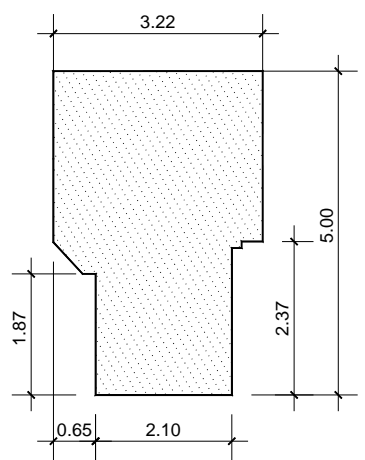

$\left(a_{2}\right)$

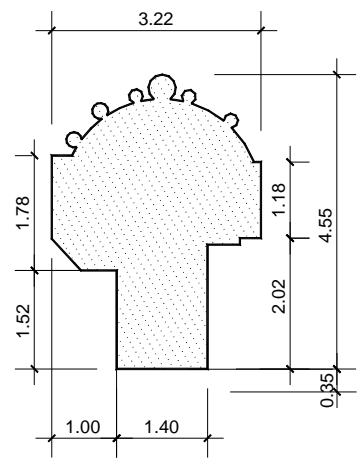

$\left(b_{2}\right)$

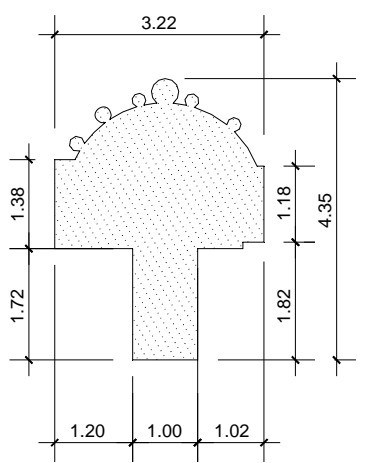

$\left(c_{2}\right)$

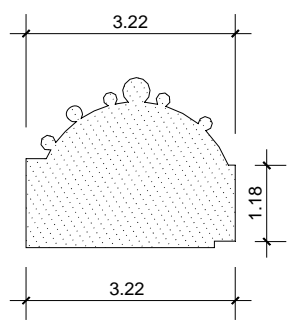

$\left(d_{2}\right)$

CF V (contrafortes tipo V)

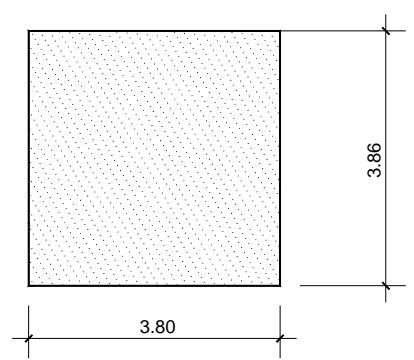

$\left(a_{3}\right)$

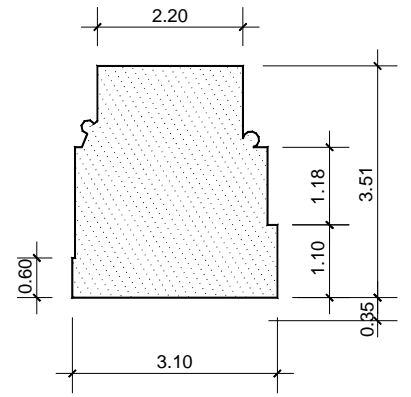

$\left(b_{3}\right)$

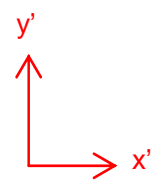

Figura 2.21- Seções transversais consideradas para os contrafortes tipo III, IV e V: (a) da base; $\left(b_{1}\right)$ e $\left(b_{3}\right)$ até a elevação de 16,14 metros; $\left(b_{2}\right)$ até a elevação de 11,0 metros; $\left(c_{2}\right)$ até a elevação de 16,14 metros; $\left(d_{2}\right)$ até a elevação de 23,0 metros. 
CF VI (contrafortes tipo VI)

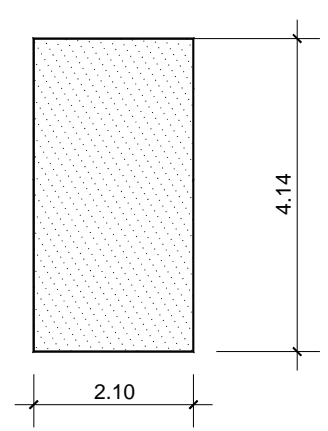

$\left(a_{1}\right)$

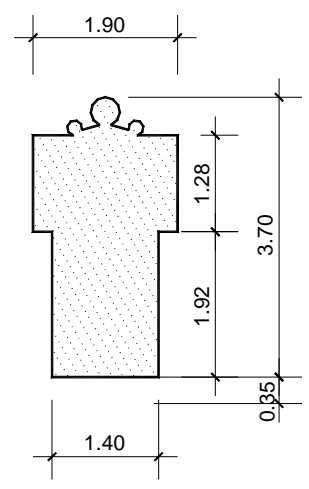

$\left(b_{1}\right)$

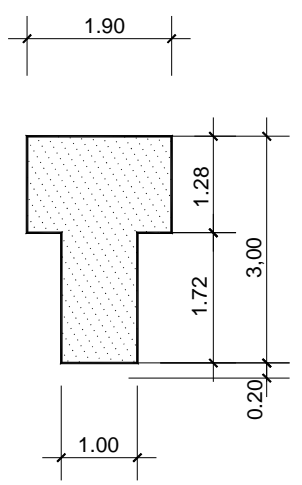

$\left(\mathrm{c}_{1}\right)$

CF VII (contrafortes tipo VII)

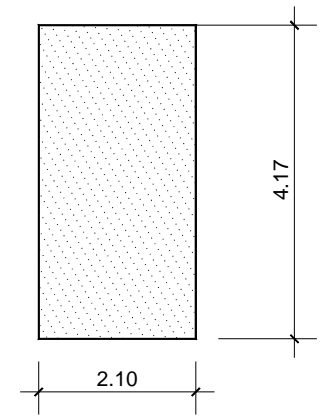

$\left(\mathrm{a}_{2}\right)$

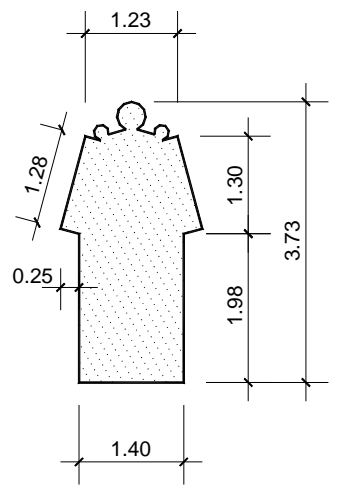

$\left(b_{2}\right)$

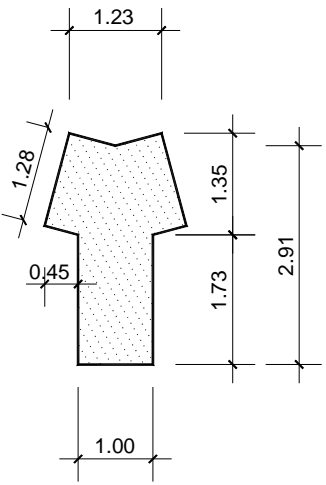

$\left(c_{2}\right)$

Figura 2.22- Seções transversais consideradas para os contrafortes tipo VI, VII: (a) da base; (b) até a elevação de 11,0 metros; (c) terceiro trecho até a elevação de 15,89 metros.

Maciço posterior ou CF VIII
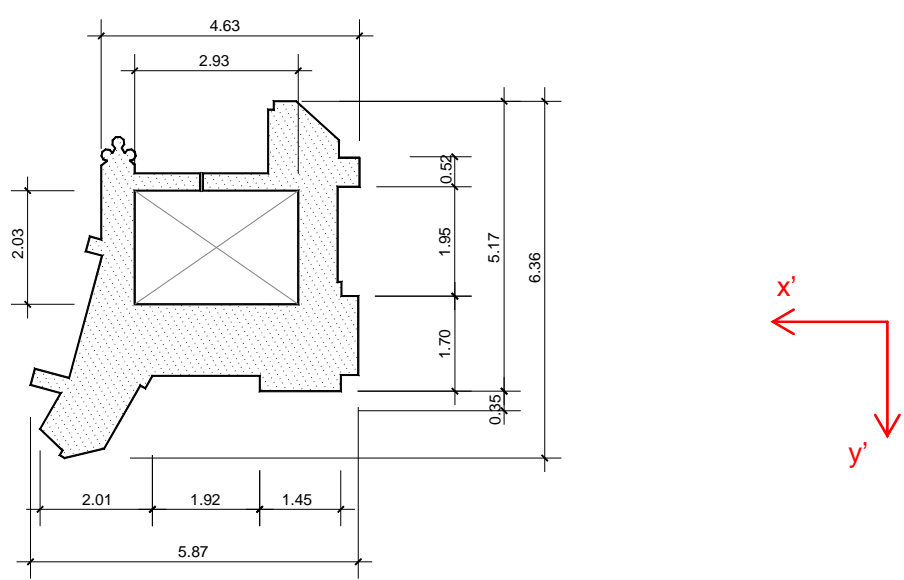

Figura 2.23 - Seção transversal considerada para o maciço posterior ou contraforte tipo VIII.

Para efeito desta pesquisa e para a análise, as seções transversais originais dos contrafortes estão aproximadas por seções equivalentes. 


\subsubsection{Características geométricas}

Um modo de obter as características geométricas das seções transversais poligonais é através do próprio SAP, utilizando o Section Designer, uma ferramenta que permite desenhar a geometria de seções irregulares como a dos contrafortes, e conseguir informações como área e momentos de inércia e, ainda, a locação do centro de gravidade.

De posse das características geométricas das seções transversais originais dos contrafortes, elas são transformadas para equivalentes retangulares.

Apesar de a solução não ser exata, por resultar em dois pares de valores próximos para a base e altura das seções, ela permite adotar valores para $b_{2}$ e $h_{2}$ que representem a seção total equivalente. Esta metodologia está exemplificada a seguir com um dos trechos dos contrafortes da Catedral.

Exemplo: Seção transversal do corpo principal do contraforte tipo II

A partir das características geométricas da seção transversal irregular:

$$
\begin{aligned}
& A_{T}=5,16 m^{2} \\
& I x_{T}=5,28 m^{4} \\
& I y_{T}=0,92 m^{4}
\end{aligned}
$$

O objetivo é transformá-la em uma seção retangular equivalente (Figura 2.24).

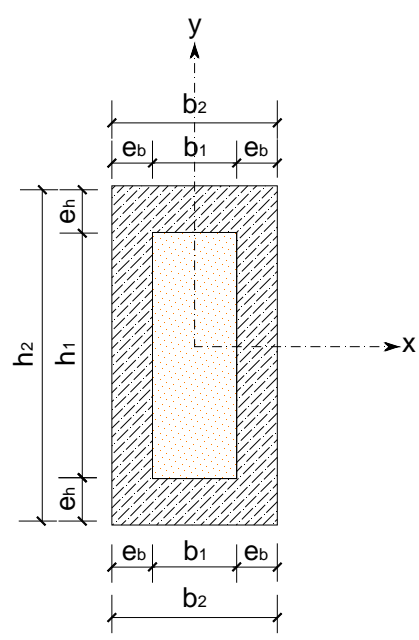

$$
\begin{aligned}
& \text { onde: } \\
& \text { b }_{1} \text { base do núcleo } \\
& \mathrm{b}_{2} \text { : base do revestimento } \\
& \mathrm{h}_{1} \text { : altura do núcleo } \\
& \mathrm{h}_{2} \text { altura do revestimento } \\
& \text { eb: espessura na base do revestimento } \\
& \text { en: espessura na altura do revestimento }
\end{aligned}
$$

Figura 2.24 - Seção retangular equivalente. 
Da área $\left(A_{2}\right)$ e do momento de inércia em relação a $x\left(I_{2}\right)$ de uma seção retangular:

$$
\left.\begin{array}{l}
\begin{array}{l}
A_{2}=b_{2} \cdot h_{2} \Rightarrow b_{2}=\frac{A_{2}}{h_{2}} \\
e
\end{array} \\
I x_{2}=\frac{b_{2} \cdot h_{2}^{3}}{12} \Rightarrow h_{2}^{3}=\frac{12 \cdot I x_{2}}{b_{2}}
\end{array}\right\} h_{2}=\sqrt{\frac{12 \cdot I x_{2}}{A_{2}}} \quad \text { e, por conseqüência, } b_{2}
$$

Resultam $\mathrm{h}_{2}$ igual a 3,51 metros e $\mathrm{b}_{2}$ igual 1,47 metros.

Da área $\left(A_{2}\right)$ e do momento de inércia em relação a y $\left(\mathrm{ly}_{2}\right)$ de uma seção retangular:

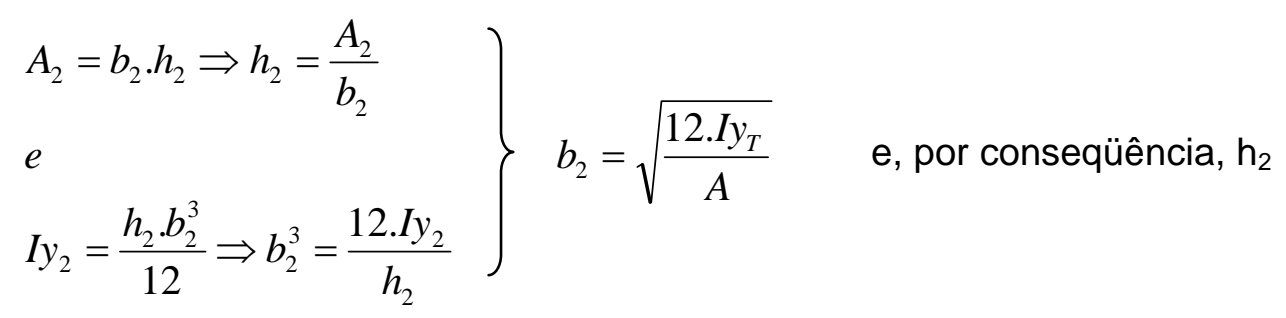

Resulta o segundo par de valores com $b_{2}$ igual a 1,46 metros e $h_{2}$ igual 3,52 metros.

Os valores médios resultam em $b_{2}$ igual a 1,47 metros e $h_{2}$ igual a 3,52 metros, e servem de referência para adoção das dimensões finais para esta seção transversal.

A base e a altura do núcleo, $b_{1}$ e $h_{1}$ respectivamente, são obtidas descontandose a espessura do revestimento estimada em 20 centímetros para o corpo principal.

Como se admite que a seção transversal do núcleo seja a mesma na base dos contrafortes, a espessura do revestimento da base, de maiores dimensões, é obtida para cada tipo de contraforte, já que $b_{1}$ e $h_{1}$ estão definidas.

Considera-se para os contrafortes, com exceção do contraforte tipo I, que o núcleo tenha seção transversal retangular e o revestimento, seção transversal retangular vazada, como mostram as Figuras 2.25 a 2.28. 
Contrafortes tipo I

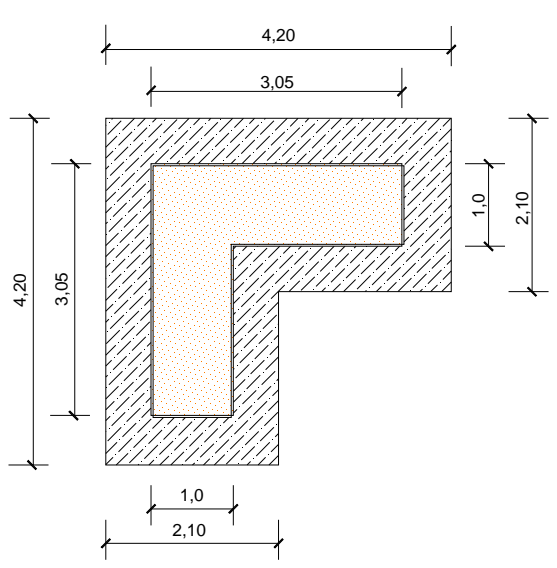

$\left(a_{1}\right)$

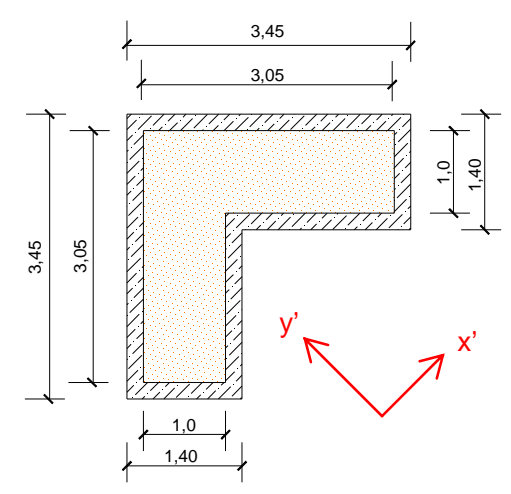

$\left(b_{1}\right)$

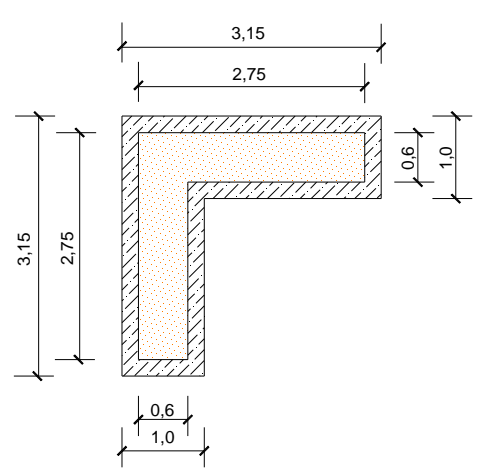

$\left(c_{1}\right)$

Contrafortes tipo II

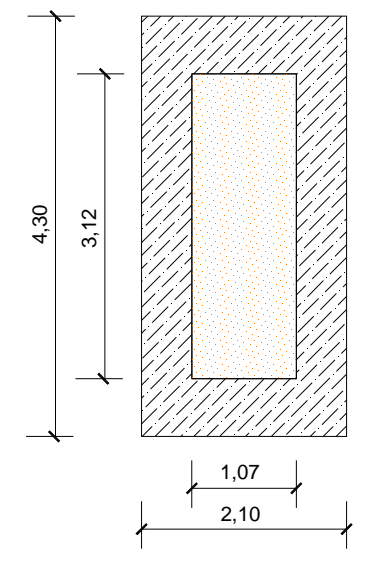

$\left(a_{2}\right)$

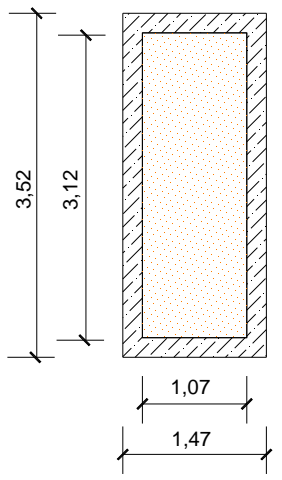

$\left(b_{2}\right)$
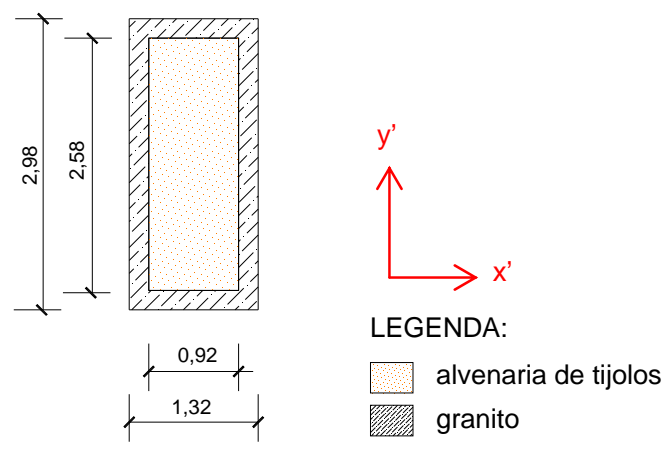

$\left(c_{2}\right)$

Figura 2.25 - Seções transversais equivalentes para os contrafortes tipo I e II: (a) da base; (b) até a elevação de 11,0 metros; (c) terceiro trecho até a elevação de 16,14 metros.

Como comentado, a espessura do revestimento de granito admitida nos contrafortes é de 20 centímetros à exceção do alargamento das bases, uma vez que a seção transversal do núcleo é considerada constante da base ao topo para os contrafortes tipo III, IV e V.

No caso dos contrafortes que possuem a variação de seção na elevação de 11 metros, admite-se que, no terceiro trecho, a espessura do revestimento seja mantida em 20 centímetros e o núcleo, portanto, a partir desta elevação, tenha redução de dimensões. 
Contrafortes tipo III

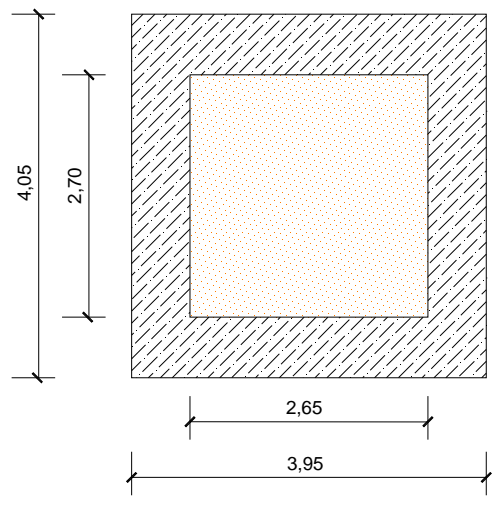

$\left(a_{1}\right)$

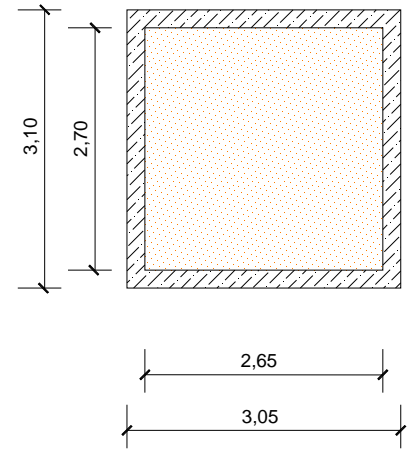

$\left(b_{1}\right)$

Contrafortes tipo IV

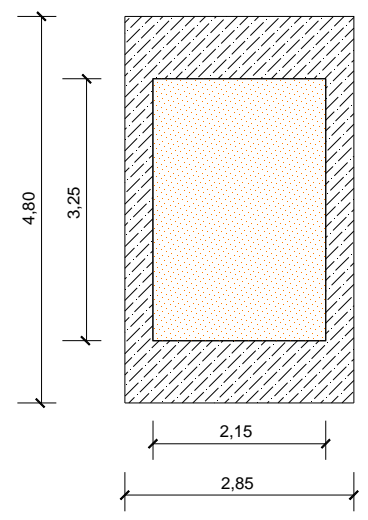

$\left(a_{2}\right)$

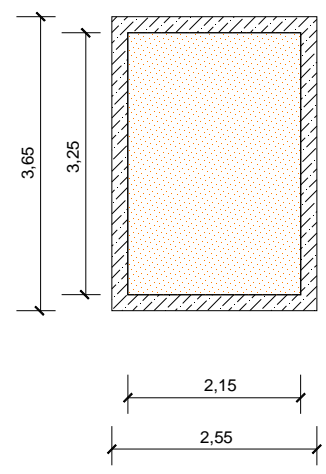

$\left(b_{2}\right)$

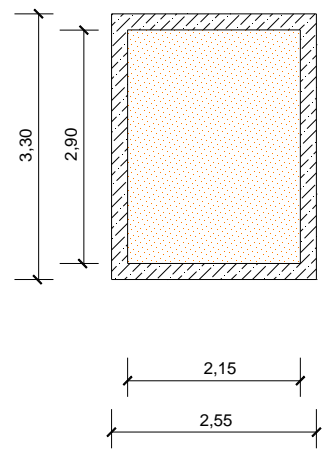

$\left(c_{2}\right)$
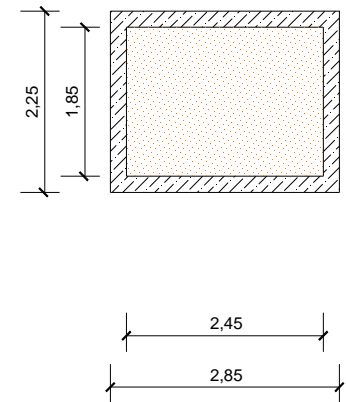

$\left(d_{2}\right)$

\section{Contrafortes tipo V}

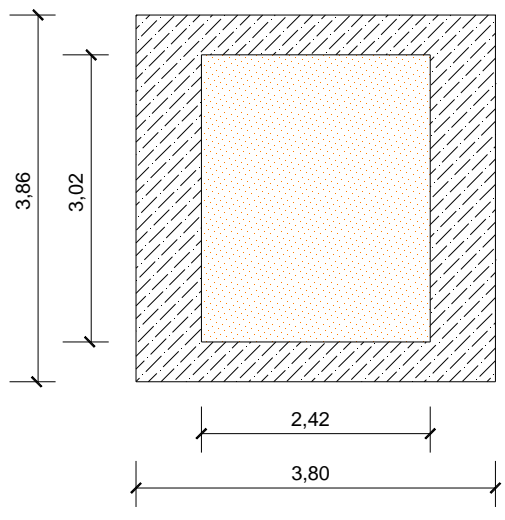

$\left(a_{3}\right)$

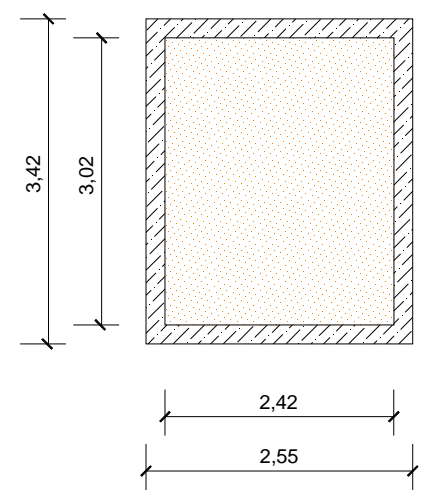

$\left(b_{3}\right)$

Figura 2.26 - Seções transversais equivalentes para os contrafortes tipo III, IV e V: (a) da base; $\left(b_{1}\right)$ e $\left(b_{3}\right)$ até a elevação de 16,14 metros; $\left(b_{2}\right)$ até a elevação de 11,0 metros; $\left(c_{2}\right)$ até a elevação de 16,14 metros; $\left(\mathrm{d}_{2}\right)$ até a elevação de 23,0 metros. 
Contrafortes tipo VI

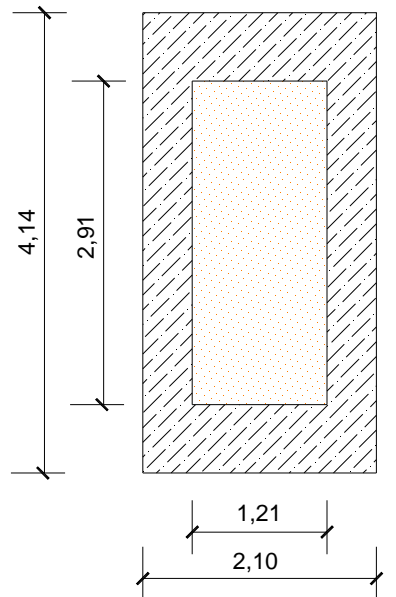

$\left(a_{1}\right)$

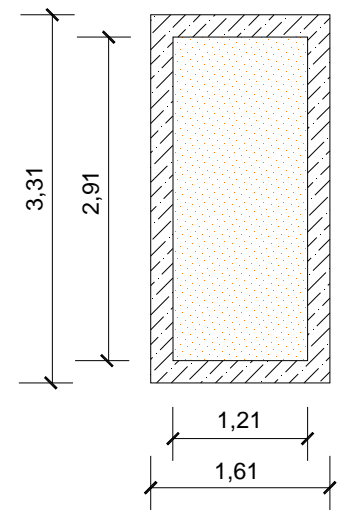

$\left(b_{1}\right)$

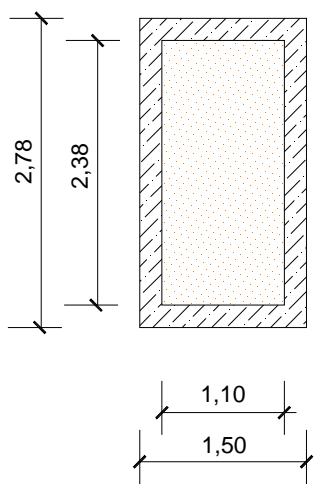

$\left(c_{1}\right)$

Contrafortes tipo VII

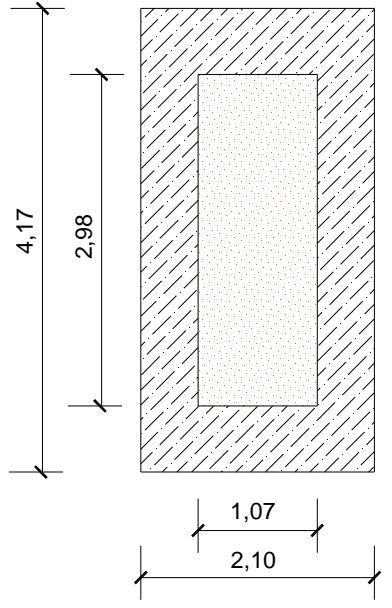

$\left(\mathrm{a}_{2}\right)$

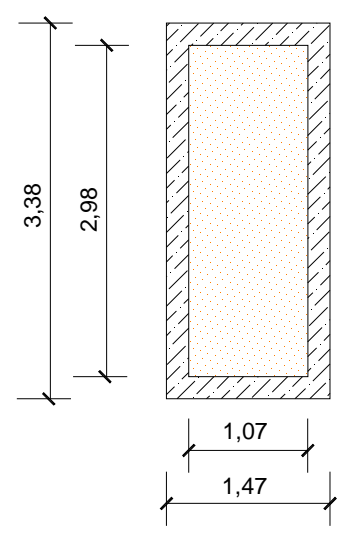

$\left(b_{2}\right)$

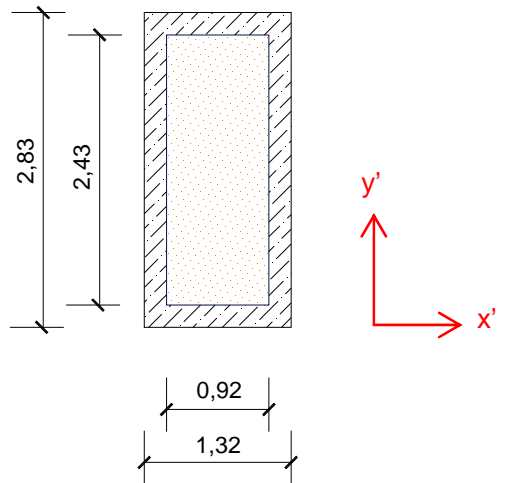

$\left(c_{2}\right)$

Figura 2.27- Seções transversais equivalentes para os contrafortes tipo VI, VII: (a) da base; (b) até a elevação de 11,0 metros; (c) terceiro trecho até a elevação de 15,89 metros.

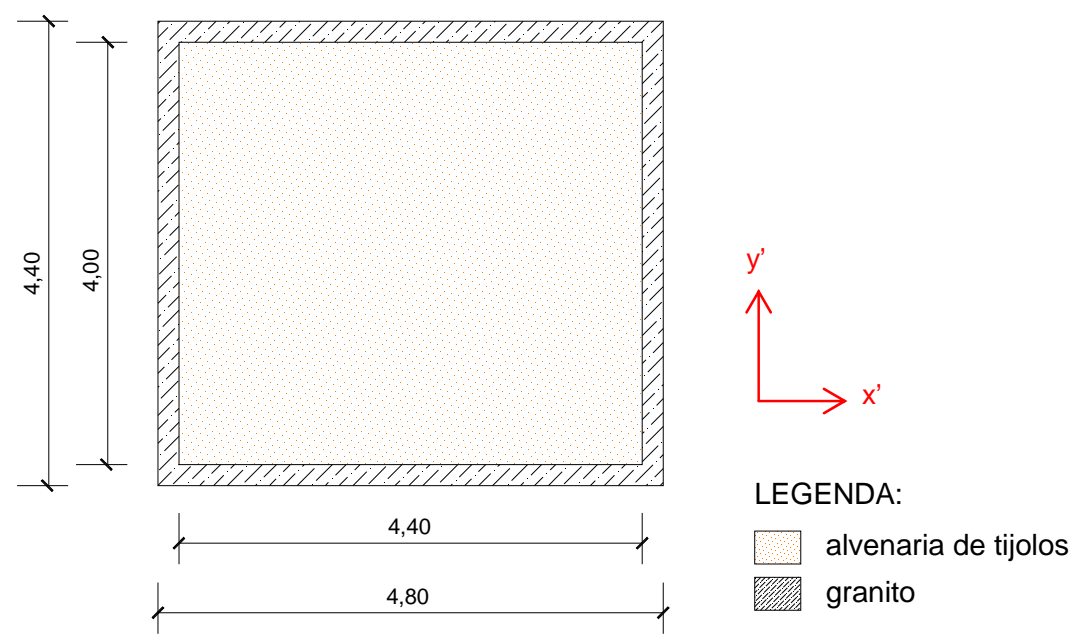

Figura 2.28 - Seção transversal considerada para o maciço posterior ou contraforte tipo VIII. 
Nas Tabelas 2.1 e 2.2, respectivamente, estão apresentadas as dimensões e as características geométricas admitidas para o núcleo e revestimento de cada um dos tipos de contrafortes em relação aos eixos locais x' e y'.

Tabela 2.1 - Características geométricas das seções transversais adotadas para o núcleo dos contrafortes e do maciço posterior.

\begin{tabular}{|c|c|c|c|c|c|c|c|}
\hline \multirow{2}{*}{\multicolumn{2}{|c|}{$\begin{array}{c}\text { Contrafortes e Maciço } \\
\text { Posterior }\end{array}$}} & \multicolumn{3}{|c|}{ Dimensões do núcleo (m) } & \multirow{3}{*}{$\begin{array}{c}\begin{array}{c}\text { Área } \\
\left(\mathrm{m}^{2}\right)\end{array} \\
\text { A }\end{array}$} & \multicolumn{2}{|c|}{$\begin{array}{l}\text { Momento de } \\
\text { inércia }\left(\mathrm{m}^{4}\right)\end{array}$} \\
\hline & & \multirow{2}{*}{$\begin{array}{c}\text { base } \\
b_{1}\end{array}$} & \multirow{2}{*}{$\frac{\text { altura }}{\mathrm{h}_{1}}$} & \multirow{2}{*}{$\begin{array}{c}\text { espessura } \\
\mathrm{bf}_{1}=\mathrm{hf}_{1}\end{array}$} & & \multirow{2}{*}{$\mathrm{I}_{\mathrm{X}}$} & \multirow{2}{*}{$\mathrm{I}_{Y}$} \\
\hline & & & & & & & \\
\hline \multirow{3}{*}{ CF-I } & Base & 3,05 & 3,05 & 1,00 & 5,10 & 1,91 & 5,74 \\
\hline & $\begin{array}{l}\text { Corpo } \\
\text { Principal }\end{array}$ & 3,05 & 3,05 & 1,00 & 5,10 & 1,91 & 5,74 \\
\hline & $3^{\circ}$ Trecho & 2,75 & 2,75 & 0,60 & 2,94 & 0,85 & 2,99 \\
\hline \multirow{3}{*}{ CF-II } & Base & 1,07 & 3,12 & - & 3,34 & 2,71 & 0,32 \\
\hline & $\begin{array}{l}\text { Corpo } \\
\text { Principal }\end{array}$ & 1,07 & 3,12 & - & 3,34 & 2,71 & 0,32 \\
\hline & $3^{\circ}$ Trecho & 0,92 & 2,58 & - & 2,37 & 1,32 & 0,17 \\
\hline \multirow[b]{2}{*}{ CF-III } & Base & 2,65 & 2,70 & - & 7,16 & 4,35 & 4,19 \\
\hline & $\begin{array}{l}\text { Corpo } \\
\text { Principal } \\
\end{array}$ & 2,65 & 2,70 & - & 7,16 & 4,35 & 4,19 \\
\hline \multirow{4}{*}{ CF-IV } & Base & 2,15 & 3,25 & - & 7,01 & 6,18 & 2,71 \\
\hline & $\begin{array}{l}\text { Corpo } \\
\text { Principal }\end{array}$ & 2,15 & 3,25 & - & 7,01 & 6,18 & 2,71 \\
\hline & $3^{\circ}$ Trecho & 2,15 & 2,90 & - & 6,24 & 4,37 & 2,40 \\
\hline & $4^{\circ}$ Trecho & 2,45 & 1,85 & - & 4,53 & 1,29 & 2,27 \\
\hline \multirow[b]{2}{*}{ CF-V } & Base & 2,42 & 3,02 & - & 7,31 & 5,55 & 3,57 \\
\hline & $\begin{array}{l}\text { Corpo } \\
\text { Principal }\end{array}$ & 2,42 & 3,02 & - & 7,31 & 5,55 & 3,57 \\
\hline \multirow{3}{*}{$\mathrm{CF}-\mathrm{VI}$} & Base & 1,21 & 2,91 & - & 3,52 & 2,48 & 0,43 \\
\hline & $\begin{array}{l}\text { Corpo } \\
\text { Principal }\end{array}$ & 1,21 & 2,91 & - & 3,52 & 2,48 & 0,43 \\
\hline & $3^{\circ}$ Trecho & 1,10 & 2,38 & - & 2,62 & 1,24 & 0,26 \\
\hline \multirow{3}{*}{ CF-VII } & Base & 1,07 & 2,98 & - & 3,19 & 2,36 & 0,30 \\
\hline & $\begin{array}{l}\text { Corpo } \\
\text { Principal }\end{array}$ & 1,07 & 2,98 & - & 3,19 & 2,36 & 0,30 \\
\hline & $3^{\circ}$ Trecho & 0,92 & 2,43 & - & 2,24 & 1,10 & 0,16 \\
\hline \multicolumn{2}{|c|}{ Maciço Posterior } & 4,40 & 4,00 & - & 17,60 & 23,47 & 28,39 \\
\hline
\end{tabular}


Tabela 2.2 - Características geométricas das seções transversais adotadas para o revestimento dos contrafortes e do maciço posterior.

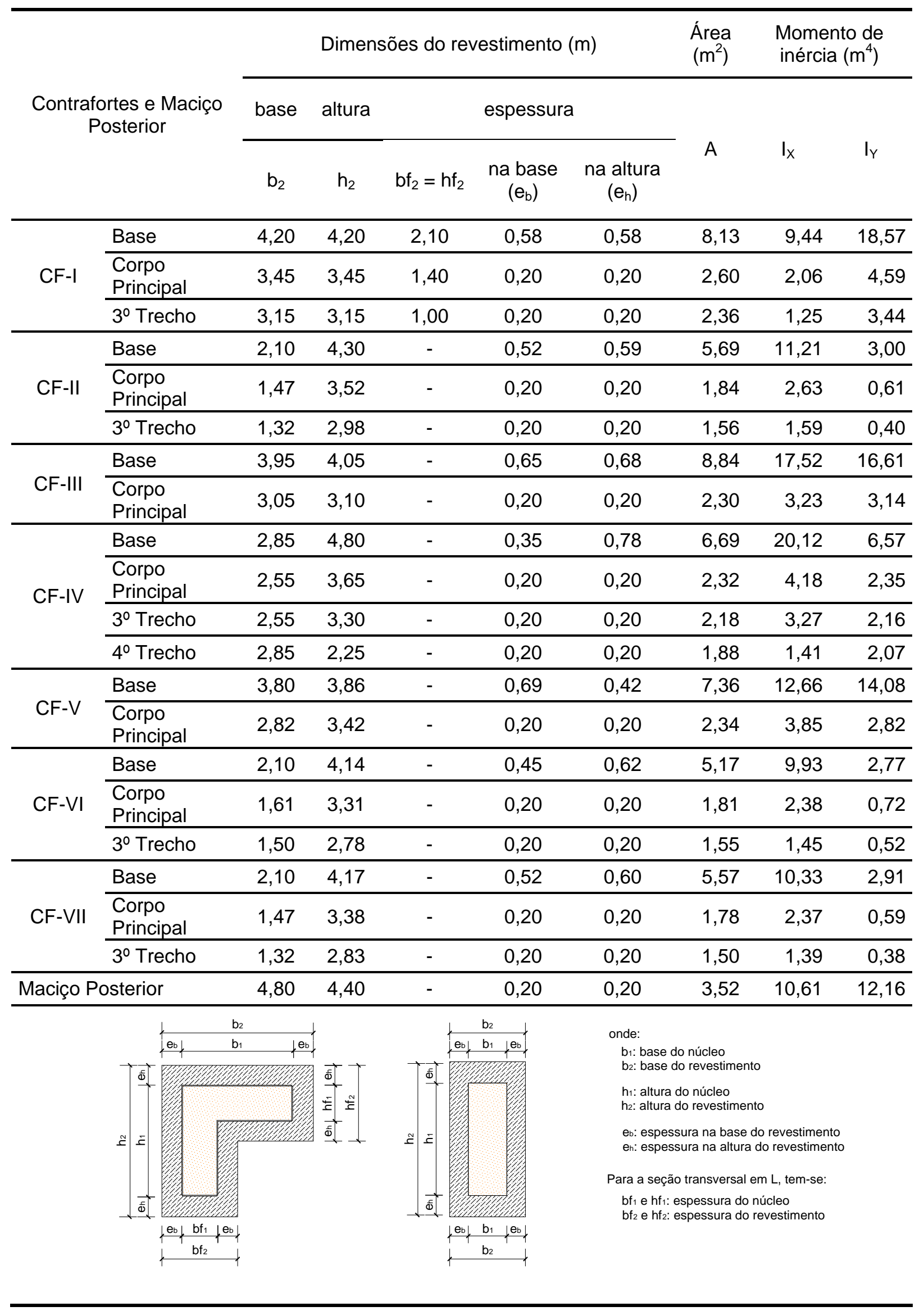




\subsection{Geometria dos arcobotantes}

Como comentado, os arcobotantes têm a função de transmitir os empuxos horizontais resultantes dos arcos até os contrafortes. Este sistema estrutural, típico do gótico, permite paredes menos espessas, continuidade do espaço desde o piso até as abóbadas, elevadas alturas e maior luminosidade.

Considera-se que os arcobotantes da Catedral da Sé sejam maciços, de granito. A geometria destes elementos apresenta uma bifurcação, como apresentado na Figura 2.29. A seção transversal tem 0,75 metros de largura. O trecho acima da bifurcação tem altura de 0,70 metros, a inferior, de 0,80 metros, e na junção, 1,50 metros. No modelo, os arcobotantes estão representados por elementos de barra.

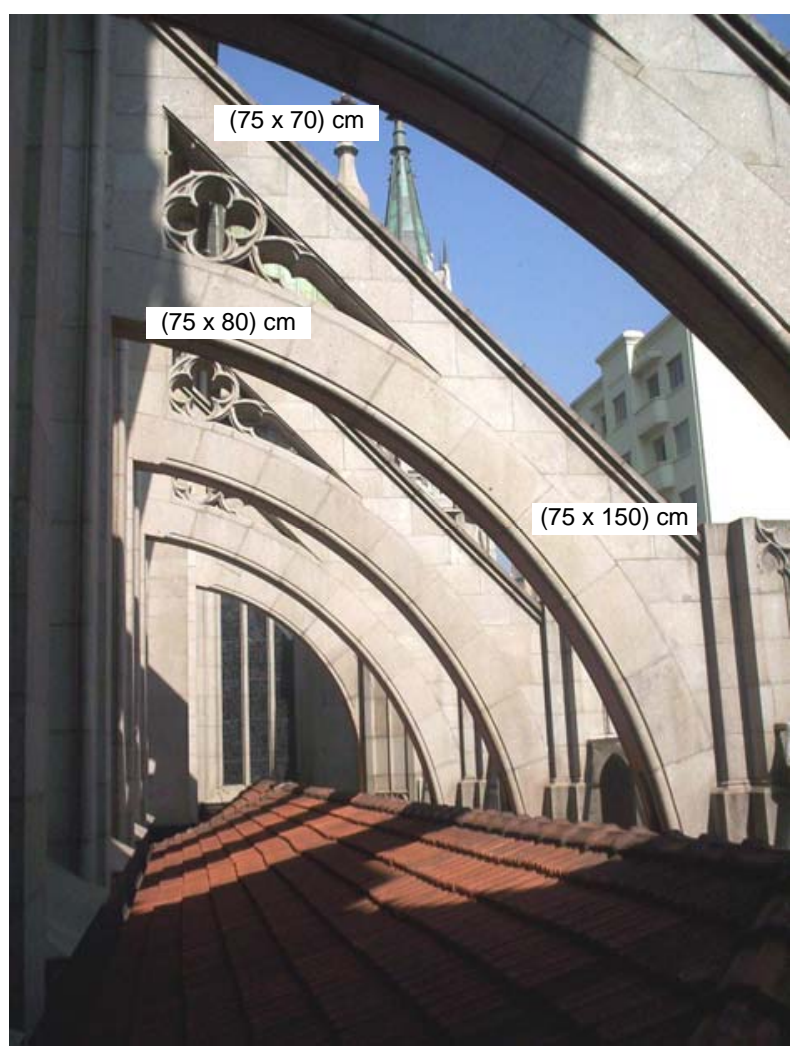

(a)

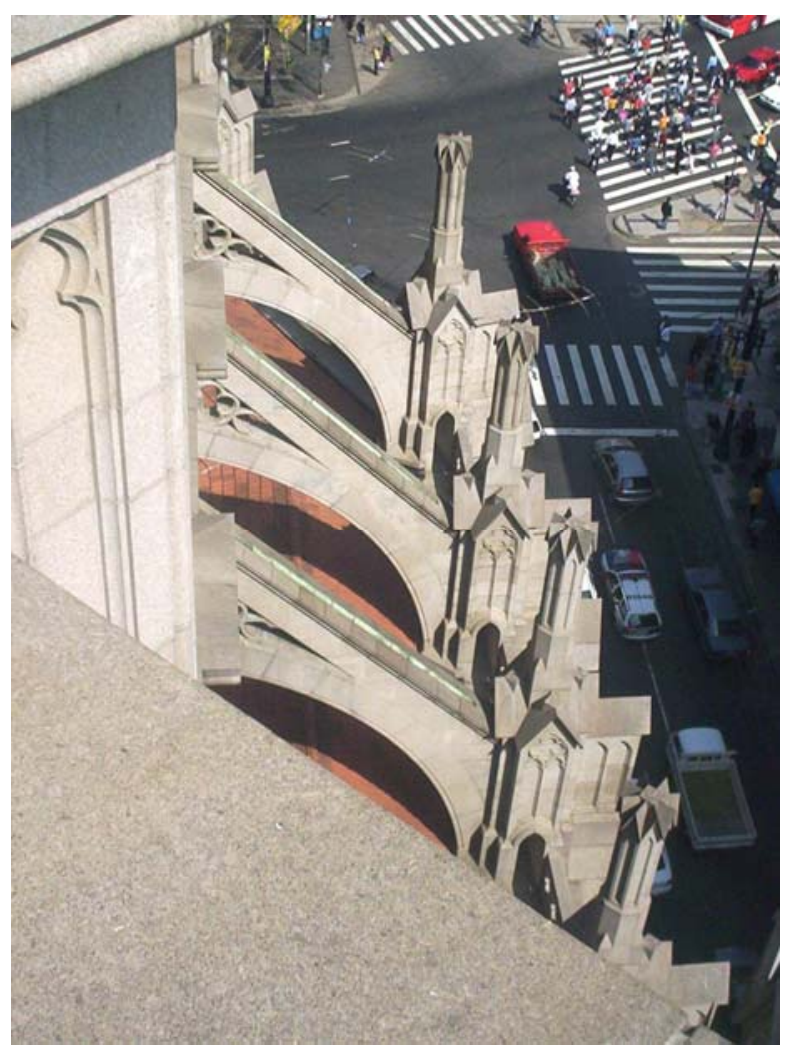

(b)

Figura 2.29 - Arcobotantes da Catedral da Sé: (a) vista lateral; (b) vista superior. 


\subsection{Geometria dos pilares}

$\mathrm{Na}$ Catedral da Sé, há cinqüenta e seis pilares, trinta contrafortes e as duas grandes torres frontais, que participam do equilíbrio global da igreja.

Todos os pilares da igreja elevam-se por 23 metros e possuem um alargamento na base que se estende até $1,30 \mathrm{~m}$ de altura em relação ao piso de referência.

Os pilares da Catedral da Sé também são constituídos por dois materiais. Eles possuem um núcleo de concreto simples ou de alvenaria de tijolos dependendo de sua localização, envolvido por granito.

Os pilares da região do octógono têm seção transversal maior que os do restante da igreja, com três metros de diâmetro mais as saliências como mostra a Figura 2.30. O núcleo de concreto simples é revestido pelo granito.

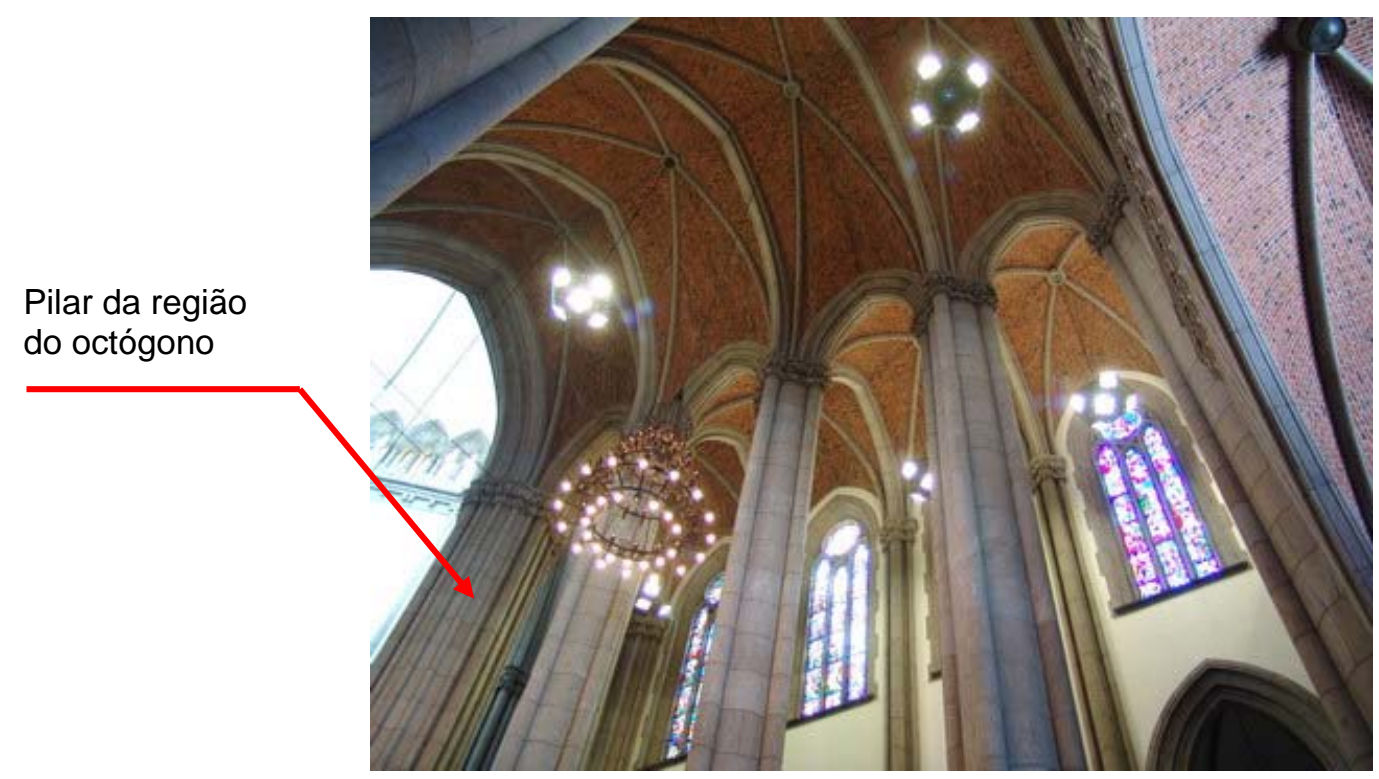

Figura 2.30 - Vista dos pilares da nave central; à esquerda um dos grandes pilares do octógono.

Já em relação aos pilares das regiões frontal e posterior da igreja, vale ressaltar que os pilares centrais, locados nos eixos 3 e 4, do mesmo modo que os pilares do octógono, são constituídos por um núcleo de concreto simples revestido por granito, mas de menores dimensões, com 1,50 metros de diâmetro em seu corpo principal, mais as saliências (Figura 2.31). 


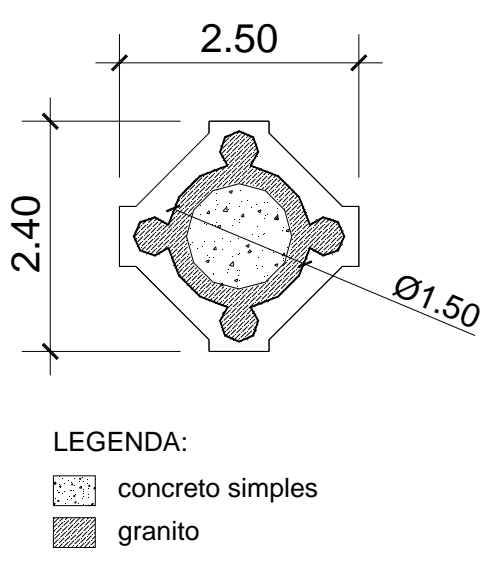

(a)

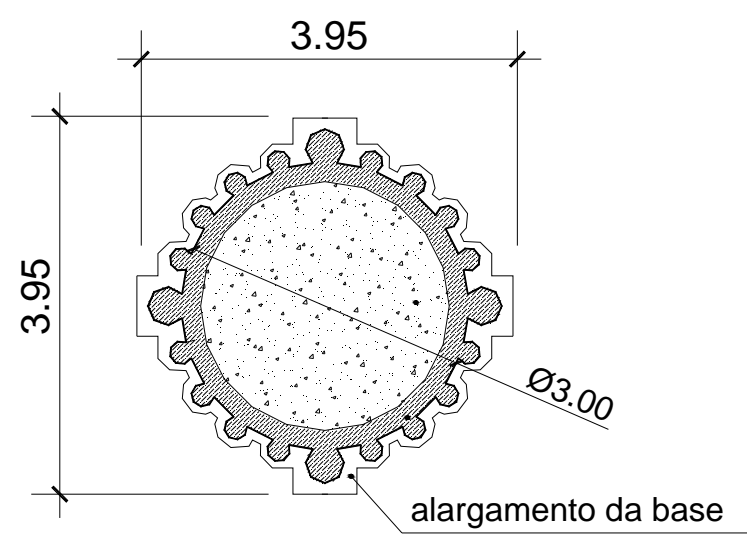

medidas em metros

$\varnothing$ equivale ao diâmetro

Figura 2.31 - Seção transversal e alargamento da base: (a) pilares centrais até o topo e pilares laterais até a elevação de 11 metros da região frontal e posterior da igreja; (b) todos os pilares da região do octógono.

A mesma seção apresentada na Figura 2.31 (a) também está presente nos pilares laterais das regiões frontal e posterior, locados nos eixos 2 e 5 . No entanto, há mudança de seção transversal a partir dos 11 metros de altura, elevação na qual surgem as paredes de fechamento das naves laterais (Figura 2.32).

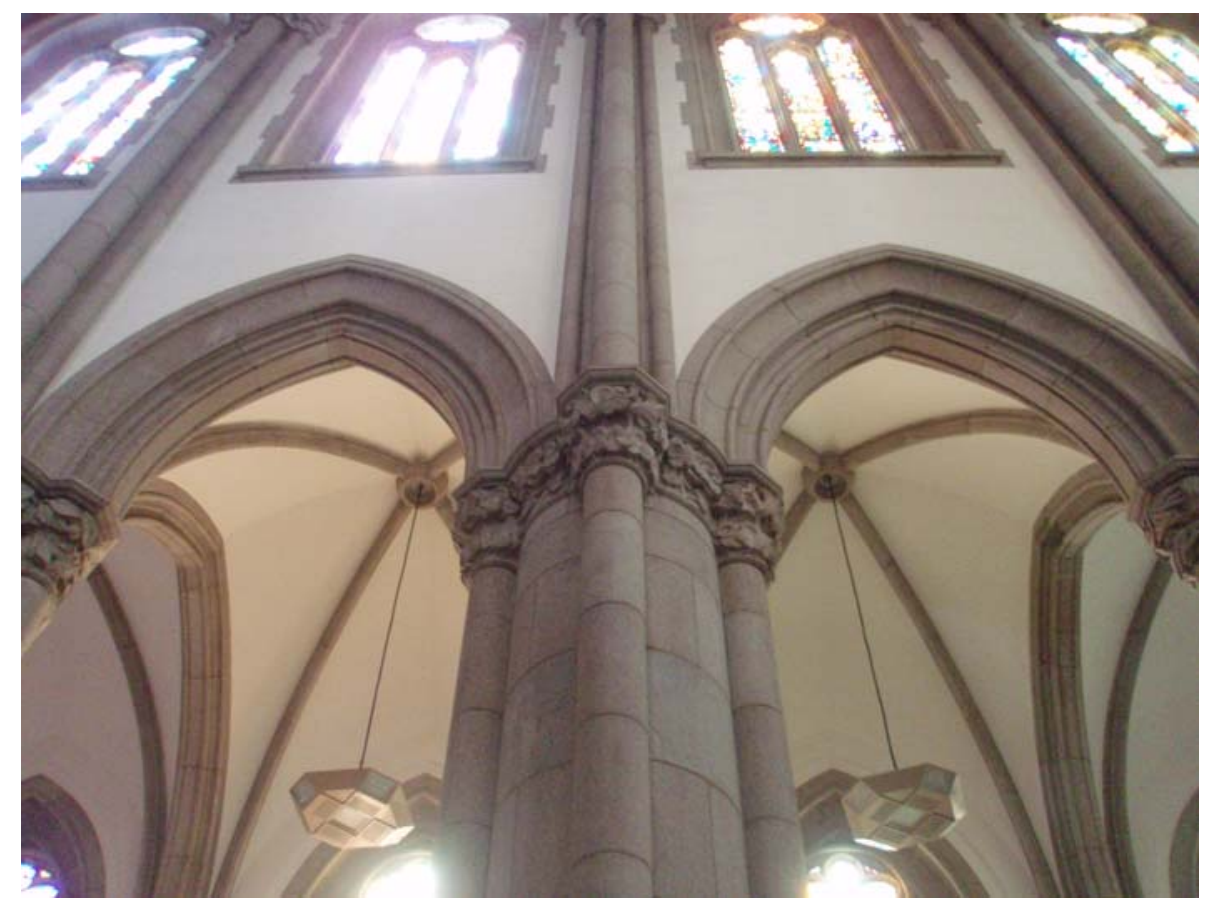

Figura 2.32 - Mudança de seção transversal dos pilares locados nos eixos 2 e 5 - região frontal e posterior (LINDENBERG NETO, 2007). 
O terceiro trecho destes pilares é constituído de alvenaria de tijolos e granito, cuja seção transversal admitida está ilustrada na Figura 2.33.
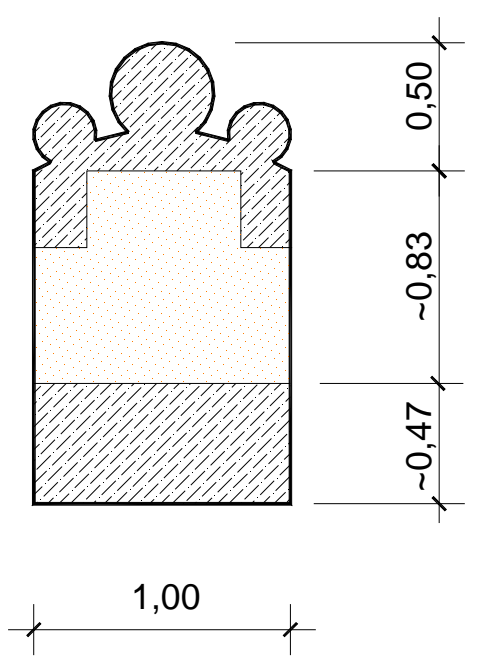

LEGENDA:

alvenaria de tijolos

granito

medidas em metros

Figura 2.33 - Seção transversal do terceiro trecho dos pilares locados nos eixos 2 e 5 - região frontal e posterior.

A espessura do revestimento de granito admitida nos pilares também é de 20 centímetros mais as saliências, à exceção do alargamento das bases; nos pilares centrais e nos pilares laterais até a elevação de 11 metros, a seção transversal do núcleo é considerada constante desde a base. A exceção da espessura também é válida para a seção transversal do terceiro trecho dos pilares laterais da Catedral.

Para efeito de análise, são adotadas algumas simplificações. Admite-se no modelo que o núcleo de concreto tenha seção transversal circular e que o revestimento com suas saliências de granito tenha uma seção transversal tubular equivalente, como ilustrado nas Figuras 2.34 a 2.36.

O núcleo dos pilares do octógono tem 2,60 metros de diâmetro, enquanto o núcleo dos pilares da região frontal e posterior tem 1,10 metros.

Para o terceiro trecho dos pilares laterais, a seção transversal é representada por um núcleo de tijolo retangular e por um revestimento de granito com seção retangular vazada, cujas dimensões estão apresentadas adiante, na Figura 2.35. 
De posse da área $\left(A_{T}\right)$ e do momento de inércia totais $\left(1_{T O T}\right)$ das seções transversais reais dos pilares da Catedral e, admitido o diâmetro do núcleo (d), a parcela correspondente à área $\left(A_{1}\right)$ e ao momento de inércia do núcleo $\left(I_{1}\right)$ são subtraídas do total para obter as características geométricas correspondentes ao revestimento, $\mathrm{A}_{2} \mathrm{e} \mathrm{I}_{2}$, que deve ser transformado numa seção equivalente tubular.

Tomam-se como exemplo, os pilares do octógono em que:

$$
\begin{array}{lll}
A_{T}=8,18 m^{2} & A_{1}=5,31 m^{2} & A_{2}=2,87 m^{2} \\
I_{\text {TOT }}=5,45 m^{4} & I_{1}=2,24 m^{4} & I_{2}=3,21 m^{4} \\
& d=2,60 m &
\end{array}
$$

Assim, a partir de $A_{2}$ e $I_{2}$, resultam dois diâmetros $D$ equivalentes para 0 revestimento, 3,23 metros e 3,25 metros respectivamente.

$$
\begin{aligned}
& A_{2}=\frac{\pi}{4} \cdot\left(D^{2}-d^{2}\right) \\
& e \\
& I_{2}=\frac{\pi}{64} \cdot\left(D^{4}-d^{4}\right)
\end{aligned}
$$

Apesar de a solução não ser exata, por resultar em dois valores de diâmetros muito próximos, ela permite adotar a dimensão que represente a seção transversal equivalente. Neste caso, admite-se diâmetro $D$ igual a 3,27 metros com espessura de 0,31 metros.

As características geométricas para o núcleo e o revestimento utilizadas no modelo correspondem às das seções equivalentes e estão apresentadas nas Tabelas 2.3 e 2.4 . 


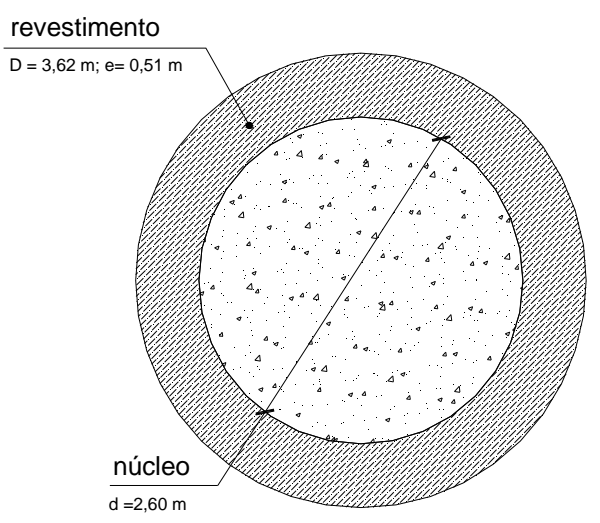

(a)

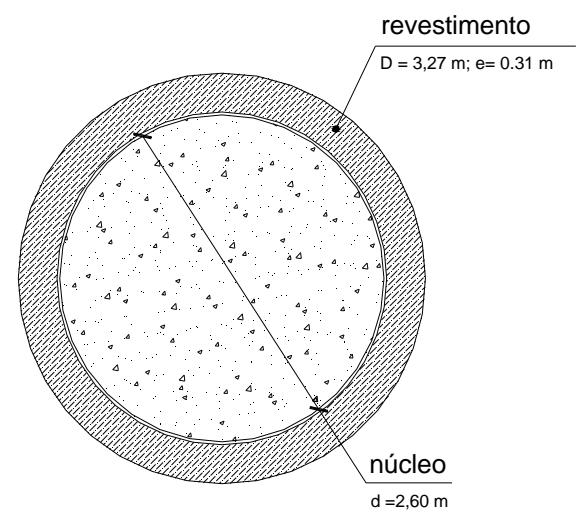

(b)

\section{LEGENDA:}

concreto simples granito

Figura 2.34 - Seções transversais simplificadas para os pilares da região do octógono: (a) base; (b) corpo principal.

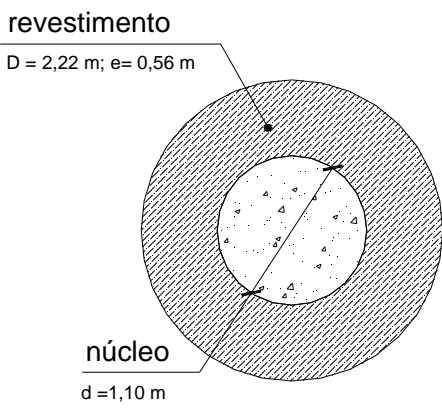

(a)

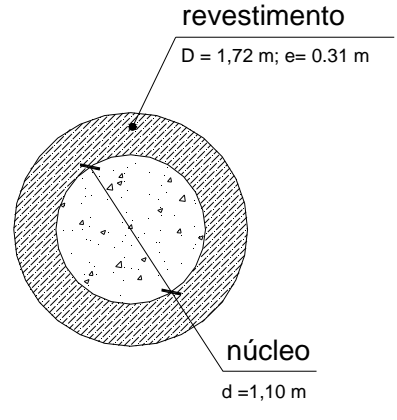

(b)

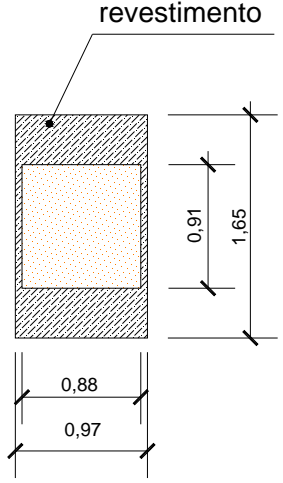

(c)

LEGENDA:
concreto simples alvenaria de tijolos granito

Figura 2.35 - Seções transversais simplificadas para os pilares laterais, locados nos eixos 2 e 5 da região frontal e posterior: (a) base; (b) segundo trecho ou corpo principal; (c) terceiro trecho. 


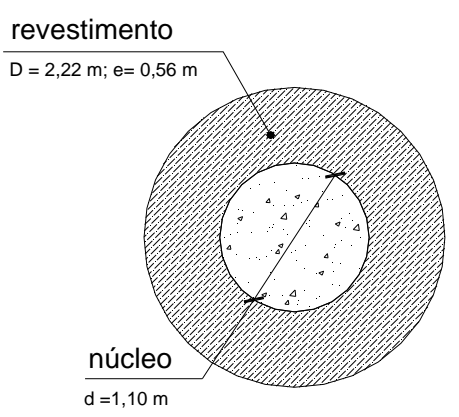

(a)

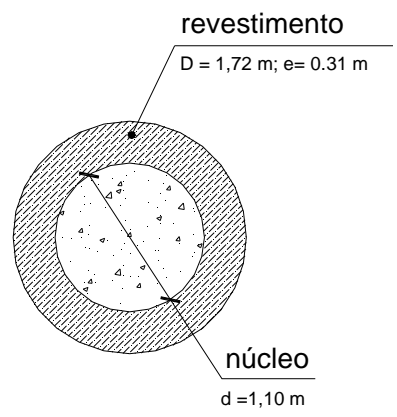

(b)
LEGENDA:

concreto simples

granito

Figura 2.36 - Seções transversais simplificadas para os pilares centrais, locados nos eixos 3 e 4 da região frontal e posterior: (a) base; (b) corpo principal.

Tabela 2.3 - Características geométricas das seções transversais adotadas para o núcleo dos pilares.

\begin{tabular}{|c|c|c|c|c|c|c|}
\hline \multicolumn{2}{|c|}{ Pilares } & \multirow{2}{*}{$\begin{array}{c}\text { Seção } \\
\text { transversal do } \\
\text { núcleo }\end{array}$} & \multirow[t]{2}{*}{$\begin{array}{c}\text { Dimensões } \\
(\mathrm{m})\end{array}$} & \multirow{2}{*}{$\begin{array}{c}\text { Área } \\
\left(\mathrm{m}^{2}\right)\end{array}$} & \multicolumn{2}{|c|}{$\begin{array}{l}\text { Momento de } \\
\text { inércia }\left(\mathrm{m}^{4}\right)\end{array}$} \\
\hline & & & & & $I_{x}$ & $\mathrm{I}_{\mathrm{Y}}$ \\
\hline \multirow{3}{*}{$\begin{array}{l}\text { Região frontal } \\
\text { e posterior }\end{array}$} & Base & & & & & \\
\hline & $\begin{array}{c}\text { Corpo } \\
\text { Principal }\end{array}$ & circular & $\varnothing 1,10$ & 0,95 & 0,07 & 0,07 \\
\hline & $3^{\circ}$ Trecho* & retangular & $0,88 \times 0,91$ & 0,80 & 0,06 & 0,05 \\
\hline \multirow{2}{*}{$\begin{array}{l}\text { Região do } \\
\text { octógono }\end{array}$} & Base & & & & & \\
\hline & $\begin{array}{c}\text { Corpo } \\
\text { Principal }\end{array}$ & circular & $\varnothing 2,60$ & 5,31 & 2,24 & 2,24 \\
\hline
\end{tabular}

Tabela 2.4 - Características geométricas das seções transversais adotadas para o revestimento dos pilares.

\begin{tabular}{|c|c|c|c|c|c|c|c|}
\hline \multicolumn{2}{|c|}{ Pilares } & \multirow{2}{*}{$\begin{array}{c}\text { Seção } \\
\text { transversal } \\
\text { simplificada para } \\
\text { o revestimento }\end{array}$} & \multirow[t]{2}{*}{$\begin{array}{l}\text { Dimensões } \\
(\mathrm{m})\end{array}$} & \multirow[t]{2}{*}{$\begin{array}{l}\text { Espessura } \\
\text { (m) }\end{array}$} & \multirow{2}{*}{$\begin{array}{c}\begin{array}{c}\text { Área } \\
\left(\mathrm{m}^{2}\right)\end{array} \\
\mathrm{A}\end{array}$} & \multicolumn{2}{|c|}{$\begin{array}{l}\text { Momento de } \\
\text { inércia }\left(\mathrm{m}^{4}\right)\end{array}$} \\
\hline & & & & & & $\mathrm{I}_{\mathrm{X}}$ & $\mathrm{I}_{Y}$ \\
\hline \multirow{3}{*}{$\begin{array}{l}\text { Região frontal } \\
\text { e posterior }\end{array}$} & Base & tubular & $\varnothing 2,22$ & 0,56 & 2,91 & 1,12 & 1,12 \\
\hline & $\begin{array}{c}\text { Corpo } \\
\text { Principal }\end{array}$ & tubular & $\varnothing 1,72$ & 0,31 & 1,37 & 0,36 & 0,36 \\
\hline & $3^{\circ}$ Trecho* & $\begin{array}{c}\text { retangular } \\
\text { vazada }\end{array}$ & $0,97 \times 1,65$ & $\begin{array}{c}0,05 \mathrm{e} \\
0,37\end{array}$ & 0,80 & 0,31 & 0,08 \\
\hline \multirow{2}{*}{$\begin{array}{l}\text { Região do } \\
\text { octógono }\end{array}$} & Base & tubular & $\varnothing 3,62$ & 0,51 & 4,96 & 6,14 & 6,14 \\
\hline & $\begin{array}{c}\text { Corpo } \\
\text { Principal }\end{array}$ & tubular & $\varnothing 3,27$ & 0,31 & 2,88 & 3,18 & 3,18 \\
\hline
\end{tabular}




\subsection{Geometria dos arcos}

O traçado dos arcos está definido com base nas plantas existentes no arquivo da Cúria Metropolitana de São Paulo. Nos casos de escassez de informações para alguns dos arcos, a análise por fotografias tornou-se bastante útil.

Visitas à Catedral da Sé e a inspeção visual amparada por medições no local permitem admitir que as seções transversais dos arcos estão posicionadas rente às saliências do pilares e contrafortes, como ilustra genericamente a Figura 2.37.
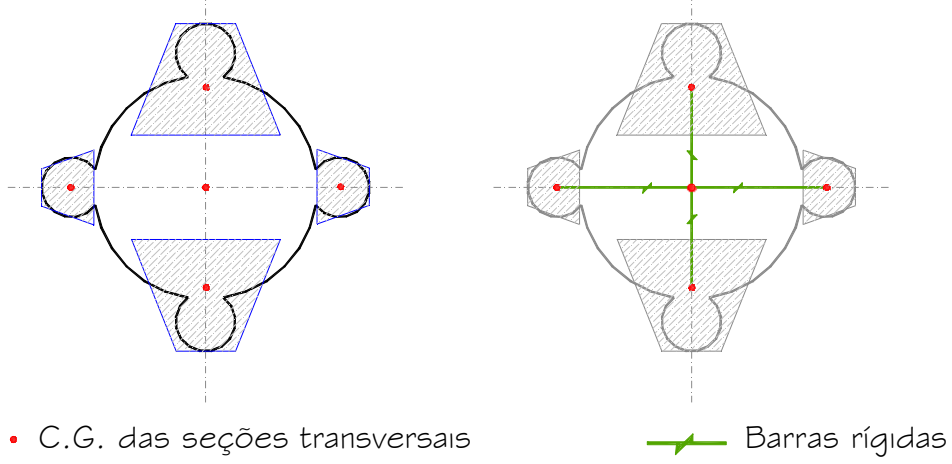

Figura 2.37 - Esquema genérico de apoio dos arcos no pilar e da representação das ligações dos arcos ao pilar com barras rígidas. Em azul, na ilustração à esquerda, as seções transversais dos arcos.

São os capitéis que fazem a concordância entre as seções do arco e do pilar. A maioria dos arcos da igreja apresenta seção aproximadamente trapezoidal (Figura 2.38), sendo constatado por inspeção visual que somente alguns poucos arcos, localizados no deambulatório, possuem seção retangular.

As dimensões das seções transversais dos arcos foram medidas no local, ao longo de cinco visitas à Catedral.

Assim, de posse da curvatura do arco - obtida pelas plantas da Cúria -, dos centros de gravidade das seções e, por conseqüência, do vão por ele vencido, a geometria dos arcos foi completada. 


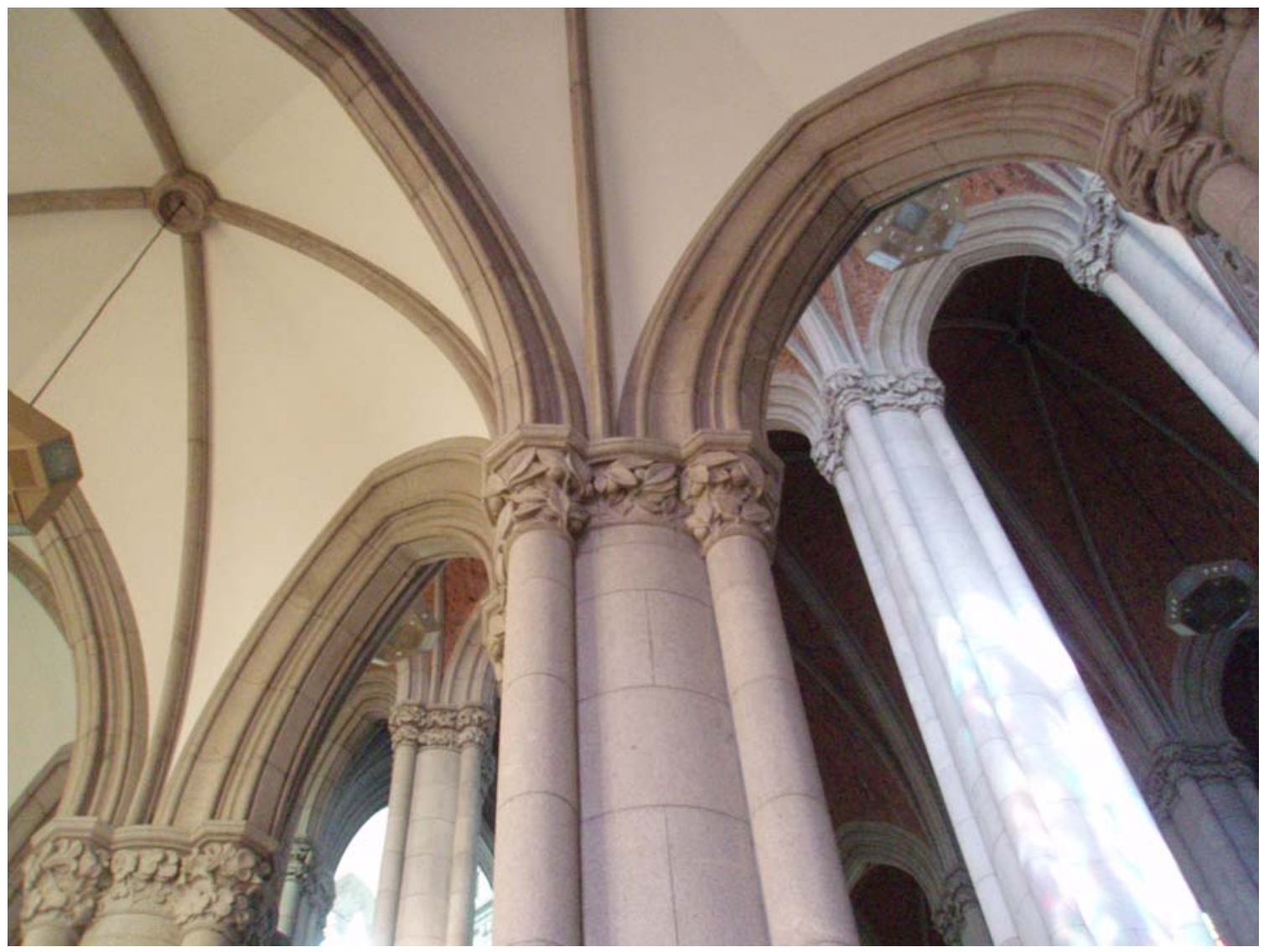

Figura 2.38 - Detalhe da chegada dos arcos no pilar - nave lateral externa esquerda (LINDENBERG NETO, 2007).

As Figuras 2.39 e 2.40 ilustram seções em dois eixos transversais, uma na parte frontal e outra na parte posterior do templo, nas quais estão identificadas as naves de acordo com as elevações e locações em que seus arcos despontam. 


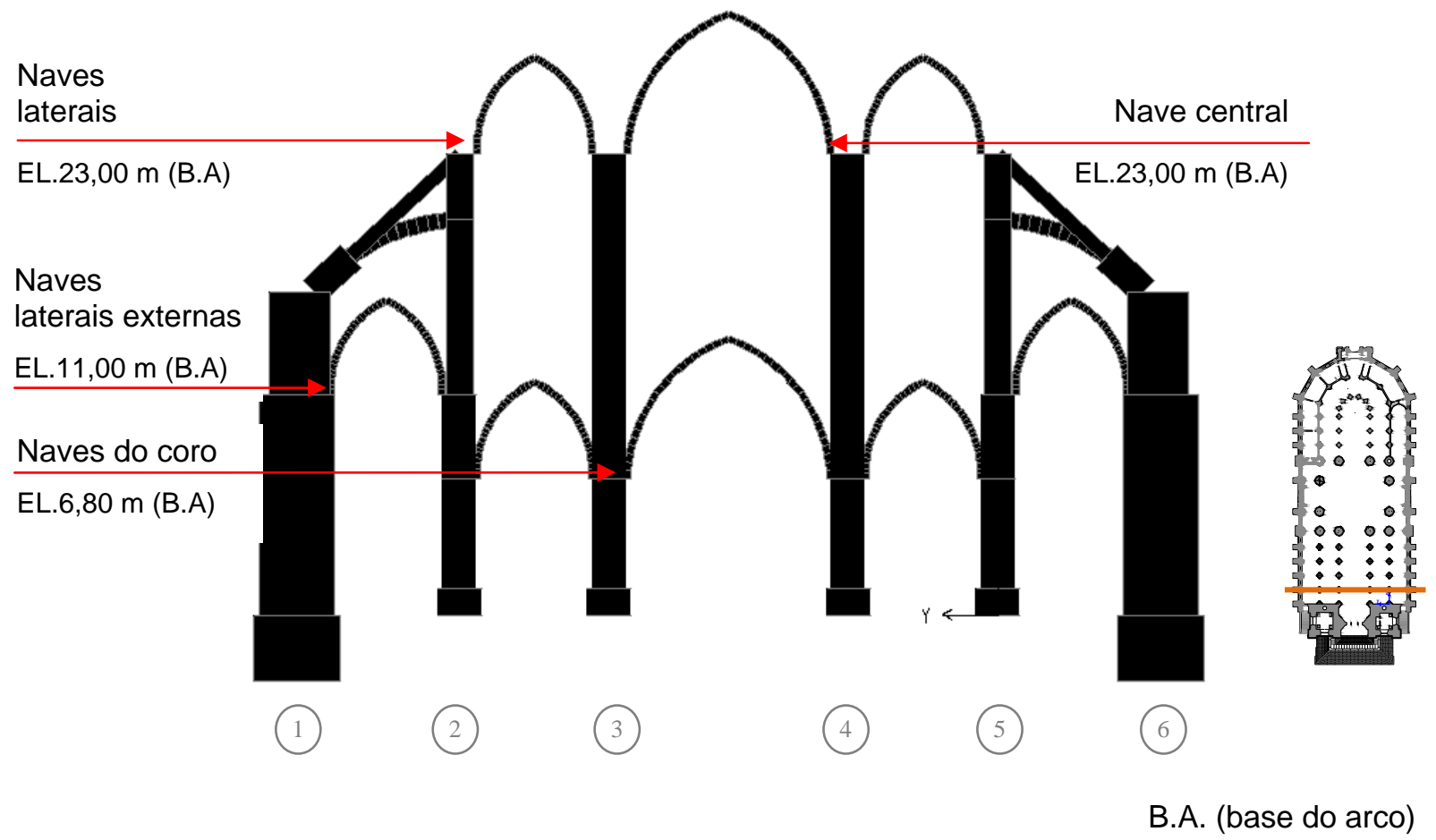

Figura 2.39 - Classificação dos espaços da igreja - Corte no eixo B.

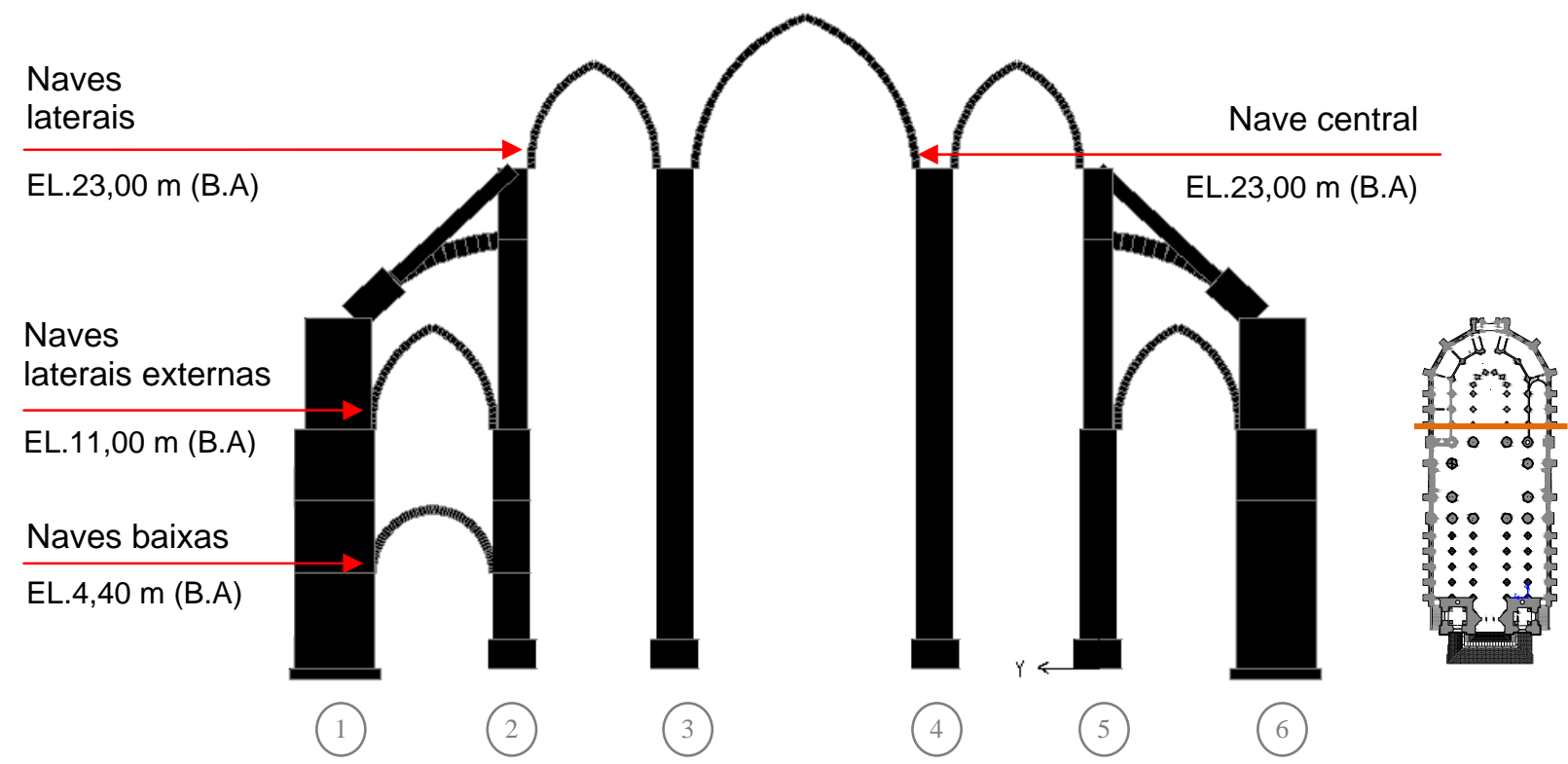

Figura 2.40 - Classificação dos espaços da igreja - Corte no eixo J.

B.A. (base do arco) 


\subsection{Geometria das abóbadas}

As abóbadas ogivais da Catedral da Sé são em sua maioria quadripartidas, com exceção das localizadas na parte posterior da igreja, que possuem cinco panos (Figura 2.41).

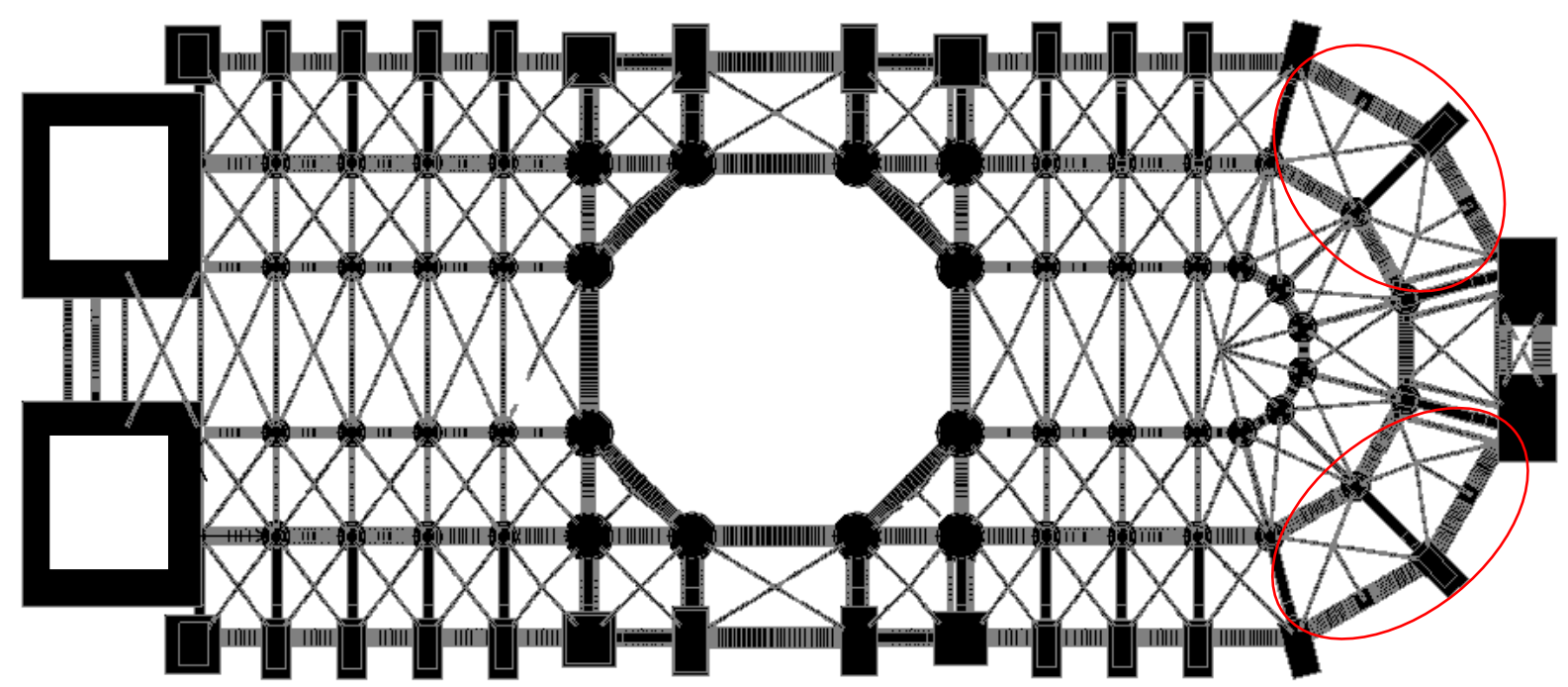

(a)
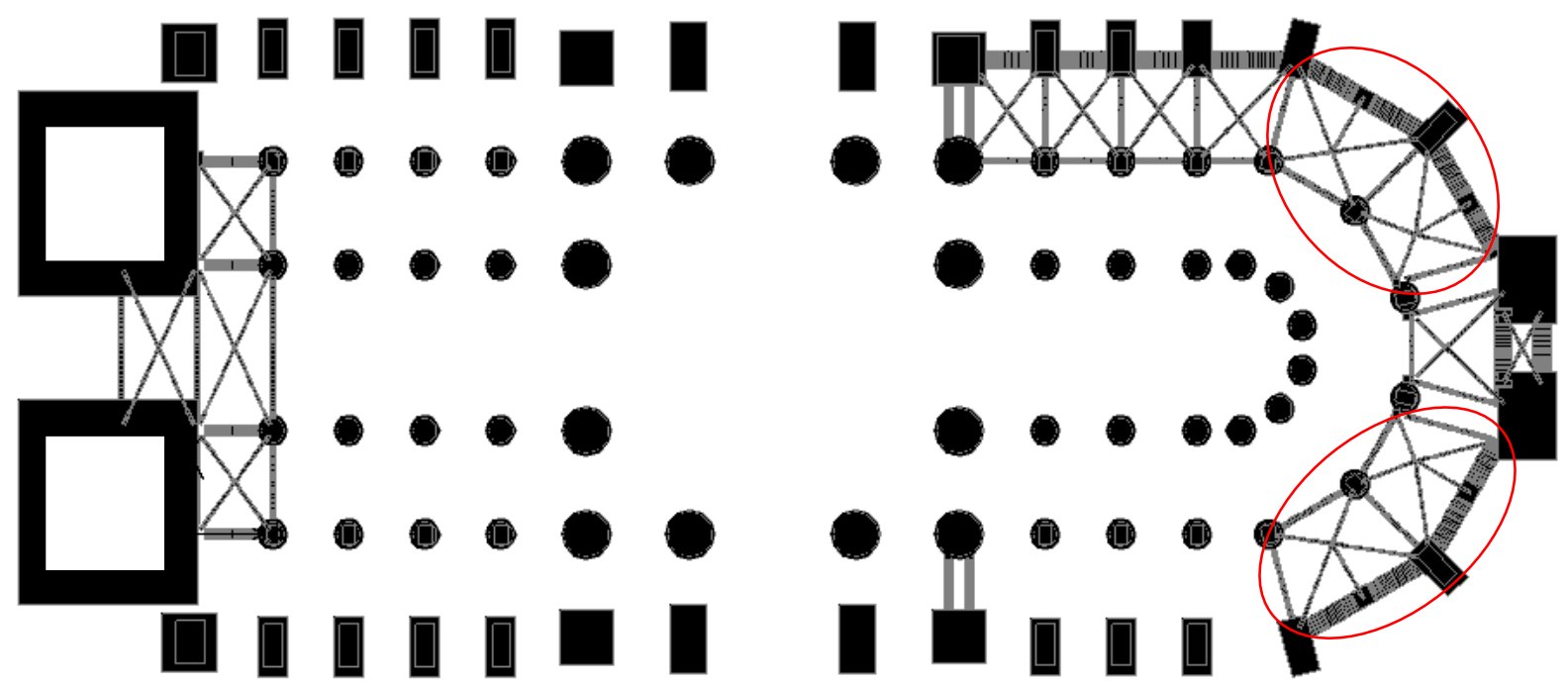

(b)

Abóbadas com cinco panos

Figura 2.41 - Planta da Catedral - esquema geral das abóbadas com suas nervuras; destaque para as abóbadas com cinco panos: (a) abóbadas das naves central, laterais e laterais externas; (b) abóbadas do coro e das naves baixas. 
A escassez de informações com relação às curvaturas das nervuras e dos panos levou a estimativas aproximadas de seus traçados, tendo como base os arcos que as delimitam e as alturas até o anel de fecho.

Ao todo, 82 abóbadas estão modeladas com suas nervuras e panos; as alturas dos anéis de fecho estão apresentadas na Figura 2.42.

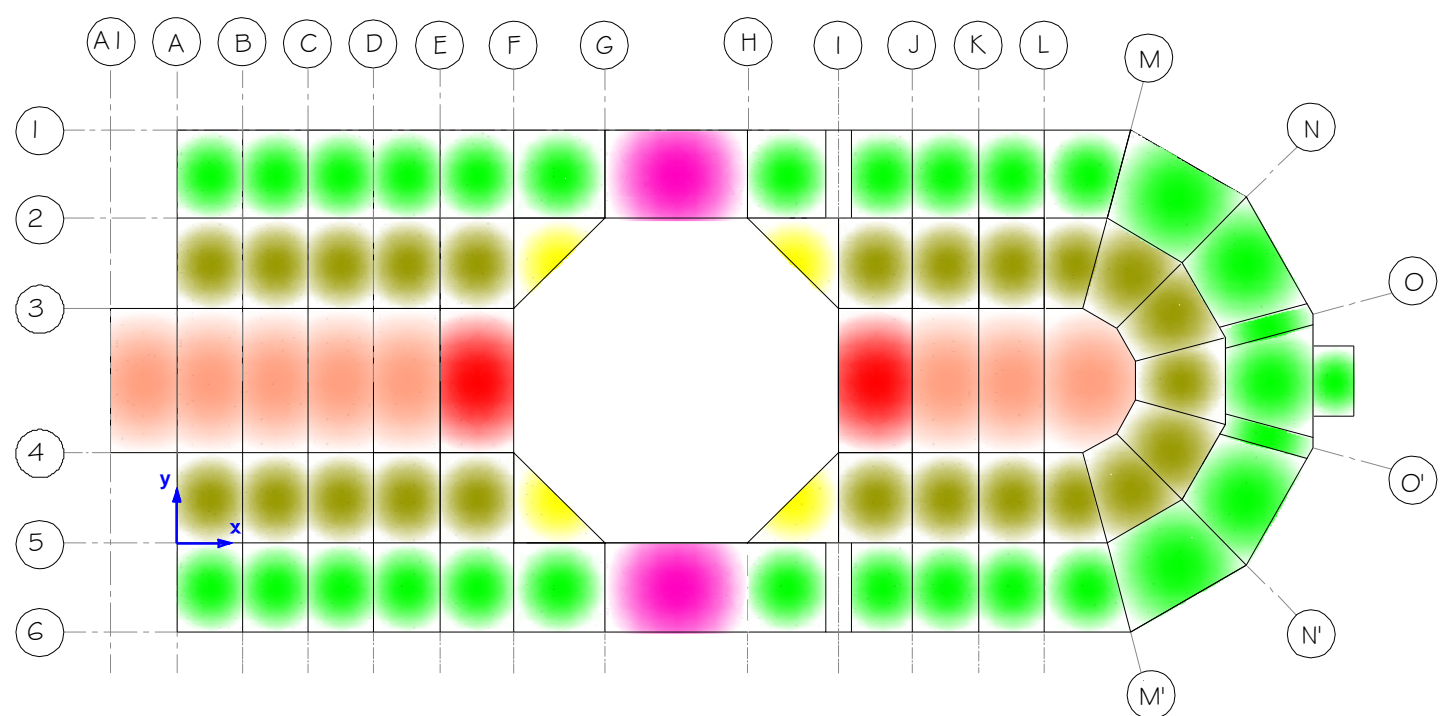

(a)

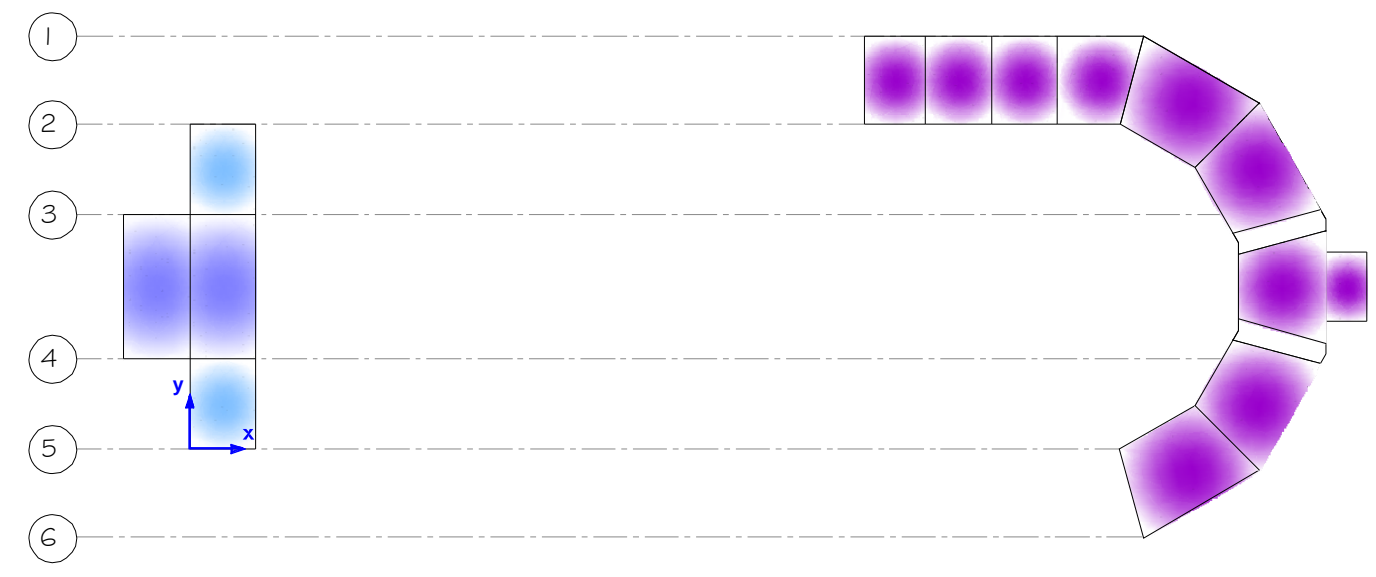

(b)

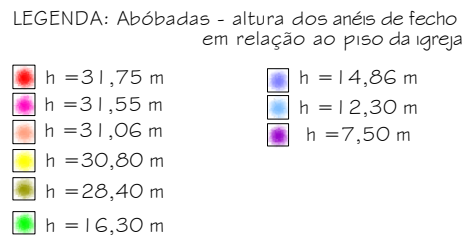

Figura 2.42 - Abóbadas da Catedral da Sé modeladas - mapeamento das alturas dos anéis de fecho: (a) abóbadas das naves central, laterais e laterais externas; (b) abóbadas da região do coro e da região de apoio - naves baixas. 


\subsection{Geometria das torres frontais}

As torres frontais da Catedral da Sé alcançam 92 metros de altura. Só suas flechas têm 32 metros de altura cada (Figura 5.43).

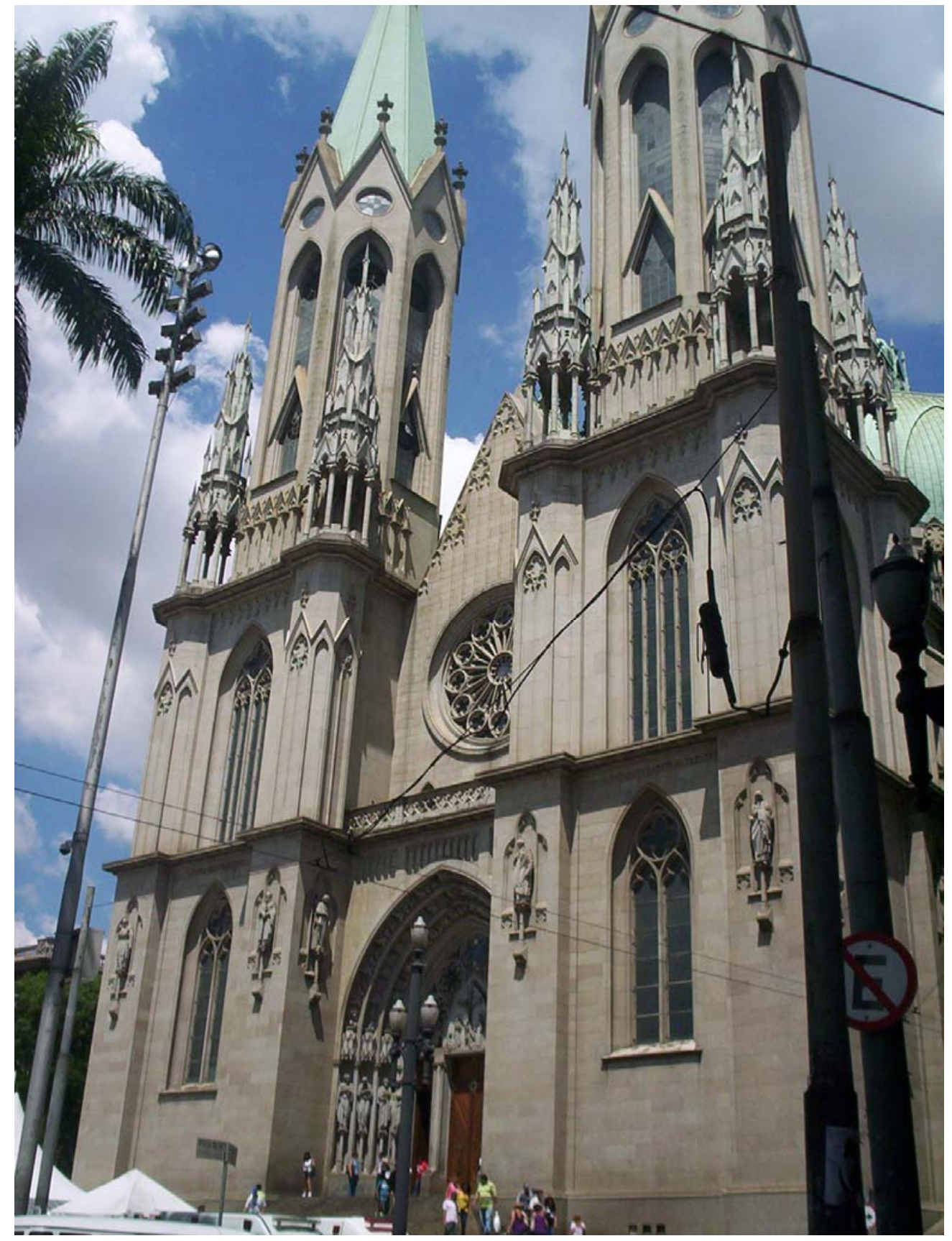

Figura 2.43 - Vista das torres frontais. 
As torres foram inseridas com elementos de barra até o nível da segunda cornija, ou seja, a 29,20 metros do piso de referência, e sua geometria incorpora três pilares da Catedral. A seção transversal original das torres é apresentada na Figura 2.44 .
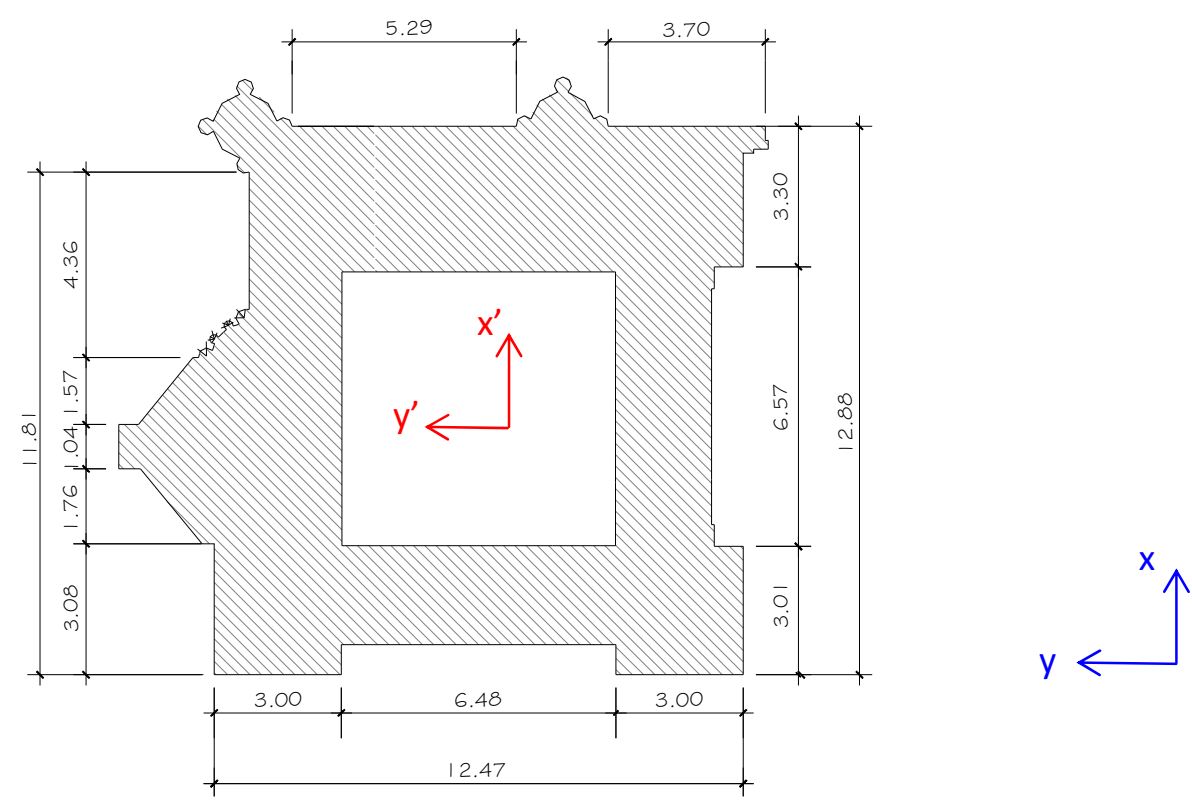

$$
x, y-\text { eixo global }
$$

$x^{\prime}, y^{\prime}-$ eixo local

Figura 2.44 - Seção transversal original das torres até o nível da segunda cornija.

Assim como os contrafortes, para as torres frontais admitiram-se seções equivalentes.

As torres frontais são constituídas por alvenaria de tijolos maciços de barro assentados com argamassa e revestidas somente externamente com granito de espessura estimada em 40 centímetros, de modo que tanto o núcleo como o revestimento estão representados por seção retangular vazada como mostra a Figura 2.45. 


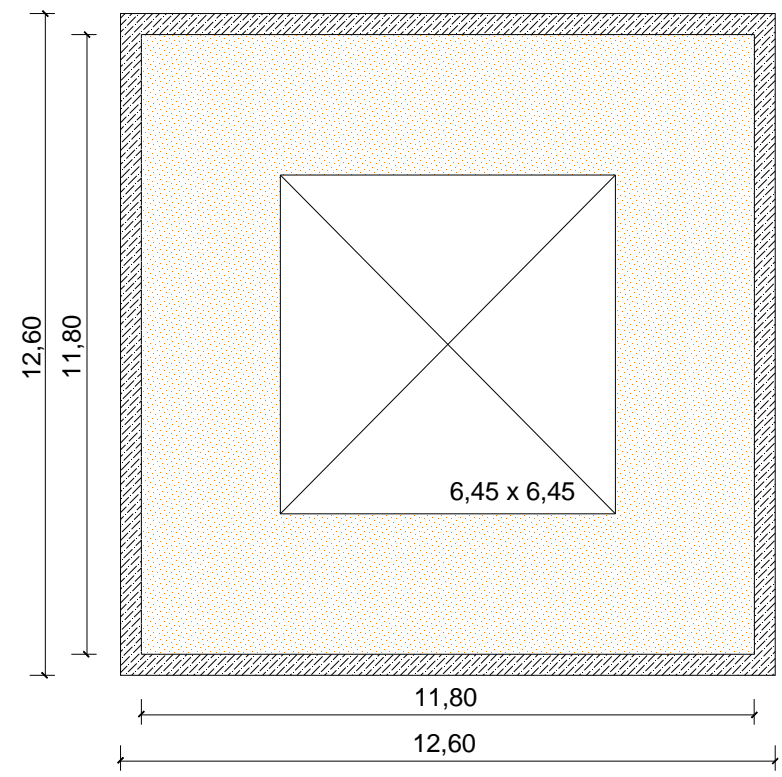

LEGENDA:

alvenaria de tijolos granito

Figura 2.45 - Seção transversal simplificada para as torres frontais.

As características geométricas estão apresentadas na Tabela 2.5.

Tabela 2.5 - Características geométricas das seções transversais adotadas para as torres frontais.

\begin{tabular}{|c|c|c|c|c|c|c|}
\hline \multirow{2}{*}{ Torres Frontais } & \multicolumn{3}{|c|}{ Dimensões (m) } & \multirow{2}{*}{$\begin{array}{c}\text { Área }\left(\mathrm{m}^{2}\right) \\
\text { A }\end{array}$} & \multicolumn{2}{|c|}{ Momento de inércia $\left(\mathrm{m}^{4}\right)$} \\
\hline & base & altura & espessura & & Ix & $l_{Y}$ \\
\hline Núcleo & 11,8 & 11,8 & 2,68 & 97,64 & 1471,42 & 1471,42 \\
\hline Revestimento & 12,6 & 12,6 & 0,40 & 19,52 & 484,75 & 484,75 \\
\hline
\end{tabular}

No modelo, os torreões, que ladeiam cada uma das torres e se apóiam no maciço de alvenaria, e a própria cornija de granito estão aplicados como carga.

O corpo das torres, internamente, possui quatro pilares em concreto armado sem ligação com o maciço de alvenaria de tijolos como mostra a Figura 2.46, e, por esta razão, eles não estão modelados. Sua principal função é de sustentar a estrutura da torre de concreto armado existente acima do nível da segunda cornija, que inclui o vigamento dos níveis superiores da torre e a agulha (RAMIREZ, 2005, p.126-140). 


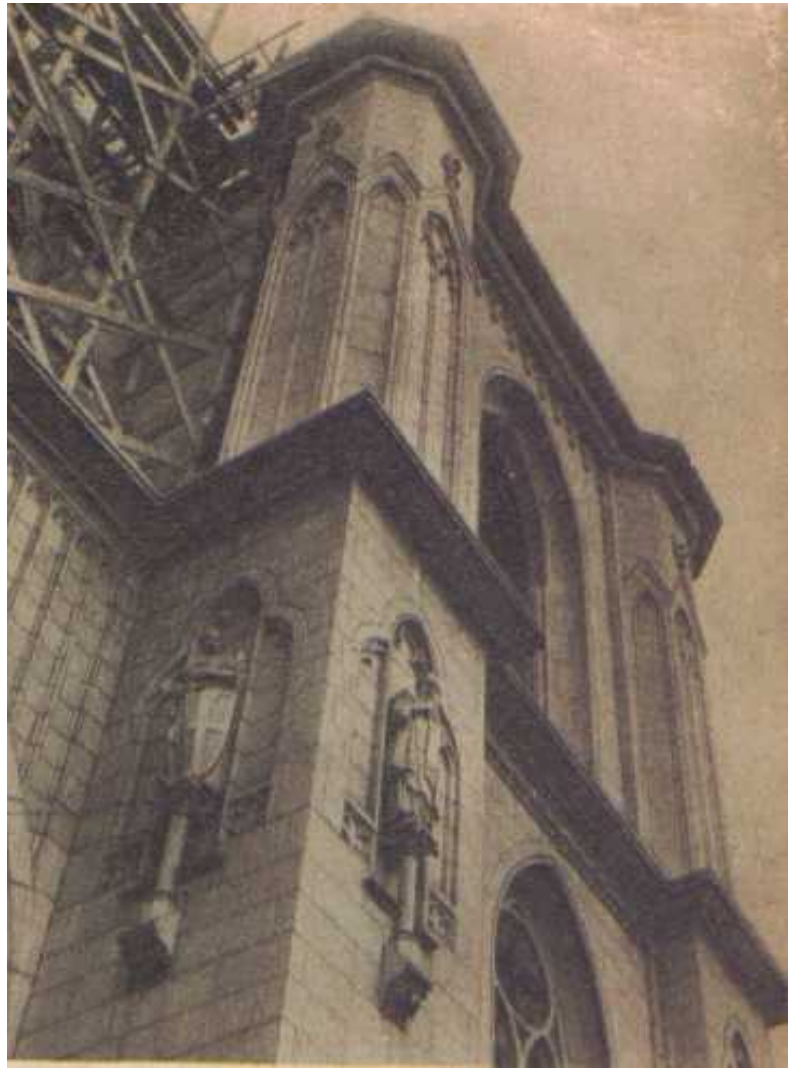

(a)

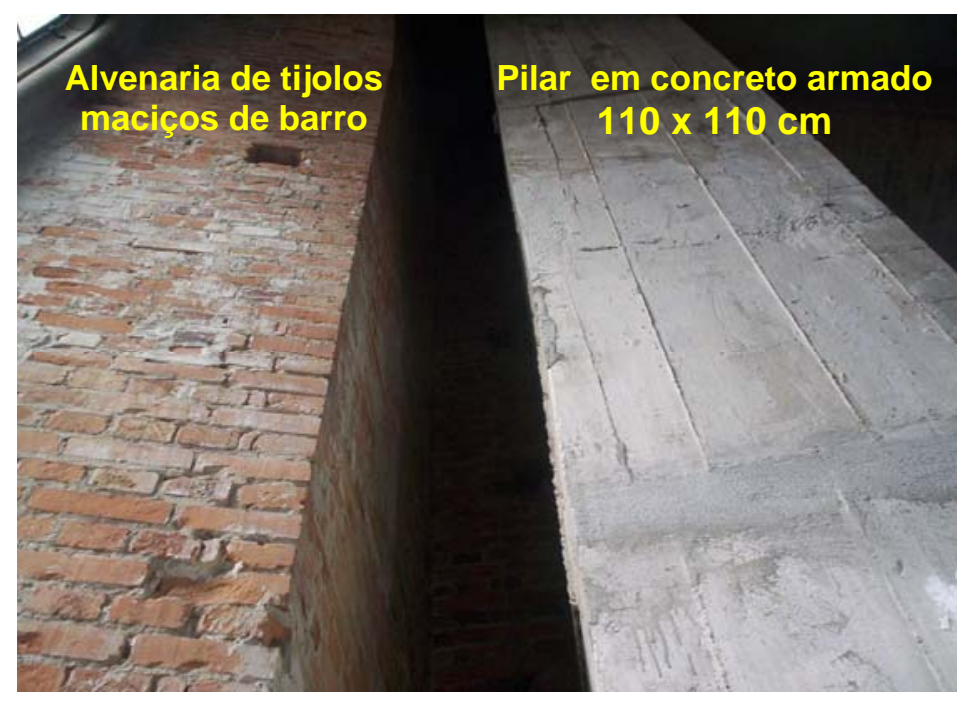

(c)

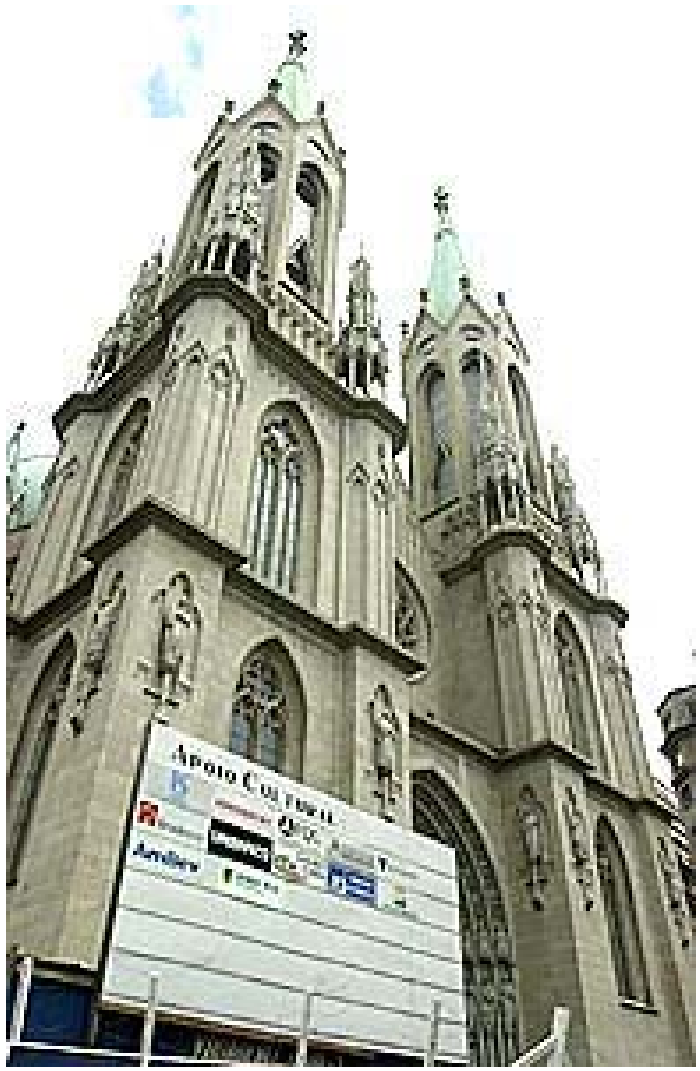

(b)

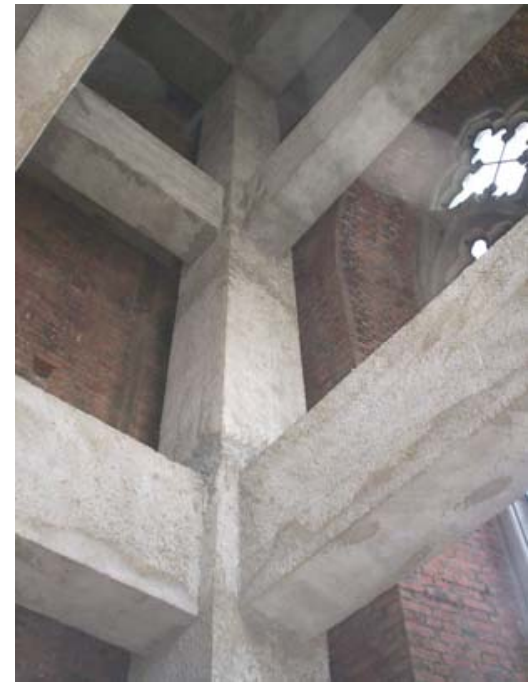

(d)

Figura 2.46 - Torres frontais da Catedral da Sé: (a) torre direita em construção até a altura da segunda cornija (COMISSÃO EXECUTIVA DAS OBRAS DA NOVA CATEDRAL DE SÃO PAULO, [194-], sem numeração de página); (b) vista das duas grandes torres durante a reforma (FOLHA on line: site, 2002); (c) torre esquerda - maciço de alvenaria de tijolos e pilar de concreto; (d) estrutura de concreto da torre direita - vigas e pilares entre a primeira e segunda cornija (RAMIREZ, 2005, p.129 130). 


\section{MATERIAIS E SUAS CARACTERÍSTICAS MECÂNICAS}

Uma definição precisa das características mecânicas dos materiais exigiria ensaios destrutivos à edificação, o que não se teve a disponibilidade de realizar. Admitiram-se propriedades mecânicas com base em revisão da literatura associada à identificação dos materiais existentes no local.

$\mathrm{Na}$ análise elástica linear, devem ser fornecidas ao programa duas características mecânicas: o módulo de elasticidade e coeficiente de Poisson.

Os materiais que compõem os elementos estruturais são o concreto simples, o concreto armado, a alvenaria de tijolos maciços de barro cozido e a de granito, sendo que esta última encontra-se tanto em forma de placas de revestimento como na forma de maciços talhados. O granito nacional foi extraído uma pedreira já em início de exploração e localizada a quatro quilômetros da estação de Ribeirão Pires, tendo sido adquirida pela Comissão Executiva de obras da Catedral (MATTOS, 1992). No modelo, admite-se para todos estes materiais homogeneidade e isotropia.

\subsection{Peso específico $[\gamma]$}

Para a alvenaria de granito, o peso específico adotado é de $28 \mathrm{kN} / \mathrm{m}^{3}$, seguindo a recomendação da norma NBR 6120 (1980): cargas para cálculo de estruturas em edificações, que, aliás, também serve como referência para a alvenaria de tijolos e para os concretos.

No caso da alvenaria de tijolos maciços de barro, o peso específico adotado é de $18 \mathrm{kN} / \mathrm{m}^{3}$. Moliterno (1995, p.10) apresenta uma faixa de valores para o material entre 16 e $18 \mathrm{kN} / \mathrm{m}^{3}$.

Já para o concreto simples, o peso específico admitido é de $24 \mathrm{kN} / \mathrm{m}^{3}$, e para o concreto armado, o peso específico é $25 \mathrm{kN} / \mathrm{m}^{3}$. 


\subsection{Coeficiente de Poisson $[\nu]$}

O coeficiente de Poisson para o granito encontra-se numa faixa entre 0,2 e 0,3 segundo Gere (1997, p.889). Para efeitos desta pesquisa, admite-se o valor médio, com $\nu$ igual a 0,25 .

Em relação à alvenaria de tijolos, pode-se dizer que é dificultoso definir suas características mecânicas, por se tratar de um material heterogêneo e anisotrópico e que tem como variável o tipo de argamassa. Lourenço (2001, p.103), apesar de não especificar o tipo de tijolo, admite coeficiente de Poisson 0,2 , valor este que é adotado para o material presente na Catedral da Sé.

Já para os concretos simples e armado, o coeficiente de Poisson é igual a 0,2 (NBR 6118, 2000).

\subsection{Módulo de elasticidade [E]}

Na literatura, os valores para o módulo de elasticidade da alvenaria de granito são muito variáveis, pois dependem de como as unidades estão dispostas, de modo regular ou irregular, se foram talhadas ou não, assim como da qualidade e da espessura da argamassa de assentamento. Lembra-se que o valor do módulo de elasticidade da alvenaria de granito é muito menor que o da própria pedra de granito ensaiada isoladamente.

Em Lubowiecka (2009), admitem-se para a alvenaria de granito de uma ponte do século XV valores para o módulo de elasticidade entre $15.000 \mathrm{MPa}$ e 23.000 MPa; neste estudo não há descrição da argamassa de assentamento.

Já Zeng (2009) apresenta resultados na determinação do módulo de elasticidade em alvenarias de granito a partir de ensaios experimentais. Estes valores encontram-se entre 28.400 MPa e 31.300 MPa. Os blocos de granito foram cortados e dispostos em fiadas de modo regular e assentados com argamassa de cimento Portland e agregados miúdos com espessura uniforme com 12,7 milímetros.

Em Beton Kalender, (1954, p.97) se apresenta o módulo de elasticidade da alvenaria de granito em duas situações; se ela estiver disposta em fiadas, o módulo 
de elasticidade é de $30.000 \mathrm{MPa}$ e, para a alvenaria de granito com a pedra talhada, é de $35.000 \mathrm{MPa}$.

Na Catedral da Sé, as pedras foram talhadas manualmente e estão dispostas de modo regular, justapostas formando um conjunto quase homogêneo. A argamassa de assentamento é de cal, areia e cimento com espessura de 8,0 milímetros nos contrafortes e na base dos pilares e, de 5,0 milímetros no corpo principal dos pilares (Figura 3.1). Admite-se para a alvenaria de granito da Catedral da Sé, módulo de elasticidade de $32.000 \mathrm{MPa}$, valor intermediário aos propostos em Beton Kalender (1954).

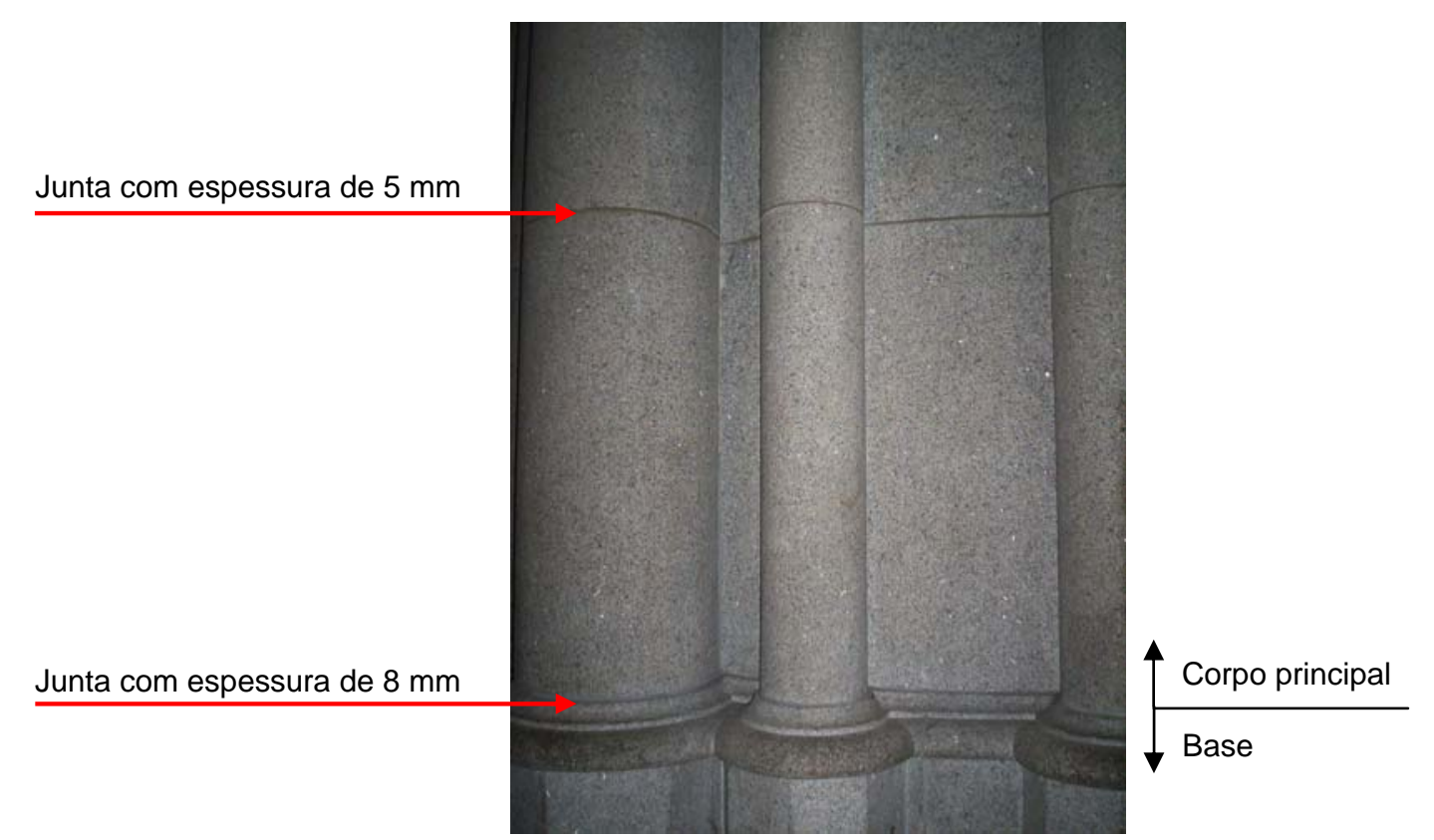

Figura 3.1 - Alvenaria de granito de um dos pilares do octógono; destaque para as juntas de argamassa.

Para a alvenaria de tijolos de barro cozido, adota-se o módulo de elasticidade 5.000 MPa. Kaushik (2007), por exemplo, afirma que a alvenaria de tijolos de barro assentada com argamassa de boa qualidade pode ser considerada com um módulo de elasticidade entre 3.500 e 5.200 MPa.

Em relação ao concreto, considerando a época de construção da Catedral da Sé, principalmente durante a primeira metade do século $X X$, estima-se que 0 concreto simples tenha resistência à compressão característica, fck igual a $12 \mathrm{MPa} e$ que o concreto armado tenha um fck de $15 \mathrm{MPa}$.

A NBR 6118, item 7.1.8, recomenda que, na avaliação do comportamento global da estrutura, possa-se assumir o módulo de elasticidade Eci. E como não 
foram encontrados dados mais precisos sobre os concretos da Catedral, nem foram realizados ensaios, o módulo de elasticidade inicial, Eci, para o concreto aos 28 dias pode ser estimado pela seguinte expressão:

$$
E_{c i}=5600 . f c k^{\frac{1}{2}}
$$

onde Eci e fck são dados em MPa.

Assim, na análise global da estrutura, em que são avaliadas as deformações do conjunto, adota-se para o concreto simples módulo de elasticidade de 20.000 $\mathrm{MPa}$, e para o concreto armado, 22.000 MPa.

Em resumo, as características mecânicas dos materiais estruturais consideradas no estudo do comportamento da Catedral da Sé de São Paulo estão apresentadas na Tabela 1.

Tabela 3.1 - Características mecânicas dos materiais

\begin{tabular}{cccc}
\hline Material & $\begin{array}{c}\text { Módulo de elasticidade } \\
(\mathrm{MPa})\end{array}$ & Coeficiente de Poisson & $\begin{array}{c}\text { Peso específico } \\
\left(\mathrm{kN} / \mathrm{m}^{3}\right)\end{array}$ \\
\hline Alvenaria de granito & 32000 & 0,25 & 28 \\
\hline $\begin{array}{c}\text { Alvenaria de tijolos de } \\
\text { barro }\end{array}$ & 5000 & 0,20 & 18 \\
\hline Concreto simples & 20000 & 0,20 & 24 \\
\hline Concreto armado & 22000 & 0,20 & 25 \\
\hline
\end{tabular}

\subsection{Materiais dos elementos estruturais modelados}

Como comentado no Capítulo 2, os pilares da Catedral da Sé possuem um núcleo de concreto simples envolvido por granito, exceto para os pilares laterais acima da elevação de 11 metros que, como os contrafortes, são constituídos por alvenaria de tijolos envolvidos por granito.

No modelo, os dois materiais que constituem os contrafortes, os pilares e as torres frontais estão representados por elementos de barra distanciados entre si de um milímetro. 
Admite-se que a ligação entre o núcleo e o revestimento ao longo dos elementos de apoio seja contínua. No modelo, isto está simulado com barras rígidas horizontais ligando os dois materiais a cada 25 milímetros. A Figura 3.2 mostra os materiais aplicados nos pilares, contrafortes e torres do modelo desenvolvido.

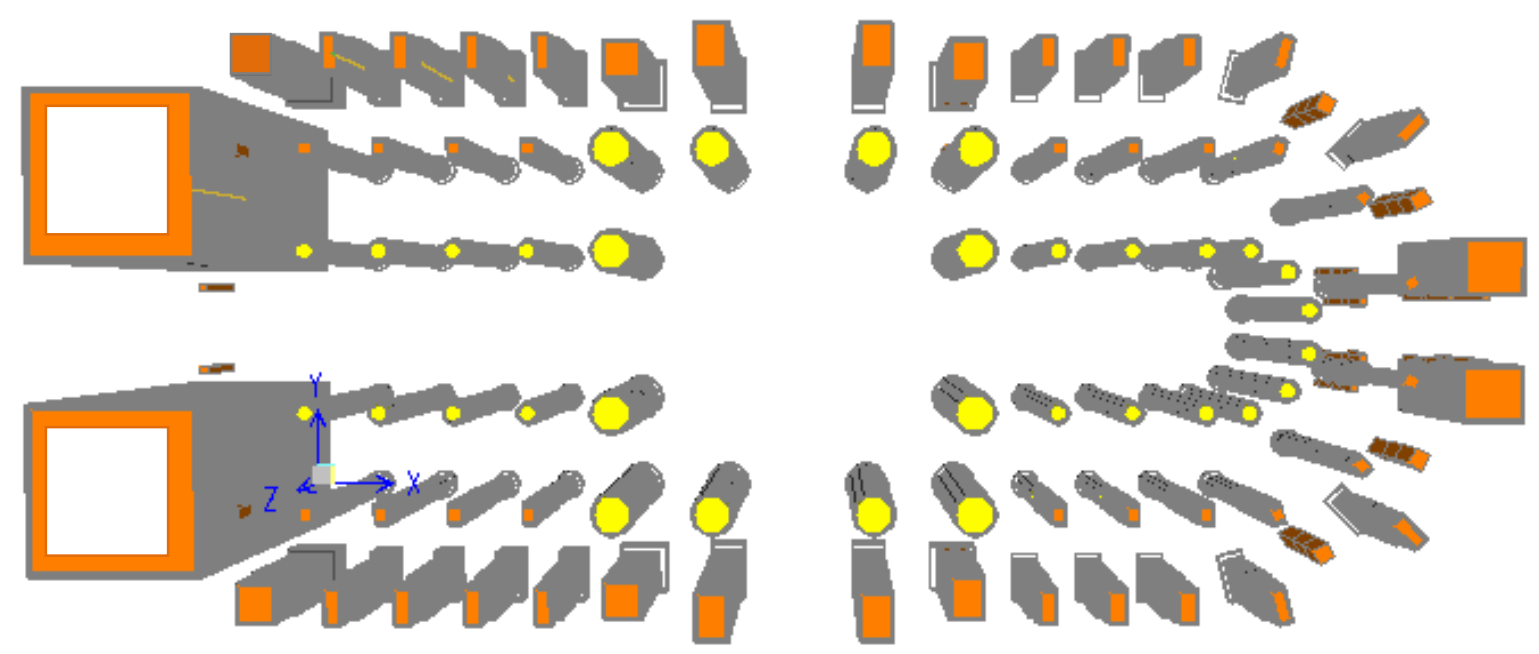

(a)

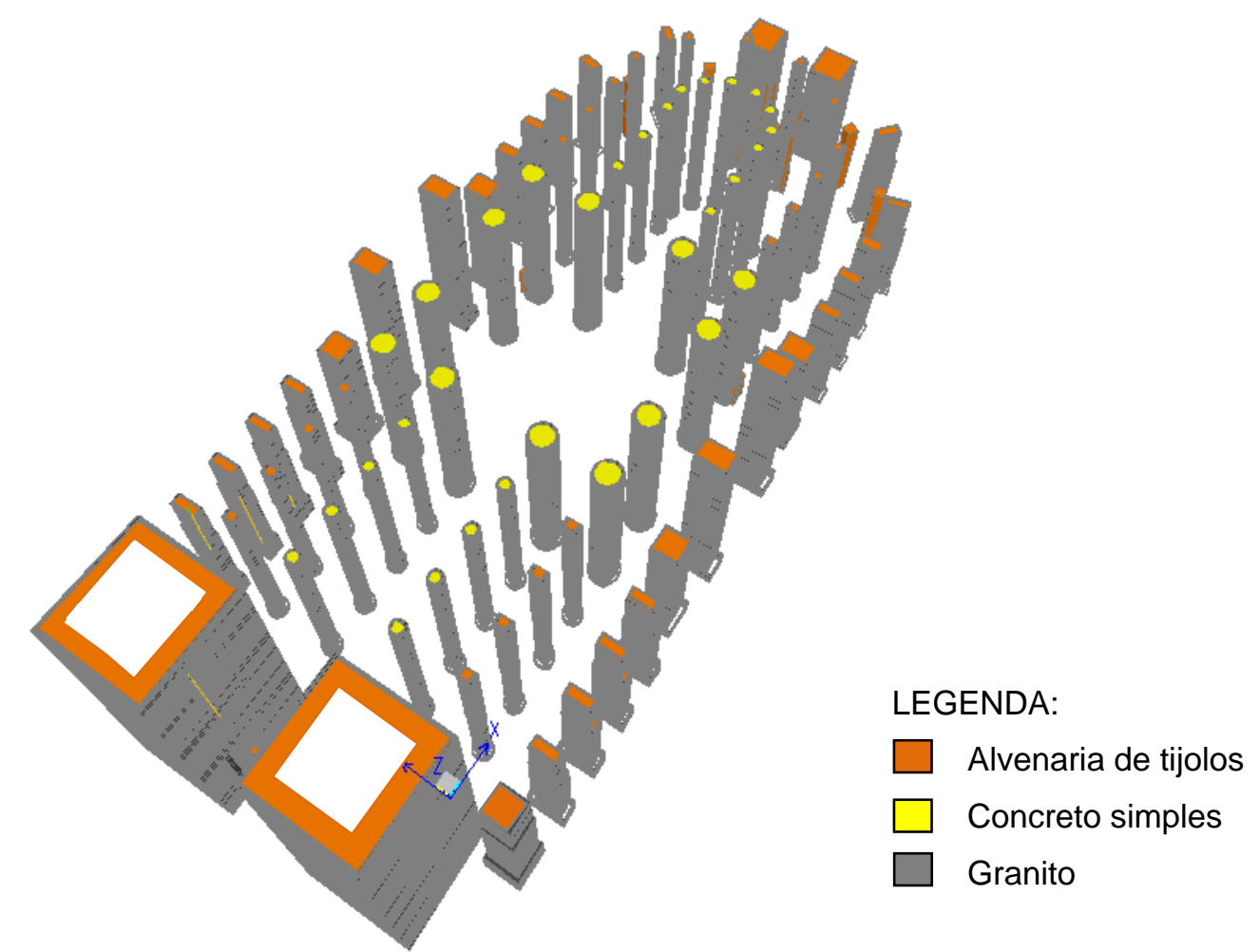

(b)

Figura 3.2 - Modelo da Catedral da Sé: materiais aplicados nos pilares, contrafortes e nas duas torres frontais: (a) vista superior; (b) vista superior oblíqua. 
Os arcobotantes da Catedral desenvolvem-se a partir da elevação de 16 metros até o topo dos pilares, e, como comentado, admite-se que sejam constituídos por maciços de granito (Figura 3.3).
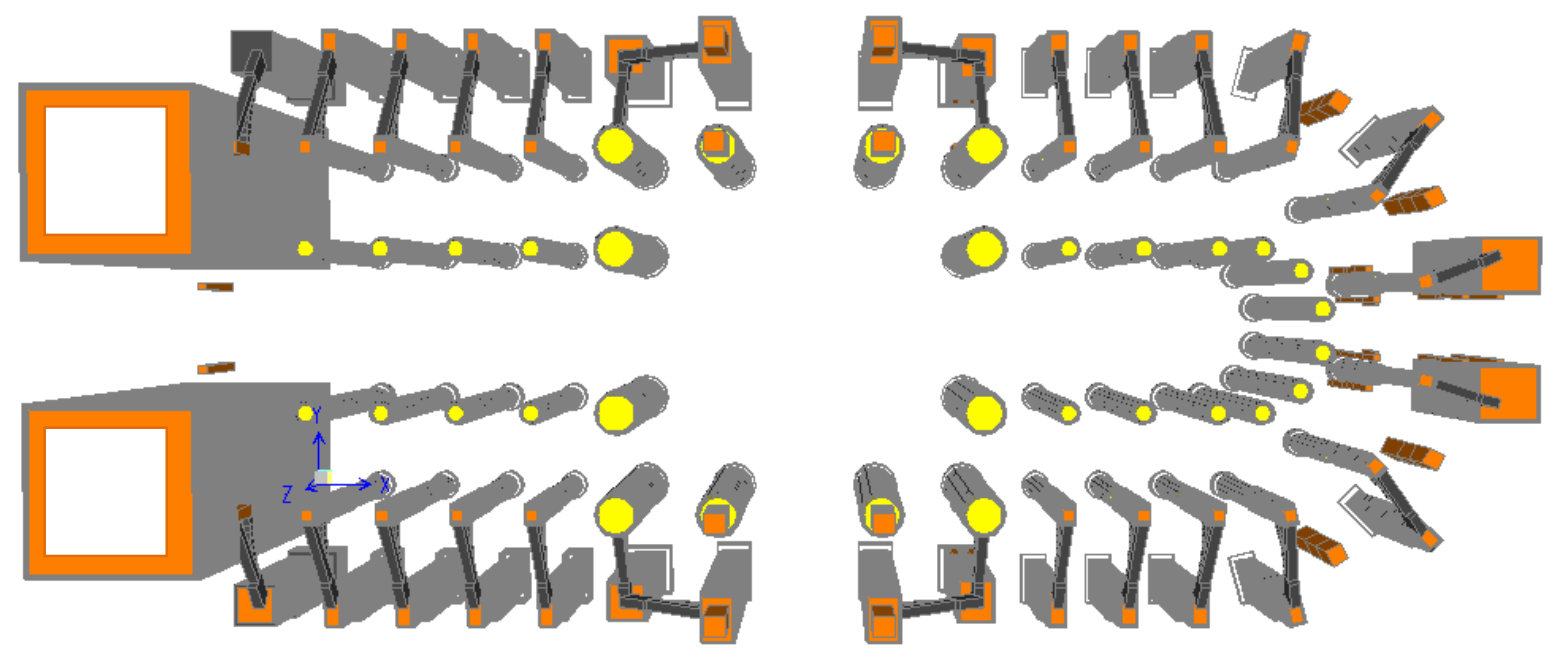

(a)
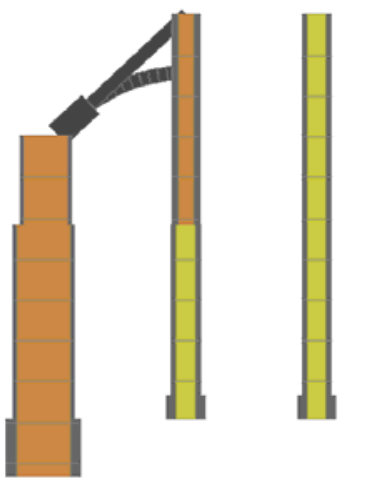

(b)
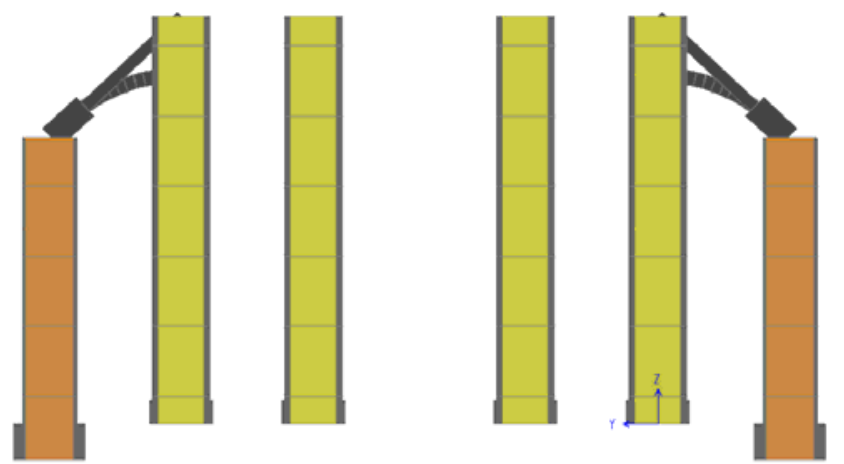

(c)

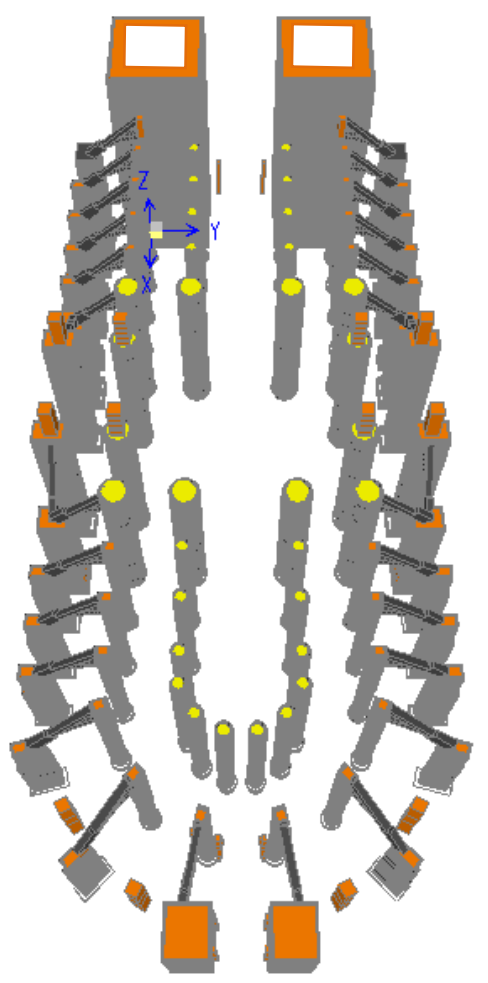

(d)

LEGENDA:

Alvenaria de tijolos

Concreto simples

Granito

Figura 3.3 - Modelo da Catedral da Sé: (a) locação dos arcobotantes em planta; (b) seção no eixo E; (c) seção no eixo F; (d) vista da região posterior. 
O granito, talhado manualmente pelos trabalhadores ao longo da primeira metade do século XX, constitui a maioria dos arcos da Catedral da Sé.

Abaixo, a Figura 3.4 mostra os poucos arcos que se admitiu serem de alvenaria de tijolos após inspeção visual em visitas à igreja.

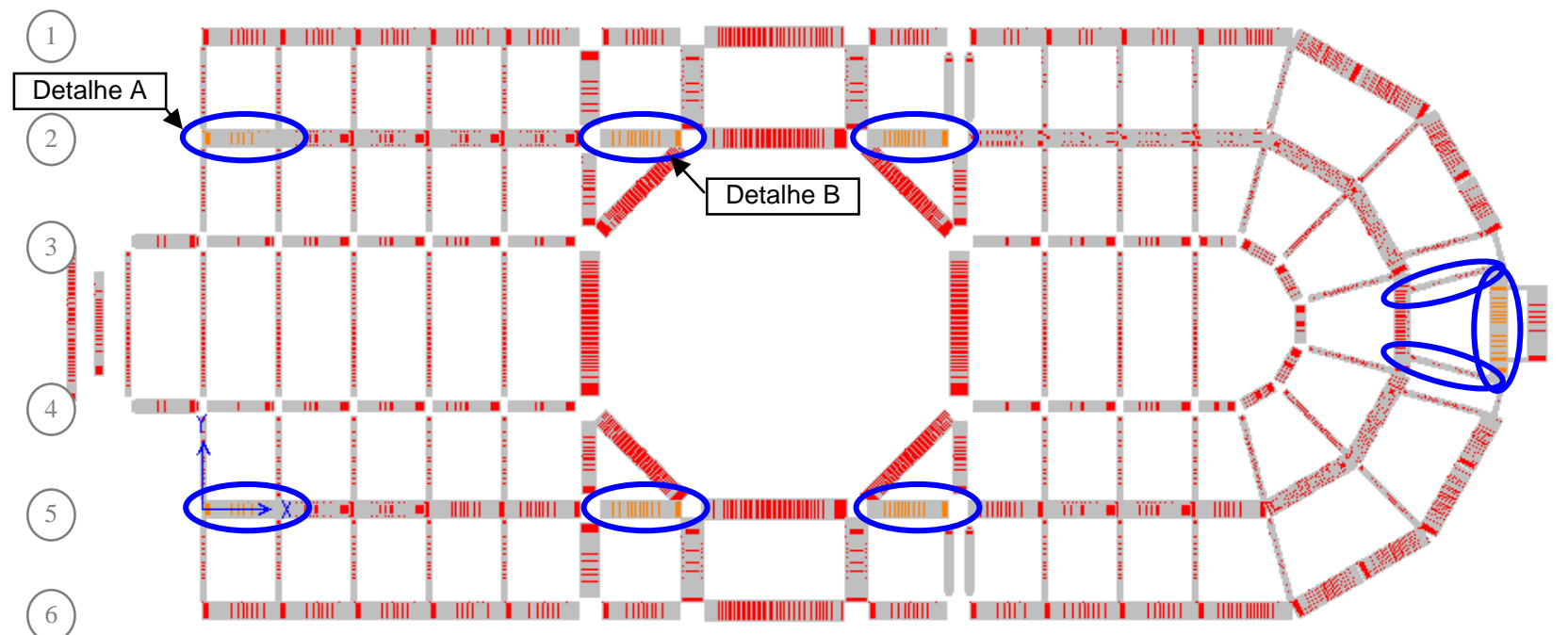

(a)
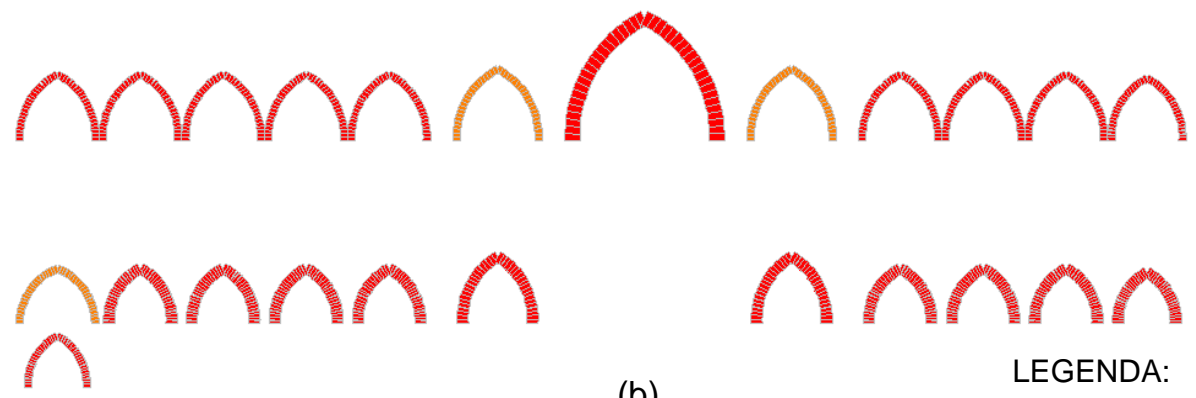

(b)

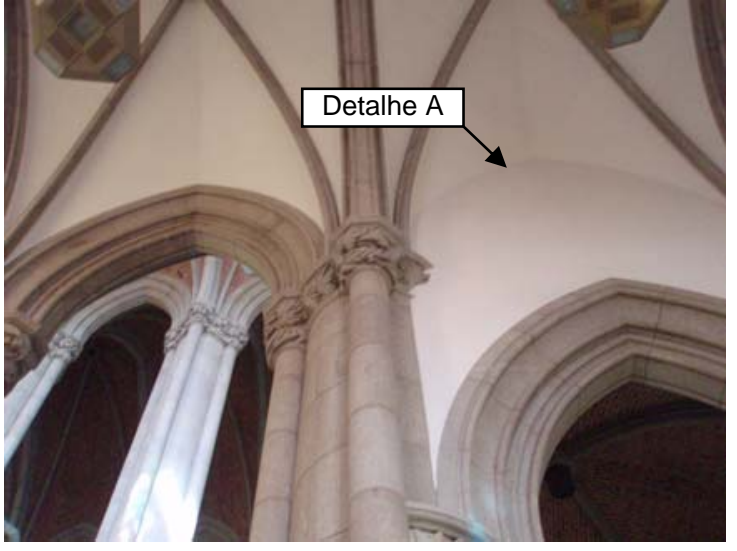

(c)

\section{LEGENDA:}

$\square$ Alvenaria de tijolos

$\square$ Granito

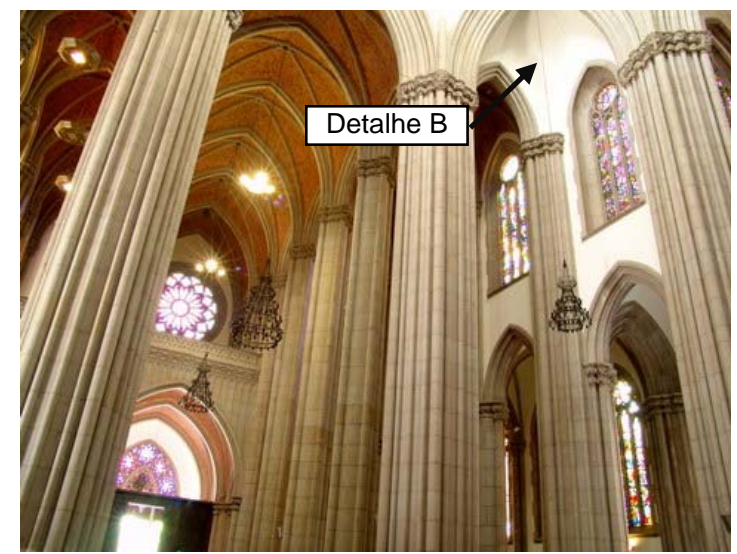

(d)

Figura 3.4 - Mapeamento dos materiais dos arcos da Catedral da Sé: (a) marcação em planta dos arcos de alvenaria de tijolos; (b) modelo com corte longitudinal do eixo 5; (c) detalhe A (LINDENBERG NETO, 2007); (d) detalhe B (DACIOLE, 2008). 
Os materiais que constituem a maioria das abóbadas da Catedral são o granito presente em suas nervuras e os tijolos de barro dispostos em fiadas que formam os seus panos. Dependendo da sua localização, estas abóbadas são revestidas internamente com argamassa.

Já as abóbadas do transepto e as abóbadas dos nomeados "triângulos", localizadas junto ao octógono, são de concreto armado (Figura 3.5), segundo Nishida (informação verbal, 2004) ${ }^{2}$.

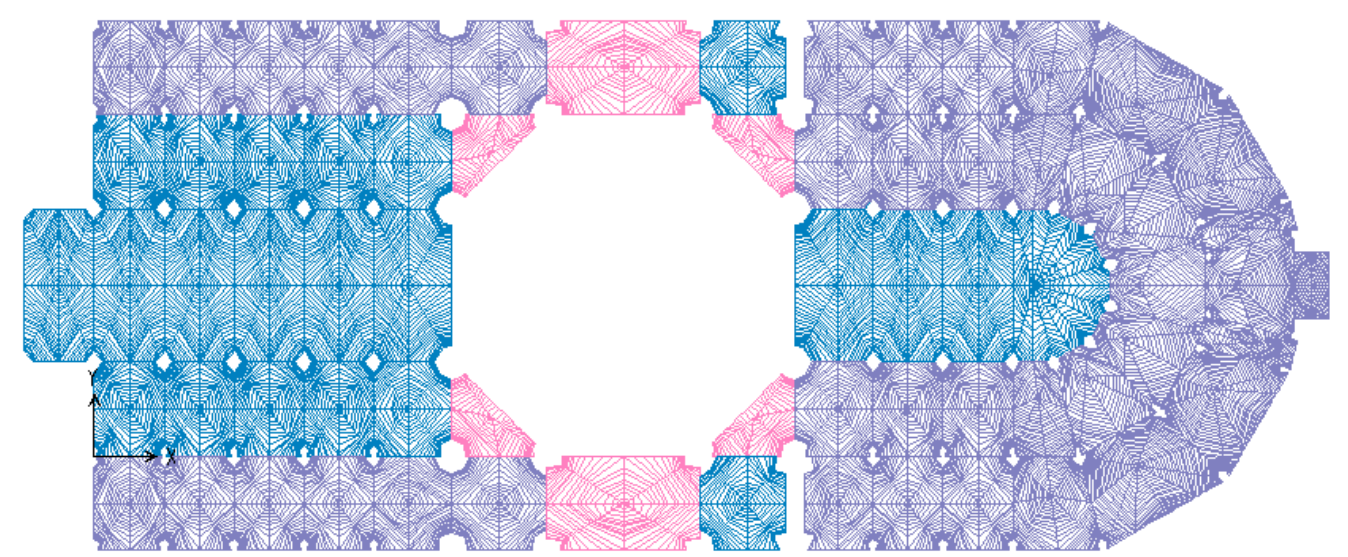

(a)
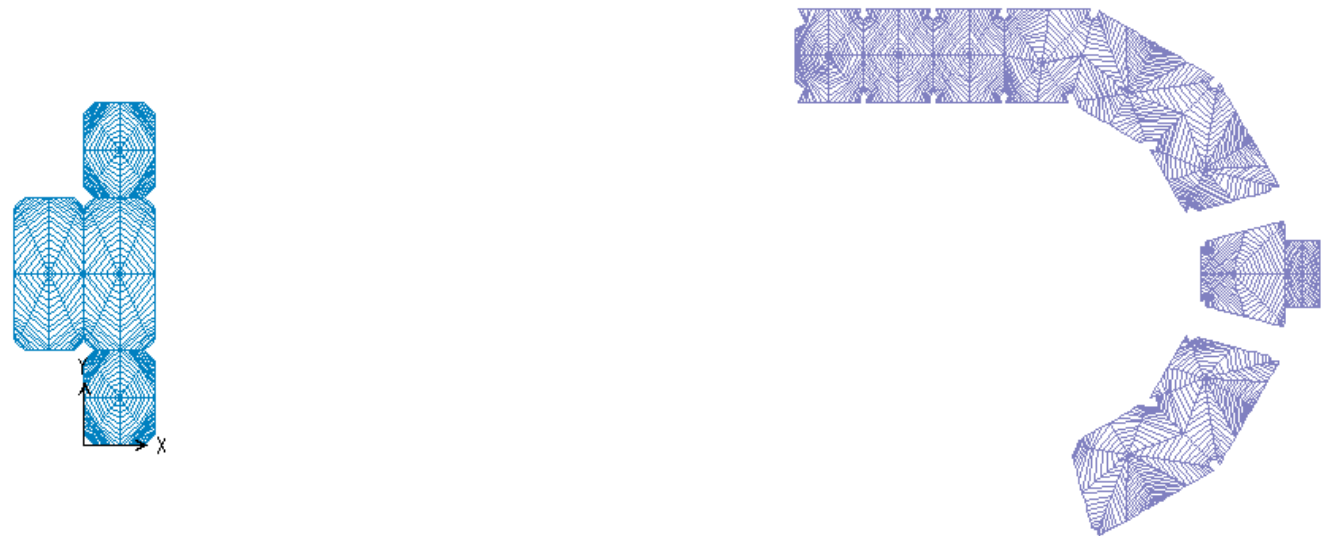

(b)

LEGENDA:

Material do pano das abóbadas da Catedral

$\square \quad$ Alvenaria de tijolos revestida com argamassa

$\square \quad$ Alvenaria de tijolos sem revestimento

$\square \quad$ Concreto armado

Figura 3.5 - Elementos de casca no modelo da Catedral: (a) abóbadas das naves principal, laterais e laterais externas; (b) abóbadas do coro e abóbadas do nível baixo - áreas de apoio.

\footnotetext{
${ }^{2}$ Informação fornecida por Nishida, M.K. Concrejato Serviços Técnicos de Engenharia S/A em 2 ago de 2004. (Depoimento).
} 
Para avaliar a correta rigidez da Catedral é necessário considerar a presença das abóbadas, que foram geradas a partir de elementos de casca.

A disposição das fiadas de tijolos é ilustrada na Figura 3.6. Admite-se que os panos das abóbadas tenham 22 centímetros de espessura e quando revestidos com argamassa, 24,5 centímetros. Quanto às nervuras de granito, admite-se uma seção transversal aproximada retangular de 20 x 30 centímetros.

Para as abóbadas de concreto armado modeladas, adota-se espessura de 20 centímetros.

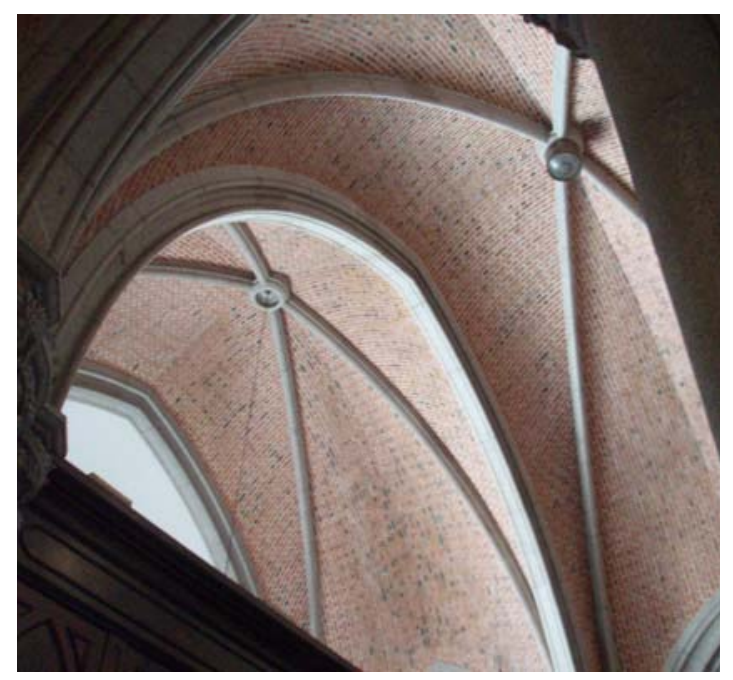

(a)

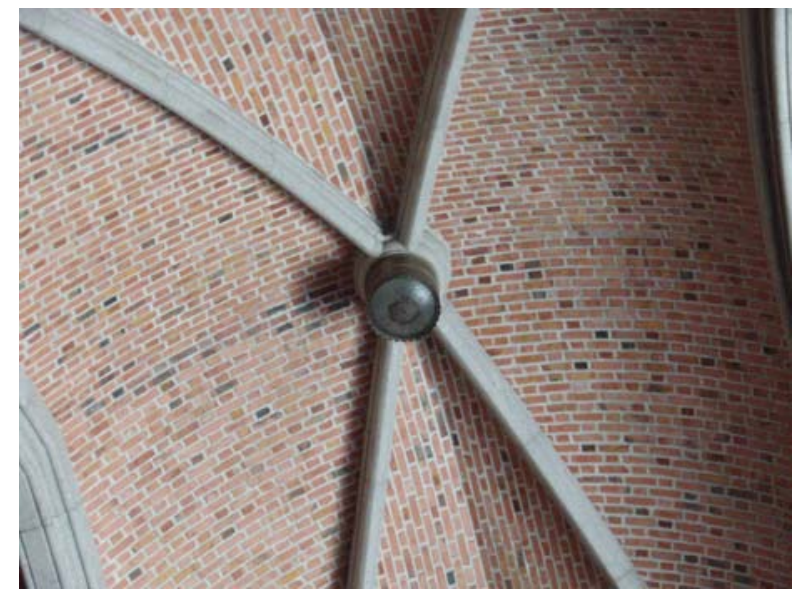

(c)

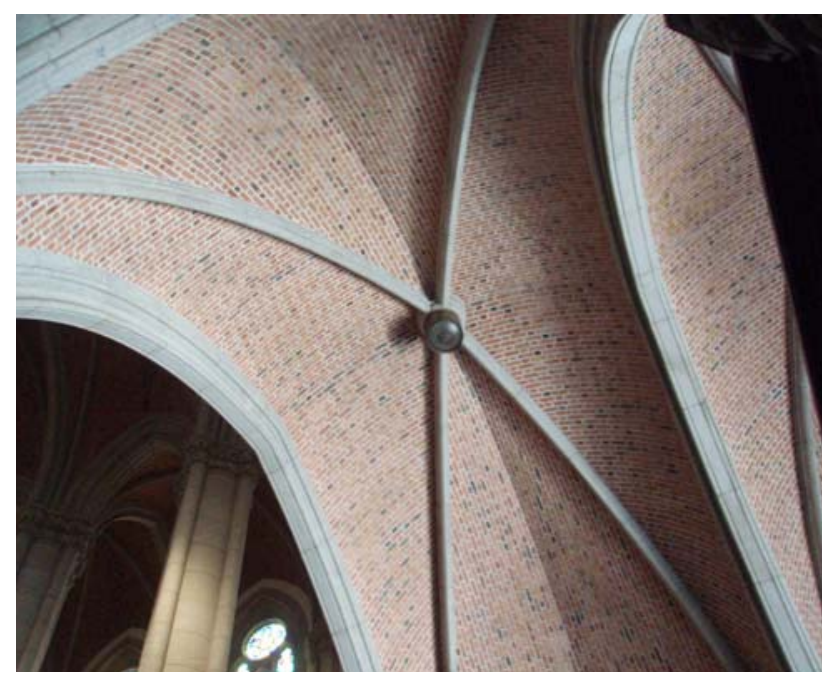

(b)

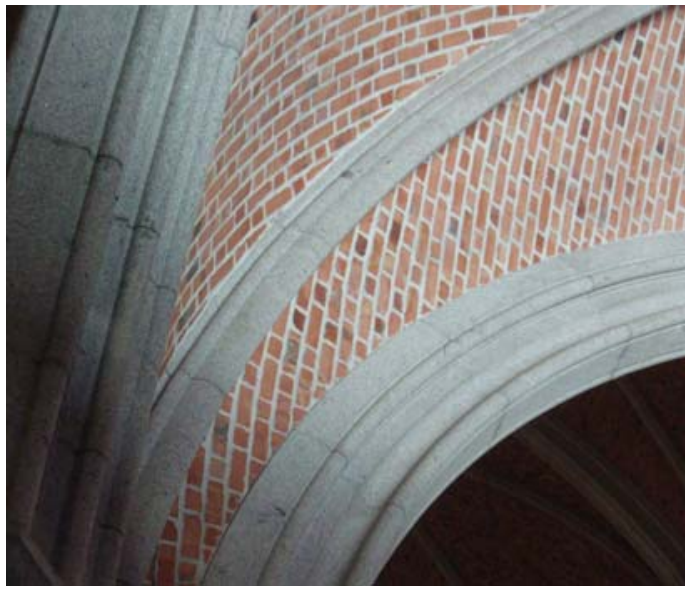

(d)

Figura 3.6 - Detalhe da disposição das fiadas de tijolos nos panos das abóbadas: (a) abóbadas quadripartidas da nave central; (b) abóbada sobre os arcos que suportam o coro, com vão de 12 metros; (c) detalhe do anel de fecho e da disposição das fiadas de tijolos; (d) detalhe da chegada da fiada na nervura de granito (LINDENBERG NETO, 2007). 
O tambor octogonal em que se apóia a cúpula também foi modelado. As nervuras graníticas estão representadas com elementos de barra enquanto a alvenaria de tijolos, por elementos de casca (Figura 3.7).

A cúpula interna, de concreto armado, possui oito nervuras representadas por elementos de barras e seus panos, por elementos de casca. A cúpula externa, composta por meridianos e paralelos, está toda representada por elementos de barra, seguindo a geometria apresentada no Capítulo 2.

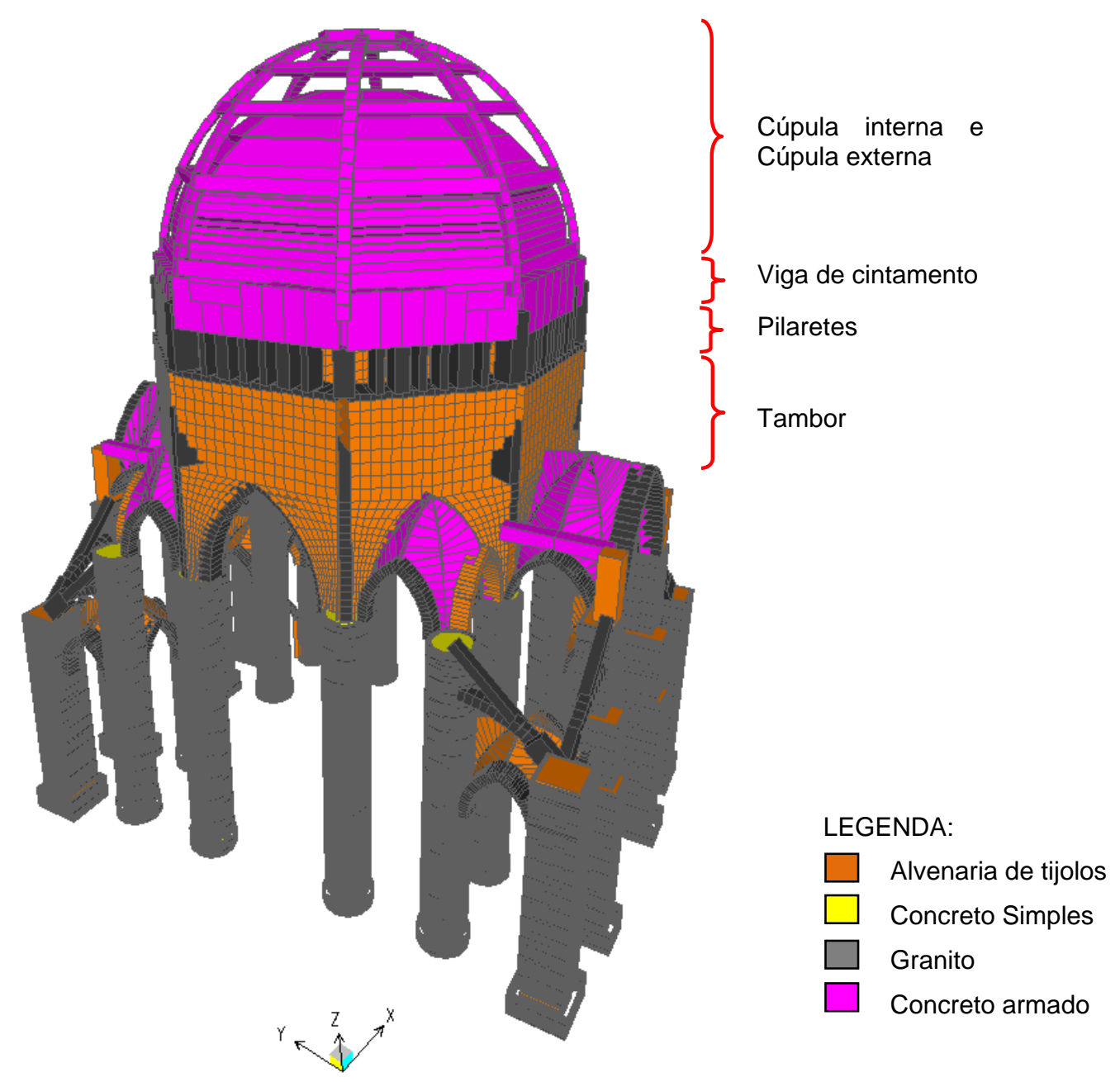

Figura 3.7 - Modelo da região do octógono. 
Abaixo, a Figura 3.8 ilustra a estrutura da Catedral da Sé modelada e os seus materiais.

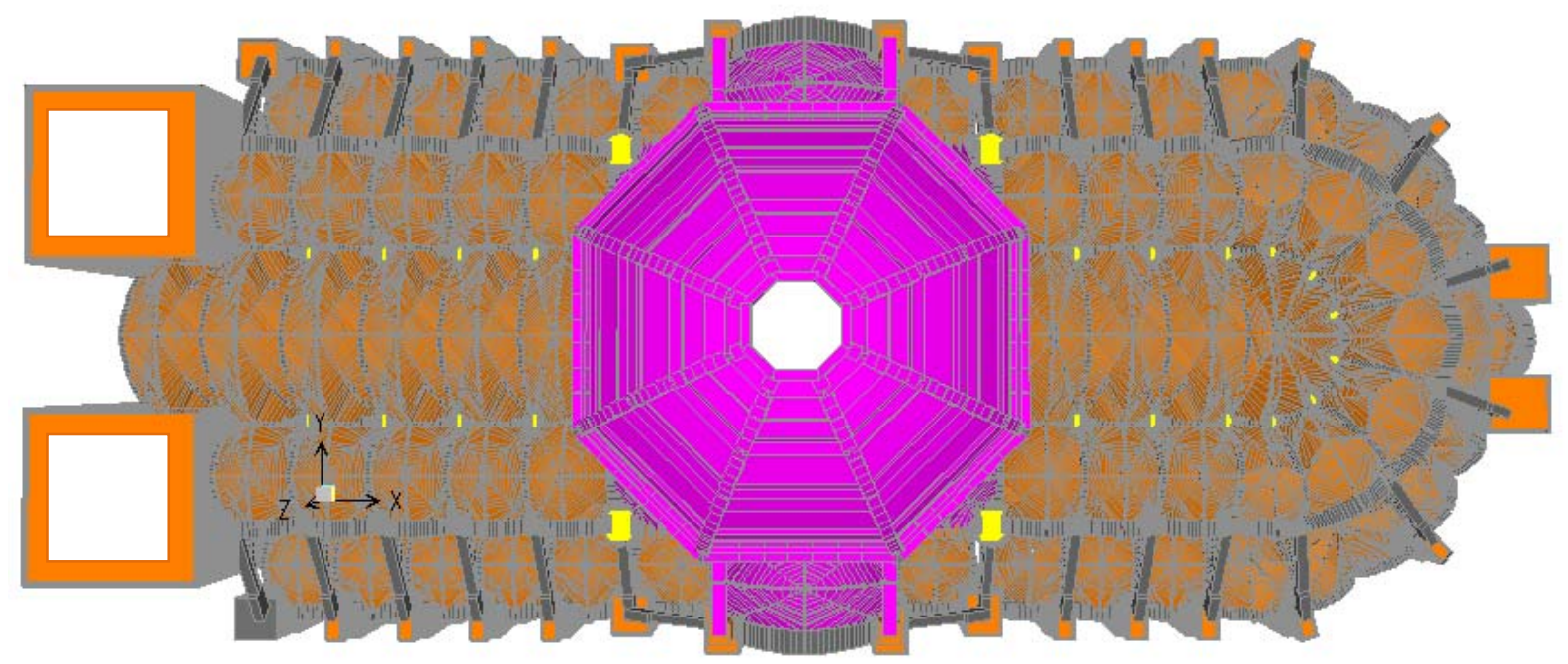

(a)

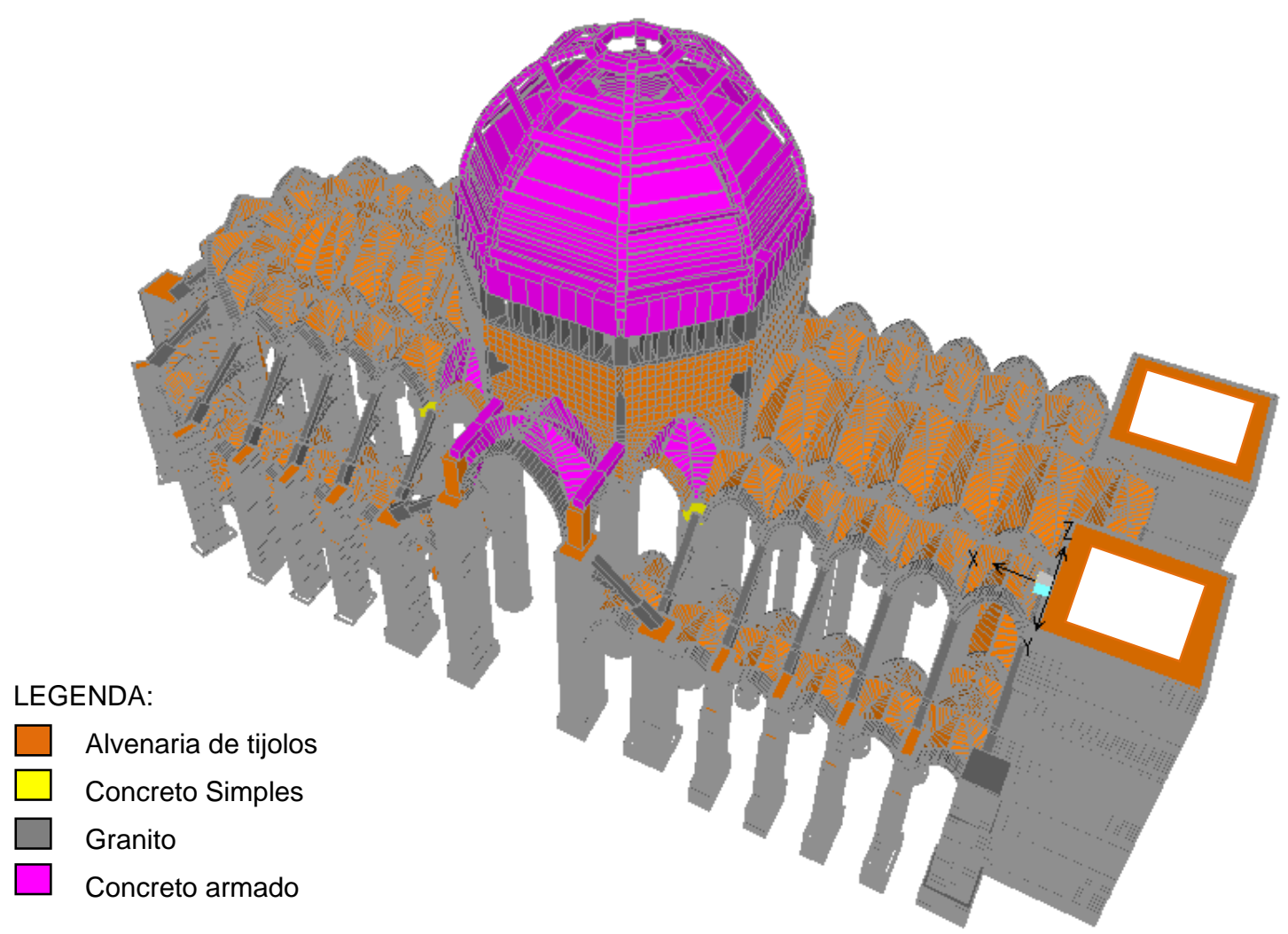

(b)

Figura 3.8 - Modelo da Catedral da Sé de São Paulo - materiais estruturais: (a) vista superior; (b) vista oblíqua. 


\section{ESTIMATIVA DOS CARREGAMENTOS}

Neste capítulo, são apresentados os carregamentos atuantes na Catedral da Sé. São eles a carga permanente, a sobrecarga e os carregamentos horizontais do vento e do desaprumo.

A carga permanente aqui tratada corresponde a todo o peso da edificação, e inclui pilares, contrafortes, paredes, abóbadas, arcos, arcobotantes, tambor, cúpula, lanternim, telhados, torres e escadas; e ainda as cornijas, os pináculos, as lajes, os vitrais e os adornos fixos típicos do gótico.

Considerou-se além desta, a sobrecarga estimada de acordo com a NBR 6120: cargas para o cálculo de estruturas em edificações, e inclui a circulação de pessoas, a presença de móveis e todo o carregamento que pode atuar na estrutura em função de seu uso.

Há ainda a ação do vento, calculada a partir da NBR 6123: ações do vento em edificações.

Com relação à ação permanente do desaprumo, a norma alemã DIN 1053: alvenaria - cálculo e execução e a norma brasileira de concreto NBR 6118, item 11.2.3.4, recomendam que ela seja comparada com a ação do vento, verificando qual é mais significativa para a estrutura da igreja.

De acordo com a NBR 6118, a ação do vento e a ação do desaprumo não precisam ser superpostas. Entre elas, pode ser considerada somente aquela que provoca o maior momento de tombamento na base da construção. A consideração da ação do vento nas edificações é obrigatória. Mas, entende-se que, se, no caso, o desaprumo for mais desfavorável à edificação, então este deverá ser aplicado.

\subsection{Carga permanente}

O software SAP permite que a estrutura modelada, aquela propriamente desenhada, tenha seu peso próprio gerado automaticamente. No modelo da Catedral da Sé, estão neste grupo os pilares, os contrafortes, os arcobotantes, os arcos, as abóbadas, as lajes da parte posterior do templo, o conjunto do octógono - 
tambor, pilaretes, viga de cintamento e cúpulas, e as duas torres frontais até a elevação da segunda cornija (Figura 4.1).

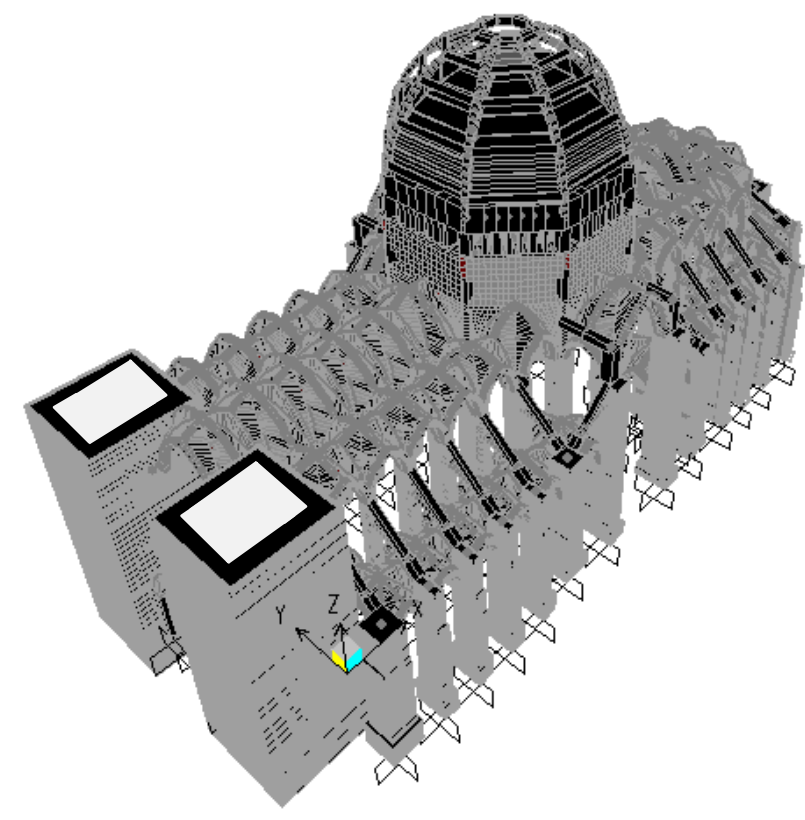

(a)

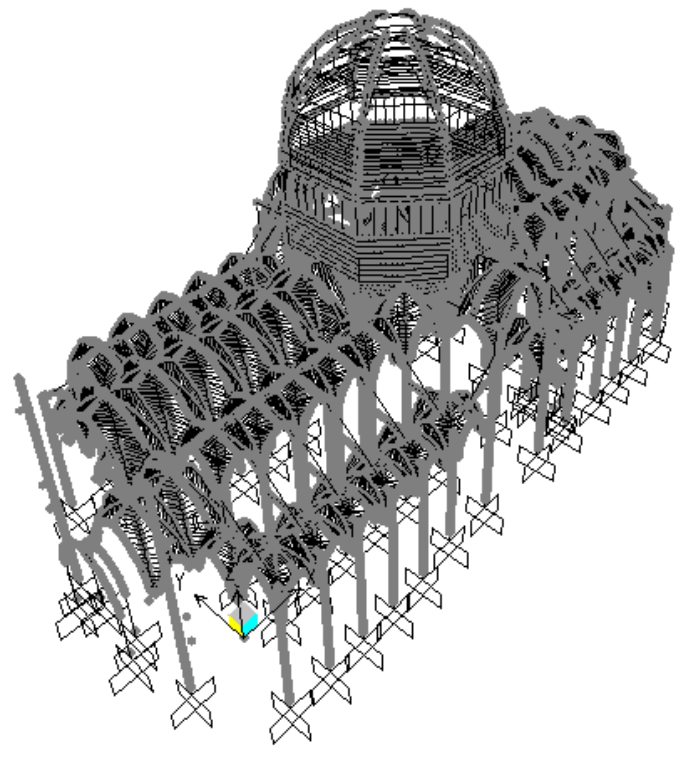

(b)

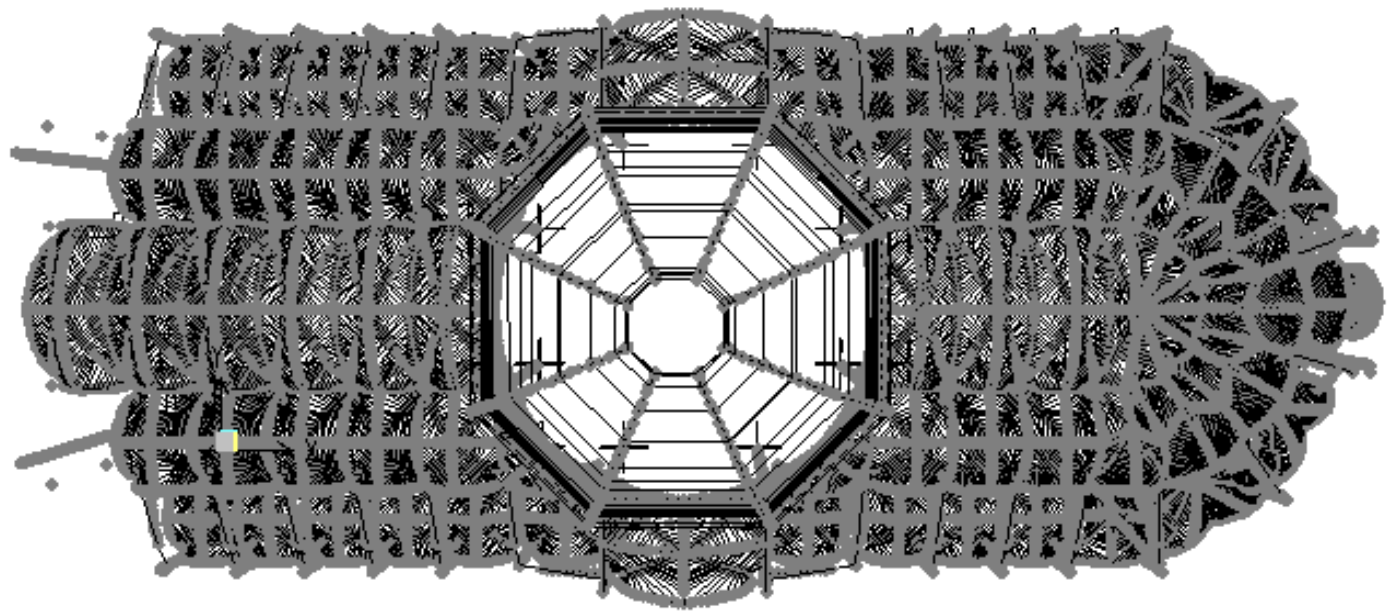

(c)

Figura 4.1 - Modelo global da Catedral da Sé: (a) elementos modelados - vista 3D; (b) vista lateral oblíqua com elementos de barra e de casca; (c) vista superior.

Já as paredes existentes sobre os arcos, os telhados de cobre e de barro, 0 lanternim, os novos torreões finalizados por ocasião da reforma em 2002, os pináculos, as cornijas, os vitrais, as escadas e as lajes do coro, que não representadas no modelo, estão consideradas somente como carregamento atuante.

Estima-se que o peso das cúpulas e do lanternim submeta cada um dois oito 
pilares a uma compressão de 637 kN, sendo a cúpula interna responsável por 200 kN, a cúpula externa por 413 kN e o lanternim por 24 kN.

Como comentado no Capítulo 2, sob as cúpulas, encontra-se uma viga de concreto armado, que funciona como uma cinta resistindo aos esforços de tração decorrentes da tendência de abertura da cúpula. Abaixo desta viga, pilaretes graníticos e um tambor de alvenaria de tijolos servem de apoio às cúpulas (Figura 4.2).

Todo este conjunto situado sob a cúpula - viga de cintamento, pilaretes graníticos e tambor - está modelado, portanto também é peso próprio gerado, que se distribui sobre os arcos do octógono, gerando empuxo horizontal na estrutura. Estima-se que este conjunto implique num carregamento vertical distribuído de aproximadamente 413 kN/m sobre os arcos do octógono.

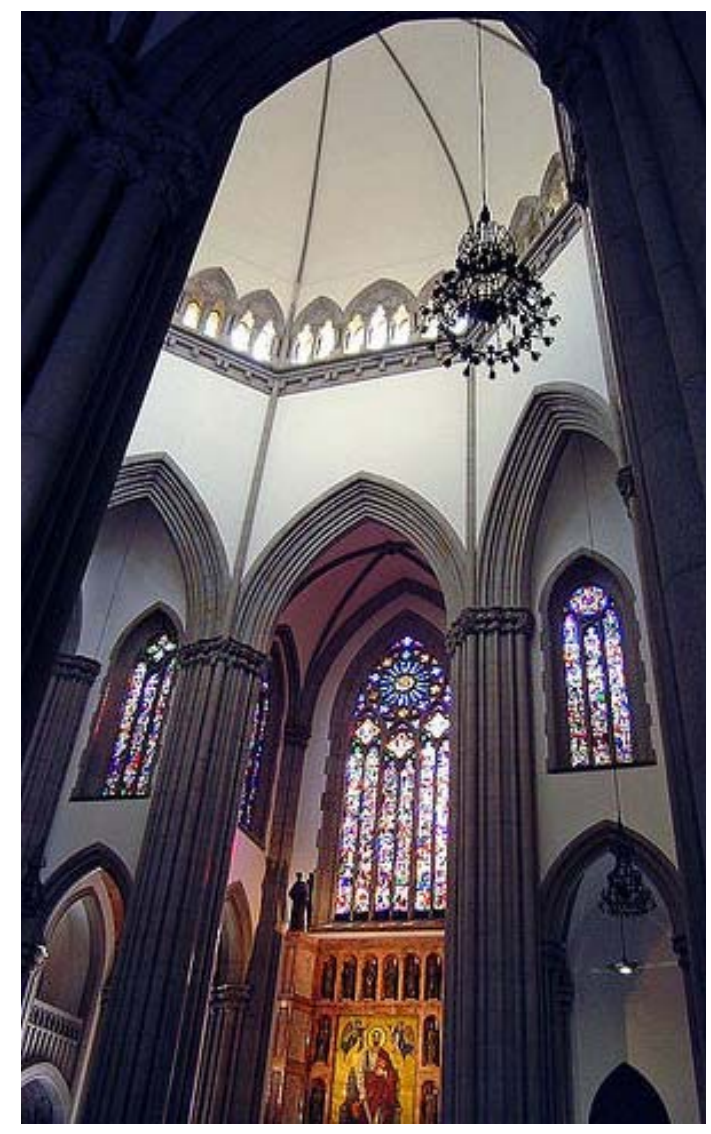

(a)

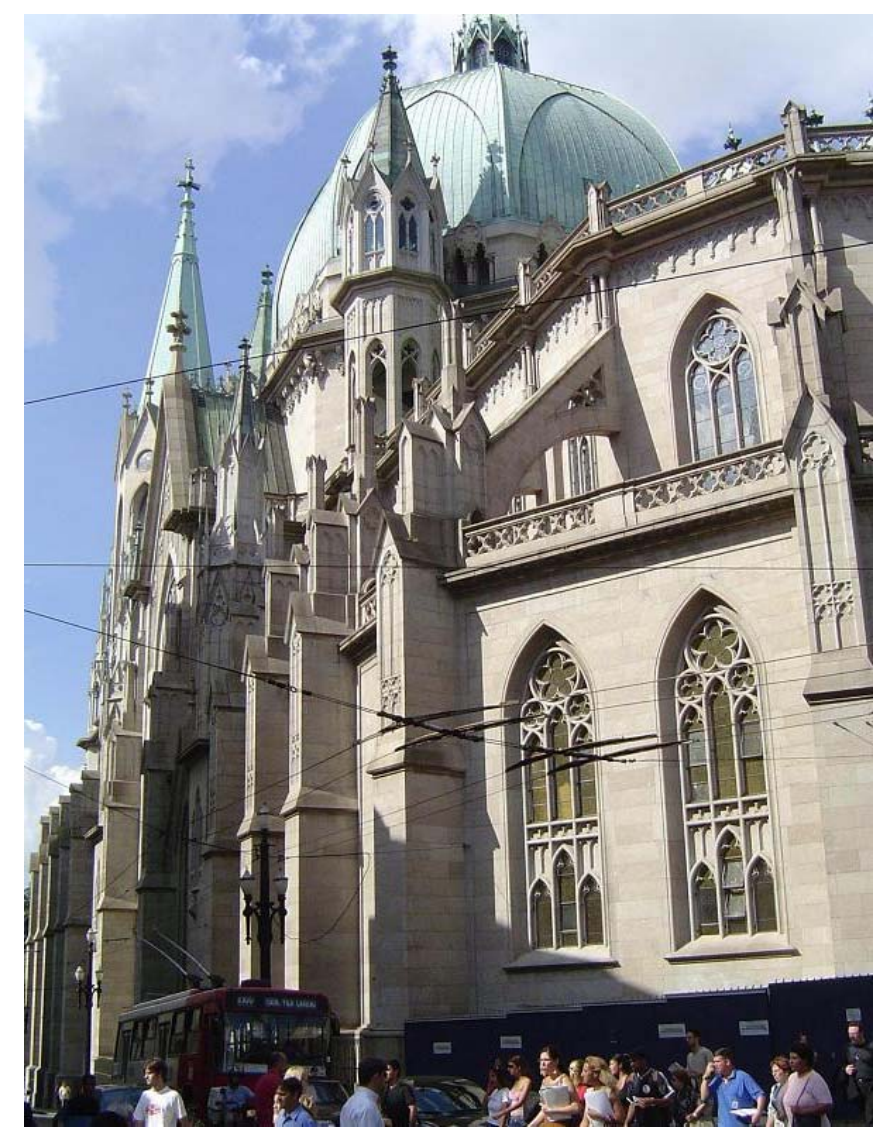

(b)

Figura 4.2 - Catedral da Sé: (a) vista interna do tambor, pilaretes e cúpula (AJOESP, 2008); (b) vista externa (ROSTEY, 2008). 
Em relação às duas torres frontais, Figura 4.3, vale ressaltar que até a elevação da segunda cornija, a 29,2 metros de altura em relação ao piso da Catedral, estes elementos estruturais estão modelados. O peso próprio gerado de cada uma das torres até esta elevação corresponde a 76.139 kN.

A segunda cornija, aplicada como carga, pesa 268 kN e os três torreões que a ladeiam cada torre frontal somam $765 \mathrm{kN}$, totalizando no modelo $77.172 \mathrm{kN}$ por torre.

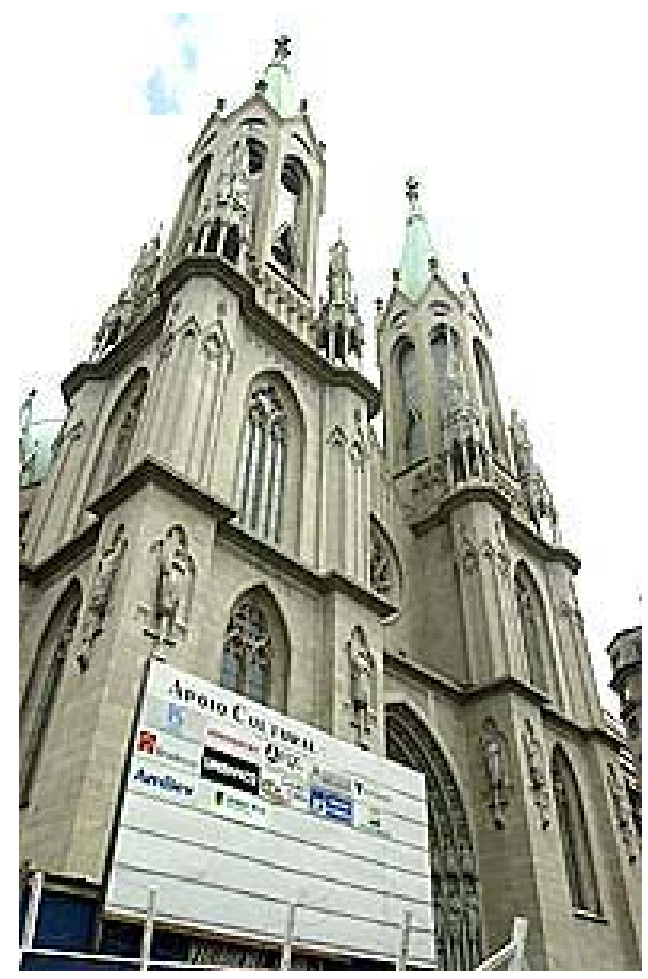

(a)

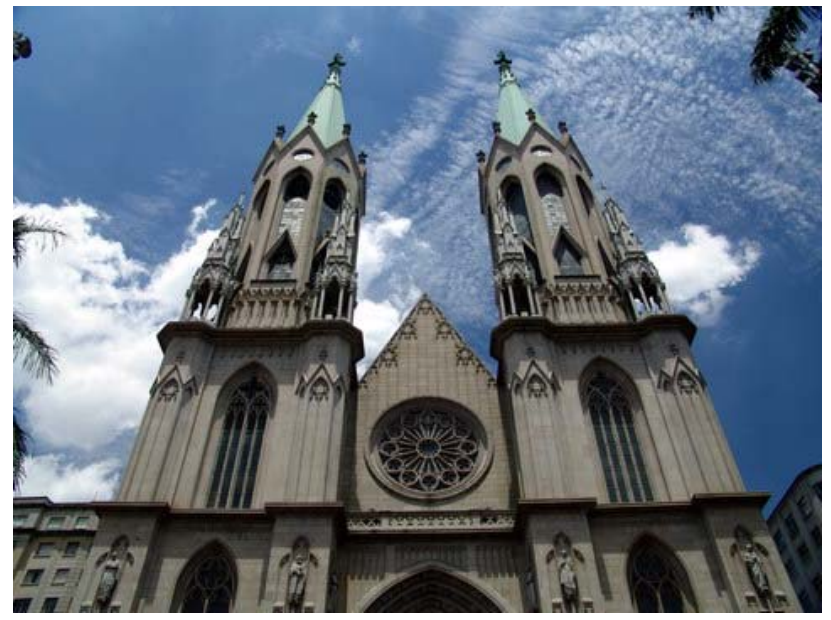

(b)

Figura 4.3 - Torres da Catedral da Sé: (a) vista (FOLHA on line, 2002); (b) vista frontal (DACIOLE, 2008).

Como também comentado no Capítulo 2, no interior de cada uma das torres existem quatro pilares de concreto armado, sem ligação com o maciço de alvenaria de tijolos e por isso não estão modelados. O peso destes pilares e da estrutura por eles sustentada que fica acima da segunda cornija - corpo principal e agulha - está estimado em 5.617 kN.

Considerando-se também estes pilares de concreto armado e toda a estrutura que neles se apóia, calcula-se que cada uma das torres tenha um peso total de $82.789 \mathrm{kN}$. 
Estima-se que a Catedral da Sé tenha um peso total de aproximadamente 650.000 kN devido à carga permanente, distribuídos em seus cinqüenta e seis pilares, trinta contrafortes e nas duas grandes torres. A Figura 4.4 mostra a carga na base dos pilares, contrafortes e torres da igreja.

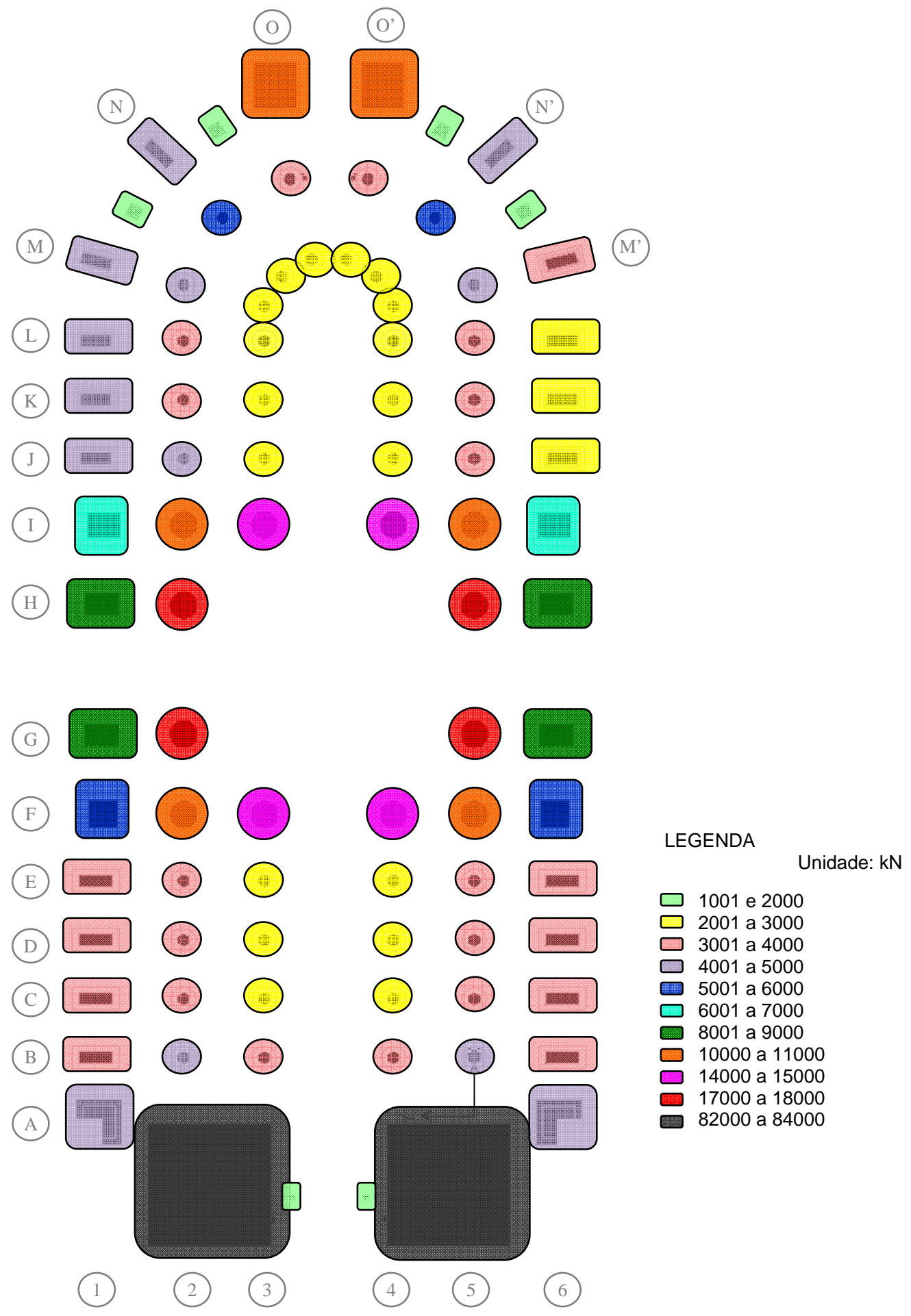

Figura 4.4 - Carga nos pilares, contrafortes e torres. 
O peso próprio da alvenaria de tijolos está distribuído sobre todos os arcos longitudinais da igreja, sobre os arcos do coro e sobre arcos transversais das naves laterais, tendo grande influência no comportamento global da igreja em termos de deslocamentos (Figura 4.6).

Visitas à Catedral da Sé permitiram verificar, por inspeção visual, ao acessar o interior da cobertura de cobre por um alçapão lateral, que há paredes de alvenaria de tijolos sobre os arcos transversais de suas naves laterais, como mostra esquematicamente a Figura 4.5.

Além de estar presente sobre os arcos transversais das naves laterais, a alvenaria de tijolos também é encontrada, neste local, sobre os arcos longitudinais da edificação não somente para servir de apoio aos telhados com chapa de cobre (Figura 4.7), mas também por razões estruturais, como será visto adiante.

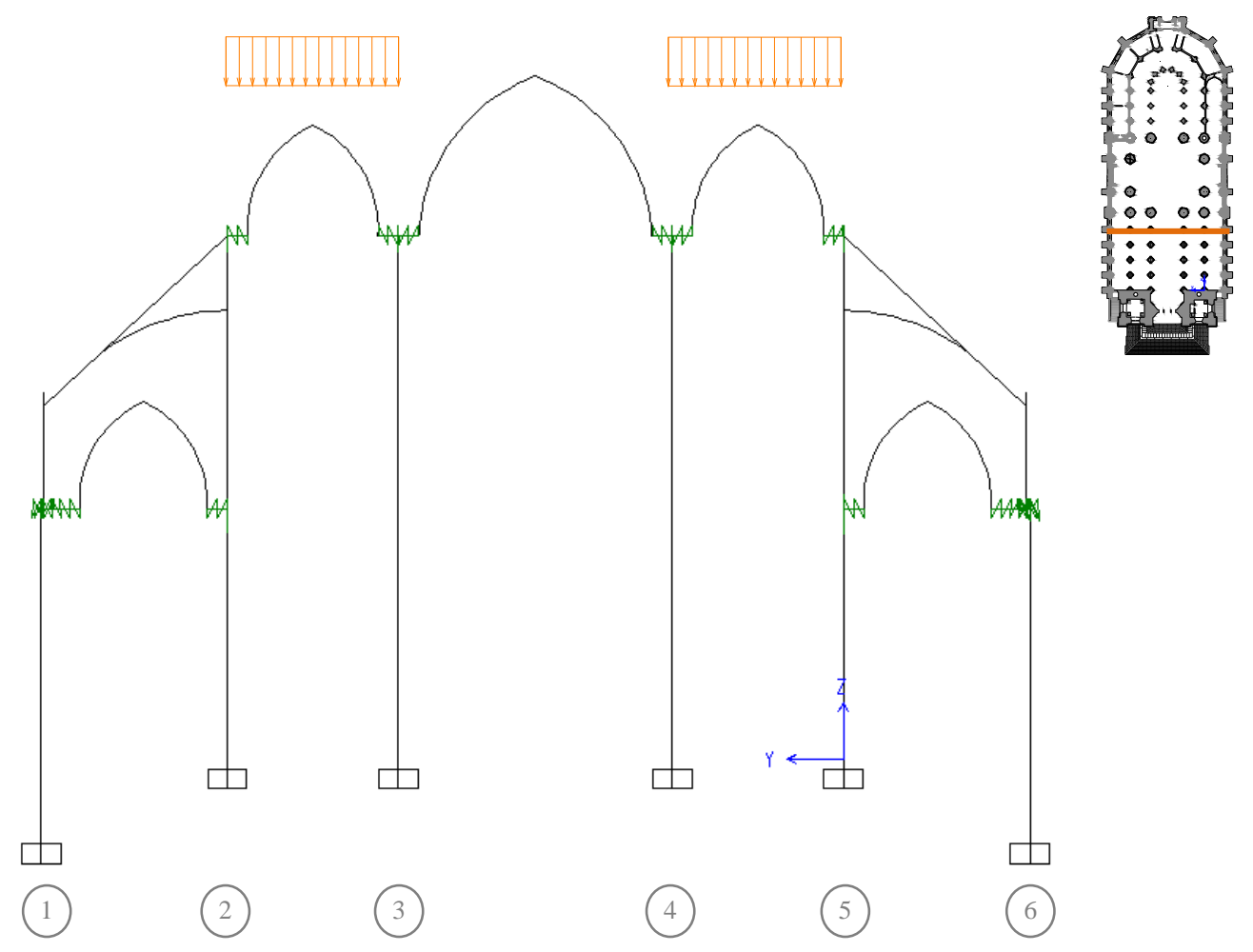

Figura 4.5 - Esquema da carga das paredes sobre os arcos transversais das naves laterais numa seção típica da região frontal. 


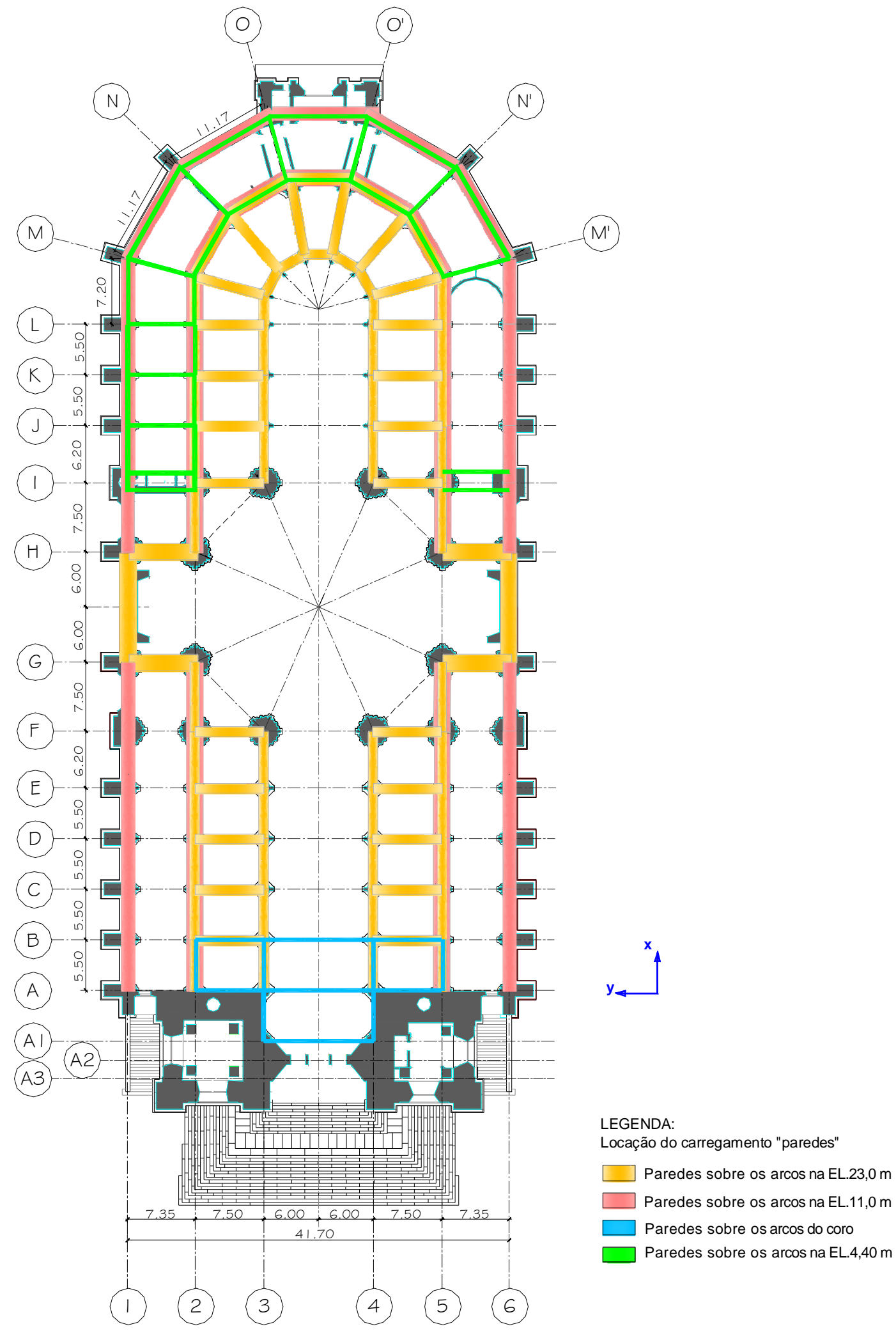

Figura 4.6 - Locação das paredes. 


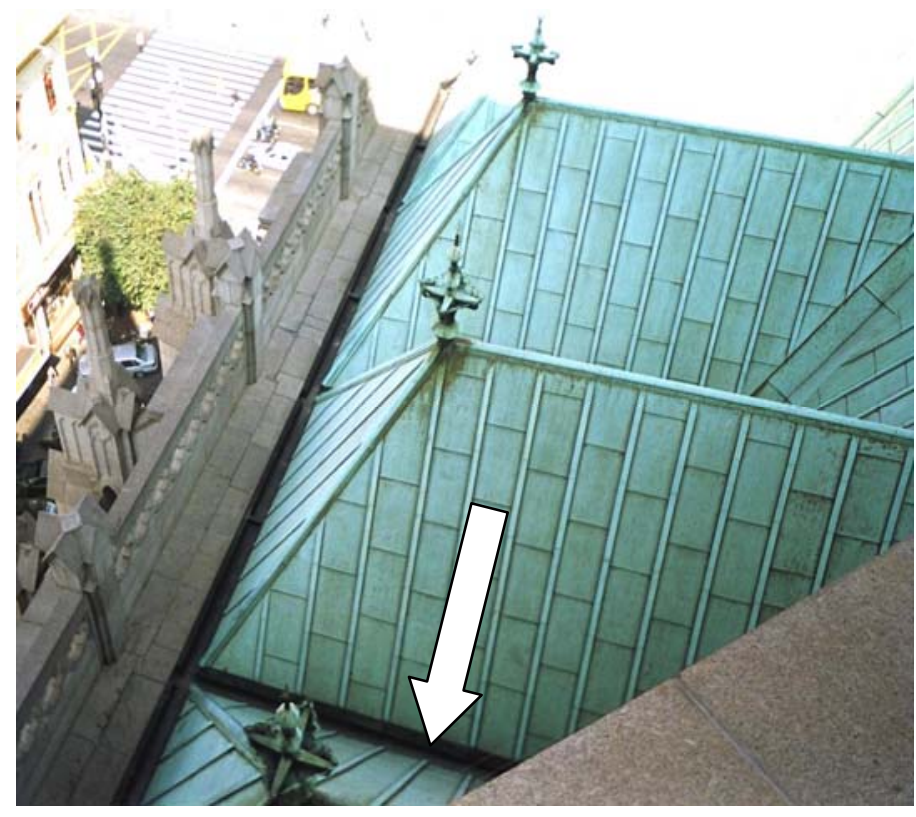

(a)

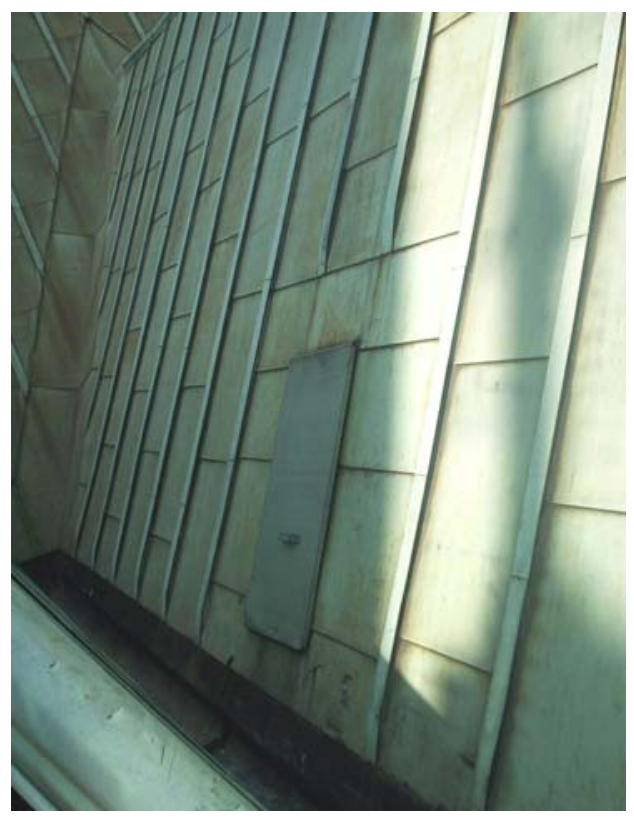

(b)

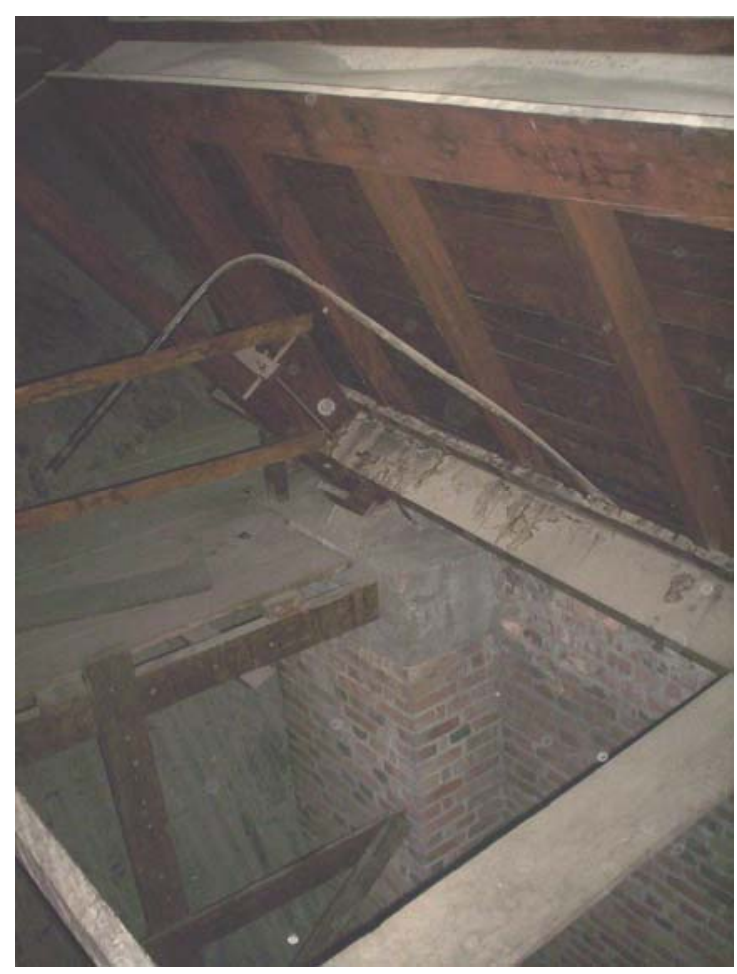

(c)
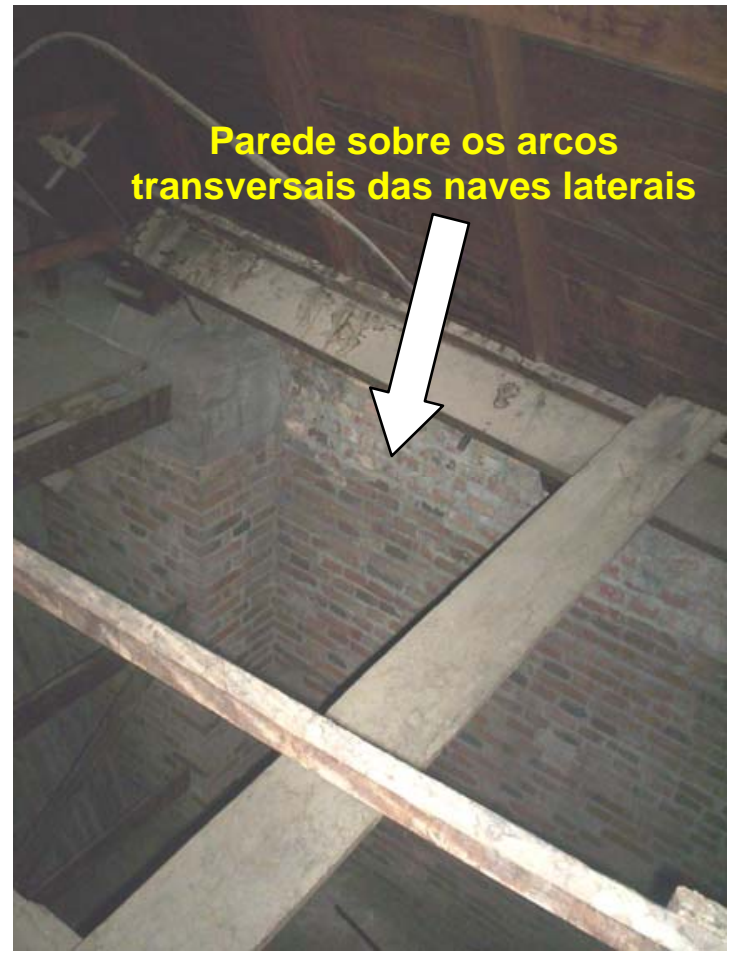

(d)

Figura 4.7 - Locação das paredes: (a) vista da cobertura lateral de cobre; (b) acesso pelo alçapão lateral junto à cobertura das naves laterais; (c) vista do interior; (d) alvenaria de tijolos sobre os arcos, que serve de apoio à tesoura de madeira (RAMIREZ, 2005 p.146, 148-149). 
Outra parcela do carregamento permanente refere-se aos telhados da Catedral da Sé (Figura 4.8). Admite-se para a cobertura com telha de barro e tesouras de madeira, presente sobre as naves laterais externas, o peso próprio estimado em 700 $\mathrm{N} / \mathrm{m}^{2}$.

Sobre a nave central e sobre as naves laterais, está a cobertura com chapas de cobre e tesouras de madeira na parte frontal da igreja, e tesouras metálicas na parte posterior. Adota-se para estas coberturas peso próprio de $500 \mathrm{~N} / \mathrm{m}^{2}$.

Na Figura 4.8, além das coberturas, pode-se observar a disposição de paredes longitudinais na parte posterior do templo.

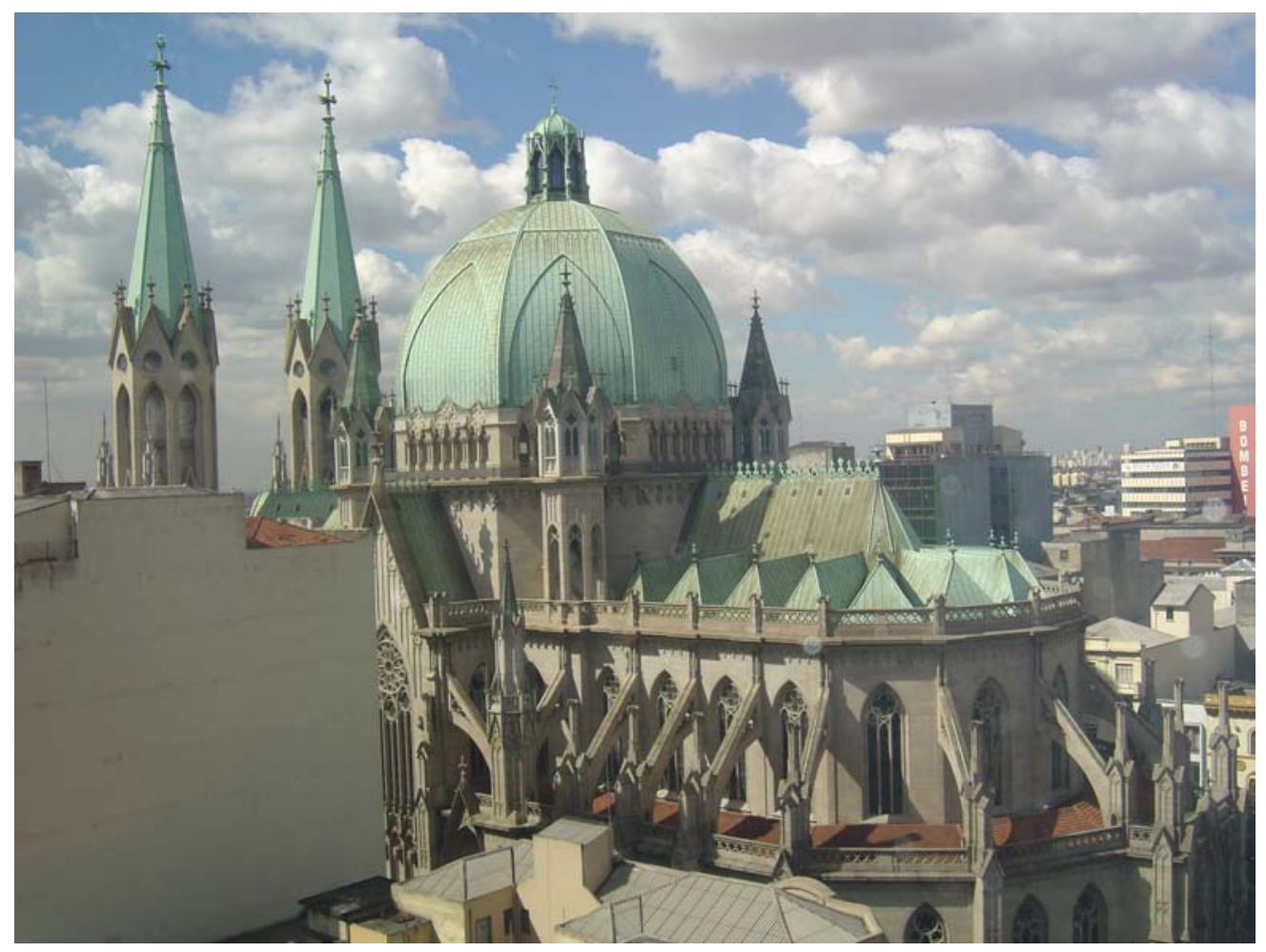

Figura 4.8 - Vista da parte posterior da Catedral da Sé: coberturas e paredes (ARPEN-SP, 2008).

As demais cargas, como os torreões concluídos por ocasião da reforma em 2002 e os pináculos, estão aplicadas no modelo sob a forma de cargas pontuais, sendo que os últimos, sobre os contrafortes. As cornijas e o peso próprio das lajes do coro estão distribuídos sobre os arcos. 


\subsection{Sobrecarga}

No caso da Catedral da Sé, a sobrecarga é aplicada nas áreas que permitem a circulação de pessoas, a manutenção e também a presença de móveis. Nas coberturas, poderiam ser considerados $150 \mathrm{~N} / \mathrm{m}^{2}$.

Está prevista nas lajes e escadas de acesso presentes na parte posterior do templo, assim como nas lajes do coro e da capela lateral. Observando os valores de sobrecarga estipulados pela NBR 6120 (1980, p.3-4), admite-se uma sobrecarga genérica de $3000 \mathrm{~N} / \mathrm{m}^{2}$ nestes locais.

Por atuar em zonas localizadas da igreja e possuir menor ordem de grandeza, esta sobrecarga não tem grande influência no comportamento global da estrutura.

\subsection{Vento}

O vento é representado por forças estáticas equivalentes e é aplicado segundo cada uma das direções principais.

Para estimar a ação do vento na Catedral da Sé, têm-se como referência as recomendações da NBR 6123: forças devidas ao vento em edificações.

A velocidade básica, $\mathrm{V}_{0}$, vento na cidade de São Paulo, pelo mapa das isopletas é de $40 \mathrm{~m} / \mathrm{s}$ (ABNT NBR 6123, 1988, p.6). A pressão dinâmica do vento, q, varia entre 440 a $800 \mathrm{~N} / \mathrm{m}^{2}$ dependendo da altura do trecho considerado em relação à base da escadaria da Catedral.

O estudo do vento e sua ação na estrutura consideram a situação em que a igreja permanece toda fechada e a situação em que há uma abertura dominante, correspondente à entrada principal da Catedral. Estabelecidos os coeficientes de pressão e de forma para as diferentes situações, os carregamentos mais desfavoráveis foram aplicados ao modelo tridimensional.

Os efeitos mais significativos do vento em termos de deslocamentos e tensões ocorrem quando é analisada sua ação incidindo a 90 graus, ou seja, perpendicular à face lateral da igreja.

Os resultados revelam os efeitos secundários da ação do vento no comportamento global frente às elevadas cargas verticais que atuam na Catedral da 
Sé. Os resultados principais em termos de deslocamentos e tensões serão apresentados posteriormente.

Como comentado no início deste Capítulo, algumas normas como a NBR 6118, item 11.2.3.4, recomendam que a ação do vento seja comparada com a ação do desaprumo.

\subsection{Desaprumo}

De acordo com a NBR 6118, a ação do vento e a ação do desaprumo não precisam ser superpostas. Dentre elas, pode ser considerada somente aquela que provoca o maior momento de tombamento na base da construção.

Em geral, a consideração da ação do vento nas edificações é obrigatória. Mas, entende-se que, se, no caso, o desaprumo for mais desfavorável à edificação, então este deverá ser aplicado, como força horizontal equivalente, calculado multiplicandose a carga vertical $\mathrm{P}$ que é aplicada no pilar ou contraforte - e inclui o peso próprio destes elementos - pelo ângulo do desaprumo $\theta$ a (Figura 4.9).

$$
H=P \cdot \theta_{a}
$$

O ângulo para o desaprumo pode ser obtido em função da altura da edificação e do número de prumadas de pilares pelas equações:

$$
\begin{gathered}
\theta_{a}=\theta_{1} \cdot \sqrt{\frac{1+\frac{1}{n}}{2}} \\
\theta_{1}=\frac{1}{100 \cdot \sqrt{l}}
\end{gathered}
$$

Onde:

$\theta_{1 \text { min }} 1 / 400$ para estruturas de nós fixos

1/300 para estruturas deslocáveis ou efeito de imperfeições locais

$\theta_{1 \max } 1 / 200$

I é a altura total da estrutura em metros.

n é número de prumadas de pilares. 
Өa é o ângulo de desaprumo, que deve ser calculado para cada direção, em função do número $\mathrm{n}$ de prumadas de pilares e de $\theta_{1}$.

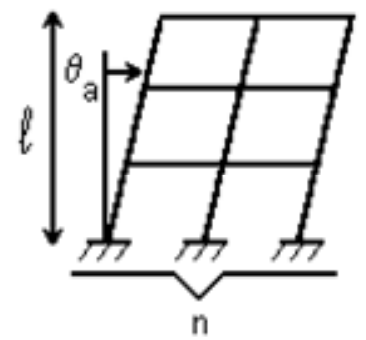

Figura 4.9 - Esquema da ação das imperfeições geométricas globais (ABNT NBR 6118, item 11.2.3.4.1, p.54)

Admite-se o efeito oblíquo do desaprumo sobre os pilares e os contrafortes, ou seja, o efeito do desaprumo na direção x e na direção y.

A ação horizontal do desaprumo está aplicada no topo dos pilares e contrafortes da igreja. Nos pilares laterais e nos contrafortes, o desaprumo também está aplicado na elevação de 11 metros, pois recebem os arcos das naves laterais externas.

Já na região posterior da Catedral, os contrafortes e os pilares que recebem os arcos das naves baixas têm o desaprumo também aplicado na elevação 4,40 metros. 


\section{ANÁLISE DOS DESLOCAMENTOS}

Este capítulo é dedicado à avaliação do comportamento global da estrutura da Catedral da Sé em termos de deslocamentos.

É feita uma análise qualitativa em termos de deslocamentos verticais e horizontais, na qual são identificadas as parcelas do carregamento mais influentes e determinantes para o comportamento da igreja.

Inicialmente, o estudo volta-se para a ação da carga permanente. Em seguida, as ações do vento e do desaprumo são consideradas, destacando-se os efeitos mais desfavoráveis para a edificação.

Os pilares e contrafortes que apresentam maiores deslocamentos são um provável indicativo dos elementos estruturais mais solicitados e alguns destes são selecionados para posterior análise de tensões no Capítulo 6.

O Capítulo 5 também tem o objetivo de avaliar a importância de alguns elementos estruturais para o equilíbrio do conjunto. Para tanto, além da estrutura real, são apresentadas outras duas simulações; a primeira com a retirada dos arcobotantes responsáveis pela transferência dos empuxos horizontais e, em seguida, com a retirada das duas torres frontais, de modo a permitir uma avaliação de suas influências no comportamento da igreja.

O modelo tridimensional é orientado segundo os eixos globais $x, y$ e $z$ que representam as direções longitudinal, transversal e vertical da Catedral (Figura 5.1). Como comentado, no modelo são utilizados elementos de barra para representar os arcobotantes, os contrafortes, os pilares, as torres, os arcos e as nervuras, e elementos de casca para os panos das abóbadas e da cúpula, e o tambor.

Apesar de os resultados decorrerem da interação do efeito das cargas nas três direções, eles são apresentados no plano, por meio de plantas orientadas pelos eixos x e y e, também, por meio de cortes transversais orientados pelos eixos y e $z$ e cortes longitudinais, pelos eixos x e z (Figura 5.2). 


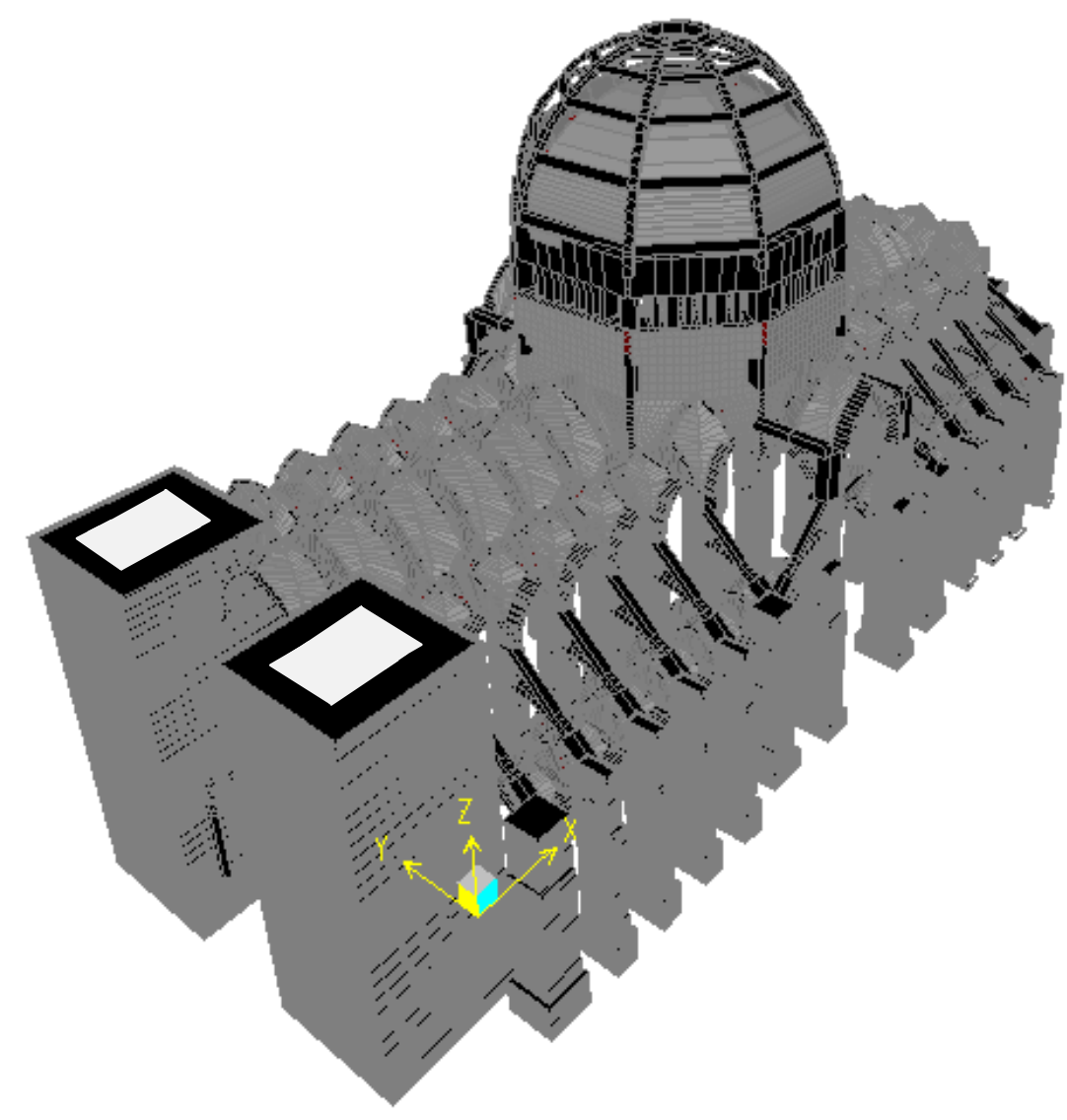

Figura 5.1 - Orientação dos eixos globais.

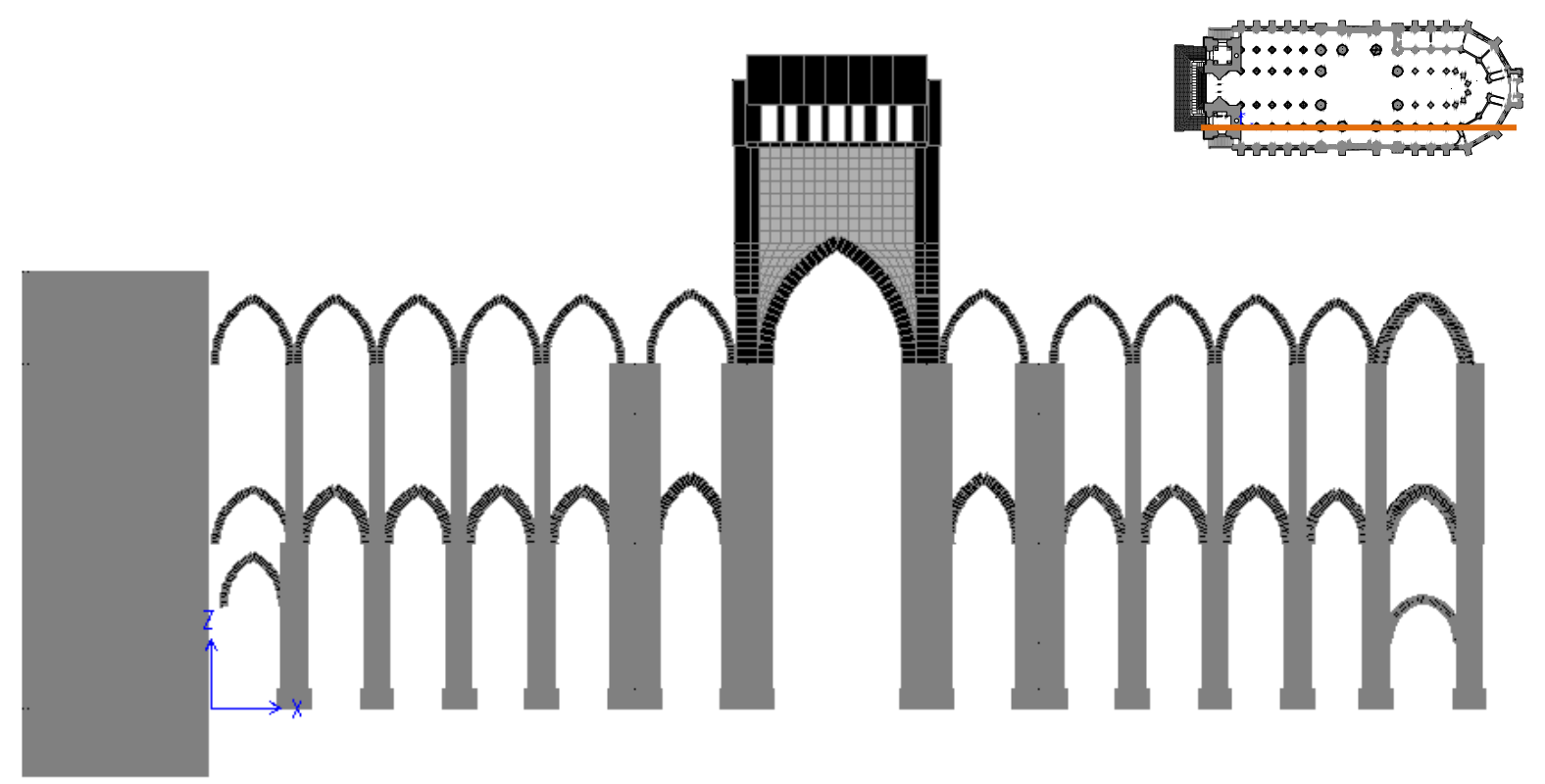

Figura 5.2 - Corte longitudinal no eixo 5: vista. 


\subsection{Estrutura real}

Basicamente, o sistema estrutural da Catedral da Sé de São Paulo consiste em cinco naves cobertas por abóbadas ogivais apoiadas em pilares e contrafortes; as abóbadas geram empuxos horizontais no topo dos pilares e contrafortes, deslocando-os nas direções transversal e longitudinal. Na região do octógono, o enorme tambor funciona como uma cinta a conter os deslocamentos horizontais de seus pilares.

Uma primeira avaliação revela que os deslocamentos são pequenos e que a estrutura tem elementos de elevada rigidez.

Para o entendimento do comportamento global da igreja, é tomada a planta do topo dos pilares e contrafortes da edificação (Figura 5.3). O topo dos pilares encontra-se a 23 metros de altura em relação ao piso e o dos contrafortes, a aproximadamente 16,0 metros.

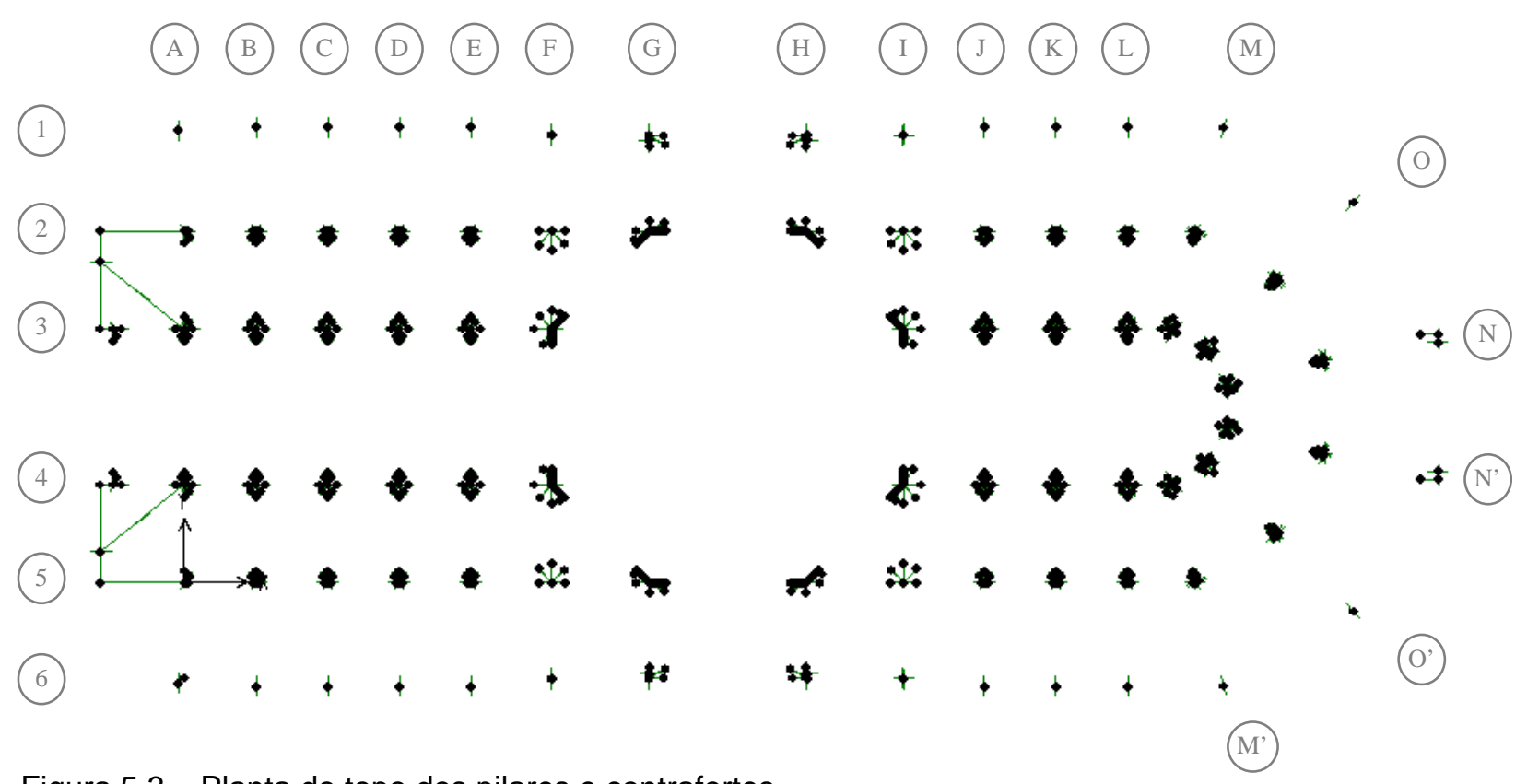

Figura 5.3 - Planta do topo dos pilares e contrafortes.

Como os deslocamentos são muito pequenos, da ordem do milímetro, a escala utilizada para ilustrá-los na configuração deformada, na grande maioria das plantas, está aumentada em 3000 vezes no desenho, ou seja, está numa escala 3000:1. No caso dos cortes longitudinais e transversais, na maioria dos casos, a escala dos deslocamentos está aumentada em 1500 vezes. 
Os pilares e contrafortes da Catedral da Sé podem ser identificados por meio do sistema de eixos mostrado na Figura 5.3. A nomenclatura P.3D, por exemplo, indica que se trata do pilar do eixo 3 na seção do eixo D. A nomenclatura C.1H se refere ao contraforte do eixo 1 na seção do eixo $\mathrm{H}$, que ainda, com o auxílio da Figura 2.16 da p.47, está classificado como contraforte tipo IV.

A Figura 5.4 apresenta o mapa dos deslocamentos do topo dos pilares e contrafortes devidos à carga permanente e a tendência de abertura da igreja. A configuração indeformada está indicada em cinza e a deformada, em azul.

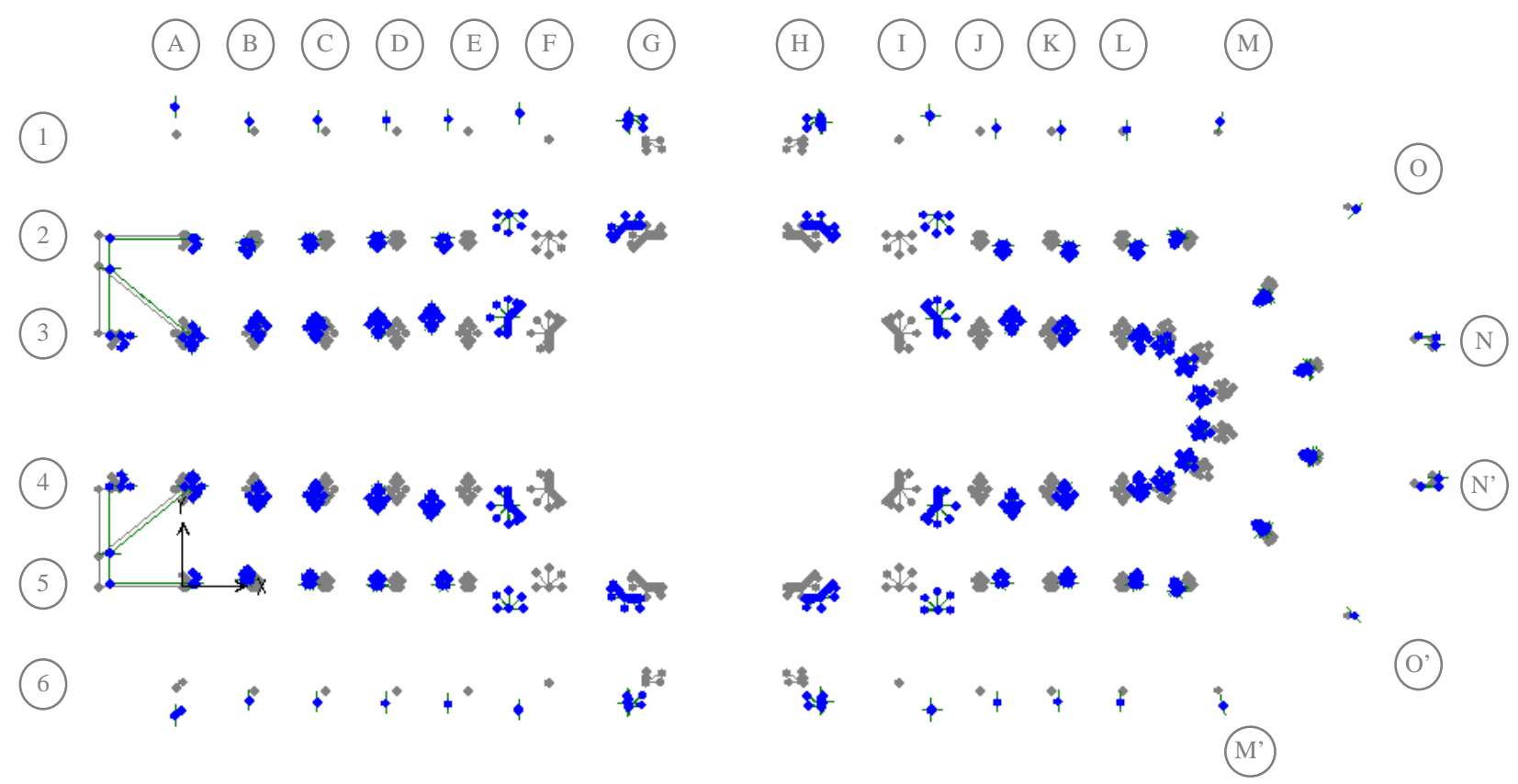

Figura 5.4 - Mapa dos deslocamentos devidos à carga permanente - planta - escala dos deslocamentos 3000:1.

A configuração deformada acima mostra que todos os contrafortes deslocamse para o exterior da edificação, comportamento esperado para os elementos do estilo gótico, que são concebidos para resistir à tendência de abertura da igreja. Os arcos ogivais geram um empuxo horizontal no topo dos pilares e contrafortes, deslocando a igreja nas direções longitudinal e transversal.

Na Figura 5.4 destacam-se os contrafortes da região do octógono, tipo III e V. Sob a influência das elevadas cargas do tambor e da cúpula, estes elementos apresentam deslocamento horizontal total $u_{R}$ que chega ao valor máximo de 1,06 milímetros no topo das peças, como mostra a Tabela 5.1. 
Os primeiros contrafortes ao lado das torres frontais, que são do tipo I e estão localizados nos eixos 1 e 6 da seção A, também apresentam deslocamentos horizontais que se destacam em relação ao conjunto. Eles atingem 1,04 milímetros. Por se tratar de contrafortes de extremidade, seus deslocamentos são maiores que os dos contrafortes contíguos, uma vez que neles não se apóiam arcos e nervuras que se oporiam ao seu deslocamento (Tabela 5.2).

Tabela 5.1 - Deslocamentos no topo dos contrafortes da região do octógono

\begin{tabular}{cccccc}
\hline \multirow{2}{*}{$\begin{array}{c}\text { Tipo de } \\
\text { Contraforte }\end{array}$} & Nó & $\begin{array}{c}\text { Deslocamento } \\
\text { Vertical }\end{array}$ & \multicolumn{3}{c}{ Deslocamento Horizontal } \\
\cline { 2 - 6 } & & $\mathbf{u}_{\mathbf{z}}$ & $\mathbf{u}_{\mathbf{x}}$ & $\mathbf{u}_{\mathbf{y}}$ & $\left|\mathbf{u}_{\mathbf{R}}\right|$ \\
& & $\mathrm{mm}$ & $\mathrm{mm}$ & $\mathrm{mm}$ & $\mathrm{mm}$ \\
\hline \multirow{2}{*}{ CF.III } & C.1F & $-0,50$ & $-0,77$ & 0,67 & 1,02 \\
\cline { 2 - 6 } & C.6F & $-0,50$ & $-0,78$ & $-0,67$ & 1,03 \\
\hline \multirow{3}{*}{ CF. IV } & C.1G & $-1,10$ & $-0,47$ & 0,66 & 0,81 \\
\cline { 2 - 6 } & C.6G & $-1,10$ & $-0,49$ & $-0,66$ & 0,82 \\
\cline { 2 - 6 } & C.1H & $-1,10$ & 0,54 & 0,61 & 0,81 \\
\cline { 2 - 6 } & C.6H & $-1,10$ & 0,50 & $-0,65$ & 0,82 \\
\hline \multirow{2}{*}{ CF.V } & C.1I & $-0,53$ & 0,83 & 0,63 & 1,04 \\
\cline { 2 - 6 } & C.6I & $-0,52$ & 0,80 & $-0,69$ & 1,06 \\
\hline
\end{tabular}

Tabela 5.2 - Deslocamentos no topo dos contrafortes tipo I

\begin{tabular}{cccccc}
\hline \multirow{2}{*}{$\begin{array}{c}\text { Tipo de } \\
\text { Contraforte }\end{array}$} & Nó & $\begin{array}{c}\text { Deslocamento } \\
\text { Vertical }\end{array}$ & \multicolumn{3}{c}{ Deslocamento Horizontal } \\
\cline { 3 - 6 } & & $\mathbf{u}_{\mathbf{z}}$ & $\mathbf{u}_{\mathbf{x}}$ & $\mathbf{u}_{\mathbf{y}}$ & $\left|\mathbf{u}_{\mathrm{R}}\right|$ \\
& & $\mathrm{mm}$ & $\mathrm{mm}$ & $\mathrm{mm}$ & $\mathrm{mm}$ \\
\hline \multirow{2}{*}{ CF.I } & C.1A & $-0,32$ & $-0,02$ & 1,04 & 1,04 \\
\cline { 2 - 7 } & C.6A & $-0,32$ & $-0,02$ & $-1,04$ & 1,04 \\
\hline
\end{tabular}

Vale ressaltar que, na Catedral da Sé, há assimetrias na parte posterior do templo, como a presença da capela lateral entre os eixos 5 e 6 e as naves baixas, de apoio, entre os eixos 1 e 2. Esta assimetria leva a pequenas diferenças nos deslocamentos quando se comparam pilares e contrafortes em posições simétricas com relação ao eixo longitudinal central.

Dentre os pilares da Catedral, os maiores deslocamentos horizontais, apesar de muito pequenos, também ocorrem na região do octógono, como mostra a Tabela 5.3. 
Os pilares dos eixos 2 e 5 das seções $\mathrm{G}$ e H apresentam encurtamento de 1,61 milímetros e deslocamento horizontal de até 0,63 milímetros.

No entanto, são os pilares laterais da seção $F$ que alcançam os maiores deslocamentos horizontais, de até 1,19 milímetros; na direção vertical, movem-se 0,78 milímetros.

Tabela 5.3 - Deslocamentos no topo dos pilares da região do octógono

\begin{tabular}{lcccc}
\hline & $\begin{array}{c}\text { Deslocamento } \\
\text { Vertical }\end{array}$ & \multicolumn{3}{c}{ Deslocamento Horizontal } \\
\cline { 2 - 5 } & $\mathbf{u}_{\mathbf{z}}$ & $\mathbf{u}_{\mathbf{x}}$ & $\mathbf{u}_{\mathbf{y}}$ & $\left|\mathbf{u}_{\mathbf{R}}\right|$ \\
& $\mathrm{mm}$ & $\mathrm{mm}$ & $\mathrm{mm}$ & $\mathrm{mm}$ \\
\hline P.2F & $-0,78$ & $-1,04$ & 0,56 & 1,18 \\
\hline P.2G & $-1,61$ & $-0,55$ & 0,25 & 0,61 \\
\hline P.2H & $-1,61$ & 0,48 & 0,26 & 0,55 \\
\hline P.2I & $-0,78$ & 0,98 & 0,53 & 1,12 \\
\hline P.5F & $-0,78$ & $-1,05$ & $-0,56$ & 1,19 \\
\hline P.5G & $-1,61$ & $-0,56$ & $-0,28$ & 0,63 \\
\hline P.5H & $-1,61$ & 0,47 & $-0,27$ & 0,54 \\
\hline P.5I & $-0,78$ & 0,98 & $-0,59$ & 1,14 \\
\hline P.3F & $-1,53$ & $-1,07$ & 0,40 & 1,14 \\
\hline P.4F & $-1,53$ & $-1,07$ & $-0,41$ & 1,14 \\
\hline P.3I & $-1,53$ & 0,97 & 0,38 & 1,04 \\
\hline P.4I & $-1,53$ & 0,97 & $-0,42$ & 1,05 \\
\hline & & & &
\end{tabular}

A Figura 5.4 mostra ainda que sob a ação da carga permanente nem todos os pilares seguem a tendência de se deslocarem para fora da igreja. Os pilares laterais das regiões frontal e posterior, localizados nos eixos 2 e 5, por exemplo, movimentam-se para o interior da igreja na direção transversal.

Já os pilares sob a geometria curva, na região posterior do Catedral, se deslocam para o interior da edificação tanto na direção longitudinal como na transversal.

Os deslocamentos horizontais dos pilares se reduzem à medida que se distanciam da influência das significativas cargas que incidem diretamente sobre os arcos do octógono. Nas Figuras 5.5 e 5.6, mostram-se os deslocamentos horizontais das abóbadas nas direções x e y devidos à ação da carga permanente. 

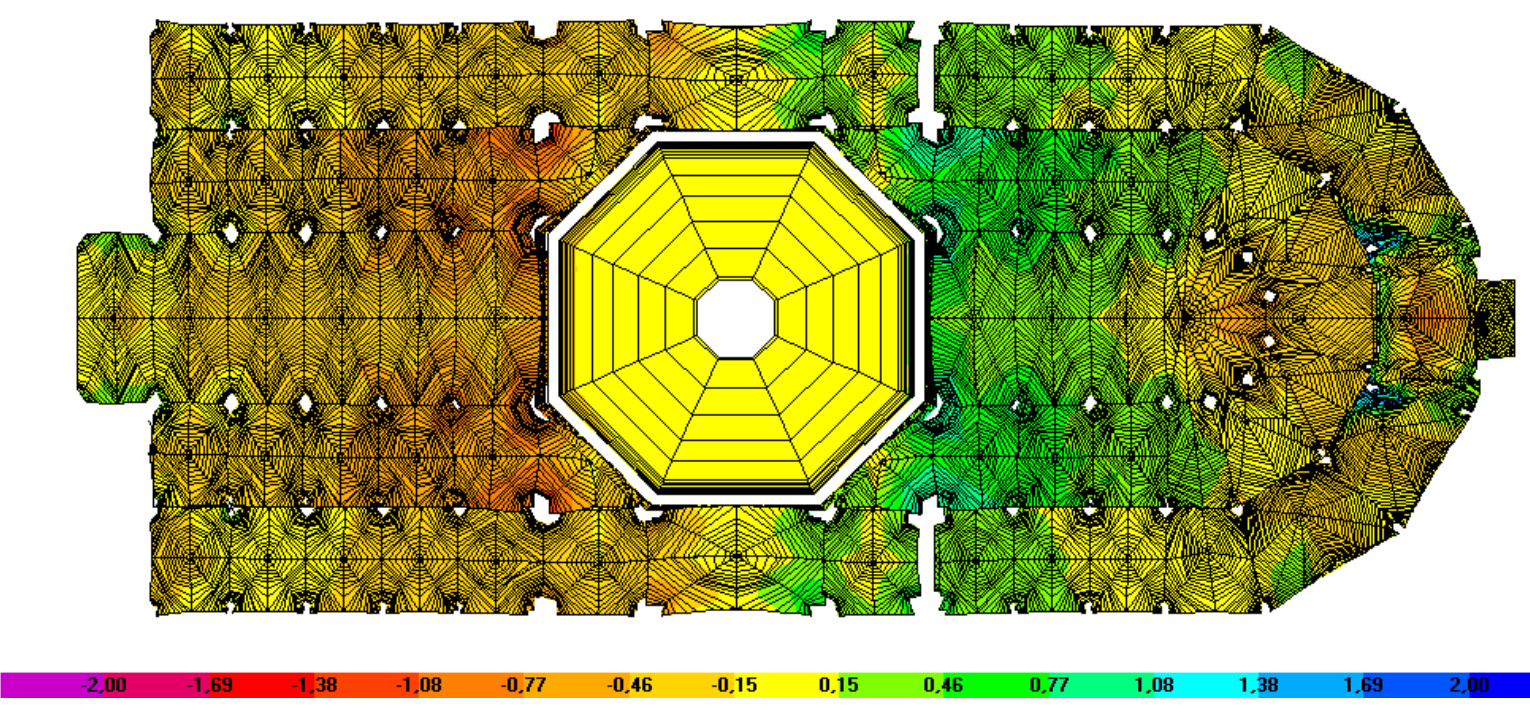

Os valores indicados nesta escala estão em milímetros.

Figura 5.5 - Deslocamento das abóbadas na direção x devido à ação da carga permanente - planta escala dos deslocamentos 800:1.
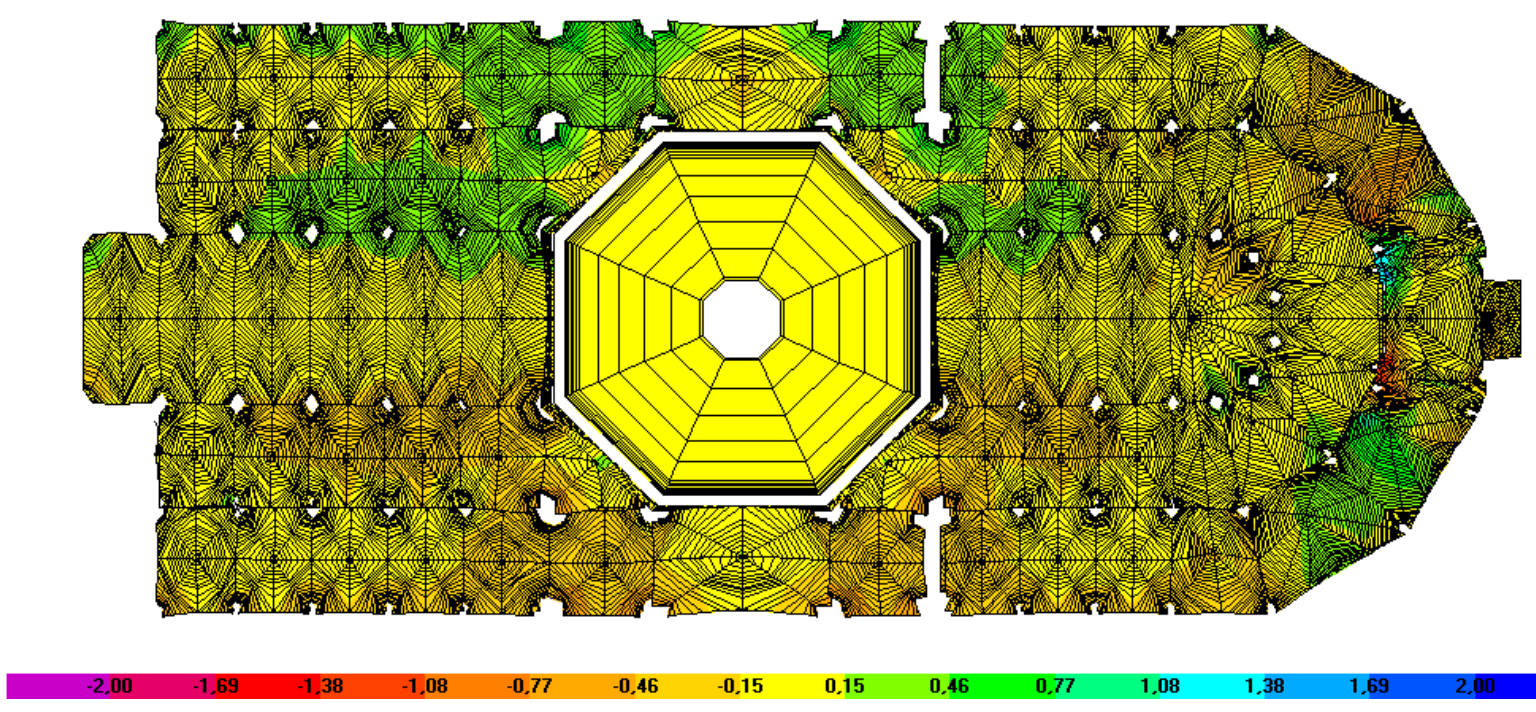

$\begin{array}{llll}0.77 & 1,08 & 1,38 & 1,69\end{array}$

Os valores indicados nesta escala estão em milímetros.

Figura 5.6 - Deslocamento das abóbadas na direção y devido à ação da carga permanente - planta escala dos deslocamentos 800:1. 
Com relação aos deslocamentos verticais, na direção z, a Figura 5.7 mostra que os maiores valores ocorrem nas abóbadas do octógono.
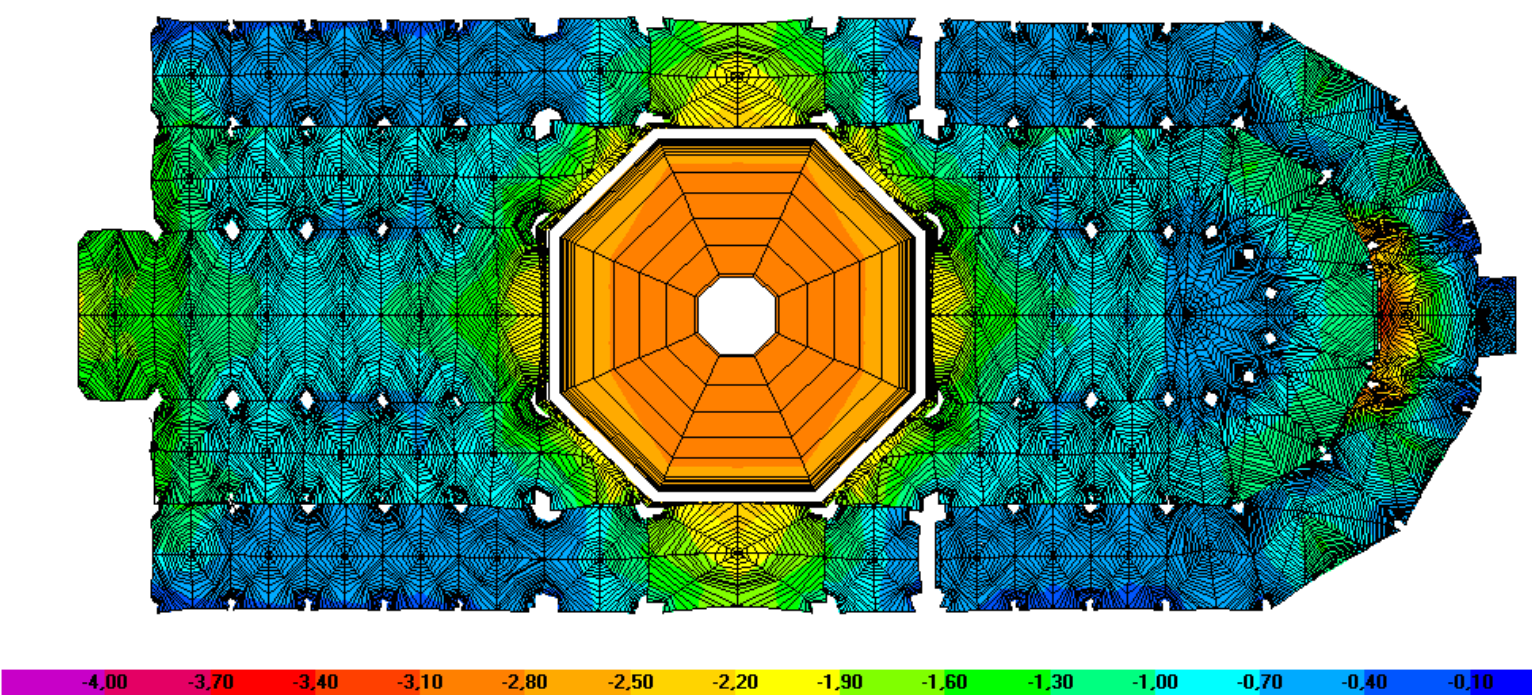

Os valores indicados nesta escala estão em milímetros.

Figura 5.7 - Deslocamento vertical das abóbadas, na direção z, devido à ação da carga permanente - planta - escala dos deslocamentos 800:1.

Finalmente, os deslocamentos totais das abóbadas devidos à ação da carga permanente podem ser observados na Figura 5.8.
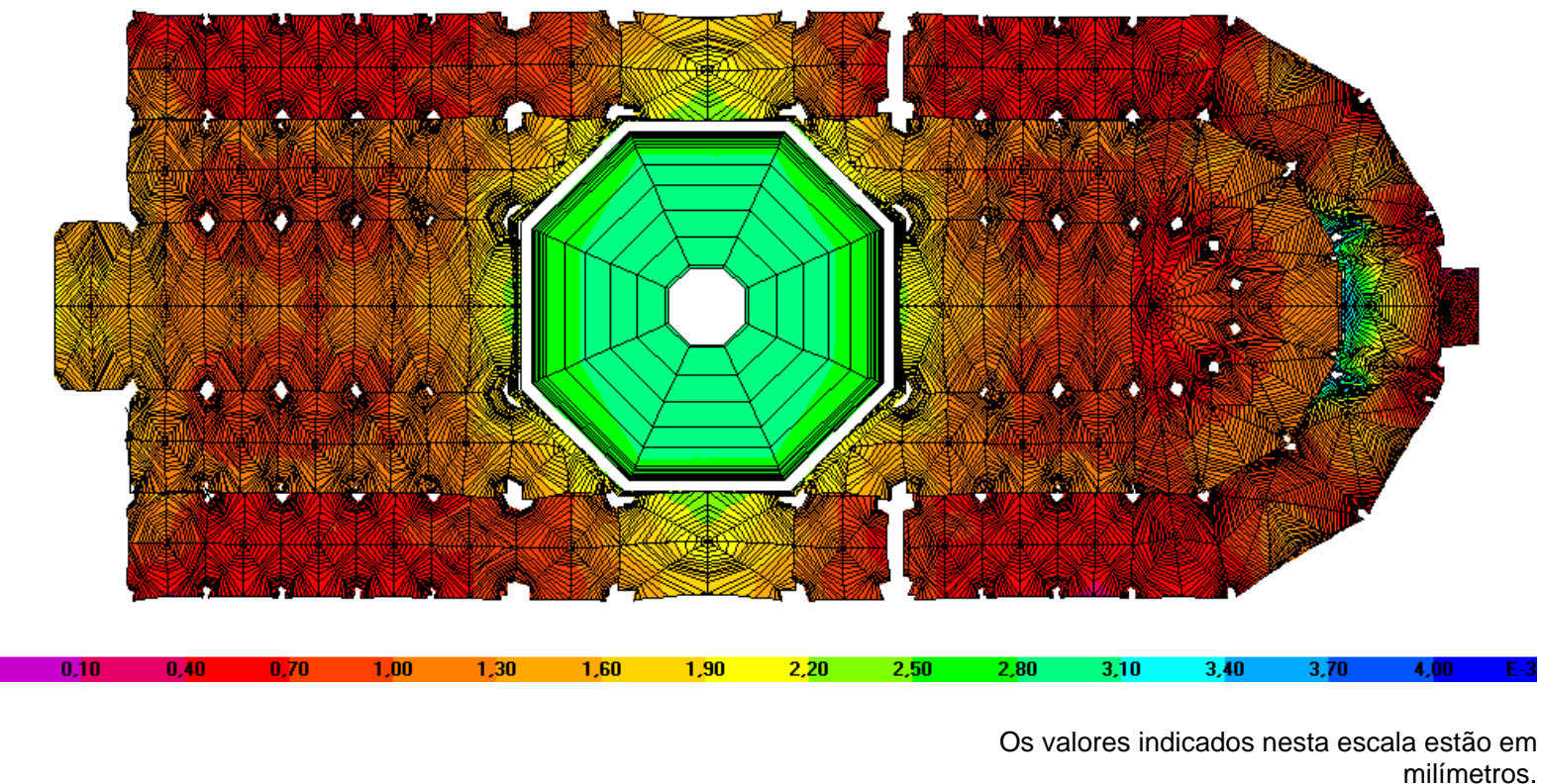

Figura 5.8 - Deslocamento total das abóbadas devido à ação da carga permanente - planta - escala dos deslocamentos 800:1. 
Como os contrafortes e os arcobotantes, as duas torres frontais também contêm os deslocamentos da estrutura, restringindo, com sua elevada rigidez, a tendência de abertura da edificação na direção longitudinal (Figura 5.9).

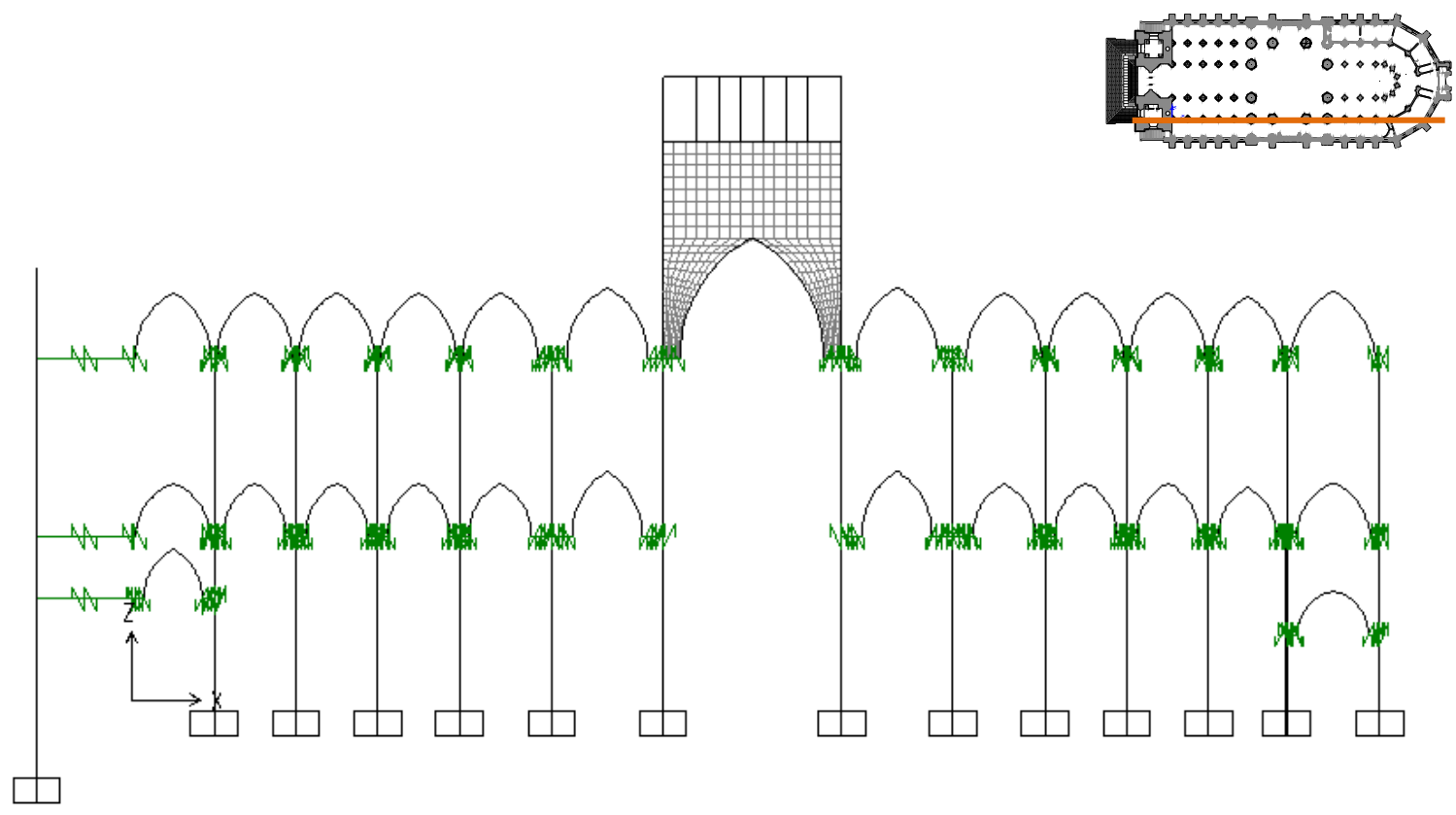

(a)

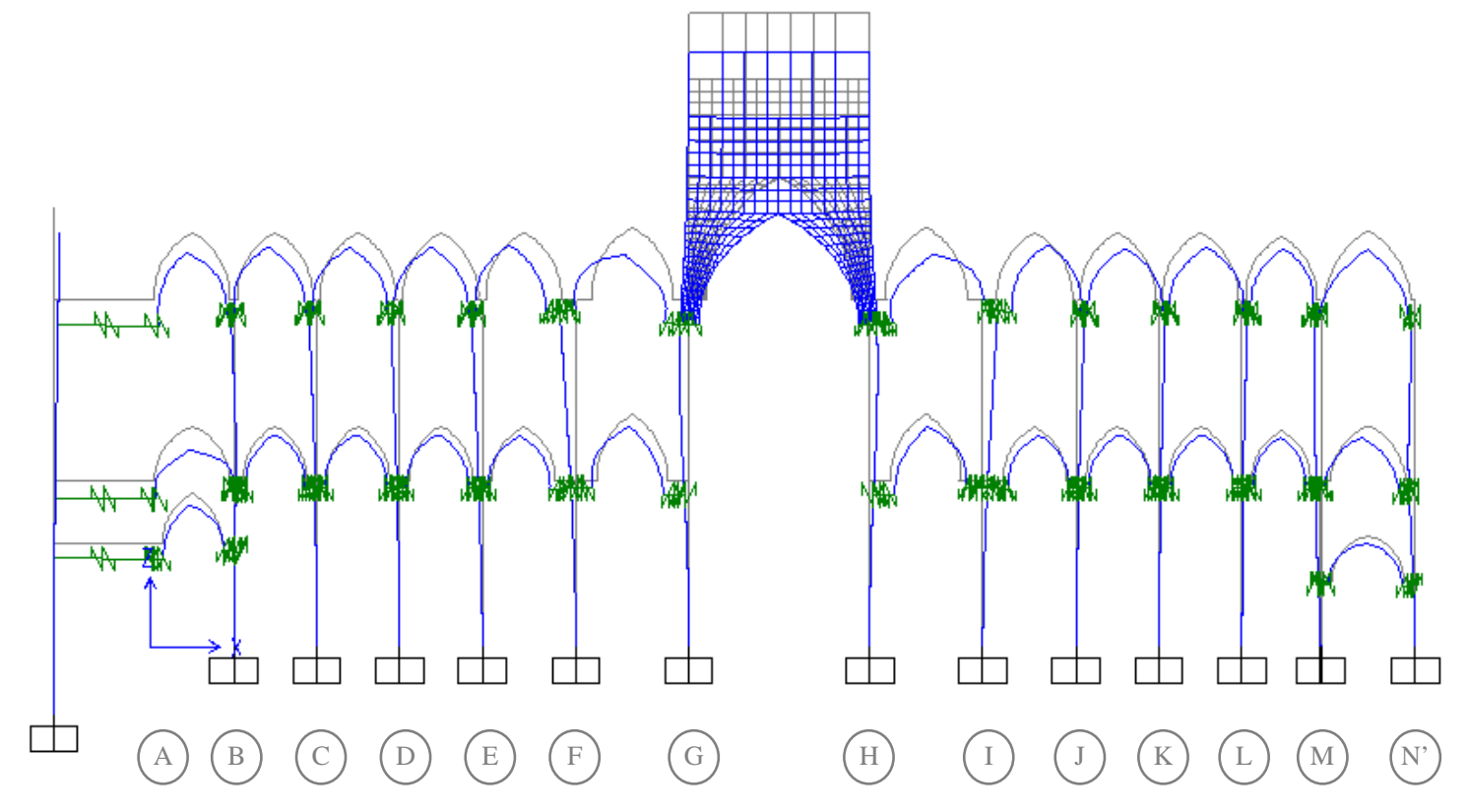

(b)

H barra rígida

Figura 5.9 - Corte longitudinal no eixo 5: (a) configuração indeformada; (b) deslocamentos devidos à carga permanente - escala dos deslocamentos 1000:1. 


\subsubsection{Ação do carregamento horizontal}

Os efeitos do vento ou os do desaprumo sobre os deslocamentos da Catedral da Sé são secundários frente às elevadas cargas verticais.

A ação do vento, por exemplo, nos deslocamentos longitudinais é muito menos significativa que nos deslocamentos transversais, pois, além dos enormes contrafortes que são as duas torres frontais, o número de pilares em seqüência na direção longitudinal é bem maior.

A Figura 5.10 mostra os deslocamentos da estrutura sob a ação da carga permanente mais o vento aplicado no sentido $+y$, aqui chamado de vento aplicado a 90 graus, perpendicular ao eixo longitudinal da igreja e incidente, portanto, na fachada lateral da Catedral. É nesta situação que surgem os maiores deslocamentos transversais nos elementos de apoio dos eixos 1, 2 e 3.

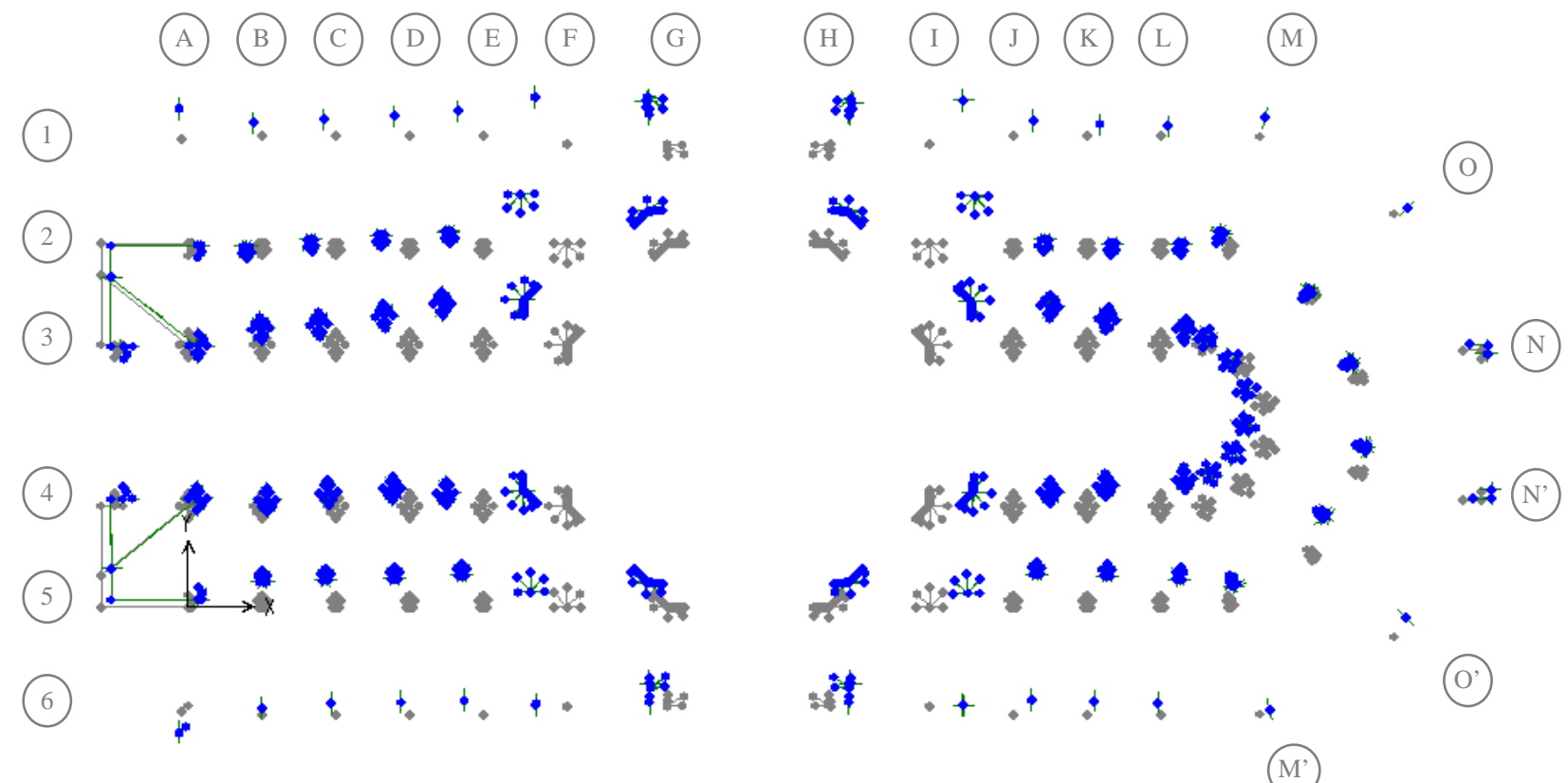

Figura 5.10 - Mapa dos deslocamentos devidos à carga permanente mais vento a 90 graus - planta escala dos deslocamentos 3000:1.

Tomando-se uma seção típica da região frontal, a seção do eixo $D$, e uma seção da região do octógono, a seção do eixo F, por exemplo, comparam-se os deslocamentos sem e com a presença do vento nas Figuras 5.11 e 5.12 respectivamente. 


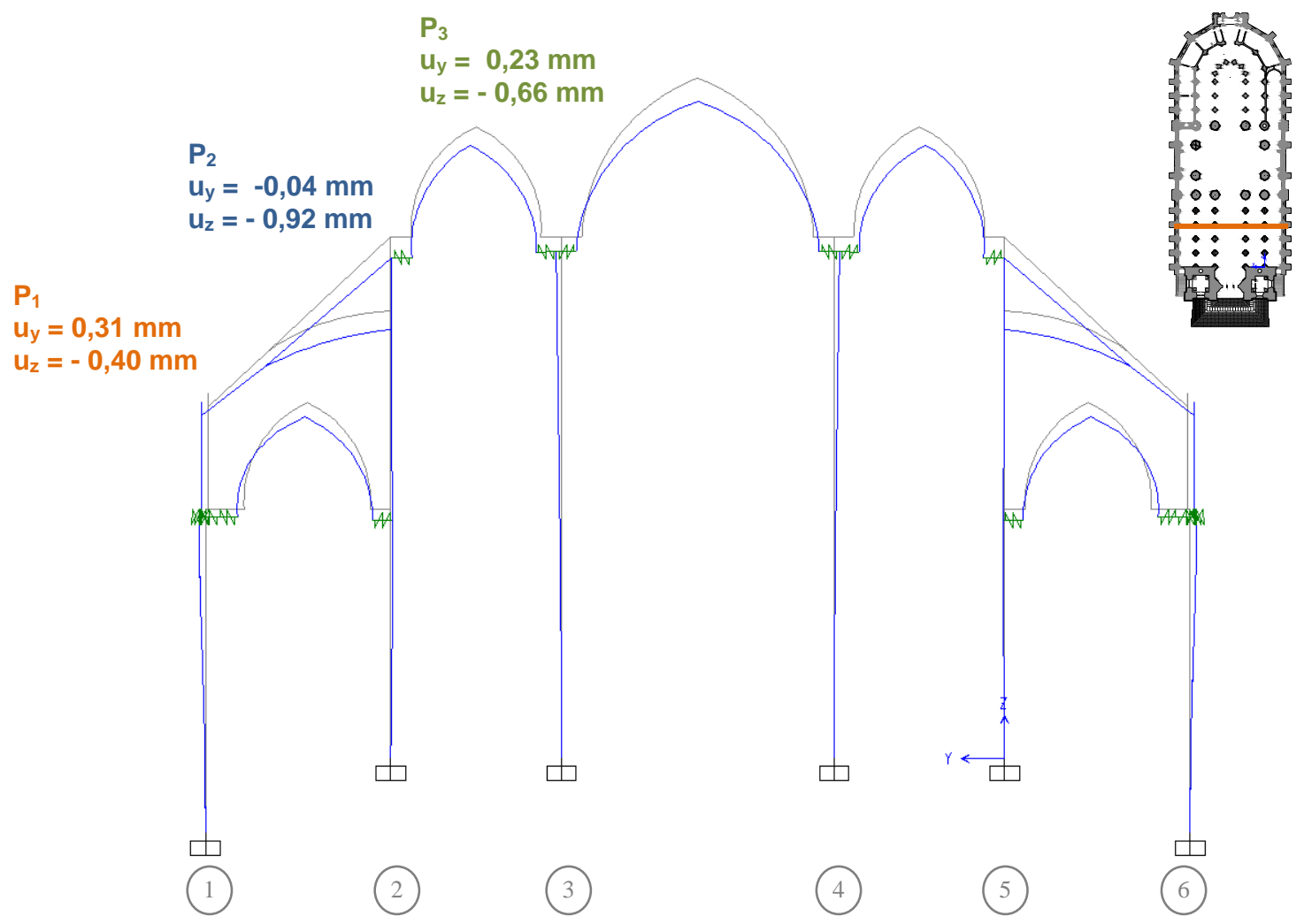

(a)

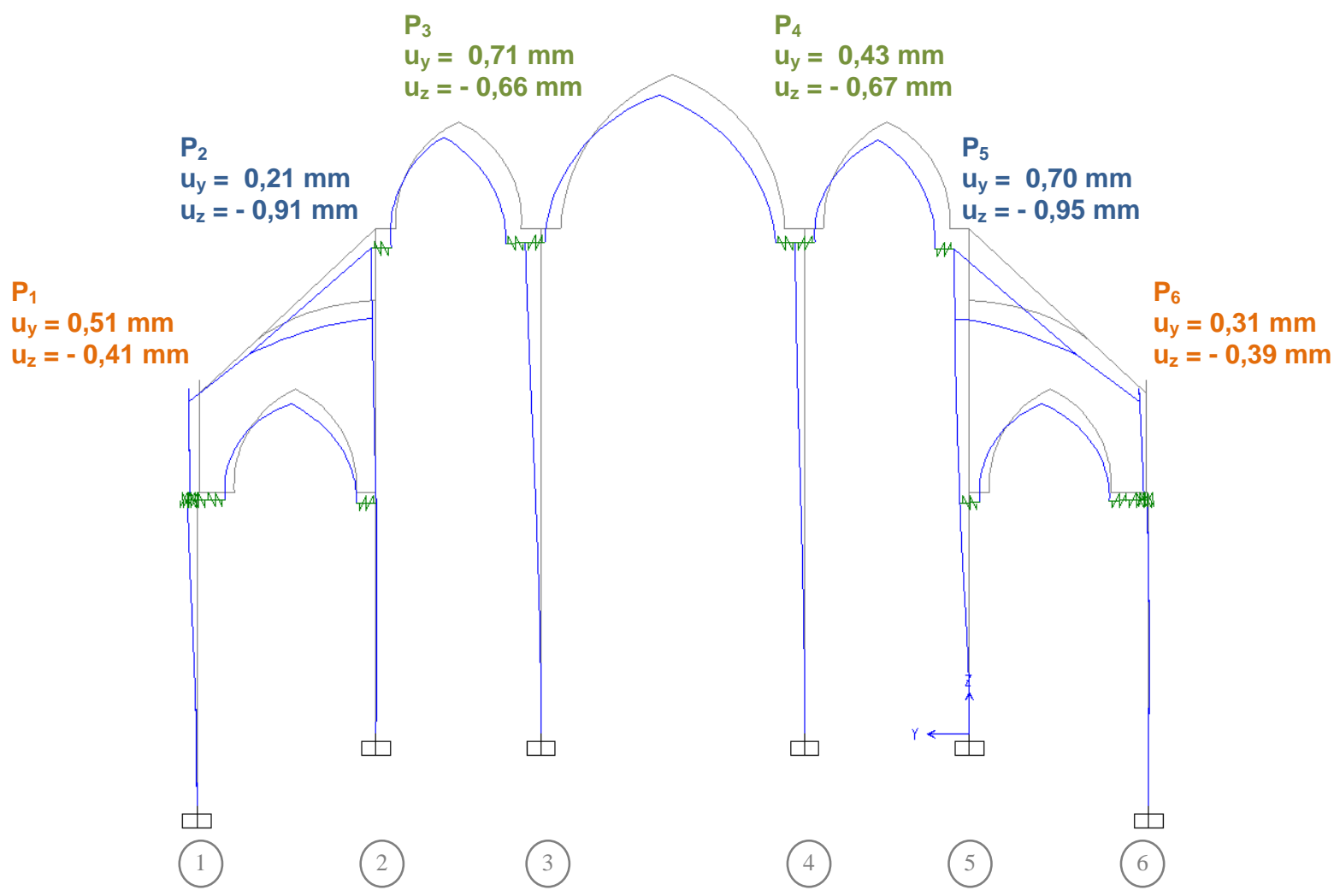

(b)

* barra rígida

Figura 5.11 - Deslocamentos transversais na seção do eixo D: (a) devidos à carga permanente; (b) devidos à carga permanente mais o vento a 90 graus - escala dos deslocamentos 1000:1. 


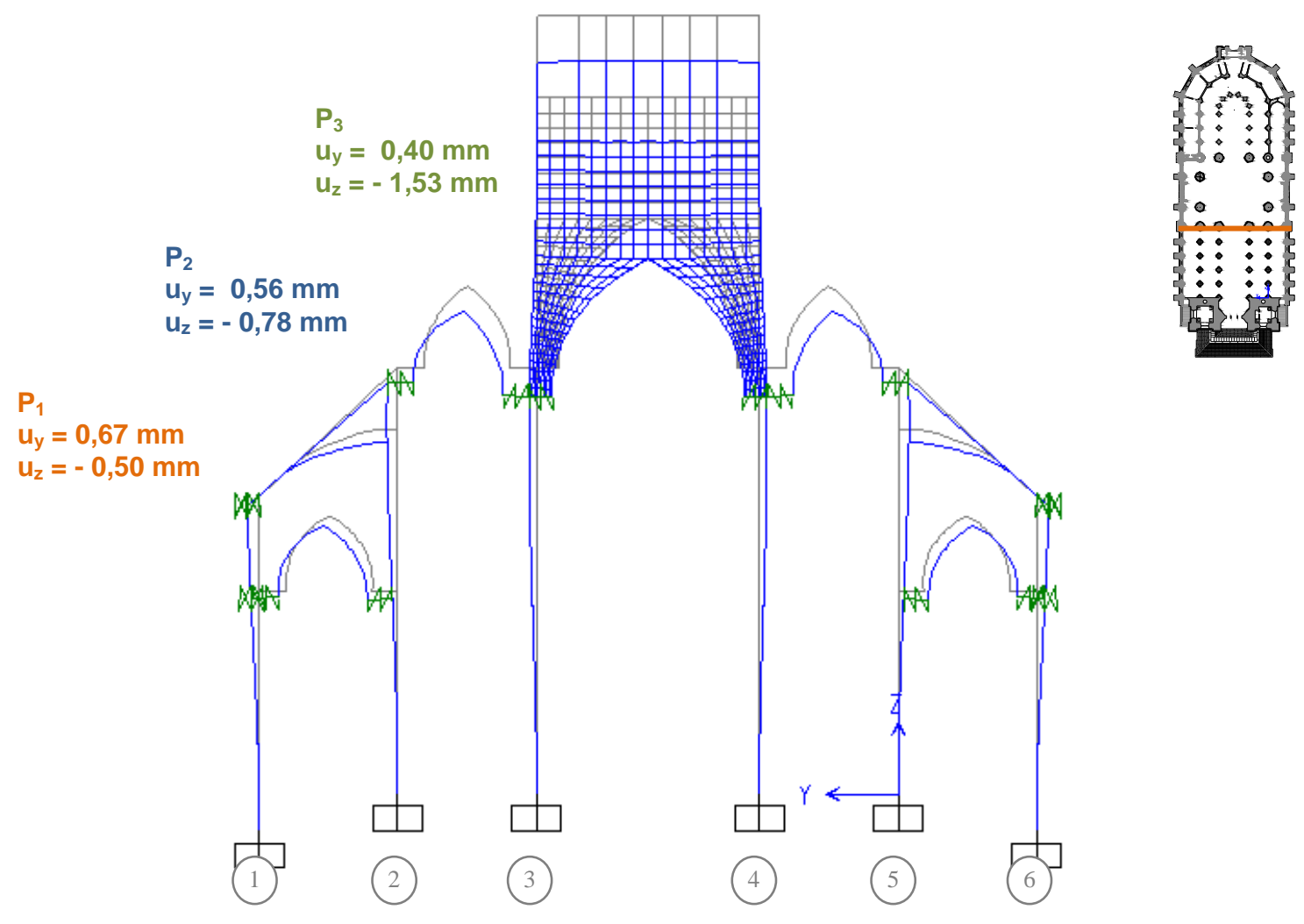

(a)

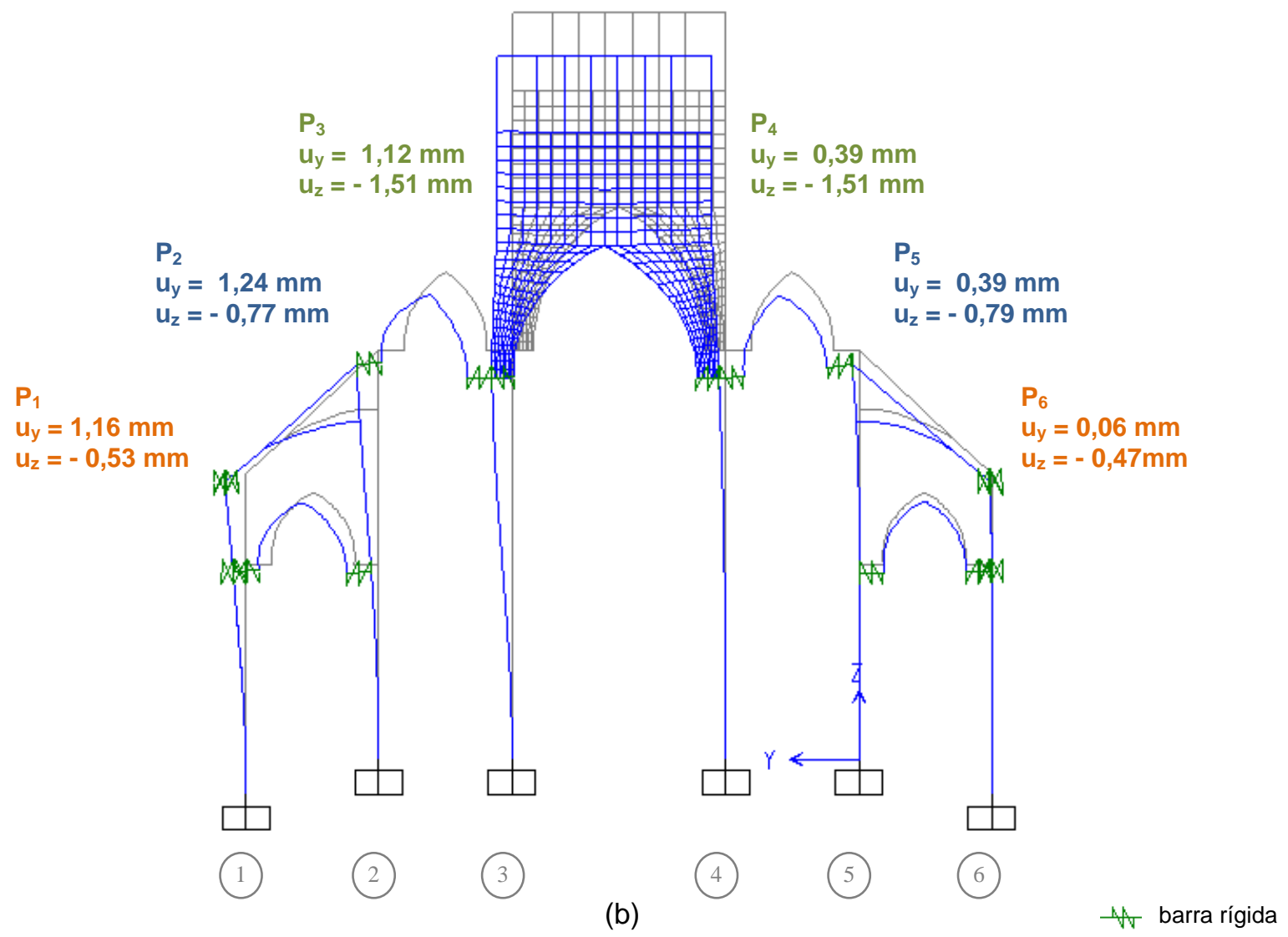

Figura 5.12 - Deslocamentos transversais na seção do eixo F: (a) devidos à carga permanente; (b) devidos à carga permanente mais o vento a 90 graus - escala dos deslocamentos 1000:1. 
Nota-se que na maioria dos contrafortes do eixo 6, nos quais incide diretamente a pressão do vento a 90 graus, o deslocamento transversal é para o interior da edificação. Comparando-se com a situação em que atua somente a carga permanente, as maiores variações de deslocamentos transversais encontram-se nestes contrafortes, em até mais de $100 \%$, como no contraforte C.6E.

Vale ressaltar que o estudo da influência do vento e do desaprumo nos deslocamentos dos elementos de apoio deve ser feito caso a caso. Mas o que pôde constatar-se é que, na maioria dos casos, o vento a 90 graus gera nos pilares e contrafortes maiores deslocamentos totais, mas não muito distantes daqueles provocados pelo desaprumo.

O desaprumo combinado nas direções $+x$ e +y acentua os deslocamentos dos pilares e contrafortes da região do octógono nas seções $\mathrm{H}$ e I e os dos pilares da região posterior do templo, salvo os da região curva, já que mesmo somente sob a ação da carga permanente apresentam a tendência de deslocar-se para o interior da edificação. Já o desaprumo combinado nas direções $-x$ e +y acentua os deslocamentos horizontais totais dos pilares da região frontal e da região do octógono nas seções F e G como mostra a Figura 5.13. 


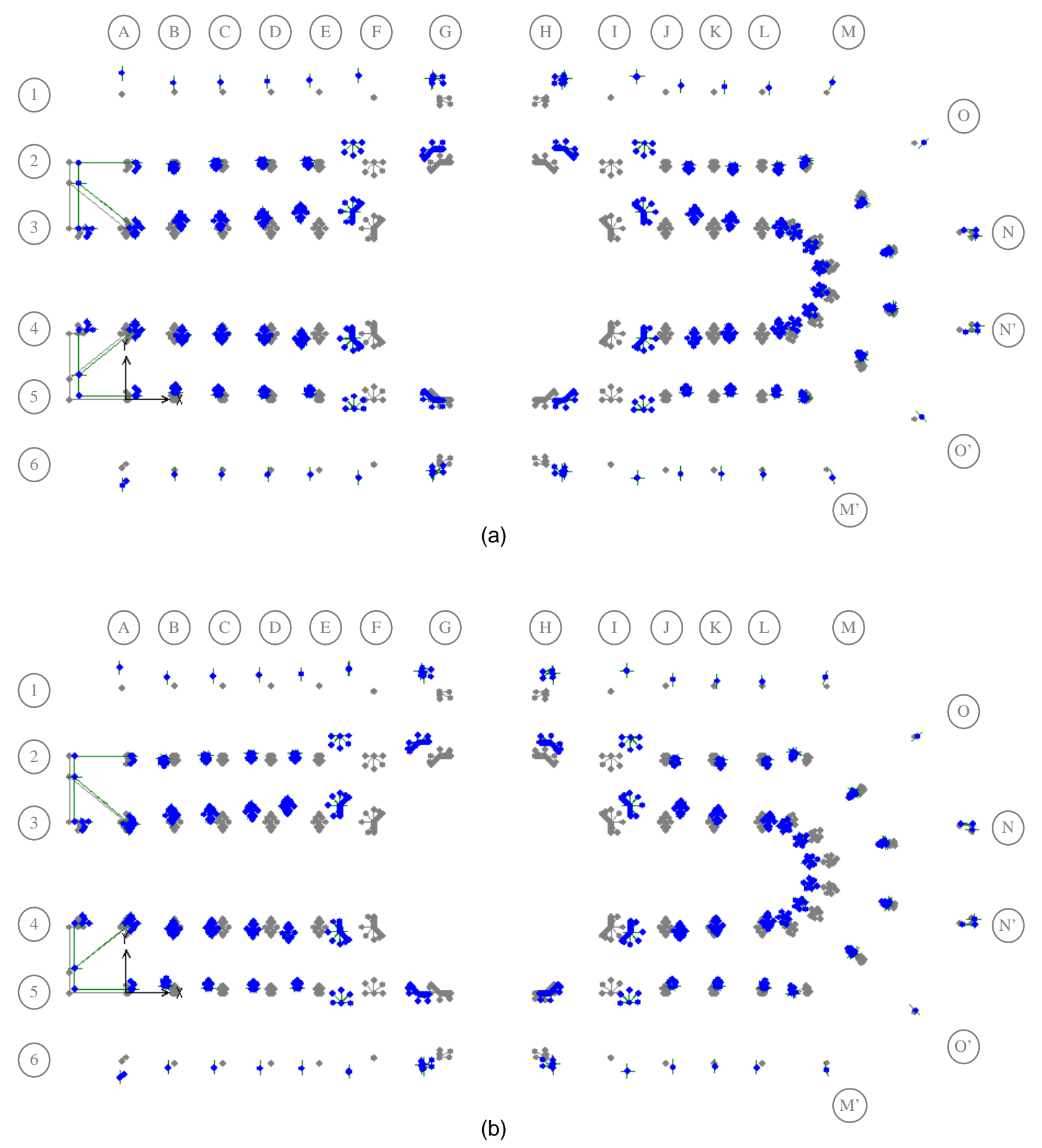

Figura 5.13 - Mapa dos deslocamentos: (a) devidos à carga permanente mais desaprumo $(+x+y)$; (b) devidos à carga permanente mais desaprumo $(-x+y)$ - planta - escala dos deslocamentos 3000:1. 


\subsection{Simulações - importância dos elementos estruturais}

Esta seção apresenta a função de alguns elementos estruturais para o equilíbrio da Catedral da Sé a partir da análise do comportamento global e qualitativo do conjunto em termos de deslocamentos.

\subsubsection{Os arcobotantes}

A dificuldade de construir uma catedral alta e iluminada são os empuxos horizontais gerados pelas abóbadas e telhados.

Nas igrejas românicas, estes empuxos eram resistidos pelas paredes laterais da nave central, o que fazia com que elas não pudessem ser muito altas nem com muitas aberturas.

Foi somente com o advento do arcobotante que se conseguiu obter o espaço pretendido pelo gótico, um ambiente com elevadas alturas e grande luminosidade interior, idealizado pelo abade Suger para a Abadia de Saint-Denis no século XII, em Saint-Denis, na atual grande Paris, cuja reconstrução foi finalizada em 1144 (FREITAS (a), 2009).

Os empuxos horizontais são transmitidos pelos arcobotantes até os rígidos contrafortes, mantendo o equilíbrio destas igrejas (Figura 5.14).

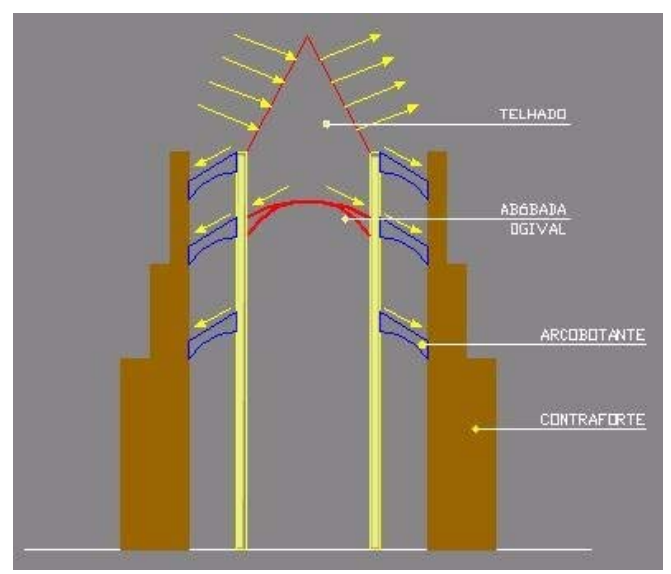

Figura 5.14 - Esquema de transmissão dos esforços em uma catedral gótica (FREITAS (c), (2009)).

A simulação da estrutura real, apresentada na seção 5.1 , mostra que sob a ação da carga permanente nem todos os pilares seguem a tendência de se 
deslocarem para fora da igreja. Os pilares laterais das regiões frontal e posterior movimentam-se para o interior da edificação na direção transversal, e os pilares sob a geometria curva se deslocam para o interior da igreja em ambas as direções.

Simulando-se a retirada dos arcobotantes do modelo, os deslocamentos horizontais resultantes dos pilares aumentam consideravelmente, levando-os para o exterior da edificação e maximizando os deslocamentos na direção transversal, como mostram as Figuras 5.15 a 5.17.

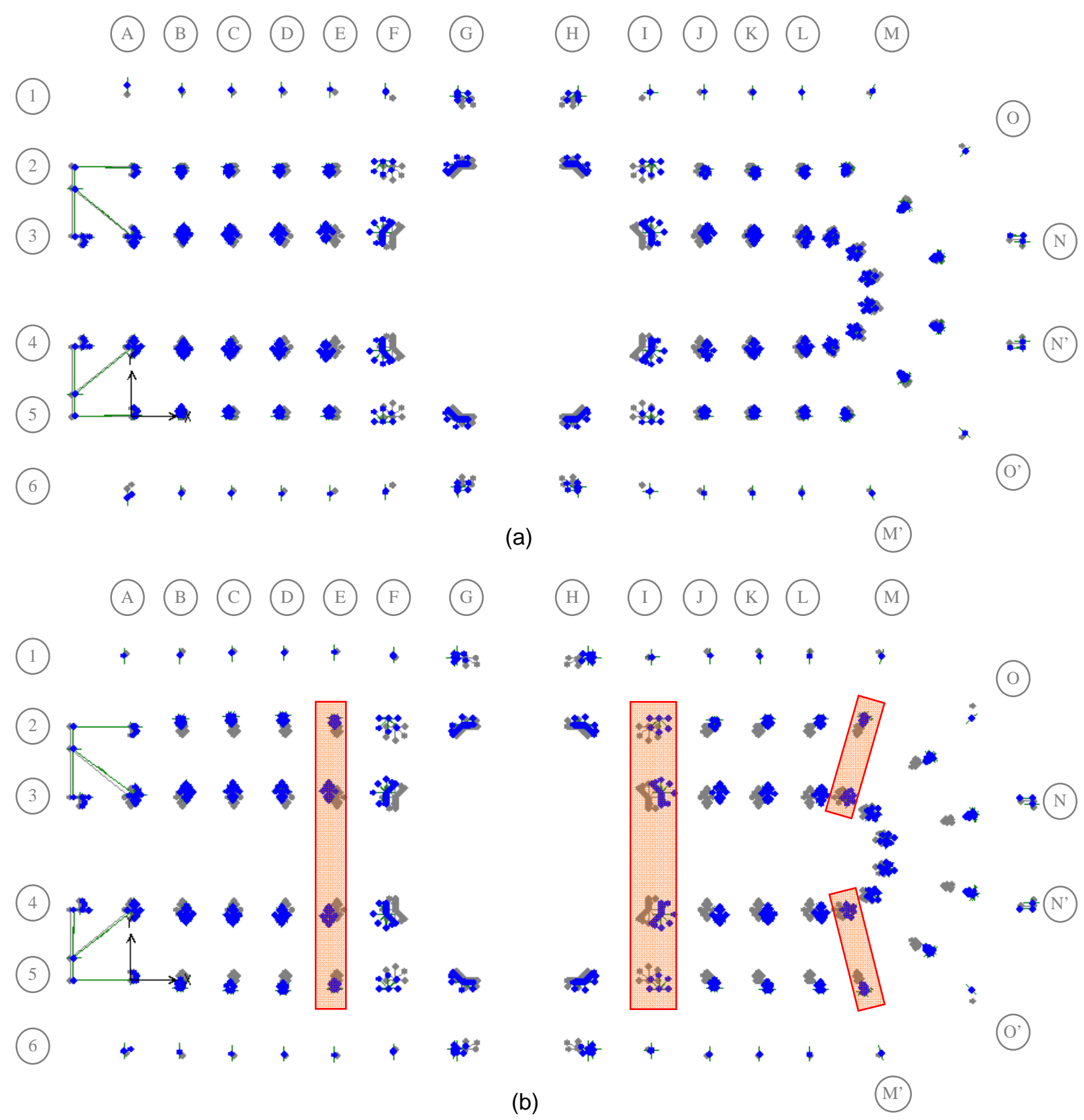

Figura 5.15 - Mapa dos deslocamentos devidos à carga permanente: (a) estrutura real; (b) simulação sem os arcobotantes - planta - escala dos deslocamentos 1000:1. 


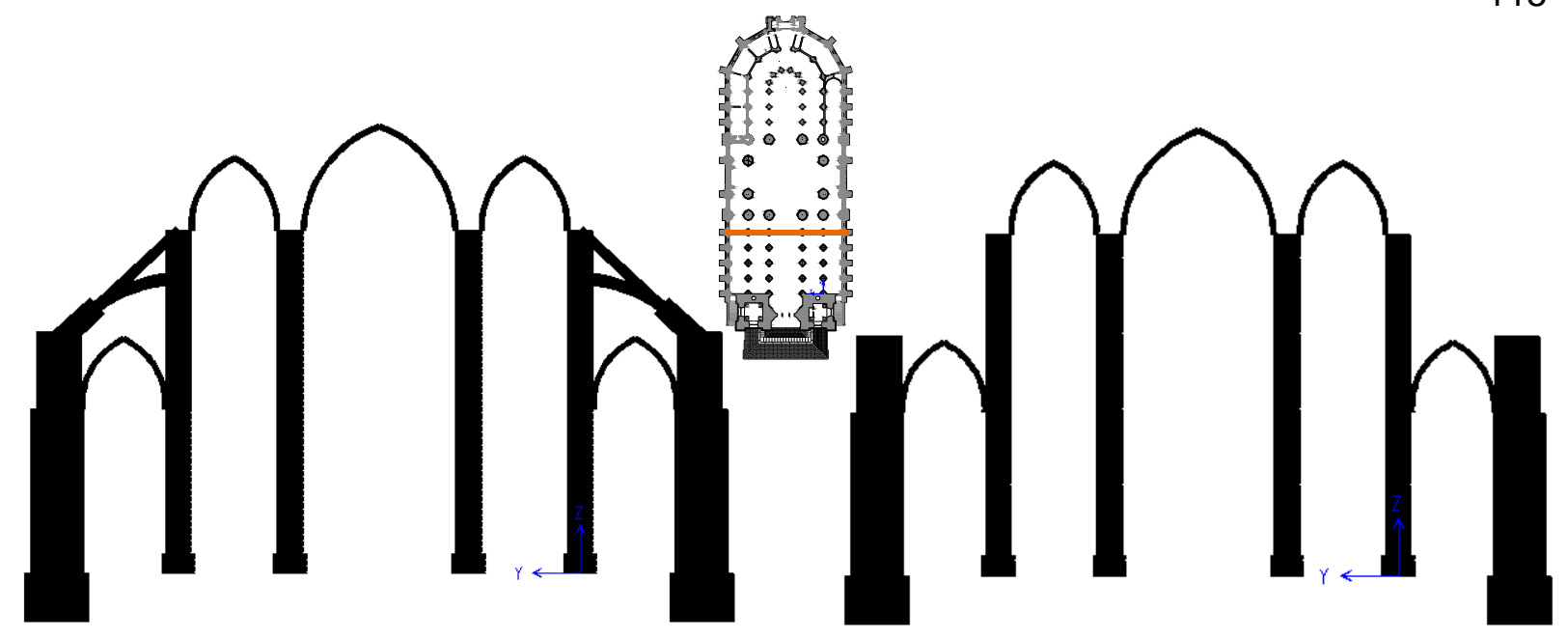

$\left(a_{1}\right)$

$\left(b_{1}\right)$

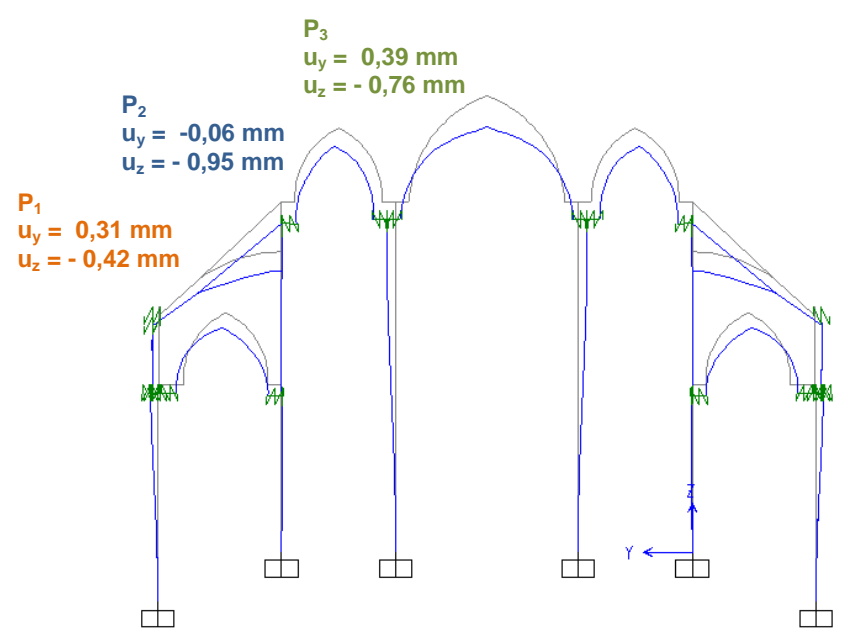

$\left(a_{2}\right)$

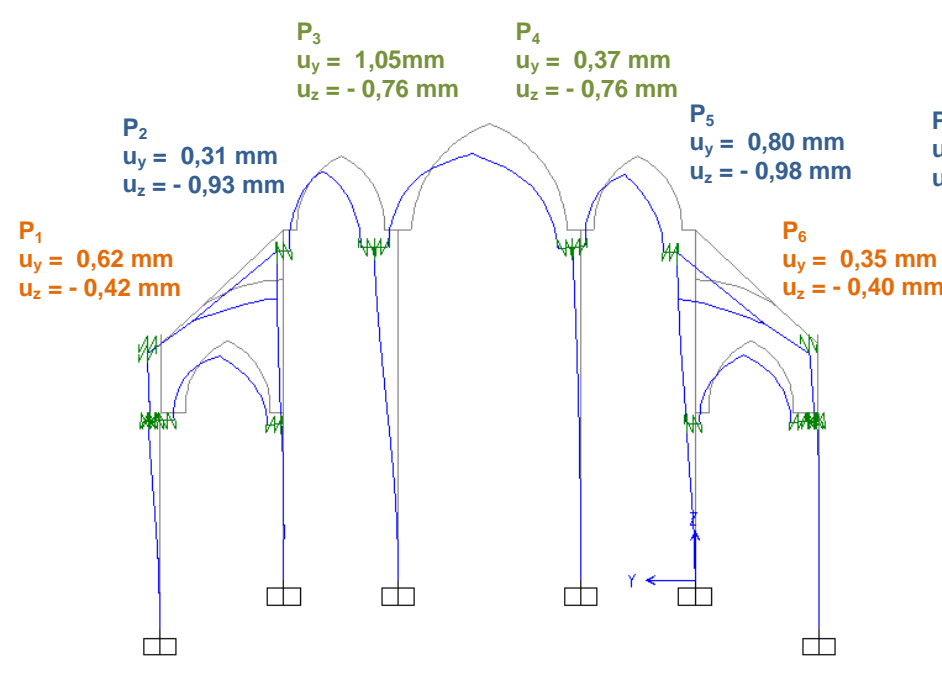

$\left(a_{3}\right)$

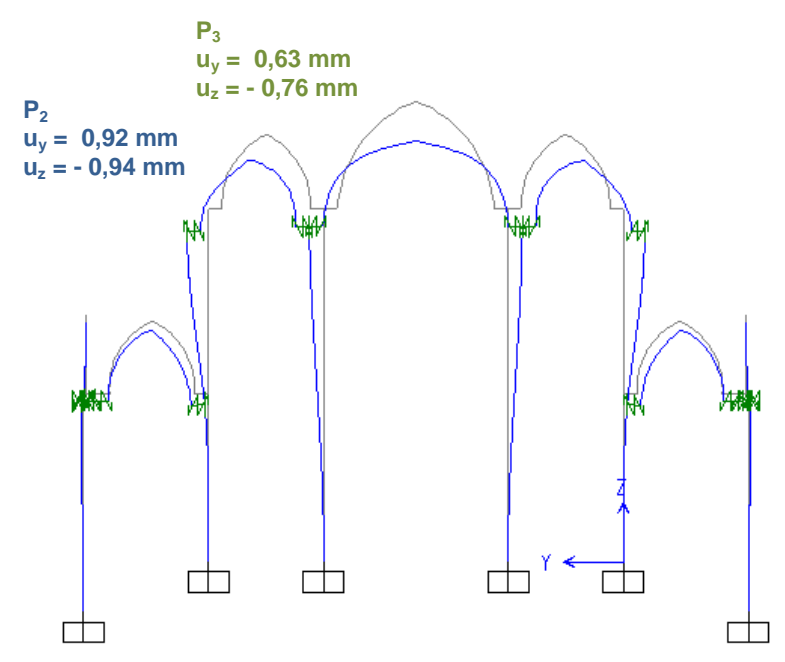

$\left(b_{2}\right)$

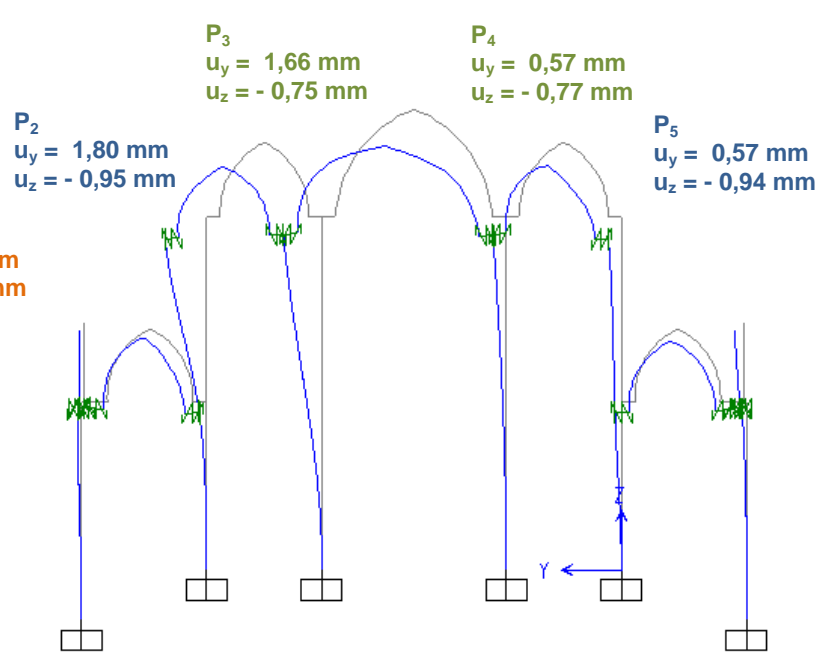

$\left(b_{3}\right) \quad$ barra rígida

Figura 5.16 - Deslocamentos na seção do eixo E: (a) estrutura real - $\left(a_{1}\right)$ vista; $\left(a_{2}\right)$ sob a ação da carga permanente; $\left(a_{3}\right)$ sob a ação da carga permanente mais o vento a 90 graus; (b) simulação sem os arcobotantes - $\left(b_{1}\right)$ vista; $\left(b_{2}\right)$ sob a ação da carga permanente; $\left(b_{3}\right)$ sob a ação da carga permanente mais o vento a 90 graus - escala dos deslocamentos 1500:1. 


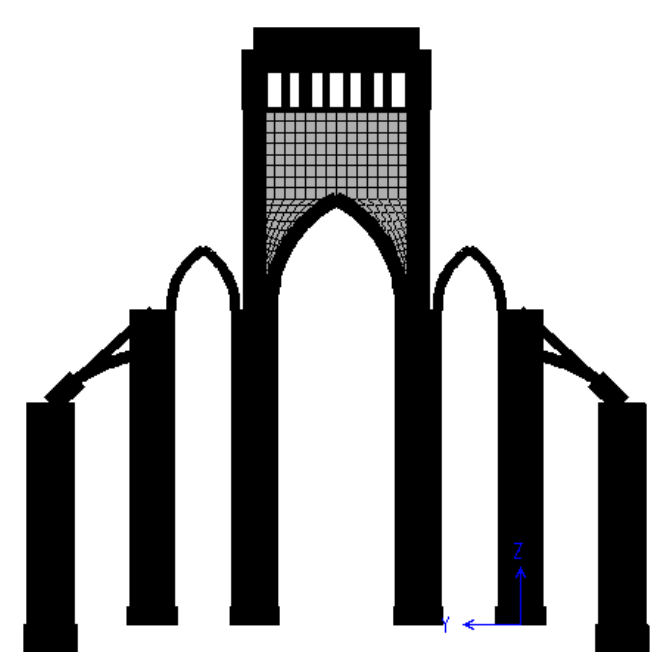

$\left(a_{1}\right)$

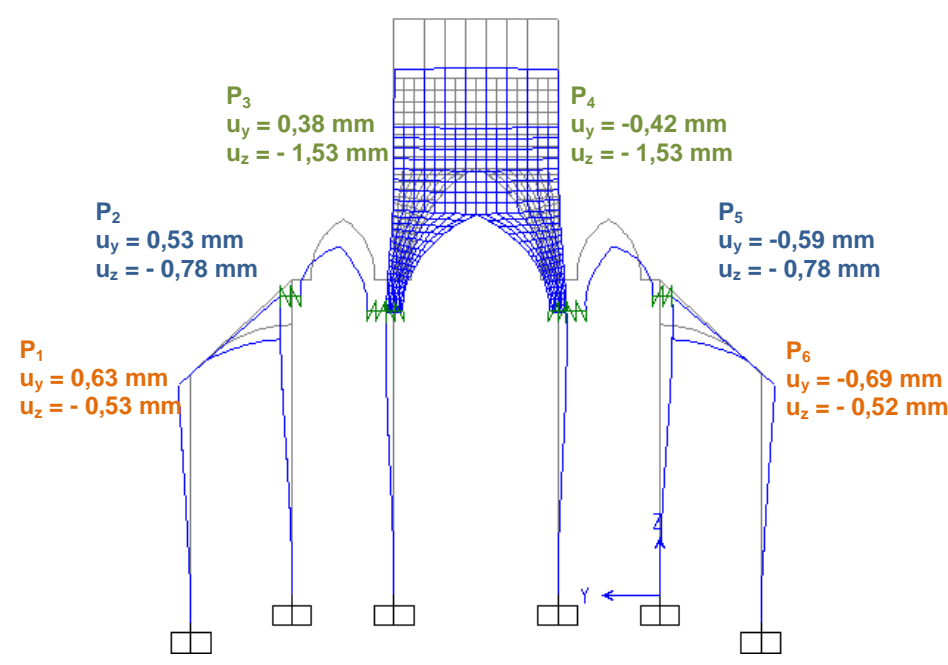

$\left(\mathrm{a}_{2}\right)$

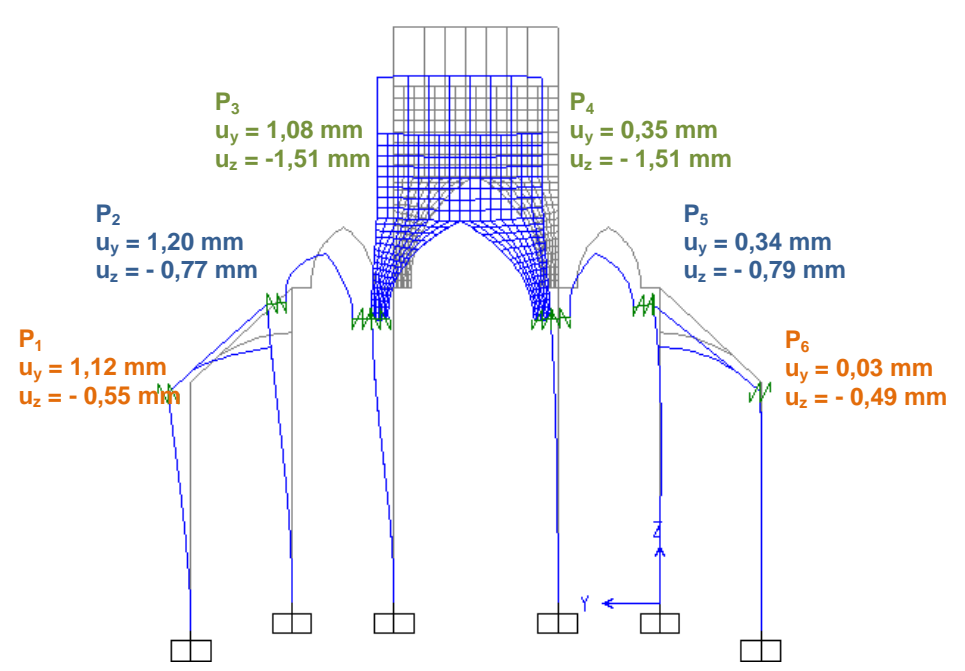

$\left(a_{3}\right)$

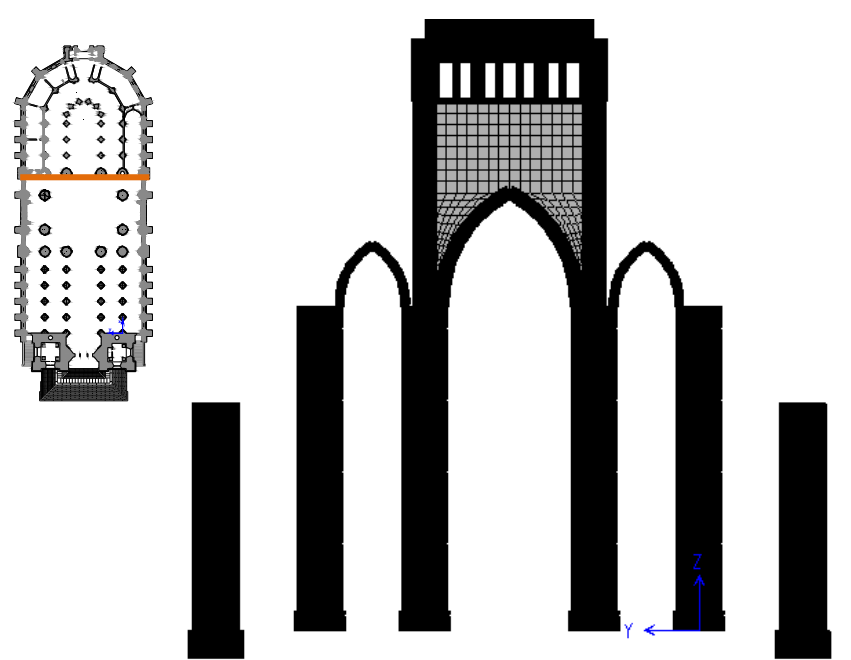

$\left(b_{1}\right)$

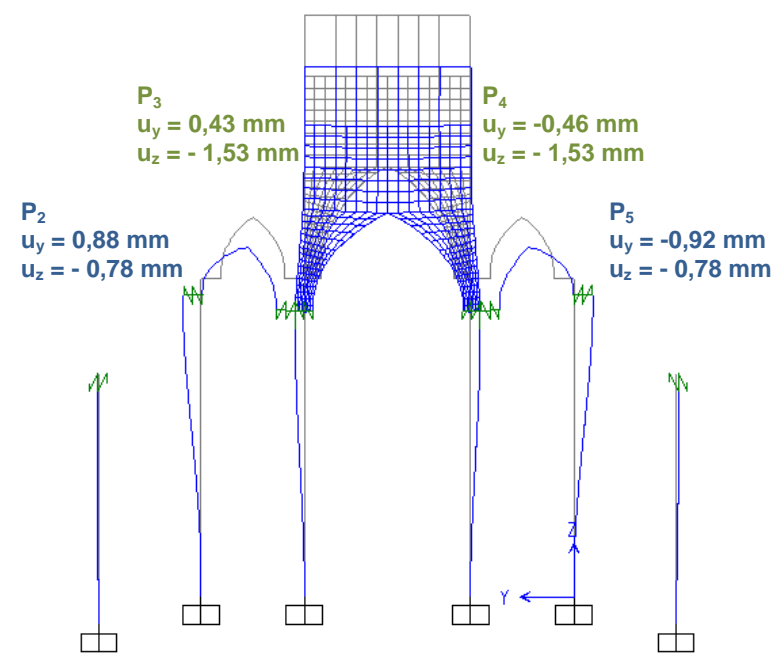

$\left(b_{2}\right)$

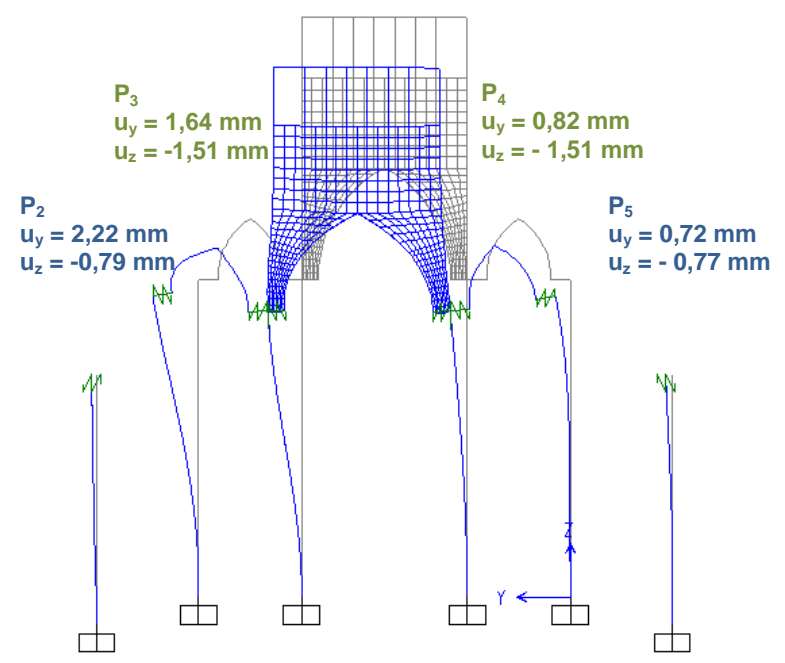

$\left(b_{3}\right) \quad$ barra rígida

Figura 5.17 - Deslocamentos na seção do eixo I: (a) estrutura real - $\left(a_{1}\right)$ vista; $\left(a_{2}\right)$ sob a ação da carga permanente; $\left(a_{3}\right)$ sob a ação da carga permanente mais o vento a 90 graus; (b) simulação sem os arcobotantes - $\left(b_{1}\right)$ vista; $\left(b_{2}\right)$ sob a ação da carga permanente; $\left(b_{3}\right)$ sob a ação da carga permanente mais o vento a 90 graus - escala dos deslocamentos 1500:1. 
Destacam-se ainda, na Figura 5.15, alguns pilares da região posterior da igreja sob a geometria curva, cuja transferência dos empuxos pelos arcobotantes ocorre em duas direções. Nota-se que, sem os arcobotantes, os pilares dos eixos M e M', por exemplo, deslocam-se para o exterior da igreja. A Tabela 5.4 mostra os deslocamentos horizontais destes pilares na estrutura real e na simulação em que os arcobotantes são retirados, sob duas condições de carregamento.

Tabela 5.4 - Comparativo dos deslocamentos no topo dos pilares da região posterior - eixos M e M' - sem os arcobotantes.

\begin{tabular}{|c|c|c|c|c|c|}
\hline \multicolumn{6}{|c|}{ Estrutura real } \\
\hline \multirow{3}{*}{ Carregamento } & \multirow{3}{*}{ Nó } & $\begin{array}{c}\text { Deslocamento } \\
\text { Vertical }\end{array}$ & \multicolumn{3}{|c|}{ Deslocamento Horizontal } \\
\hline & & $\mathbf{u}_{\mathbf{z}}$ & $u_{x}$ & $\mathbf{u}_{\mathrm{y}}$ & $\left|u_{R}\right|$ \\
\hline & & $\mathrm{mm}$ & $\mathrm{mm}$ & $\mathrm{mm}$ & $\mathrm{mm}$ \\
\hline \multirow{4}{*}{$\begin{array}{c}\text { Carga } \\
\text { permanente }\end{array}$} & P.2M & $-1,03$ & $-0,32$ & 0,03 & 0,32 \\
\hline & P.3M & $-0,53$ & $-0,04$ & $-0,34$ & 0,34 \\
\hline & P.4M' & $-0,53$ & $-0,04$ & 0,25 & 0,25 \\
\hline & P.5M' & $-1,00$ & $-0,33$ & $-0,12$ & 0,35 \\
\hline \multirow{4}{*}{$\begin{array}{c}\text { Carga } \\
\text { permanente } \\
+ \\
\text { Vento a } 90^{\circ}\end{array}$} & P.2M & $-1,01$ & $-0,25$ & 0,29 & 0,39 \\
\hline & P.3M & $-0,53$ & 0,03 & 0,15 & 0,13 \\
\hline & P.4M' & $-0,53$ & 0,13 & 0,87 & 0,86 \\
\hline & P.5M' & $-1,02$ & 0,08 & 0,52 & 0,52 \\
\hline \multicolumn{6}{|c|}{ Estrutura sem os arcobotantes } \\
\hline \multirow{3}{*}{ Carregamento } & \multirow{3}{*}{ Nó } & $\begin{array}{c}\text { Deslocamento } \\
\text { Vertical }\end{array}$ & \multicolumn{3}{|c|}{ Deslocamento Horizontal } \\
\hline & & $\mathbf{u}_{\mathbf{z}}$ & $\mathbf{u}_{\mathrm{x}}$ & $\mathrm{u}_{\mathrm{y}}$ & $\left|u_{R}\right|$ \\
\hline & & $\mathrm{mm}$ & $\mathrm{mm}$ & $\mathrm{mm}$ & $\mathrm{mm}$ \\
\hline \multirow{4}{*}{$\begin{array}{c}\text { Carga } \\
\text { permanente }\end{array}$} & P.2M & $-1,02$ & 0,61 & 1,17 & 1,32 \\
\hline & P.3M & $-0,54$ & 0,82 & $-0,09$ & 0,83 \\
\hline & P.4M' & $-0,54$ & 0,81 & 0,03 & 0,81 \\
\hline & P.5M' & $-1,00$ & 0,59 & $-1,26$ & 1,39 \\
\hline \multirow{4}{*}{$\begin{array}{c}\text { Carga } \\
\text { permanente } \\
+ \\
\text { Vento a } 90^{\circ}\end{array}$} & P.2M & $-1,03$ & 0,64 & 2,24 & 2,33 \\
\hline & P.3M & $-0,54$ & 0,92 & 1,14 & 1,47 \\
\hline & P.4M' & $-0,54$ & 1,13 & 1,45 & 1,84 \\
\hline & P.5M' & $-1,00$ & 1,08 & 0,32 & 1,13 \\
\hline
\end{tabular}




\subsubsection{As torres frontais}

Outro elemento estrutural chave para o equilíbrio da Catedral são suas duas torres frontais, que funcionam como enormes contrafortes a conter os deslocamentos horizontais, principalmente na direção longitudinal.

Numa simulação em que estas torres são retiradas, os deslocamentos longitudinais dos pilares e contrafortes sob a ação da carga permanente aumentam consideravelmente (Figura 5.18).

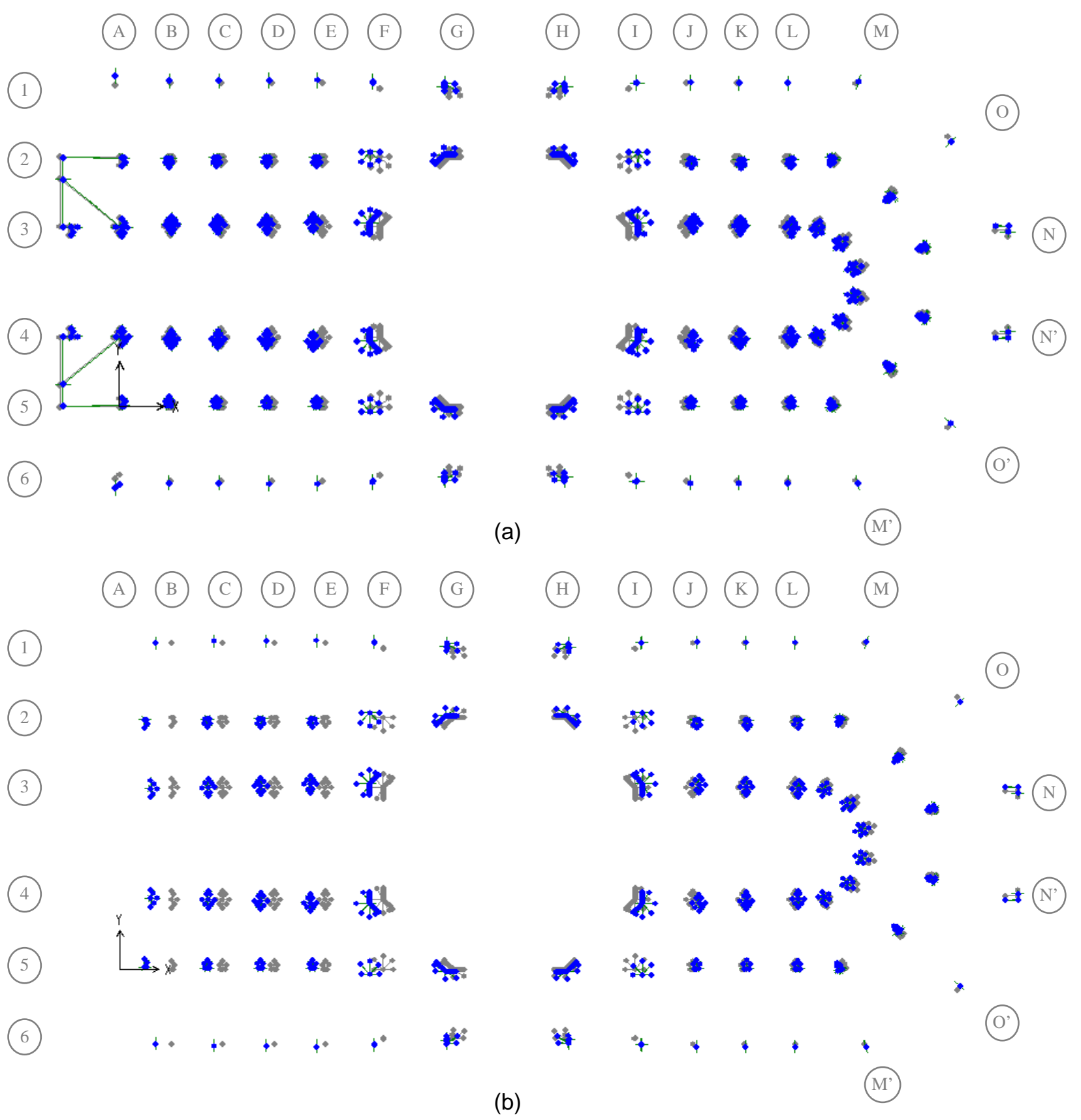

Figura 5.18 - Mapa dos deslocamentos devidos à carga permanente: (a) estrutura real; (b) simulação sem as torres frontais - planta - escala dos deslocamentos 1000:1. 
Nas Tabelas 5.5 e 5.6, comparam-se as diferenças nos deslocamentos horizontais dos pilares e contrafortes do eixo $B$ e de alguns pilares da região do octógono nas situações da presença e da ausência das duas grandes torres.

Os deslocamentos longitudinais dos pilares do eixo B sem as torres, por exemplo, chegam a ser até 16 vezes maiores que os da estrutura real, como mostra a Tabela 5.5, movimentando-se para o exterior da igreja. Nota-se, no entanto, que na direção transversal estes pilares deslocam-se para o interior e os contrafortes mantém sua tendência para fora.

Tabela 5.5 - Comparativo dos deslocamentos horizontais no topo dos pilares e contrafortes do eixo $\mathrm{B}$, devido à ação da carga permanente.

\begin{tabular}{cccc}
\hline \multicolumn{4}{c}{ Estrutura real } \\
\hline & \multicolumn{3}{c}{ Deslocamento Horizontal } \\
\cline { 2 - 4 } Nó & $\mathbf{u}_{\mathbf{x}}$ & $\mathbf{u}_{\mathbf{y}}$ & $\left|\mathbf{u}_{\mathbf{R}}\right|$ \\
& $\mathrm{mm}$ & $\mathrm{mm}$ & $\mathrm{mm}$ \\
\hline C.1B & $-0,12$ & 0,29 & 0,32 \\
\hline P.2B & $-0,19$ & $-0,14$ & 0,24 \\
\hline P.3B & 0,14 & 0,20 & 0,24 \\
\hline P.4B & 0,15 & $-0,21$ & 0,26 \\
\hline P.5B & $-0,19$ & 0,14 & 0,23 \\
\hline C.6B & $-0,13$ & $-0,30$ & 0,32 \\
\hline
\end{tabular}

\begin{tabular}{cccc}
\hline \multicolumn{3}{c}{ Estrutura sem as torres frontais } \\
\hline \multirow{3}{*}{ Nó } & \multicolumn{3}{c}{ Deslocamento Horizontal } \\
\cline { 2 - 4 } & $\mathbf{u}_{\mathbf{x}}$ & $\mathbf{u}_{\mathbf{y}}$ & $\left|\mathbf{u}_{\mathbf{R}}\right|$ \\
& $\mathrm{mm}$ & $\mathrm{mm}$ & $\mathrm{mm}$ \\
\hline C.1B & $-1,61$ & 0,01 & 1,61 \\
\hline P.2B & $-2,94$ & $-0,25$ & 2,95 \\
\hline P.3B & $-2,23$ & $-0,14$ & 2,24 \\
\hline P.4B & $-2,23$ & 0,13 & 2,23 \\
\hline P.5B & $-2,93$ & 0,26 & 2,94 \\
\hline C.6B & $-1,62$ & $-0,01$ & 1,62 \\
\hline
\end{tabular}

Tabela 5.6 - Comparativo dos deslocamentos horizontais no topo dos pilares da região do octógono, devido à ação da carga permanente.

\begin{tabular}{cccc}
\hline \multicolumn{4}{c}{ Estrutura real } \\
\hline \multirow{4}{*}{ Nó } & \multicolumn{2}{c}{ Deslocamento Horizontal } \\
\cline { 2 - 4 } & $\mathbf{u}_{\mathbf{x}}$ & $\mathbf{u}_{\mathbf{y}}$ & $\left|\mathbf{u}_{\mathbf{R}}\right|$ \\
& $\mathrm{mm}$ & $\mathrm{mm}$ & $\mathrm{mm}$ \\
\hline P.2F & $-1,04$ & 0,56 & 1,18 \\
\hline P.2G & $-0,55$ & 0,25 & 0,61 \\
\hline P.2H & 0,48 & 0,26 & 0,55 \\
\hline P.2I & 0,98 & 0,53 & 1,12 \\
\hline P.3F & $-1,07$ & 0,40 & 1,14 \\
\hline P.3I & 0,97 & 0,38 & 1,04 \\
\hline
\end{tabular}

\begin{tabular}{cccc}
\hline \multicolumn{4}{c}{ Estrutura sem as torres frontais } \\
\hline \multirow{3}{*}{ Nó } & \multicolumn{3}{c}{ Deslocamento Horizontal } \\
\cline { 2 - 4 } & $\mathbf{u}_{\mathbf{x}}$ & $\mathbf{u}_{\mathbf{y}}$ & $\left|\mathbf{u}_{\mathbf{R}}\right|$ \\
& $\mathrm{mm}$ & $\mathrm{mm}$ & $\mathrm{mm}$ \\
\hline P.2F & $-1,43$ & 0,51 & 1,52 \\
\hline P.2G & $-0,82$ & 0,18 & 0,84 \\
\hline P.2H & 0,24 & 0,21 & 0,32 \\
\hline P.2I & 0,82 & 0,51 & 0,96 \\
\hline P.3F & $-1,46$ & 0,40 & 1,52 \\
\hline P.3I & 0,53 & 0,63 & 0,83 \\
\hline
\end{tabular}

Vale ressaltar, que sem as torres frontais, como ilustram as Figuras $5.18 \mathrm{e}$ 5.19, os pilares da parte posterior da igreja e os pilares dos eixos $\mathrm{H}$ e I na região do 
octógono deslocam-se menos para o exterior da edificação, pois a Catedral tende a movimentar-se no sentido das torres ausentes (Tabela 5.6).
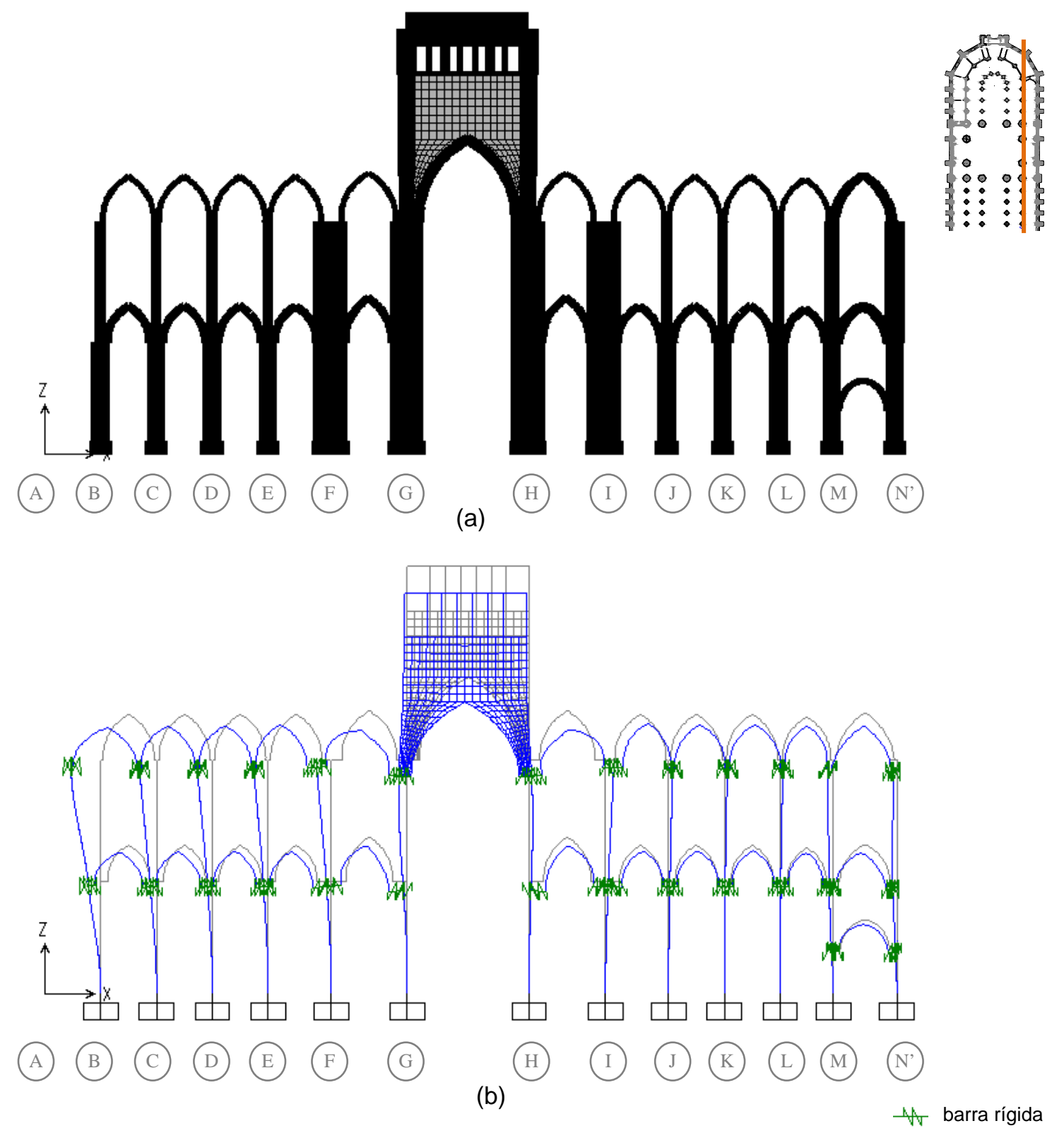

Figura 5.19 - Corte longitudinal no eixo 5 sem as torres frontais: (a) vista; (b) deslocamentos devidos à carga permanente - escala dos deslocamentos 1000:1.

$\mathrm{Na}$ Figura 5.20, comparam-se as deformadas na direção longitudinal dos pilares do eixo 5 da igreja, na situação real e na ausência das torres sob a ação da carga permanente. 

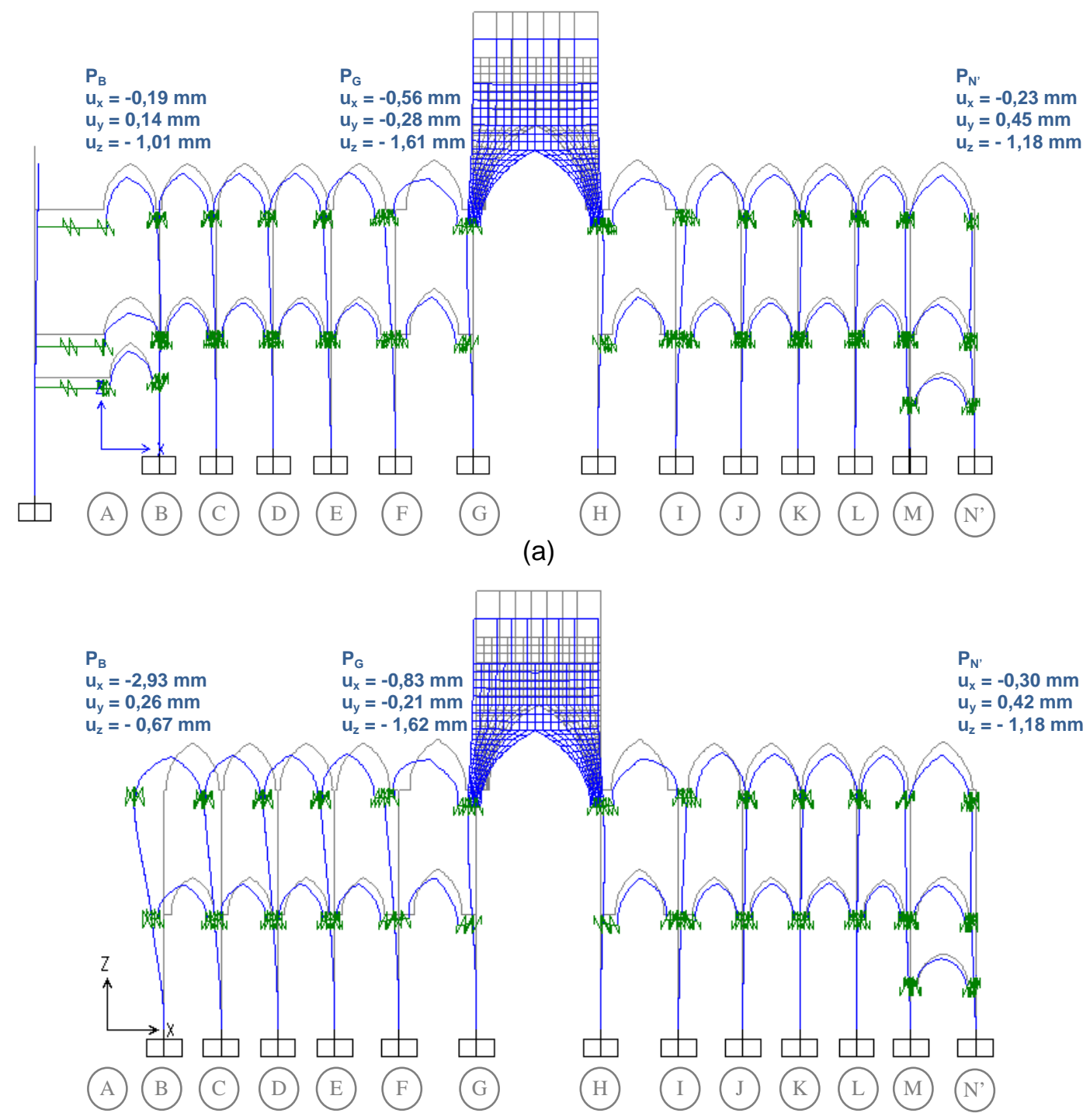

(b)

* barra rígida

Figura 5.20 - Comparativo dos deslocamentos na direção longitudinal no eixo 5 devidos à carga permanente: (a) simulação com as torres frontais; (b) simulação sem as torres frontais - escala dos deslocamentos 1000:1.

As simulações apresentadas permitem fazer considerações sobre a influência dos elementos estruturais retirados.

$\mathrm{Na}$ Tabela 5.7, a título de exemplo, são apresentados os resultados das simulações para alguns dos pilares do octógono, por se tratar de uma região exposta às elevadas cargas do tambor e da cúpula.

Como observado, sem as torres frontais, os deslocamentos horizontais totais dos pilares da região frontal e dos eixos F e G aumentam em relação à estrutura real e são maximizados, enquanto que os pilares dos eixos $\mathrm{H}$ e I e os pilares da parte posterior da igreja se deslocam menos para o exterior da edificação. 
Tabela 5.7 - Comparativo dos deslocamentos no topo de alguns pilares na região do octógono sob ação da carga permanente.

\begin{tabular}{ccccc}
\hline \multicolumn{5}{c}{ Estrutura real } \\
\hline \multirow{5}{*}{ Nó } & $\begin{array}{c}\text { Deslocamento } \\
\text { Vertical }\end{array}$ & \multicolumn{3}{c}{ Deslocamento Horizontal } \\
\cline { 2 - 5 } & $\mathbf{u}_{\mathbf{z}}$ & $\mathbf{u}_{\mathbf{x}}$ & $\mathbf{u}_{\mathbf{y}}$ & $\left|\mathbf{u}_{\mathbf{R}}\right|$ \\
& $\mathrm{mm}$ & $\mathrm{mm}$ & $\mathrm{mm}$ & $\mathrm{mm}$ \\
\hline P.2F & $-0,78$ & $-1,04$ & 0,56 & 1,18 \\
\hline P.2G & $-1,61$ & $-0,55$ & 0,25 & 0,61 \\
\hline P.2H & $-1,61$ & 0,48 & 0,26 & 0,55 \\
\hline P.2I & $-0,78$ & 0,98 & 0,53 & 1,12 \\
\hline P.3F & $-1,53$ & $-1,07$ & 0,40 & 1,14 \\
\hline P.3I & $-1,53$ & 0,97 & 0,38 & 1,04 \\
\hline \multicolumn{5}{c}{ Estrutura sem os arcobotantes } \\
\hline & Deslocamento & Deslocamento Horizontal \\
\cline { 2 - 6 } Vertical & $\mathbf{u}_{\mathbf{z}}$ & $\mathbf{u}_{\mathbf{x}}$ & $\mathbf{u}_{\mathbf{y}}$ & $\left|\mathbf{u}_{\mathbf{R}}\right|$ \\
& $\mathrm{mm}$ & $\mathrm{mm}$ & $\mathrm{mm}$ & $\mathrm{mm}$ \\
\hline Nóy & $-0,77$ & $-0,76$ & 0,91 & 1,19 \\
\hline P.2F & $-1,63$ & $-0,38$ & 0,19 & 0,43 \\
\hline P.2G & $-1,63$ & 0,72 & 0,19 & 0,74 \\
\hline P.2H & $-0,78$ & 1,13 & 0,88 & 1,43 \\
\hline P.2I & $-1,53$ & $-1,00$ & 0,45 & 1,09 \\
\hline P.3F & $-1,53$ & 1,35 & 0,43 & 1,42 \\
\hline P.3I & \multicolumn{3}{c}{} \\
\hline
\end{tabular}

\begin{tabular}{ccccc}
\hline \multicolumn{5}{c}{ Estrutura sem as torres frontais } \\
\hline \multirow{4}{*}{ Nó } & $\begin{array}{c}\text { Deslocamento } \\
\text { Vertical }\end{array}$ & \multicolumn{3}{c}{ Deslocamento Horizontal } \\
\cline { 2 - 5 } & $\mathbf{u}_{\mathbf{z}}$ & $\mathbf{u}_{\mathbf{x}}$ & $\mathbf{u}_{\mathbf{y}}$ & $\left|\mathbf{u}_{\mathbf{R}}\right|$ \\
& $\mathrm{mm}$ & $\mathrm{mm}$ & $\mathrm{mm}$ & $\mathrm{mm}$ \\
\hline P.2F & $-0,77$ & $-1,43$ & 0,51 & 1,52 \\
\hline P.2G & $-1,62$ & $-0,82$ & 0,18 & 0,84 \\
\hline P.2H & $-1,62$ & 0,24 & 0,21 & 0,32 \\
\hline P.2I & $-0,78$ & 0,82 & 0,51 & 0,96 \\
\hline P.3F & $-1,52$ & $-1,46$ & 0,40 & 1,52 \\
\hline P.3I & $-1,52$ & 0,81 & 0,39 & 0,90 \\
\hline
\end{tabular}

Já na ausência dos arcobotantes, os deslocamentos horizontais totais dos pilares dos eixos $\mathrm{H}$ e I, próximos à parte posterior da igreja, são maximizados. Estes resultados são influenciados pela geometria curva da região posterior da Catedral, onde a transferência dos empuxos ocorre em duas direções. Além disso, as torres frontais estão presentes nesta simulação, restringindo maiores deslocamentos na parte frontal da igreja, e, conseqüentemente, nas seções dos eixos F e G.

Sem os arcobotantes, todos os pilares movimentam-se para fora, e os deslocamentos na direção transversal também são maximizados, com exceção dos pilares dos eixos $\mathrm{G}$ e $\mathrm{H}$, mais afetados pela ausência de vigas de concreto existentes no transepto. A ausência destas vigas é muito menos influente sobre os deslocamentos da Catedral do que a falta das torres frontais ou dos arcobotantes. 


\subsection{Elementos estruturais do estilo gótico}

Composta por arcos e abóbadas ogivais, pilares, arcobotantes, contrafortes e altas torres, a Catedral da Sé parece obedecer fielmente aos anseios de uma catedral gótica medieval.

A Catedral da Sé possui algumas dimensões muito similares a algumas construções góticas da Europa, como, por exemplo, à Abadia de Saint-Denis, cujas abóbadas da nave central alcançam a altura de 29 metros e uma largura de 12,5 metros; esta edificação tem 108 metros de comprimento.

No entanto, a Catedral da Sé possui menores dimensões quando comparada às grandes catedrais ogivais, pertencentes ao período do Alto Gótico, representado pelas Catedrais de Chartres, Reims e Amiens, e ainda mais distante quando comparada à Catedral de Beauvais.

A Catedral de Chartres, construída entre 1194 e 1220, possui 130 metros de comprimento e três naves cobertas por abóbadas quadripartidas. A nave central tem 36,5 metros de altura e uma largura de 16,4 metros e, as naves laterais atingem 13,8 metros de altura numa largura de oito metros. Já a Catedral de Reims, reconstruída após um incêndio em 1210 e terminada no século XIV, possui 150 metros de comprimento e também é dotada de três naves. A nave central alcança 38 metros de altura numa largura de 14,6 metros e as naves laterais têm 16,4 metros de altura e quase oito metros de largura, cobertas por abóbadas quadripartidas (COSSE, 2001).

A Catedral de Amiens foi reconstruída entre 1220 e 1401, também depois de um grande incêndio ocorrido em 1218, que destruiu a antiga igreja em estilo românico (FREITAS (b), 2009) e, como Chartres e Reims, possui três naves (Figura 5.21). São 145 metros de comprimento; as abóbadas quadripartidas da nave central atingem 42,5 metros de altura e cobrem 14,6 metros de largura e a das naves laterais alcançam 18,8 metros de altura e oito metros e meio de largura.

Finalmente, localizada a $60 \mathrm{~km}$ ao norte de Paris, está a Catedral de Beauvais, também conhecida como a Catedral Inacabada, por ter apenas o coro e o transepto construídos. 
As abóbadas do coro elevam-se a 48,2 metros de altura numa largura de 15,6 metros; as abóbadas do deambulatório alcançam 21,2 metros de altura numa largura de sete metros (COSSE, 2001).
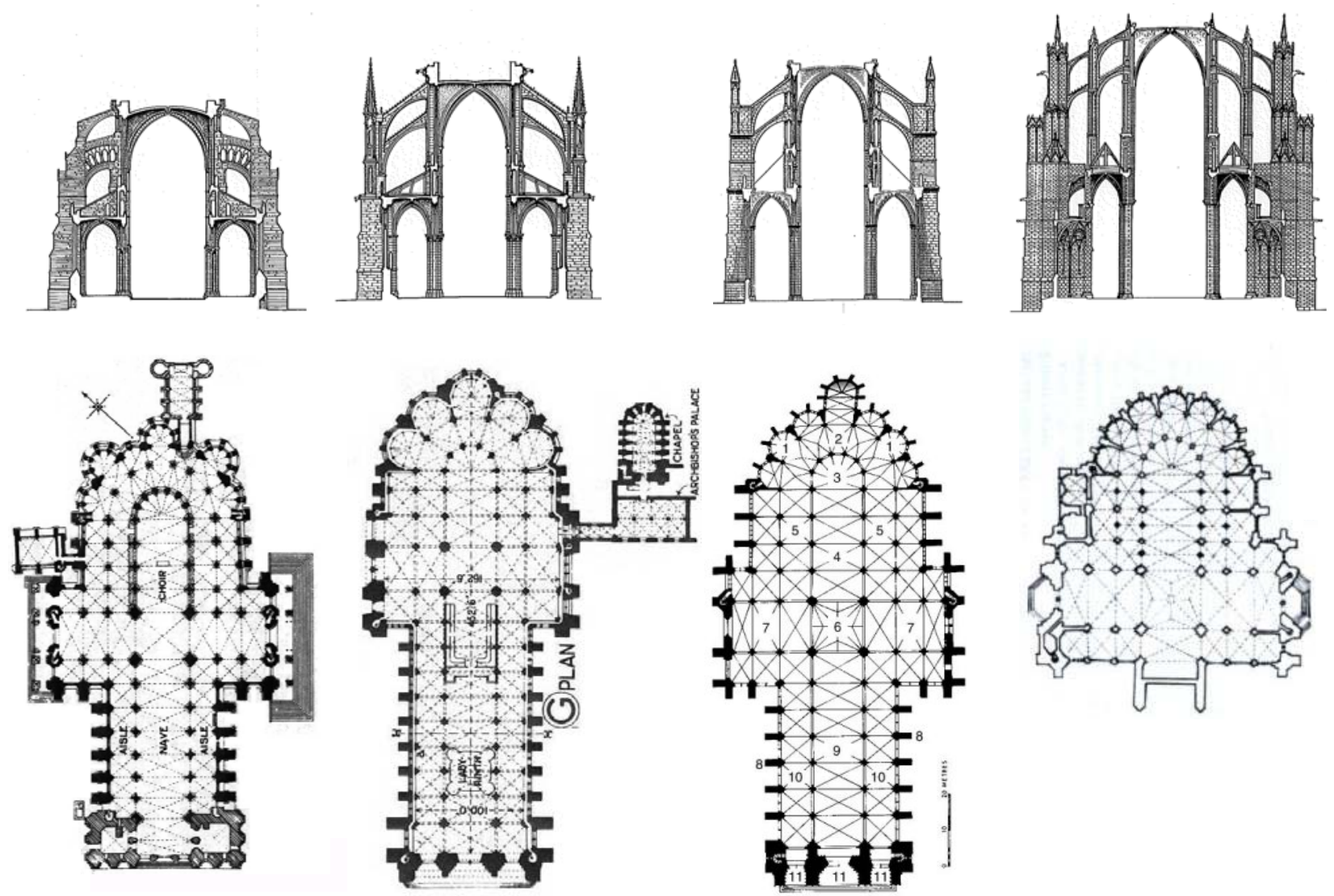

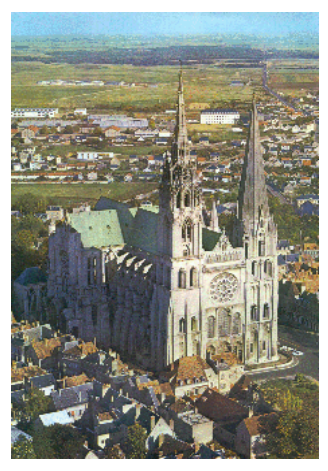

(a)

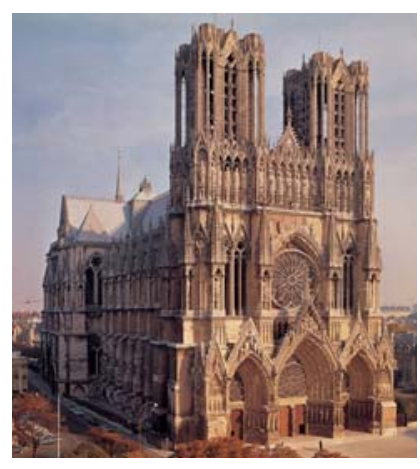

(b)

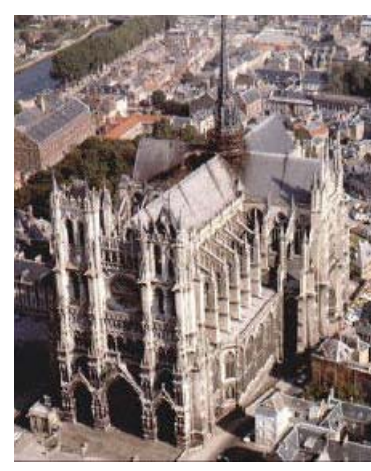

(c)

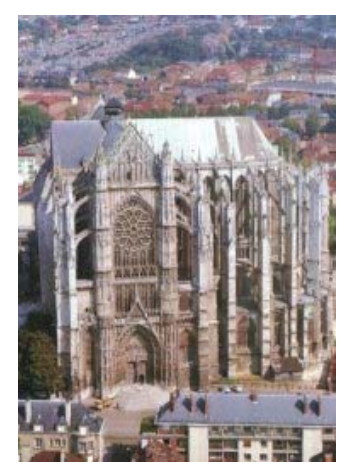

(d)

Figura 5.21- Catedrais góticas francesas - corte transversal, planta e vista ${ }^{3}$ : (a) Catedral de Chartres; (b) Catedral de Reims; (c) Catedral de Amiens; (d) Catedral de Beauvais.

\footnotetext{
${ }^{3}$ Fontes: cortes transversais (MARK, 1990, p.94); planta de Chartres (FLETCHER, 2000, p.432); planta de Reims (FLETCHER, 2000, p.438); planta de Amiens (AMIENS CATHEDRAL, 2004); planta de Beauvais (SALVADORI, 1990, p.218); vista de Chartres (ART on line, 2004); vista de Reims (KALIPÉDIA, 2010, sem numeração de página); vista de Aims (CHEAP EURO TOUR, 2010, sem numeração de página); vista de Beauvais (Postal).
} 
Em 1284, ocorreu a queda das abóbadas do coro da Catedral de Beauvais, que foi atribuída à elevada distância entre os pilares, que chegava a oito metros e vinte centímetros longitudinalmente. Sua reconstrução ocorreu entre 1322 e 1337, com a colocação de pilares intermediários entre os pilares do coro, cuja inserção fez com que fossem também necessários pilares externos, arcobotantes e contrafortes correspondentes.

Entre as possíveis causas apontadas estão a má qualidade da alvenaria utilizada, ou, como sugeriu Mark (1990), a ação do vento na face lateral da igreja, que levou ao colapso da estrutura. Recentemente, Como (2009) apresentou um estudo que mostra que a esbeltez dos pilares associada às excentricidades das cargas axiais e às deformações lentas da argamassa na alvenaria dos pilares podem ser consideradas como as causas do colapso.

Um aspecto interessante a notar é que as catedrais comentadas anteriormente apresentam somente três naves, sendo a central bem mais alta que as laterais.

Já na Catedral da Sé, a nave central e as naves laterais possuem abóbadas que se desenvolvem a partir da mesma elevação, o que visualmente gera um efeito de verticalidade menor.

A Catedral de Bourges, iniciada em 1192, também possui cinco naves como a Catedral da Sé, mas, diferentemente dela, sua nave central é bem mais alta que as demais; as abóbadas hexapartidas da nave central alcançam 37 metros de altura numa largura de 15 metros. As abóbadas quadripartidas das naves laterais alcançam 21 metros de altura e as das naves laterais externas nove metros; a construção possui internamente 118 metros de comprimento (Figura 5.22).

Na Catedral de Milão, projeto do final do século XIV, a nave central também é mais alta que as demais. A igreja italiana possui cinco naves totalizando 59 metros de largura total (FLETCHER, 2000) e 157 metros de comprimento. As abóbadas quadripartidas da nave central alcançam 45 metros de altura, enquanto as das naves laterais e as das naves laterais externas atingem, respectivamente, 30 metros e 22 metros de altura. No cruzeiro do transepto desta igreja, um octógono dá apoio a uma torre que, a partir do piso, atinge a elevação de 106 metros. 

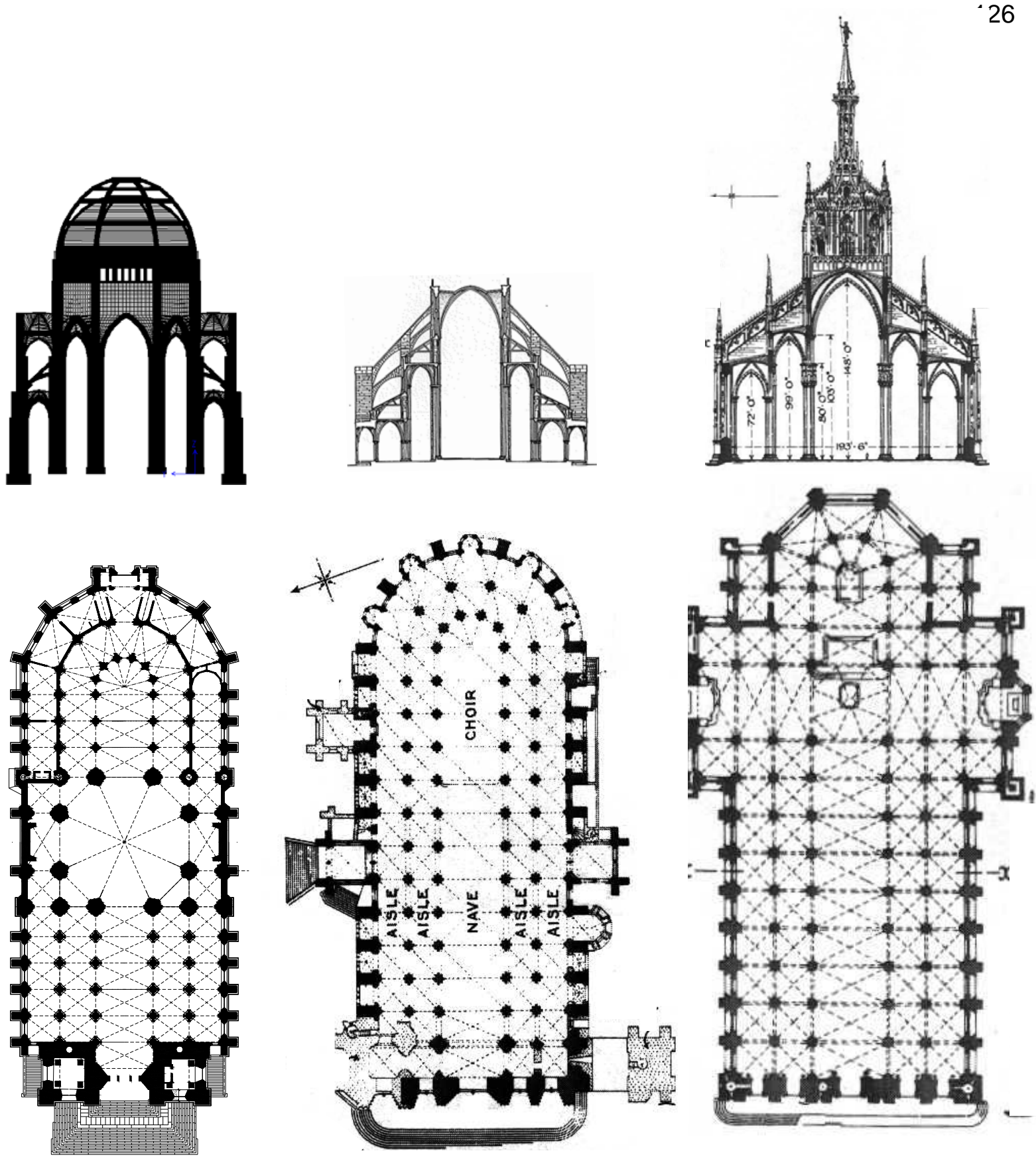

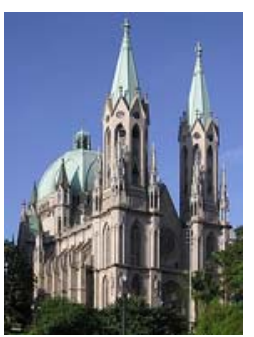

(a)

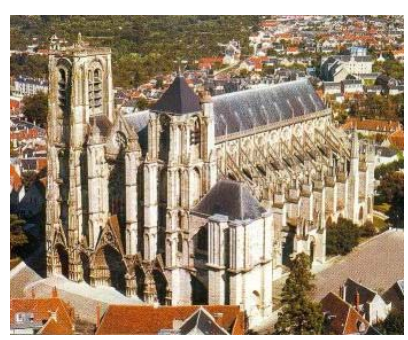

(b)

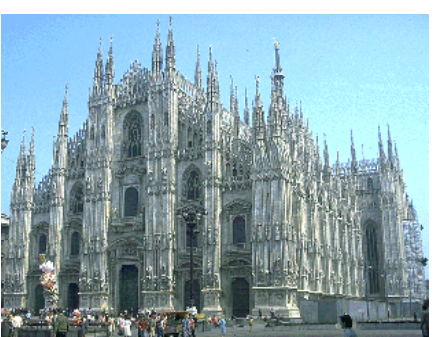

(c)

Figura 5.22 - Catedrais góticas com cinco naves: corte transversal, planta e vista ${ }^{4}$ : (a) Catedral da Sé de São Paulo; (b) Catedral de Bourges; (c) Catedral de Milão.

\footnotetext{
${ }^{4}$ Fontes: corte transversal de Bourges (MARK, 1990, p.94); corte transversal de Milão (FLETCHER, 2000, p.537); planta da Catedral da Sé (CONCREJATO, 2002, FL. 01/04 adaptada); planta de Bourges (FLETCHER, 2000, p.432); planta de Milão (FLETCHER, 2000, p.537); vista da Sé (FIND TARGET, 2010, sem numeração de página; vista de Bourges (LILTROLL AND SILVARA'S, 2004, sem numeração de página); vista de Milão (KIOTO - INET, 2005, sem numeração de página).
} 
Assim, a Catedral de Bourges e a Catedral de Milão possuem cinco naves, mas, como as primeiras catedrais francesas apresentadas, a nave central é mais alta que as demais, diferentemente do que ocorre na Catedral da Sé, como pode ser observado na Figura 5.22.

Na Catedral de Milão, além dos arcobotantes, há tirantes ligando o topo dos pilares para resistir aos empuxos horizontais e conter os deslocamentos transversais.

Já na Catedral da Sé, há alguns poucos tirantes, e não se sabe ao certo a época e a razão de sua colocação (Figura 5.23).

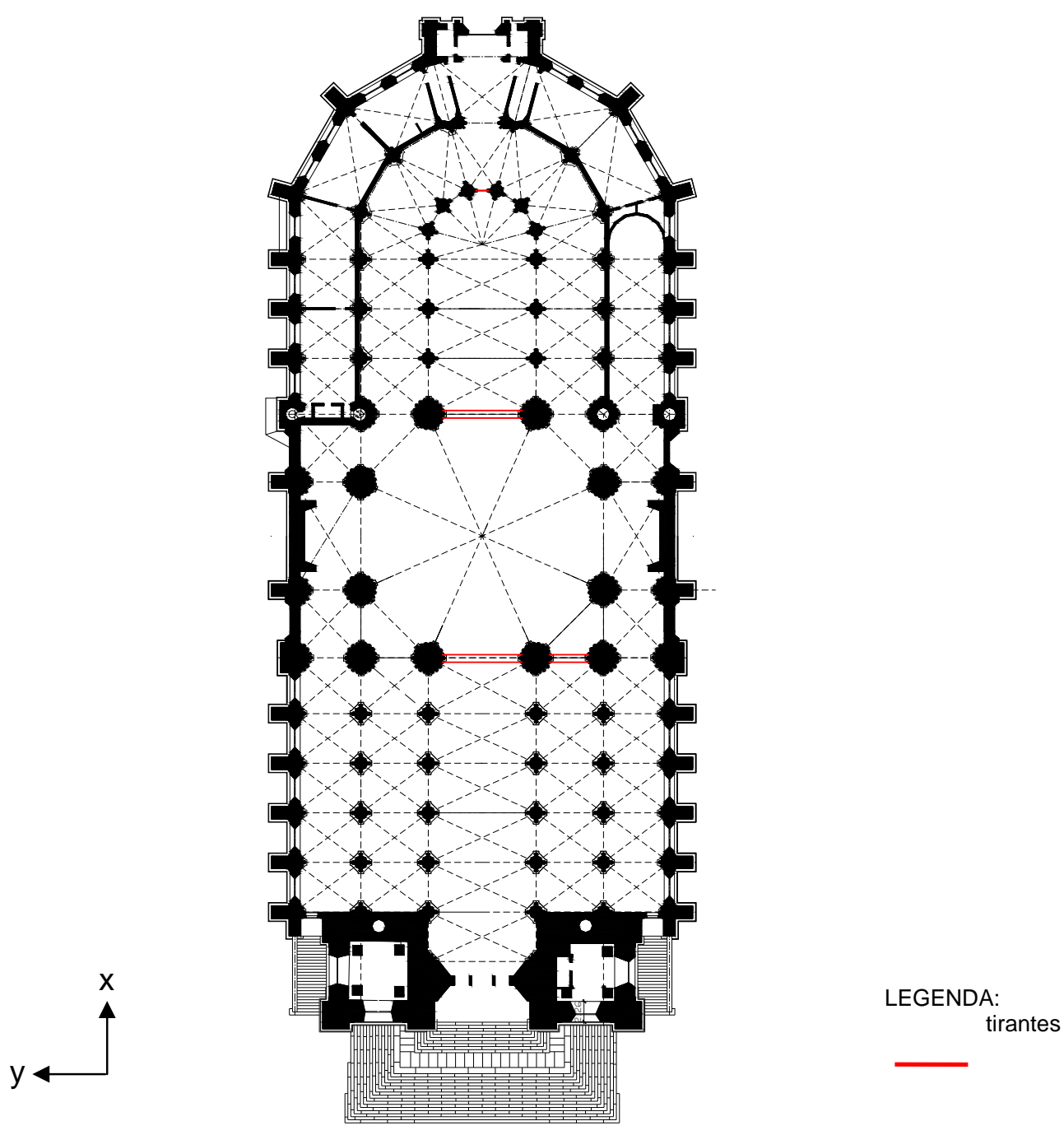

Figura 5.23 - Locação dos tirantes na Catedral da Sé.

É possível que estes tirantes de pequenas dimensões tenham sido colocados como elementos de segurança adicional e não como elemento estrutural 
fundamental, uma vez que estão dispostos em poucos vãos e de modo assimétrico (RAMIREZ, 2005, p.115).

Na Catedral da Sé, ao invés de uma flecha ou de uma torre que muitas vezes se encontra nas igrejas góticas, há uma cúpula apoiada sobre um tambor octogonal.

Elementos estruturais como esses e similaridades arquitetônicas com a Catedral da Sé podem ser observados também na Catedral de Notre-Dame de Coutances, do século XIII; com 33 metros de largura e 95 metros de comprimento, possui cinco naves e caracteriza-se por apresentar no cruzeiro do transepto uma base octogonal para a torre que aí se ergue. Além disso, na fachada frontal suas duas grandes torres e a divisão das cornijas lembram muito a do templo de São Paulo (Figura 5.24).

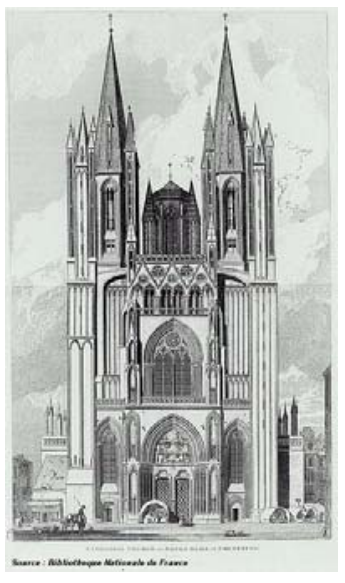

(a)

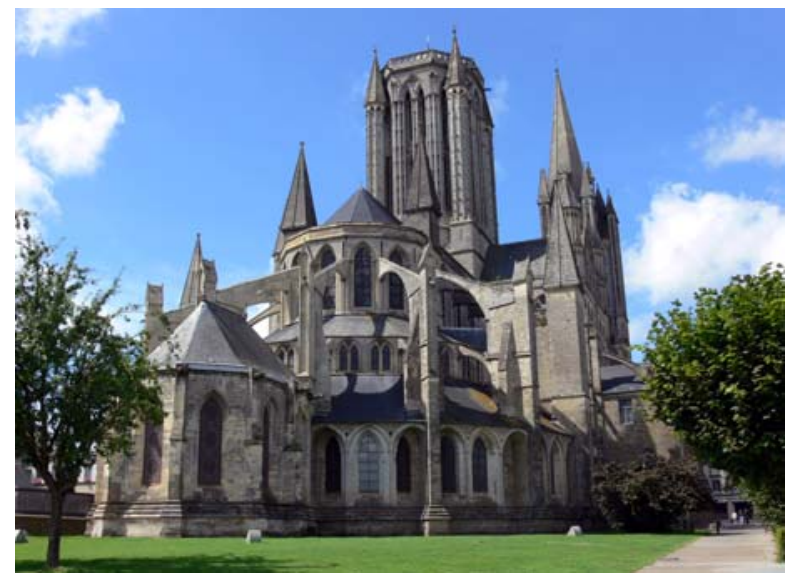

(b)

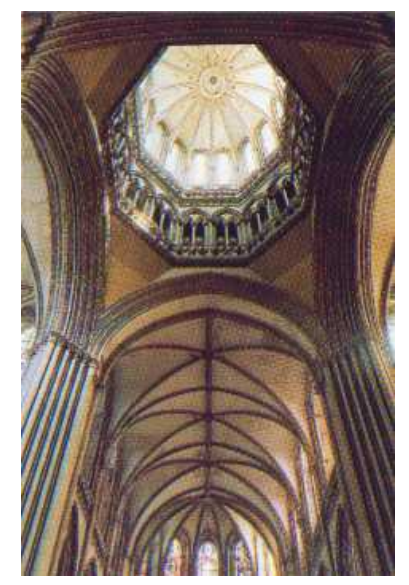

(c)

Figura 5.24 - Catedral de Coutances: (a) esquema da fachada frontal (WIKIPÉDIA (a), 2004); (b) vista (SIEIRO, 2010); (c) espaço octogonal no cruzeiro do transepto (WENZLER, 1997, p.31).

Já na Catedral de Florença, o mais notório é a presença de uma cúpula em meio uma construção gótica, e com quase total certeza pode-se afirmar que foi a Catedral de Florença que inspirou Maximiliano Hehl a colocar uma cúpula renascentista na Catedral da Sé.

Sobre uma base octogonal, a cúpula da Catedral de Florença vence 42 metros de vão, tendo sido idealizada pelo pintor, escultor e arquiteto Filippo Brunelleschi, que assumiu a responsabilidade de construí-la em 1420 (Figura 5.25). A igreja tem 152 metros de comprimento e três naves totalizando 40 metros de largura. Como não há arcobotantes, os empuxos horizontais são absorvidos por tirantes.

A cúpula da Catedral de Florença também foi utilizada como argumento 
favorável para o projeto arquitetônico da Catedral da Sé e de seu polêmico domo, por aqueles que defendiam a não rigidez na unidade estilística do templo. Uma discussão sobre o estilo arquitetônico da Catedral da Sé de São Paulo encontra-se em Ramirez (2005, p.69-72).

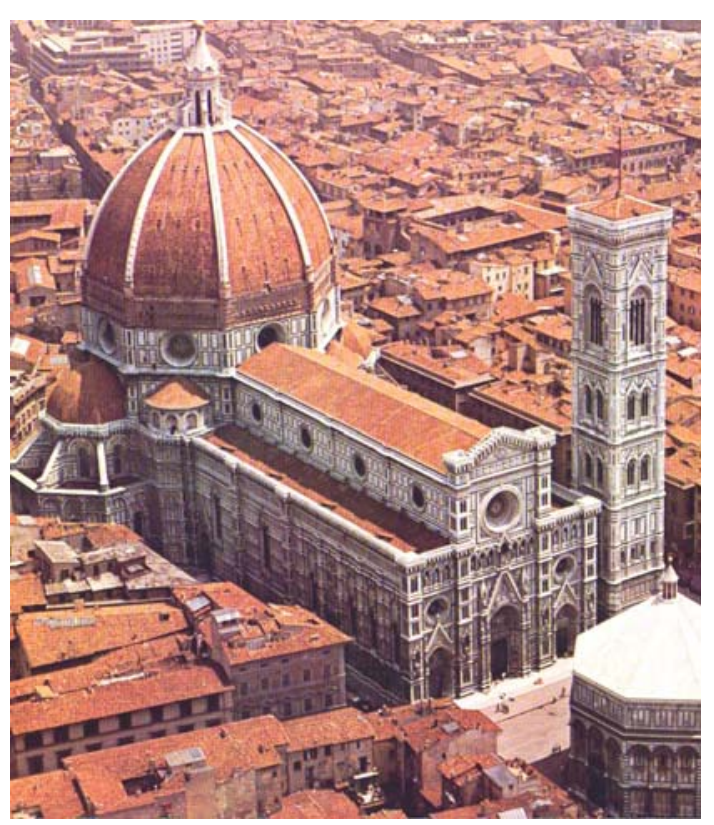

(a)

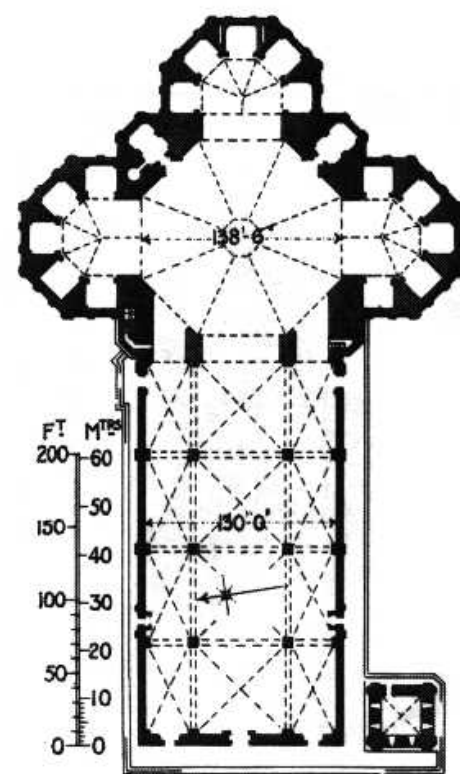

(b)

Figura 5.25 - Catedral de Florença: (a) vista (MARCHINI, 1972, p.32); (b) planta (FLETCHER, 2000, p.548)

Os traços arquitetônicos de Maximiliano Hehl para a Catedral da Sé também são encontrados na Catedral de Santos, também de sua autoria, como a presença de uma cúpula no cruzeiro do transepto e a decoração da entrada principal (Figura 5.26). Possui somente três naves, a central mais elevada que as laterais. Iniciada em 1909 e inaugurada inacabada em 1924, as obras da Catedral de Santos foram consideradas finalizadas somente em 1967. 


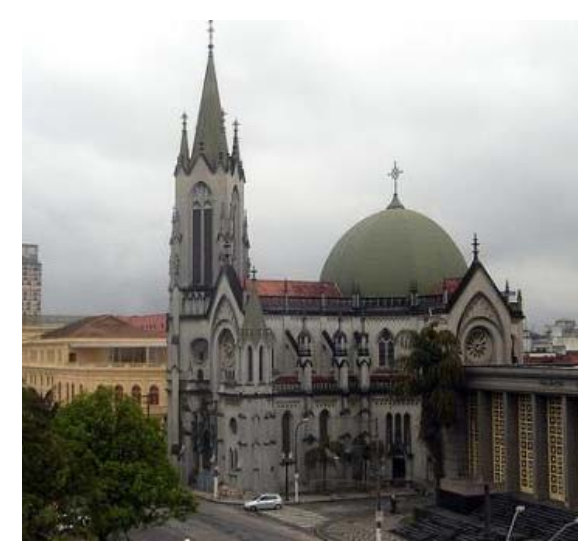

(a)

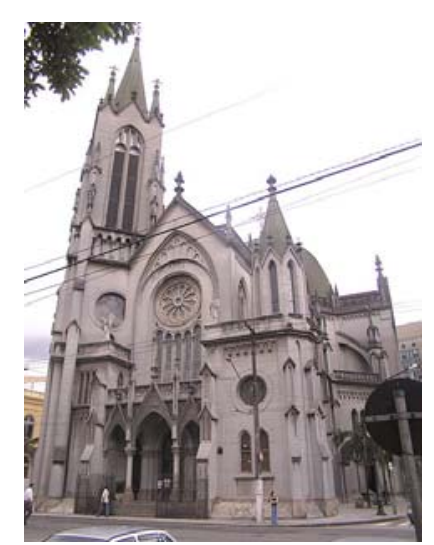

(b)

Figura 5.26 - Catedral de Santos: (a) vista (ROBSONLAGES, 2010, sem numeração de página); (b) vista frontal (WIKIPÉDIA (b), 2010, sem numeração de página).

Apesar de algumas semelhanças com as antigas catedrais góticas, nota-se, que a Catedral da Sé de São Paulo não tem longas naves se comparadas com o comprimento ocupado pela região do octógono e que suas naves laterais estão à mesma altura da nave central, de modo que esta igreja não é uma catedral gótica tradicional.

Para o entendimento do comportamento global do templo em termos de deslocamentos, faz-se necessário verificar como funcionam os principais elementos estruturais góticos da Catedral, isolando-os da ação do octógono.

Em seguida, por meio de uma simulação em que se atribui peso zero à estrutura da igreja com exceção ao octógono, é apresentada a influência do tambor e da cúpula nos deslocamentos dos demais elementos estruturais da Catedral.

Finalmente, são identificados os carregamentos mais influentes em termos dos deslocamentos do conjunto.

Como comentado, nas catedrais góticas, os esforços horizontais provenientes do telhado e das abóbadas são transferidos para os contrafortes por meio dos arcobotantes e daí levados até as suas fundações.

Considerando a estrutura real da Catedral, recorda-se que, na configuração deformada devido à carga permanente, os pilares laterais, locados nos eixos 2 e 5 , não seguem a tendência de abertura e deslocam-se para o interior da igreja (Figura 5.4). 
Para observar como funcionam os elementos góticos da Catedral da Sé e avaliar a transmissão de esforços horizontais, fez-se a análise de um trecho da parte frontal da igreja, isolado do octógono e de sua cúpula, de modo a confirmar se o sistema de arcobotantes e de contrafortes do templo desempenha a mesma função que nas estruturas góticas tradicionais (Figura 5.27).
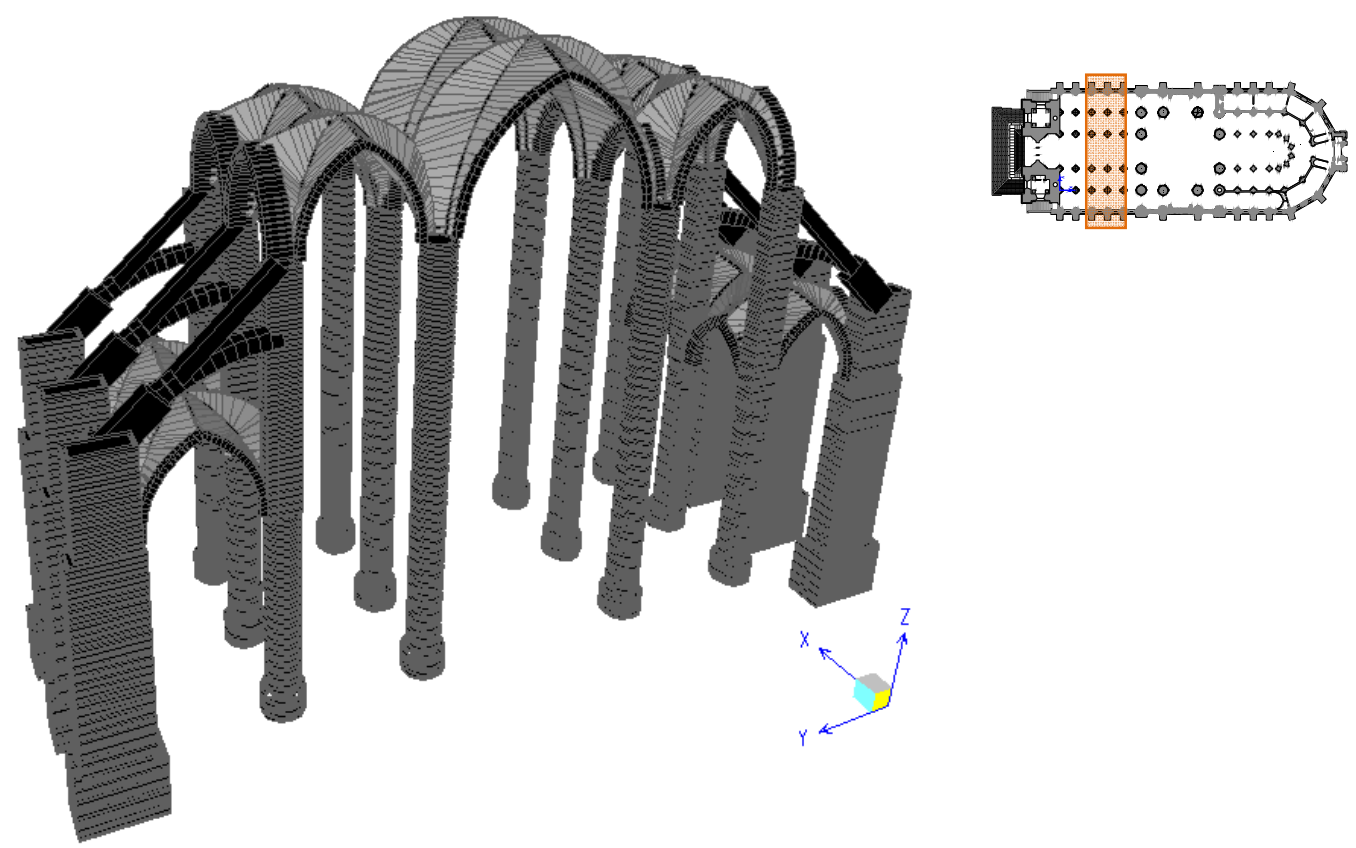

Figura 5.27 - Faixa em estudo.

Da faixa selecionada, a seção analisada é a central, aqui nomeada genericamente D', aproveitando-se da simetria dos deslocamentos na direção longitudinal. Esta faixa foi replicada várias vezes, de modo a torná-la longa o bastante para minimizar os efeitos longitudinais, já que o estudo se concentra no comportamento transversal da seção, na direção y.

Os carregamentos verticais mais influentes na igreja são o peso próprio gerado e as paredes. Quando considerado somente o peso próprio dos elementos modelados, os pilares centrais e laterais se deslocam para o exterior da edificação como mostra a Figura 5.28 (a).

Como comentado no Capítulo 4, as paredes aqui tratadas são aquelas presentes sobre todos os arcos longitudinais da igreja, sobre os arcos do coro e sobre arcos transversais das naves laterais. As paredes, portanto, estão presentes tanto na direção transversal como na direção longitudinal da igreja, influenciando os 
deslocamentos diferentemente.

Numa primeira fase, é mostrado o efeito do carregamento dessas paredes atuantes em conjunto, tanto na direção transversal como na longitudinal, e o que se verifica é que tanto os pilares centrais como os pilares laterais deslocam-se para o interior da igreja (Figura 5.28 (b)).

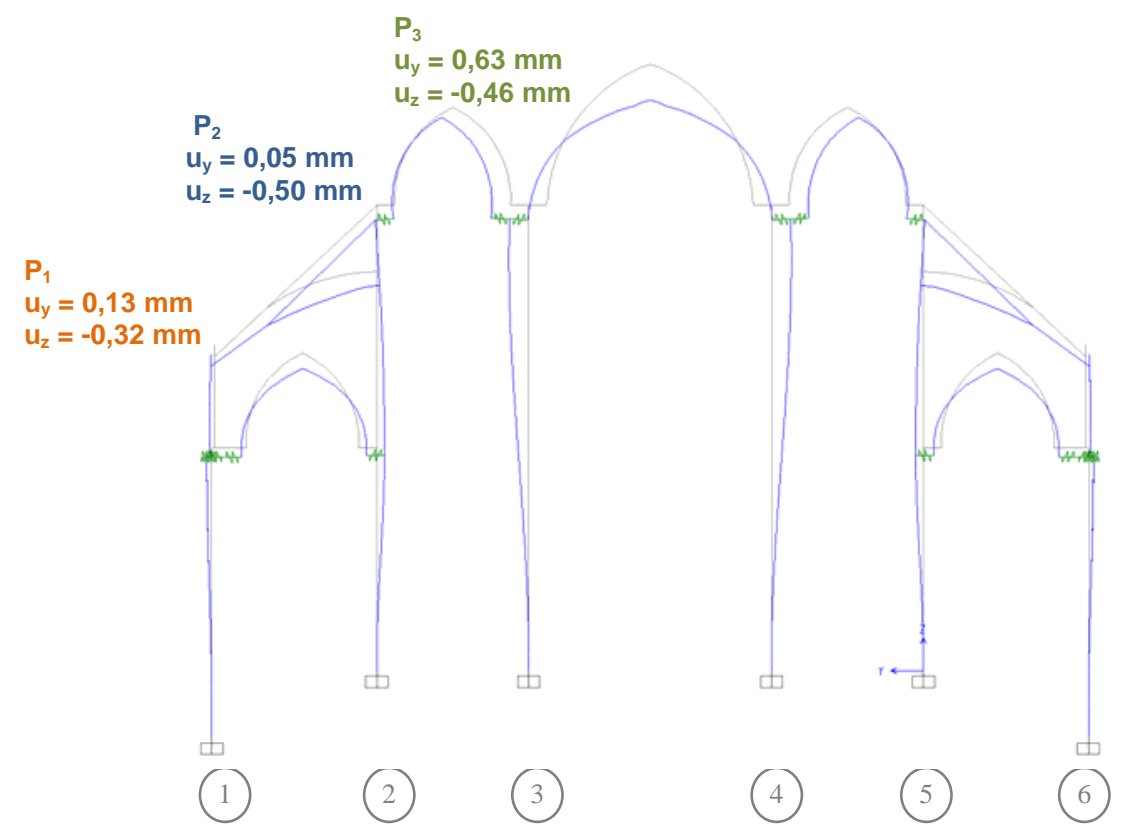

(a)

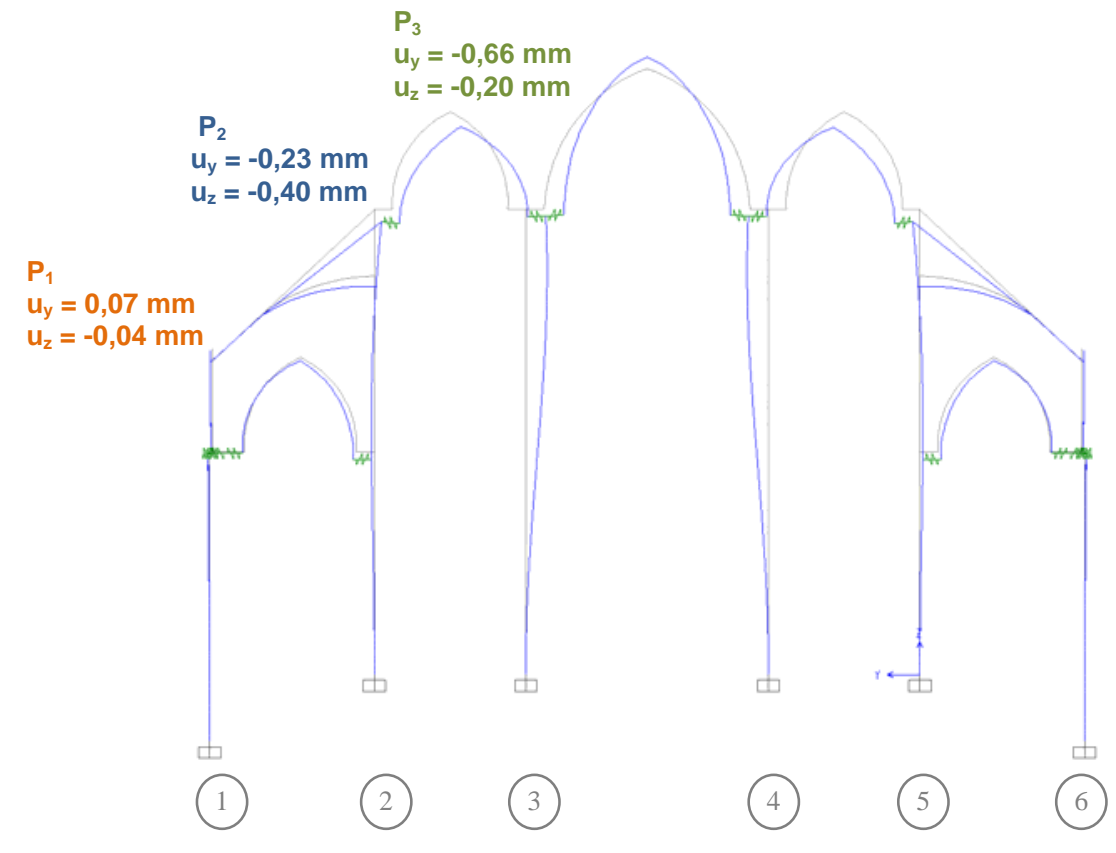

(b)

Figura 5.28 - Deformada da seção no eixo D': (a) devido à carga do peso próprio gerado; (b) devido à carga das paredes sobre os arcos transversais das naves laterais e sobre todos os longitudinaisescala dos deslocamentos 1500:1. 
Os deslocamentos da seção D' sob ação da carga permanente estão apresentados na Figura 5.29.

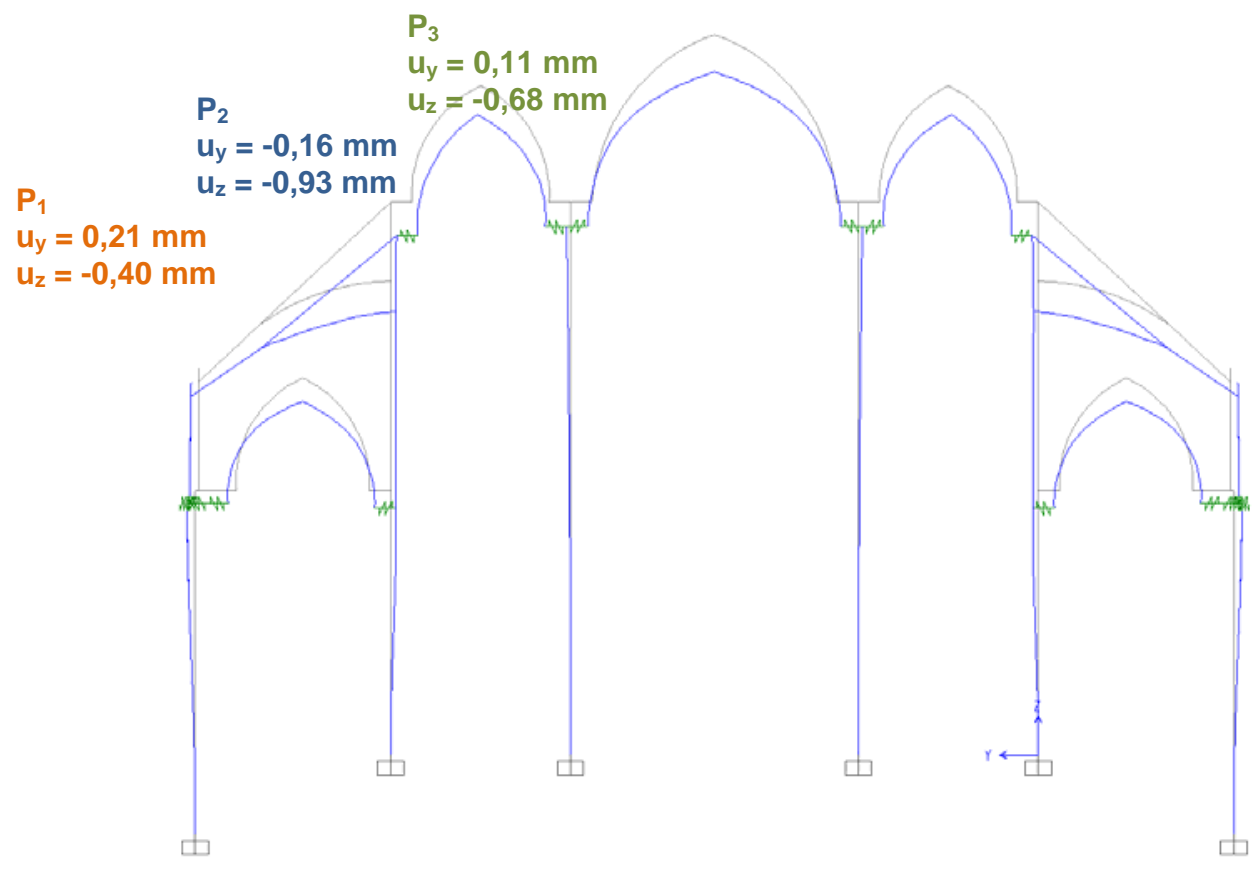

Figura 5.29 - Deformada da seção do eixo D' devido à carga permanente - escala dos deslocamentos 1500:1.

Ao analisar separadamente o efeito das paredes sobre os arcos transversais das naves laterais, constata-se que a resultante do empuxo horizontal deste carregamento leva os pilares centrais para o interior da edificação, mas os pilares laterais e os contrafortes têm aumentados os seus deslocamentos transversais para o exterior da igreja (Figuras 5.30 e 5.31). 


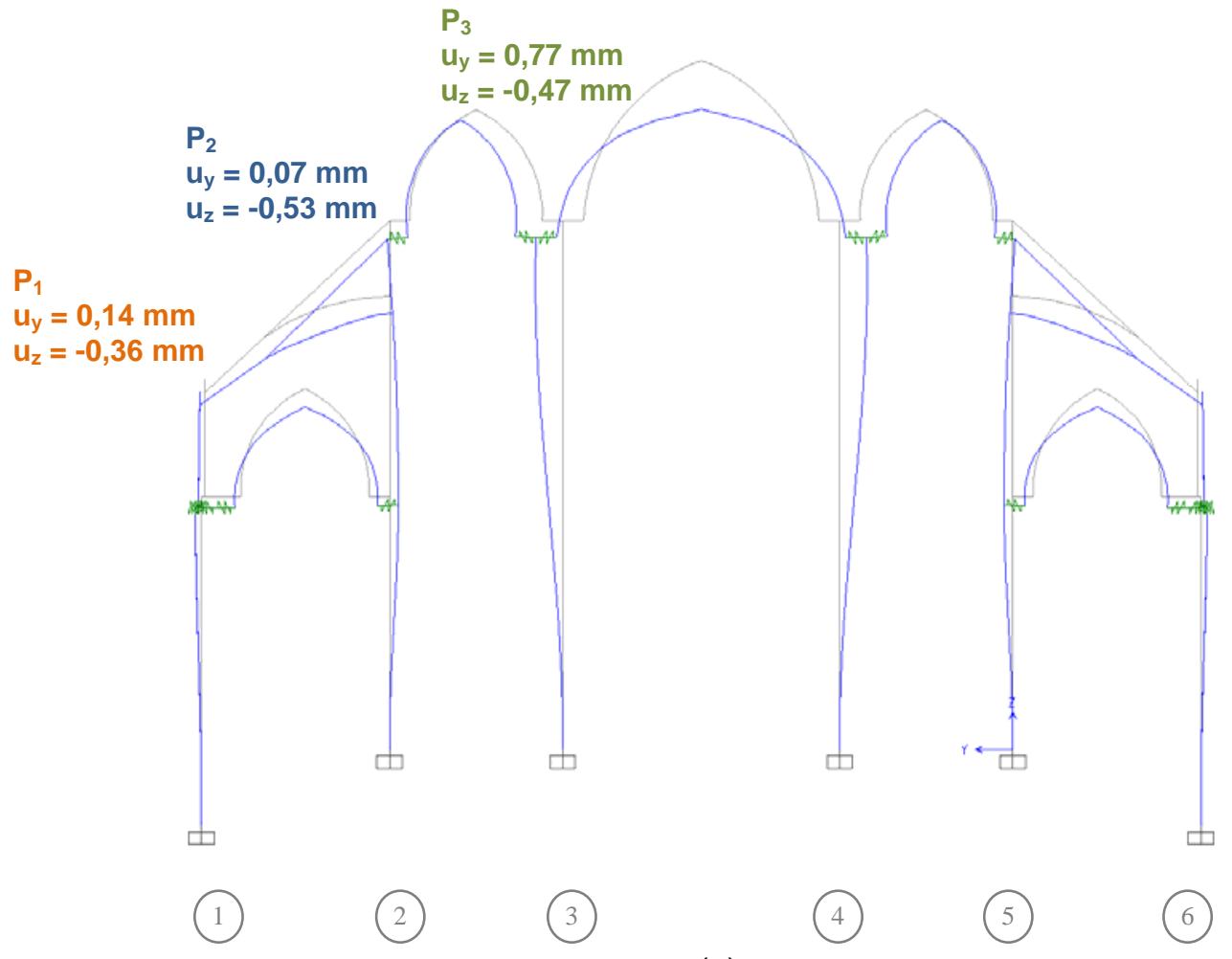

(a)

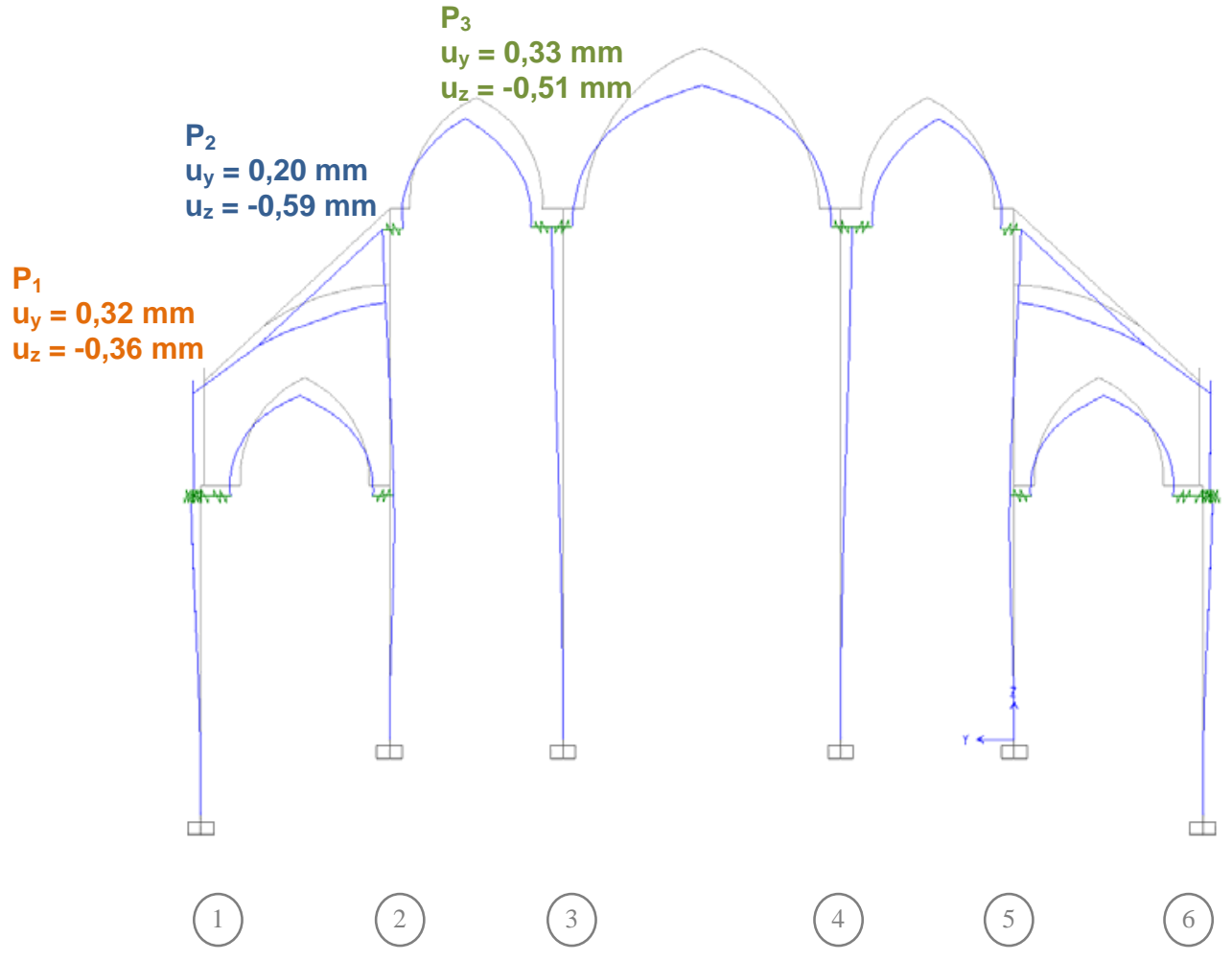

(b)

Figura 5.30 - Simulação sem o carregamento das paredes sobre os arcos longitudinais - análise da deformada da seção do eixo D': (a) devido à carga permanente sem as paredes sobre os arcos transversais das naves laterais; (b) devido à carga permanente - escala dos deslocamentos 1500:1. 


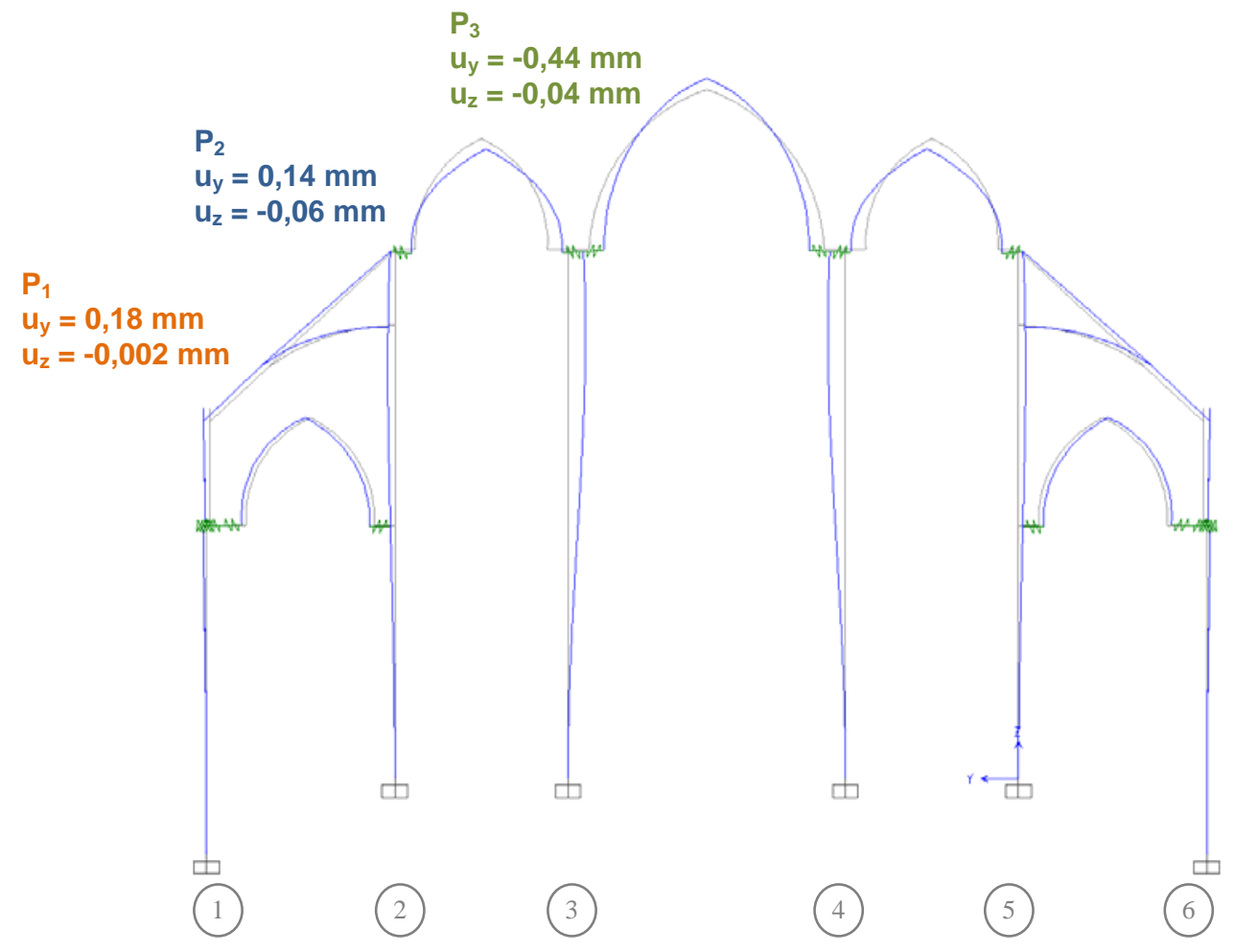

Figura 5.31 - Deformada da seção do eixo D' devido somente à carga das paredes sobre os arcos transversais das naves laterais - escala dos deslocamentos 1500:1.

Observa-se, portanto, que, além de darem apoio ao telhado com chapa de cobre, as paredes sobre os arcos transversais das naves laterais têm uma importante função estrutural, ao reduzirem significativamente os deslocamentos transversais dos pilares centrais para o exterior da igreja.

As paredes sobre os arcos longitudinais movimentam os pilares e os contrafortes para o exterior da igreja na direção longitudinal. Mas, ao mesmo tempo, estas paredes levam os pilares para o interior da Catedral na direção transversal, associadas às condições geométricas da igreja, mais especificamente as das abóbadas. Isto pode ser observado a partir de uma simulação mais simples, considerando um trecho de naves com simetria na geometria e no carregamento e com paredes presentes somente sobre os arcos longitudinais (Figura 5.32).

Como é de se esperar, sob a ação da carga das paredes sobre os arcos longitudinais, os pilares de extremidade deslocam-se para fora, aumentam os vãos dos arcos longitudinais, e conseqüentemente, dos panos e das nervuras que geram esforços tanto na direção longitudinal como na transversal como mostra a Figura 5.32 (b) e (c). Este esforço transversal leva a flexão dos pilares na direção transversal e deslocam os pilares para o interior. 
Quando consideradas todas as naves do trecho em estudo, este efeito amplifica-se pela assimetria geométrica e de cargas entre os eixos longitudinais, que existe, por exemplo, entre os eixos dos arcos que limitam as naves laterais.

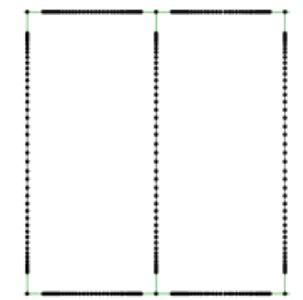

$\because \div \quad \because$

: : :

(a)

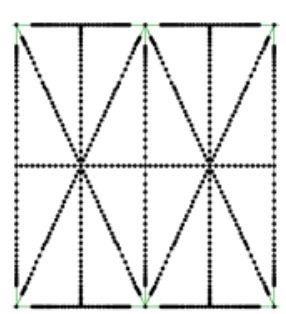

$\because$

$\dot{\therefore} \quad \therefore \quad \dot{ }$

(b)
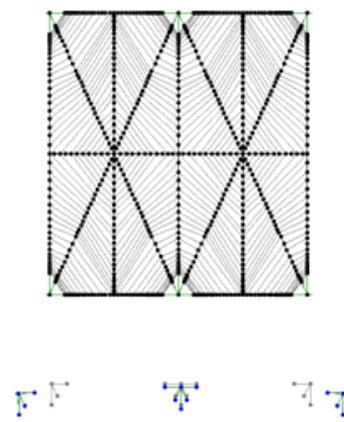

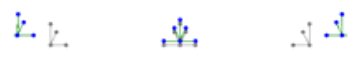

(c)

Figura 5.32 - Simulação de um trecho de nave simétrica com o carregamento das paredes sobre os arcos longitudinais - esquema estrutural e deformada: (a) somente arcos; (b) arcos e nervuras das abóbadas; (c) abóbadas completas - escala dos deslocamentos 3000:1.

As paredes sobre os arcos longitudinais, portanto, deslocam os pilares e os contrafortes para o interior da igreja na direção transversal (Figura 5.33).

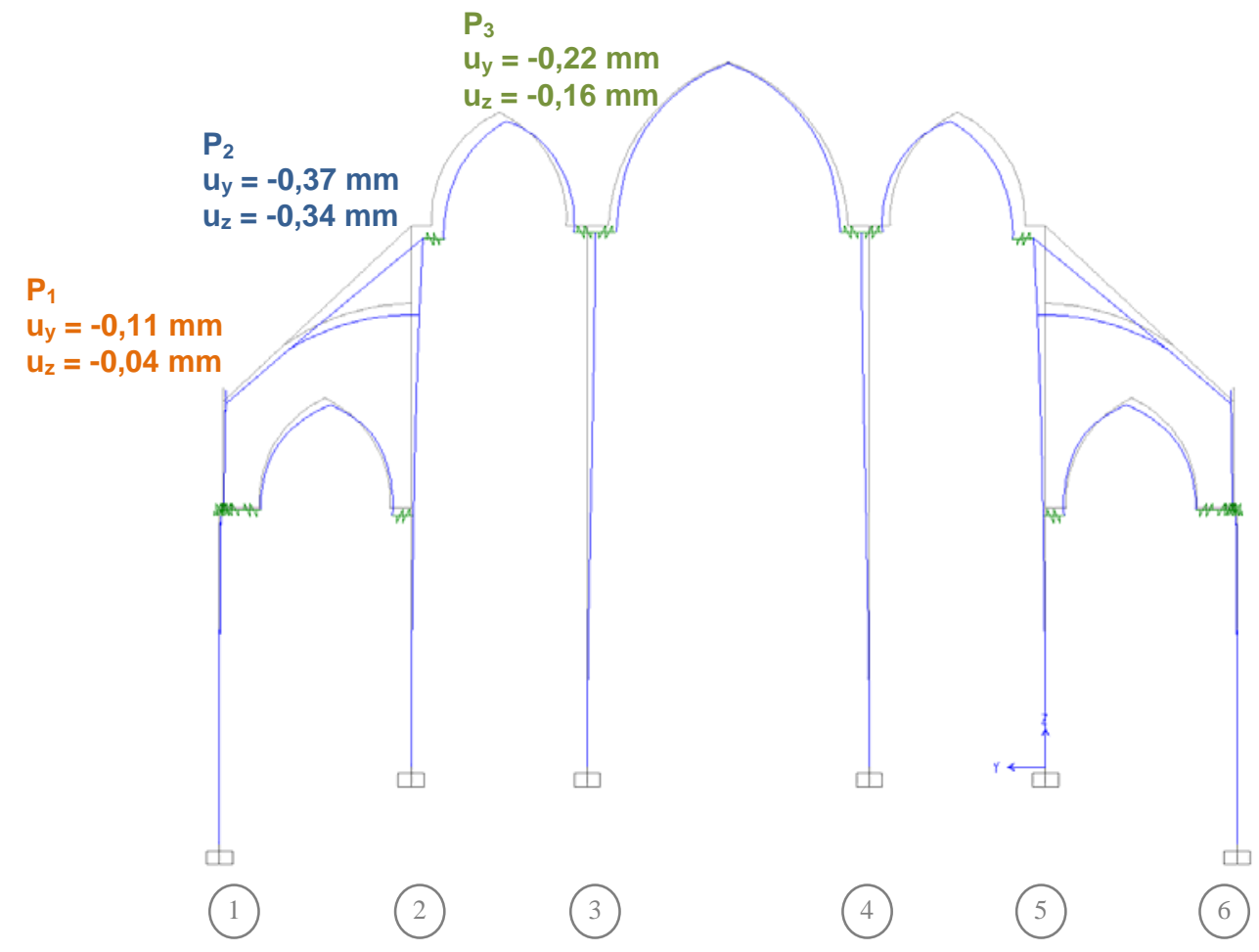

Figura 5.33 - Deformada da seção do eixo D' devido somente à carga das paredes sobre os arcos longitudinais - escala dos deslocamentos 1500:1. 
No entanto, quando considerada a ação de toda a carga permanente, e isto inclui tanto as paredes transversais como as longitudinais, somente os pilares laterais da seção transversal em estudo apresentam deslocamento para o interior da igreja na direção transversal.

Destaca-se ainda o fato de que o empuxo gerado pelo arco central, mesmo sob todas as condições geométricas e de carregamento, ainda é suficiente para mover os pilares centrais para fora.

O esquema da Figura 5.34 mostra que sob a ação da carga permanente, com a presença do carregamento de todas as paredes, o empuxo horizontal do arco lateral $\mathrm{H} 2$ ainda é menor que o empuxo horizontal do arco central $\mathrm{H} 1$, e o pilar central ainda tende para fora da edificação, como mostrado na Figura 5.29. Se a carga da parede é retirada, $\mathrm{H} 2$ é reduzido ainda mais, e todos os pilares deslocam-se para o exterior, como mostrado na Figura 5.30.a.

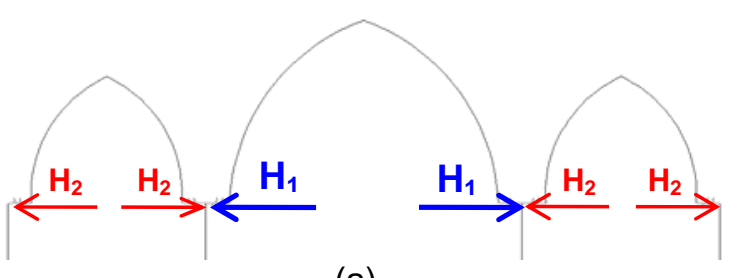

(a)

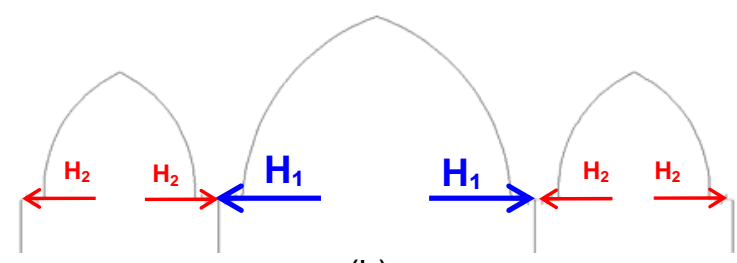

(b)

$\mathrm{H}_{1}$ - empuxo do arco central $\mathrm{H}_{2}$ - empuxo do arco lateral

Figura 5.34 - Esquema dos empuxos horizontais atuantes no topo dos pilares centrais: (a) com carregamento das paredes: $\mathrm{H}_{2}<\mathrm{H}_{1}$; (b) sem carregamento das paredes: $\mathrm{H}_{2}<<\mathrm{H}_{1}$.

Além da ação da carga das paredes, há também a influência dos arcos das naves laterais externas, mais baixos, cuja resultante horizontal reduz os deslocamentos dos pilares laterais para o exterior da igreja, mas que não chega a deslocar estes pilares para o interior da mesma (Figura 5.35).

Isto pode ser verificado ao se comparar a seção do eixo D' em estudo com uma simulação em que são retirados os arcos das naves laterais externas, sob a ação da carga permanente sem a parcela referente às paredes; o que se observa é que de fato a alvenaria sobre os arcos longitudinais é a responsável pelo deslocamento dos 
pilares laterais para o interior da edificação.
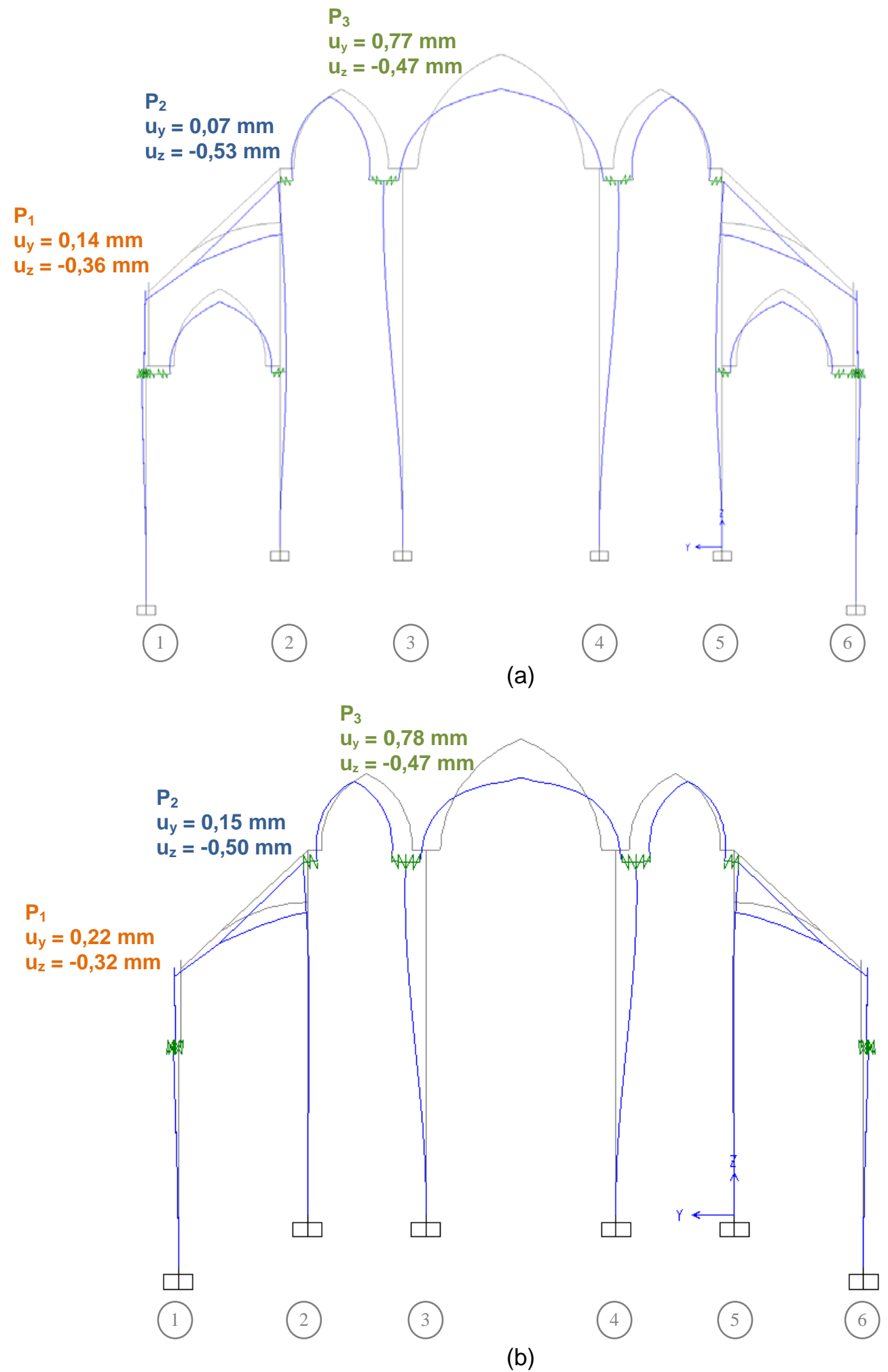

Figura 5.35 - Deformada da seção do eixo D' devido à carga permanente sem as paredes transversais e longitudinais: (a) com os arcos das naves laterais externas; (b) sem os arcos das naves laterais externas - escala dos deslocamentos 1500:1.

Quanto aos arcobotantes, vale destacar que eles assumem seu papel ao 
transmitir os empuxos horizontais aos contrafortes e ao evitar que os pilares se movimentem mais para fora, o que pode ser observado comparando-se a simulação apresentada na Figura 5.35 (b) com a Figura 5.36; sem os arcobotantes, como era de se esperar, os deslocamentos horizontais dos pilares aumentam consideravelmente.

A simulação a seguir mostra o comportamento das naves central e laterais desprovidas do conjunto de arcobotantes e contrafortes (Figura 5.36).

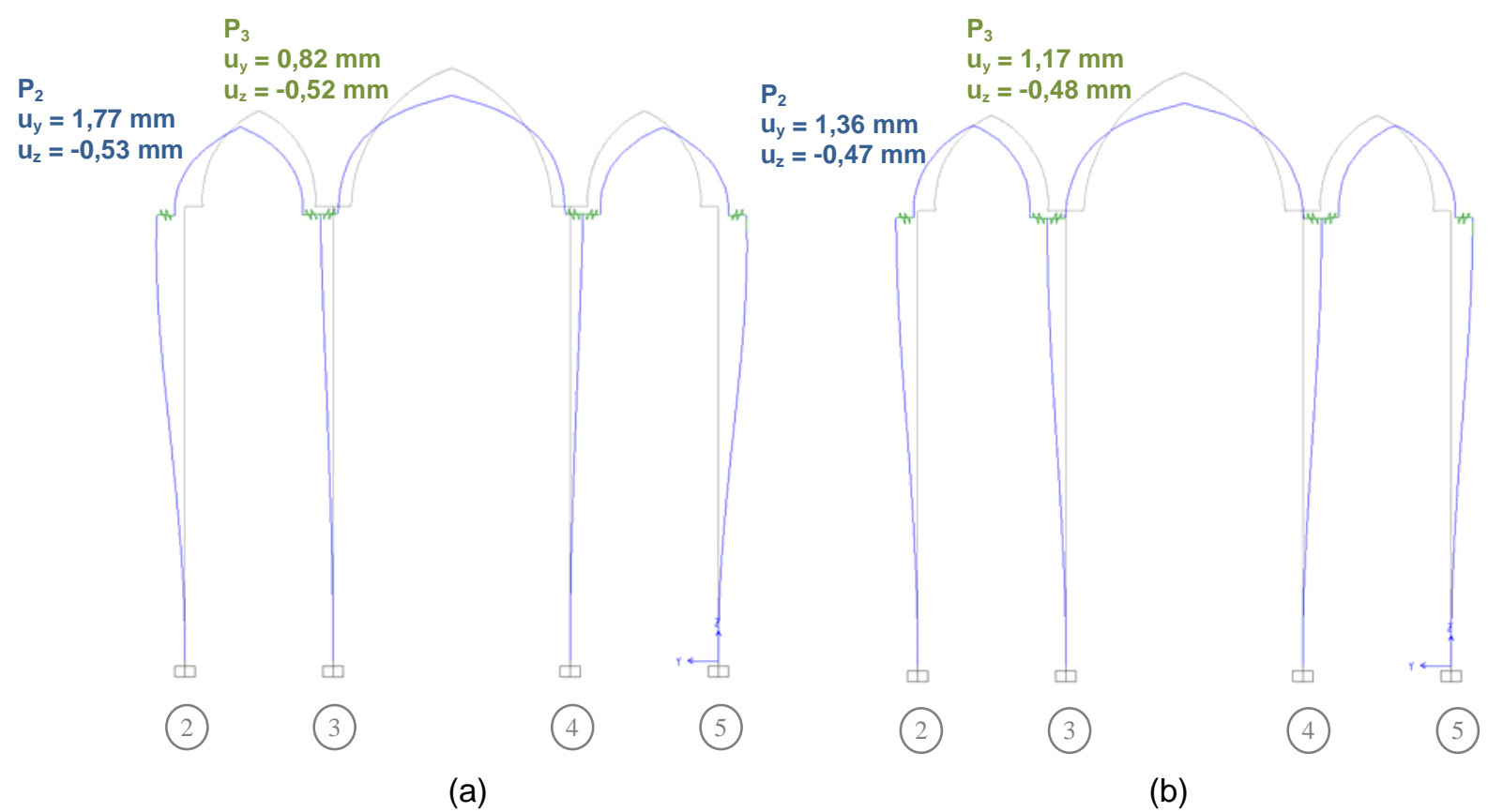

Figura 5.36 - Seção do eixo D' sem arcobotantes e sem paredes longitudinais: (a) deformada devido à carga permanente; (b) deformada devido à carga permanente sem as paredes transversais - escala dos deslocamentos 800:1.

Assim, o estudo da seção no eixo D', isolada da ação do octógono, mostra que os elementos da igreja funcionam como os de uma catedral gótica tradicional e os arcobotantes desempenham sua função ao impedir que a estrutura se abra.

As paredes sobre os arcos transversais das naves laterais têm grande influência no comportamento da igreja, pois, ao gerarem empuxos horizontais, reduzem os deslocamentos dos pilares centrais para o exterior da edificação e movimentam os pilares laterais e contrafortes para fora.

Já as paredes sobre os arcos longitudinais deslocam todos os pilares e contrafortes para o interior da igreja na direção transversal e com isso, na configuração final dos deslocamentos, mesmo sob a ação de toda carga permanente, os pilares laterais permanecem deslocados para interior da Catedral na 
direção transversal. Assim, a tendência de deslocamento para o exterior da estrutura só não ocorre nos pilares laterais devido à presença da alvenaria sobre os arcos longitudinais.

Como se pode constatar, as paredes sobre os arcos têm uma importante função estrutural ao ajudarem os arcobotantes e contrafortes a reduzir os deslocamentos horizontais. Muito provavelmente, já na concepção da estrutura da igreja esta função estrutural das paredes foi considerada e as alvenarias foram colocadas não apenas para servirem de fechamento lateral - no caso das paredes sobre os arcos longitudinais - e de apoio para os telhados - também no caso das paredes sobre os arcos transversais -, mas para colaborarem com os arcobotantes e contrafortes na redução dos deslocamentos horizontais dos pilares.

Voltando à igreja real, ao retirar a parcela de carregamento referente às paredes da carga permanente, ou seja, desconsiderando a alvenaria de tijolos presente sobre os arcos transversais das naves laterais, sobre todos os arcos longitudinais e sobre os arcos do coro, observa-se por meio da Figura 5.37 que a maioria dos pilares se movimenta para fora na direção transversal.

O estudo que acaba de ser apresentado mostra que, se a Catedral da Sé fosse longa o bastante, suas seções transversais mais distantes acabariam por comportarse como a das catedrais góticas tradicionais, assim como acontece com a seção no eixo D' isolada da ação do octógono.

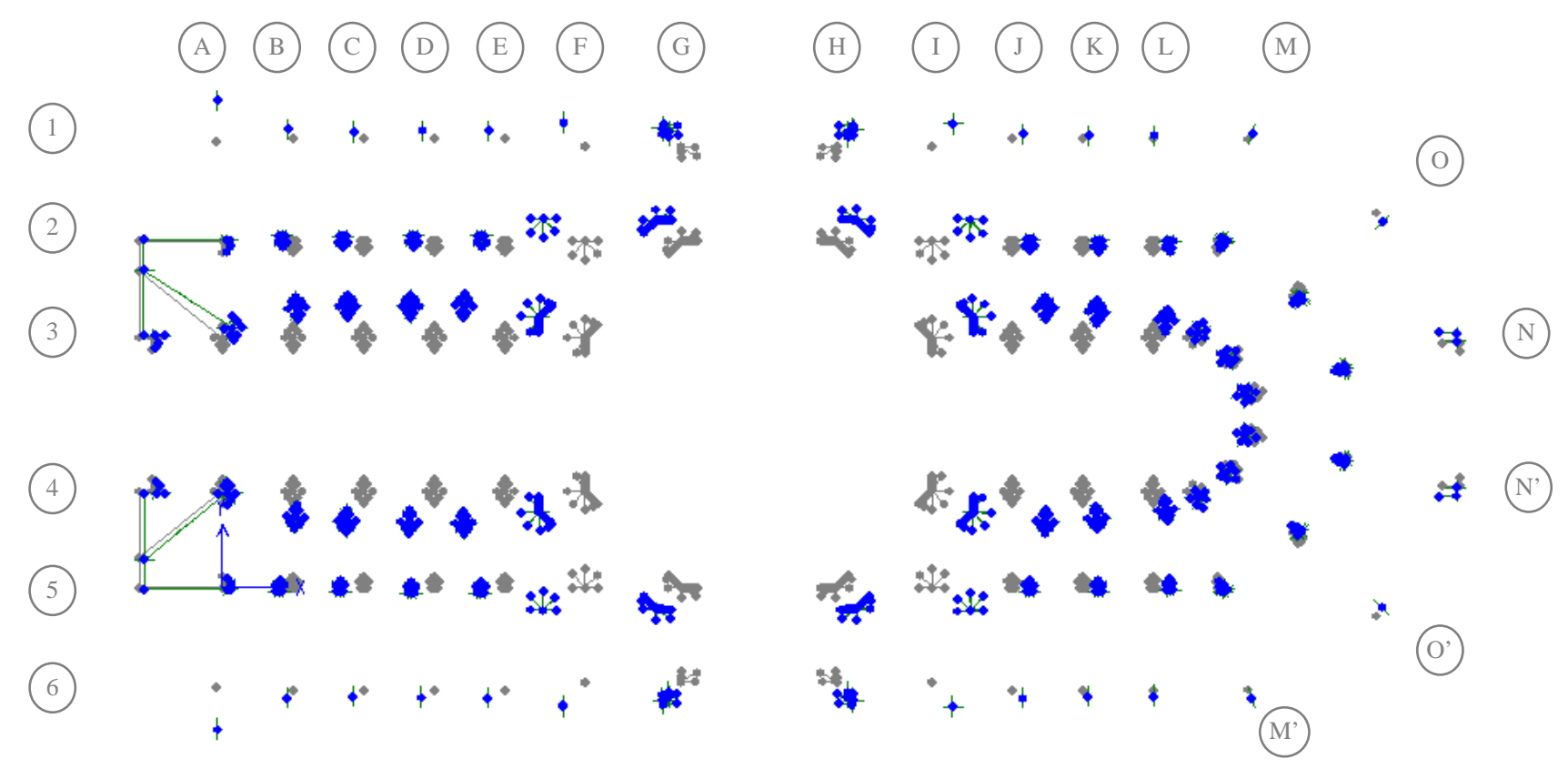

Figura 5.37 - Mapa de deslocamentos devidos à ação da carga permanente menos "parede"- plantaescala dos deslocamentos 3000:1. 
Na estrutura real, no entanto, os deslocamentos são maiores devidos à ação do octógono. Vale lembrar que a Catedral é dotada do espaço octogonal, e as elevadas cargas que lá incidem levam a estrutura da igreja a deslocar-se para fora em ambas as direções.

\subsection{0 espaço octogonal}

Como comentado, o estilo gótico na Catedral da Sé é interrompido por um espaço octogonal delimitado por arcos, sobre os quais se ergue um conjunto de apoio para a cúpula renascentista e seu lanternim.

Este conjunto de apoio é constituído por uma viga de cintamento de concreto armado, por pilaretes de granito e por um tambor de alvenaria de tijolos assentados em arcos que se apóiam em oito pilares situados nos vértices do octógono, como mostram as Figura 5.38 e 5.39. O carregamento correspondente a este conjunto de apoio à cúpula, denominado simplesmente como "tambor", distribui-se sobre os oito arcos e gera empuxos horizontais que levam os pilares da região do octógono a apresentarem os maiores deslocamentos dentre os pilares da Catedral da Sé.

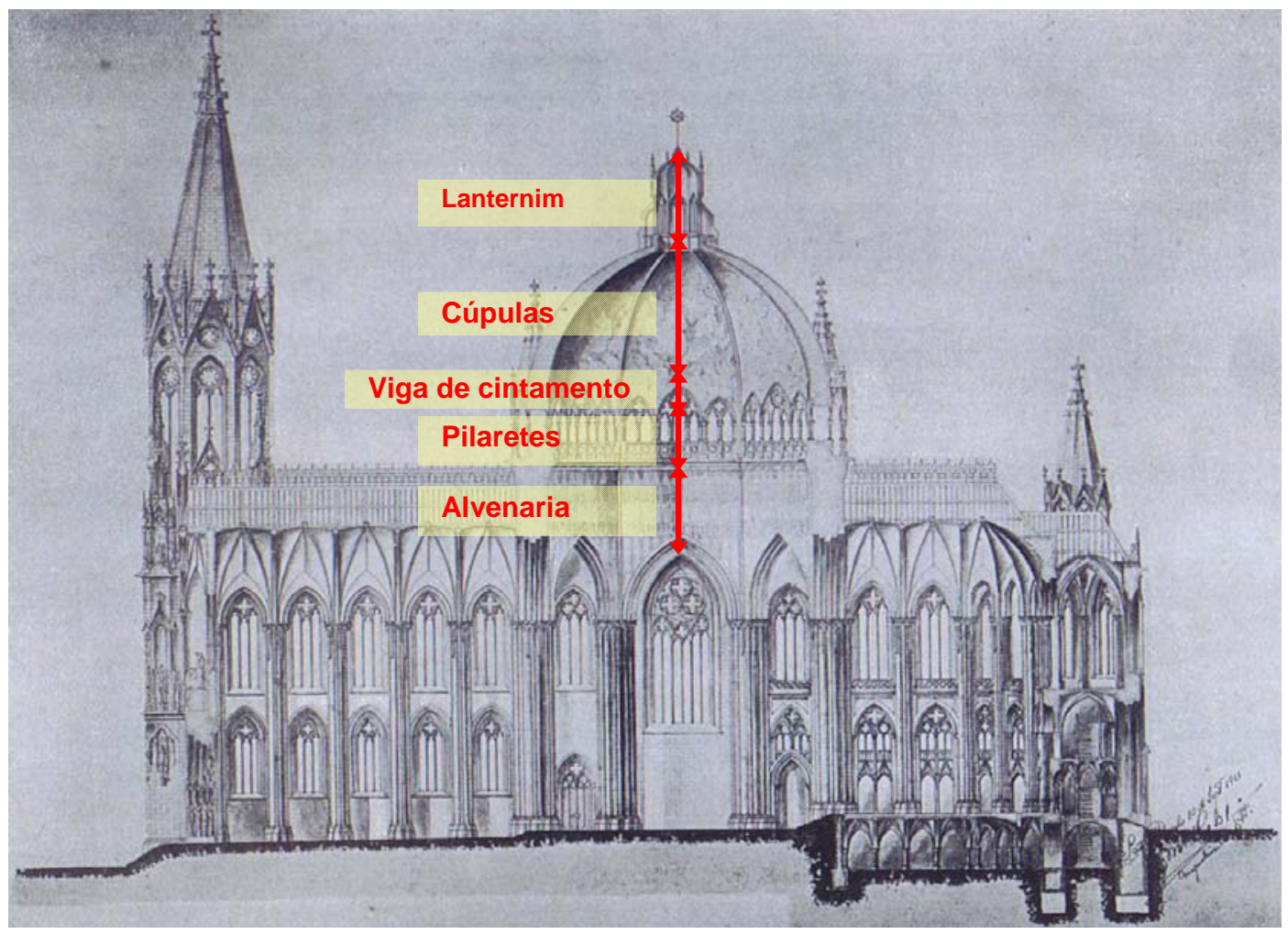

Figura 5.38 - A cúpula e o seu tambor. Corte longitudinal (Projeto arquitetônico original de Maximiliano Hehl adaptado. A CATHEDRAL DE SÃO PAULO, [1911?], sem numeração de página). 


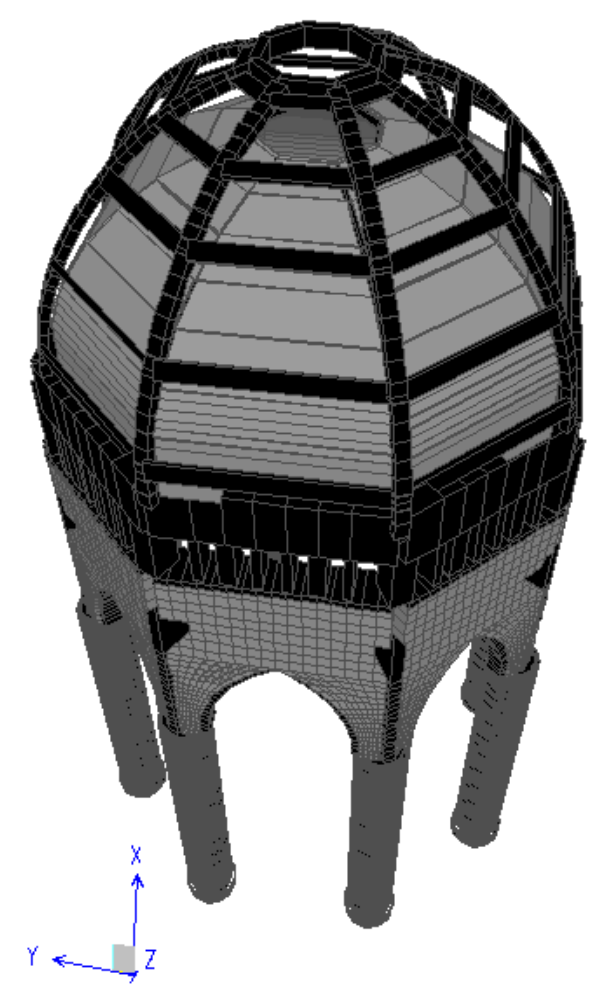

(a)

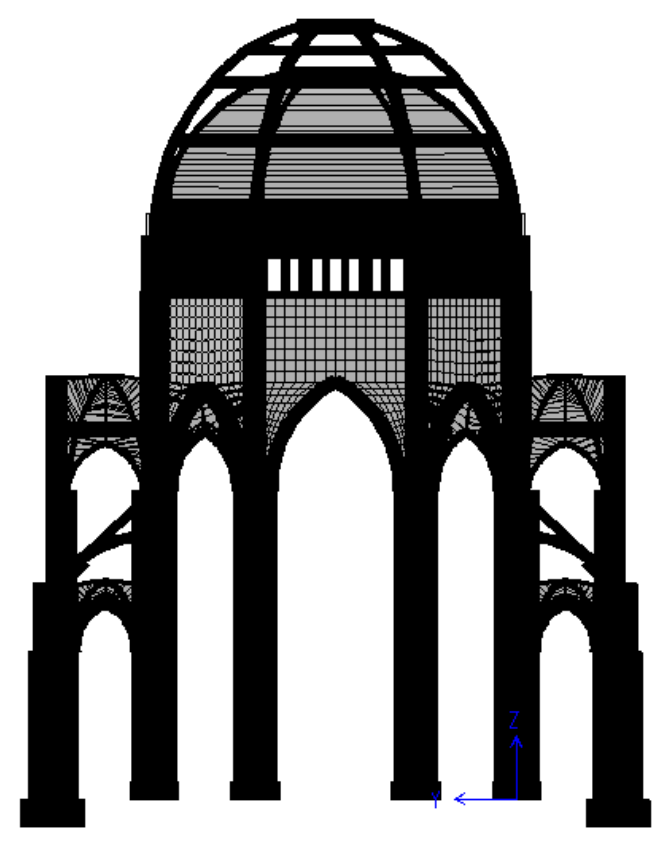

(b)

Figura 5.39 - Modelo do espaço octogonal da Catedral: (a) vista superior; (b) região do octógono.

O tambor, ao mesmo tempo, atua como uma enorme cinta a diminuir os deslocamentos dos pilares do próprio octógono para fora, mas estes deslocamentos continuam existindo.

Além disso, quando considerada toda a carga permanente da estrutura real, a parcela referente às paredes presentes sobre os arcos da igreja reduz o deslocamento horizontal total nos pilares do octógono, uma vez que o empuxo horizontal gerado por elas age no sentido oposto ao de tendência de abertura do octógono.

Os efeitos dos empuxos horizontais gerados pelo tambor se propagam para os demais pilares da Catedral. E este efeito fica mais claro quando é feita uma simulação em que se atribui peso zero ao restante da igreja e somente o octógono permanece com seu peso e suas cargas (Figura 5.40). 


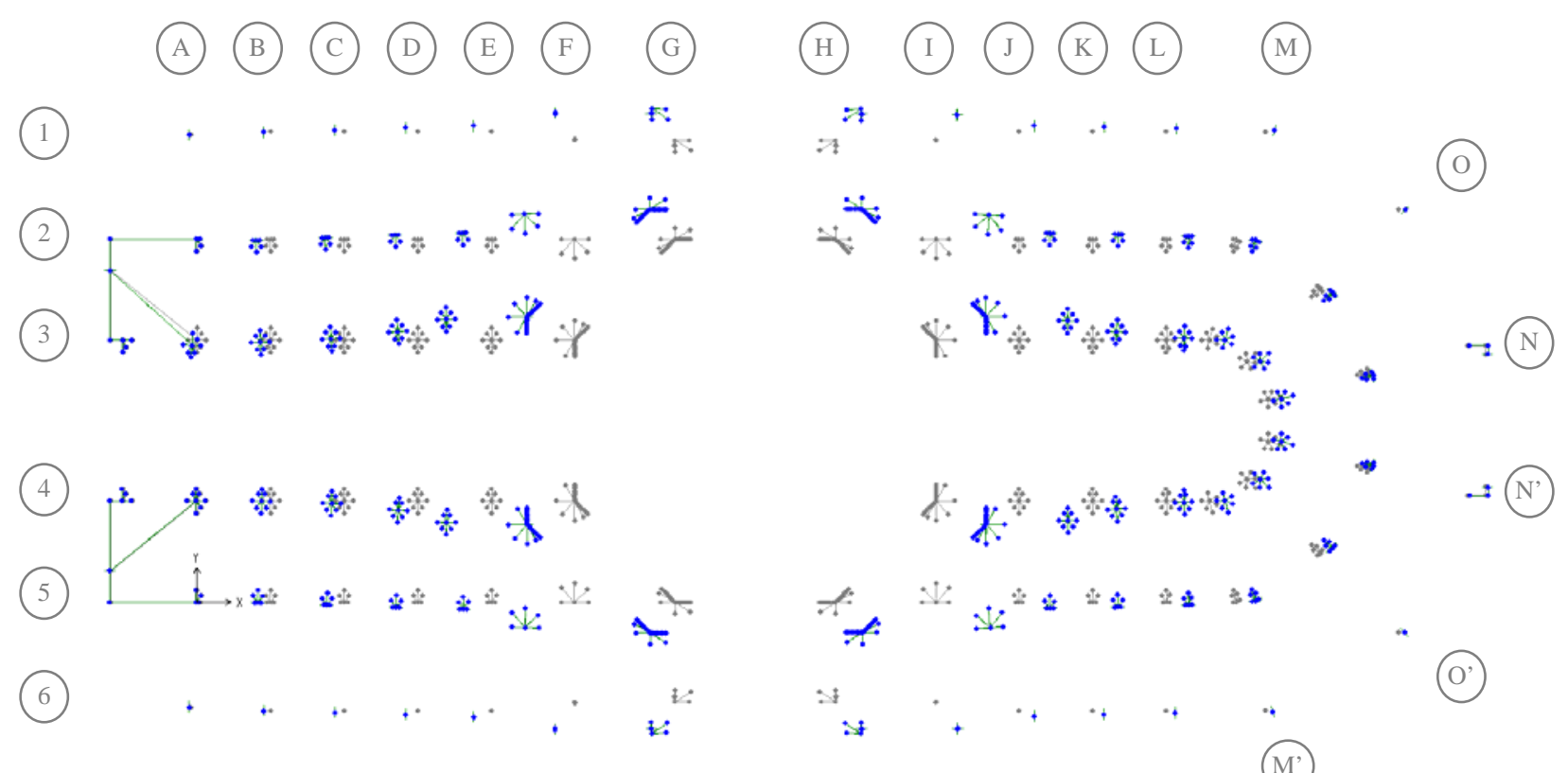

Figura 5.40 - Mapa dos deslocamentos devidos à carga permanente: simulação em que somente ao octógono são atribuídos peso e cargas - planta - escala dos deslocamentos 3000:1.

Observa-se que o tambor octogonal com suas elevadas cargas tem papel determinante ao maximizar os deslocamentos horizontais e movimentar a igreja para fora.

Os deslocamentos reais dos pilares da região do octógono sob a ação da carga permanente, por exemplo, podem ser comparados com aqueles gerados somente pelo octógono e suas cargas na Tabela 5.8. Verifica-se que o efeito octógono sobre os deslocamentos horizontais é significativo e que os deslocamentos reais são menores devido à ação do restante da estrutura.

Tabela 5.8 - Comparativo dos deslocamentos horizontais no topo dos pilares da região octógono.

\begin{tabular}{cccc}
\hline \multicolumn{4}{c}{ Estrutura real } \\
\hline \multirow{4}{*}{ Nó } & \multicolumn{2}{c}{ Deslocamento Horizontal } \\
\cline { 2 - 4 } & $\mathbf{u}_{\mathbf{x}}$ & $\mathbf{u}_{\mathbf{y}}$ & $\left|\mathbf{u}_{\mathbf{R}}\right|$ \\
& $\mathrm{mm}$ & $\mathrm{mm}$ & $\mathrm{mm}$ \\
\hline P.2F & $-1,04$ & 0,56 & 1,18 \\
\hline P.2G & $-0,55$ & 0,25 & 0,61 \\
\hline P.2H & 0,48 & 0,26 & 0,55 \\
\hline P.2I & 0,98 & 0,53 & 1,12 \\
\hline P.3F & $-1,07$ & 0,40 & 1,14 \\
\hline P.3I & 0,97 & 0,38 & 1,04 \\
\hline
\end{tabular}

\begin{tabular}{cccc}
\hline \multicolumn{4}{c}{$\begin{array}{c}\text { Estrutura somente com peso do } \\
\text { octógono }\end{array}$} \\
\hline \multirow{3}{*}{ Nó } & \multicolumn{2}{c}{ Deslocamento Horizontal } \\
\cline { 2 - 4 } & $\mathbf{u}_{\mathbf{x}}$ & $\mathbf{u}_{\mathbf{y}}$ & $\mathbf{u}_{\mathbf{R}} \mid$ \\
& $\mathrm{mm}$ & $\mathrm{mm}$ & $\mathrm{mm}$ \\
\hline P.2F & $-1,32$ & 0,74 & 1,52 \\
\hline P.2G & $-0,64$ & 0,74 & 0,98 \\
\hline P.2H & 0,66 & 0,74 & 1,00 \\
\hline P.2I & 1,39 & 0,71 & 1,56 \\
\hline P.3F & $-1,20$ & 0,59 & 1,33 \\
\hline P.3I & 1,25 & 0,60 & 1,38 \\
\hline
\end{tabular}




\subsection{Influência dos carregamentos permanentes na Catedral da Sé}

Após o entendimento de como se comportam os principais elementos estruturais góticos da Catedral da Sé e o funcionamento do octógono e sua interação com geometria da igreja, o objetivo desta seção é apresentar e ilustrar, pela sobreposição de seus efeitos, a influência das diferentes parcelas da carga permanente nos deslocamentos dos pilares e contrafortes.

A Tabela 5.9 apresenta as parcelas da carga permanente agrupadas.

Tabela 5.9 - Agrupamento dos carregamentos.

\begin{tabular}{ll}
\hline Carregamento & Descrição \\
\hline PESO PRÓPRIO GERADO & $\begin{array}{l}\text { Arcos, nervuras, panos das abóbadas, pilares, } \\
\text { contrafortes, arcobotantes, torres frontais até o nível } \\
\text { da segunda cornija, lajes da região posterior, tambor, } \\
\text { pilaretes, viga de cintamento, cúpula interna e cúpula } \\
\text { externa. }\end{array}$ \\
\hline PAREDES & $\begin{array}{l}\text { Paredes sobre os arcos longitudinais, sobre os arcos } \\
\text { transversais das naves laterais e sobre os arcos do } \\
\text { coro. }\end{array}$ \\
\hline OUTROS & $\begin{array}{l}\text { Pináculos e suas bases, lanternim, lajes do coro, } \\
\text { cornijas e torreões. }\end{array}$ \\
\hline CARGA PERMANENTE & $\begin{array}{l}\text { Carga permanente corresponde à soma do peso } \\
\text { próprio gerado, paredes e outros. }\end{array}$ \\
\hline
\end{tabular}

A primeira seqüência, apresentada nas Figuras 5.41 e 5.42, ilustra como a tendência de abertura da igreja sob ação do peso próprio gerado é diminuída pela presença das paredes, sobretudo na região do octógono de acordo com o que foi apresentado no item 5.4 .

A Figura 5.41 (a) mostra que, devido ao peso próprio gerado, os pilares centrais e laterais permanecem deslocados para fora da igreja, com exceção de alguns pilares localizados na parte posterior, devido à geometria curva, já que neste trecho os arcobotantes transmitem os empuxos horizontais decompostos e, portanto, de menor ação nas duas direções; os arcobotantes contêm os deslocamentos na direção transversal e longitudinal. 
Seqüência I: peso próprio gerado + paredes + outros = carga permanente

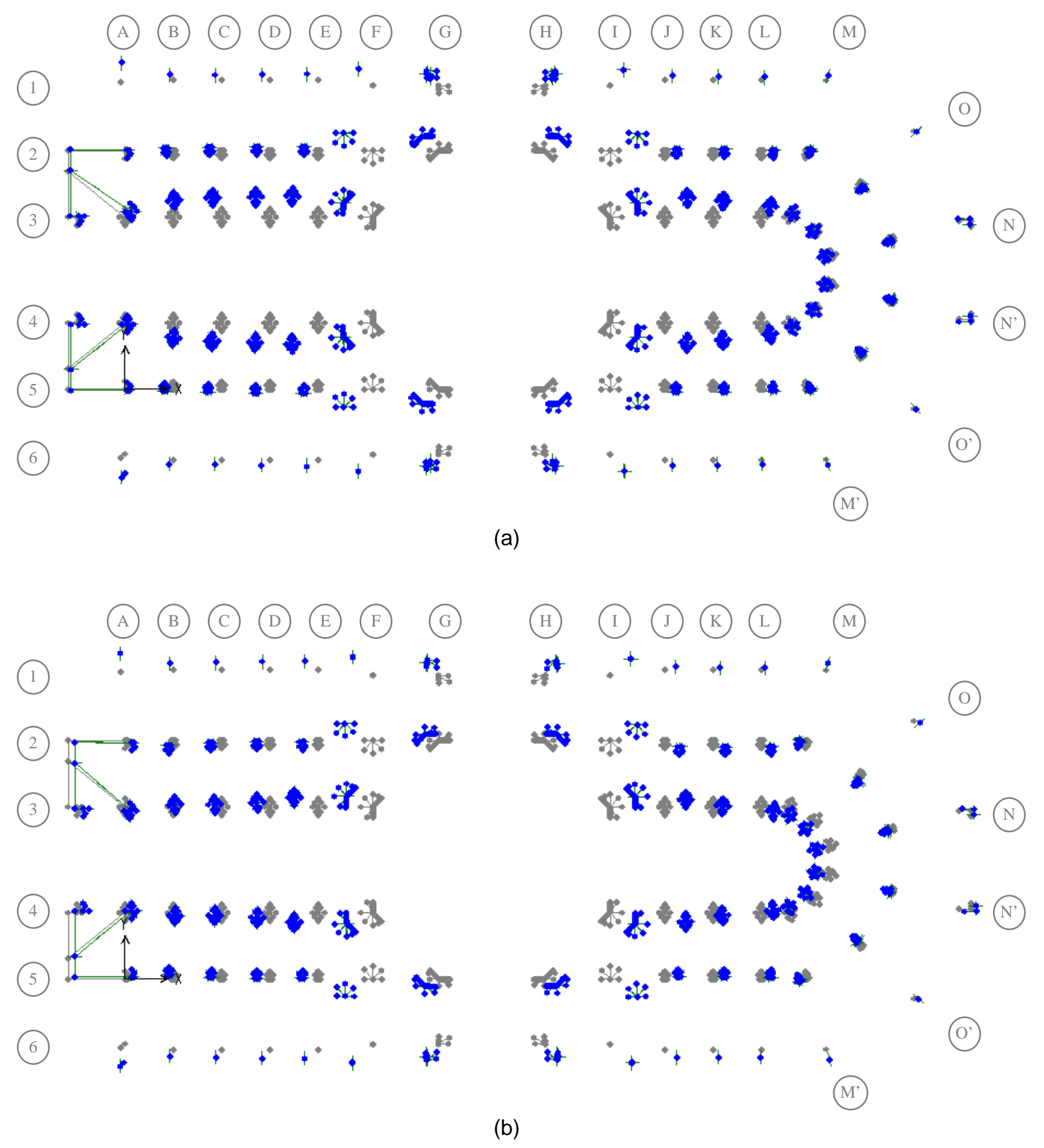

Figura 5.41 - Mapa dos deslocamentos - planta - escala dos deslocamentos 3000:1: (a) devidos ao peso próprio gerado; (b) devidos ao peso próprio gerado + paredes.

Somente com a presença das paredes, na Figura 5.41 (b), é que os outros pilares têm seus deslocamentos reduzidos para o exterior da igreja.

A introdução das demais parcelas do carregamento permanente pouco altera a 
configuração final dos deslocamentos da Catedral; os pilares laterais mantêm-se deslocados para o interior da igreja.

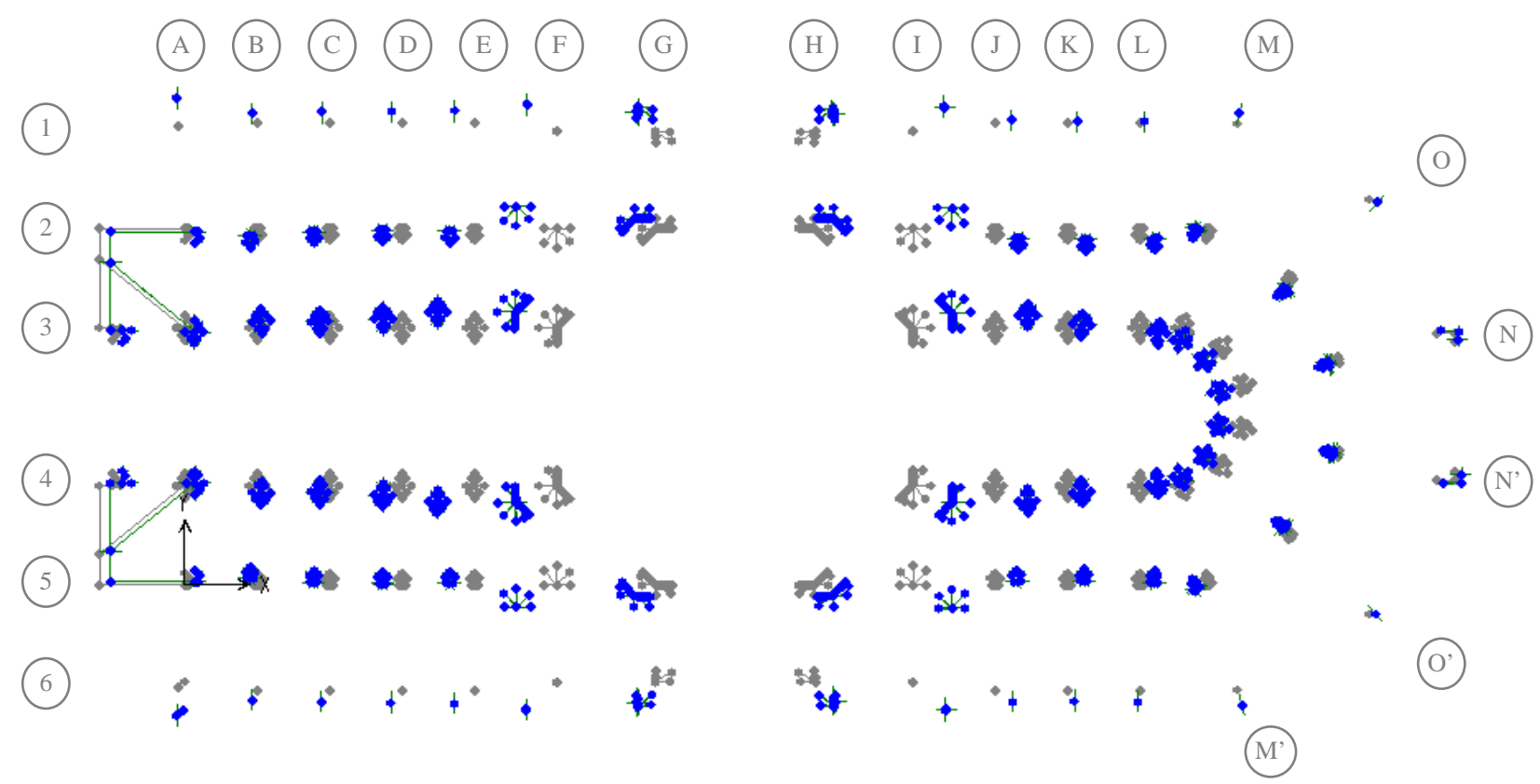

Figura 5.42 - Mapa dos deslocamentos - planta - escala dos deslocamentos 3000:1: devidos às paredes + peso próprio gerado + outros $=$ carga permanente.

A segunda seqüência se inicia com o efeito isolado do carregamento das paredes na estrutura do templo e segue com a inclusão dos demais carregamentos (Figuras 5.43 e 5.44).

Quando se considera somente a parcela do carregamento das paredes, Figura 5.43 (a), os pilares centrais e laterais deslocam-se para o interior da edificação tanto na direção transversal como na longitudinal, inclusive os pilares do octógono.

Ao observar, por exemplo, os pilares P.3E e P3F destacados na Figura 5.43, ao considerar o peso próprio dos elementos gerados, estes pilares mudam de orientação e deslocam-se para fora nas duas direções e o peso próprio do tambor ajuda a aumentar estes deslocamentos, ainda que pequenos. 
Seqüência II: paredes + peso próprio gerado + outros = carga permanente
A B C D E F G
(H) I ( ) $\mathrm{K}$ ( L
(M)
(1)

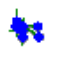
$*++\downarrow$

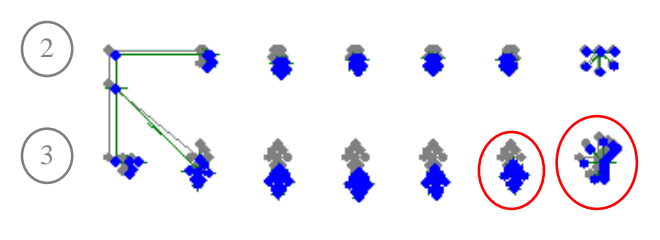
幽

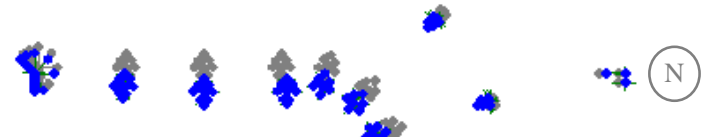
(4) $4+1+14$
$4 *+* *^{*} *$ N
(5)
$\uparrow$
$+2$
क्ष
* * * * *
6

$$
\text { * }
$$
(a)

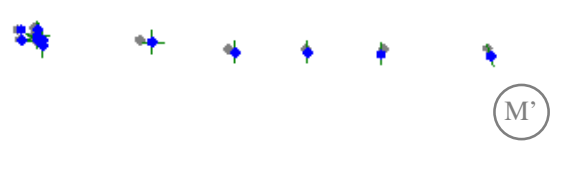
(O)

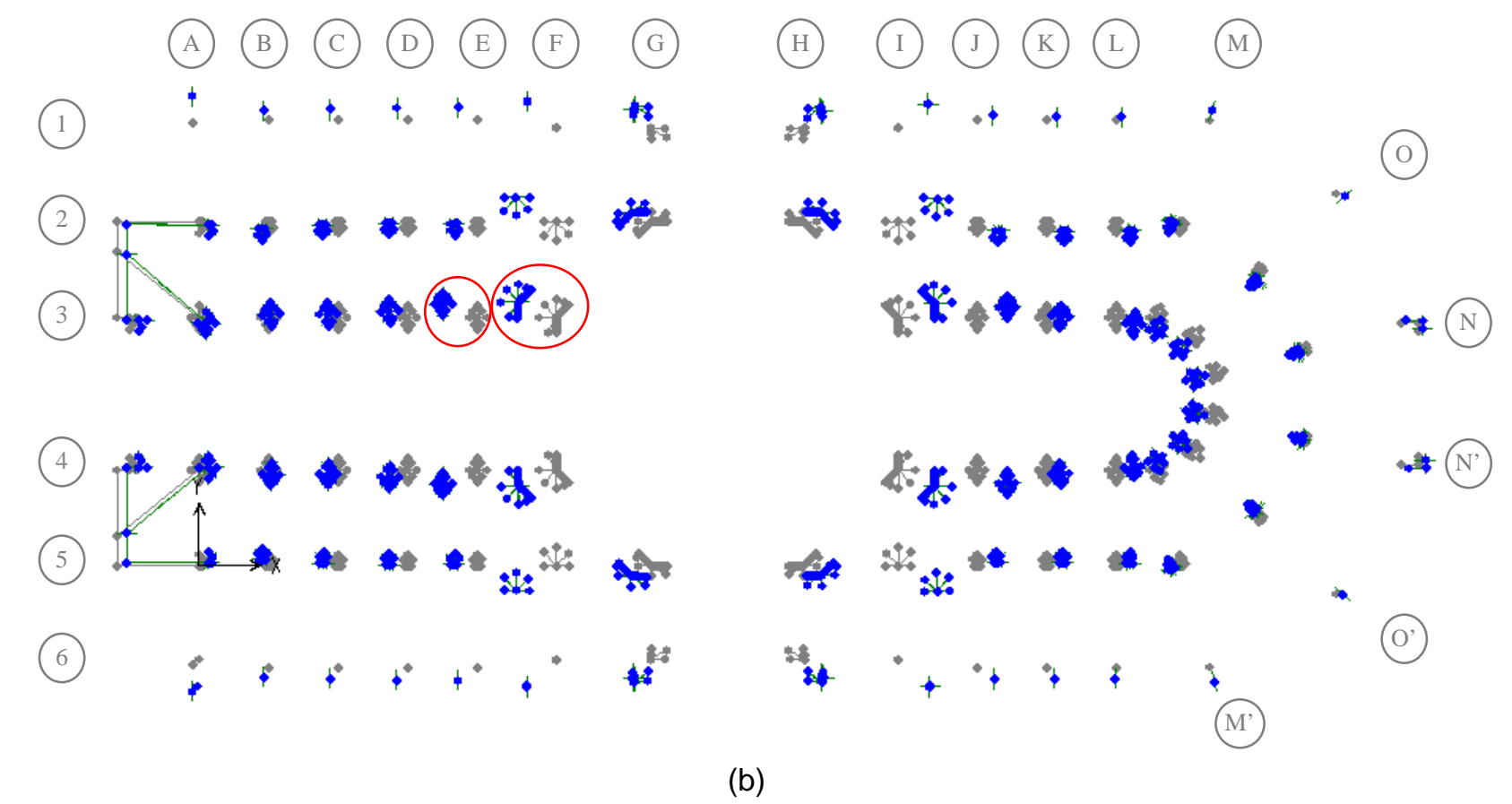

Figura 5.43 - Mapa dos deslocamentos - planta - escala dos deslocamentos 3000:1: (a) devidos às paredes; (b) devidos às paredes + peso próprio gerado. 


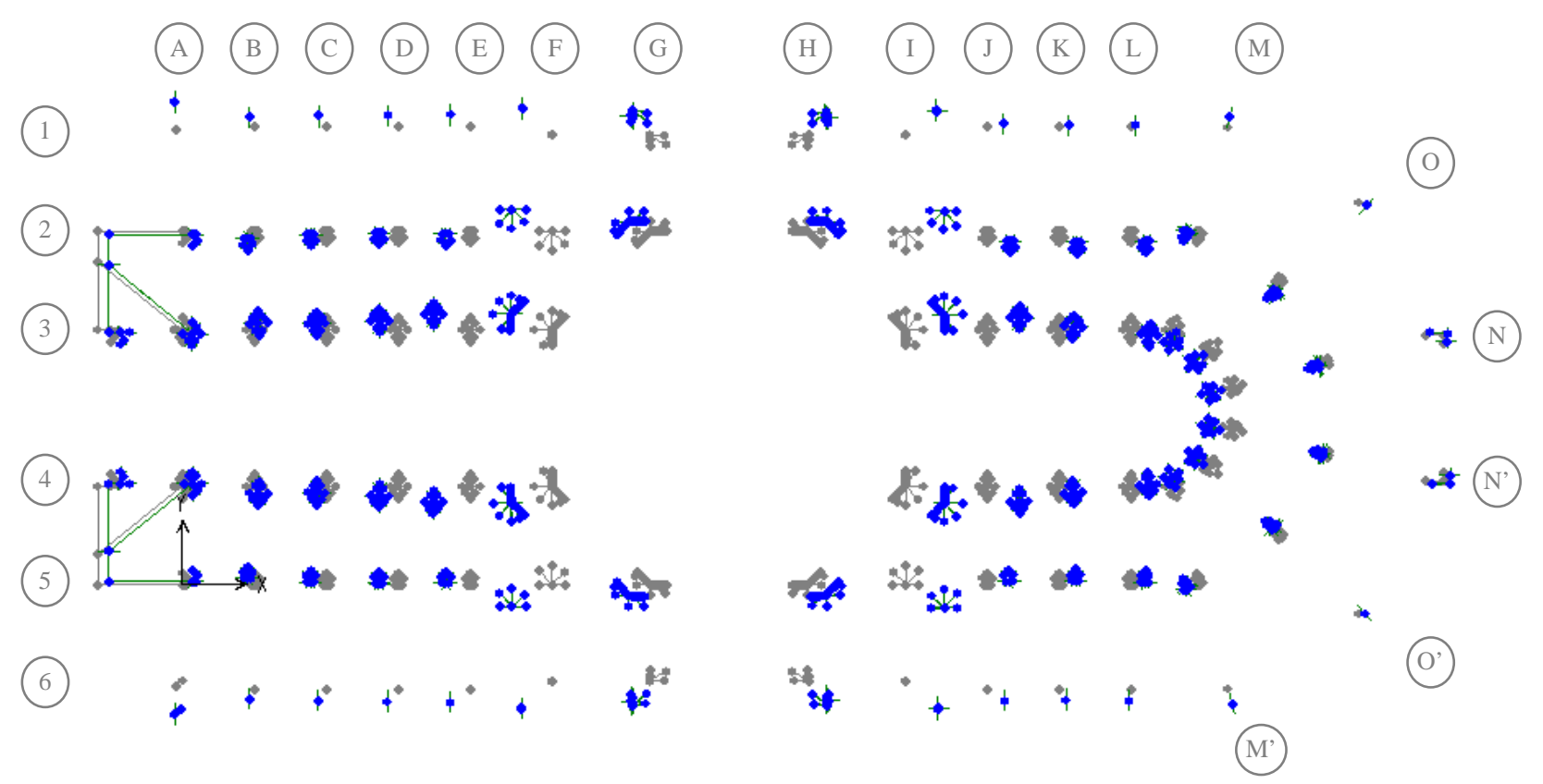

Figura 5.44 - Mapa dos deslocamentos - planta - escala dos deslocamentos 3000:1: devidos às paredes + peso próprio gerado + outros = carga permanente.

\subsection{Considerações sobre a análise dos deslocamentos}

A Catedral da Sé, arquitetonicamente, é bastante diferente de uma igreja gótica tradicional pelo fato de haver um espaço octogonal a interromper o ambiente de arcos e abóbadas ogivais e sobre o qual se encontra sua cúpula.

O efeito de verticalidade sobre a estrutura é menor se comparado com as igrejas góticas tradicionais, pois, diferentemente das demais igrejas analisadas, na Catedral da Sé as abóbadas das naves laterais desenvolvem-se a partir da mesma elevação das abóbadas da nave central. Visualmente, isto acarreta a uma menor verticalidade em relação a Chartres, Reims e Amiens, por exemplo.

O estudo de uma seção típica da região frontal da igreja isolada da ação do octógono mostrou que os elementos da igreja funcionam como os de uma catedral gótica tradicional, de modo que se a Catedral da Sé fosse longa o bastante suas seções transversais mais distantes se comportariam como tal.

Especificamente, as paredes sobre os arcos longitudinais reduzem os deslocamentos de todos os pilares e contrafortes para o exterior da igreja na direção 
transversal, levando os pilares laterais a se deslocarem para o interior. Já as paredes sobre os arcos transversais das naves laterais reduzem os deslocamentos para fora somente dos pilares centrais, enquanto que os pilares laterais e contrafortes deslocam-se para fora.

Os arcos das naves laterais externas geram empuxos horizontais que reduzem os deslocamentos dos pilares e contrafortes para o exterior da edificação. Observase ainda que mesmo sob as condições de geometria e de carregamento, a tendência de abertura dos contrafortes se mantém.

Já o empuxo horizontal resultante no topo dos pilares centrais, mesmo com a influência das paredes, ainda é para o exterior.

Os arcobotantes cumprem o seu papel, pois transferem os empuxos horizontais aos contrafortes, impedindo que a estrutura se abra; sem eles os deslocamento horizontais aumentam consideravelmente.

O estudo dos deslocamentos da Catedral da Sé mostra ainda a influência dos carregamentos permanentes, especialmente do tambor e suas elevadas cargas sobre o octógono, que tem papel determinante para a configuração final dos deslocamentos por maximizá-los e movimentar a igreja para fora nas duas direções.

Os carregamentos do tambor e o das paredes deslocam os elementos estruturais para sentidos opostos. Enquanto o peso próprio do tambor, por exemplo, empurra os pilares do octógono para fora, as paredes os levam para o interior da edificação.

$\mathrm{Na}$ parte posterior da igreja, a geometria curva propicia que arcobotantes contenham os deslocamentos transversais e longitudinais. Já na região frontal, os deslocamentos longitudinais, principalmente, são contidos pelas torres frontais que funcionam como enormes contrafortes.

Já o estudo dos carregamentos horizontais, vento e desaprumo, nos deslocamentos dos elementos de apoio mostra que o vento a 90 graus gera nos pilares e contrafortes maiores deslocamentos resultantes, mas não muito distantes daqueles provocados pelo desaprumo.

Em relação às simulações desenvolvidas, destaca-se que sem as torres frontais, a Catedral tende a movimentar-se no sentido das torres ausentes. Com 
isso, os deslocamentos horizontais totais dos pilares da região frontal e das seções F e G são maximizados, enquanto nos pilares das seções $\mathrm{H}$ e I, e nos pilares da parte posterior da igreja, há uma redução dos deslocamentos para o exterior da edificação.

Estes últimos pilares têm seus deslocamentos horizontais maximizados somente quando são retirados os arcobotantes, influenciados pela geometria curva da região posterior da Catedral. As torres frontais, presentes nesta simulação, restringem os deslocamentos dos pilares da parte frontal da igreja e nos elementos das seções F e G.

Este capítulo buscou apresentar os principais aspectos do comportamento estrutural da Catedral da Sé em termos de deslocamentos, a seguir é apresentado um breve estudo sobre as tensões. 


\section{ANÁLISE DAS TENSÕES}

Este capítulo apresenta a análise de tensões de alguns dos elementos estruturais da Catedral da Sé.

A análise dos deslocamentos desenvolvida no capítulo anterior fornece um indicativo dos pilares e contrafortes que podem apresentar maiores tensões.

Os contrafortes e pilares estão sob efeito de flexão e elevadas forças de compressão, que é predominante nestes elementos. Nesta situação, a linha neutra não coincide com os eixos principais de inércia, e, se a linha neutra vier a cortar a seção transversal então uma região estará submetida à tração, o que poderá levar à fissuração, principalmente em materiais pouco resistentes a esta solicitação, como é o caso dos materiais estruturais empregados na Catedral.

O estudo realizado mostrou, entretanto, que as seções transversais de todos os pilares e os contrafortes da igreja permanecem totalmente comprimidas, mesmo na situação em que são consideradas as ações horizontais do desaprumo ou as do vento.

O carregamento horizontal, como vento ou o desaprumo, de menores proporções, tem sua influência notada por aumentar a diferença entre as tensões extremas na seção transversal, mas para o efeito global é secundário frente à carga permanente, que define o comportamento estrutural do templo.

As tensões nos pilares e contrafortes da igreja também são estudadas a partir de simulações em que são retirados elementos estruturais considerados importantes para o equilíbrio da Catedral, como os arcobotantes e as duas torres frontais, para deste modo verificar seu papel na resistência da igreja.

Quanto às abóbadas, a partir do estado de tensão decorrente dos carregamentos, estuda-se sua possível relação com as fissuras mapeadas por ocasião da recente reforma. 


\subsection{Tensões atuantes}

As tensões normais atuantes num ponto de uma seção transversal são obtidas, genericamente, pela equação 6.1, onde x e y correspondem às distâncias do ponto em análise até o centro de gravidade da seção.

$$
\sigma=\frac{N}{A}+\frac{M_{x}}{I_{x}} . y-\frac{M_{y}}{I_{y}} . x
$$

Especificamente, para os contrafortes e para o terceiro trecho dos pilares laterais, que têm seção transversal aproximada para retangular e para retangular vazada (Figura 6.1), as máximas tensões normais de compressão atuantes no núcleo e no revestimento, respectivamente, são obtidas pelas equações:

$$
\begin{gathered}
\sigma_{\text {NUC.máx. }}=-\frac{\left|N_{1}\right|}{h_{1} \cdot b_{1}}-\frac{6 \cdot\left|M_{1 x}\right|}{h_{1}^{2} \cdot b_{1}}-\frac{6 \cdot\left|M_{1 y}\right|}{b_{1}^{2} \cdot h_{1}} \\
\sigma_{\text {REV.máx. }}=-\frac{\left|N_{2}\right|}{\left(h_{2} \cdot b_{2}-h_{1} \cdot b_{1}\right)}-\frac{6 \cdot\left|M_{2 x}\right| \cdot h_{2}}{\left(h_{2}^{3} \cdot b_{2}-h_{1}^{3} \cdot b_{1}\right)}-\frac{6 \cdot\left|M_{2 y}\right| \cdot b_{2}}{\left(b_{2}^{3} \cdot h_{2}-b_{1}^{3} \cdot h_{1}\right)}
\end{gathered}
$$

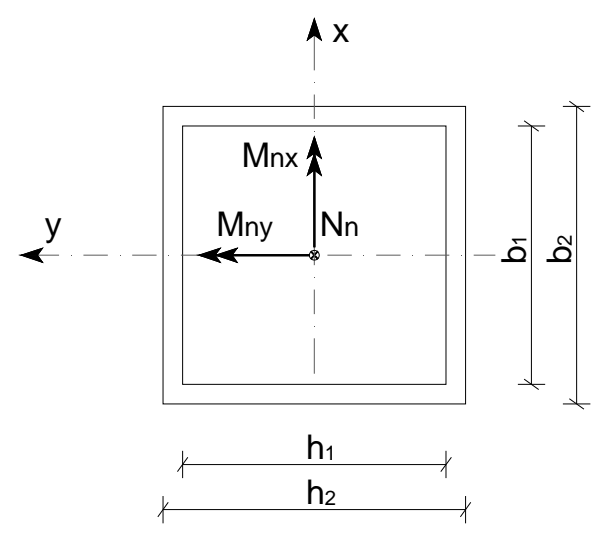

Nota: $n$ corresponde ao material 1 ou 2, referente ao núcleo ou ao revestimento

Figura 6.1 - Esquema geral dos esforços numa seção retangular.

\section{Onde:}

$\mathrm{N}_{1}$ é o esforço axial atuante no núcleo

$M_{1 x}$ é o momento fletor atuante no núcleo em torno do eixo global x 
$\mathrm{M}_{1 y}$ é o momento fletor atuante no núcleo em torno do eixo global y

$\mathrm{N}_{2}$ é o esforço axial atuante no revestimento

$M_{2 x}$ é o momento fletor atuante no revestimento em torno do eixo global $x$

$M_{2 y}$ é o momento fletor atuante no revestimento em torno do eixo global y

$\mathrm{b}_{1}, \mathrm{~h}_{1}$ são as dimensões da seção transversal do núcleo paralelas aos eixos x e y respectivamente.

$b_{2}, h_{2}$ são as dimensões da seção transversal do revestimento paralelas aos eixos $x$ e y respectivamente.

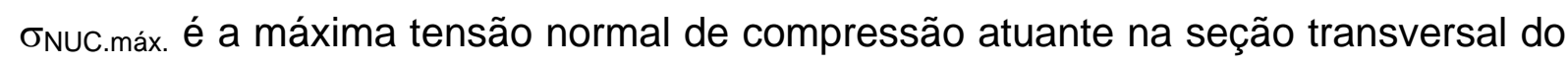
núcleo.

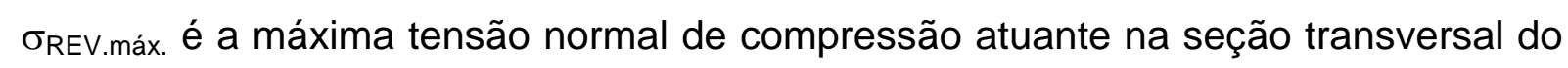
revestimento.

Analogamente, para os pilares com núcleo de seção circular e revestimento de seção tubular, as tensões máximas de compressão atuantes são obtidas respectivamente pelas equações:

$$
\begin{gathered}
\sigma_{\text {NUC.máx. }}=-\frac{4\left|N_{1}\right|}{\pi \cdot d^{2}}-\frac{32 \cdot\left|M_{1 R}\right|}{\pi \cdot d^{3}} \\
\sigma_{\text {REV.máx. }}=-\frac{4\left|N_{2}\right|}{\pi \cdot\left(D^{2}-d^{2}\right)}-\frac{32\left|M_{2 R}\right| \cdot D}{\pi\left(D^{4}-d^{4}\right)}
\end{gathered}
$$

Onde:

d é o diâmetro da seção transversal do núcleo;

D é o diâmetro externo da seção transversal do revestimento.

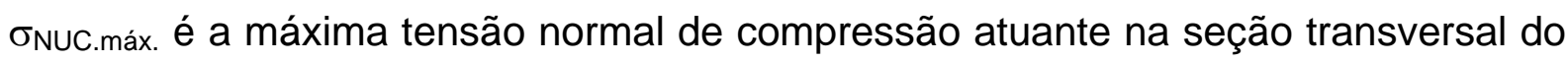
núcleo.

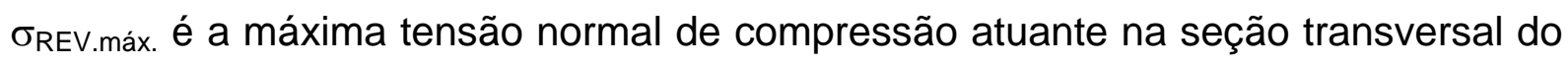
revestimento. 
Vale ressaltar que nas seções circulares não há flexão oblíqua, pois, como momento de inércia em relação aos eixos que passam pelo centro de gravidade é sempre o mesmo, a flexão sempre será normal, com o momento dado pelas equações 6.6 e 6.7 .

$$
M_{1 R}=\sqrt{M_{1 x}{ }^{2}+M_{1 y}{ }^{2}}
$$

Onde: $M_{1 R}$ é o momento fletor total atuante no núcleo.

$$
M_{2 R}=\sqrt{M_{2 x}^{2}+M_{2 y}^{2}}
$$

Onde: $M_{2 R}$ é o momento fletor total atuante no revestimento.

Nos dimensionamentos, pode-se admitir que materiais como o concreto simples, as alvenarias de granito e de tijolos não resistam à tração. Nesta situação, as equações apresentadas anteriormente deixariam de valer se viessem a ocorrer tensões de tração pois, conseqüentemente, haveria fissuração da seção transversal. Neste caso, as tensões normais na seção transversal seriam dadas por outras equações, em decorrência da redução da seção resistente.

No entanto, o estudo aqui apresentado consiste em uma verificação estrutural e a resistência à tração dos materiais é considerada; as equações 6.1 a 6.5 deixarão de valer caso a tensão de ruptura obtida em um ensaio de tração simples desses materiais venha a ser ultrapassada.

Como comentado, os resultados da análise das tensões mostram que os pilares e os contrafortes encontram-se totalmente comprimidos, mesmo sob a ação das cargas horizontais do vento e do desaprumo, o que é verificado com a locação da linha neutra que passa fora das seções transversais, como será apresentado adiante.

Como se admite que as seções transversais permanecem planas e perpendiculares ao eixo da barra após a deformação, a posição da linha neutra é a mesma para núcleo e para o revestimento.

A linha neutra, em que a tensão normal é nula, pode ser determinada, por exemplo, para seções retangulares, a partir da eq. 6.1, e pode ser reescrita para obter as coordenadas dos pontos nos quais a linha neutra corta os eixos $x$ e $y$ (Figura 6.2). 


$$
y=\frac{\left(-\frac{N}{A}+\frac{M y}{I y} \cdot x\right)}{M x} \cdot I x=\frac{\left(+\frac{N}{A}+\frac{M x}{I x} \cdot y\right)}{M y} I y
$$

Assim, quando $x_{a}=0$, o ponto em que a linha neutra corta o eixo y é dado por:

$$
y_{a}=\frac{\left(-\frac{N}{A}\right)}{M x} \cdot I x
$$

$E$ quando $y_{b}=0$, o ponto em que a linha neutra corta o eixo $\mathrm{x}$ é dado por

$$
x_{b}=\frac{\left(\frac{N}{A}\right)}{M y} . I y
$$

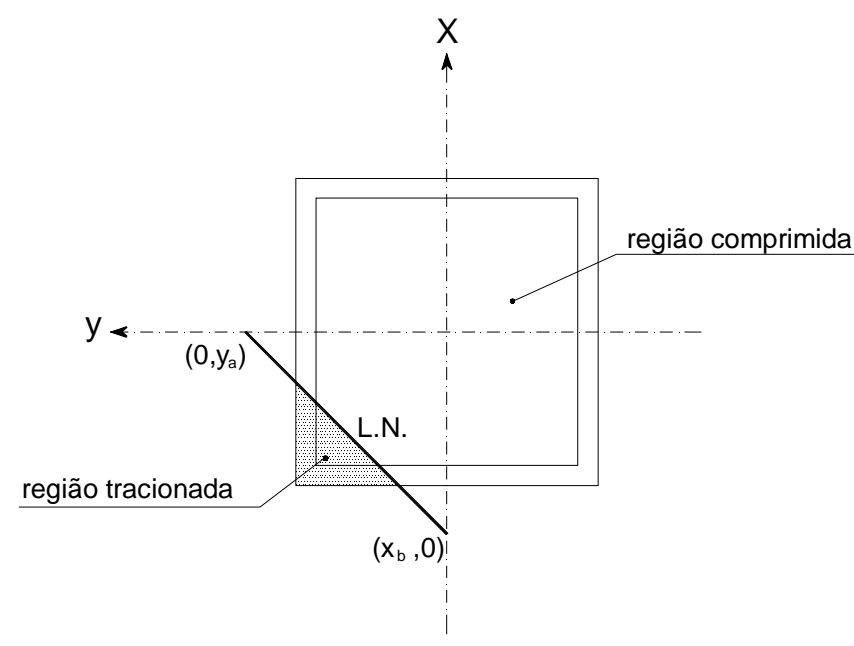

Figura 6.2 - Esquema geral da posição da linha neutra numa seção retangular. 


\subsection{Estudo das tensões nos contrafortes e pilares}

São apresentadas as tensões normais atuantes em alguns pilares e contrafortes submetidos a maiores deslocamentos se comparados com os demais elementos deste tipo na igreja; a maioria está localizada na região do octógono por receberem elevadas cargas, e por isso tornam-se uma orientação para o início da análise das tensões.

$\mathrm{Na}$ metodologia desenvolvida, primeiro foram estudados estes pilares e contrafortes, mas a análise estendeu-se aos demais elementos da igreja, tendo-se confirmado, para a maioria dos casos, a existência de maiores tensões naqueles inicialmente selecionados, como será visto adiante.

Os pilares do octógono são alguns dos elementos que apresentam os maiores deslocamentos da igreja, não somente verticais, mas principalmente horizontais, devido à tendência de abertura do octógono. Apesar de o tambor funcionar como uma enorme cinta a conter os deslocamentos, ainda assim a tendência é de abertura. Nestes pilares, não somente as forças normais de compressão são elevadas, mas momentos fletores consideráveis atuam em suas seções transversais, e é nestas situações que se encontram algumas das máximas tensões de compressão.

A seguir, são apresentados alguns pilares e contrafortes que estão sob elevadas solicitações, localizados na região do octógono, e também outros de menor rigidez localizados em eixos adjacentes a este trecho da Catedral. As peças selecionadas representam grupos de pilares ou contrafortes, seja em termos de geometria, seja em grau de solicitação.

\subsubsection{Pilares e contrafortes da seção no eixo F}

Toma-se como exemplo a análise dos elementos estruturais da seção do eixo F, uma das mais solicitadas por encontrar-se na região do octógono. Seus pilares e contrafortes são mais rígidos que a maioria das peças localizadas nas regiões frontal e posterior da Catedral, e é também neles que ocorrem os maiores deslocamentos, como apresentado no Capítulo 5. 
Os diagramas dos esforços solicitantes, força normal e momento fletor, estão ilustrados nas Figuras 6.3 e 6.4.
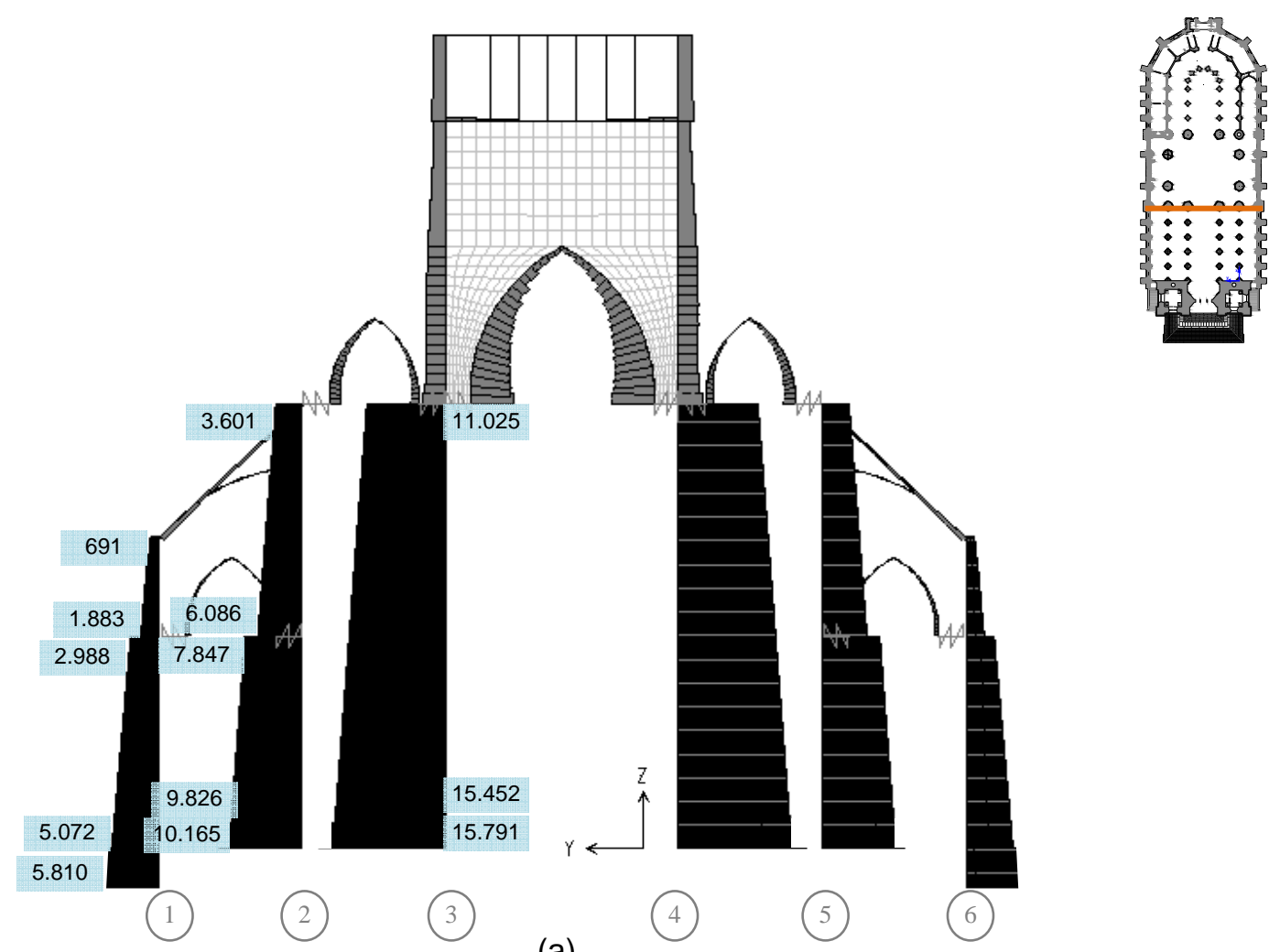

(a)

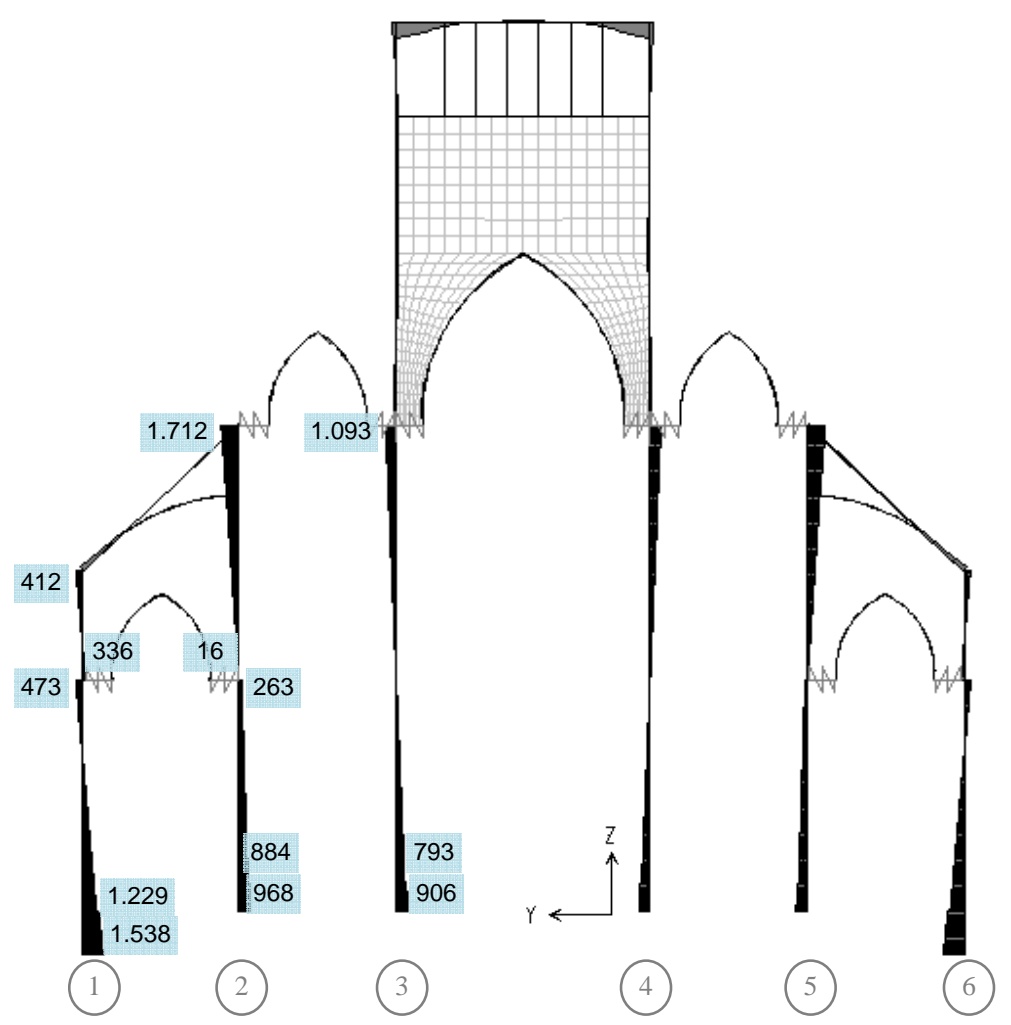

(b)

Unidades: kN; kN.m

Figura 6.3 - Diagrama dos esforços solicitantes na seção do eixo $\mathrm{F}$ devidos à carga permanente escala 0,0007:1: (a) força normal; (b) momento fletor em torno de $\mathrm{x}$. 


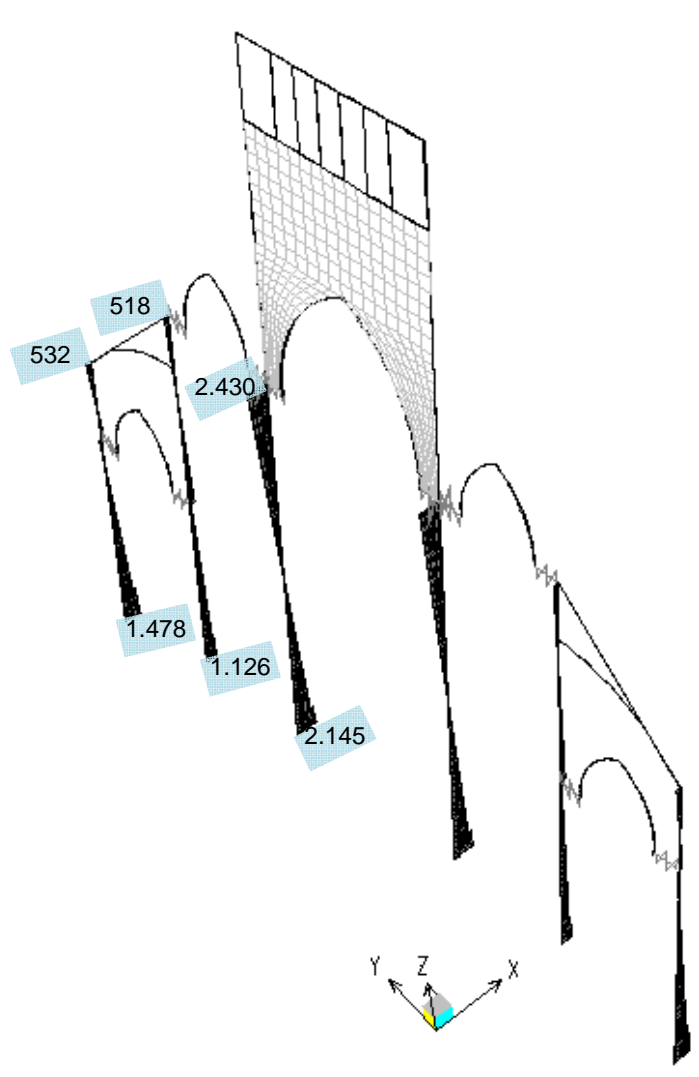

Unidade: kN.m

Figura 6.4 - Diagrama dos esforços solicitantes na seção do eixo $\mathrm{F}$ devidos à carga permanente momento fletor em torno de y- escala 0,0007:1

Para a análise das tensões normais nos pilares e contrafortes da seção no eixo $F$, são tomados os esforços atuantes nas seções mais solicitadas ao longo de cada peça. E verifica-se que, tanto para os contrafortes como para os pilares, as tensões normais resultantes nas fibras extremas da seção são somente de compressão.

As linhas neutras construídas para as diferentes seções em nenhum momento cortam as seções transversais e encontram-se distantes das mesmas, ou seja, as peças estão totalmente comprimidas. No entanto, a influência dos momentos fletores atuantes sobre cada um dos pilares e contrafortes é observada à medida que é maior a inclinação do diagrama das tensões.

A proximidade da linha neutra às seções transversais e a inclinação dos diagramas das tensões mostram um efeito razoável dos momentos fletores em relação às forças axiais de compressão que atuam nos pilares da igreja.

Nos pilares laterais, sob a ação da carga permanente, a tensão máxima de compressão encontrada no revestimento de granito é de 1,95 $\mathrm{MPa}$, enquanto no núcleo de concreto simples é de 1,23 MPa (Figura 6.5). 
Pilar lateral 2F

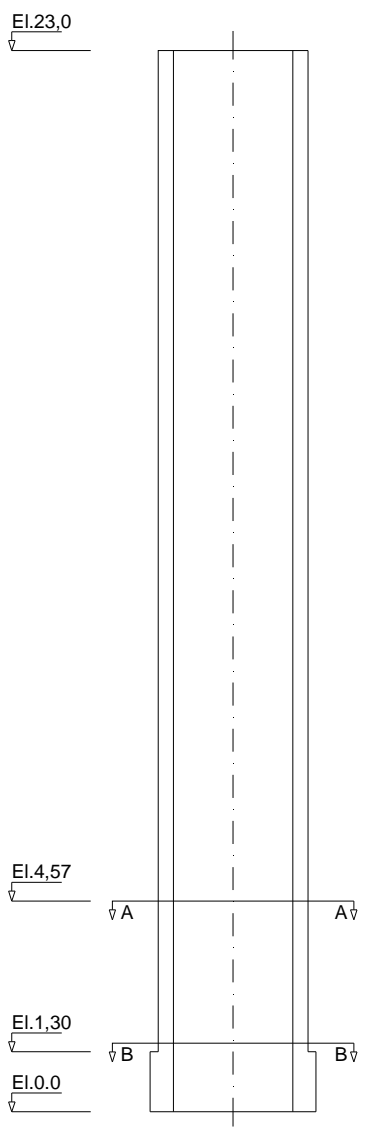

(a)

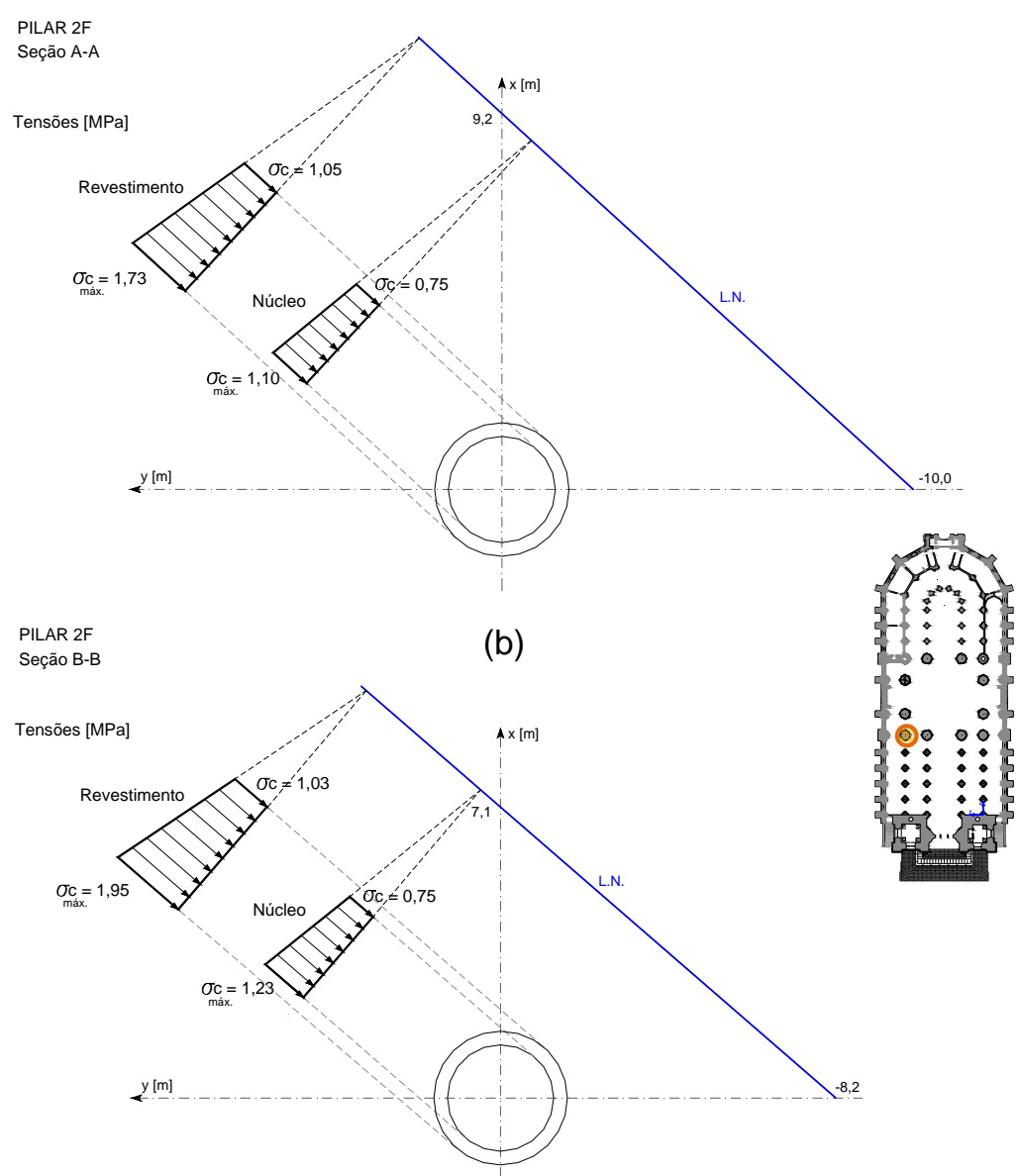

(c)

Figura 6.5 - Tensões normais resultantes no pilar lateral $2 \mathrm{~F}$ devidas à ação da carga permanente: (a) elevação; (b) corte A; (c) corte B.

Se os carregamentos horizontais forem considerados, como, por exemplo, o desaprumo, a linha neutra aproxima-se ainda mais das seções transversais e as tensões máximas de compressão nestes materiais aumentam até 7,7\%, devido à maior ação dos momentos fletores. As máximas tensões normais obtidas são de 2,10 MPa no revestimento e 1,31 MPa no núcleo (Figura 6.6). 
Pilar lateral 2F

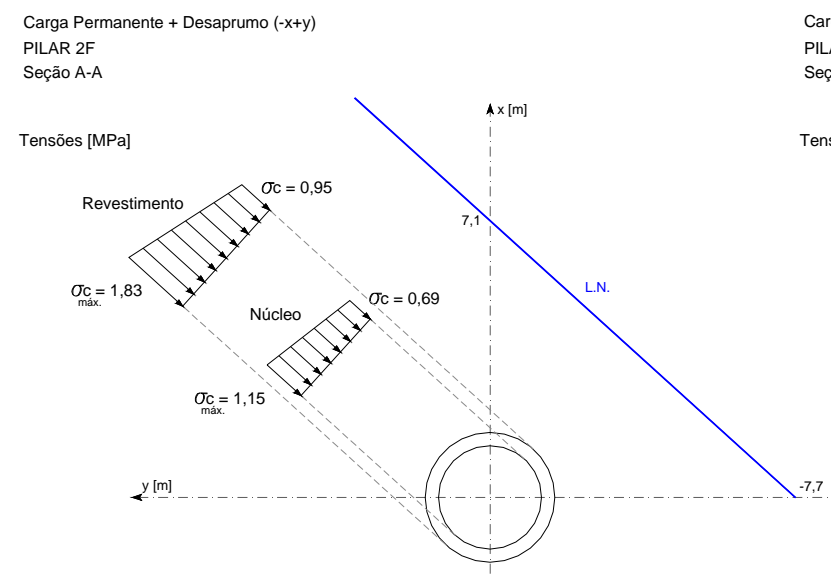

(a)

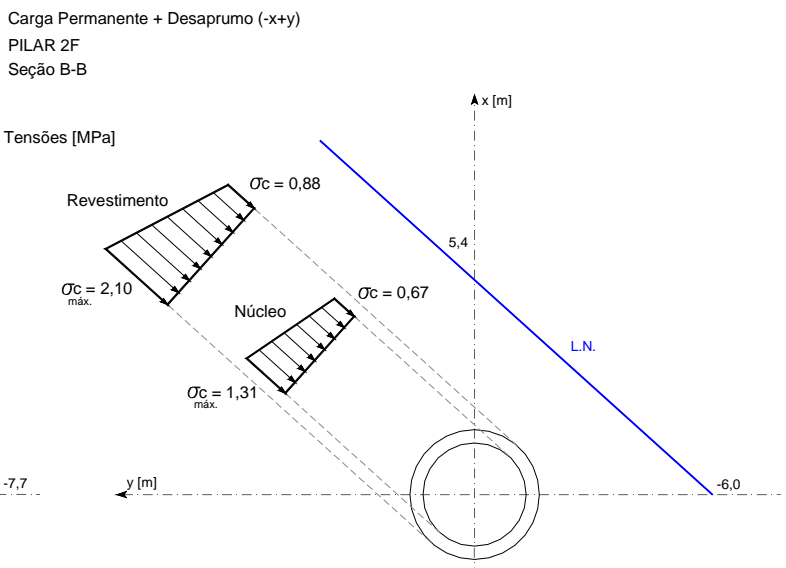

(b)

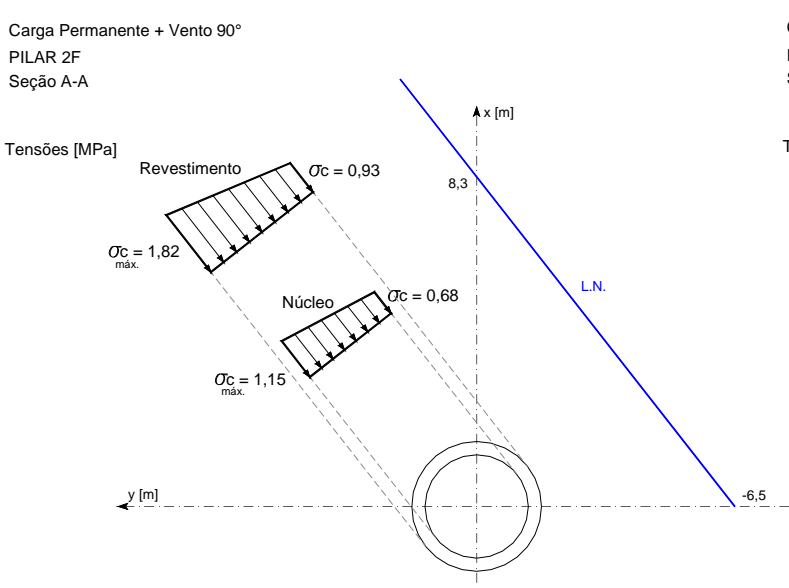

(c)

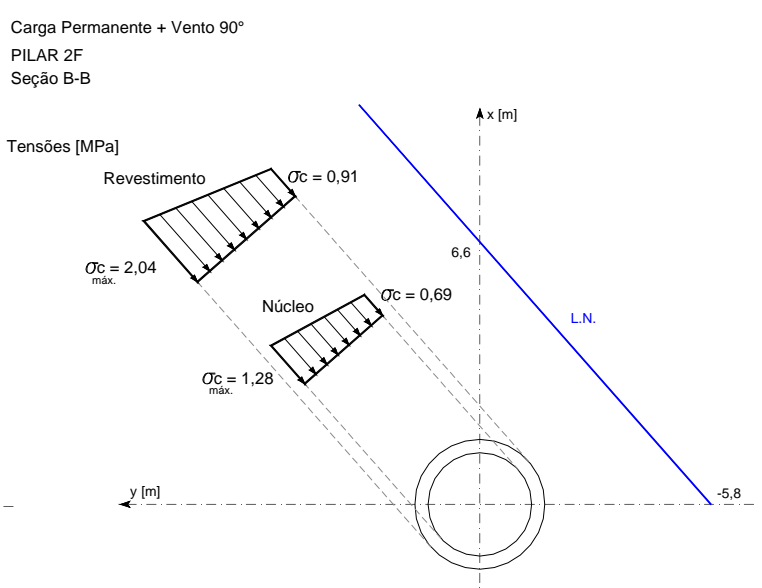

(d)

Figura 6.6 - Tensões normais resultantes no pilar lateral 2F devidas à ação da carga permanente mais o desaprumo nas direções $-x$ e +y: (a) corte $A$; (b) corte $B$ e; devidas à ação da carga permanente mais o vento a $90^{\circ}$, no sentido +y: (c) corte $A$; (d) corte $B$.

Assim, ao considerar-se a ação dos carregamentos horizontais, a diferença entre as tensões extremas atuantes na seção transversal aumenta, pois são acrescidos os momentos fletores produzidos pelo desaprumo ou pelo vento.

Nos pilares centrais da seção F, muito mais solicitados por se encontrarem diretamente sob o tambor e a cúpula, o revestimento apresenta tensão de compressão de até 3,04 MPa, enquanto o núcleo está com 1,92 MPa sob ação da carga permanente, como mostra a Figura 6.7. 
Pilar central 3F

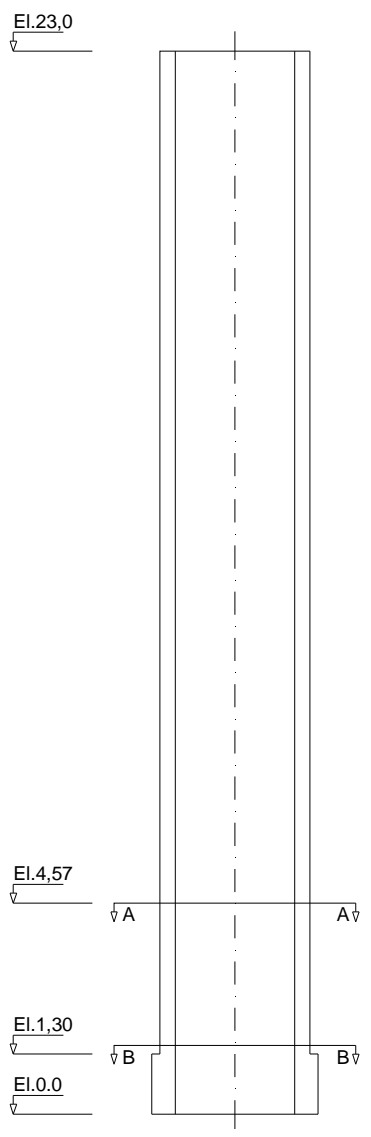

(a)

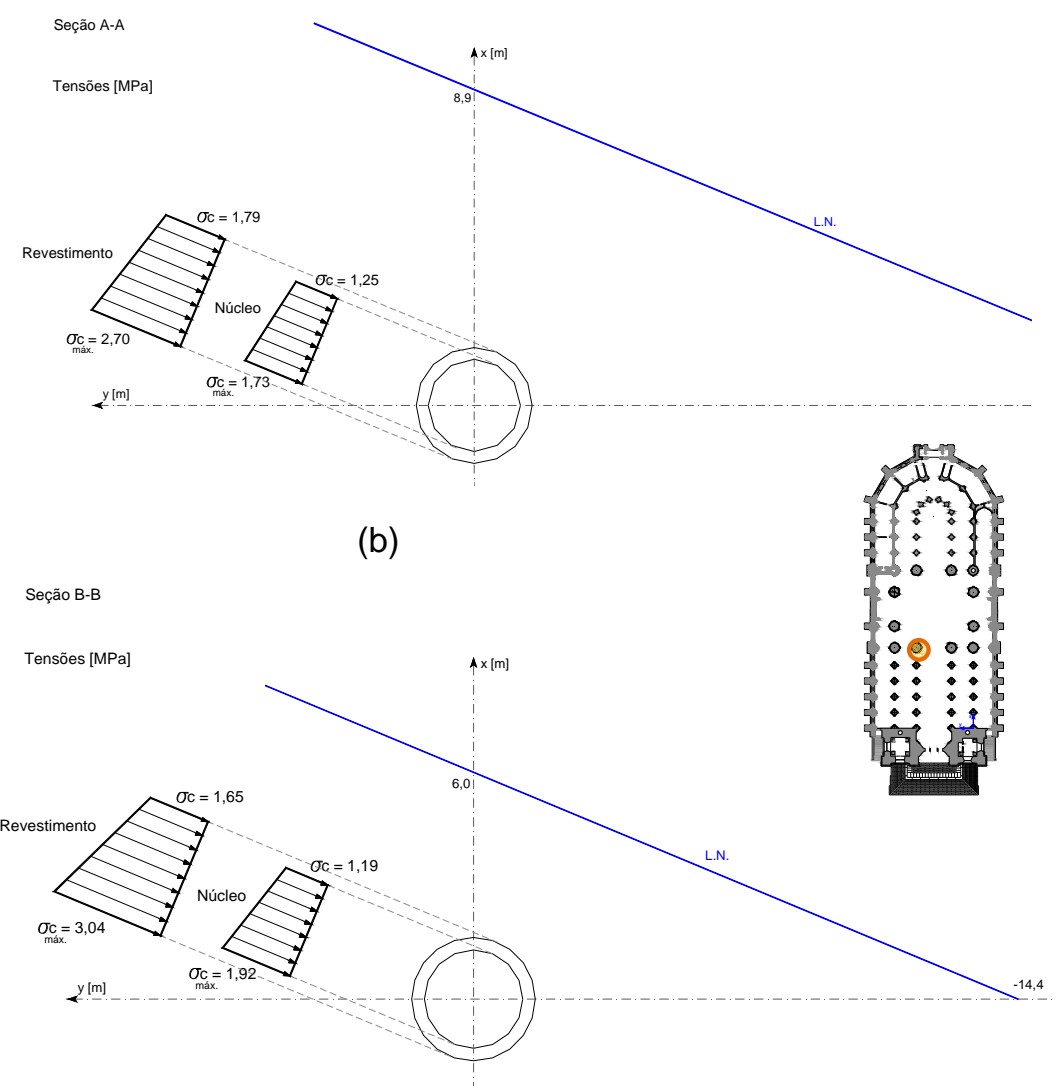

(c)

Figura 6.7 - Tensões normais resultantes no pilar central 3F devidas à ação da carga permanente: (a) elevação; (b) corte A; (c) corte B.

É nos pilares centrais da seção $F$ que se encontram as maiores tensões de compressão nos materiais que constituem estes elementos de apoio, granito e concreto simples. Considerando o desaprumo, as tensões máximas de compressão aumentam até 3,6\%, alcançando $3,15 \mathrm{MPa}$ no revestimento e 1,98 MPa no núcleo, valores da mesma ordem de grandeza se considerada a ação do vento a $90^{\circ}$, como mostra a Figura 6.8. 
Pilar central 3F

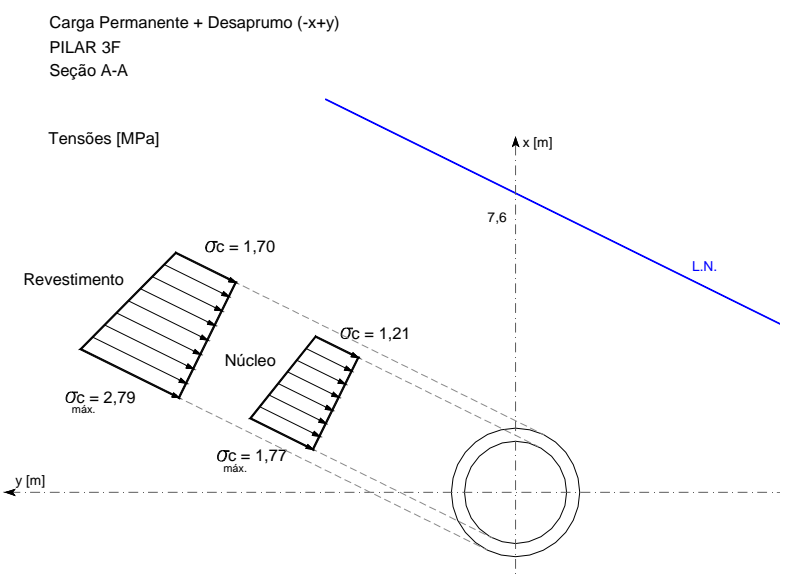

(a)

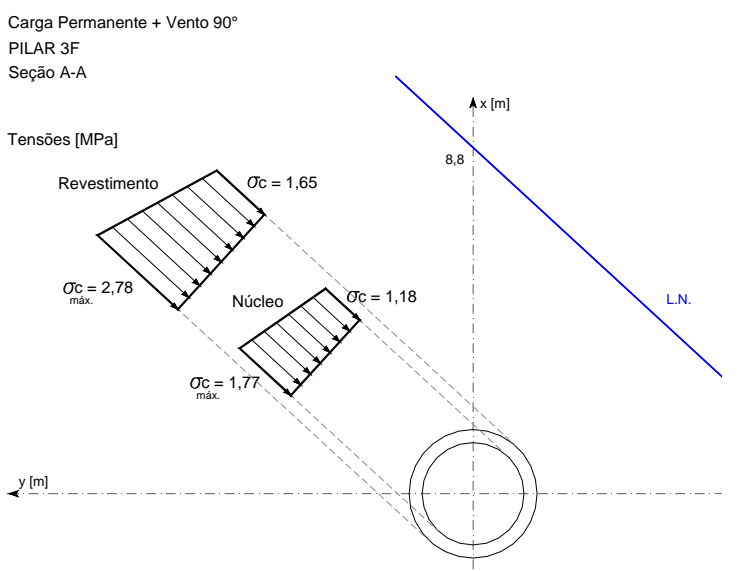

(c)

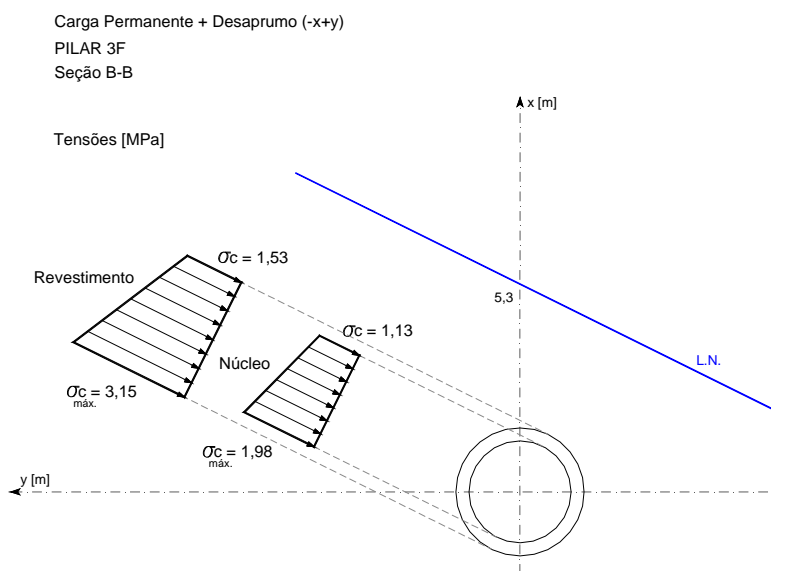

(b) Carga Permanente + Vento 90
PILAR 3F
Seção B-B

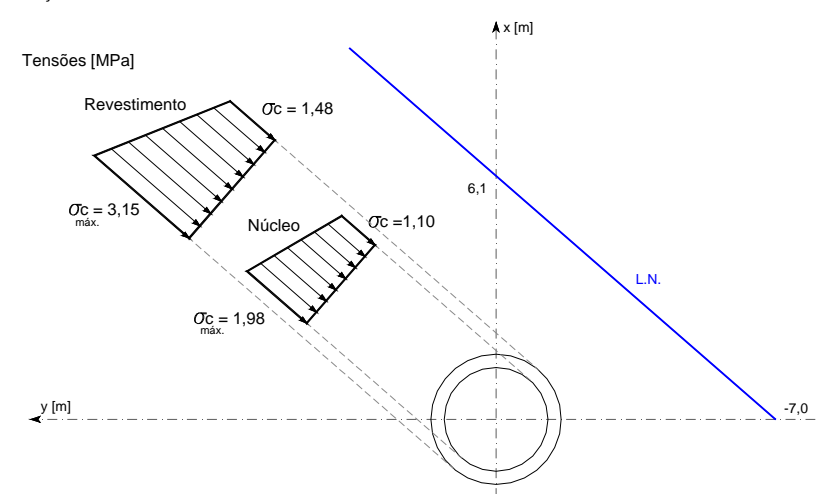

(d)

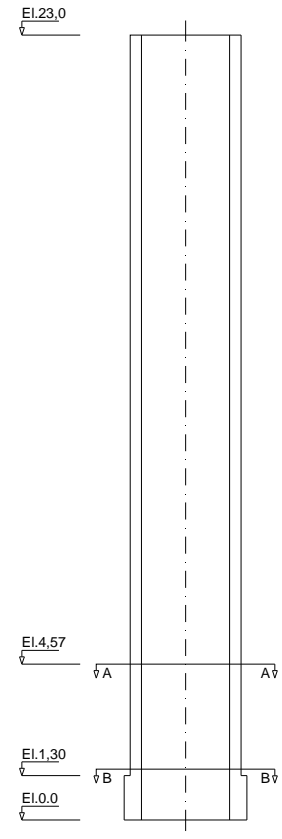

(e)

Figura 6.8 - Tensões normais resultantes no pilar lateral 3F devidas à ação da carga permanente mais o desaprumo nas direções - $x$ e +y: (a) corte $A$; (b) corte $B$; e devidas à ação da carga permanente mais vento a $90^{\circ}$ no sentido +y: (c) corte A; (d) corte B; (e) elevação. 
Finalmente, no contraforte tipo III, um dos que apresentam maiores deslocamentos, as tensões máximas de compressão sob a ação da carga permanente são de 2,46 MPa no revestimento de granito e 0,37 MPa no núcleo, que é de alvenaria de tijolos de barro.

Nota-se, na Figura 6.9, que, nos contrafortes, a linha neutra encontra-se mais próxima das seções transversais se comparada à posição da mesma nos pilares da seção F. Isto mostra que os contrafortes estão mais sujeitos à ação da flexão, uma vez que são eles que, por meio dos arcobotantes, recebem os empuxos horizontais resultantes e os transferem às fundações.

Contraforte $1 \mathrm{~F}$ (tipo III)
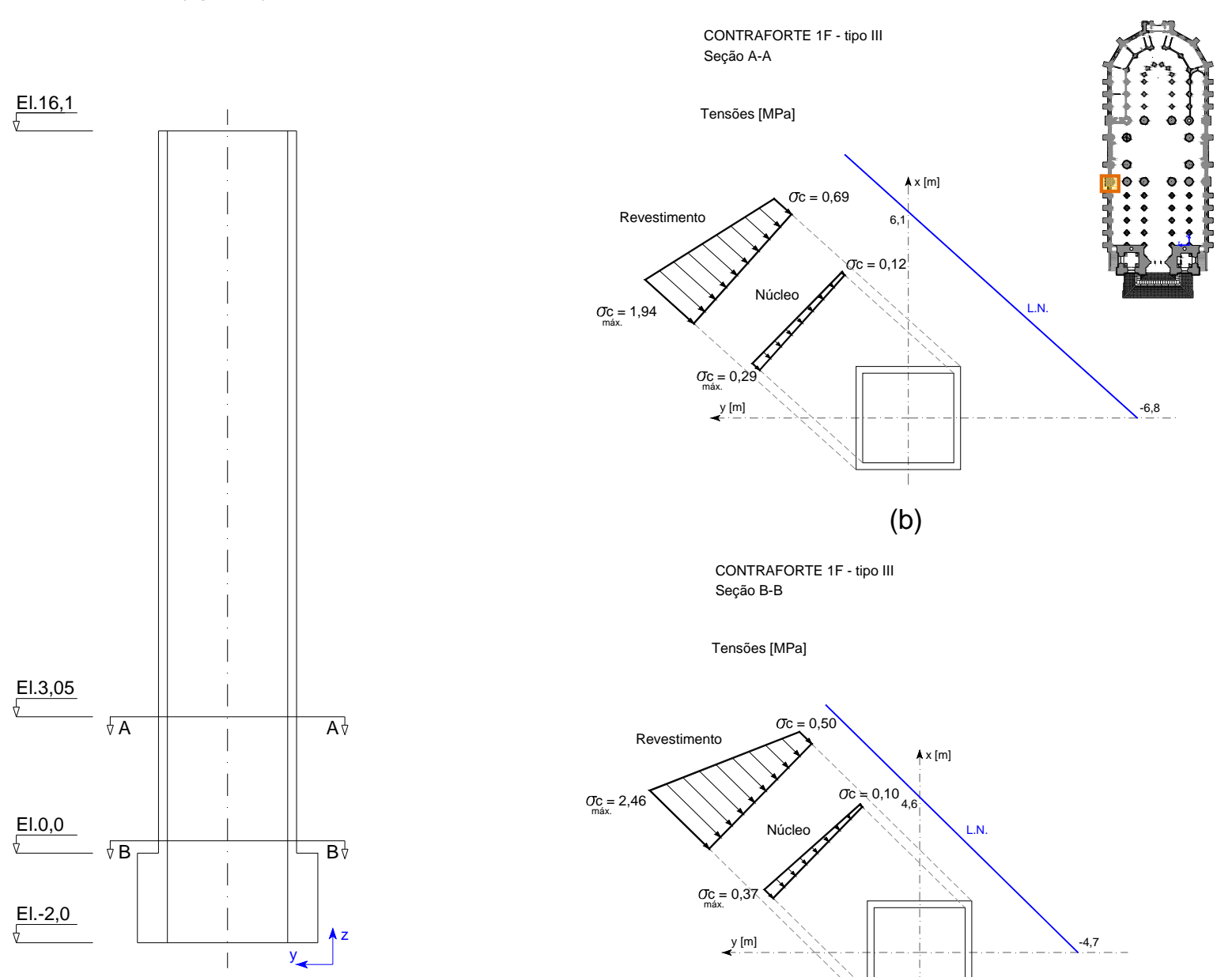

(b)

CONTRAFORTE $1 F$ - tipo III Seção B-B

Tensões [MPa]

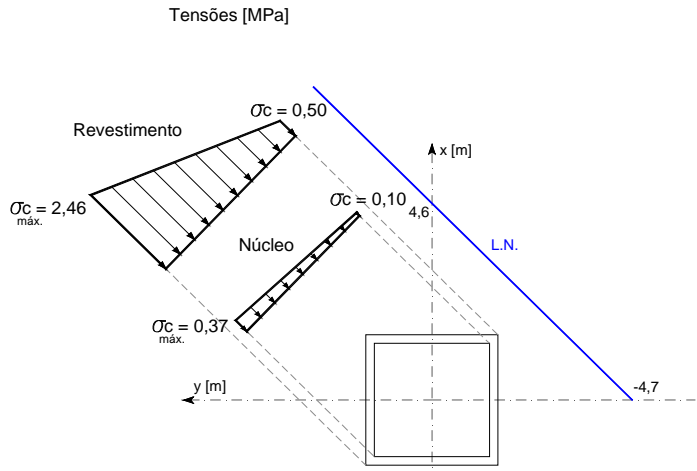

(a)

(c)

Figura 6.9 - Tensões normais resultantes no contraforte 1F devidas à ação da carga permanente: (a) elevações; (b) corte A; (c) corte B. 
Apesar de a carga permanente ser determinante, ao somar-se a ação do carregamento horizontal, no caso o vento a $90^{\circ}$, os contrafortes permanecem comprimidos e a variação das tensões normais nestas peças da seção $F$ chega a $13,4 \%$, com as máximas de compressão de 2,79 $\mathrm{MPa}$ no revestimento e 0,41 MPa no núcleo (Figura 6.10).

Contraforte 1F (tipo III)

Carga Permanente + Desaprumo $(-x+y)$

CONTRAFORTE $1 \mathrm{~F}$ - tipo III

Seção A-A

Tensões [MPa]

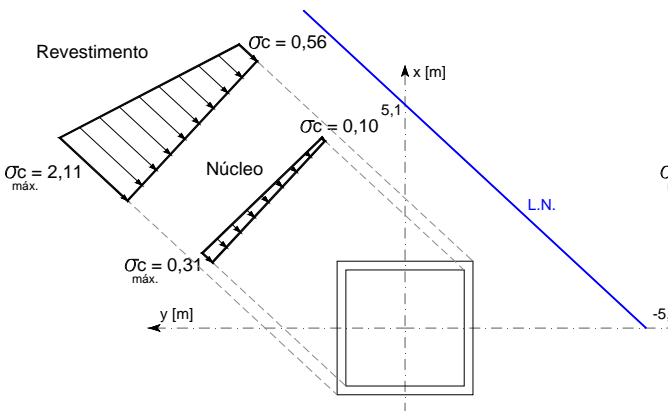

(a)

Carga Permanente + Vento $90^{\circ}$

CONTRAFORTE $1 \mathrm{~F}$ - tipo III

Seção A-A

Tensões [MPa]

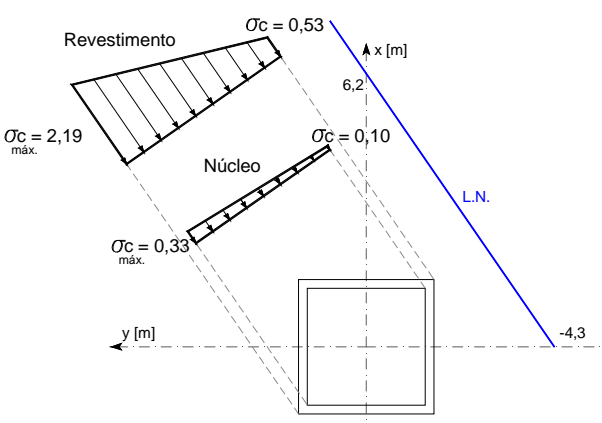

(c)
Carga Permanente + Desaprumo $(-x+y)$
CONTRAFORTE $1 F$ - tipo III

CONTRAFORTE $1 \mathrm{~F}$ - tipo III

Tensões [MPa]

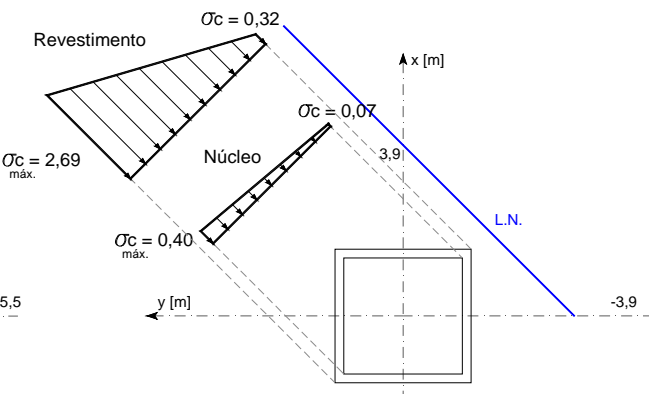

(b)

Carga Permanente + Vento $90^{\circ}$

CONTRAFORTE $1 \mathrm{~F}$ - tipo III

Seção B-B

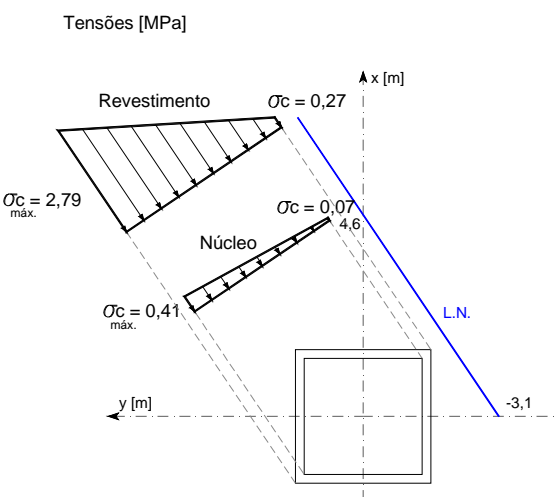

(d)

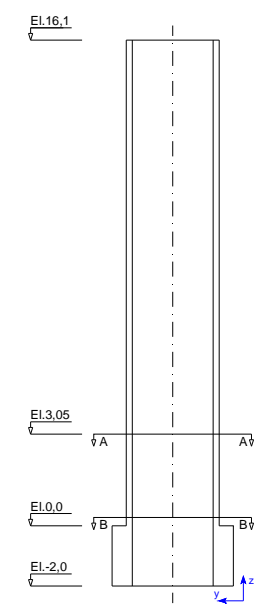

(e)

Figura 6.10 - Tensões normais resultantes no contraforte $1 \mathrm{~F}$ devidas à ação da carga permanente mais o desaprumo nas direções - $x$ e +y: (a) corte $A$; (b) corte $B$; e devidas à ação da carga permanente mais o vento a $90^{\circ}$, na direção +y: (c) corte $A$; (d) corte $B$; (e) elevação. 


\subsubsection{Pilares e contrafortes da seção no eixo E}

Nos pilares e contrafortes das regiões frontal e posterior da Catedral, as seções transversais também se apresentam totalmente comprimidas. Nas Figuras $6.11 \mathrm{e}$ 6.12, são apresentados os diagramas dos esforços solicitantes, força normal e momento fletor, dos pilares e contrafortes da seção no eixo $\mathrm{E}$.

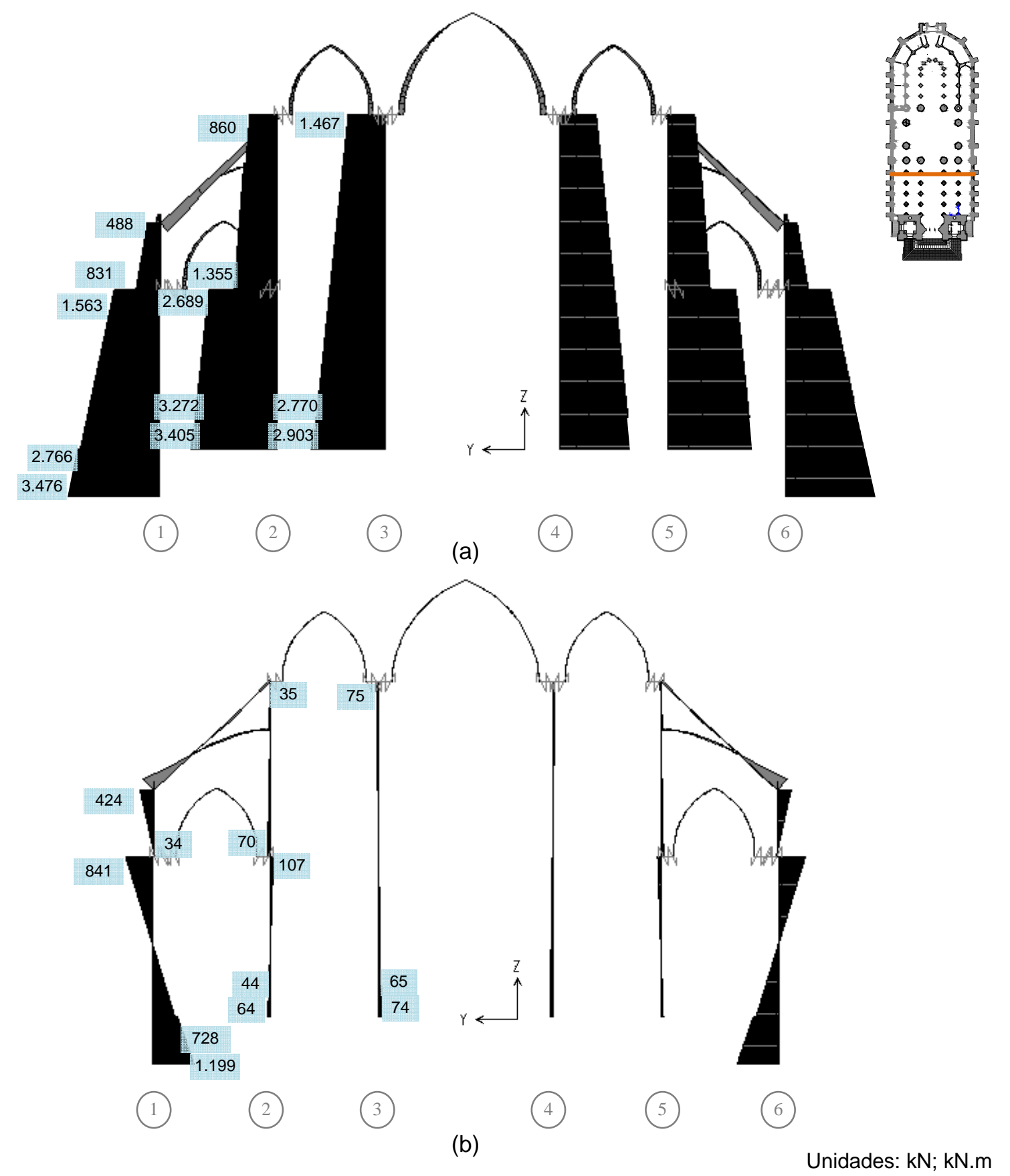

Figura 6.11 - Diagrama dos esforços solicitantes na seção $E$ devidos à carga permanente - escala 0,0025:1: (a) força normal; (b) momento fletor em torno de $x$. 


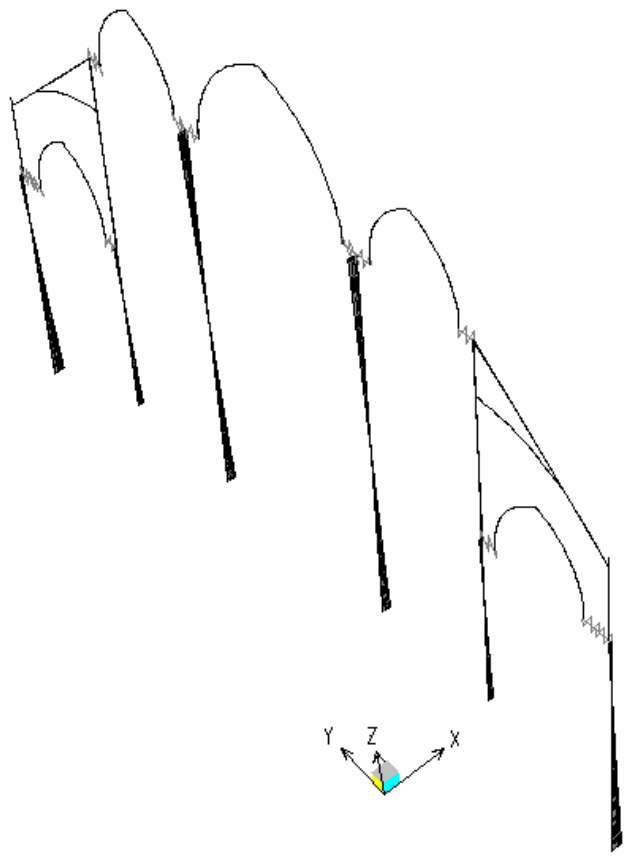

(a)

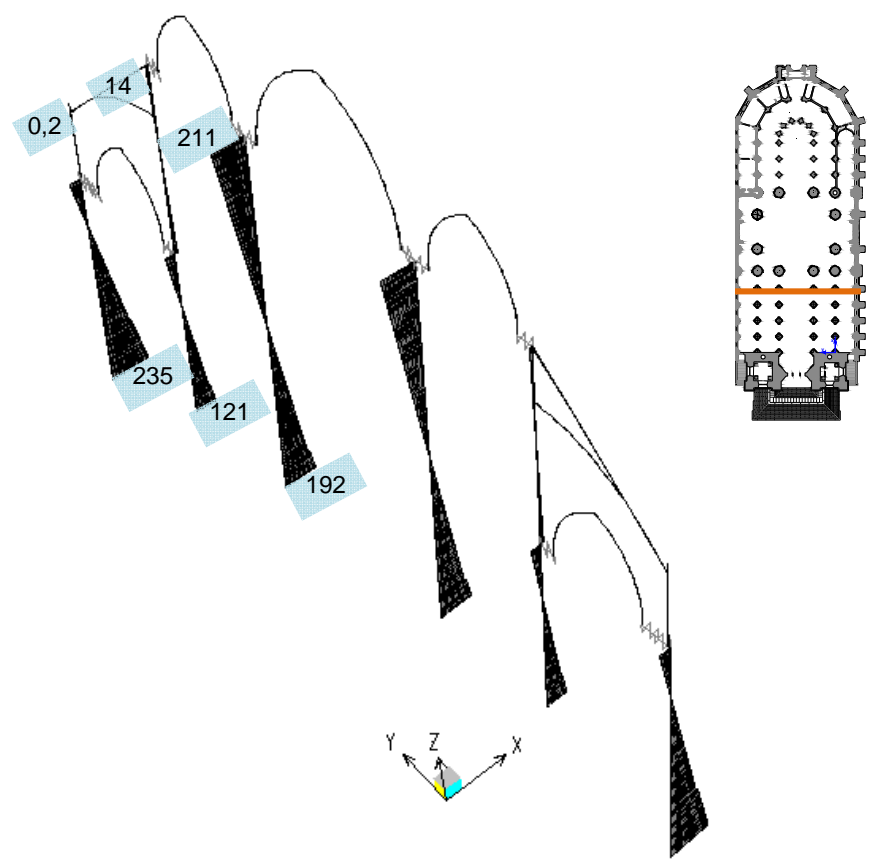

(b)

Unidade: kN.m

Figura 6.12 - Diagrama dos esforços solicitantes na seção $E$ devidos à carga permanente - momento fletor em torno de y (a) escala 0,0025:1; (b) escala 0,01:1.

São apresentados os resultados das tensões normais atuantes nos pilares e contrafortes da seção no eixo $\mathrm{E}$, devido à sua proximidade com a região do octógono e pelo fato de os seus elementos de apoio apresentarem deslocamentos maiores que os demais pilares e contrafortes de mesma rigidez.

Nos pilares laterais, sob a ação da carga permanente, a tensão máxima de compressão encontrada no revestimento de granito é de 1,90 MPa, enquanto que no núcleo de concreto simples é de 1,13 MPa (Figura 6.13).

Considerando-se a ação do desaprumo, as tensões normais máximas passam para 1,97 MPa no revestimento e 1,16 MPa no núcleo, um aumento aproximado de $3,7 \%$ e $2,7 \%$ respectivamente (Figura 6.14 ). 
Pilar lateral 2E
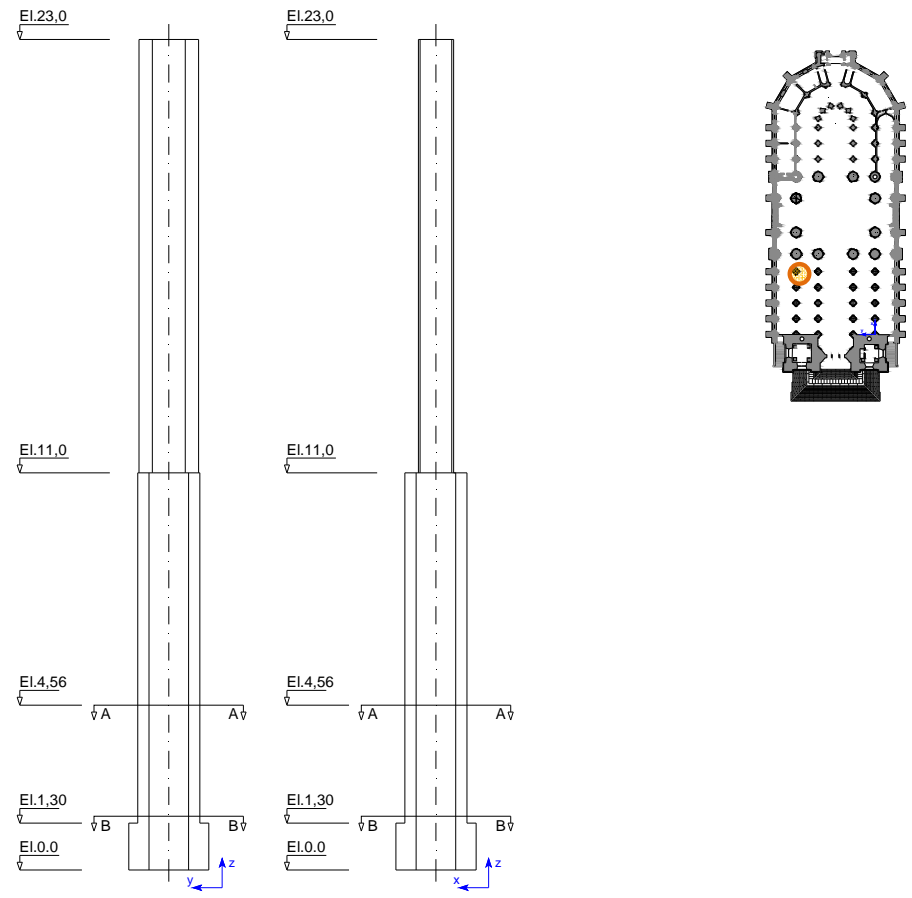

(a)

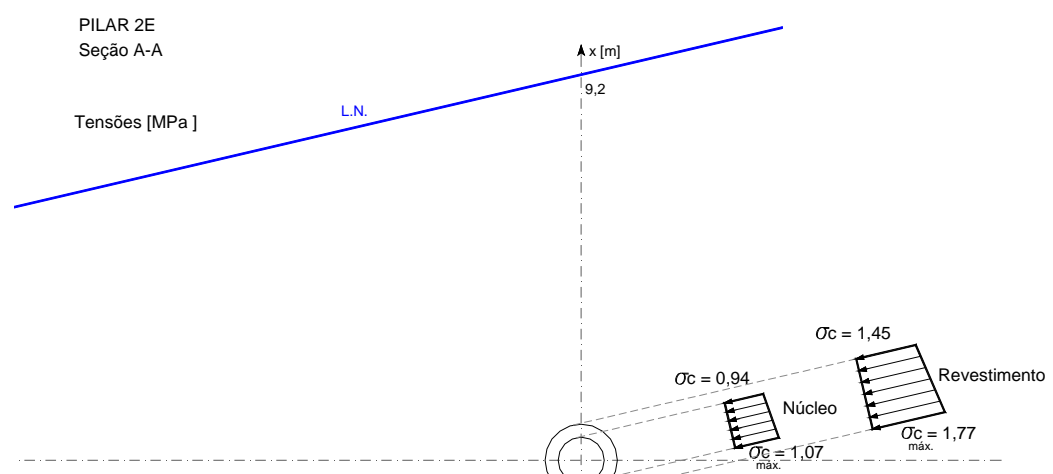

(b)

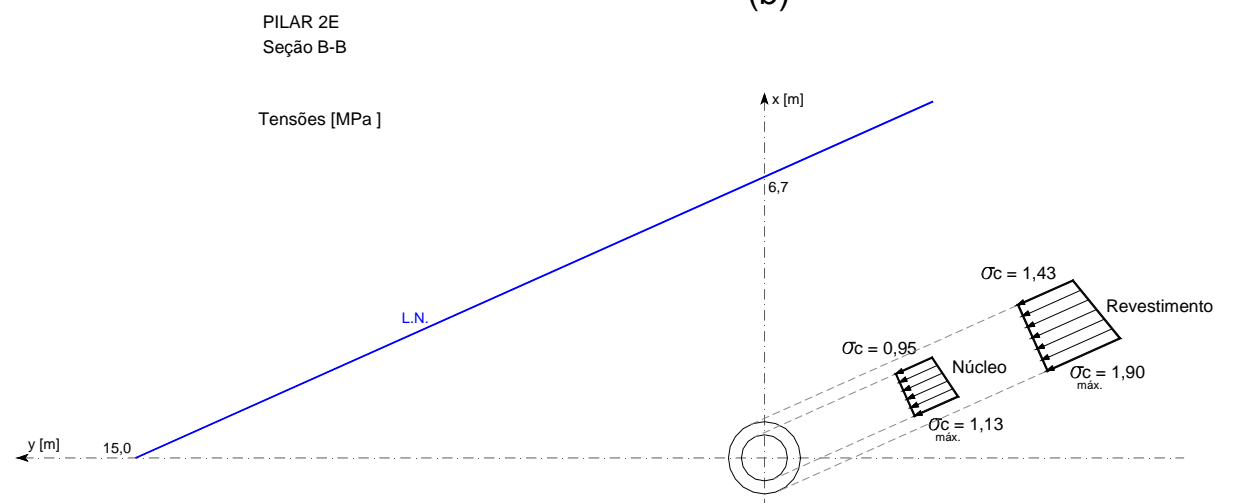

(c)

Figura 6.13 - Tensões normais resultantes no pilar lateral 2E devidas à ação da carga permanente: (a) elevação; (b) corte A; (c) corte B. 
Pilar lateral 2E

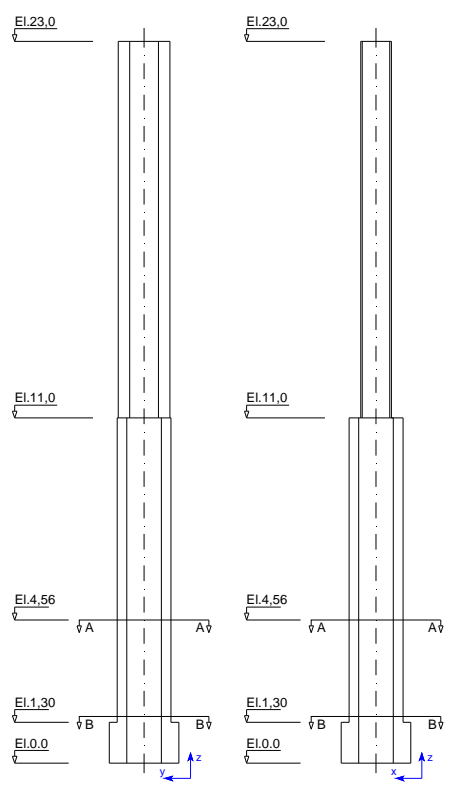

(a)

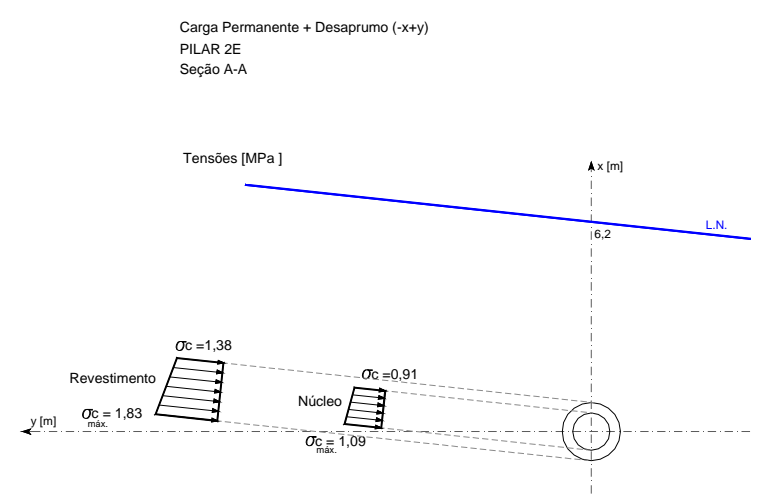

(b)

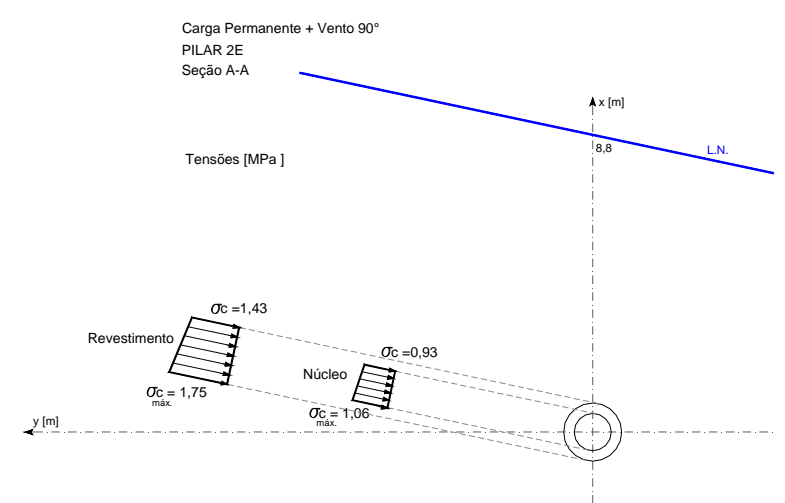

(d)

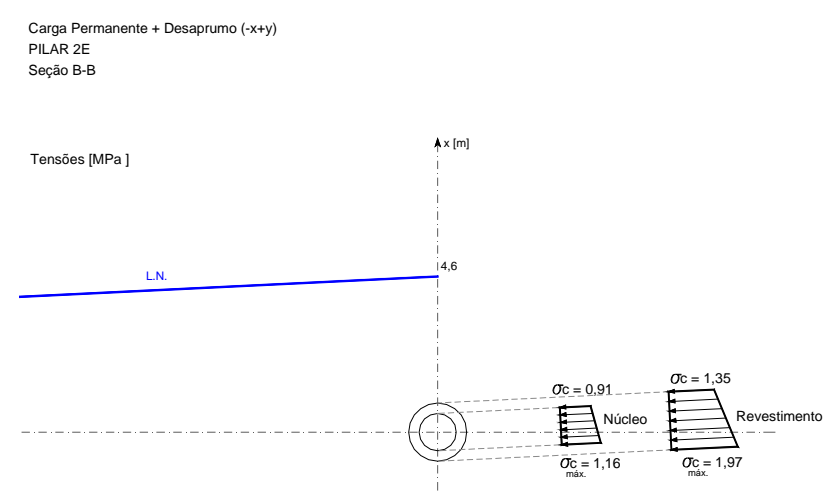

(c)

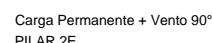

PILAR 2E

Seção B-B

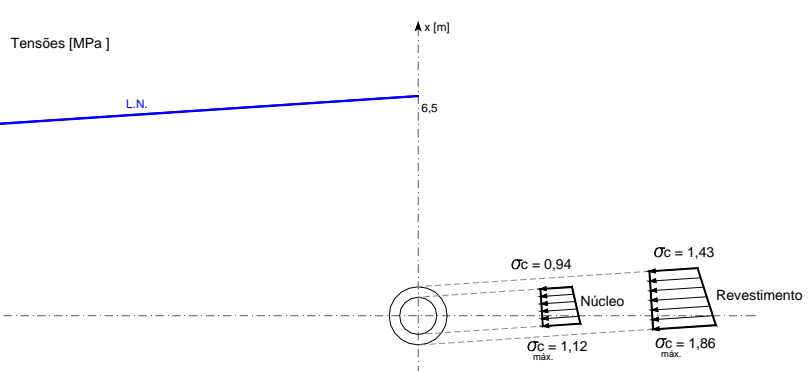

(e)

Figura 6.14 - Tensões normais resultantes no contraforte 2E devidas à ação da carga permanente mais o desaprumo nas direções -x e +y: (a) elevação; (b) corte $A$; (c) corte $B$; e devidas à ação da carga permanente mais o vento a 90, na direção +y: (d) corte $A$; (e) corte $B$. 
Nos pilares centrais, as tensões normais são um pouco menores, 1,80 MPa no revestimento e 1,08 MPa no núcleo (Figura 6.15).

As ações horizontais do vento e do desaprumo resultam em tensões de compressão da mesma ordem de grandeza; a máxima tensão normal no revestimento é de 1,89 $\mathrm{MPa}$, enquanto no núcleo é de 1,15 MPa (Figura 6.16).

Pilar central 3E

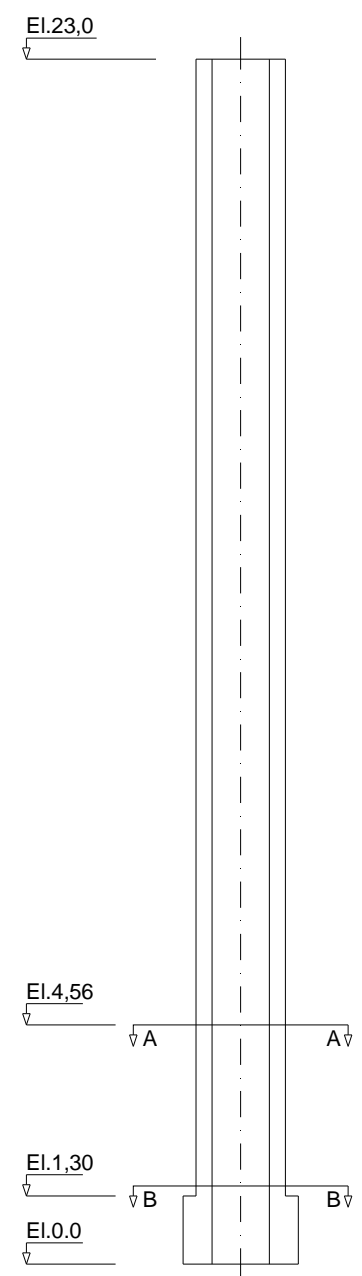

(a)

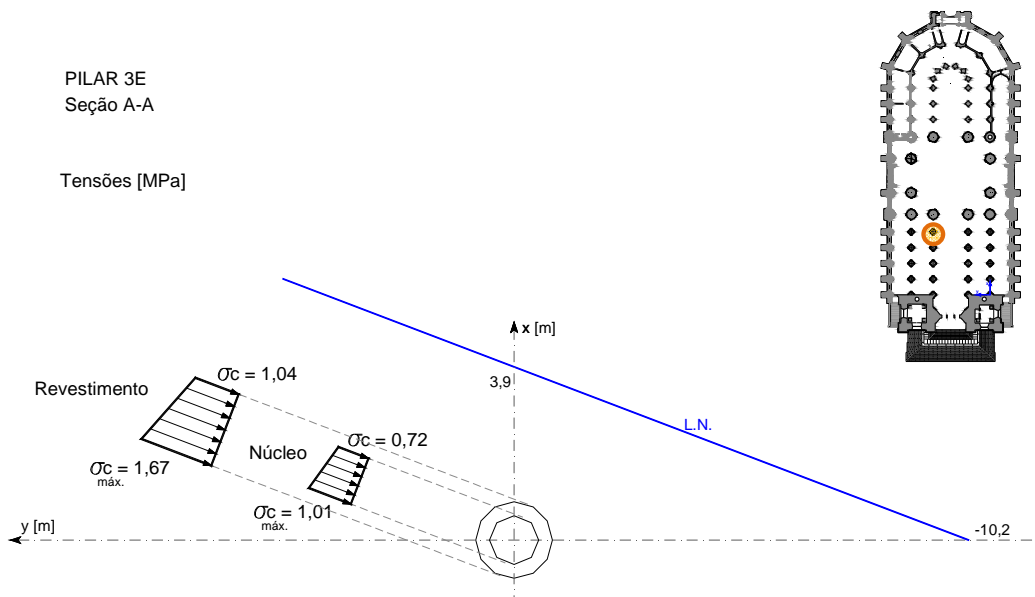

(b)

$$
\begin{aligned}
& \text { PILAR 3E } \\
& \text { Seção B-B } \\
& \text { Tensões [MPa] }
\end{aligned}
$$

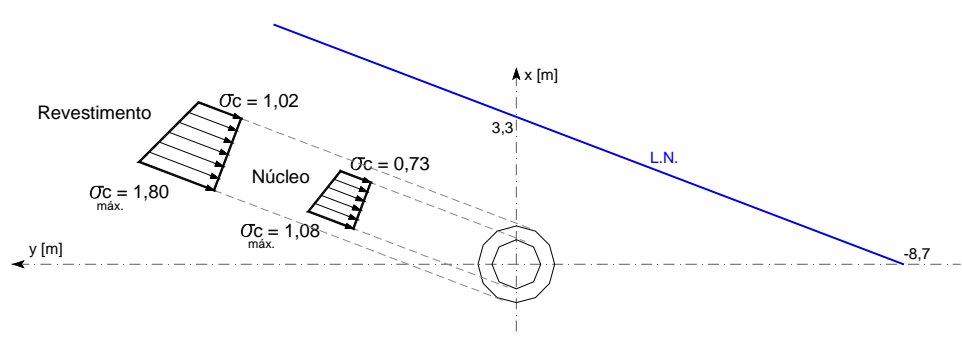

(c)

Figura 6.15 - Tensões normais resultantes no pilar central 3E devidas à ação da carga permanente: (a) elevação; (b) corte A; (c) corte B. 
Pilar central 3E

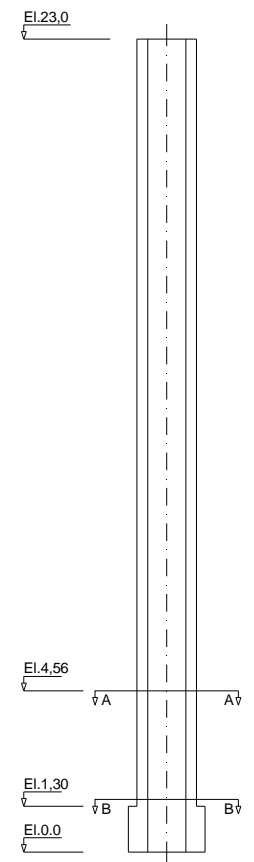

(a)

Carga Permanente + Desaprumo $(-x+y)$

PILAR 3E

Seção A-A

Carga Permanente + Desaprumo $(-x+y)$
PILAR 3E
Seção B-B

-ensões [MPa]

Tensões [MPa]

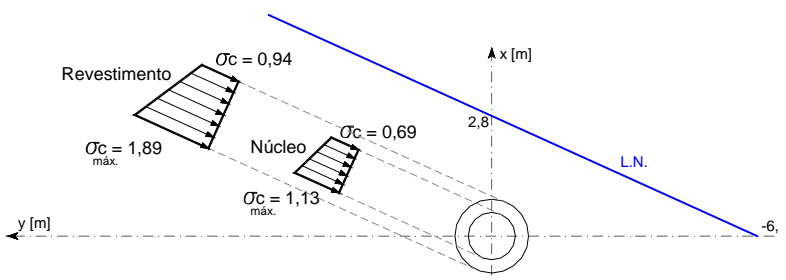

(b)

(c)

Carga Permanente + Vento $90^{\circ}$

PILAR 3E

PILAR $3 E$

Seção B-B

Tensões [MPa]

Tensões [MPa]

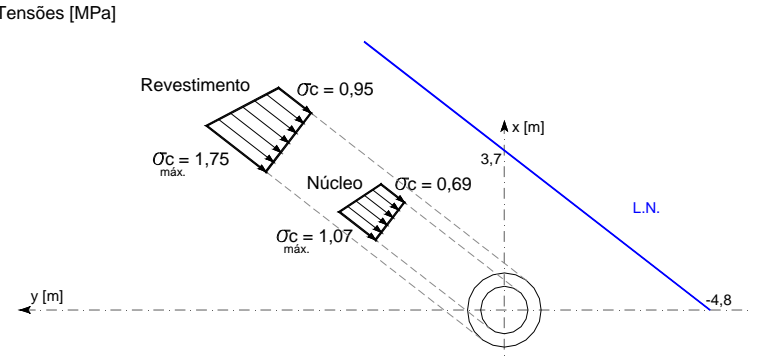

(d)

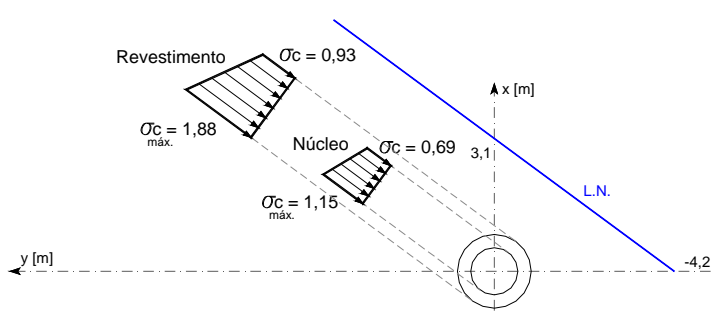

(e)

Figura 6.16 - Tensões normais resultantes no pilar central 3E devidas à ação da carga permanente mais o desaprumo nas direções -x e +y: (a) elevação; (b) corte $A$; (c) corte $B$; e devidas à ação da carga permanente mais o vento a $90^{\circ}$, na direção +y: (d) corte $A$; (e) corte $B$. 
Nos contrafortes da seção E, do tipo II, as tensões normais máximas atingem 1,78 MPa no revestimento e de 0,26 MPa no núcleo de alvenaria de tijolos. A ação do carregamento horizontal, como o vento na direção y, maximiza estas tensões em $12,9 \%$ e 11,5\%, respectivamente, alcançando 2,01 MPa na alvenaria de granito e $0,29 \mathrm{MPa}$ na alvenaria de tijolos (Figuras 6.17 e 6.18).

Contraforte 1E (tipo II)
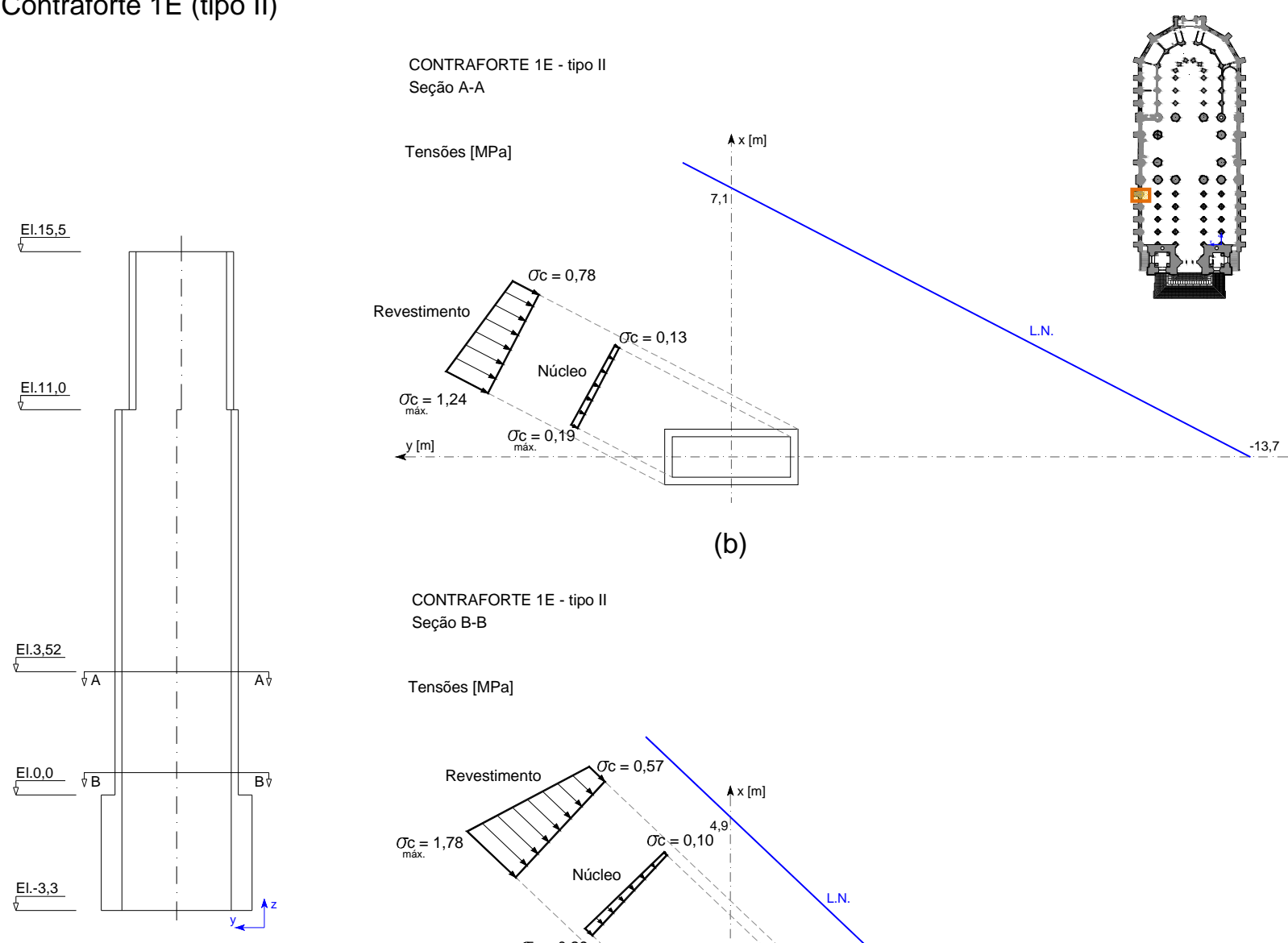

(b)

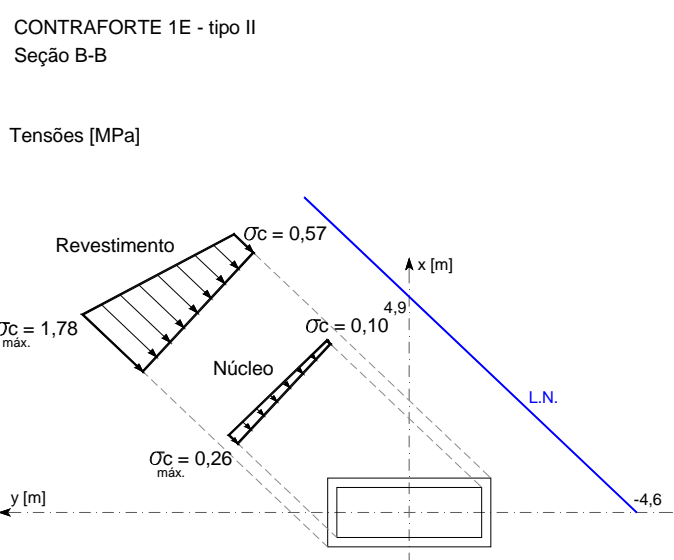

(a)

(c)

Figura 6.17 - Tensões normais resultantes no contraforte $1 \mathrm{E}$ devidas à ação da carga permanente: (a) elevações; (b) corte A; (c) corte B. 
Contraforte 1E (tipo II)
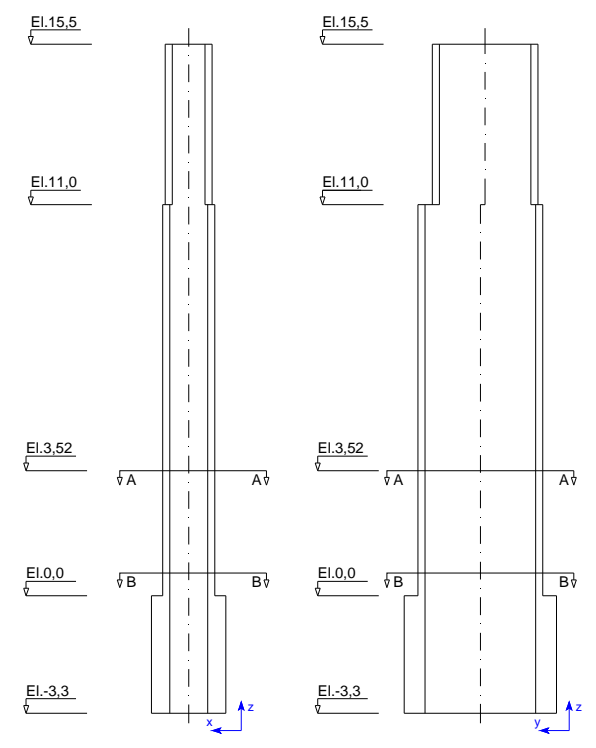

(a)

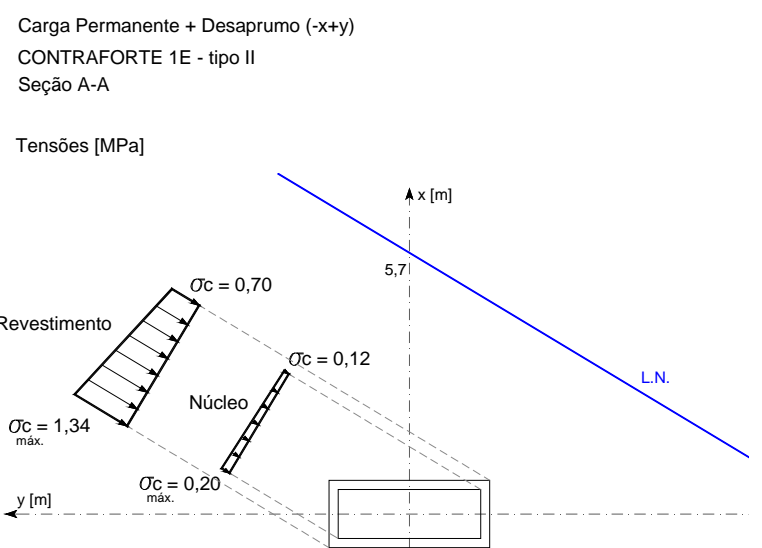

(b)

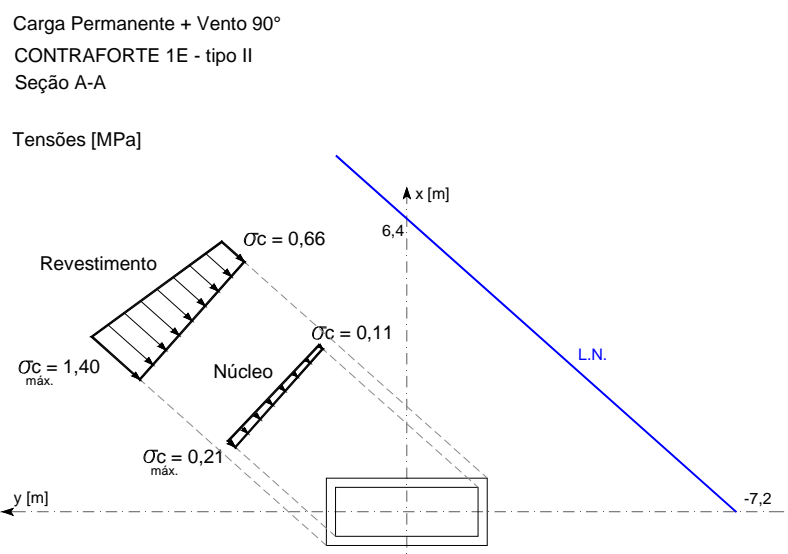

(d)
Carga Permanente + Desaprumo $(-x+y)$ CONTRAFORTE $1 E$ - tipo II

Seção B-B

Tensões [MPa]

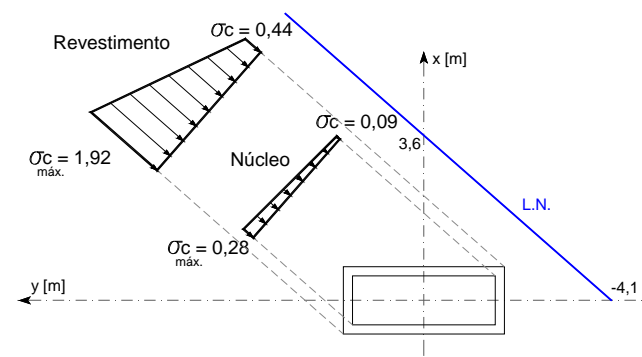

(c)

Carga Permanente + Vento $90^{\circ}$ CONTRAFORTE $1 \mathrm{E}$ - tipo II Seção B-B

Tensões [MPa]

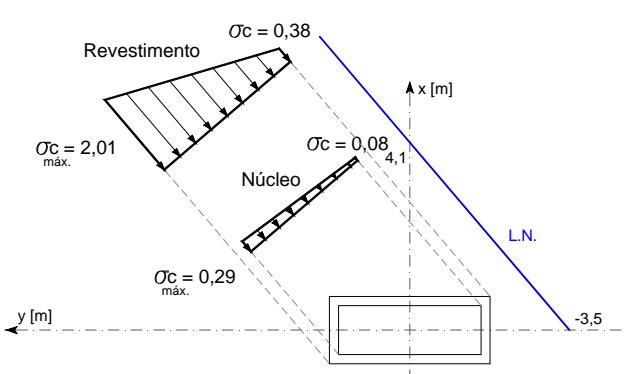

(e)

Figura 6.18 - Tensões normais resultantes no contraforte 1E devidas à ação da carga permanente mais o desaprumo nas direções -x e +y: (a) elevação; (b) corte $A$; (c) corte $B$; e devidas à ação da carga permanente mais o vento a $90^{\circ}$, na direção +y: (d) corte $A$; (e) corte $B$. 
6.2.3 Pilares e contrafortes do transepto - seção no eixo G

O transepto está localizado na região do octógono; seus contrafortes são do tipo IV e seus pilares possuem a mesma rigidez daqueles da seção no eixo F.

Os diagramas dos esforços solicitantes, força normal e momento fletor, dos pilares e contrafortes da seção no eixo G são apresentados nas Figuras 6.19 e 6.20.

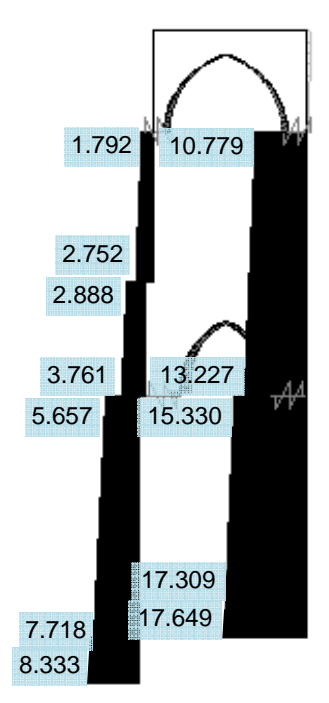

(1) 2

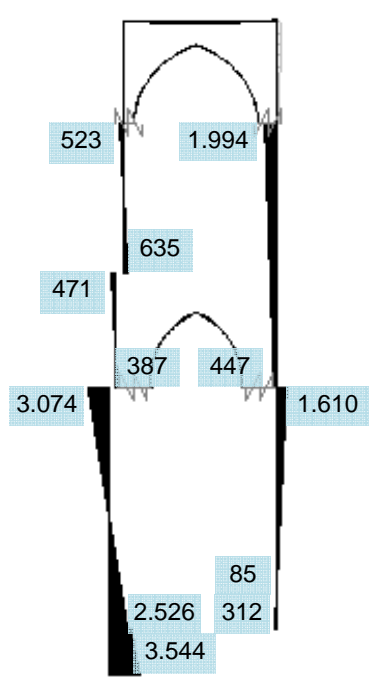

(1)

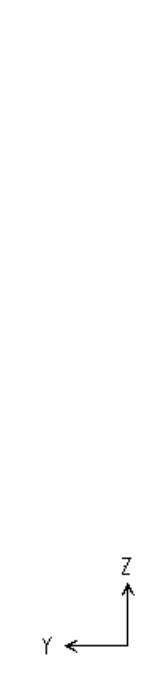

(a)
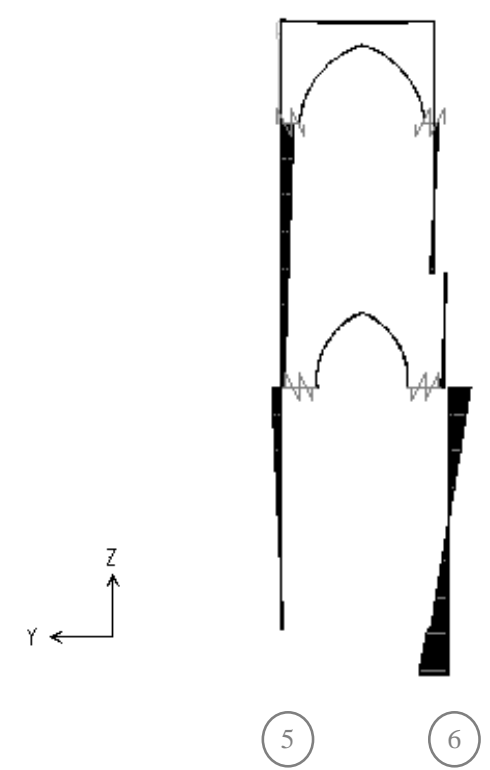

Unidades: kN; kN.m

(b)

Figura 6.19 - Diagrama dos esforços solicitantes na seção do eixo $\mathrm{G}$ devidos à carga permanente escala 0,0004:1: (a) força normal; (b) momento fletor em torno de $\mathrm{x}$. 


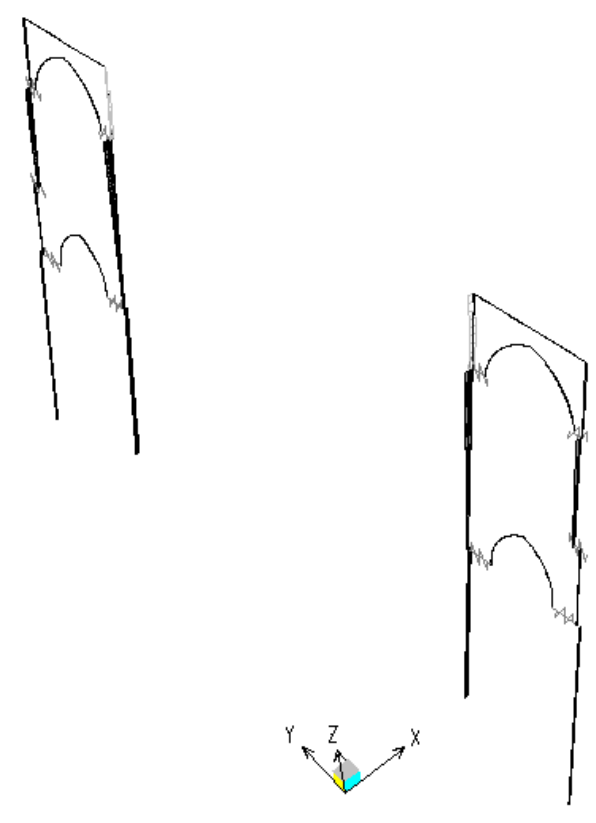

(a)

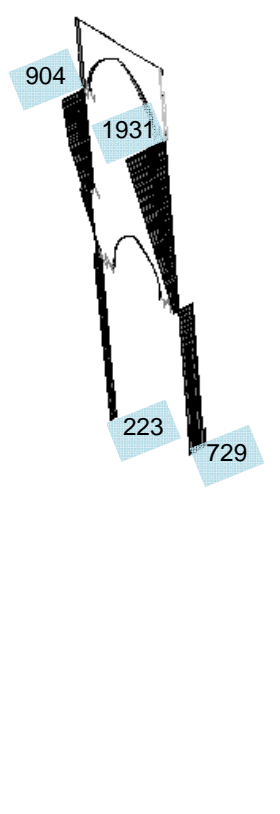

(b)

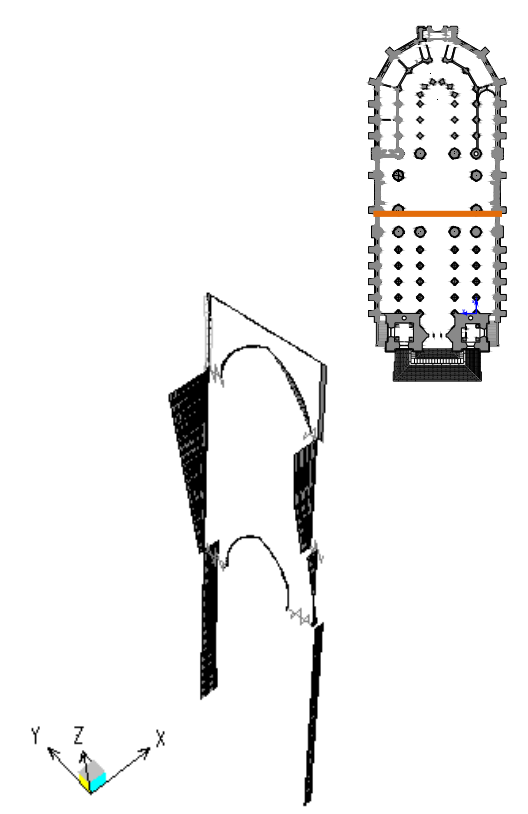

Unidade: kN.m

Figura 6.20 - Diagrama dos esforços solicitantes na seção do eixo $\mathrm{G}$ devidos à carga permanente momento fletor em torno de y (a) escala 0,0004:1; (b) escala 0,002:1.

Dentre os pilares laterais, são os das seções $\mathrm{G}$ e $\mathrm{H}$ aqueles em que se encontram as maiores tensões de compressão. No revestimento de granito, atua uma tensão de compressão de 2,87 MPa e no núcleo de concreto simples, de 1,88 $\mathrm{MPa}$. Se o desaprumo for considerado, o aumento das tensões normais é de 5,9\% e 4,3\% respectivamente, ou seja, atinge 3,04 MPa no revestimento e 1,96 MPa no núcleo (Figuras 6.21 e 6.22). Maiores tensões do que estas somente são encontradas nos pilares centrais da seção $\mathrm{F}$, como comentado anteriormente. Todos estes pilares formam o octógono e apóiam diretamente o tambor da cúpula.

Nos contrafortes da seção no eixo G, atuam as maiores tensões normais nos materiais (Figura 6.23); na alvenaria de granito, a tensão de compressão chega mesmo a ser maior do que aquelas que agem nos revestimentos dos pilares até aqui estudados. Atua no revestimento uma tensão de compressão de 3,27 MPa e no núcleo de alvenaria de tijolos, de 0,49 MPa. 
Pilar lateral 2G

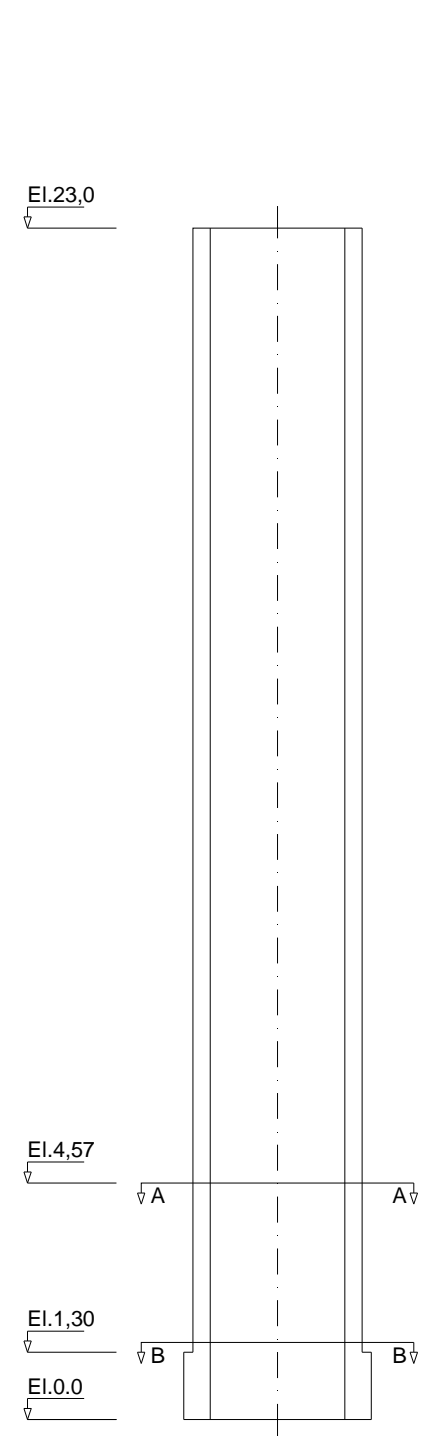

(a)

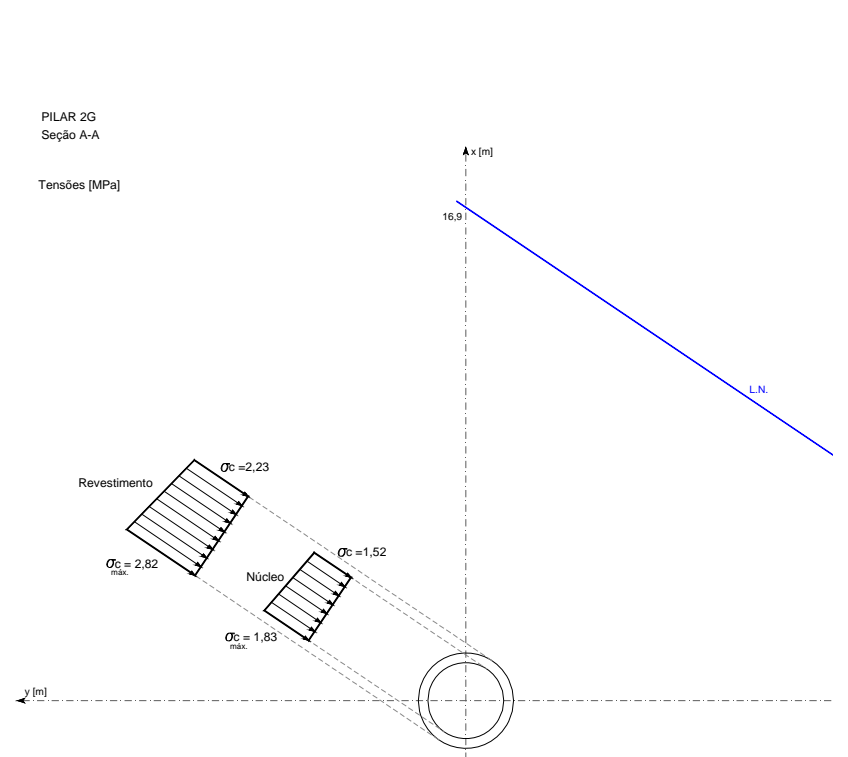

(b)

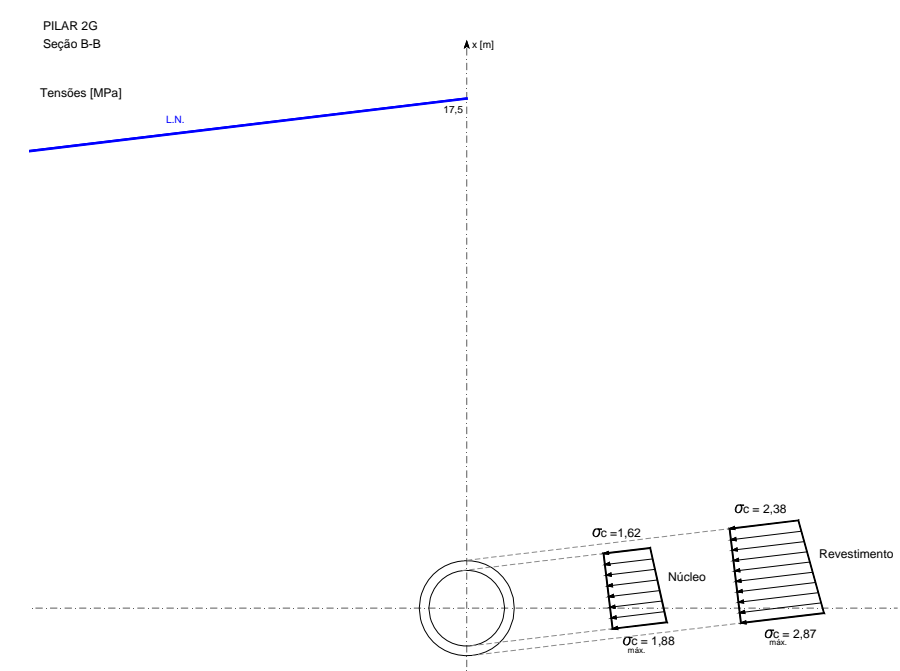

(c)

Figura 6.21 - Tensões normais resultantes no pilar lateral $2 \mathrm{G}$ devidas à ação da carga permanente: (a) elevação; (b) corte A; (c) corte B. 
Pilar lateral 2G

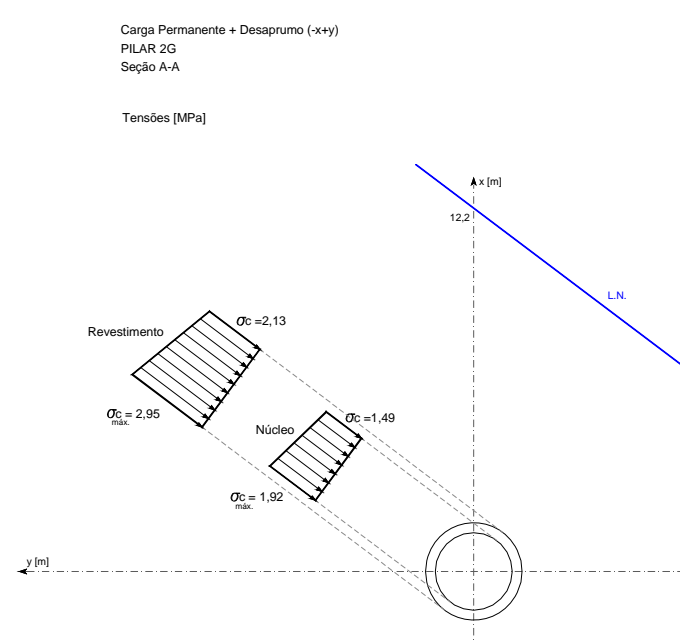

(a)

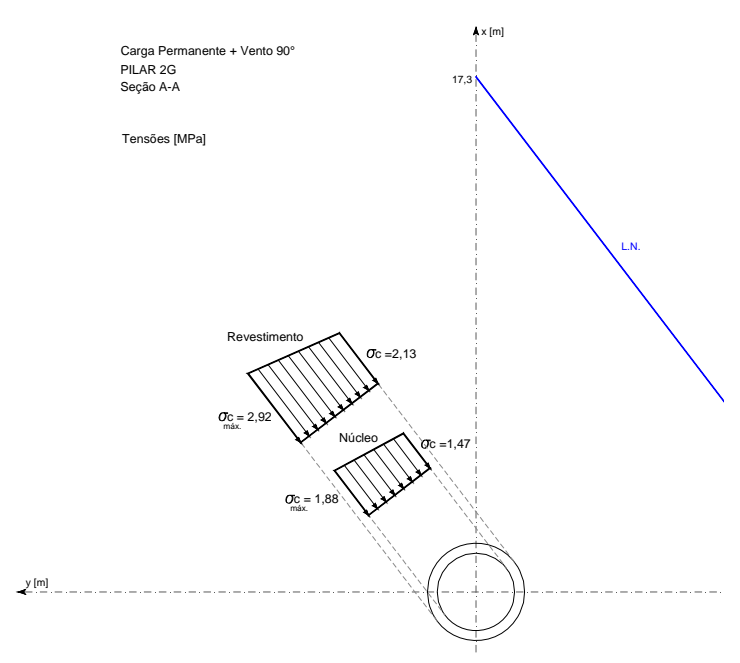

(c)

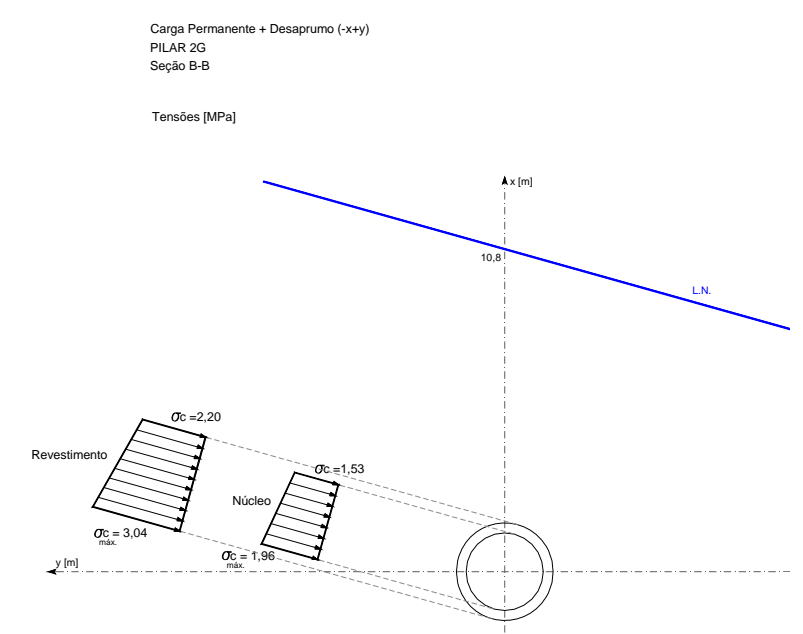

(b)

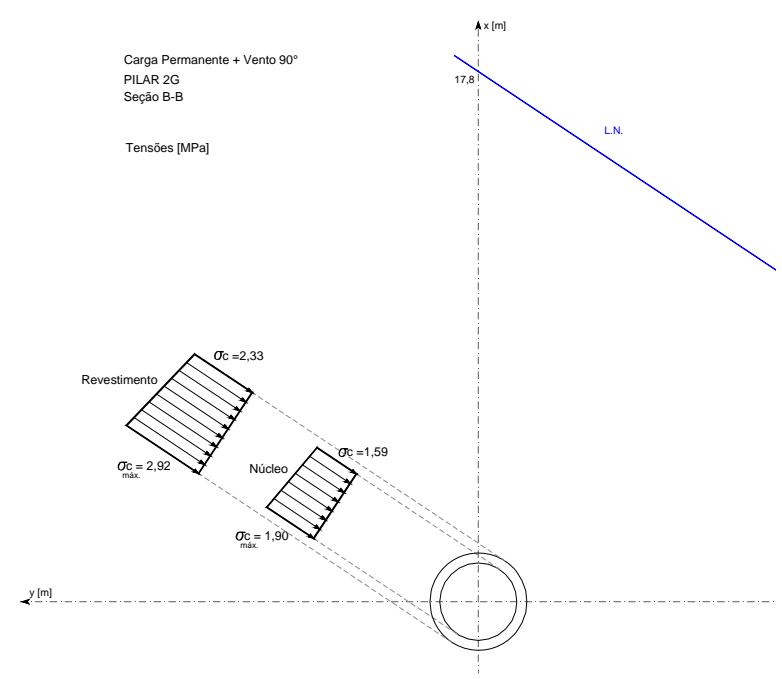

(d)

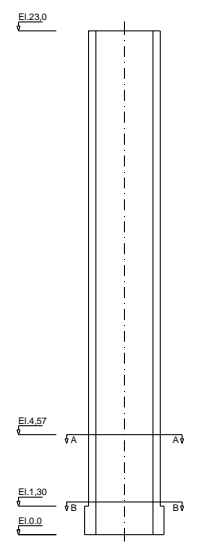

(e)

Figura 6.22 - Tensões normais resultantes no pilar lateral $2 G$ devidas à ação da carga permanente mais o desaprumo nas direções - $x$ e +y: (a) corte $A$; (b) corte $B$; e devidas à ação da carga permanente mais o vento a $90^{\circ}$, na direção +y: (c) corte $A ;$ (d) corte $B$; (e) elevação. 
Contraforte 1G (tipo IV)

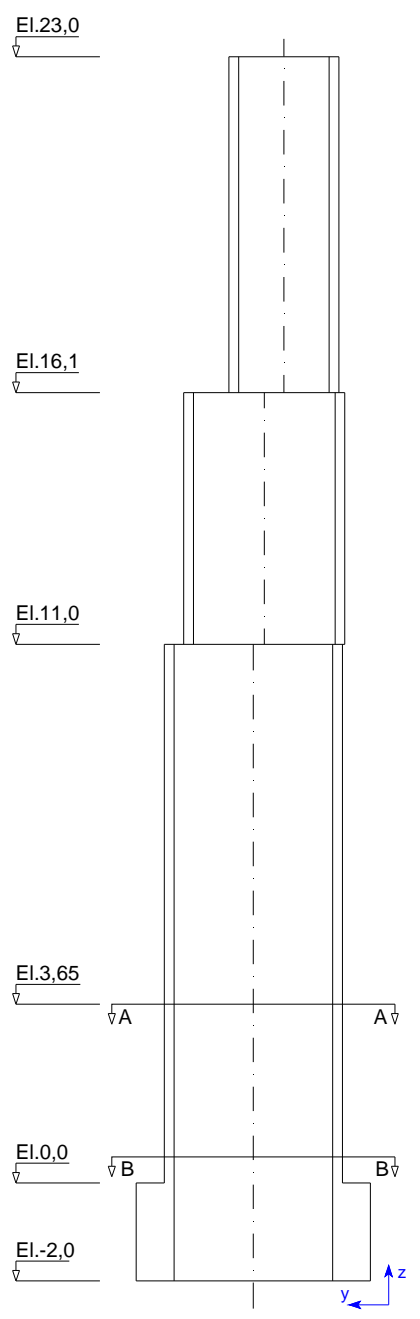

(a)

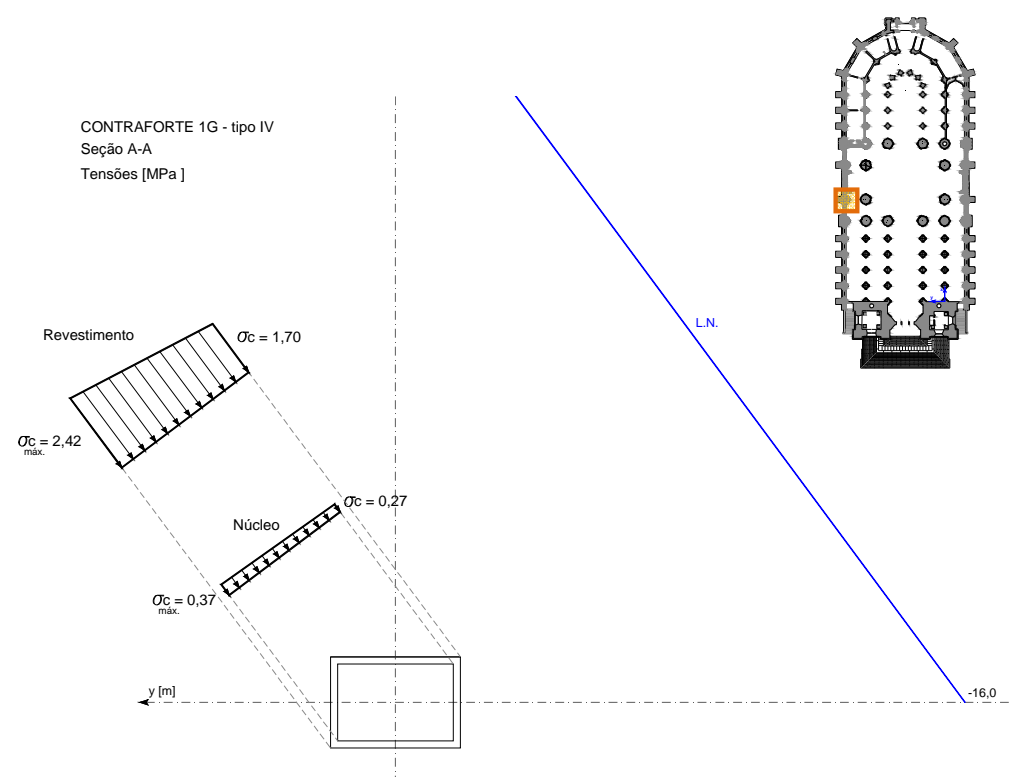

(b)

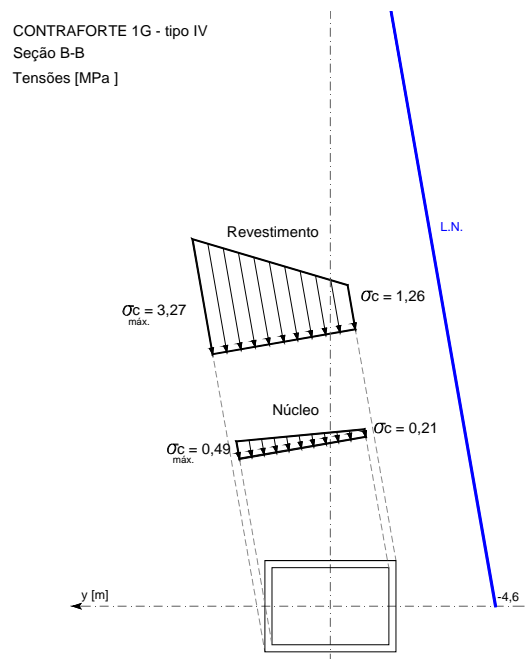

(c)

Figura 6.23 - Tensões normais resultantes no contraforte 1G, devidas à ação da carga permanente: (a) elevação; (b) corte A; (c) corte B.

Sob a ação do vento a $90^{\circ}$, as tensões máximas de compressão nos contrafortes do transepto alcançam 3,47 $\mathrm{MPa}$ no revestimento e 0,52 $\mathrm{MPa}$ no núcleo, variação de aproximadamente $6 \%$, bem menor do que o que ocorre nos contrafortes 1E e 1F, anteriormente apresentados (Figura 6.24). 
Contraforte 1G (tipo IV)

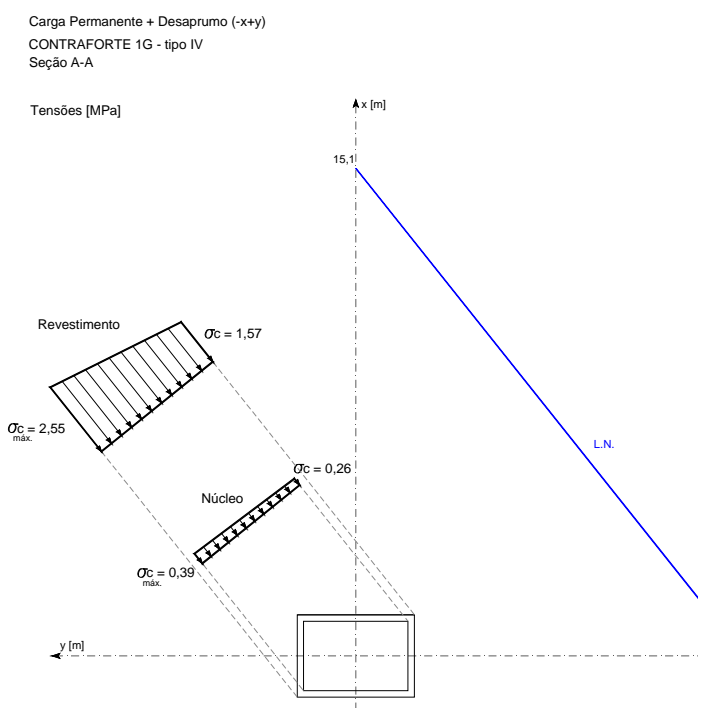

(a)

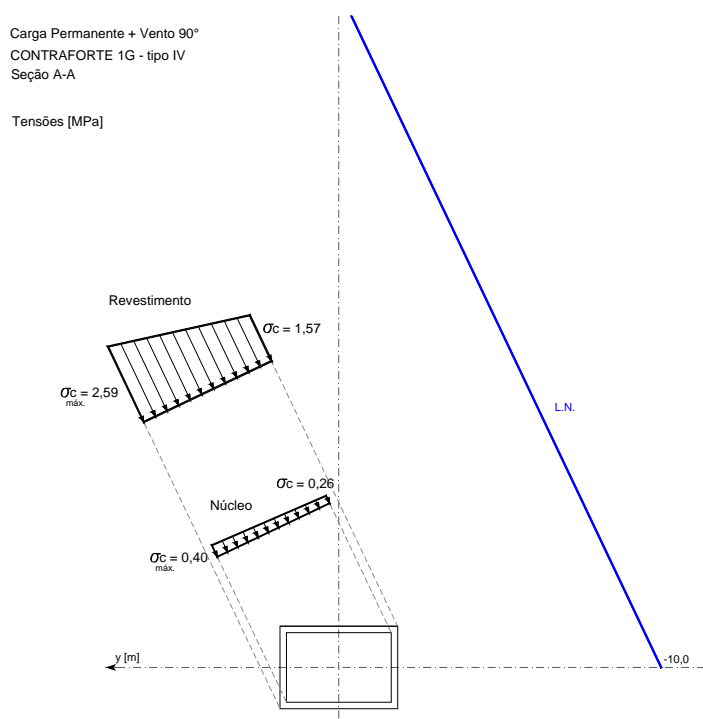

(c)

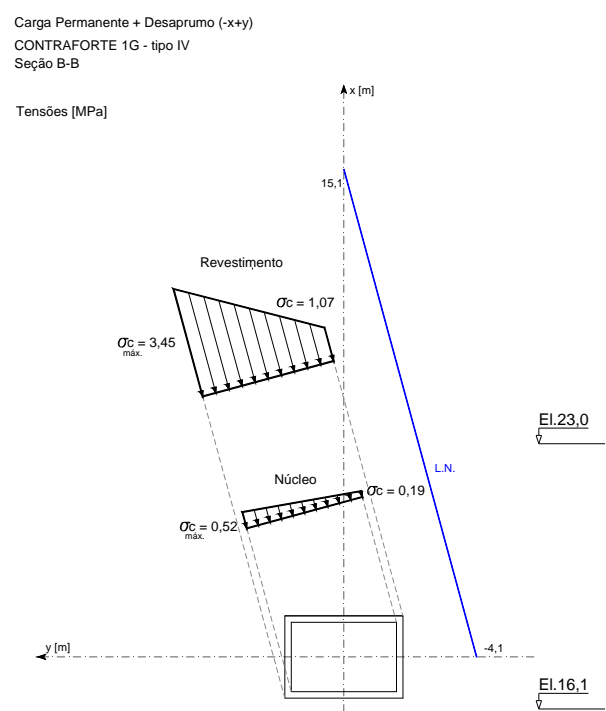

(b)

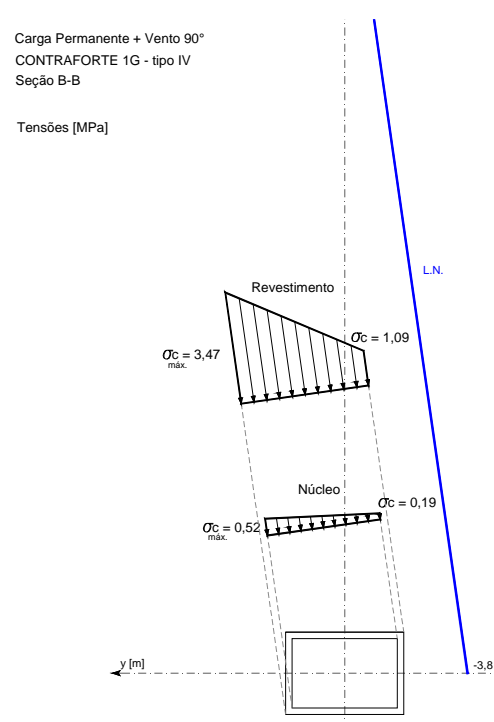

(d)

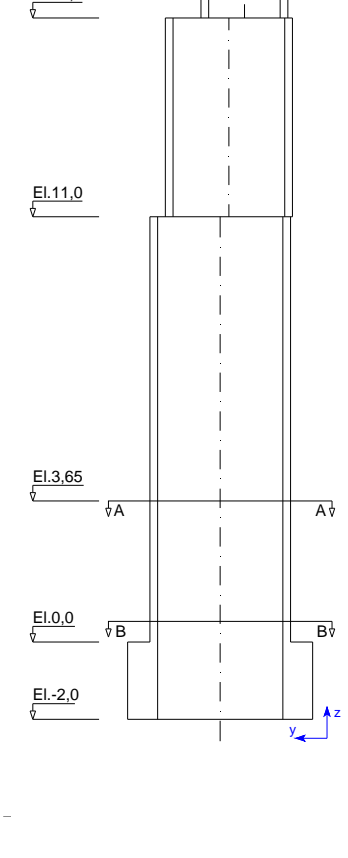

(e)

Figura 6.24 - Tensões normais resultantes no contraforte 1G, devidas à ação da carga permanente mais o desaprumo nas direções - $x$ e +y: (a) corte $A$; (b) corte $B$; e devidas à ação da carga permanente mais o vento a $90^{\circ}$, na direção +y: (c) corte $A$; (d) corte $B$; (e) elevação.

A análise das tensões normais permite fazer algumas considerações quanto à influência dos carregamentos no comportamento estrutural dos contrafortes e pilares da Catedral da Sé. A variação de tensões normais máximas mostra que, ao se acrescentar cargas horizontais, o vento a $90^{\circ}$ tem maior influência do que 0 desaprumo nos contrafortes da igreja, mas que, apesar desta influência, as seções transversais permanecem comprimidas. 
É nos pilares da região do octógono e nos contrafortes do transepto que se encontram as maiores tensão de compressão. As máximas tensões normais atuantes no granito e na alvenaria de tijolos ocorrem nos contrafortes tipo IV, enquanto as máximas tensões no concreto simples ocorrem nos pilares centrais das seções F. Na Tabela 6.1, são apresentadas as tensões normais máximas atuantes em cada um dos materiais constituintes dos pilares e contrafortes da Catedral da Sé.

Tabela 6.1 - Tensões normais máximas atuantes nos pilares e contrafortes.

\begin{tabular}{|c|c|c|}
\hline \multicolumn{3}{|c|}{ Tensões máximas atuantes de compressão [MPa] } \\
\hline Material Elemento & Pilares & Contrafortes \\
\hline $\begin{array}{l}\text { Alvenaria de } \\
\text { granito }\end{array}$ & $3,15(3 F)$ & $3,47(1 G)$ \\
\hline $\begin{array}{l}\text { Alvenaria de } \\
\text { tijolos }\end{array}$ & $0,33(5 N)^{\star}$ & $0,52(1 G)$ \\
\hline $\begin{array}{l}\text { Concreto } \\
\text { simples }\end{array}$ & $1,98(3 F)$ & - \\
\hline $\begin{array}{l}\text { (*) Alvenaria de ti }^{\text {elevação de } 11,0 \mathrm{~m}}\end{array}$ & contrada no & res laterais aci \\
\hline
\end{tabular}

Dentre os pilares laterais de menor dimensão, as maiores tensões de compressão encontradas no núcleo de alvenaria de tijolos, existente a partir da elevação dos 11 metros, ocorrem nos pilares localizados nos eixos $\mathrm{N}$ e N', na região curva da parte posterior da Catedral e alcançam a máxima de 0,33 $\mathrm{MPa}$, sob a ação da carga permanente mais a ação do vento a $90^{\circ}$.

Na região posterior da Catedral, nos contrafortes tipo VII, localizados nos eixos M e M', as maiores tensões de compressão na alvenaria de tijolos, sob a ação da carga permanente, chegam a $0,47 \mathrm{MPa}$ e, quando adicionada a ação do vento a $90^{\circ}$, atingem $0,50 \mathrm{MPa}$.

Estes resultados são influenciados pela geometria curva da região posterior da Catedral, em que a transferência dos empuxos é mais ampla, por ocorrer nas duas direções. 


\subsection{Simulações: retirada dos elementos estruturais}

No capítulo anterior, item 5.2, simulações mostraram a influência de alguns elementos estruturais nos deslocamentos dos pilares e contrafortes da Catedral da Sé.

Do mesmo modo, nesta seção, são apresentados os resultados em termos de tensão normal quando da retirada dos arcobotantes e das duas torres frontais, assim como seu impacto no equilíbrio do conjunto.

\subsubsection{Retirada dos arcobotantes}

$\mathrm{Na}$ simulação em que são retirados todos os arcobotantes da Catedral, constata-se que as seções transversais de quase todos os pilares permanecem totalmente comprimidas. Para estes pilares, as tensões máximas de compressão atuantes estão apresentadas na Tabela 6.2.

Tabela 6.2 - Tensões normais máximas atuantes nos pilares: simulação sem os arcobotantes e variação percentual em relação às máximas da situação real.

\begin{tabular}{|c|c|c|}
\hline \multicolumn{3}{|c|}{ Tensões máximas atuantes de compressão [MPa] } \\
\hline Material Elemento & Pilares & $\begin{array}{l}\text { Variação entre } \\
\text { as tensões } \\
\text { máximas }\end{array}$ \\
\hline $\begin{array}{l}\text { Alvenaria de } \\
\text { granito }\end{array}$ & $3,37(3 \mathrm{l})$ & $7,0 \%$ \\
\hline $\begin{array}{l}\text { Alvenaria de } \\
\text { tijolos }\end{array}$ & $0,36(2 \mathrm{~L})$ & $9,1 \%$ \\
\hline $\begin{array}{l}\text { Concreto } \\
\text { simples }\end{array}$ & $2,09(3 \mathrm{l})$ & $5,6 \%$ \\
\hline $\begin{array}{l}\text { Nota: alvenaria de } \\
\text { laterais acima da ele }\end{array}$ & $\begin{array}{l}\text { é encontra } \\
\text { o de } 11,0 \mathrm{~m}\end{array}$ & núcleo dos pilares \\
\hline
\end{tabular}

Analisando os pilares da região do octógono, vale ressaltar que, na situação real, as maiores tensões de compressão ocorrem nos centrais da seção no eixo F. No granito, atingem 3,15 MPa, enquanto que no concreto simples, atingem 1,98 MPa sob a ação da carga permanente mais a ação horizontal do vento a $90^{\circ}$ ou do 
desaprumo nas direções $-\mathrm{x}$ e +y.

Quando são retirados os arcobotantes, as máximas tensões normais passam a ocorrer nos pilares centrais da seção I e atingem na alvenaria de granito 3,37 MPa sob a ação da carga permanente mais o vento a $90^{\circ}$, enquanto no concreto simples alcançam 2,09 MPa (Figura 6.25). Isto se deve ao fato de que, nesta simulação, na região frontal da igreja permanecem as duas grandes torres a resistir os empuxos horizontais gerados, enquanto que as demais faces da construção ficam desprovidas de seus arcobotantes.

Pilar central 31
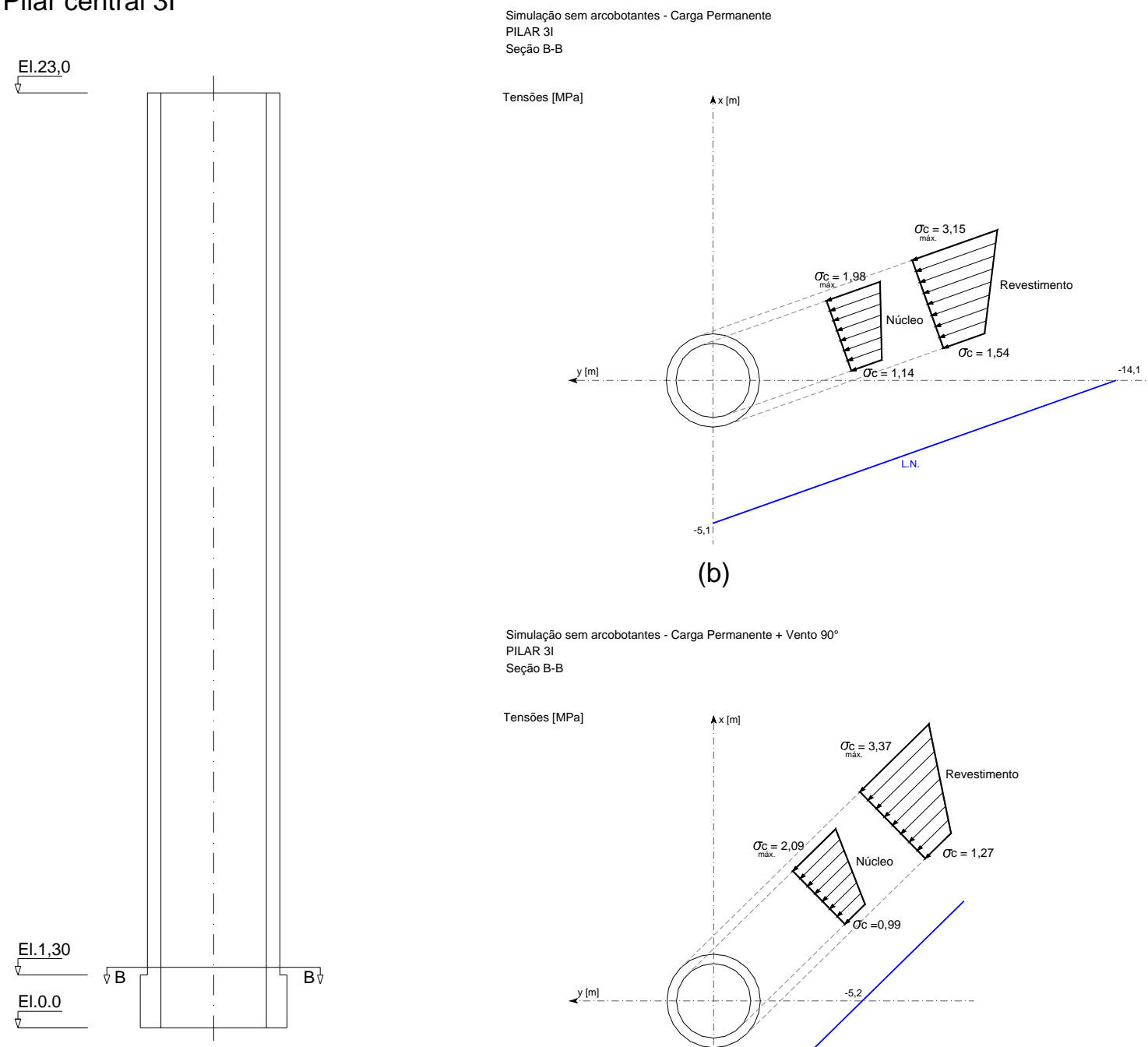

(b)

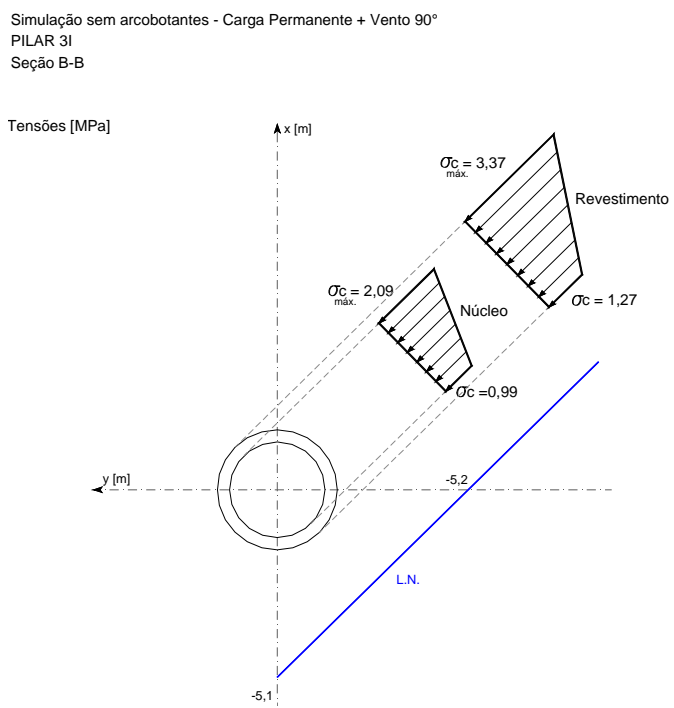

(a)

(c)

Figura 6.25- Tensões normais resultantes no pilar lateral 3I na simulação sem os arcobotantes: (a) elevação; (b) devidas à ação da carga permanente; (c) devidas à ação da carga permanente mais o vento a $90^{\circ}$. 
Sem estes elementos estruturais, aumentam os deslocamentos na direção transversal da igreja e principalmente dos momentos atuantes Mx. Especificamente, nos pilares da região posterior e das seções $\mathrm{H}$ e I, há também o aumento dos deslocamentos na direção longitudinal +x e, com isso, dos momentos My.

Como os pilares são mais solicitados pelo acréscimo dos momentos, as tensões normais aumentam nos materiais. O comparativo entre as tensões máximas de compressão atuantes em alguns pilares, na situação real e na simulação em que se retiram os arcobotantes, está na Tabela 6.3.

Tabela 6.3 - Comparativo de tensões normais máximas atuantes nos pilares: situação real x simulação sem os arcobotantes.

\begin{tabular}{|c|c|c|c|c|c|c|}
\hline \multicolumn{7}{|c|}{ Tensões máximas atuantes de compressão [MPa] } \\
\hline Material & Pilares & $\begin{array}{l}\text { Situação } \\
\text { Real }\end{array}$ & COMB. & $\begin{array}{l}\text { Simulação sem } \\
\text { os arcobotantes }\end{array}$ & COMB. & $\begin{array}{c}\text { Variação } \\
(\%)\end{array}$ \\
\hline \multirow{3}{*}{$\begin{array}{l}\text { Alvenaria } \\
\text { granito }\end{array}$} & $3 F$ & 3,15 & $C P+D(-x+y)$ & 3,26 & $\mathrm{CP}+\mathrm{V} 90^{\circ}$ & 3,5 \\
\hline & 31 & 3,13 & $\mathrm{CP}+\mathrm{VO}^{\circ}$ & 3,37 & $\mathrm{CP}+\mathrm{V} 90^{\circ}$ & 7,7 \\
\hline & $5 N$ & $\begin{array}{l}2,94 \\
1,83\end{array}$ & $\begin{array}{c}C P+D(-x+y) \\
C P+V 90^{\circ}\end{array}$ & $\begin{array}{l}3,11 \\
4,03^{*}\end{array}$ & $\begin{array}{c}C P+D(-x+y) \\
C P+V 0^{\circ}\end{array}$ & $\begin{array}{l}5,8 \\
120\end{array}$ \\
\hline \multirow{3}{*}{$\begin{array}{l}\text { Alvenaria } \\
\text { tijolos }\end{array}$} & 2B & 0,29 & $\mathrm{CP}+\mathrm{V} 90^{\circ}$ & 0,31 & $\mathrm{CP}+\mathrm{V} 90^{\circ}$ & 6,9 \\
\hline & $2 \mathrm{~L}$ & 0,27 & $\mathrm{CP}+\mathrm{V} 0^{\circ}$ & 0,36 & $\mathrm{CP}+\mathrm{V} 90^{\circ}$ & 33,3 \\
\hline & $5 N$ & 0,33 & $\mathrm{CP}+\mathrm{V} 90^{\circ}$ & 0,46 & $\mathrm{CP}+\mathrm{V} 90^{\circ}$ & 39,4 \\
\hline \multirow{3}{*}{$\begin{array}{l}\text { Concreto } \\
\text { simples }\end{array}$} & $3 F$ & 1,98 & $C P+D(-x+y)$ & 2,04 & $\mathrm{CP}+\mathrm{V} 90^{\circ}$ & 3,0 \\
\hline & 31 & 1,97 & $\mathrm{CP}+\mathrm{VO}^{\circ}$ & 2,09 & $\mathrm{CP}+\mathrm{V} 90^{\circ}$ & 6,1 \\
\hline & $5 \mathrm{~N}$ & 1,74 & $C P+D(-x+y)$ & 1,81 & $C P+D(-x+y)$ & 4,0 \\
\hline
\end{tabular}

Nota: alvenaria de tijolos é encontrada no núcleo dos pilares laterais acima da elevação de 11,0 metros.

* Acima da elevação de 11,0 m.

Ressalta-se ainda que com a retirada dos arcobotantes, nas seções transversais dos pilares laterais dos eixos N, N', O e O', localizados na região posterior, na parte curva da Catedral, surgem tensões de tração no revestimento de granito a partir da elevação dos 11 metros. Estas tensões, no entanto, não 
ultrapassam a tensão de ruptura à tração da alvenaria de granito obtida em um ensaio de tração simples. No pilar $5 \mathrm{~N}$, encontram-se as máximas tensões atuantes na alvenaria de granito que alcançam uma tração de 0,98 MPa e uma compressão 4,03 MPa. Na alvenaria de tijolos, a máxima tensão de compressão é de 0,46 MPa.

A retirada dos arcobotantes, portanto, nas condições de carregamento estudadas, não leva ao colapso dos pilares laterais. 


\subsubsection{Retirada das torres frontais}

Como apresentado no Capítulo 5, as torres frontais funcionam como enormes contrafortes a conter os deslocamentos dos pilares da região frontal para o exterior da igreja.

Numa simulação em que elas são retiradas, a igreja tende a se movimentar no sentido das torres ausentes, os momentos My aumentam nos pilares da região frontal e das seções $F$ e $G$, e, com isso, aumentam as tensões atuantes nos materiais que os constituem.

Os pilares mais próximos às torres, ou seja, aqueles localizados na seção do eixo $\mathrm{B}$, apresentam mudança de orientação da linha neutra em relação à situação real. Especificamente nos pilares laterais, surgem tensões de tração próximas à base destes pilares, mas somente quando considerada, além da carga permanente, a ação de carregamentos horizontais do desaprumo (Figuras 6.26 e 6.27).

Pilar lateral 2B

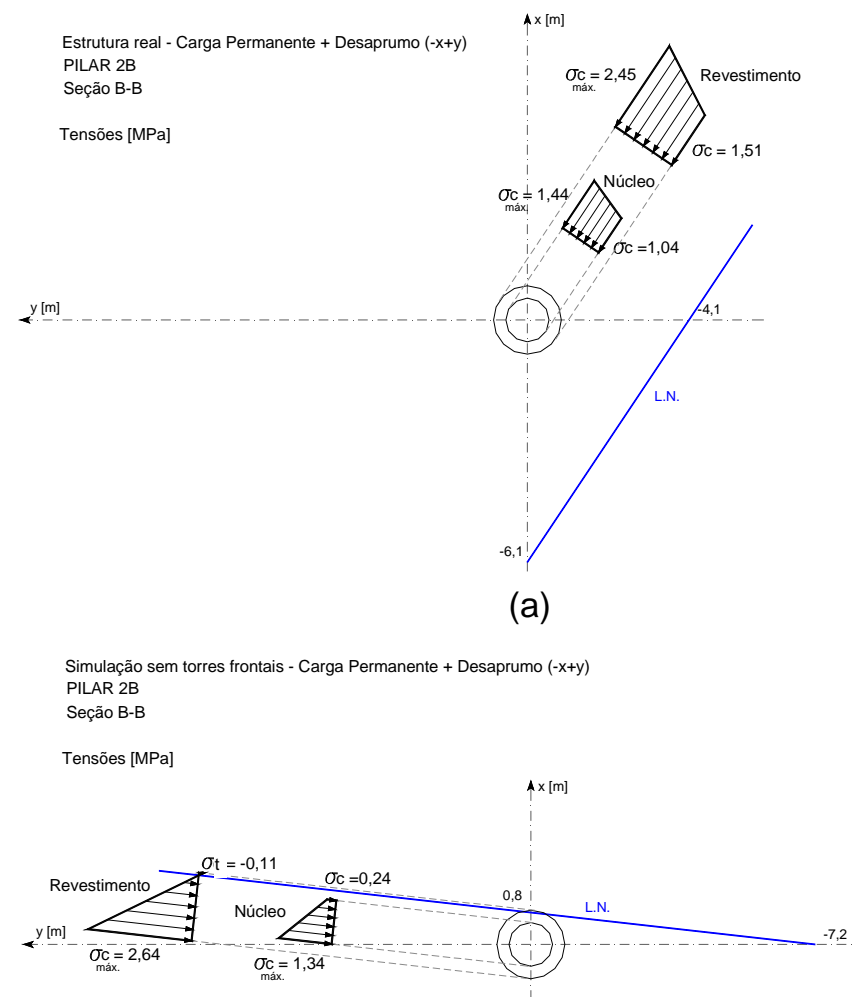

(b)

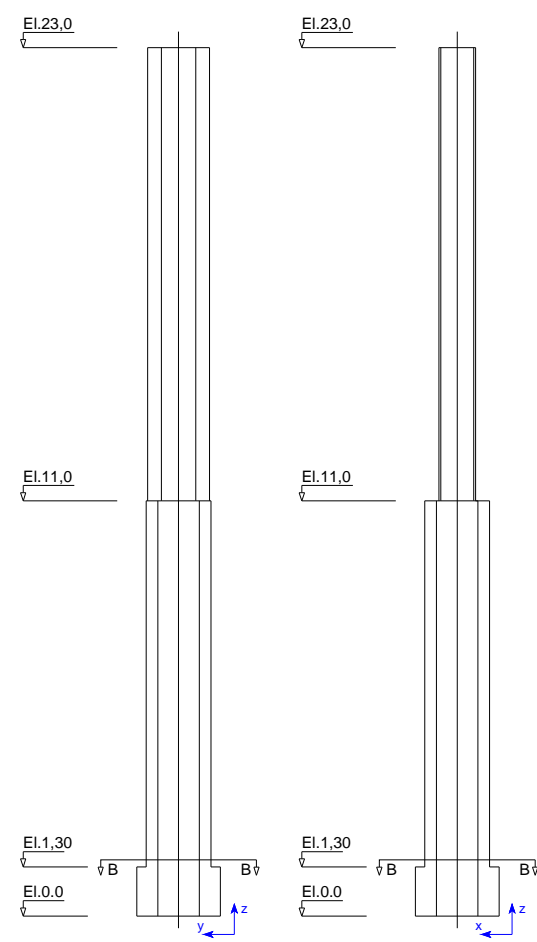

(c)

Figura 6.26 - Tensões normais resultantes no pilar lateral 2B devidas à ação da carga permanente mais desaprumo nas direções -x+y: (a) situação real; (b) na simulação sem as torres frontais; (c) elevação. 
Pilar central 3B

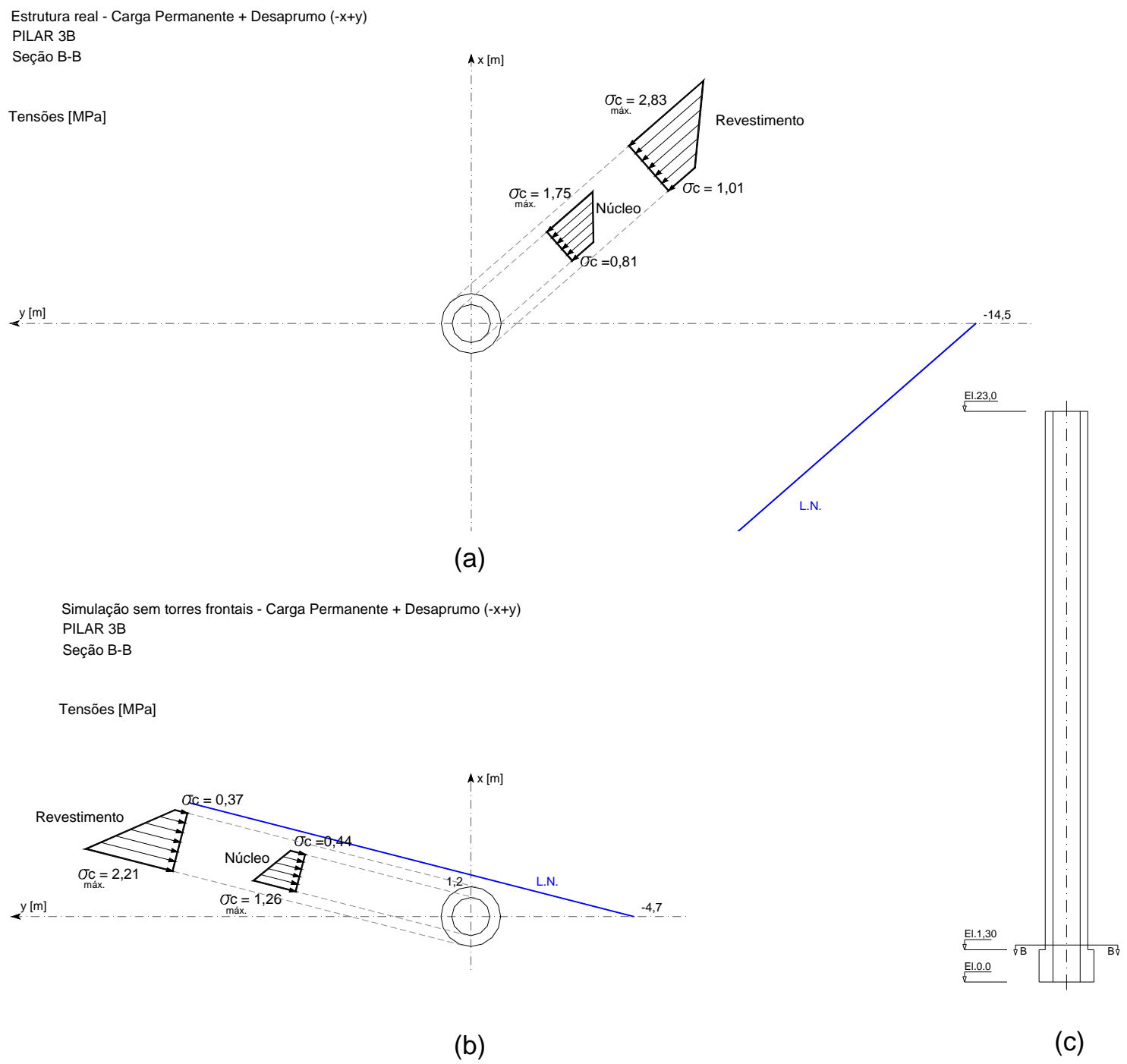

Figura 6.27 - Tensões normais resultantes no pilar central 3B devidas à ação da carga permanente mais desaprumo nas direções - $x+y$ : (a) situação real; (b) na simulação sem as torres frontais; (c) elevação.

Nos pilares centrais da seção $B$, as tensões de tração são encontradas na região superior, a partir da elevação de 18 metros e não ultrapassam a tensão de ruptura à tração dos materiais e, portanto, não há fissuração das peças; na alvenaria de granito, a tensão de tração atinge 0,35 MPa e no concreto simples, apenas 0,05 MPa.

Com exceção dos pilares da seção $B$, os demais elementos de apoio permanecem totalmente comprimidos.

As tensões máximas de compressão atuantes nos pilares e contrafortes da Catedral da Sé para esta simulação estão apresentadas na Tabela 6.4. 
Tabela 6.4 - Tensões normais máximas atuantes nos pilares: simulação sem as torres frontais.

\begin{tabular}{|c|c|c|}
\hline \multicolumn{3}{|c|}{ Tensões máximas atuantes de compressão [MPa] } \\
\hline $\begin{array}{l}\text { Elemento } \\
\text { Material }\end{array}$ & Pilares & Contrafortes \\
\hline $\begin{array}{l}\text { Alvenaria de } \\
\text { granito }\end{array}$ & $3,30(3 F)$ & $3,52(1 \mathrm{G})$ \\
\hline $\begin{array}{l}\text { Alvenaria de } \\
\text { tijolos }\end{array}$ & $0,33(5 N)^{*}$ & $0,53(1 \mathrm{G})$ \\
\hline $\begin{array}{l}\text { Concreto } \\
\text { simples }\end{array}$ & $2,06(3 F)$ & - \\
\hline $\begin{array}{l}{ }^{*} \text { ) Alvenaria de tijo } \\
\text { elevação de } 11,0 \mathrm{me}\end{array}$ & contrada no $n$ & res laterais aci \\
\hline
\end{tabular}

Sem as torres frontais, as máximas tensões de compressão ocorrem nos pilares centrais da seção $\mathrm{F}$, em que atingem 3,30 MPa na alvenaria de granito e 2,06 MPa no concreto simples sob ação da carga permanente mais o desaprumo nas direções -x e +y (Figura 6.28).

Pilar central 3F

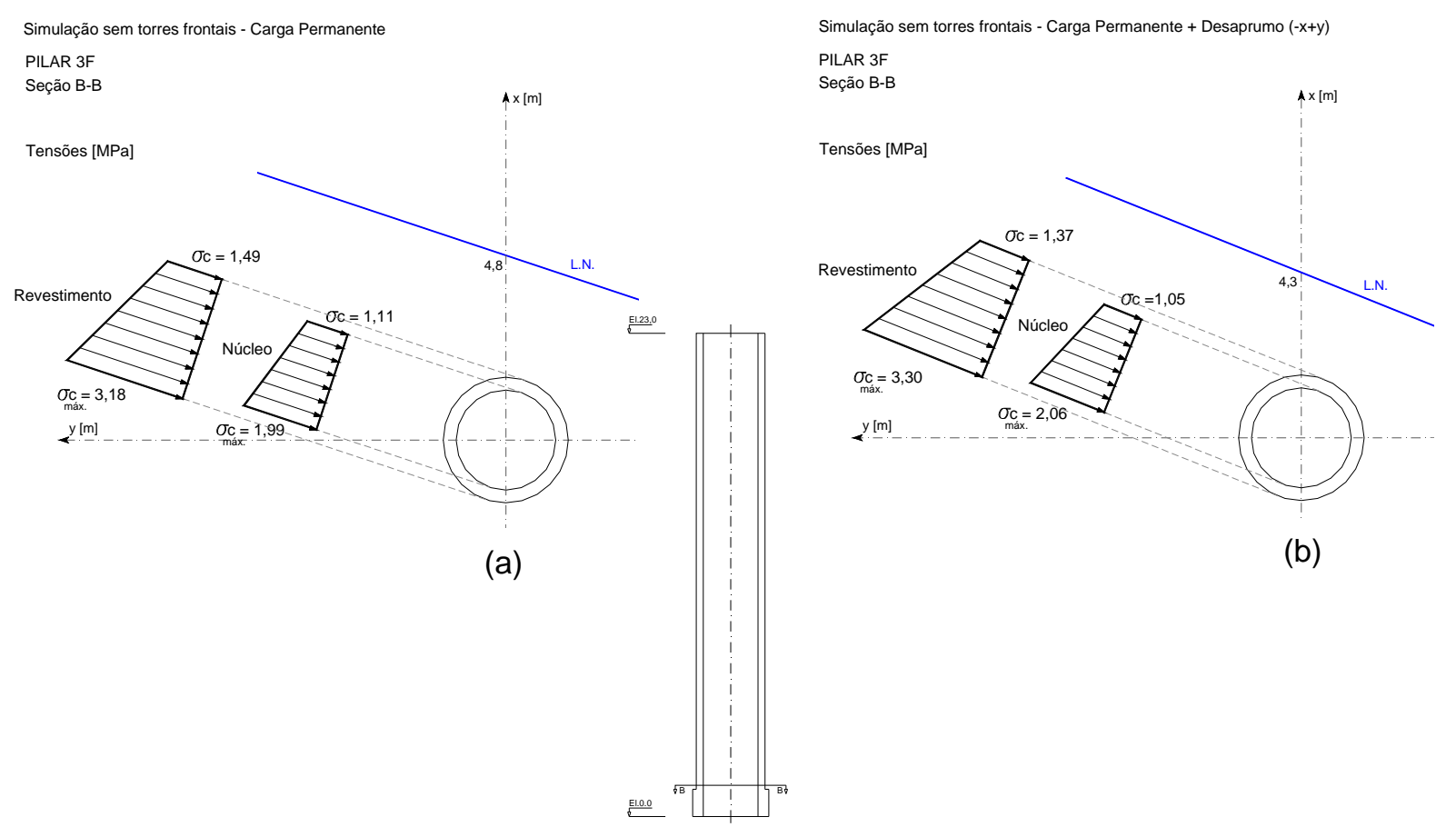

(c)

Figura 6.28 - Tensões normais resultantes no pilar central 3F na simulação sem as torres frontais: (a) devidas à ação da carga permanente; (b) devidas à ação da carga permanente mais desaprumo nas direções -x+y; (c) elevação. 
Nos contrafortes do transepto, permanecem as máximas tensões de compressão, que alcançam 3,52 MPa na alvenaria de granito e 0,53 MPa na alvenaria de tijolo sob a ação da carga permanente mais o vento a 90 (Figura 6.29).

Contraforte 1G

Simulação sem torres frontais - Carga Permanente

CONTRAFORTE $1 G$ - tipo IV

Seção B-B

Tensões [MPa]

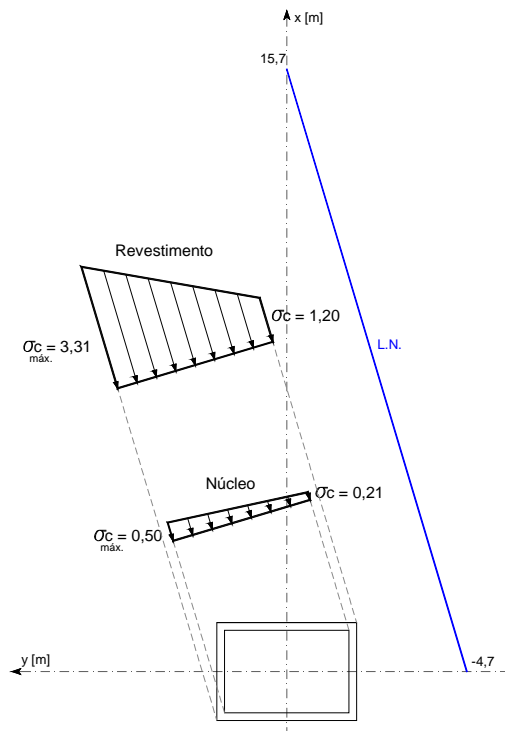

(a)

Simulação sem torres frontais - Carga Permanente + Vento $90^{\circ}$

CONTRAFORTE $1 \mathrm{G}$ - tipo IV

Seção B-B

Tensões [MPa]

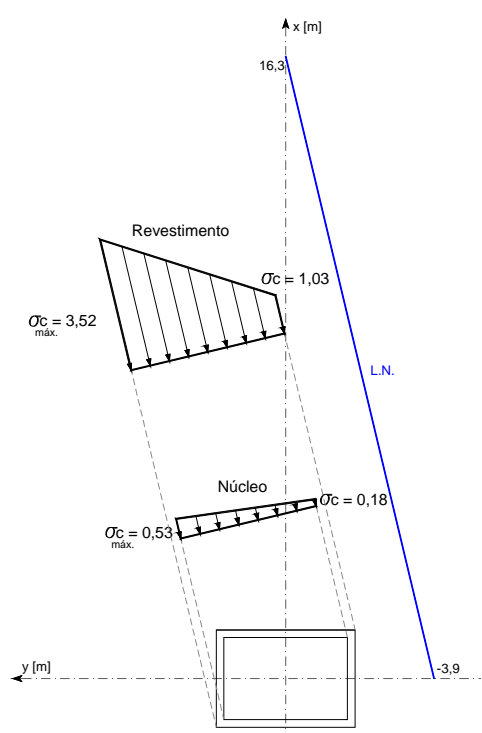

(b)

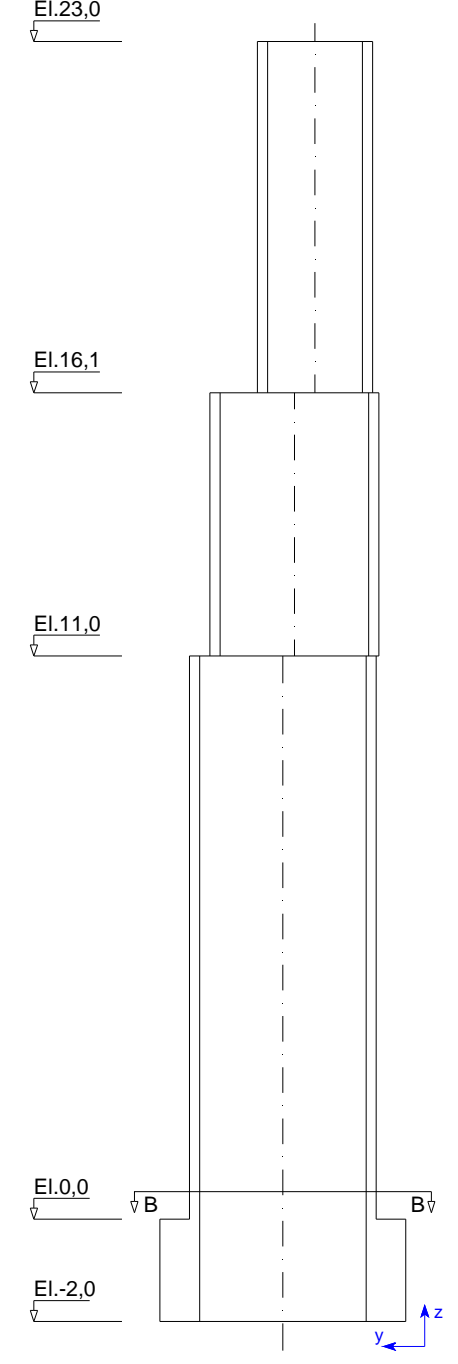

(c)

Figura 6.29 - Tensões normais resultantes no contraforte $1 \mathrm{G}$ na simulação sem as torres frontais: (a) devidas à ação da carga permanente; (b) devidas à ação da carga permanente mais vento a $90^{\circ}$; (c) elevação. 
Os contrafortes da seção $B$, por exemplo, os mais próximos às torres retiradas, permanecem com a seção transversal comprimida. As diferenças da posição da linha neutra e das tensões normais máximas atuantes encontradas na situação real e nesta simulação estão apresentadas na Figura 6.30.

\section{Contraforte 1B}

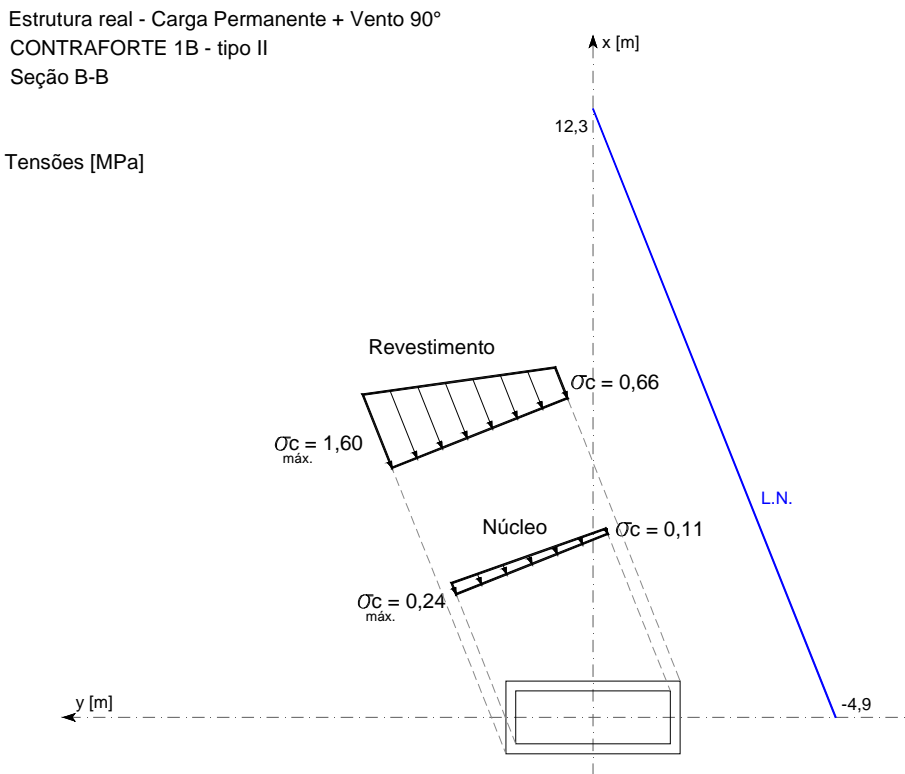

(a)

Simulação sem torres frontais - Carga Permanente + Vento $90^{\circ}$ CONTRAFORTE $1 \mathrm{~B}$ - tipo II

Seção B-B

Tensões [MPa]

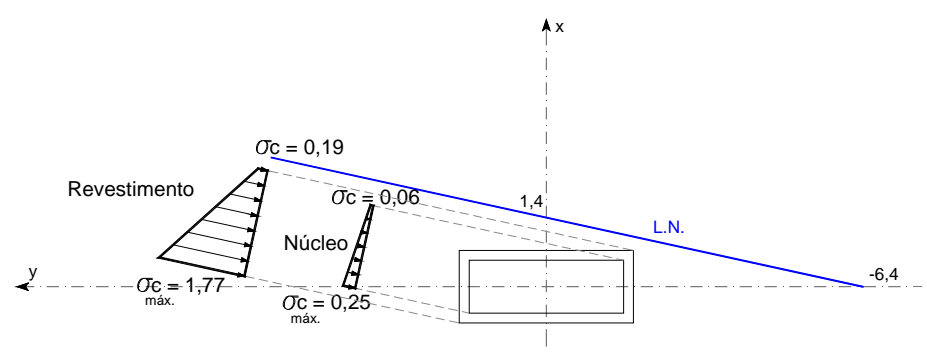

(b)

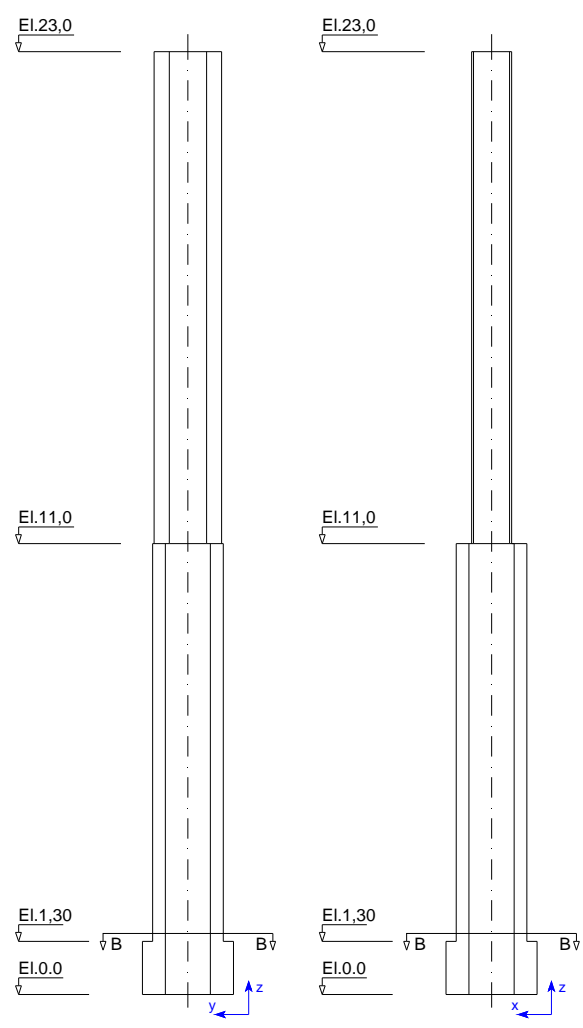

(c)

Figura 6.30 - Tensões resultantes no contraforte 1B devidas à ação da carga permanente mais vento a 90: (a) situação real; (b) simulação sem as torres frontais; (c) elevação. 
O comparativo entre as tensões máximas de compressão atuantes na situação real e na simulação sem as torres frontais para alguns pilares e contrafortes da Catedral está na Tabela 6.5.

Tabela 6.5 - Comparativo de tensões normais máximas atuantes nos pilares e contrafortes: situação real x simulação sem as torres frontais.

\begin{tabular}{|c|c|c|c|c|c|c|}
\hline \multicolumn{7}{|c|}{ Tensões máximas atuantes de compressão [MPa] } \\
\hline Material & Pilares & $\begin{array}{l}\text { Situação } \\
\text { Real }\end{array}$ & COMB. & $\begin{array}{l}\text { Simulação sem } \\
\text { as torres frontais }\end{array}$ & COMB. & $\begin{array}{c}\text { Variação } \\
(\%)\end{array}$ \\
\hline \multirow{6}{*}{$\begin{array}{l}\text { Alvenaria de } \\
\text { granito }\end{array}$} & $1 G$ & 3,47 & $\mathrm{CP}+\mathrm{V} 90^{\circ}$ & 3,52 & $\mathrm{CP}+\mathrm{VO}^{\circ}$ & 1,4 \\
\hline & 2B & 2,60 & $C P+D(+x+y)$ & 2,64 & $C P+D(-x+y)$ & 1,5 \\
\hline & 3B & 2,99 & $C P+D(+x+y)$ & 2,21 & $C P+D(-x+y)$ & $-26,1$ \\
\hline & $3 F$ & 3,15 & $C P+D(-x+y)$ & 3,30 & $C P+D(-x+y)$ & 4,7 \\
\hline & 31 & 3,13 & $\mathrm{CP}+\mathrm{VO}^{\circ}$ & 3,09 & $\mathrm{CP}+\mathrm{V} 90^{\circ}$ & $-1,3$ \\
\hline & $5 \mathrm{~N}$ & 2,94 & $C P+D(-x+y)$ & 2,96 & $C P+D(-x+y)$ & 0,7 \\
\hline \multirow{3}{*}{$\begin{array}{l}\text { Alvenaria de } \\
\text { tijolos }\end{array}$} & $1 G$ & 0,52 & $\mathrm{CP}+\mathrm{V} 90^{\circ}$ & 0,53 & $\mathrm{CP}+\mathrm{VO}^{\circ}$ & 1,9 \\
\hline & $2 \mathrm{~B}$ & 0,29 & $\mathrm{CP}+\mathrm{V} 90^{\circ}$ & 0,27 & $\mathrm{CP}+\mathrm{V} 90^{\circ}$ & $-6,9$ \\
\hline & $5 \mathrm{~N}$ & 0,33 & $\mathrm{CP}+\mathrm{V} 90^{\circ}$ & 0,33 & $\mathrm{CP}+\mathrm{V} 90^{\circ}$ & $-0,7$ \\
\hline \multirow{4}{*}{$\begin{array}{l}\text { Concreto } \\
\text { simples }\end{array}$} & $2 \mathrm{~B}$ & 1,49 & $C P+D(+x+y)$ & 1,34 & $C P+D(-x+y)$ & $-10,1$ \\
\hline & $3 B$ & 1,81 & $C P+D(+x+y)$ & 1,26 & $C P+D(-x+y)$ & $-30,4$ \\
\hline & $3 F$ & 1,98 & $C P+D(-x+y)$ & 2,06 & $C P+D(-x+y)$ & 4,0 \\
\hline & 31 & 1,97 & $\mathrm{CP}+\mathrm{VO}^{\circ}$ & 1,95 & $\mathrm{CP}+\mathrm{VO}^{\circ}$ & $-1,0$ \\
\hline
\end{tabular}




\subsection{Tensões de ruptura e tensões admissíveis}

\subsubsection{Tensões de compressão}

Em Moliterno (1995, p.13), os valores para a tensão admissível à compressão na alvenaria de granito, assentada com argamassa de areia e cimento está entre está entre 3,0 e 5,0 MPa para pilares curtos, e entre 1,0 e 2,0 MPa para pilares esbeltos, de acordo com o traço da argamassa. Já Mills (1967, p.111) especifica que alvenaria de granito assentada com argamassa de cimento Portland apresenta tensão admissível à compressão de 4,2 MPa.

Em Petrucci (1978, p.297), a tensão de segurança na compressão recomendada para alvenaria de granito é 3,5 $\mathrm{MPa}$, informação extraída também do Código de Obras do Distrito Federal - decreto 6000 de 19/7/1937. No entanto, dependendo da qualidade da argamassa de assentamento e da resistência da própria pedra, a tensão admissível pode chegar a 7,5 MPa.

Para a alvenaria de granito assentada com argamassa de cal, cimento e areia, presente na Catedral da Sé, admite-se tensão admissível de compressão de 4,0 MPa.

Assim, ao comparar as tensões atuantes de compressão no revestimento dos pilares e contrafortes da igreja, verifica-se que a pior situação ainda é admissível, pois o valor máximo de tensão atinge $3,47 \mathrm{MPa}$ na alvenaria de granito dos contrafortes do transepto, como é o caso do contraforte $1 \mathrm{G}$.

Nos pilares centrais da região do octógono, sob o tambor da cúpula, a tensão de compressão chega a 3,15 MPa na alvenaria de granito, como é caso do pilar 3F, e, nos pilares laterais da região posterior da igreja, de menor dimensão, a tensão máxima alcança 2,94 $\mathrm{MPa}$, caso do pilar $5 \mathrm{~N}$, como apresentado anteriormente na Tabela 6.3.

Em relação à alvenaria de tijolos da Catedral, a tensão de ruptura à compressão simples admitida é de 3,0 MPa e a tensão admissível à compressão é de 0,6 MPa, com um coeficiente de segurança igual a 5.

Moliterno (1995, p.13) faz referência à tensão de compressão admissível na alvenaria de tijolos, que varia com a esbeltez da peça e com a argamassa utilizada. 
Seguindo suas recomendações, e de acordo a esbeltez de cada contraforte, as resistências adotadas estariam entre 0,6 MPa e 1,4 MPa. Já Petrucci (1978, p.47) admite resistência admissível à compressão para alvenaria de tijolos da ordem de 1,2 MPa.

Como comentado, as máximas tensões de compressão atuantes na alvenaria de tijolos dos elementos de apoio da igreja estão presentes nos núcleos dos contrafortes do transepto da igreja, do tipo IV, equivalentes a 0,52 MPa. A mesma ordem de tensões normais é encontrada nos contrafortes tipo VII, especificamente nos eixos M e M'. Nos contrafortes da região frontal, por exemplo, no tipo II, a tensão máxima atuante de compressão é de 0,30 MPa.

Já no núcleo dos pilares laterais das regiões frontal e posterior da igreja, acima da elevação dos 11,0 metros, também de alvenaria de tijolos, a tensão atuante máxima de compressão atinge 0,27 e 0,33 MPa respectivamente.

Portanto, também se verifica que a alvenaria de tijolos dos contrafortes e dos pilares mais solicitados está ainda em uma situação admissível.

Finalmente, quanto ao material concreto, encontra-se em Moliterno (1995, p.10), tensão admissível à compressão entre 4,0 e 8,0 MPa, de acordo com a dosagem. Já Langendonck (1954, p.187) admite valores que são encontrados na norma brasileira NB-1: Cálculo e execução de Obras de Concreto Armado.

A norma brasileira NB-1: Cálculo e execução de Obras de Concreto Armado de 1950, Capítulo VII, apresenta as tensões admissíveis à compressão que podem ser adotadas para os concretos. No caso das abóbadas e da cúpula que trabalham a esforços axiais, o coeficiente de segurança adotado poderia ser 3,0, o que corresponde a uma tensão admissível à compressão de 5,0 MPa. Acredita-se que para os elementos de concreto armado, executados aproximadamente a partir da década de 40, a dosagem tenha sido racional, exigindo-se que se tenha estabelecido uma relação água / cimento, uma relação entre os agregados miúdos e graúdos e ainda sua dosagem submetida à aprovação do órgão responsável pela fiscalização da obra (NB-1, 1950, art.87).

Em uma posição mais conservadora, pode-se considerar que o concreto armado da Catedral tenha sido dosado empiricamente, como é o que se admite também para o concreto simples dos pilares executados nos primeiros anos das 
obras da igreja. Nesta situação, a NB1 recomenda que tensão admissível à compressão seja de 4,0 MPa caso a peça esteja submetida à compressão axial e de 4,5 MPa caso a peça esteja submetida à flexão simples ou composta para análise das tensões nas bordas da seção transversal.

Deste modo, considerando as recomendações da NB1 para o concreto armado, a tensão admissível à compressão estaria numa faixa entre 4,0 e 5,0 MPa. Para efeitos desta pesquisa, adota-se para este material 4,5 MPa, o que corresponde a um coeficiente de segurança de 3,3.

$\mathrm{Na}$ Tabela 6.6, são apresentadas as tensões de ruptura e as tensões admissíveis à compressão dos materiais utilizadas para a análise dos resultados.

Tabela 6.6 - Tensões dos materiais na compressão

\begin{tabular}{lrrr}
\hline Material & $\begin{array}{c}\text { Tensão de Ruptura } \\
(\mathrm{MPa})\end{array}$ & $\begin{array}{c}\text { Tensão Admissível } \\
(\mathrm{MPa})\end{array}$ & $\begin{array}{r}\text { Coeficiente de } \\
\text { Segurança }[\gamma]\end{array}$ \\
\hline Concreto simples & 12,0 & 3,6 & 3,3 \\
\hline Concreto armado & 15,0 & 4,5 & 3,3 \\
\hline Alvenaria de tijolos & 3,0 & 0,6 & 5,0 \\
\hline Alvenaria de granito & - & 4,0 & - \\
\hline
\end{tabular}

Para o concreto simples, presente no núcleo dos pilares da igreja submetidos à flexão composta, é mantido este mesmo coeficiente de segurança e a tensão admissível à compressão admitida é de 3,6 MPa.

Na Catedral da Sé, como comentado, é nos pilares centrais da região do octógono, como os da seção $\mathrm{F}$, que atuam as máximas tensões de compressão no concreto simples, que atingem 1,98 MPa; verifica-se, portanto, também uma situação admissível para este material.

Em relação às duas simulações realizadas, sem arcobotantes e sem as torres frontais, verifica-se que as máximas tensões de compressão atuantes nos pilares e contrafortes da igreja mantêm-se em uma situação admissível para cada um dos materiais analisados. 
No entanto, ressalta-se que ao simular tanto a retirada dos arcobotantes como a dos contrafortes, alguns pilares apresentariam tensões de tração em suas seções transversais, como comentado nas p.182-185. Nestas situações, as máximas tensões de tração não ultrapassariam a tensão de ruptura dos materiais e, portanto, não haveria fissuras nestas peças.

\subsubsection{Tensões de tração}

Como apresentado, os pilares e os contrafortes da Catedral permanecem totalmente comprimidos e não há, portanto, tensões de tração em suas seções transversais mesmo com a ação horizontal do vento ou do desaprumo.

No entanto, nas simulações em que são retirados os arcobotantes, como comentado, nos pilares laterais dos eixos N, N', O e O', na região posterior da igreja, a partir da elevação de 11 metros, atuariam tensões de tração na alvenaria de granito, que não ultrapassariam a tensão de ruptura à tração do material obtida em um ensaio de tração simples. A máxima tensão de tração atingiria 0,98 MPa.

Já sem as torres frontais, surgiriam tensões de tração nos pilares centrais da seção B a partir da elevação de 18 metros em todas as situações de carregamento e, nos pilares laterais, tensões de tração próximas à base quando considerada somente a carga permanente somada à ação do desaprumo nas direções $-x$ e $+y$. Nestas situações, tampouco se atingiria a tensão à ruptura à tração da alvenaria de granito, sequer do concreto simples e, portanto, não ocorreria fissuração das peças.

Para a alvenaria de granito, Moliterno (1995, p.14) afirma que a tensão admissível à tração não deva ultrapassar 0,22 MPa. Para efeitos de análise, nesta pesquisa, admite-se 0,20 MPa.

Destaca-se no caso de serem retirados os arcobotantes que, apesar de a máxima tensão de tração atuante na alvenaria de granito não ultrapassar a tensão de ruptura à tração simples deste material, o seu valor seria quase cinco vezes o da tensão admissível.

Embora não viesse a ocorrer o colapso desses pilares na ausência dos arcobotantes e nas condições de modelagem estabelecidas, a presença dos 
arcobotantes é necessária para garantir a segurança da construção e, portanto, a estrutura de Maximiliano Hehl foi bem concebida ao se inserir estes elementos estruturais.

Em relação à alvenaria de tijolos, admite-se que a resistência de ruptura à tração simples seja de 0,3 MPa. Moliterno (1995, p.13) apresenta uma faixa de resistência para este material que varia entre 0,1 a 0,3 MPa. Adotando coeficiente de segurança igual a 5, a tensão admissível à tração estimada é de 0,06 MPa.

Para o concreto armado, admitiu-se que a tensão de ruptura à tração seja estimada em 1/10 da tensão de compressão simples, ou seja, 1,5 MPa e o coeficiente de segurança adotado é 3,3, o que implica numa tensão admissível de 0,45 MPa. Vale ressaltar, no entanto, que como o concreto é armado, as tensões de tração devem ser resistidas pela armadura. Este mesmo critério é aplicado para determinar as tensões de tração para o concreto simples.

$\mathrm{Na}$ Tabela 6.7 são apresentadas as tensões de ruptura à tração e as respectivas tensões admissíveis dos materiais utilizadas para a análise dos resultados.

Tabela 6.7 - Tensões dos materiais na tração

\begin{tabular}{lrrr}
\hline Material & $\begin{array}{c}\text { Tensão de Ruptura } \\
(\mathrm{MPa})\end{array}$ & $\begin{array}{r}\text { Tensão Admissível } \\
(\mathrm{MPa})\end{array}$ & $\begin{array}{r}\text { Coeficiente de } \\
\text { Segurança }[\gamma]\end{array}$ \\
\hline Concreto simples & 1,20 & 0,36 & 3,3 \\
\hline Concreto armado & 1,50 & 0,45 & 3,3 \\
\hline Alvenaria de tijolos & 0,30 & 0,06 & 5,0 \\
\hline Alvenaria de granito & 1,20 & 0,20 & 6,0 \\
\hline
\end{tabular}




\subsection{Estudo das tensões nas abóbadas}

Nesta seção, são apresentados mapeamentos das tensões principais atuantes nas abóbadas da Catedral da Sé de São Paulo. Ressalta-se que os valores positivos correspondem a tensões de tração e os valores negativos, a tensões de compressão.

Os resultados de tensões nas cascas são fornecidos pelo software de cálculo considerando a face superior ou a face inferior do elemento.

Nas Figuras 6.31 e 6.32, está mapeada a tensão principal máxima $\sigma_{1}$ atuante na fibra superior e na fibra inferior de cada um dos elementos de casca. São propostas duas visualizações para estes mapas, ambas limitadas inferiormente por zero a fim de que se destaquem as tensões de tração.

Uma das propostas está limitada superiormente pela tensão de ruptura à tração da alvenaria de tijolos que é de 0,3 MPa; neste mapeamento, pode-se observar que a tensão de ruptura é atingida em alguns trechos das abóbadas sobre as naves laterais externas na região curva da Catedral (Figura 6.31).

Em outra escala, mais ampla e limitada superiormente pela tensão de ruptura à tração do concreto armado, que é de 1,5 MPa, são apresentados os mesmos resultados de $\sigma_{1}$, o que permite identificar que as máximas tensões de tração atuam nas abóbadas da região do octógono, que são de concreto armado (Figura 6.32).

Nota-se que, nas abóbadas dos "triângulos", as máximas tensões de tração chegam próximo a 1,5 $\mathrm{MPa}$, justificando a necessidade de nelas se utilizar o concreto armado.

Uma questão que se coloca é se estas abóbadas foram concebidas de concreto armado por Maximiliano Hehl ou se esta foi uma decisão tomada durante o período de construção. Nos relatórios da Comissão Executiva de Obras, referências a esta questão não estão abordadas. O que se sabe é que a cúpula inicialmente havia sido concebida em alvenaria de tijolos e que em 1950 tomou-se a decisão de executá-la de concreto armado, possibilitando a redução das cargas sobre os pilares e evitar uma possível fissuração que poderia ocorrer devido a recalques (RAMIREZ, 2005).

Quando foi tomada a decisão de se construir a cúpula de concreto armado, o 
tambor de alvenaria de tijolos já havia sido executado. Provavelmente, a repercussão do possível abalo da estrutura em 1950, a ser comentado adiante, e as possibilidades oferecidas pelo concreto armado em termos de menor peso e dimensões tenham definido a proposta final da cúpula do templo.

Como a cúpula foi inicialmente concebida em alvenaria de tijolos, é provável que também as abóbadas dos "triângulos", adjacentes ao octógono, também o tenham sido e que a decisão de executá-las em concreto armado tenha sido tomada durante a construção.
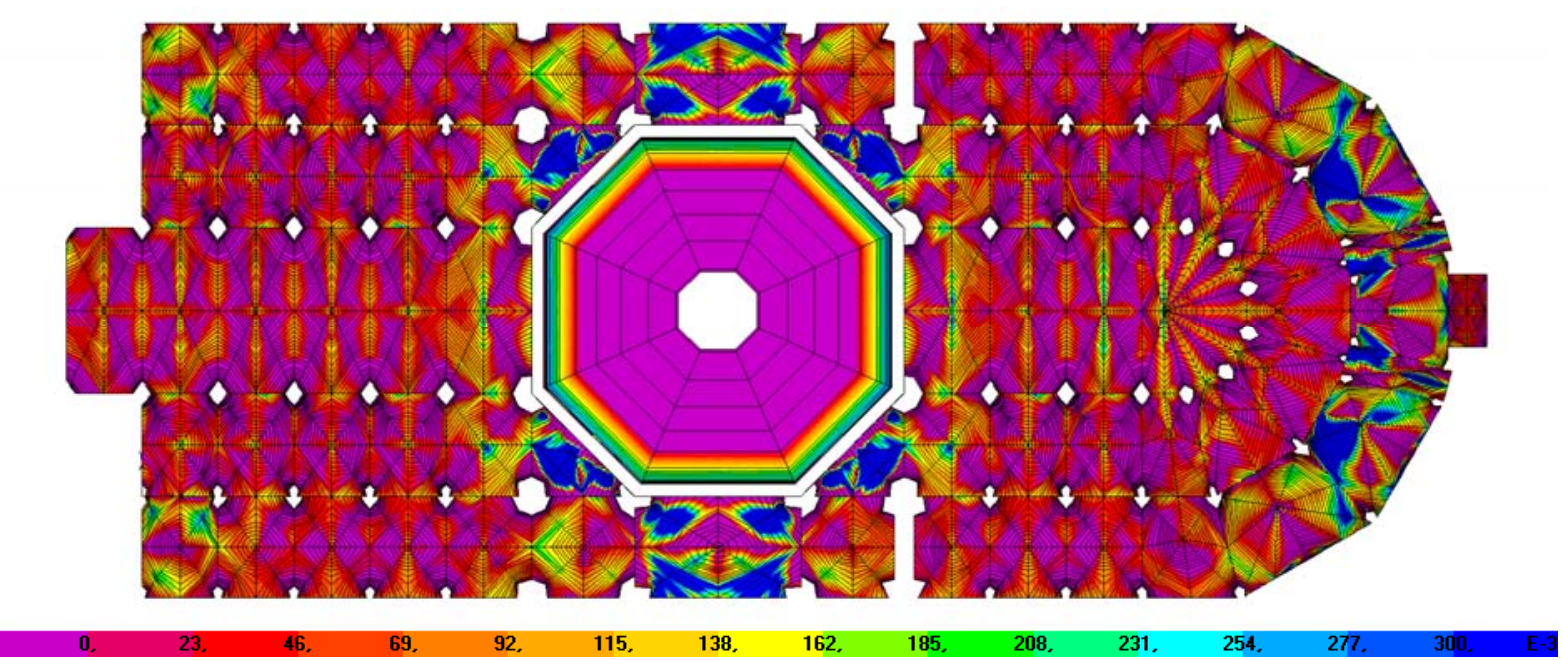

(a)

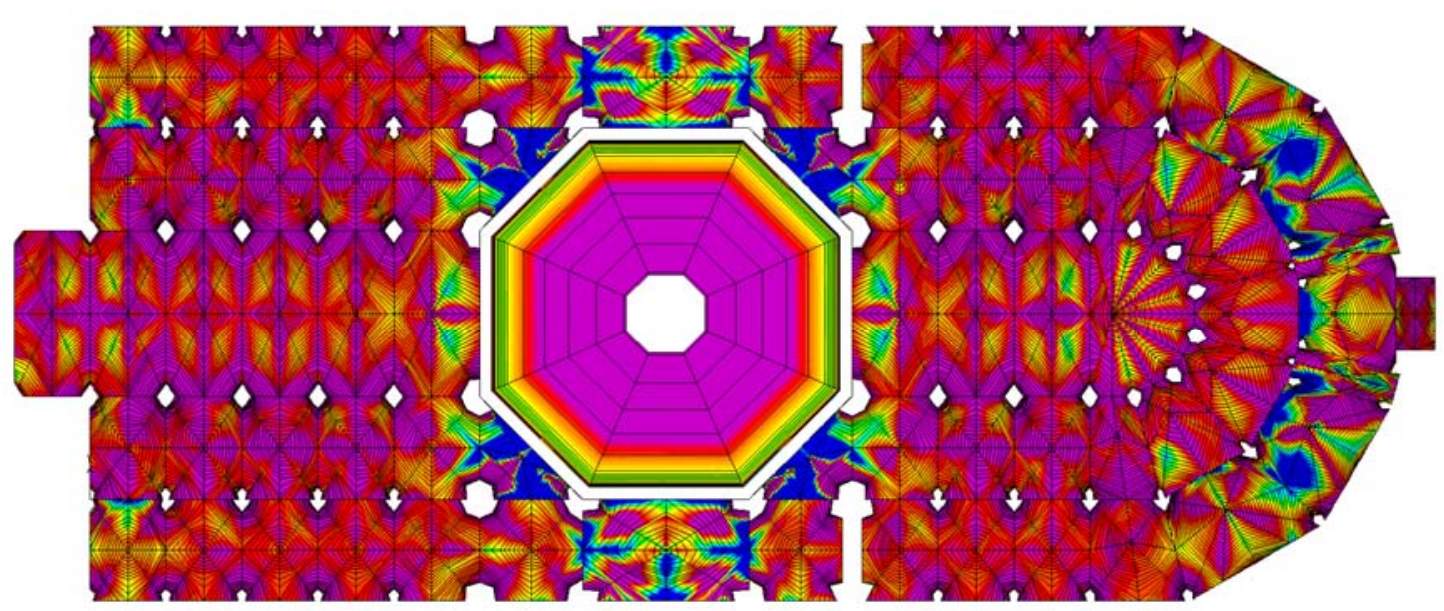

69. 92. 115, 138 .

162.185

208. 231, 25

Os valores das tensões normais indicados

(b) nesta escala estão em MPa

Figura 6.31 - Mapeamento das tensões principais máximas, $\sigma_{1}$, nas abóbadas e na cúpula interna devidas à ação da carga permanente: (a) na face superior do elemento de casca; (b) na face inferior do elemento de casca - escala limitada superiormente pela tensão de ruptura à tração da alvenaria de tijolos. 


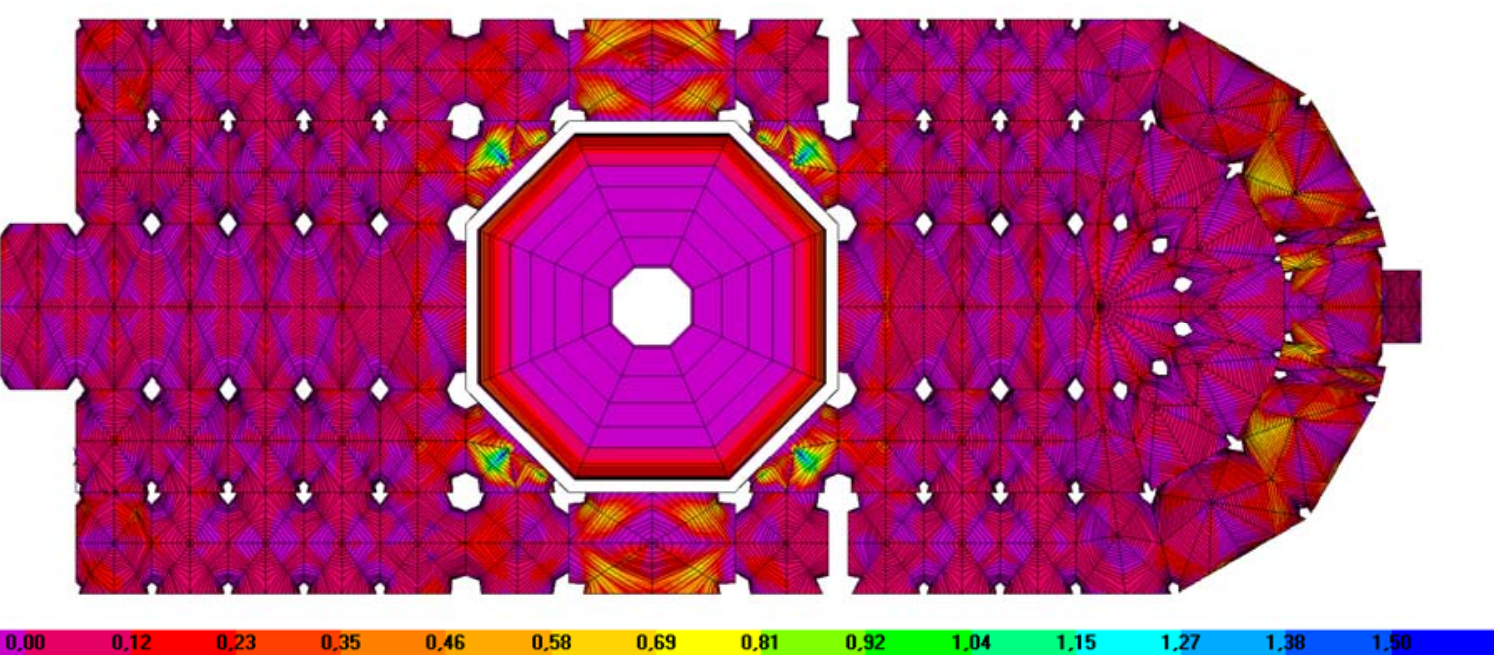

(a)

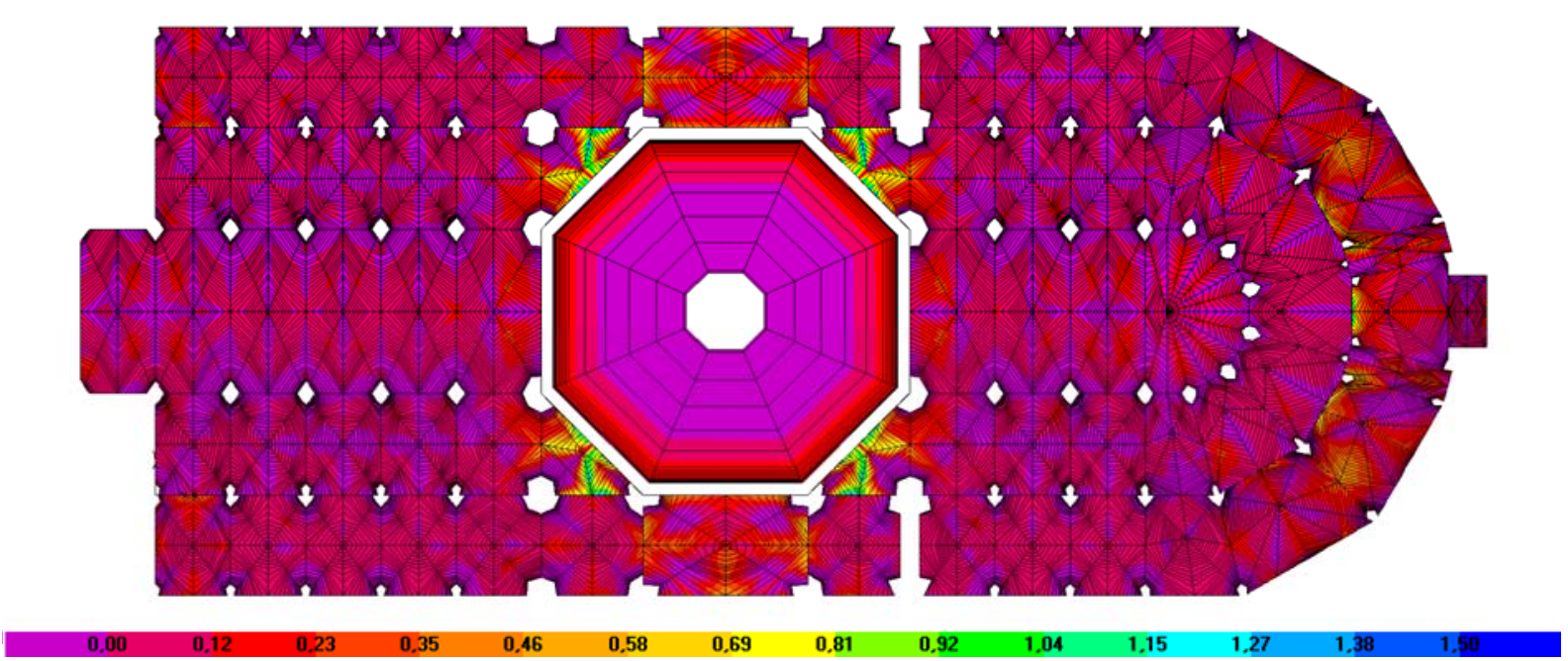

Os valores das tensões normais indicados

(b) nesta escala estão em MPa

Figura 6.32 - Mapeamento das tensões principais máximas, $\sigma_{1}$, nas abóbadas e na cúpula interna devidas à ação da carga permanente: (a) na face superior do elemento de casca; (b) na face inferior do elemento de casca - escala mais ampla limitada superiormente pela tensão de ruptura à tração do concreto armado.

Nas Figuras 6.31 e 6.32, observa-se que em todas as abóbadas da igreja ocorrem tensões principais de tração.

Nas abóbadas de alvenaria de tijolos, localizadas no trecho curvo da igreja, as maiores tensões principais de tração variam entre 0,40 e 0,70 MPa, muito acima da tensão de ruptura para este material, estimada em 0,30 MPa; valores extremos, em zonas muito restritas, atingem 0,88 MPa. Nas demais abóbadas de alvenaria de tijolos, as tensões principais máximas são da ordem de 0,27 MPa. 
Há outros trechos das abóbadas em que a tensão principal máxima não ultrapassa a tensão de ruptura em um estado simples de tração, mas, além disso, a tensão principal mínima também é de tração e neste caso, a ruptura pode ocorrer sem que a tensão do estado simples de tração seja atingida, já que a ruptura está relacionada ao estado duplo de tensão.

A Figura 6.33 mostra a tensão principal mínima $\sigma_{2}$ atuante na fibra superior e na fibra inferior dos elementos de casca das abóbadas e da cúpula interna da Catedral. O tom mais escuro de azul indica $\sigma_{2}$ de tração.

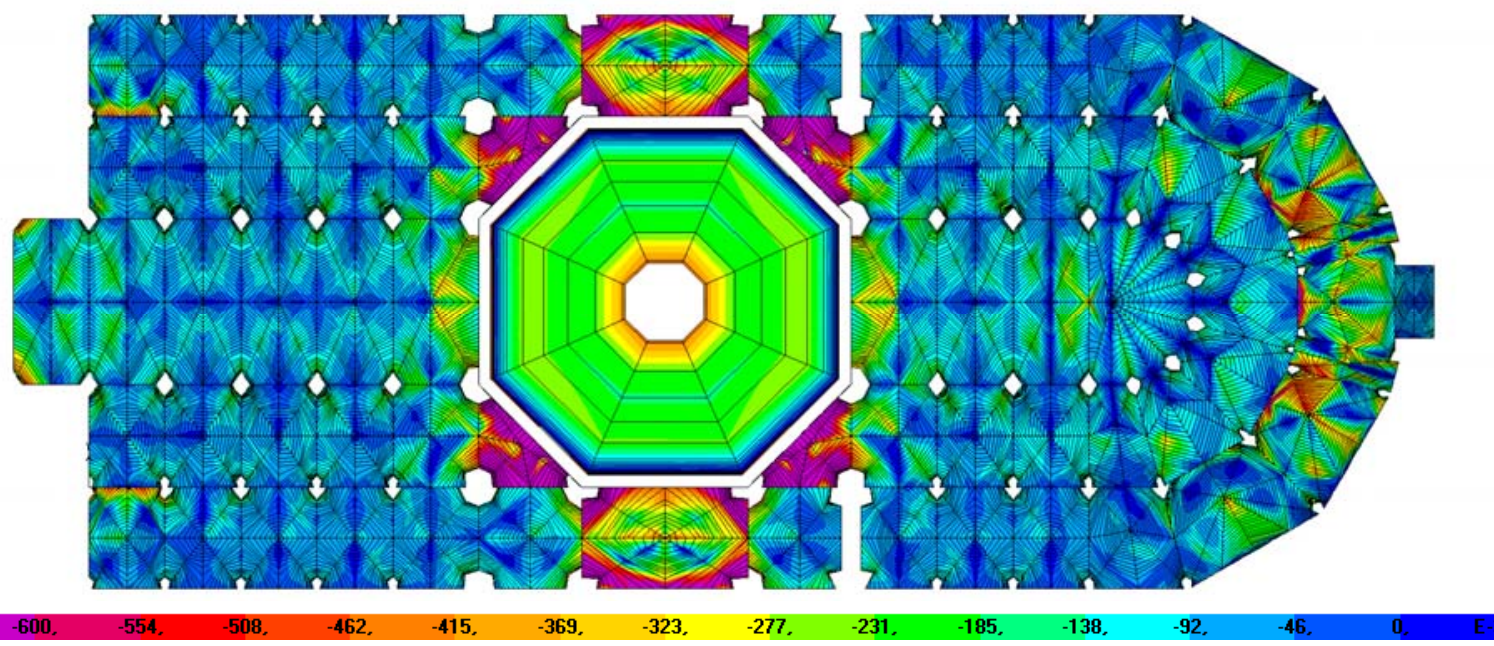

(a)

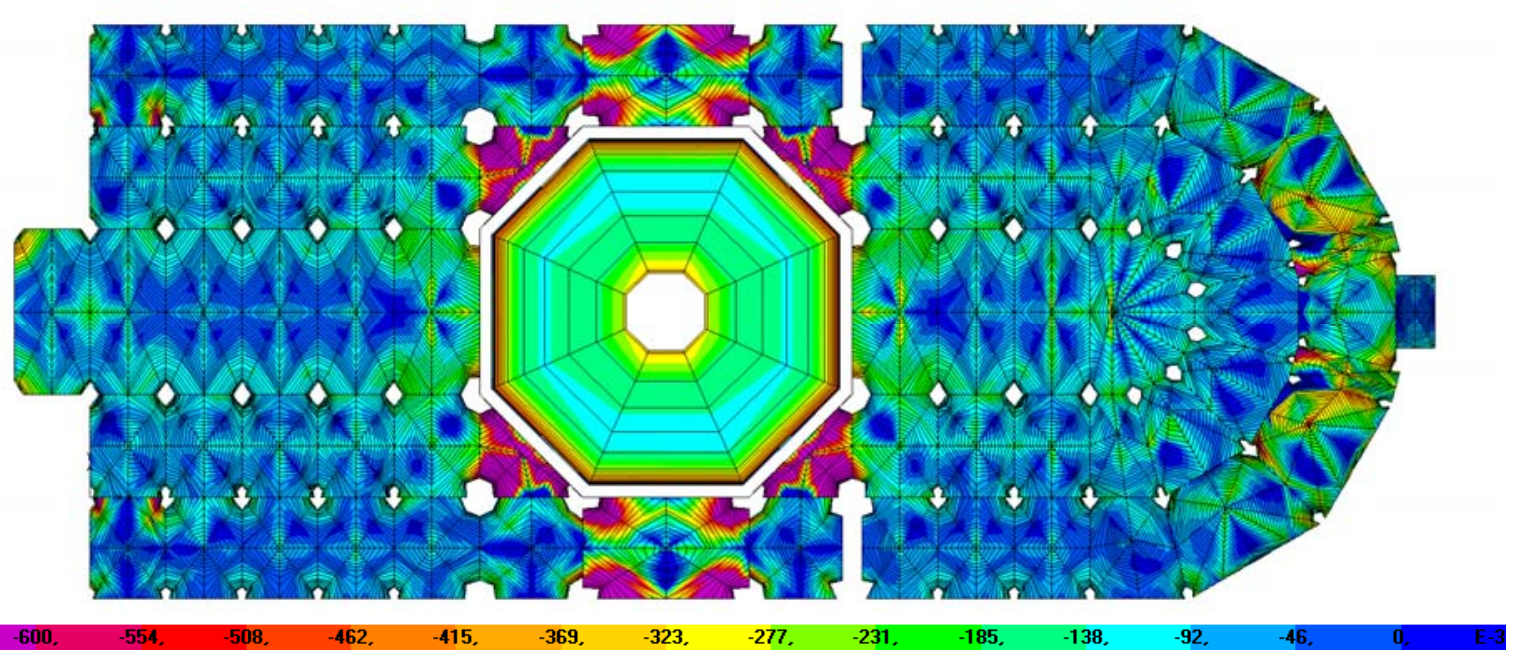

Os valores das tensões normais indicados

(b) nesta escala estão em MPa

Figura 6.33 - Mapeamento das tensões principais mínimas, $\sigma_{2}$, nas abóbadas e na cúpula interna devidas à ação da carga permanente: (a) na face superior do elemento de casca; (b) na face inferior do elemento de casca - escala limitada inferiormente pela tensão admissível à compressão da alvenaria de tijolos. 
Nas abobadas de concreto armado, as tensões de compressão atuantes atingem até 2,0 MPa, inferior à tensão admissível adotada em 4,5 MPa.

Já nas abóbadas de alvenaria de tijolos, sobre as naves laterais externas da região posterior do templo, os maiores valores de compressão chegam a aproximadamente 1,0 MPa, superior à tensão admissível de compressão adotada em 0,6 MPa, mas inferior à de ruptura, de 3,0 MPa. Nas demais abóbadas de alvenaria de tijolos, as maiores tensões de compressão são da ordem de 0,5 MPa.

Como comentado, nota-se que, em alguns trechos de abóbadas, a tensão principal mínima também é de tração encontrando-se destacadas na Figura 6.33 com o tom de azul mais escuro. Na maioria dos trechos das abóbadas, entretanto, $\sigma_{2}$ é de compressão.

Vale ressaltar que o foco dos estudos das tensões nas cascas da igreja, devese ao fato de que havia fissuras nas abóbadas e até na cúpula da Catedral antes de sua recente reforma, e, portanto, as atenções estão voltadas às tensões de tração.

Em 1950, algumas fissuras existentes principalmente nas alvenarias de tijolos levaram a crer num possível abalo estrutural. No entanto, segundo o engenheiro Luiz Anhaia Mello, responsável pela construção da Catedral na época, elas não afetavam a integridade estrutural da igreja, já que se tratava apenas de um assentamento das fundações (JORNAL FOLHA DA NOITE, 1950). É provável que muitas das fissuras mapeadas antes da recente reforma sejam daquela época.

Em 1999, a queda de alguns tijolos das abóbadas da nave da igreja alertou para a necessidade de recuperação da edificação, tanto que, em julho do mesmo ano, a Prefeitura Municipal da cidade de São Paulo optou pelo fechamento da Catedral da Sé pela falta de segurança aos seus visitantes.

A Figura 6.34 mostra o mapeamento de fissuras realizado pela Concremat, empresa responsável pelo restauro da igreja, e o intuito desta seção é verificar se estas fissuras, preliminarmente, podem ter alguma relação com os carregamentos estudados.

O relatório da Concremat (1999) destaca a abertura de trincas e fissuras em algumas abóbadas. Estabeleceu-se que as fissuras eram aquelas com menos de três milímetros de abertura, e acima disso, trincas. 


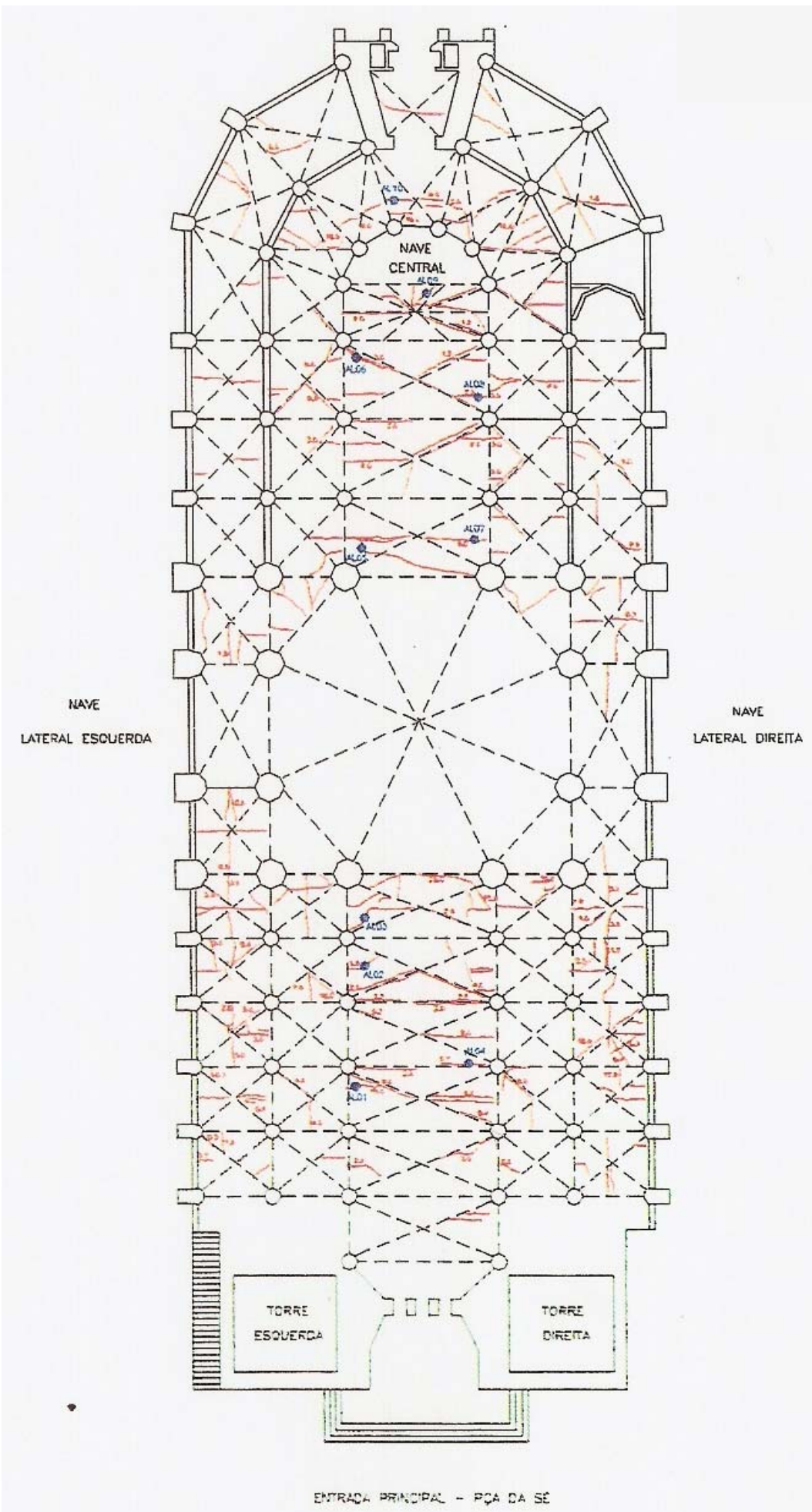

Figura 6.34 - Mapeamento das fissuras presentes nas abóbadas da Catedral da Sé antes da reforma (CONCREMAT, 1999, p.22).

O levantamento realizado pela empresa de restauro constatou cerca de 4.470 metros de fissuras nas abóbadas, na cúpula e na alvenaria de tijolos das paredes externas da Catedral (DELLELIS, 2002). A empresa ainda associa estas fissuras às 
variações térmicas ocorridas ao longo do tempo e compartilha do parecer do engenheiro Luiz Anhaia Mello, atribuindo aos recalques diferenciais o fato da presença das aberturas: "[...] as prováveis causas dessas apontam mais para a movimentação da estrutura da igreja, em função da acomodação do terreno e de interferências externas no meio urbano do que falhas construtivas ou de projeto." (CONCREMAT, 1999?, p.9-10).

Em Nasser (2000?), comenta-se ainda a existência de trincas em duas abóbadas, não explicitamente identificadas, mas ditas próximas à cúpula e que apresentavam abertura de 80 milímetros.

Como se observou, na maior parte da superfície das abóbadas, uma das tensões principais é de tração, enquanto a outra é de compressão. Em relação aos trechos das abóbadas em que a tensão principal máxima ultrapassa a de ruptura à tração e em que a fissura lhe está perpendicularmente disposta, a possível associação entre o carregamento e a fissuração é imediata.

Também, como foi visto, existem alguns trechos em que ambas as tensões principais são de tração, e, nessas regiões, fissuras podem ocorrer em situações mesmo que a tensão principal máxima seja inferior à tensão de ruptura do material em um ensaio de tração simples.

Nestes casos, como se trata de um material frágil, utiliza-se o critério de resistência de Mohr-Coulomb no intuito identificar uma possível ruptura associada ao estado de tensão na abóbada.

Neste modelo, a partir das tensões de ruptura à compressão e à tração simples admitidas para a alvenaria de tijolos, $\sigma_{R c}$ e $\sigma_{R t}$ respectivamente, é construída uma região na qual se diz que o material não falha, delimitada pelas retas que tangenciam as duas circunferências, uma envoltória (Figura 6.35).

Considerando estado plano de tensão, é verificado se o círculo de Mohr construído para cada par de tensões principais atuantes tangencia ou ultrapassa a envoltória. 


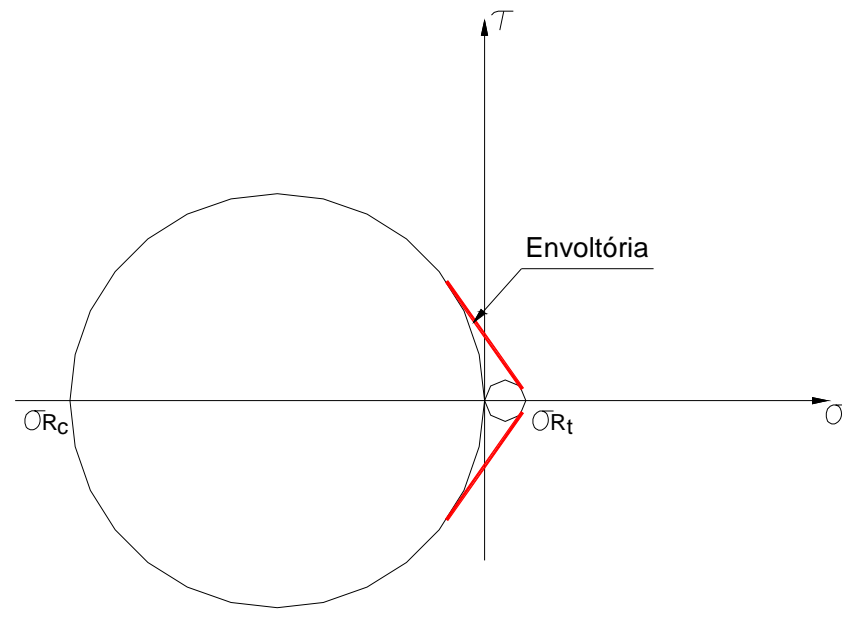

Figura 6.35 - Envoltória para a alvenaria de tijolos pelo critério de resistência de Mohr-Coulomb.

Nas Figuras 6.36, 6.37 e 6.38, sobre o mapeamento das tensões principais máximas e mínimas, estão marcadas as fissuras nas abóbadas da região frontal, da região posterior e da região do octógono, respectivamente, e que possivelmente estão associadas aos estados de tensão decorrentes dos carregamentos considerados. Vale ressaltar que a associação entre fissuras e tensões é indicativa, já que elas podem ocorrer sob outra combinação de carregamento que não apresentada nas Figuras, como por exemplo, sob o acréscimo da ação horizontal do vento.

Em preto, estão destacadas as fissuras nas abóbadas quando $\sigma_{1}$ ultrapassa a tensão de ruptura à tração do material. Em azul, destacam-se as fissuras nos trechos em que as duas tensões principais são de tração e inferiores à de ruptura, mas que verificadas pelo critério de resistência de Mohr-Coulomb também indicam falha do material. E, em branco, estão marcadas as fissuras não associadas aos carregamentos.

Vale destacar que no mapa das tensões principais máximas, a seguir, as zonas em azul escuro indicam que a tensão de ruptura da alvenaria de tijolos à tração simples é atingida sob a ação da carga permanente. Na região frontal, algumas destas zonas localizam-se nas primeiras abóbadas das naves laterais externas, próximo às torres, e nas abóbadas das naves central e laterais próximas à região do octógono. 
Face superior
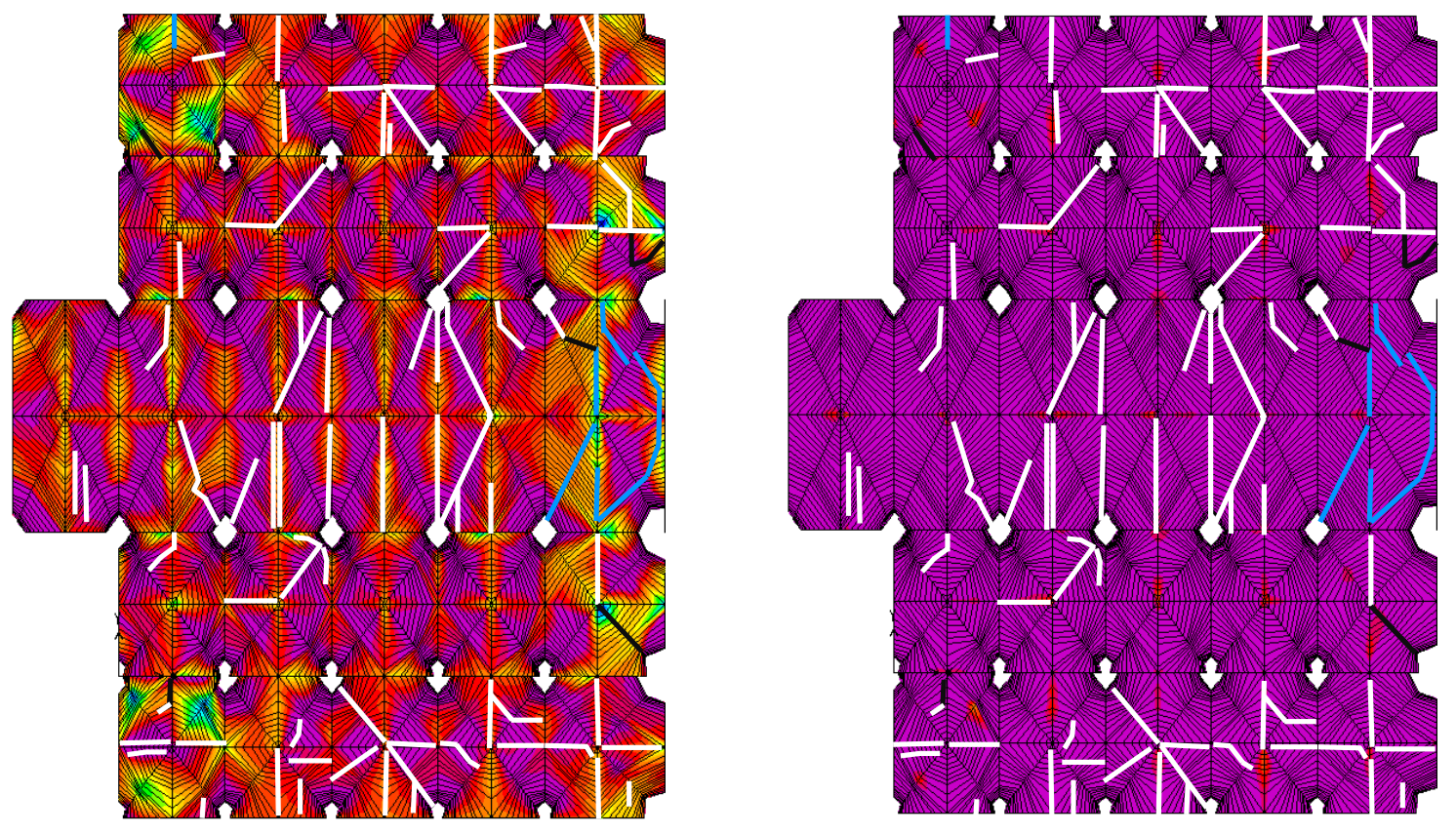

(a)

Face inferior
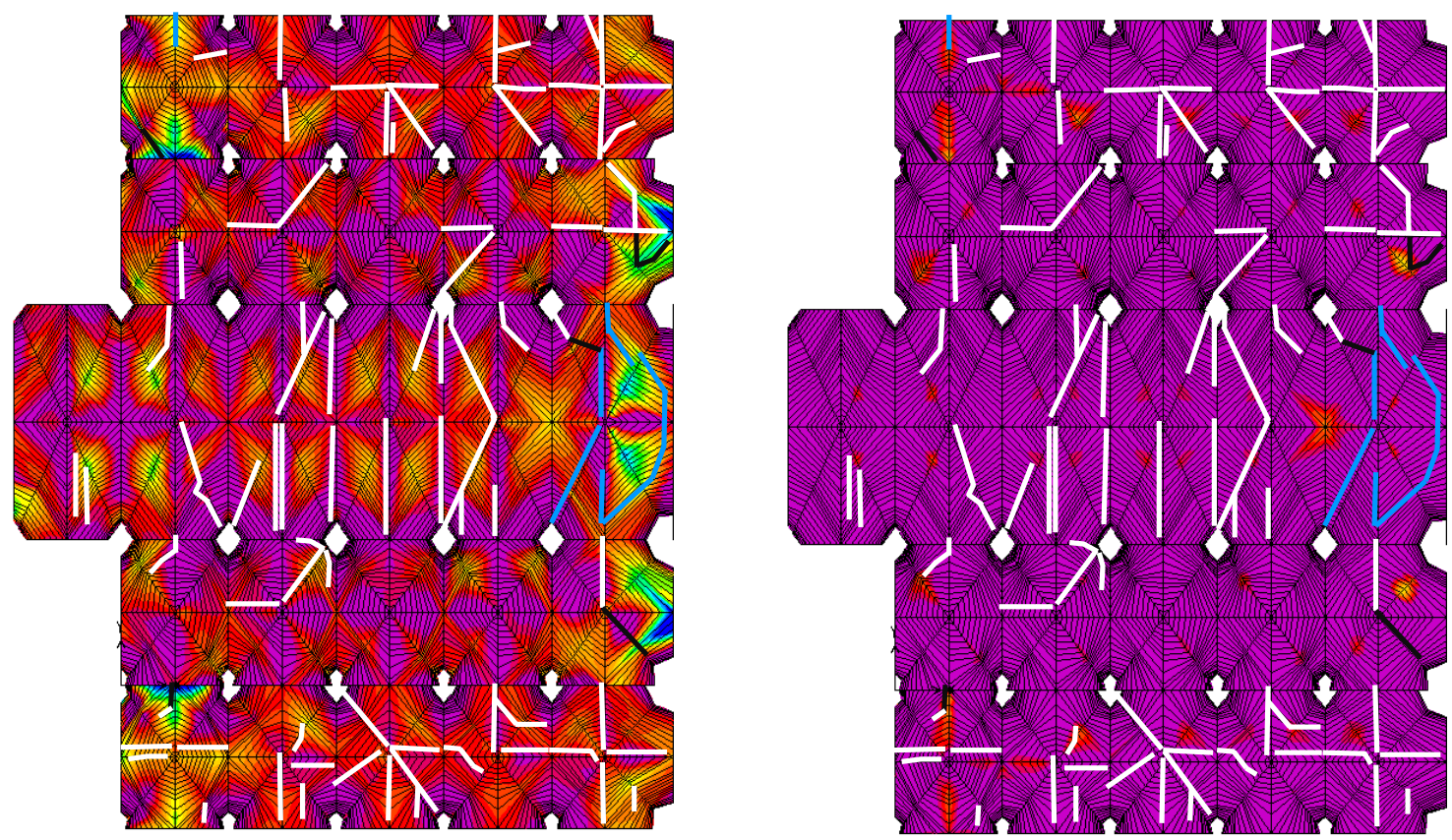

69. $92, \quad 115, \quad 138$.

162.

208.

(b)

Os valores das tensões normais indicados nesta escala estão em MPa.

Figura 6.36 - Marcação das fissuras na região frontal da igreja sobre os mapas das tensões principais máximas e mínimas: (a) na face superior da abóbada; (b) na face inferior da abóbada. 
Face superior
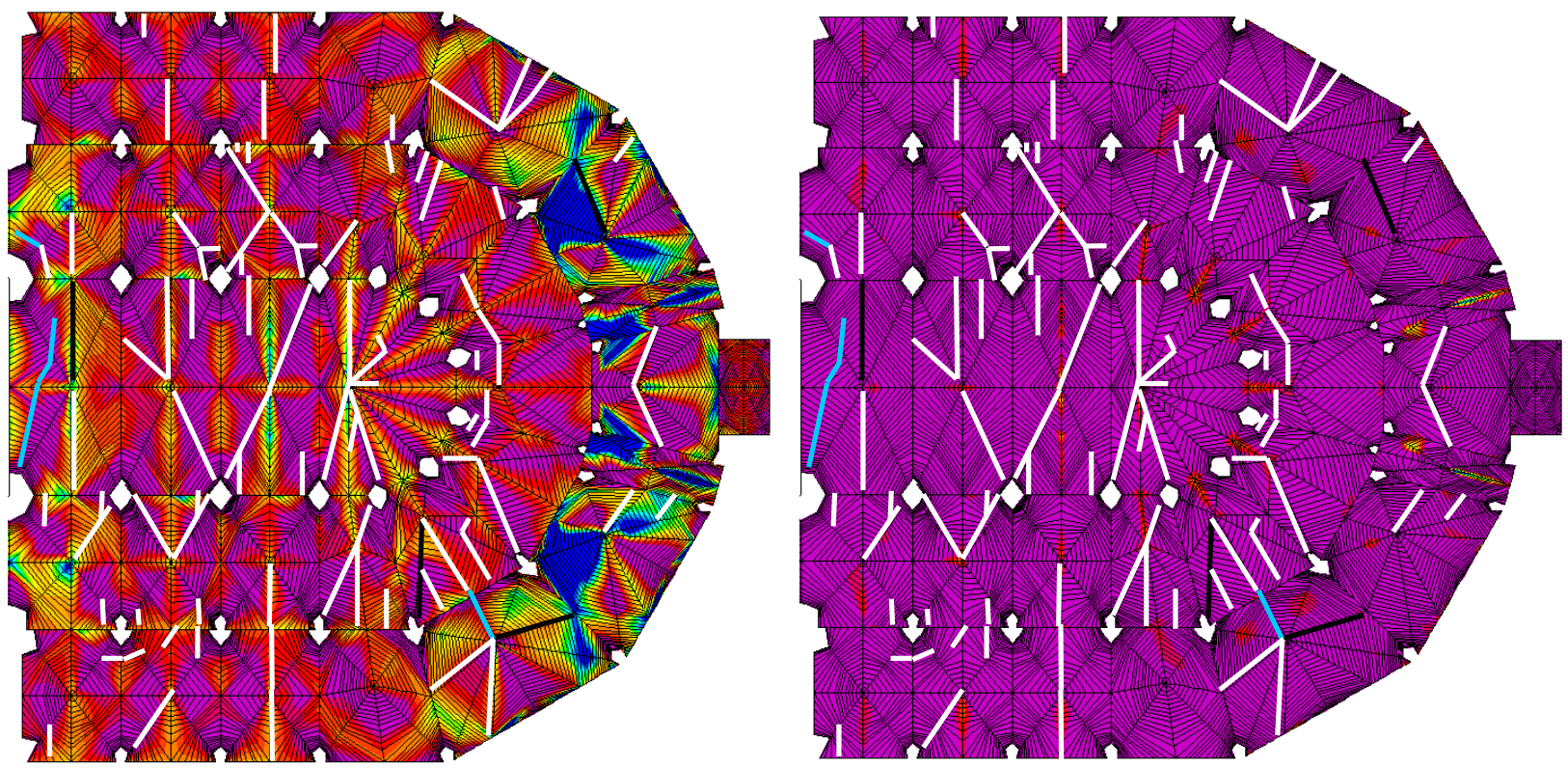

(a)

Face inferior
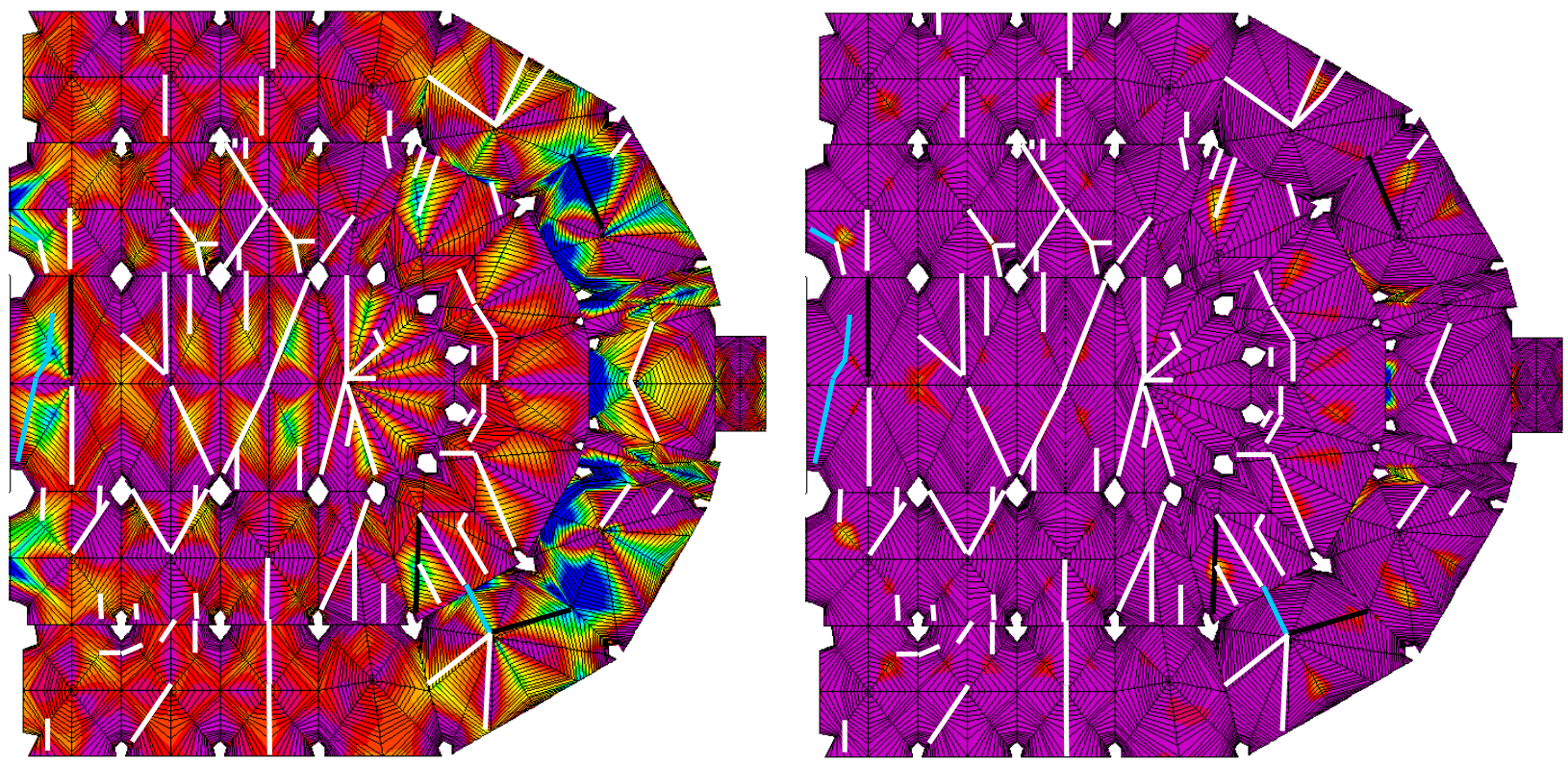

(b)

Os valores das tensões normais indicados nesta escala estão em MPa.

Figura 6.37 - Marcação das fissuras na região posterior da igreja sobre os mapas das tensões principais máximas e mínimas: (a) na face superior da abóbada; (b) na face inferior da abóbada.

Como comentado, na região posterior do templo, também há trechos em que $\sigma_{1}$ 
ultrapassa o valor de ruptura: nas abóbadas sobre a nave central e sobre as naves laterais mais próximas à região do octógono, e principalmente nas abóbadas sobre as naves laterais externas, na parte curva da igreja.

$\mathrm{Na}$ região do octógono, as abóbadas de alvenaria de tijolos também apresentam fissuras associadas ao carregamento (Figura 6.38).

Face superior
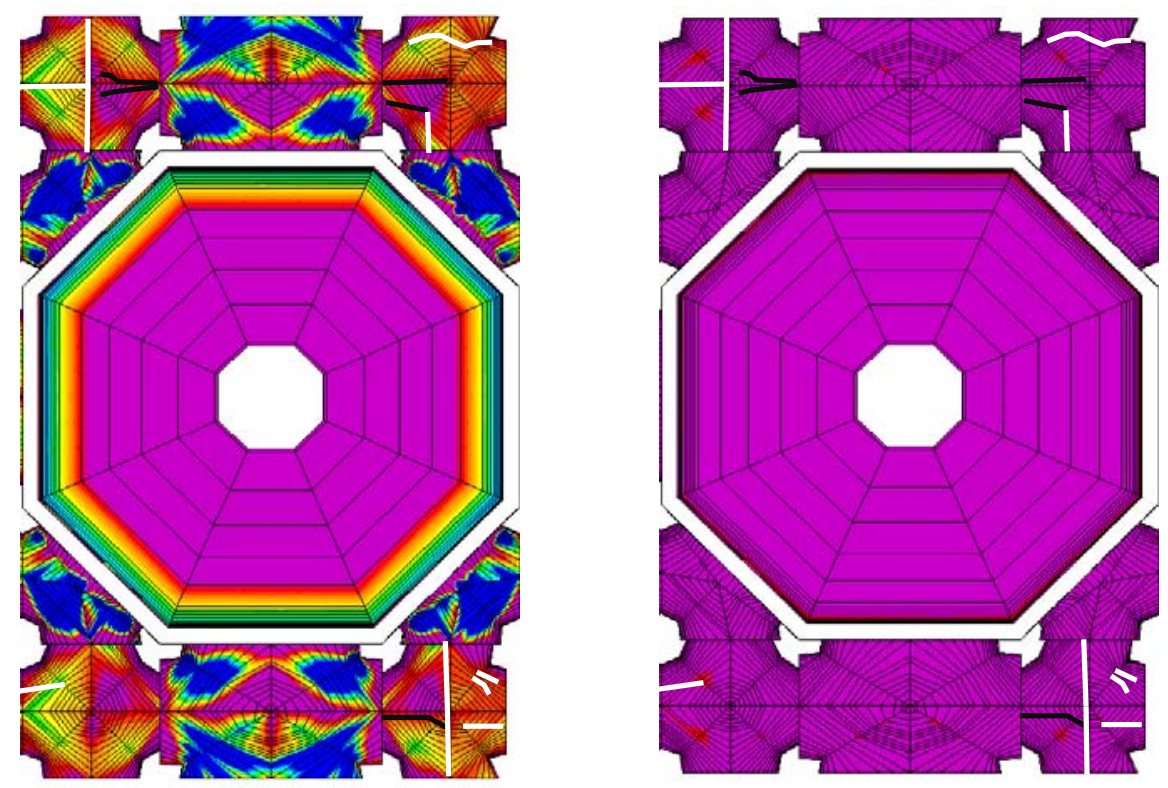

(a)

Face inferior
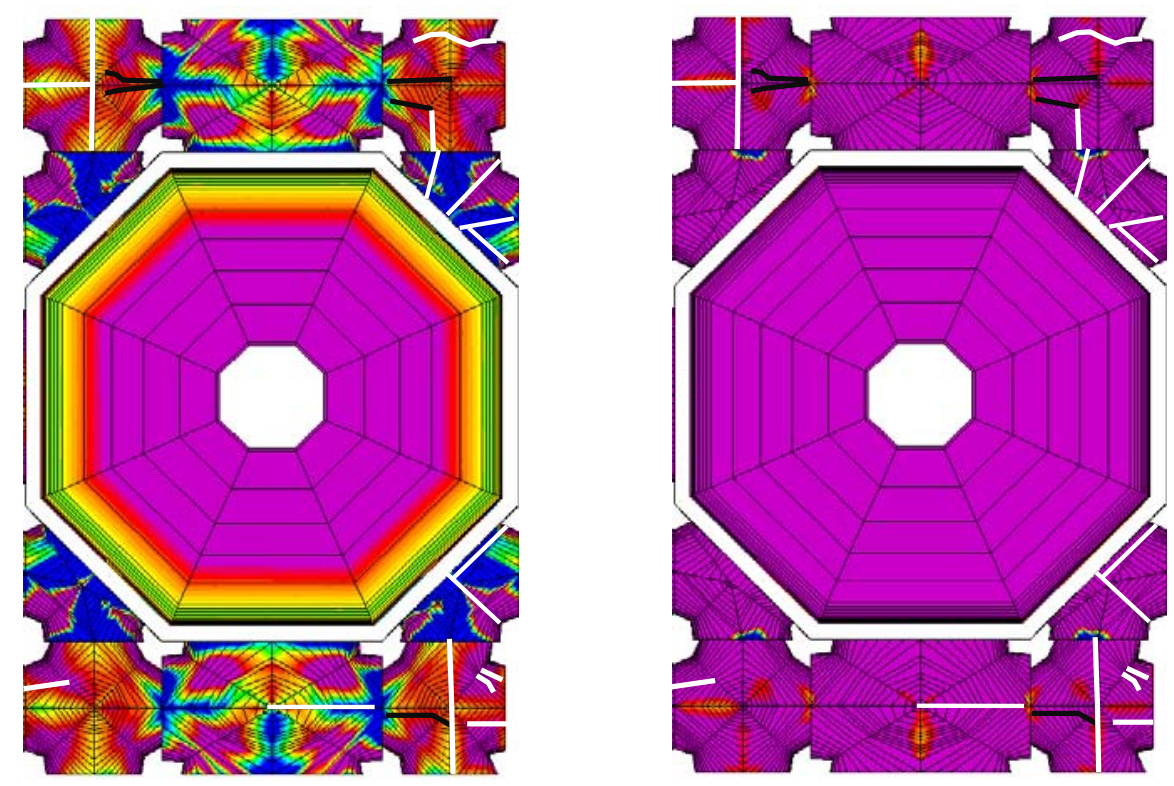

62. 185, 208, 231, 254, 277.

(b)

Os valores das tensões normais indicados nesta escala estão em MPa.

Figura 6.38 - Marcação das fissuras na região do octógono sobre os mapas das tensões principais máximas e mínimas: (a) na face superior da abóbada; (b) na face inferior da abóbada. 
Durante a reforma, as fissuras mapeadas foram reparadas, fechadas com a argamassa de revestimento pela parte inferior dos panos e tratadas com injeção de argamassa não retrátil pela parte superior da abóbada. No caso da trinca, o trecho da abóbada foi refeito, procedendo-se à remoção dos tijolos deteriorados e à reconstrução do pano com argamassas e tijolos de mesma dimensão (NASSER, 2000?).

Em visita à Catedral da Sé realizada recentemente, após a reforma da igreja, é possível verificar que estas fissuras permanecem reparadas e na grande maioria das abóbadas, pelo menos visualmente, essas fissuras não voltaram a se abrir.

Nos panos das abóbadas de alvenaria de tijolos aparente, os trechos das fissuras reparadas apresentam uma coloração mais escura. Já nas abóbadas com revestimento, as marcas foram ocultadas com uma nova demão de pintura com tinta látex branca como originalmente, e, segundo Dellelis (2002), a pintura incluiu os panos não reparados para haver padronização da cor interna.

Na região posterior da Catedral, entretanto, em algumas das abóbadas das naves laterais externas da região curva, onde atuam maiores tensões de tração, é possível constatar que, mesmo após a reforma, estão novamente presentes algumas fissuras em seus panos, ainda de que em menor número (Figura 6.39).

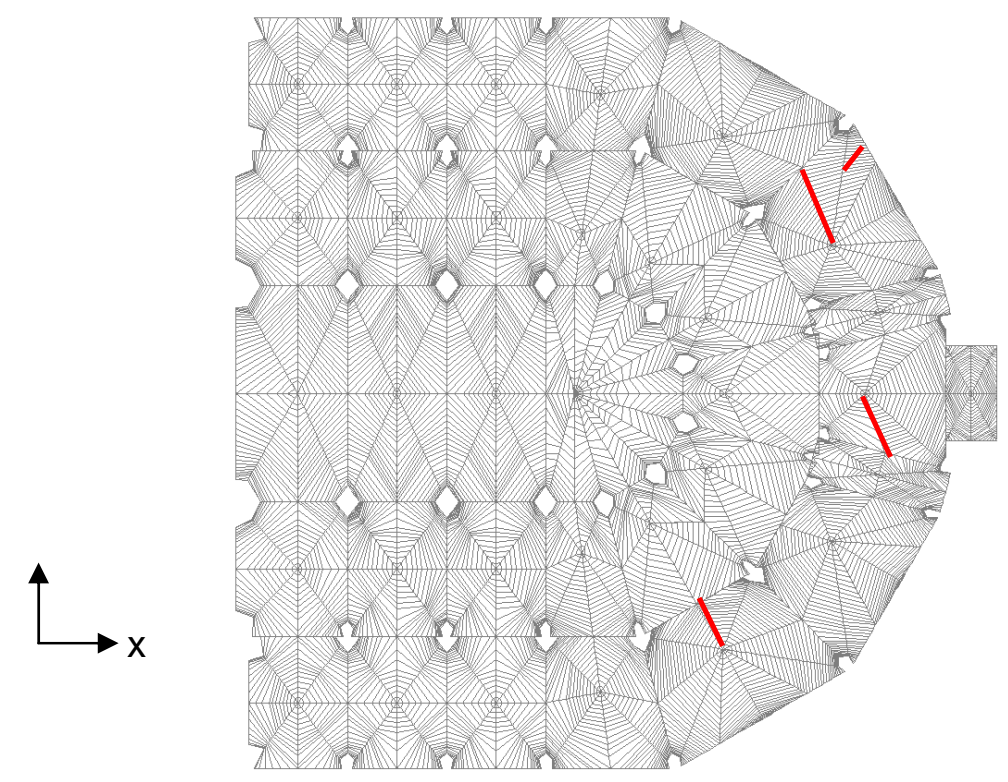

Figura 6.39 - Fissuras mapeadas na região posterior da Catedral após a reforma. 
Esta análise realizada sobre as fissuras da Catedral da Sé é preliminar e apenas indicativa de quais aberturas necessitariam de um estudo mais apurado em relação às questões estruturais.

Provavelmente, os recalques diferenciais e as variações de temperatura sejam os responsáveis pelo surgimento das demais fissuras nas abóbadas da Catedral da Sé.

\subsection{Considerações sobre a análise das tensões}

O estudo das tensões mostrou que os pilares e contrafortes da Catedral permanecem totalmente comprimidos e que as maiores tensões de compressão ocorrem naqueles elementos localizados na região do octógono. Apesar de nestes pilares e contrafortes atuarem as maiores tensões, estes valores não ultrapassam a tensão de ruptura à compressão dos materiais.

Quando realizadas as simulações em que são retirados os arcobotantes ou as torres frontais, surgem, em alguns poucos pilares, tensões de tração que não ultrapassam a tensão de ruptura obtida em um ensaio uniaxial de tração, de modo que para as condições de carregamento estudadas, a retirada destes elementos estruturais não leva à redução da seção transversal resistente destes pilares.

Como comentado, na seção 6.5, nas abóbadas da região do octógono se encontram as maiores tensões principais de tração, e, pelo fato de serem muito elevadas, estas abóbadas são de concreto armado, já que a alvenaria de tijolos não resistiria às tensões que nelas atuam. No caso das abóbadas dos "triângulos", encontram-se os valores máximos de tensão que estão em torno de 1,5 MPa, mas nelas são as armaduras que absorvem a tração.

Nas Figuras 6.36 a 6.38 apresentadas, notam-se também os trechos das abóbadas em que a tensão principal mínima também é de tração.

Assim, na maioria das abóbadas de alvenaria de tijolos da região frontal e também da região posterior da igreja, a tensão de ruptura à tração não é ultrapassada e mesmo quando ambas as tensões principais são de tração, o círculo de Mohr correspondente a este estado de tensão permanece no interior da 
envoltória, não se atingindo, portanto a ruptura.

Contudo, em algumas abóbadas da igreja, como apresentado, há trechos específicos nos quais o estado de tensão ultrapassa a envoltória, o que indica ruptura do material.

Esta análise é preliminar e permite afirmar que algumas poucas fissuras presentes nas abóbadas podem estar relacionadas à ação do carregamento. Elas estão localizadas principalmente nas abóbadas das naves laterais externas da região posterior da igreja e nas abóbadas da nave central e das naves laterais próximas ao octógono. Outras fissuras associadas ainda são encontradas nas primeiras abóbadas das naves laterais externas próximas às torres frontais.

Deve-se considerar o fato de que há outras variáveis que interferem na formação e abertura de fissuras, como falhas de construção e desgaste do material, como as perdas de rejunte que reduzem a resistência dos panos.

Nas demais abóbadas da Catedral, apesar de certa simetria no panorama de fissuração notada, por exemplo, nas abóbadas localizadas sobre a nave central, principalmente na direção y, transversal à igreja -, aparentemente elas não estão associadas ao carregamento e, nestes casos, outras são as causas prováveis.

Dentre elas, a movimentação da estrutura originada pelo recalque diferencial das fundações influenciada pela interferência do homem no espaço urbano - com vibrações provenientes do trânsito externo, demolições, construções como a estação do metrô, oscilação do nível de lençol freático - ou mesmos às variações de temperatura ocorridas ao longo dos anos.

Futuras pesquisas poderiam considerar a deformabilidade do solo e a ação dos recalques diferenciais, sobretudo porque esta é uma das razões já levantadas por Anhaia Melo em 1950. 


\section{CONSIDERAÇÕES FINAIS}

Esta pesquisa buscou apresentar os principais aspectos do comportamento estrutural global da Catedral da Sé de São Paulo em termos de deslocamentos e de tensões, a partir da elaboração de um modelo numérico tridimensional simplificado que considera comportamento elástico-linear dos materiais.

Além de uma análise estrutural, esta pesquisa propõe futuras práticas de estudo das construções que compõem o patrimônio artístico e cultural das cidades brasileiras, apropriando-se de sua posição particular e trazendo-o para o plano acadêmico no estudo da engenharia, como um meio de valorizá-lo e colocá-lo nos circuitos de pesquisas e discussões internacionais.

A Catedral da Sé de São Paulo possui seu papel social como um espaço de expressão popular ao testemunhar ao longo de sua história importantes manifestações religiosas, políticas e sociais. Estudos desenvolvidos a seu respeito são fundamentais para a preservação de sua memória e a da própria construção. A recente reforma pela qual passou entre 2000 e 2004, após a queda de tijolos das abóbadas e que levou à interdição do templo, alertou para a necessidade de se compreender melhor a estrutura da igreja.

A Catedral da Sé é uma estrutura prestes a completar cem anos do lançamento da pedra fundamental, em 1913, e a 60 anos de sua inauguração, em 1954; com o passar do tempo, registros e documentos foram perdidos ou dispersos, e assim também um pouco da história da cidade de São Paulo.

Com esta pesquisa, foram recuperadas informações sobre a sua estrutura, enfim uma reconstituição que permitiu descobrir a essência e os pormenores desta construção e torná-los acessíveis. Espera-se que esta tese se constitua em um registro da estrutura da Catedral da Sé e do comportamento estrutural do edifício e contribua para futuras tomadas de decisão caso haja a necessidade de intervenções na igreja.

Com suas abóbadas ogivais, pilares, arcobotantes, contrafortes, pináculos e altas torres, a Catedral da Sé parece obedecer fielmente aos anseios de uma catedral gótica medieval, a não ser pela presença da polêmica cúpula renascentista 
no cruzeiro do transepto.

Sob a cúpula, o enorme tambor de alvenaria de tijolos funciona como uma cinta a conter os deslocamentos horizontais dos pilares do octógono, provenientes do empuxo gerado pelos arcos do próprio espaço octogonal. Apesar de reduzidos, estes deslocamentos continuam existindo e são maiores, justamente, nos pilares e contrafortes da região do octógono.

Ao mesmo tempo, a estrutura do octógono, com o tambor e suas elevadas cargas, tem papel determinante, por maximizar os deslocamentos horizontais e movimentar a estrutura da igreja para fora.

Outra característica interessante da Catedral é a presença de paredes localizadas sobre todos os arcos longitudinais e sobre os arcos transversais das naves laterais. Estas paredes reduzem o deslocamento horizontal total dos pilares do octógono e agem no sentido oposto ao de tendência de abertura provocada por ele, tendo, provavelmente, sido concebidas também com este propósito.

Especificamente, a alvenaria sobre os arcos transversais das naves laterais reduzem somente os deslocamentos dos pilares centrais para fora, enquanto os demais elementos de apoio são movimentados para o exterior.

Já a alvenaria sobre os arcos longitudinais associados à geometria da igreja leva, na direção transversal, todos os pilares e contrafortes para dentro. Assim, sob a ação da carga permanente, resulta que somente os pilares laterais permanecem deslocados para o interior da edificação.

Quanto à importância das torres frontais, mostrou-se que funcionam como enormes contrafortes a conter, sobretudo, os deslocamentos longitudinais do templo e que, sem elas, a estrutura se movimentaria no sentido das torres ausentes.

Finalmente, o estudo de uma seção típica isolada da ação do octógono mostrou que os elementos estruturais da igreja funcionam como os de uma catedral gótica tradicional, com pilares e contrafortes movimentados para o exterior da mesma.

No entanto, as paredes sobre os arcos resultam em uma configuração, que, mesmo sob ação de toda a carga permanente, leva os pilares laterais a se deslocarem transversalmente para o interior da construção. 
Os contrafortes orientados para fora cumprem sua função ao reduzirem os deslocamentos horizontais da Catedral, assim como os arcobotantes ao transferirem os empuxos horizontais a estes contrafortes.

Quanto ao estudo das tensões, verificou-se que as seções transversais de todos os pilares e contrafortes da Catedral da Sé permanecem totalmente comprimidas, mesmo na situação em que são consideradas as ações horizontais do desaprumo ou do vento.

Estes elementos estruturais estão sob efeito de flexão e de elevada e predominante axial de compressão e é nos pilares centrais da região do octógono e nos contrafortes do transepto que atuam as maiores tensões de compressão nos materiais.

Caso fossem retirados os arcobotantes, as seções transversais dos pilares da igreja permaneceriam totalmente sob tensão de compressão, com exceção das seções dos pilares laterais dos eixos N, N', O e O', na região posterior e curva da Catedral. Nestes pilares, surgiriam tensões de tração nas seções transversais do revestimento de granito que, no entanto, não ultrapassariam a tensão de ruptura à tração simples deste material, mas estariam muito acima da tensão admissível estabelecida

A retirada das torres frontais implicaria no surgimento de tensões de tração nas seções transversais dos pilares do eixo $B$, o mais próximo às torres, que também não ultrapassariam a tensão de ruptura à tração dos materiais envolvidos.

Assim, na ausência dos arcobotantes ou das torres frontais, sob as condições de carregamento estudadas, não ocorreria o colapso sequer dos pilares ou dos contrafortes, e, por seguinte, da estrutura. Não se configura nestas situações de estudo, portanto, a possibilidade de colapso progressivo.

Vale destacar que apesar de o estudo desenvolvido ter mostrado que a ausência dos arcobotantes ou das torres frontais não levaria à ruptura de pilares, a presença destes elementos estruturais é necessária para a garantia da segurança e, portanto, a estrutura de Maximiliano Hehl foi bem concebida com a inserção destes elementos.

As tensões nas abóbadas também foram analisadas com o intuito de entender as causas das fissuras mapeadas por ocasião da recente reforma ocorrida entre 
2000 e 2004.

Como comentado, em 1950, fissuras já existentes levaram a crer num possível abalo estrutural. No entanto, segundo o engenheiro Luiz Anhaia Mello, responsável pela construção da catedral na época, elas não afetavam a integridade estrutural da igreja, já que se tratava apenas de um assentamento das fundações.

Na maioria das abóbadas de alvenaria de tijolos da região frontal e também da região posterior da igreja, a tensão de ruptura à tração não é ultrapassada e mesmo quando ambas as tensões principais são de tração, o círculo de Mohr correspondente a este estado de tensão permanece no interior da envoltória, não se atingindo, portanto a ruptura.

Em algumas abóbadas da igreja, no entanto, há trechos específicos nos quais o estado das tensões principais ultrapassa a envoltória, o que indica ruptura do material, e as fissuras lá mapeadas podem estar associadas ao carregamento. Esta análise indica que estas fissuras estão localizadas principalmente nas abóbadas das naves laterais externas da região posterior e curva da igreja, nas abóbadas mais próximas ao octógono e nas primeiras abóbadas das naves laterais externas próximas às torres frontais.

Nas demais abóbadas da Catedral, as causas prováveis da fissuração podem estar relacionadas ao assentamento das fundações influenciado pela interferência do homem no espaço urbano ou mesmos às variações de temperatura ocorridas ao longo dos anos.

Em visita à Catedral da Sé realizada recentemente, após a reforma da igreja, é possível verificar que a maioria das fissuras permanece reparada, mas que algumas surgiram novamente nas abóbadas de alvenaria de tijolos das naves laterais externas da região curva, trecho mais crítico por nele serem encontradas as maiores tensões de tração.

Esta análise sobre as fissuras da Catedral da Sé é preliminar e apenas indicativa de quais aberturas podem estar associadas ao carregamento. Torna-se necessário estudar os outros prováveis agentes, como efeitos de recalque e de temperatura.

Sugere-se que o avanço das pesquisas deva considerar a deformabilidade do solo, com o levantamento de possíveis recalques diferenciais, de modo a verificar 
seu efeito sobre o comportamento da igreja, sobretudo porque a condição do solo é uma das razões apontadas no passado por Anhaia Melo como a provável causa do surgimento de fissuras na construção.

Apesar de a análise linear ter-se mostrado muito adequada para o estudo desenvolvido para a Catedral da Sé, uma vez que os resultados mostraram pequenos deslocamentos e baixas tensões nos pilares e contrafortes, outra possibilidade de continuidade das pesquisas é desenvolver uma análise não-linear, que é uma opção muito utilizada para estruturas que necessitam de reforço e principalmente quando se constata que os resultados fornecidos pela análise linear, como deslocamentos, não condizem com a realidade, como é o caso da abóbada do Teatro Lethes em Faro.

Uma análise paramétrica das características mecânicas dos materiais estruturais também se mostra como uma possibilidade de estudo, de modo a verificar a influência de sua variabilidade no comportamento da estrutura tanto em termos qualitativos como quantitativos, assim como a influência de possíveis assimetrias nas cargas que atuam na construção.

As pesquisas também podem seguir o rumo da verificação da segurança estrutural por meio do método dos estados limites, utilizando-se de coeficientes de majoração das ações, e de redução da resistência, de modo que se comparem os esforços e não as tensões. O método dos estados limites apresenta-se como uma opção para tratar a questão de segurança de forma probabilística, ou seja, as variabilidades são consideradas tanto nas ações como na resistência.

A elaboração de um estudo qualitativo e quantitativo da Catedral da Sé de São Paulo permitiu o entendimento e discussão sobre o comportamento tridimensional do templo e de seus deslocamentos, avaliar a importância de elementos estruturais para o equilíbrio do conjunto e identificar as regiões mais solicitadas. As regiões da igreja que apresentam os maiores deslocamentos também são aquelas mais críticas em termos de tensão e, algumas fissuras mapeadas podem ter relação com os carregamentos analisados nesta pesquisa.

O modelo desenvolvido nesta pesquisa representa bem o comportamento global esperado, e a análise mostrou que a estrutura foi muito bem concebida por Maximiliano Hehl e que os seus elementos principais comportam-se estruturalmente 
como os das catedrais góticas originais.

Espera-se que esta pesquisa abra caminho para futuros estudos relacionados à Catedral da Sé de São Paulo quanto a alguns dos temas aqui tratados, assim como, a influência dos recalques no comportamento estrutural da igreja e a verificação de sua segurança por meio do método dos estados limites; e também sirva de estímulo ao desenvolvimento de trabalhos de engenharia relacionados ao patrimônio arquitetônico e cultural brasileiro. 


\section{LISTA DE REFERENCIAS}

A CATHEDRAL de São Paulo. São Paulo: [s.n], [1911?].

AJOESP. Associação dos Oficiais de Justiça do Estado de São Paulo. City Tour. Disponível em:<http://www.aojesp.org.br/passeio centro.html>. Acesso em: 17 dez. 2008. (il.).

AMIENS CATHEDRAL web site. Amiens Cathedral Project. Disponível em: $<$ http://www.mcah.columbia.edu/Mcahweb/index-frame.html $>$. Acesso em: 7 abr. 2010.

ANHAIA: continuará a construção da catedral. Sondagens do solo para saber se a construção da cúpula pode ser iniciada. Folha da Noite, São Paulo, 24 nov. 1950. Ano XXIX, n. 9.038.

ARPEN-SP. Associação de Registradores de Pessoas Naturais do Estado de São Paulo. Catedral da Sé. Disponível em:

$<$ http://www.arpensp.org.br/principal/index.cfm?pagina id=232>. Acesso em: $21 \mathrm{dez}$. 2008.

ART on line. Gótico. Arquitectura. Catedral de Chartres. 1194-1245. Disponível em: <http://cv.uoc.es/ 991 0400501 web/fitxer/perc34.html>. Acesso em: 29 nov. 2004.

ASSOCIAÇÃO BRASILEIRA DE NORMAS TÉCNICAS. NB-1: cálculo e execução de obras de concreto armado, 1950. 18p.

ASSOCIAÇÃO BRASILEIRA DE NORMAS TÉCNICAS. NBR 6118: projeto de estruturas de concreto. Rio de Janeiro, 2003. 221p.

ASSOCIAÇÃO BRASILEIRA DE NORMAS TÉCNICAS. NBR 6120: cargas para cálculo de estruturas em edificações. Rio de Janeiro, 1980. 5p.

ASSOCIAÇÃO BRASILEIRA DE NORMAS TÉCNICAS. NBR 6123: forças devidas ao vento em edificações. Rio de Janeiro, 1988. 66p. 
BETON KALENDER. Manual teórico-prático del hormigón. Buenos Aires: Ed. El Ateneo, 1954. v.1.

CASSIMIRO, R. Catedral da Sé. Galeria de Fotos. Folha on line. Disponível em: $<$ http://www1.folha.uol.com.br/folha/galeria/album/p catedral se 04.shtml >. Acesso em: 20 abr. 2010. (il. 4 - 5).

CHEAP EURO TOUR. Amiens atractions, France. Disponível em: $<$ http://www.cheapeurotour.com/france/amiens/amiens attractions.html $>$. Acesso em: 7 abr. 2010.

COMISSÃO EXECUTIVA DAS OBRAS DA NOVA CATEDRAL DE SÃO PAULO. Aspectos da Catedral. São Paulo: [s.n], [194-].

COMISSÃO EXECUTIVA DA NOVA CATEDRAL DE SÃO PAULO. Catedral da Sé de São Paulo: 1937 a 1942. São Paulo: Instituto D. Anna Rosa, 1942. 15p. (Relatório n.24).

COMO, M. The collapse of the Beauvais Cathedral in 1284: the conjecture of the creep buckling piers. In: INTERNATIONAL CONGRESS ON CONSTRUCTION HISTORY, 3., Mai. 2009, Germany. Proceedings. Germany: Faculty of Architecture, Civil Engineering and Urban Planning at the BTU Cottbus, 2009. p.393-400.

Disponível em: <https://www-docs.tucottbus.de/bautechnikgeschichte/public/openaccess/comomario oa.pdf $>$. Acesso em: abr. 2010.

CONCREJATO Serviços Técnicos de Engenharia S/A. Planta do térreo. Levantamento Métrico Arquitetônico Atualizado. Projeto de Adaptação, Complementação e Restauro. São Paulo, ago. 2002, FL. 01/04. Escala 1:100.

CONCREMAT. Catedral Metropolitana de São Paulo. São Paulo: [1999?]. 29p. (Relatório n.1).

COSSE, J. Initiation à l'art des cathédrales. 2.ed. França: Zodiaque, 2001. 337p.

DACIOLE, F. Fotos do Brasil. Catedral da Sé. Disponível em: $<$ http://www.fotosdobrasil.fot.br/Sudeste/SaoPaulo/CatedralDaSe.htm>. Acesso em: abril de 2008. 
DELELLIS, R.; LESCHER, A.; CANNABRAVA, I. Catedral da Sé. Arte e engenharia. São Paulo: FormArte, 2002. 228p.

FIND TARGET reference. Roman Catholic Archdiocese of São Paulo. Catedral da Sé. Disponível em:

$<$ http://reference.findtarget.com/search/Roman\%20Catholic\%20Archdiocese $\% 20$ of\% 20S\%C3\%A30\%20Paulo/>. Acesso em: 8 abr. 2010.

FLETCHER, B. Sir Banister Fletcher's. A history of architecture. 20.ed. London: Architectural Press, 2000. 1794 p.

FOLHA on line. A nova Catedral. Disponível em:

$<$ http://www1.folha.uol.com.br/folha/especial/2002/catedraldase/>. Acesso em 24 abr. 2002.

FREITAS, O. P.; LINDENBERG NETO, H. (a). Abadia de Saint-Denis. Escola Politécnica da Universidade de São Paulo. Disponível em: $<$ http://www.Imc.ep.usp.br/people/hlinde/estruturas/Abadia\%20de\%20Saint-

Denis.htm>. Acesso em: 25 abr. 2009.

Politécnica da Universidade de São Paulo. Disponível em: $<$ http://www.Imc.ep.usp.br/people/hlinde/Estruturas/amiens.htm>. Acesso em: 25 abr. 2009.

(c). Sistema estrutural das catedrais góticas. Escola Politécnica da Universidade de São Paulo. Disponível em: $<$ http://www.Imc.ep.usp.br/people/hlinde/Estruturas/sistest.htm>. Acesso em: 25 abr. 2009.

GAGO, A.S.; LAMAS, A.R.G. Explicação das fendas da abóbada da Igreja de S. Francisco em Évora. Portugal: Instituto Superior Técnico Lisboa. Disponível em: $<$ http://www.civil.ist.utl.pt/ gago/Artigos/Artigo9.pdf>. Acesso em 10 out. 2009. GERE, J.M.; TIMOSHENKO, S.P. Mechanics of Materials. 4.ed. Boston: PWS Publishing Company. 1997. 912p.

KALIPÉDIA. Tipos arquitectônicos góticos. La Catedral. Fachada de la Catedral de Reims. Disponível em:

$<$ http://uy.kalipedia.com/arte/tema/edadmedia/catedral.html?x=20070718klparthis 50 .Kes\&ap=0>. Acesso em: 7 abr.2010.

KAUSHIK, H. B.; RAI, D. C.; JAIN, S.K. Uniaxial compressive stress-strain model for clay brick masonry. Current Science, v. 92, n. 4, p.497-501, fev. 2007.

Disponível em: <http://www.ias.ac.in/currsci/feb252007/497.pdf>. Acesso em: 
ago.2009.

KIOTO - INET. History of gothic architecture. Duomo, Milano n.1. Disponível em: $<$ http://web.kyoto-inet.or.jp/org/orion/eng/hst/gothic/milanoc.html>. Acesso em: 3 jan. 2005.

LANGENDONCK, TELEMACO van. Cálculo de concreto armado. 2.ed. São Paulo: Associação Brasileira de Cimento Portland, 1954, v.1. 500p.

LILTROLL and Silvara's. Travels. Catedral de Bourges. Disponível em: <http://perso.wanadoo.fr/liltroll-silvara.webpage/france/spanish/bourgeses.html>. Acesso em: 14 dez. 2004.

LINDENBERG NETO, H. Catedral da Sé. 2005 - 2009. Fotografias, color.

LOURENÇO, P.B. Análise do teatro Lethes em Faro: um exemplo do valor acrescentado do MEF. Guimarães: Universidade do Minho, 2000. Disponível em: <http://www.civil.uminho.pt/masonry/Publications/Update Webpage/2000 Lourenco2 .pdf>. Acesso em: fev. 2009.

LOURENÇO P.B.; ROCA P. Analysis of historical constructions: from thrust-lines to advanced simulations. Universidade do Minho, Departamento de Engenharia Civil. Guimarães: Historical Constructions, 2001. pp. 91-115. Disponível em: $<$ http://www.civil.uminho.pt/masonry/Publications/Historical\%20constructions/page\% 2091-116\%20 Lourenco .pdf>. Acesso em: dez. 2006.

LUBOWIEKA, I. et al. Historic bridge modeling using laser scanning, ground penetrating radar and finite element methods in the context of structures dynamics. Elservier: Journal Engineering Structures, v.31, n.11, p.2667-2676, nov., 2009.

MARCHINI, G. El baptisterio y el duomo de Florencia. Una guia artística. Firenze: Becocci Editore, 1972.

MARK, R. Light, wind and structure. The mystery of the master builders. 2.ed. Massachusetts: New Liberal Arts Series, 1990. p.94.

MATTOS, M. S. M. A Nova Catedral de São Paulo. São Paulo: Arquidiocese de São Paulo, 1992. 
MELE, E.; GATTO, D.; LUCA, A.. Structural analysis of basilica churches: a case study. Guimarães: Historical Constructions, p.729-738, 2001. Disponível em: $<$ http://www.csarmento.uminho.pt/docs/ncr/historical constructions/page\%20729738\%20 126 .pdf>. Acesso em: set. 2009.

MILLS, A; HAYWARD, H.W.; RADER, L.F.. Materials of construction. Their manufacture and properties. 6.ed. New York: John Willey \& Sons, jun. 1967. p.311.

MOLITERNO, A. Caderno de estruturas de alvenaria e concreto simples. São Paulo: Editora Edgard Blücher Ltda., 1995. 374p.

NASSER, M.A; POMPEI, A.; NISHIDA, M.K. Da construção à restauração. Relatório. São Paulo: [2000?].

PETRUCCI, E.G.R. Materiais de construção. 3.ed. Porto Alegre: Editora Globo, 1978. 435p.

PIRES, W.; SAIA, H. Da capela à metrópole. 1.ed. São Paulo: Imagem Data, dez. 1997. 128p. (Coleção Imagens e Construção).

PONZIO, A.F. O Arquiteto da Sé. URBS, v.5, n.31, jul. - ago. 2003. Disponível em: <http://www.vivaocentro.org.br/publicacoes/urbs/urbs31.htm>. Acesso em: set. 2008.

RAMIREZ, K.N. Catedral da Sé de São Paulo: aspectos históricos, arquitetônicos e estruturais. 2005. 167p. Dissertação (Mestrado) - Escola Politécnica, Universidade de São Paulo, São Paulo, 2005.

ROBSONLAGES. Catedral de Santos. Disponível em:

<http://www.robsonlages.com/o casamento.jsp>. Acesso em: 9 abr. 2010.

ROSTEY, G. Minhas fotos da Catedral da Sé. SKYSCRAPERCITY. Disponível em: <http://www.skyscrapercity.com/showthread.php?t=236402>. Acesso em: dez.2008.

SALVADORI, M. Why buildings stand up. New York: WW Norton \& Company, 1990. 323p.

SIEIRO, C. Coutances Catedral. Site Panoramio. Disponível em: <http://www.panoramio.com/photo/13878663 >. Acesso em: 8 abr. 2010. 
SILVA, V.C.; LOURENÇO, P.B.; MESQUITA, C.G.. Accounting for the "block effect" in structural interventions in Lisbon's old "Pombaline" downtown buildings. Historical Constructions, Gimarães, p.943 - 952, 2001. Disponível em:

$<$ http://www.civil.uminho.pt/masonry/Publications/2001 Silva et al.pdf $>$. Acesso em: mai.2009.

STATIC.FLICKR. A praça da Sé por uma perspectiva oriental. Disponível em: $<$ http://farm4.static.flickr.com/3106/2661133017 3b6128852d.jpg>. Acesso em: 06 jan. 2009.

WENZLER, C. Architecture religieuse gothique. Rennes: Editions Ouest-France, 1997. 31p. (Collection Architecture).

WIKIPÉDIA. A enciclopédia livre (a). Cathédrale Notre-Dame de Coutances. Disponível em: <http://fr.wikipedia.org/wiki/Cath\%C3\%A9drale de Coutance>. Acesso em: 23 nov. 2004.

(b). Catedral de Santos. 2008. MORIO. Disponível em: <http://pt.wikipedia.org/wiki/Ficheiro:Cathedral 1 Santos Brasil2.jpg>. Acesso em: 9 abr. 2010.

ZENG, F.; LIN, F.B.. Experimental investigation on granite masonry behavior under compression. In: STUCTURES 2009: don't mess with structural engineers, 2009, Texas. Proceedings. Texas: ASCE, 2009. p.1639-1647. 


\section{REFERÊNCIAS CONSULTADAS}

Abala-se a estrutura da Catedral de São Paulo. Folha da Tarde, São Paulo, 24 nov. 1950. Ano XXIX, n. 9.140.

ARQUIVO DA CÚRIA METROPOLITANA DE SÃO PAULO. Plantas da Catedral da Sé. Corte longitudinal. [19--]. MAP - 02 - 08 - 01 A/B.

Plantas da Catedral da

Sé. Corte longitudinal da frente até o centro da cúpula. [19--]. MAP-02-09-06 B

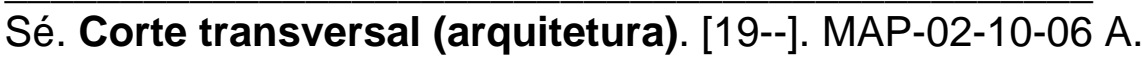

Plantas da Catedral da

Sé. Arcos do octógono. 1943. MAP-02-02-06 C.

. Plantas da Catedral da

Sé. Arcos e abóbadas do côro. 1943. MAP-02-02-06 D.

- Plantas da Catedral da

Sé. 5a abóbada. [19--]. MAP-02-11-04 A/D. Escala 1:20.

Plantas da Catedral da

. Plantas da Catedral da

Sé. Abóbada sobre a entrada na Praça João Mendes. [19--]. MAP-02-11-04 B/C. Escala 1:20.

- Plantas da Catedral da

Sé. Abóbada do centro. [19--]. MAP-02-11-04 E. Escala 1:20.

- Plantas da Catedral da

Sé. Arcos do octógono entre as colunas tipo I. 1943. MAP-02-14-05 C. Escala 1:20.

Sé. Arco. [19--]. MAP-01-13-04 B.

- Plantas da Catedral da 
Sé. Arco tipo III para o tipo V. [19--]. MAP-01-13-04 C.

Plantas da Catedral da

Sé. $1^{\mathrm{a}}$ e $2^{\mathrm{a}}$ abóbadas da nave central. [19--]. MAP-01-15-05 A.

Plantas da Catedral da

Sé. Abóbadas do transepto. [19--]. MAP-01-15-05 B.

- Plantas da Catedral da

Sé. Arcos entre tipos II e VI. [19--]. MAP-01-15-05 A.

- Plantas da Catedral da

Sé. Arcos. [19--]. MAP-01-15-05 B/C/D.

. Plantas da Catedral da

Sé. Arcos. [19--]. MAP-01-13-02 B.

- Plantas da Catedral da

$\overline{\text { Sé. Arco entre coluna tipo I e VI. [19--]. MAP-01-13-02 D. }}$

Plantas da Catedral da - Plantas da Catedral da Sé. Arcos e arestas do pavimento baixo. 1940. MAP-02-01-03. Escala 1:50.

ASHBY, M. F.; JONES, D. R. Engineering materials 1: an introduction to their properties \& applications. 2.ed. London: Butterworth Heinemann, 1996.

ASSOCIAÇÃO BRASILEIRA DE NORMAS TÉCNICAS. NBR 10837: cálculo de alvenaria estrutura de blocos vazados de concreto. Rio de Janeiro, 1989. 20p.

BELLEI, I.H. Edifícios Industriais. Projeto e Cálculo em aço. 3ed. São Paulo: Pini, 2000. p.77. 489p.

BOOTHBY, T, E. Load rating of masonry arch bridges. ASCE: Journal of Bridge Engineering, p.79-86, Mar.- Apr. 2001. 
CONCREJATO Serviços Técnicos de Engenharia S/A. Planta coro. Levantamento Métrico Arquitetônico Atualizado. Projeto de Adaptação, Complementação e Restauro. São Paulo, ago. 2002, FL. 03/04. Escala 1:100.

Levantamento Métrico Arquitetônico Atualizado. Projeto de Adaptação, Complementação e Restauro. São Paulo, ago. 2002, FL. 04/04. Escala 1:100.

COMITE EURO-INTERNATIONAL DU BETON. CEB-FIP Model Code 1990. Bulletin d'information. Lausanne, Chapters 6-14. n.16. mar.1990. p.6-72 - 6-79.

DRYSDALE, R.G.; HAMID, A.A.; BAKER, L.R.. Mansonry structures. Behavior and Design. New Jersey: Ed. Prentice Hall, 1994. 800p.

ESCOLA POLITÉCNICA DA UNIVERSIDADE DE SÃO PAULO. História. Histórico de 1893 a 1900. Disponível em:

<http://www.poli.usp.br/Organizacao/Historia/Historico/1893-1900.asp>. Acesso em: ago. 2008.

GAGO, A.S.; ALFAIATE, J.; ALMEIDA, J.R. Simulação numérica de um ensaio experimental efectuado numa ponte de alvenaria de pedra. In: CONGRESSO DE MECÂNICA APLICADA E COMPUTACIONAL, 7., 14-16 abr. 2003., Évora. Anais. Évora: Universidade de Évora, 2003. Disponível em:

<http://www.civil.ist.utl.pt/ gago/Artigos/Artigo8.pdf>. Acesso em: abr. 2009.

GODART, B.; TIVERON, M.; DUVAL, D. Modélisation de la cathédrale de Strasbourg à l'aide du code de calcul aux éléments finis CÉSAR-LCPC. Étude de l'influence de mouvements d'appuis sur le comportement d'unne partie de l'édifice. Ministère de l'Equipament, du Logement, des Transports et du Tourisme : Bulletin des laboratoires des ponts et chaussees, n. 206, p.41-62, nov.-déc. 1996

GRIMM, C.T. Durability of Brick Masonry: a review of the literature. ASTM: Masonry: research, application and problems, p.202-234, Jan., 1985.

HASHIDA, T.; TAKAHASHI, H. Simple determination of effective Young's modulus of rock by compliance method. ASTM: Journal of Testing and Evaluation. v.13, n.1, p.77-84, Jan.1985.

HIBBELER, R.C. Resistência dos Materiais. 5ed. São Paulo: Pearson Prentice Hall, 2004. 670p. 
LANGENDONCK, TELEMACO van. Tensões. Rio de Janeiro: Editora científica, 1956. 300p.

LENTZ, J. Manual prático da alvenaria e do betão armado. Lisboa: Ed. CETOP, 1976. 207p. (Coleção construcção e móveis).

MOURÃO, S.M.C. Estudo do comportamento sísmico do conjunto monumental do Mosteiro dos Jerónimos. 2001. 160p. Dissertação (Mestrado) - Universidade do Minho, Portugal, 2001.

NARAYANANA, R. Concrete framed structures. Stability and strength. New York: Elsevier Applied Science Publishers, 1986. p.55-69.

NOVO MILÊNIO. Histórias e lendas de santos. Igrejas - Embaré. O engenheiro M. Helh. 2007. Disponível em: <http://www.novomilenio.inf.br/santos/h0188p7.htm>. Acesso em: abr. 2010.

OLIVEIRA, D.; LOURENÇO, P.B.; ROCA, P. Comportamento experimental de muros de pedra sujeitos a esforços de compressão e de corte. In: ENCONTRO NACIONAL SOBRE CONSERVAÇÃO E REABILITAÇÃO DE ESTRUTURAS, 2000, Portugal. Anais. Portugal: Universidade do Minho, 2000. p.345-354. Disponível em: $<$ http://www.civil.uminho.pt/masonry/Publications/Update Webpage/2000 Oliveira L ourenco2.pdf>. Acesso em: abr. 2009.

POPOV, E.P. Resistência dos Materiais. 2ed. Rio de Janeiro: Prentice / Hall do Brasil, 1984. 507p.

TOMAN, R. O Gótico. Arquitetura, escultura, pintura. Germany: Konemann, 2000. $521 p$.

VASCONCELOS, G.; LOURENÇO, P. B. Análise experimental do comportamento de paredes de alvenaria de pedra não reforçada sob acções cíclicas no plano. In: CONGRESSO NACIONAL DE SISMOLOGIA E ENGENHARIA SÍSMICA, 6.,2004, Guimarães. Anais. Guimarães: Departamento de Engenharia Civil da Universidade do Minho, 2004. p.531-541. 